\title{
ГЕНОФОНД И СЕЛЕКЦИЯ РАСТЕНИЙ
}

\section{V МЕЖДУНАРОДНАЯ КОНФЕРЕНЦИЯ}

11-13 ноября 2020 г.

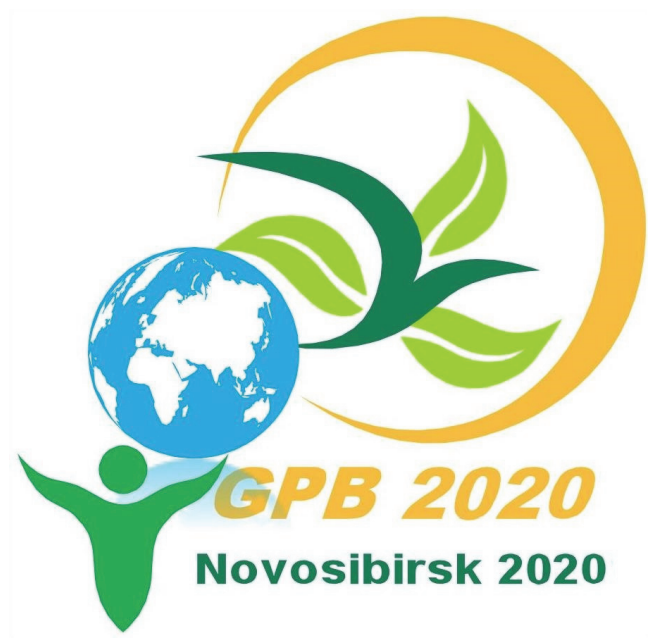




\section{Организаторы}

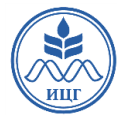

Федеральное государственное бюджетное научное учреждение «Федеральный исследовательский центр Институт цитологии и генетики Сибирского отделения Российской академии наук» (ИЦиГ СО РАН)

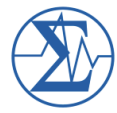

Сибирское отделение Российской академии наук (CO PAH)

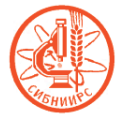

Сибирский научно-исследовательский институт растениеводства и селекции - филиал ИЦиГ $\mathrm{CO} \mathrm{PAH}$

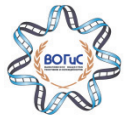

Межрегиональная общественная организация Вавиловское общество генетиков и селекционеров (МОО ВОГиС)

Новосибирское отделение ВОГиС

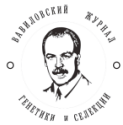

Вавиловский журнал генетики и селекции (ВЖГиС)

Новосибирский государственный аграрный университет

Кафедра цитологии и генетики НГУ,

Кафедра информационной биологии НГУ

\section{Технический партнер конференции}

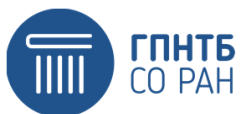

ГПНТБ СО РАН 
Федеральное государственное бюджетное научное учреждение «Федеральный исследовательский центр Институт цитологии и генетики

Сибирского отделения Российской академии наук» (ИЦиГ СО РАН)

\section{ГЕНОФОНД \\ И СЕЛЕКЦИЯ \\ РАСТЕНИЙ}

\section{V МЕЖДУНАРОДНАЯ КОНФЕРЕНЦИЯ}

11-13 ноября 2020 г.

Доклады и сообщения

Новосибирск

ИЦиГ СО РАН

2020 
Генофонд и селекция растений: доклады и сообщения V Международной конференции «Генофонд и селекция растений» (Новосибирск, 11-13 ноября 2020 г.) / Федер. исслед. центр Ин-т цитологии и генетики Сиб. отделения Росс. академии наук. - Новосибирск : ИЦиГ СО РАН, 2020. - 324 с. - ISBN 978-5-91291-052-4. - DOI 10.18699/GPB2020-00

Конференция поддержана Курчатовским геномным центром Института цитологии и генетики Сибирского отделения Российской академии наук, проект № 075-15-20191662

В сборнике материалов V Международной конференции «Генофонд и селекция растений» представлены доклады и сообщения, подготовленные по результатам изучения и сохранения генетических ресурсов растений на основе новейших исследований в области генетики, молекулярной биологии, биотехнологии и практического использования мирового генофонда культурных растений в селекции.

\section{Контакты}

E-mail орг. комитета GPB-2020: GPB2020@icg.sbras.ru

Тел.: +7 913-895-14-69

Тел./факс: +7 (383) 363-49-73; (383) 363-49-72

\section{Для бумажной корреспонденции}

630501, пос. Краснообск, Новосибирская область, ул. С-100, зд. 21, а/я 375, СИБНИИРС - филиал ИЦиГ СО РАН

ISBN 978-5-91291-052-4

(C) Коллектив авторов, 2020

(C) Институт цитологии и генетики СО РАН, 2020 


\section{Международный программный комитет}

Лихенко Иван Евгеньевич, д.с.-х.н., СибНИИРС - филиал ИЦиГ СО РАН, Новосибирск, Россия - сопредседатель

Кочетов Алексей Владимирович, д.б.н., чл.-кор. РАН, ИЦиГ СО РАН, Новосибирск, Россия - сопредседатель

Салина Елена Артемовна, д.б.н., ФИЦ ИЦиГ СО РАН, Новосибирск, Россия - заместитель председателя программного комитета

Афанасенко Ольга Сильвестровна, д.б.н., академик РАН, ФГБНУ ВИЗР, Санкт-Петербург, Россия

Баталова Галина Аркадьевна, д.с.-х.н., академик РАН, ФГБНУ Федеральный аграрный научный центр Северо-Востока им. Н.В. Рудницкого, Киров, Россия

Беспалова Людмила Андреевна, д.с.-х.н., академик РАН, ФГБНУ НЦЗ им. П.П. Лукьяненко, Краснодар, Россия

Гончаров Николай Петрович, д.б.н., академик РАН, ФИЦ ИЦиГ СО РАН, Новосибирск, Россия

Гриб Станислав Иванович, д.с.-х.н., академик НАН Беларуси, РУП НПЦ Беларуси по земледелию, Жодино, Беларусь

Кашеваров Николай Иванович, д.с.-х.н., академик РАН, ФГБУН СФНЦА РАН, Новосибирск, Россия

Косолапов Владимир Михайлович, д.с.-Х.н., академик РАН, Федеральный научный центр кормопроизводства и агроэкологии имени В.Р. Вильямса, Москва, Россия

Рудой Евгений Владимирович, д.э.н., ФГБОУ ВО Новосибирский государственный аграрный университет, Новосибирск, Россия

Санамьян Марина Феликсовна, д.б.н., Национальный университет Узбекистана, Ташкент, Узбекистан

Сурин Николай Александрович, д.с.-х.н., академик РАН, Красноярский НИИСХ ФИЦ КНЦ СО РАН, Красноярск, Россия

Хлесткина Елена Константиновна, д.б.н., ФИЦ «Всероссийский институт генетических ресурсов растений им. Н.И. Вавилова», Санкт-Петербург, Россия

Шаманин Владимир Петрович, д.с.-Х.н., ФГБОУ ВО «Омский государственный аграрный университет имени П.А. Столыпина», Омск, Россия

Шумный Владимир Константинович, д.б.н., академик РАН, ФИЦ ИЦиГ СО РАН, Новосибирск, Россия

Börner Andreas, $\mathrm{PhD}$, Институт генетики растений и исследований сельскохозяйственных культур им. Лейбница, Гатерслебен, Германия 


\section{Организационный комитет}

Лихенко Иван Евгеньевич, д.с.-Х.н., зам. директора по научной работе, ФИЦ ИЦиГ СО РАН, Новосибирск, Россия - председатель оргкомитета

Артёмова Галина Васильевна, к.б.н., зам. руководителя по научной работе,

СибНИИРС - филиал ИЦиГ СО РАН, Новосибирск, Россия

Орлова Елена Арнольдовна, к.с.-х.н., в.н.с., СибНИИРС - филиал ИЦиГ СО

РАН, Новосибирск, Россия - ученый секретарь конференции

Зубова Светлана Васильевна, зав. сектором, ФИЦ ИЦиГ СО РАН, Новоси-

бирск, Россия

Токпанов Ерлан Аскарович, нач. отдела, ФИЦ ИЦиГ СО РАН, Новосибирск, России

Карамышева Татьяна Витальевна, к.б.н., с.н.с., ФИЦ ИЦиГ СО РАН, Новосибирск, Россия

Зыбченко Дмитрий Петрович, к.с.-х.н., зам. руководителя по производству, СибНИИРС - филиал ИЦиГ СО РАН, Новосибирск, Россия

Логунов Алексей Юрьевич, зам. руководителя по инфраструктуре, СибНИИРС - филиал ИЦиГ СО РАН, Новосибирск, Россия

Агеева Елена Васильевна, к.с.-х.н., научный сотрудник, СибНИИРС филиал ИЦиГ СО РАН, Новосибирск, Россия

Бехтольд Нина Павловна, к.с.-х.н., научный сотрудник, СибНИИРС филиал ИЦиГ СО РАН, Новосибирск, Россия

Капко Татьяна Николаевна, мл. научный сотрудник, СибНИИРС - филиал ИЦиГ СО РАН, Новосибирск, Россия

Чалкова Татьяна Федоровна, начальник отдела, ФИЦ ИЦиГ СО РАН, Новосибирск, Россия

Елисеева Лариса Борисовна, специалист, ФИЦ ИЦиГ СО РАН, Новосибирск, Россия

Морковина Алина Владимировна, программист, ФИЦ ИЦиГ СО РАН, Новосибирск, Россия 


\section{Спонсоры}

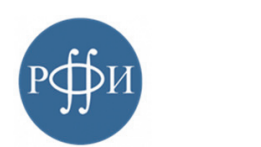

QVADROS \& Bio

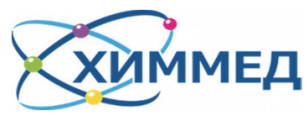

eppendorf

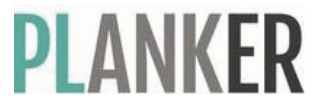

Әинтерлабсервис
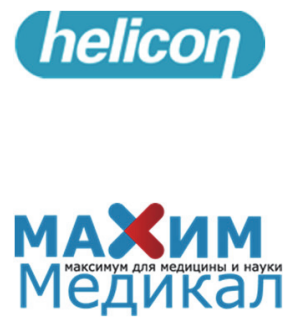

V Международная конференция

«Генофонд и селекция растений» поддержана

Российским фондом фундаментальных исследований, грант № 20-016-20006

\section{ООО «КВАДРОС-БИО»}

127287, Москва,

Петровско-Разумовский проезд, д. 29, стр. 4

Тел.: +7(495) 9818 035; Сайт: www.qvadrosbio.ru

ООО «ТД «ХИММЕД»

115230, Москва, Каширское шоссе, д. 9, к. 3

Тел.: +7(499) 682 6555; e-mail: bio@chimmed.ru 630090, Новосибирск, просп. Академика Лаврентьева, 6/1. Тел.: +7(383) 335 6108, e-mail: sibir@chimmed.ru Сайт: www.chimmed.ru

\section{ООО «ВИНТЕРШТАЙГЕР»}

117218, Москва, ул. Кржижановского, д. 14, корп. 3

Тел.: +7(495) 645 8491, доб. 252,

e-mail: petr.elizarov@wintersteiger.ru

Сайт: www.wintersteiger.ru/seedmech

ООО «ЭППЕНДОРФ РАША»

Сибирь и Дальний Восток: +7 9256259833

Москва: +7 4957435123

e-mail: zonov.ev@eppendorf.ru Сайт: www.eppendorf.ru

\section{PLANKER}

350063, Краснодар, ул. Комсомольская, 15, оф. 340

Тел.: +7 8612059010

e-mail: info@planker.ru Сайт: www.planker.ru

\section{ООО «ИНТЕРЛАБСЕРВИС»}

115035 Москва, ул. Садовническая д. 20/13, стр.2 Тел.

$+7(495) 664-28-84$

Сайт: www.interlabservice.ru

\section{ООО «Хеликон»}

121374, Москва, Кутузовский пр-т, д. 88

Тел. 8(800)770-71-21, Сайт: www.helicon.ru

Сибирь: 630090, Новосибирск, ул. Инженерная 28

Тел. +7(383)207-84-85 e-mail: novosibirsk@helicon.ru

ООО «МАКСИМ МЕДИКАЛ»

143420, МО, п. Архангельское, д. 2Б, стр.3, к.4

Тел.: +7 (495) 3746280 (24/7)

www.maxmedikal.com www.kasp.ru

email:max@maxmedikal.com 


\section{Комплексная устойчивость образцов ячменя из Эфиопии к биотическим и абиотическим стрессорам}

Абдуллаев Р.А., к.б.н., н.с., Яковлева О.В., к.б.н., с.н.с., Косарева И.А., к.б.н., в.н.с., Коновалова Г.С., к.б.н., с.н.с., Радченко Е.Е., д.б.н., г.н.с. Федеральный исследовательский иентр Всероссийский институт генетических ресурсов растений им. Н.И. Вавилова, Санкт-Петербург, Россия. e-mail:abdullaev.1988@list.ru

В лабораторных и полевых опытах изучили устойчивость к ринхоспориозу, токсичным ионам алюминия и хлоридному засолению резистентных к мучнистой росе образиов ячменя из Эфиопии. Устойчивость к ринхоспориозу выявлена у 8 образиов. Нечувствительными к хлоридному засолению при двух конщентрациях соли (0,98 и 1,26\% NaCl) оказались 7 образцов, по устойчивости к токсичным ионам выделились две формы. Bыделены образиы, обладающие комплексной устойчивостью к мучнистой росе, ринхоспориозу, хлоридному засолению и токсичным ионам алюминия.

Ключевые слова: ячмень, устойчивость, мучнистая роса, ринхоспориоз, хлоридное засоление, токсичные ионы алюминия.

\section{Complex resistance of barley accessions from Ethiopia to biotic and abiotic stressors}

Abdullaev R.A., Yakovleva O.V., Kosareva I.A., Konovalova G.S., Radchenko E.E. Federal Research Center the N.I. Vavilov All-Russian Institute of Plant Genetic Resources, St. Petersburg, Russia e-mail: abdullaev.1988@list.ru

In laboratory and field experiments, the collection accessions of Ethiopian barley which are characterized by powdery mildew resistance were investigated for scald resistance and tolerance to chloride salinity and high content of toxic aluminum ions in the soil. Scald resistance was detected in eight accessions. Seven accessions turned out to be insensitive to chloride salinity at two salt concentrations, $0.98 \%$ and $1.26 \% \mathrm{NaCl}$; two forms stood out for resistance to toxic aluminum ions. The accessions possessing complex resistance to powdery mildew, scald, chloride salinity and toxic aluminum ions were identified.

Key words: barley, resistance, powdery mildew, scald, chloride salinity, toxic aluminum ions.

Ячмень (Hordeum vulgare L.) - одна из самых важных сельскохозяйственных культур в мире, урожай которой могут существенно снизить болезни, насекомые-вредители и эдафические стрессоры. Изучение генетиче- 
ских ресурсов растений с целью использования в селекции выделенных источников устойчивости к биотическим и абиотическим стрессорам - важное направление исследований.

Огромным разнообразием, многими ценными биологическими и агрономическими качествами, в том числе устойчивостью к ряду заболеваний характеризуются ячмени Эфиопии. В результате изучения 925 образцов ячменя из коллекции Всероссийского института генетических ресурсов растений имени Н.И. Вавилова (ВИР) к северо-западной популяции возбудителя мучнистой росы Blumeria graminis (DC.) Golovin ex Speer f. sp. hordei Marchal. выделили 27 устойчивых к B. graminis образцов, 47 форм были гетерогенны по изученному признаку. С помощью молекулярных маркеров выявили 15 образцов, несущих аллель mlol1, который обеспечивает длительную устойчивость к мучнистой росе большинства современных сортов ячменя [5].

Цель настоящих исследований - оценить устойчивость к ринхоспориозу (возбудитель - Rhynchosporium secalis (Oudem.) J.J. Davis), а также к хлоридному засолению и токсичным ионам алюминия образцов ячменя из Эфиопии, которые в наших экспериментах характеризовались резистентностью к мучнистой росе.

В лабораторных и полевых экспериментах на искусственном инфекционном фоне исследовали устойчивость 33 образцов ячменя к R. secalis. Растения инокулировали изолятами патогена, выделенными из северо-западной (Ленинградская область) популяции гриба. Устойчивость растений оценивали с помощью балловых шкал. Поражение до 2 баллов соответствует реакции устойчивости, 3-5 - реакции восприимчивости [2].

При изучении солеустойчивости 39 образцов ячменя использовали рулонный метод оценки [3], основанный на учете торможения роста корней в условиях солевого $(\mathrm{NaCl})$ стресса в сравнении с контрольными условиями, без засоления. Использовали два фона засоления - 0,7 и 0,9 мПа осмотического давления (соответственно 0,98 и 1,26 \% NaCl). По степени снижения среднего значения длины корешков образцы разделили на три группы: устойчивые, среднеустойчивые и чувствительные [1]. В первую группу вошли образцы, у которых длина корешков в растворе соли 0,9 мПа осмотического давления составляла $>60 \%$ по отношению к контролю, а в растворе 0,7 мПа -> 70 \%. Во вторую группу отнесли образцы с длиной корешков 40$60 \%$ в растворе соли 0,9 мПа, а при засолении 0,7 мПа осмотического давления $-50-70 \%$.

Диагностику алюмочувствительности 43 образцов H. vulgare проводили на ранних этапах развития растений с использованием корневого теста [4]. Длину зародышевых корней семидневных проростков, выращенных в растворе с содержанием 185 мкМ ионов алюминия $(\mathrm{pH}=4,0)$, соотносили с длиной зародышевых корней растений (определяли индекс длины корня - 
ИДК), выращенных в растворе без добавления солей алюминия $(\mathrm{pH}=6,5)$. Использовали также дополнительный тестовый признак - индекс длины ростка. Длину ростка и зародышевого корня измеряли одновременно. По степени устойчивости ячмени распределили на 5 групп.

Результаты опытов продемонстрировала высокую частоту резистентных к ринхоспориозу форм среди ячменей из Эфиопии. Устойчивостью к $R$. secalis обладали 8 образцов (к-8547, к-20029, к-23065, к-23450, к-25008, к27212, к-27670, к-29720), поражение которых составило 1-2 балла.

Нечувствительными к хлоридному засолению при 0,9 мПа осмотического давления оказались 15 изученных форм, 22 образца проявили себя как среднеустойчивые. В растворе соли с давлением 0,7 мПа в группу устойчивых вошли 8 изученных форм, 28 образцов были среднеустойчивы. Образцы к-17554, к-19975, к-20029, к-20048, к-22752, к-23450, к-25009 устойчивы при двух фонах засоления.

По показателю «индекс длины корня» наиболее устойчивы к токсичным ионам алюминия образцы к-8552 (ИДК $=0,82)$ и к-22933 (ИДК $=0,88)$. Подавляющее большинство изученных форм, отнесено к среднеустойчивой и устойчивой группам. По индексу длины ростка все образцы распределились в высоко устойчивую и устойчивую группы.

Таблица - Образцы ячменя из Эфиопии с комплексной устойчивостью к болезням и неблагоприятным эдафическим факторам

\begin{tabular}{|c|c|c|c|c|c|c|}
\hline \multirow{3}{*}{$\begin{array}{l}\text { № по } \\
\text { ката- } \\
\text { логу } \\
\text { ВИР }\end{array}$} & \multirow{3}{*}{ Образец } & \multicolumn{5}{|c|}{ Устойчивость к } \\
\hline & & \multirow[t]{2}{*}{$\begin{array}{l}\text { R. secalis, } \\
\text { балл }\end{array}$} & \multicolumn{2}{|c|}{$\begin{array}{c}\mathrm{NaCl} \text { (длина ко- } \\
\text { решка в сравнении } \\
\text { с контролем), \% }\end{array}$} & \multicolumn{2}{|c|}{$\begin{array}{c}\mathrm{Al}^{3+} \text { (индекс } \\
\text { длины) }\end{array}$} \\
\hline & & & 0,7 мПа & 0,9 мПа & ростка & корня \\
\hline 23450 & H.2866 Coll.Halle EP80 & 1 & 85 & 62 & 0,92 & 0,41 \\
\hline 27670 & AHOR 416/67 & 2 & 67 & 44 & 0,89 & 0,67 \\
\hline 29720 & Ethiopia AB.2193 & 1 & 69 & 62 & 0,87 & 0,56 \\
\hline \multicolumn{2}{|c|}{ Cambrinus (воспр. контроль) } & 4 & - & - & - & - \\
\hline \multicolumn{2}{|c|}{ Одесский 70 (уст. контроль) } & - & 66,1 & 49,5 & - & - \\
\hline \multicolumn{2}{|c|}{ Полярный (уст. контроль) } & - & - & - & 0,98 & 0,91 \\
\hline
\end{tabular}

В таблице представлены образцы ячменя из Эфиопии с комплексной устойчивостью к болезням и абиотическим стрессорам. Все изученные формы устойчивы к мучнистой росе. Образцы к-23450 и к-29720 защищены геном устойчивости к грибу mlo1 1 [5], образец к-27670 имеет другой эффективный ген (гены) устойчивости к $B$. graminis. Выявленные нами формы представляют большой интерес для селекции в различных зонах России.

Благодарности: Исследование выполнено при поддержке РФФИ (грант № 18-016-00075) и бюджетного проекта № 0662-2019-0006. 


\section{Список литературы}

1. Давыдова Г.В., Коваль В.С., Лукьянова М.В. Ячмень. Характеристика селекционных и местных сортов на солеустойчивость. Каталог мировой коллекции ВИР. - Вып. 605. - Л: ВИР. - 1991. - 34 с.

2. Коновалова Г.С. Ринхоспориоз. В кн.: Изучение генетических ресурсов зерновых культур по устойчивости к вредным организмам. Методическое пособие. М.: Россельхозакадемия. - 2008. - С. 129-135.

3. Удовенко Г.В., Волкова А.М. Определение в раннем возрасте солеустойчивости зерновых злаков по комплексу ростовых параметров. Методические указания. - С.-Петербург: ВИР. - 1993. - 15 с.

4. Яковлева О.В., Ковалева О.Н. Ячмень. Характеристика образцов ячменя по устойчивости к токсичным ионам алюминия $\left(\mathrm{H}^{+}+\mathrm{Al}^{3+}\right)$. Каталог мировой коллекции ВИР. - Вып. 824. - С.-Петербург: ВИР. - 2015. - 24 с.

5. Abdullaev R.A., Lebedeva T.V., Alpatyeva N.V., Yakovleva O.V., Kovaleva O.V, Radchenko E.E. et al. Genetic diversity of barley accessions from Ethiopia for powdery mildew resistance // Russian Agricultural Sciences. - 2019. - V. 45. - №3. - P. 232-235. DOI: 10.3103/S1068367419030029.

DOI 10.18699/GPB2020-02

\section{Оценка образцов свеклы на хладостойкость}

Абекова А.М. * к.с.-х.н., с.н.с. аналитической лаборатории группь биотехнологии и молекулярно-биологического анализа; Ержебаева Р.С. к.б.н., руководитель аналитической лаборатории группь биотехнологии и молекулярнобиологического анализа; Берсимбаева Г.Х. ст. лаборант аналитической лаборатории группь биотехнологии и молекулярно-биологического анализа.

Казахский научно-исследовательский институт земледелия и растениеводства, п. Алмалььбак, Казахстан.

*e-mail:aabekova@mail.ru

Изучена холодостойкость 43 гибридов и линий сахарной свекльв в лабораторных условиях с использованием оценки прорастания семян при пониженных температурах и культуры іп vitro. По результатам оченки прорастания при температуре $+4^{\circ} \mathrm{C}$ отобраны холодостойкие образцы с наиболее высокой всхожестью семян (6,5-21,5\%), при контроле 46,6$100 \%$. На основе оиенки культуры іn vitro при низких температурах $+4^{\circ} \mathrm{C}$ отобраны 5 образцов, показавиих высокий уровень формирования пазушных почек (3-4 шт.). Вылеленные образиы могут быть использованы для селекцчии на холодостойкость.

Ключевые слова: Сахарная свекла, холодостойкость, прорастание, культура in vitro, отбор. 


\section{Assessment of sugar beet samples for gold resistance}

Abekova A.M. * Candidate of Agricultural Sciences, senior researcher, analytical laboratory of biotechnology and molecular biological analysis group; Yerzhebayeva R.S. Candidate of Biological Sciences, head of the analytical laboratory of the biotechnology and molecular biological analysis group; Bersimbaeva G.Kh. senior laboratory assistant, analytical laboratory of biotechnology and molecular biological analysis group.

Kazakh Research Institute of Agriculture and Plant Crop, Almalybak, Kazakhstan. *e-mail: aabekova@mail.ru

The cold resistance of 43 hybrids and sugar beet lines was studied under laboratory conditions using the evaluation of seed germination at low temperatures and the in vitro culture. According to the results of germination assessment at a temperature of $+4^{\circ} \mathrm{C}$, cold-resistant samples with the highest seed germination (6.5-21.5\%) were selected, with a control of 46.6-100\%. Based on an in vitro culture assessment at low temperatures of $+4^{\circ} \mathrm{C}, 5$ samples that showed a high level of axillary bud formation (3-4 buds) were selected. Selected samples can be used for selection for cold resistance.

Key words: sugar beet, cold hardiness, germination, in vitro culture, selection.

Сахарная свекла в Казахстане возделывается на юге и юго-востоке республики. Доля сахара, произведенного из отечественной сахарной свеклы, в Казахстане составляет всего 3 \%, остальные 97 \% - приходятся на импорт. При этом больше половины объема - 55 \% сахара - производится из импортного тростника, завозимого из Бразилии и Кубы [1]. В Государственной программе развития агропромышленного комплекса РК для обеспечения внутренних потребностей к 2121 году планируется увеличение объема производства сахарной свеклы до 1120 тыс. тонн [2]. Ставятся задачи по продвижению сахарной свеклы в северные регионы страны. В целом ряде регионов Казахстана весной и осенью складываются неблагоприятные погодные условия для сахарной свеклы. Факторами, влияющими на урожайность и сахаристость сахарной свеклы, являются длина вегетационного периода, способность семян прорастать при пониженных положительных температурах и переносимость растениями возврата холодов весной, а также наступления ранних осенних заморозков. В связи с выше указанным, актуальным является скрининг имеющейся коллекции сахарной свеклы на холодостойкость.

Целью наших исследований является изучение холодостойкости гибридов и линий сахарной свеклы в лабораторных условиях с использованием оценки прорастания семян при пониженных температурах и культуры in vitro.

Материалом для исследований служила коллекция из 43 гибридов и линий сахарной свеклы.

Методы. Учет устойчивости генотипов сахарной свеклы к холодовому 
стрессу вели по методике, предложенной Роик Н.В. и др. [3] с использованием физиологического (лабораторный) метода проращивания семян при низких температурах. Действие низкотемпературного стресса на семена моделировали в климатической камере BINDER KBWF 720 при температуре $+4{ }^{\circ} \mathrm{C}$ в течение 45-48 суток. Семена по 25 штук в восьмикратной повторности проращивали в стеклянных чашках Петри на бумажном ложе, увлажненном 30 мл дистиллированной воды. Контролем служили семена, пророщенные при температуре $+24{ }^{\circ} \mathrm{C}$ в термостате. Семена по 25 штук в восьмикратной повторности проращивали в стеклянных чашках Петри на бумажном ложе, увлажненном 30 мл дистиллированной воды.

В качестве эксплантов для оценки холодостойкости методом культуры in vitro были использованы черешки 15-20 дневных проростков гибридов сахарной свеклы. Стерилизацию проростков сахарной свеклы проводили $20 \%$ раствором $\mathrm{NaOCl}$ с каплей Твин-80 в течение 8-10 минут на шейкере, с последующей промывкой стерильной дистиллированной водой (трижды). Культивирование пробирочной культуры контрольного варианта проводили при температуре $+24^{\circ} \mathrm{C}$, освещении 3000-4000 ЛК и 16-часовом фотопериоде. Опытные экспланты культивировали в условиях климатической камеры при низких температурах $+4^{\circ} \mathrm{C}$ и освещении 3000-4000 ЛК. По истечении 2 месяцев экспланты переносили в светокультуральную комнату с температурой $+24^{\circ} \mathrm{C}$. Признак устойчивости определяли по восстановлению ростовых процессов и формированию пазушных почек. За контроль были приняты показатели образования пазушных почек без охлаждения.

В качестве питательной среды была использована стандартная питательная среда Murashige \& Skoog (1962) [4] с сочетанием фитогормонов: 0,5 мг/л БАП и добавлением 2,5 мг/л аскорбиновой кислоты, 30 г/л сахарозы и 7 г/л агара, $\mathrm{pH}-5,6-5,8$.

Результаты. При проращивании 43 коллекционных образцов сахарной свеклы на контрольном варианте была установлена лабораторная всхожесть, которая составила 46,6-100%. Наблюдение за динамикой появления всходов при низких положительных температурах показали, что в условиях проращивания семян при $+4^{\circ} \mathrm{C}$ прорастание происходило на 19-20 день проращивания во всех коллекционных образцах, но с разной интенсивностью: от $0,25 \%$ до 3,8 \%. У большинства образцов всхожесть оставалась на низком уровне - до $2 \%$ (рис. 1 ). 


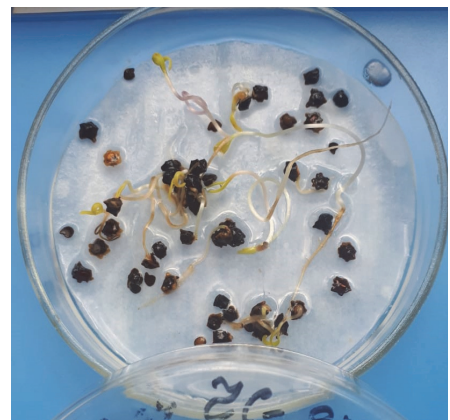

a

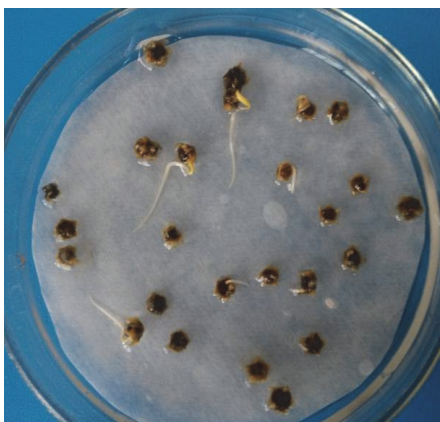

б

Рис. 1. Чашки Петри с семенами сахарной свеклы, после испытания в течение 30 дней при низких температурах $+4^{\circ} \mathrm{C}$ : a - семена ЧС97; б - семена РМС 134

На основе проращивания при низких температурах отобраны холодостойкие образцы с наиболее высокой всхожестью семян: К2023 (Киргизская $069)-21,5 \%$, К-1877 (Бийская 32) - $18 \%$, ЧС 97 - 12,5 \%, РМС 133 - 8,25 $\%$, К-2205 (Рамонская односемянная 32) - 7,5 \%, Успех - 7,75 \%, ЧС 1611 $6,5 \%$.

Все образцы (21 образец), показавшие способность прорастать при низких температурах были оценены на холодостойкость с использованием культуры in vitro (таблица).

Таблица - Результаты анализа образцов сахарной свеклы при низких температурах в условиях in vitro

\begin{tabular}{|l|c|c|c|}
\hline $\begin{array}{c}\text { Наименование } \\
\text { образца }\end{array}$ & $\begin{array}{c}\text { Образование } \\
\text { пазушных почек по- } \\
\text { сле 2 месяцев культи- } \\
\text { вирования при }+4^{0} \mathrm{C}\end{array}$ & $\begin{array}{c}\text { Восстановление } \\
\text { ростовых про- } \\
\text { цессов при } \\
+24^{\circ} \mathrm{C}, \text { шт. }\end{array}$ & $\begin{array}{c}\text { Контроль, обра- } \\
\text { зование пазуш- } \\
\text { ных почек при } \\
+24^{\circ} \mathrm{C}, \text { шт. }\end{array}$ \\
\hline Киргизская 069 & 2 & 3 & 4 \\
\hline Смена & 0,70 & 3,3 & 3,4 \\
\hline $\begin{array}{l}\text { Рамонская одно- } \\
\text { семянная 32 }\end{array}$ & 0,75 & 2,0 & 2,9 \\
\hline Бийская 32 & 1,8 & 3,0 & 4,0 \\
\hline РМС 60 & 0,2 & 0,6 & 3,2 \\
\hline РМС 133 & 1,5 & 1,2 & 3,8 \\
\hline РМС 134 & 0,6 & 2,0 & 5,2 \\
\hline РМС 136 & 1,4 & 2,4 & 3,3 \\
\hline МС2113 & 1,0 & 2,5 & 3,0 \\
\hline Руслан & 1,2 & 3,0 & 2,2 \\
\hline Кубанский & 1,0 & 3,0 & 3,7 \\
МС 95 & 1,5 & 2,9 & 3,7 \\
\hline Успех & 1,2 & & \\
\hline
\end{tabular}




\begin{tabular}{|l|c|c|c|}
\hline \multicolumn{1}{|c|}{1} & 2 & 3 & 4 \\
\hline UC 1631 & 1,3 & 2,0 & 4,7 \\
\hline 4C 1611 & 1,3 & 3,2 & 3,2 \\
\hline 4C 97 & 1,6 & 3,4 & 4,3 \\
\hline 2249 & 1,0 & 3,1 & 4,1 \\
\hline 2198 & 1,2 & 2,6 & 2,3 \\
\hline 2210 & 0,7 & 1,8 & 5,3 \\
\hline 2247 & 1,5 & 3,0 & 2,8 \\
\hline 2251 & 0,8 & 2,2 & 3,0 \\
\hline 2289 & 1,5 & 3,1 & 3,0 \\
\hline
\end{tabular}

Отобраны и выделены 5 образцов (Киргизская - 3,3 шт., ЧС-97 - 3,4 шт., РМС-60 - 3,2 шт., ЧС1611 - 3,2 шт., 2249 - 3,1 шт.), показавших высокий уровень формирования пазушных почек (3-4 шт.) на черешках после длительного культивирования ( 2 месяца) in vitro при низких температурах $+4^{\circ} \mathrm{C}$, при контроле 5-6 пазушных почек (рис. 2).

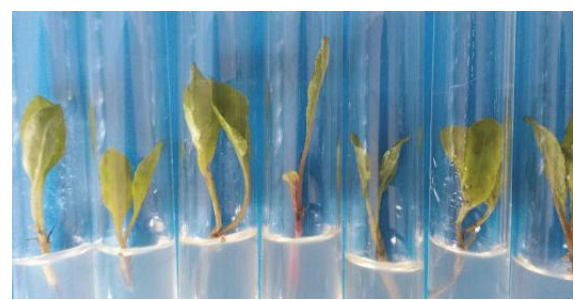

a

Рис. 2. Оценка холодостойкости сахарной свеклы с использованием культуры in vitro на питательной среде при низких температурах через 20 дней культивирования: a черешки гибрида РМС 60 на контрольной среде; б - черешки гибрида РМС 60 через 20 дней при $+4^{\circ} \mathrm{C}$.

Выделенные МС линии рекомендуются для селекции на холодостойкость.

Благодарности: Работа выполнена при финансовой поддержке Министерства образования и науки Республики Казахстан в рамках программы грантового финансирования на 2018-2020 гг. (грант в рамках бюджетной программы 217 «Развитие науки», подпрограмме 102 «Грантовое финансирование научных исследований», по приоритету «Устойчивое развитие агропромышленного комплекса и безопасность сельскохозяйственной продукции», теме: ИРН АР05131605 «Создание холодостойких и нецветушных образцов сахарной свеклы биотехнологическими и селекционными методами для северных регионов Казахстана). 


\section{Список литературы}

1. Выгодно ли выращивать сахарную свеклу в Казахстане / официальный сайт 2016 / https://www.inform.kz/ru/vygodno-li-vyraschivat-saharnuyu-sveklu-vkazahstane_a2982838.

2. Государственная программа развития агропромышленного комплекса РК на 2017-2021 годы http://mgov.kz/ru/aza-stan-respublikasyny-a-k-damytudy-2017-2021zhyldar-a-arnal-an-memlekettik-ba-darlamasy

3. Роик Н.В., Бех Н.С., Коцар М.А., Бойко И.И. Оценка и отбор холодостойких форм сахарной свеклы с использованием культуры in vitro // Сахарная свекла. 2016. - № 9. - C. 11-13.

4. Murashiga, T., Skoog F. A Revised medium for Rapid growth and Bio Assays with tobacco culture, Physiol. Plantarum, 1962, vol. 15, pp. 473-497 DOI 10.1111/j.13993054.1962.tb08052.x

\section{Характеристика синтетических и диких форм пшеницы в яровом и озимом варианте: 1. Морфология (УПОВ), NDVI, урожайность}

Абугалиева А.И., д.б.н., профессор; Кожахметов К.К., д.б.н.

Казахский научно-исследовательский институт земледелия и растениеводства, Алмальгбк, Казахстан.

e-mail:kiz_abugalieva@mail.ru

Сформирована коллекция по признаку озимость/яровость, охватывающсая формы, как альтернативные, так и промежуточные (факультативные) по объектам: дикие сородичи; линии пиенично-чужеродных гибридов пшеницы; сорта (T. аеstivum). Сравнение по формуле UPOV одного и того же генотипа в яровой и озимой репродукции позволило констатировать их неоднозначность. Для большинства генотипов усиление степени выраженности морфологических признаков отмечено в озимой репродукции. Генотипь выделялись по NDVI и в яровом и озимом варианте посева: Жетысу $х$ T. timopheevii; (Безостая $1 \times$ T. militinae) $x$ T. militinae-9 и (Безостая $1 \times T$. militinae) х T. militinae-6 как материал для генетического изучения системь Vrn генов. Максимальное значение NDVI из сородичей и видов пшеницьь отмеченое для T. timopheеviі в озимом варианте, T. militinae и T. kiharae в яровом варианте посева. Прогностическое преобладание озимого варианта над яровым по урожайности подтверждается на уровне существвенной разниць для ряда генотипов от 9,7 ия/га до 27,0 й/га. Дикие сородичи характеризутся синхронностью урожайности и элементов продуктивности в обоих вариантах озимом и яровом. 
Ключевые слова: шеница, виды, пшенично-чужеродные формы, факультативные генотипы, NDVI, урожайность, идентификация УПОВ.

\section{Characteristics of synthetic and wild forms of wheat in spring and winter form: 1. Morphology (UPOV), NDVI, productivity}

Abugaliyeva A.I., Kozhakhmetov K.K.

Kazakh Scientific Research Institute of Agriculture and Plant Growing, Almalybak, Kazakhstan.

e-mail:kiz_abugalieva@mail.ru,kenebai.kozhakhmetov@mail.ru

The facultative wheat collection has been formed on the basis of objects: wild relatives; lines of wheat-alien wheat hybrids, triticale and varieties (T.aestivum). A comparison using the UPOV formula of the same genotype in spring and winter reproductions should confirm their ambiguity. For most genotypes, an increase in the severity of morphological characters occurs in winter reproduction. In spring and winter sowing, NDVI numbers of Zhetysu $x$ T. timopheevii were allocated according to NDVI; (Bezostaya $1 x$ T. militinae) $x$ T. militinae-9 and (Bezostaya $1 \times$ T. militinae) $x$ T. militinae-6 as material for the genetic study of the Vrn gene system. The maximum NDVI value from wheat species differed for T. timopheevii in the winter reproduction and T. militinae and T. kiharae in the spring variant of sowing.

Key words: wheat-egilops and wheat-wild forms, wheat species, facultative, NDVI, productivity, UPOV identification.

Широкая адаптация пшеницы в мире основана на значительной аллельной вариабельности 3-х групп генов требовательности к яровизации $(V r n)$, отзывчивости на фотопериод $(P p d)$ и собственно скороспелости (Eps) [цит., 1]. Наиболее важные из генов адаптивности - это гены отзывчивости на яровизацию ( $V r n$-гены), доминантные аллели которых определяют не только тип развития (яровость), но и скороспелость. Генотипы ряда местных сортов яровой мягкой пшеницы Казахстана идентифицированы по системе $V r n$-генов [2, 3], в том числе и с использованием анеуплоидного анализа [1]. Природно-климатические условия Юга - Востока Казахстана дают возможность культивирования пшеницы различного типа развития (яровые, факультативные, озимые).

М.А. Есимбековой [1] определены группы спелости Vrn 1-3 генотипов на Юго-востоке Казахстана при сопоставлении с местными стандартами: ранняя - Vrn 1133, St - Казахстанская 4; средне-ранняя - Vrn 11, 33, 1133 (фотонейтральный генофон), Vrn 1122 (независимо от генофона), St Казахстанская 3; средняя - Vrn 11, 33, 2233 (фотонейтральный генофон), Vrn 2233, 1133 (фоточувствительный генофон), St - Казахстанская 10; поздняя $V r n 22$ (фотонейтральный генофон), Vrn 11, 33 (фоточувствительный 
генофон); факультативная - Vrn 22 генотип (фоточувствительный генофон).

С продвижением озимой пшеницы (как более продуктивной) на Север РК важны новые резервы и источники адаптивности и урожайности, в т.ч. по сочетанию типа развития, фоточувствительности ( $V r n, P p d)$.

С этой точки зрения, дикие сородичи представляют собой модельный объект по изучению генетической структуры признака озимость/яровость и перекрывают размах изменчивости по этому признаку для условий Казахстана.

Цель исследований: Изучение основ продуктивности и адаптивности синтетической пшеницы в зависимости от образа жизни (озимость/яровость) на фоне диких сородичей.

Материалы и методы. Объектом исследований выделены: 1) линии пшенично-чужеродных гибридов как переходной «мост» и отдельный объект селекции; 2) виды пшеницы T. militinae и T. timopheevi, T. kiharae; 3) сорта-стандарты пшеницы (T. aestivum); 4) представители Triticosecale в яровом и озимом варианте одновременно.

Закладка опытов, посев, фенонаблюдения, учеты, ведение отборов и браковки, анализ продуктивности проводились согласно «Методики государственного сортоиспытания сельскохозяйственных культур» $(1985,2002)$ в 2-х полевых повторениях на делянках $5 \mathrm{~m}^{2}$.

Фенотипирование проведено NDVI-измерением светоотражения вегетативной массой в красной и ближней инфракрасной области спектра на приборе Green Seeker [4];

- идентификация новых форм по морфологическим признакам по критериям степени их выраженности относительно сортов-анализаторов международной системы UPOV по 26 признакам морфологии.

Результаты и обсуждение. Сформирована коллекция образцов, представляющих собой формы и озимого, и ярового типа среди сортов, синтетиков озимых (13 из 48), яровых (9 из 43), диких сородичей - виды пшениц и эгилопсы (7 из 18), тритикале (4 из 10).

В литературе отмечена обширная информация по сортам-факультативам мягкой пшеницы, существует глобальная программа СИММИТ. Однако такой объект как синтетические и интрогрессивные формы, дикие сородичи является оригинальным и недостаточно изученным.

Интрогрессивные формы пшеницы были неразличимы по 8 признакам. Оригинальными (только в единственном числе) выявлены генотипы: (Безостая 1 х T. militinae) х T. militinae-9 по признаку: растение: встречаемость с наклонным флаговым степень выраженность - 7 баллов; генотип Эритроспермум 350 х T. militinae по показателю: ости: антоциановая окраска кончиков со степенью выраженности - 5 баллов; для генотипа (Безостая 1 х $T$. militinae) х T. militinae-6 по показателю: зерновка- окрашивание фенолом со степенью выраженности - 1 балл. 
Сравнение по формуле UPOV одного и того же генотипа в яровой и озимой репродукции позволило констатировать их неоднозначность по 5-17 признакам системы УПОВ для тритикале Т-989-1 и (Безостая 1 х T. militinae) х T. militinae-9 соответственно. Судя по данным результатам один и тот же генотип разного образа жизни по степени выраженности морфологических признаков может быть представлен как отличающийся генотип.

Для большинства генотипов усиление степени выраженности морфологических признаков отмечено в озимой репродукции по признакам: «Растение: $(+)\left(^{*}\right)$ встречаемость с наклонным флаговым листом», «Флаговый лист: (*) восковой налет на влагалище», «Флаговый лист: (*) восковой налет на листовой пластинке (нижняя сторона)», «Соломина $(*)$ восковой налет на верхнем междоузлии», «Колос: форма $(+)(*) »$, «Колос: $(*)$ плотность», «Нижняя (+) колосковая чешуя: форма плеча (в средней части колоса)» и

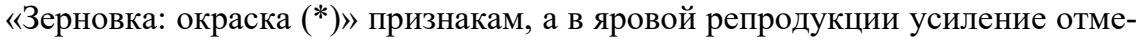
чено по признакам «Время колошения: (*) (первый колосок виден у 50 \% растений)» и «Колос $(*)$ восковой налет».

Дальнейший генетический анализ одного и того же образца в двух вариантах (озимый и яровой) позволяет дифференцировать генотипическую и фенотипическую составляющую морфологических признаков.

Впервые в урожае 2016 г. нами [5] в яровом варианте выявлено преобладание видов T. militinae и T. kiharae по максимальным значениям NDVI в большинстве замеров и фаз развития растений. Однако само значение NDVI значительно ниже, чем в озимом варианте, но более стабильно в процессе динамики, например для T. militinae, T. dicocoides, $T$. polonicum, T. turgidum. Виды T. timopheevii, T. turgidum, T. kiharae, как видно из рисунка и в яровом, и в озимом варианте отличались плавной NDVI кривой с наименьшей реакцией на стрессовые условия. Яровые дикие формы характеризуются более низким уровнем NDVI в сравнении с озимыми на примере различных видов пшениц.

Максимум NDVI в процессе вегетации отмечен для ярового варианта у видов $T$. dicoccum, $T$. polonicum, $T$. kiharae, $T$. petropavlovskyi в фазу колошения.

Таким образом, материал представляет широкий спектр изменчивости по озимости-яровости различной степени за пределами классификации казахстанских сортов [5]. В зависимости от генотипа образа жизни различно влияет на NDVI-кривую интрогрессивных форм на яровом и озимом посеве F/S (рис.1). 


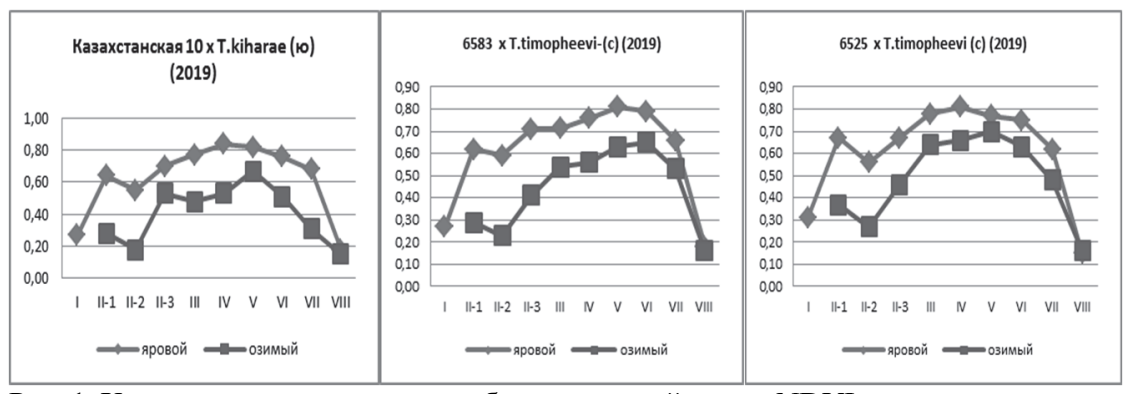

Рис. 1. Характеристика накопления биологической массы NDVI в процессе вегетации факультативных (F/W и F/S) синтетиков пшеницы и тритикале в озимом и яровом посеве 2019 г.

Одноименные образцы факультативных синтетиков пшеницы, виды пшеницы и тритикале оценены по продуктивности в озимом и яровом варианте (табл. 1). Уровень урожайности варьировал от 45 ц/га (ПЭГ 347 х T. kiharae) х Жадыра) F/W до 64 ц/га для генотипа 6631 х T. militinae в яровом посеве и от 46,8 ц/га Казахстанская 10 х T. kiharae из серии F/S до 75,0 ц/га для генотипа (Эритроспермум 350 х T. kiharae) х Эритроспермум 350 (F/W) в озимом посеве.

Таблица 1 - Характеристика урожайности факультативных синтетиков (2019 г.) по $5 \mathrm{~m}^{2}$

\begin{tabular}{|c|c|c|c|c|}
\hline \multirow{2}{*}{ Наименование образцов (F/S) } & \multicolumn{2}{|c|}{ Урожайность, ц/га } & \multicolumn{2}{|c|}{ Отклонение } \\
\hline & яровой & озимый & 2018 & 2019 \\
\hline 1 & & & 4 & 5 \\
\hline Казахстанская 10 стандарт & $42,5 \pm 1,5$ & $42,5 \pm 1,5$ & 0 & 0 \\
\hline Казахстанская 10 х T. kiharae & $43,0 \pm 1,8$ & $47,0 \pm 1,9$ & 0,2 & 4,0 \\
\hline $6525 \times$ T. timopheevii (c) & $40,0 \pm 1,4$ & $57,1 \pm 2,4$ & 9,7 & 9,7 \\
\hline Казахстанская 10 x T. dicoccum & $50,3 \pm 2,0$ & $53,3 \pm 2,1$ & 1,3 & 3,0 \\
\hline Казахстанская 25 x T. timopheevii & $47,5 \pm 1,9$ & $50,4 \pm 2,0$ & 3,3 & 2,9 \\
\hline $6628 \times$ T. timopheevii & $49,2 \pm 2,0$ & $51,2 \pm 2,0$ & 0,7 & 2,0 \\
\hline $6625 \times$ T. timopheevii- 3 & $47,5 \pm 1,9$ & $56,2 \pm 2,5$ & 1,2 & 8,7 \\
\hline $6631 \times$ T. militinae- 1 & $48,3 \pm 2,0$ & $53,3 \pm 2,1$ & 1,4 & 5,1 \\
\hline $6583 \times$ T. timopheevii & $47,2 \pm 1,7$ & $57,2 \pm 2,4$ & 9,6 & 10,0 \\
\hline \multicolumn{5}{|l|}{$\mathrm{F} / \mathrm{W}$} \\
\hline (Безостая 1 x Aegilops triaristata) x Карлыгаш & $35,0 \pm 1,5$ & $75,0 \pm 2,9$ & 11,7 & 40,0 \\
\hline Стекловидная 24 x T. timopheevii & $37,5 \pm 1,6$ & $72,2 \pm 3,0$ & 9,0 & 34,7 \\
\hline (Эритроспермум 350 x T.kiharae) x Эритроспермум 350 & $55,5 \pm 1,8$ & $52,0 \pm 2,5$ & 27,0 & 3,5 \\
\hline (Безостая 1 × T. militinae $)$ х T. militinae-6 & $40,0 \pm 1,6$ & $51,4 \pm 2,0$ & 6,6 & 11,4 \\
\hline (Безостая 1 × $T$. militinae $) \times$ T. militinae-9 & $40,0 \pm 1,7$ & $57,5 \pm 2,4$ & 18,2 & 17,5 \\
\hline Эритроспермум 350 × T. militinae & $50,0 \pm 1,9$ & $50,0 \pm 2,3$ & 7,6 & 0 \\
\hline (ПЭГ 347 х T. kiharae) х Жадыра & $25,0 \pm 1,4$ & $60,0 \pm 2,9$ & 17,8 & 35,0 \\
\hline Безостая 1 х Ae.cylindrica & $37,5 \pm 1,9$ & $52,0 \pm 2,5$ & 3,3 & 14,5 \\
\hline
\end{tabular}




\begin{tabular}{|c|c|c|c|c|}
\hline & 2 & 3 & 4 & 5 \\
\hline \multicolumn{5}{|c|}{ Тритикале } \\
\hline $409-1$ & $57,5 \pm 2,5$ & $62,6 \pm 3,2$ & 0,2 & 5,1 \\
\hline $989-1$ & $45,0 \pm 2,1$ & $70,0 \pm 3,4$ & 18,8 & 25,0 \\
\hline \multicolumn{5}{|c|}{ Дикари } \\
\hline T. timopheevii & $30,2 \pm 1,2$ & $31,2 \pm 1,3$ & 1,7 & 1,0 \\
\hline T. militinae & $12,4 \pm 1,0$ & $15,4 \pm 1,2$ & 0,2 & 3,0 \\
\hline T. dicoccoides & $23,7 \pm 1,7$ & $31,1 \pm 1,8$ & 0,6 & 7,4 \\
\hline T. kiharae & $15,6 \pm 1,1$ & $15,7 \pm 1,3$ & 0,6 & 0,1 \\
\hline T. polonicum & $30,2 \pm 1,8$ & $31,3 \pm 1,9$ & 1,4 & 1,1 \\
\hline T. dicoccum & $26,2 \pm 1,6$ & $36,7 \pm 2,0$ & 0,8 & 10,5 \\
\hline T. petropavlovsk & $20,4 \pm 1,4$ & $19,2 \pm 1,9$ & 0 & 1,2 \\
\hline
\end{tabular}

Прогностическое преобладание озимых форм по урожайности подтверждается на уровне существенной разницы для генотипов: $6525 \mathrm{x}$ T. timopheevii (c) - 9,7 ц/га; Эритроспермум 350 х T. militinae - 7,6 ц/га, (Безостая 1 х Ae. triaristata) х Карлыгаш - 11,7 ц/га; Стекловидная 24 х $T$. timopheevii - 9,0 ц/га; (Безостая 1 х T. militinae) x T. militinae-9 - 18,2 ц/га; (ПЭГ 347 х T. kiharae) х Жадыра - 17,8 ц/га и максимально для номера (Эритроспермум 350 х T. kiharae) х Эритроспермум $350-27$ ц/га.

Дикие сородичи характеризутся синхронностью урожайности и элементов продуктивности в обоих вариантах озимом и яровом (табл. 2). Для отдельных видов характерно усиление признаков в озимом посеве: высота растений для $T$. dicoccum; количество колосков для T. dicoccoides; а в яровом посеве отмечено увеличение числа зерен в колосе для T. petropavlovskyi, $T$. kiharae, T. dicoccoides. Данные факты требуют детализации для каждого вида в зависимости от условий репродукции.

Таблища 2 - Характеристика продуктивности диких форм пшеницы в яровом и озимом посеве

\begin{tabular}{|l|c|c|c|c|c|c|c|}
\hline $\begin{array}{c}\text { Наименова- } \\
\text { ние образцов }\end{array}$ & $\begin{array}{c}\text { Образ } \\
\text { жизни }\end{array}$ & $\begin{array}{c}\text { Высота } \\
\text { расте- } \\
\text { ний, см }\end{array}$ & $\begin{array}{c}\text { Длина } \\
\text { глав- } \\
\text { ного ко- } \\
\text { лоса, см }\end{array}$ & $\begin{array}{c}\text { Количе- } \\
\text { ство ко- } \\
\text { лосков, } \\
\text { шт. }\end{array}$ & $\begin{array}{c}\text { Число зе- } \\
\text { рен в глав- } \\
\text { ном ко- } \\
\text { лосе, шт. }\end{array}$ & $\begin{array}{c}\text { Масса } \\
\text { зерна с с } \\
\text { ния, г- }\end{array}$ & $\begin{array}{c}\text { Масса } \\
1000 \text { зе- } \\
\text { рен, г }\end{array}$ \\
\hline T. timopheevii & яровой & $110,2 \pm 8,1$ & $6,0 \pm 0,5$ & $16,2 \pm 1,0$ & $31,6 \pm 2,9$ & $4,8 \pm 0,4$ & $44,3 \pm 1,9$ \\
\hline T. timopheevii & озимый & $133,1 \pm 9,2$ & $7,1 \pm 0,5$ & $18,0 \pm 1,1$ & $32,2 \pm 3,2$ & $4,5 \pm 0,4$ & $39,2 \pm 2,0$ \\
\hline T. militinae & яровой & $111,1 \pm 8,2$ & $5,0 \pm 0,4$ & $18,0 \pm 1,1$ & $44,1 \pm 3,8$ & $4,7 \pm 0,4$ & $40,0 \pm 2,4$ \\
\hline T. militinae & озимый & $113,0 \pm 8,1$ & $5,0 \pm 0,4$ & $20,0 \pm 1,2$ & $38,4 \pm 3,5$ & $2,8 \pm 0,3$ & $41,7 \pm 2,5$ \\
\hline T. dicoccoides & яровой & $133,1 \pm 9,2$ & $14,3 \pm 0,9$ & $20,0 \pm 1,4$ & $57,2 \pm 4,8$ & $5,6 \pm 0,4$ & $50,0 \pm 2,8$ \\
\hline T. dicoccoides & озимый & $130,1 \pm 9,3$ & $14,0 \pm 1,0$ & $26,1 \pm 1,5$ & $42,2 \pm 3,9$ & $5,0 \pm 0,5$ & $36,4 \pm 3,0$ \\
\hline T. dicoccoides & озимый & $122,0 \pm 8,9$ & $15,1 \pm 1,0$ & $20,0 \pm 0,9$ & $40,1 \pm 3,7$ & $4,7 \pm 0,4$ & $35,0 \pm 3,0$ \\
\hline T. kiharae & яровой & $116,2 \pm 8,0$ & $11,3 \pm 0,8$ & $16,0 \pm 1,0$ & $46,2 \pm 4,0$ & $2,7 \pm 0,3$ & $50,0 \pm 3,7$ \\
\hline T. kiharae & озимый & $121,0 \pm 7,8$ & $12,0 \pm 0,9$ & $16,0 \pm 1,0$ & $24,2 \pm 2,0$ & $2,5 \pm 0,2$ & $38,1 \pm 3,0$ \\
\hline
\end{tabular}


Выводы. Сформирована коллекция по признаку озимость/яровость по объектам: дикие сородичи; линии пшенично-чужеродных гибридов пшеницы; сорта T. aestivum и T. Triticosecal. Сравнение по формуле UPOV одного и того же генотипа в яровой и озимой репродукции позволило констатировать их неоднозначность. Для большинства генотипов усиление степени выраженности морфологических признаков отмечено в озимой репродукции.

В яровом и озимом варианте посева выделялись по NDVI номера Жетысу х T. timopheevii; (Безостая 1 х T. militinae) х T. militinae-9 и (Безостая 1 х $T$. militinae) х $T$. militinae-6 как материал для генетического изучения системы Vrn генов. Максимальное значение NDVI из сородичей и видов пшеницы отличался вид T. timopheevii в озимом варианте, T. militinae и T. kiharae - в яровом варианте посева.

Прогностическое преобладание озимого варианта над яровым по урожайности подтверждается на уровне существенной разницы для ряда генотипов от 9,7 ц/га до 27,0 ц/га.

Дикие сородичи характеризутся синхронностью урожайности и элементов продуктивности в обоих вариантах озимом и яровом.

Благодарности: Работа выполнена при финансовой поддержке проекта МОН РК: №АР05134334 «Физиологические, биохимические и молекулярные основы продуктивности и адаптивности пшеницы с участием гермоплазмы диких сородичей в зависимости от образа жизни и генов яровизации (Vrn)».

\section{Список литературы}

1 Есимбекова М.А. Генетические ресурсы мягкой пшеницы для селекции на адаптивность и продуктивность: Дисс.докт.биол.наук. - Алмалыбак, 2010. -248 с.

2 Джалпакова К.Д., Гончаров Н.П., Берсимбаев Р.И. Генетический контроль типа развития у сортов мягкой пшеницы Казахстана // Генетика. - 1996. - Т. 32, № 1. - C. $73-78$.

3 Goncharov N.P. Response to vernalization in wheat: Its quantitative or qualitative nature //Cereal Res. Comm. - 2004. - Vol. 32, № 3. - P. 323-330.

4 Verhulst N., Govaerts B. The normalized difference vegetation index (NDVI) GreenSeeker TM handheld sensor: Toward the integrated evaluation of crop management. Part A.: Concepts and case studies. CIMMYT, Mexico, 2010.

5 Абугалиева А.И., Моргунов А.И., Масимгазиева А.С., Кожахметов К. Характеристика интрогрессивных форм мягкой пшеницы с участием диких сородичей методом NDVI для отбора на адаптивность и продуктивность в озимом и яровом посеве // Генофонд и селекция растений: материалы IV Межд. науч-практ. конференции (4-6 апреля 2018 г., Новосибирск, Россия). - Новосибирск: ИЦиГ СО РАН, 2018. - С. $4-8$. 


\section{Кариотипические особенности гибридных форм гексаплоидной пшеницы с вавилоидным типом ветвления колоса}

Адонина И.Г. ${ }^{1 *}$, Прокопьева М.B. ${ }^{1,2}$, Мехдиева С.П. ${ }^{3}$, Салина Е.A. ${ }^{1}$

${ }^{1}$ Федеральное государственное бюджетное научное учреждение «Федеральный исследовательский центр Институт цитологии и генетики Сибирского отделения Российской академии наук» (ИЦиГ СО РАН), Новосибирск, Россия;

${ }^{2}$ Федеральное государственное автономное образовательное учреждение выстего образования "Новосибирский национальный исследовательский государственный университет» (НГУ), Новосибирск, Россия;

${ }^{3}$ Национальный Институт Генетических Ресурсов Азербайджана, Баку, Азербайджан.

*e-mail: adonina@bionet.nsc.ru

Проведен сравнительный анализ фенотипов и кариотипов индивидуальных растений гибридных линий гексаплоидной пшеницы с различным проявлением признака ветвления колоса вавилоидного типа. По результатам анализа все исследованные растения были разделены на три группы. Растения, у которых исследуемый признак практически не проявляется, обладают стандартным кариотипом гексаплоидной пшениџы. Растения с умеренным проявлением признака характеризуются замещением хромосомы пшеницы $2 D$ на хромосому ржи $2 R$ (длинное плечо) и присутствием одной или пары телочентрических хромосом пшеницы (2DS). У растений с сильным проявлением признака ветвления колоса вавилоидного типа выявлено хромосомное замещение $2 D(2 R L)$.

Ключевые слова: гибридные линии пшеницы, вавилоидный тип ветвления колоса, GISH, FISH, молекулярно-генетический анализ.

\section{Kariotypes study of hybrid lines of hexaploid wheat with a vaviloid type of spike branching}

I.G. Adonina ${ }^{1 *}$, M.V. Prokopjeva ${ }^{1,2}$, S.P. Mehdiyeva ${ }^{3}$, E.A. Salina ${ }^{l}$

${ }^{1}$ Institute of Cytology and Genetics, Siberian Branch of Russian Academy of Sciences, Novosibirsk, Russia

${ }^{2}$ Novosibirsk State University, Novosibirsk, Russia

${ }^{3}$ Genetic Resources Institute of ANAS, Azerbaijan

*adonina@bionet.nsc.ru

We conducted a comparative phenotypes and karyotypes analysis of the individual plants of hybrid hexaploid wheat lines with different manifestation of the vaviloid type of spike branching. According to the results of the analysis, all 
the studied plants were divided into three groups. Plants in which the investigated trait is practically not manifested have the standard karyotype of hexaploid wheat. Plants with moderate manifestation of the trait are characterized by the replacement of the $2 D$ wheat chromosome with the $2 R$ rye chromosome (long arm) and the presence of one or a pair of telecentric wheat chromosomes (2DS). In plants with strong manifestation of the vaviloid type of spike branching, chromosome substitution $2 D(2 R L)$ was detected.

Key words: hybrid wheat lines, vaviloid type of spike branching, GISH, FISH, molecular-genetic analysis.

Вавилоидный тип ветвления колоса или ложная ветвистость - проявление нестандартной морфологии колоса пшеницы, при котором наблюдается удлинение оси колоска с формированием на ней дополнительных цветков. Данный признак был впервые описан у гексаплоидной пшеницы Triticum vavilovii (Thum.) Jakubz. (BBAADD), может возникать в результате отдаленной гибридизации и на настоящий момент недостаточно изучен.

Объектом исследования данной работы являлись растения гибридных линий, полученных от скрещивания тритикале BBAARR $(2 n=6 x=42)$ с гексаплоидной пшеницей Triticum aestivum L. var velutinum. Тритикале является гибридом синтетической пшеницы BBAADD (T. durum $\times$ Ae. tauschii var. meyrei) и ржи Secale cereale ssp. segetale $(2 n=2 x=14$, RR). Линии предоставлены Национальным Институтом Генетических Ресурсов Азербайджана и характеризуются различным проявлением признака ветвления колоса вавилоидного типа.

Поскольку нами были выявлены значительные различия в проявлении признака ветвления колоса вавилоидного типа даже между растениями одной и той же линии, мы провели сравнительный анализ фенотипов и кариотипов индивидуальных растений из разных линий.

Кариотипирование проводили с использованием методов GISH с ДНК ржи и FISH с зондами pSc119.2 и pAs1, позволяющими идентифицировать хромосомы пшеницы и ржи [1]. Число хромосом у отдельных растений варьировало от 42 до 44. Часть растений имела стандартный кариотип гексаплоидной пшеницы. У большинства исследованных растений было выявлено замещение хромосом 2D пшеницы на пару хромосом ржи. У ряда растений присутствовали дополнительные телоцентрические хромосомы пшеницы с субтеломерными сигналами $\mathrm{pSc1} 19.2$. В нескольких случаях была выявлена хромосома без пары, которая, по-видимому, образовалась в результате центрического слияния этих двух телоцентриков. Мы предположили, что телоцентрические хромосомы пшеницы представляют собой короткие плечи хромосом 2D. У нескольких растений мы наблюдали отсутствие короткого плеча у одного из гомологов хромосом ржи. У других растений хромосомы 
ржи выглядели укороченными. Однако в последующих экспериментах с использованием центромерных зондов pAwRc [2] и pAet6-09 [3], нами было установлено, что укороченные хромосомы ржи в действительности являются телоцентриками (предположительно - длинные плечи хромосом 2R) (рис. 1).

Молекулярно-генетический анализ с использованием маркера $F 3 h-R$ для хромосомы 2RL [4] подтвердил наши предположения о том, что телоцентрические хромосомы ржи представляют собой длинные плечи хромосом 2R. ПЦР с маркером короткого плеча хромосомы 2D пшеницы, $P p D-D 1$ [5], показал положительные результаты для растений, несущих целые хромосомы 2D, и для растений, у которых были обнаружены телоцентрические хромосомы пшеничного происхождения.

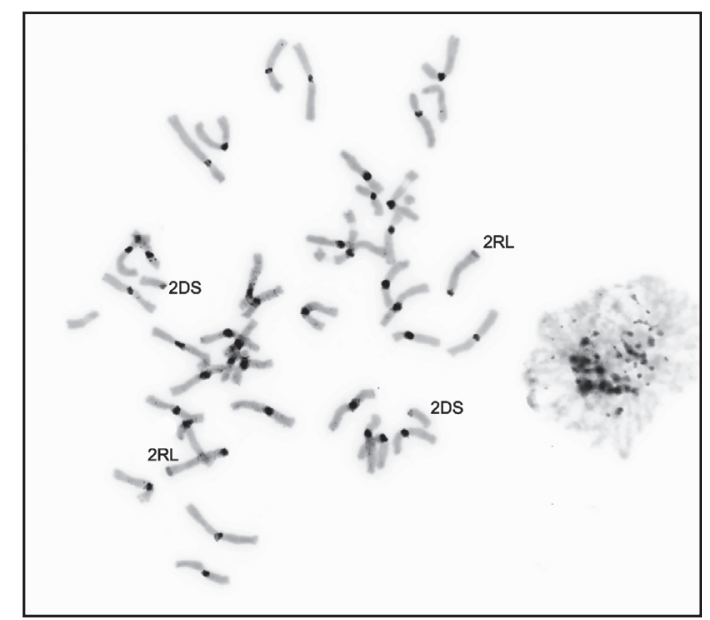

Рис. 1. FISH с центромерным зондом, pAet6-09, на метафазных хромосомах одного из растений. Обозначены телоцентрические хромосомы ржи и пшеницы.

В результате проведенного сравнительного анализа фенотипов и кариотипов все исследованные растения были разделены на три группы:

1. Растения, у которых исследуемый признак практически не проявляется (рис. 2а), обладают стандартным кариотипом гексаплоидной пшеницы.

2. Растения с умеренным проявлением признака (рис. 2б) характеризуются замещением хромосомы пшеницы 2D на хромосому ржи 2R (длинное плечо) и присутствием одной или пары телоцентрических хромосом пшеницы (2DS).

3. У растений с сильным проявлением признака ветвления колоса вавилоидного типа (рис. 2в) выявлено хромосомное замещение 2D(2RL). 


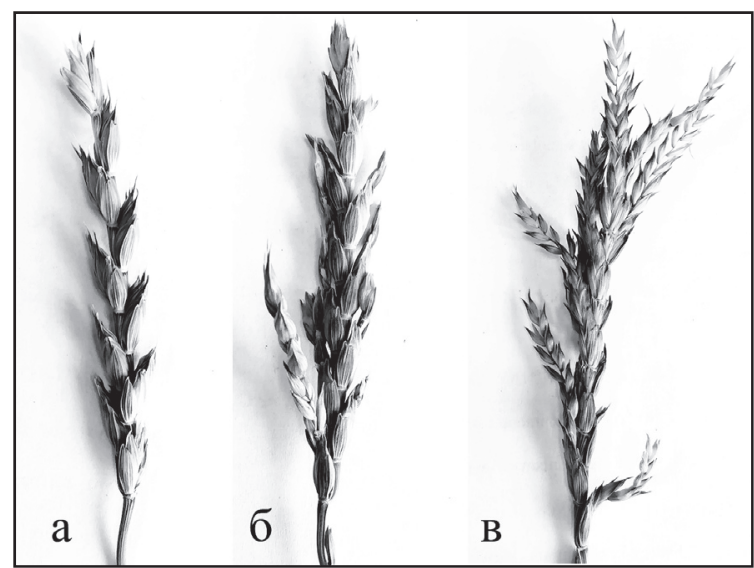

Рис. 2. Проявление признака, ветвление колоса вавилоидного типа, у индивидуальных растений.

Таким образом, кариотипические различия между растениями с разным проявлением признака ветвления колоса вавилоидного типа связаны с хромосомами второй гомеологичной группы. Присутствие короткого плеча хромосомы 2D ведет к ослаблению проявления признака, но не к полному его подавлению.

Благодарности: Работа выполнена при поддержке гранта РФФИ 20016-00122.

\section{Список литературы}

1. Schneider A., Linc G., Molnar-Lang M. Fluorescence in situ hybridization polymorphism using two repetitive DNA clones in different cultivars of wheat // Plant Breeding. 2003. V. 122. P. 396-400.

2. Francki M.G. Identification of Bilby, a diverged centromeric Ty1-copia retrotransposon family from cereal rye (Secale cereale L.) // Genome. 2001. V. 44. P. 266274.

3. Zhang P., Wanlong L., Fellers J., Friebe B., Gill B.S. BAC-FISH in wheat identifies chromosome landmarks consisting of different types of transposable elements // Chromosoma. 2004. V. 112. P. 288-299.

4. Khlestkina E.K. Anthocyanin biosynthesis genes location and expression in wheat-rye hybrids / Khlestkina E.K., Tereshchenko O.Yu., Salina E.A. // Mol. Genet. Genom. 2009. V. 282. № 5. P. 475-485.

5. Beales J., Turner A., Griffiths S., Snape J.W., Laurie D.A. A Pseudo-Response Regulator is misexpressed in the photoperiod insensitive Ppd-Dla mutant of wheat (Triticum aestivum L.) // Theor. Appl. Genet. 2007. V. 115. P. 721-733. DOI 10.1007/s00122007-0603-4. 


\section{Хромосомная изменчивость в поколениях ЭМС-мутантных линий ярового рапса}

Амосова А.В. ${ }^{{ }^{*},}$, к.б.н, с.н.с.; Земцова Л.В. ${ }^{l}$, ст. лаб.; Зощук С.А. ${ }^{l}$, к.б.н, н.с.; Гуськова Н.И. ${ }^{2}$, студент; Юркевич О.Ю. ${ }^{l}$, к.б.н, н.с.; Саматадзе Т.Е. ${ }^{l}$, к.б.н, н.с.; Муравенко О.В. ${ }^{1}$, д.б.н., г.н.с.

${ }^{I}$ ФГБУН Институт молекулярной биологии им. В.А. Энгельгардта РАН, Москва, Российская Федерачия;

${ }^{2}$ Московский государственный университет им. М.В. Ломоносова, Москва, Российская Федерация.

e-mail:amomar@mail.ru

Впервые изучены ичитогенетическая изменчивость растений хозяйственно-ценных мутантных линий рапсового и сурепичного морфотипов, выделенных в поколениях ярового рапса канола сорта Викрос после обработки ЭМС. Сравнительный анализ структуры кариотипов и хромосомного распределения локусов $45 S$ and $5 S$ рДНК у растений исходного сорта и мутантных форм показал относительную стабильность их геномов. В некоторых линиях М3-Мб обнаружены полиморфные варианты хромосом, а также гомеологическое межгеномное замещение, ди- и трисомия. Наши результаты подтвердили эффективность использования низких концентраиий ЭМС в селекции рапса, а выделенные мутантные линии рапсового и сурепичного морфотипов перспективны для получения новых хозяйственноценных сортов.

Ключевые слова: Brassica napus L., ЭМС мутагенез, кариотип, FISH.

\section{Chromosomal variability in generations of spring rapeseed ems mutant lines}

Amosova A.V. ${ }^{\text {, }, Z e m t s o v a ~ L . V . ~}{ }^{1}$, Zoshchuk S.A. ${ }^{\text {}, ~ G u s k o v a ~ N . I . ~}{ }^{2}$, Yurkevich O.Yu. ${ }^{1}$, Samatadze T.E. ${ }^{l}$, Muravenko O.V. ${ }^{1}$

${ }^{1}$ Engelhardt Institute of Molecular Biology, Russian Academy of Sciences, Moscow, Russian Federation E-mail: amomar@mail.ru

${ }^{2}$ Lomonosov Moscow State University, Moscow, Russian Federation

For the first time, the cytogenetic variability was examined in M2-M6 generations of EMS mutagenized rape seed populations of B. napus- and B. rapa-type generated from canola B. napus cv. Vikros. The comparative analysis of karyotype structure and also FISH-based chromosomal localization of $45 S$ and $5 S$ rDNA between B. napus cv. Vikros and both mutant lines demonstrated relative stability of their genomes. In several M3-M6 lines, polymorphic chromosome variants including homeologous inter-genomic substitutions, di-and trisomy were also re- 
vealed. Our findings confirmed the effectiveness of EMS treatment at low concentrations in rapeseed breeding that resulted in development of two valuable mutant lines important for development of rapeseed varieties with desired characteristics.

Key words: Brassica napus L., EMS mutagenesis, karyotype, FISH.

Рапс (Brassica napus L., 2n=38, геном AACC) является хозяйственноценной культурой многоцелевого применения. Для повышения генетического разнообразия рапса и получения новых высокопродуктивных и устойчивых сортов применяются различные методы, в том числе, химический мутагенез. Например, с помощью химического мутагенеза были получены низкоэруковые, высокоолеиновые, низколиноленовые и устойчивые к заболеваниям сорта рапса [1]. Вместе с тем, использование мутагенеза в процессе селекции может приводить к нарушению геномного гомеостаза и возникновению различных хромосомных и геномных изменений, приводящих к генетической нестабильности потомства. Большая часть исследований мутантных форм рапса, проводится по изучению аллельного полиморфизма и картированию мутантных генов, кодирующих хозяйственно-ценные признаки [2]. В настоящей работе впервые проведен анализ хромосомной изменчивости растений в М2-М6 поколений мутантных форм, выделенных после обработки этилметансульфонатом семян ярового рапса канола сорта Викрос.

Объекты и методы. Материалом для исследования послужили растения ярового рапса канола сорта Викрос, полученные из ФГБНУ ФНЦ кормопроизводства и агроэкологии им. В.Р. Вильямса (г. Москва, Россия). В результате обработки семян $0,2 \%$ раствором этилметансульфоната (ЭМС) и последующего отбора потомства по хозяйственно-ценным признакам в поколениях M2-М6 были получены мутантных форм рапсового и сурепичного морфотипов. Приготовление хромосомных препаратов, процедуру FISH c зондами $45 \mathrm{~S}$ и $5 \mathrm{~S}$ рДНК, а также анализ хромосом проводили по разработанным нами ранее методикам [3].

Результаты и обсуждение. Рапс является природным амфидиплоидом, геном которого включает А- и С-субгеномы. Поэтому этот вид представляет собой важную модель для изучения процессов геномного взаимодействия и реорганизации, происходящих в сложных геномах недавно возникших полиплоидов. Примерами такого взаимодействия служат выявленные в кариотипе рапса различные хромосомные перестройки и межгеномные замещения, возникающие, вероятно, для поддержания геномной стабильности $[4,5]$. Ранее нами показано, что под давлением искусственного отбора по определенным признакам в поколениях ресинтезантов рапса наблюдались анеуплоидные формы, различные хромосомные аберрации, потеря отдельных хромосом и даже целого субгенома, что коррелировало с фенотипической изменчивостью этих гибридов [6]. Для исследования хромо- 
сомной изменчивости мы провели сравнительный анализ структуры кариотипов исходного сорта Викрос и растений в М2-М6 поколениях обеих мутантных популяций. Обнаружено, что у большинства изученных мутантных растений рапсового типа структура кариотипов, в основном, не отличалось от исходного сорта Викрос. FISH анализ подтвердил сходство кариотипов растений этой популяции с исходным сортом по хромосомному распределению сайтов $45 \mathrm{~S}$ и $5 \mathrm{~S}$ рДНК (3 пары хромосом с отдельным локусом $45 \mathrm{~S}$ рДНК, две пары хромосом с отдельными локусами 5S рДНК и 4 пары хромосом с ко-локализованными кластерами 45S и 5S рДНК). В некоторых линиях M3-M6 обнаружены полиморфные варианты хромосом 9Ас дополнительным сигналом 5S рДНК и гетероморфизм гомологов 4А по наличию кластеров рДНК. У большинства изученных мутантных растений сурепичного типа структура кариотипов также не отличалось от исходного сорта Викрос, но выявлен полиморфизм по локализации $45 \mathrm{~S}$ и $5 \mathrm{~S}$ рДНК на хромосомах Асубгенома. Полиморфизм по числу и хромосомному распределению локусов $45 \mathrm{~S}$ и $5 \mathrm{~S}$ рдНК наблюдался и ранее у разных сортов рапса [3]. Вместе с тем, в поколениях M3-M6 в кариотипах ряда растений сурепичного типа выявлены и значительные хромосомные нарушения (гомеологическое межгеномное замещение, дисомия, двойная трисомия). Обнаруженные мутантные растения сурепичного типа с такими структурными хромосомными изменениями могут использоваться для получения форм рапса с трисомией и/или линий с замещением/дополнением хромосом. Такие анеуплоидные линии позволяют получать интрогрессивные линии растений и дают возможность контролировать экспрессию гетерологичных генов и взаимодействие между геномом-реципиентом и хромосомами-донорами у растений [7, 8]. Кроме того, наличие хромосомных аномалий у мутантных растений в разных поколениях указывает на необходимость анализа структуры кариотипов мутантных линий при их передаче на сортоиспытание.

Заключение. Проведенное в настоящей работеисследование хромосомной изменчивости у мутантных растений подтвердило эффективность использования низких концентраций ЭМС в селекции рапса, а выделенные мутантные линии рапсового и сурепичного морфотипов перспективны для получения новых хозяйственно-ценных сортов с нужными свойствами.

Благодарности: Работа выполнена при поддержке РФФИ (проект № 17-29-08034 офи-м), а также в рамках Программы фундаментальных исследований государственных академий наук на 2013-2020 годы (тема № 01201363824$)$.

\section{Список литературы}

1. Spasibionek S. New mutants of winter rapeseed (Brassica napus L.) with changed fatty acid composition // Plant Breeding. 2006. V.125. P. 259-267.

2. Mikolajczyk K., Dabert M., Karlowski W.M., Spasibionek S., Nowakowska J., Cegielska-Taras T., Bartkowiak-Broda I. Allele-specific SNP markers for the low linolenic 
mutant genotype of winter oilseed rape // Plant Breeding. 2010. V. 129. P. 502-507.

3. Amosova A.V., Zemtsova L.V., Grushetskaya Z.E., Samatadze T.E., Mozgova G.V., Pilyuk Y.E., Volovik V.T., Melnikova N.V., Zelenin A.V., Lemesh V.A., Muravenko O.V. Intraspecific chromosomal and genetic polymorphism in Brassica napus L. detected by cytogenetic and molecular markers // Journal of Genetics. 2014. V. 93. P. 133-143.

4. Xiong Z.Y., Gaeta R.T., Pires J.C. Homoeologous shuffling and chromosome compensation maintain genome balance in resynthesized allopolyploid Brassica napus // Proceedings of the National Academy of Sciences USA. 2011. V. 108. P. 7908-7913.

5. Mason A.S., Snowdon R.J. Oilseed rape: learning about ancient and recent polyploid evolution from a recent crop species // Plant Biol (Stuttg). 2016. V. 18. P. 883-892.

6. Amosova A.V., Zemtsova L.V., Yurkevich O.Y., Zhidkova E.N., Książczyk T., Shostak N.G., Muravlev A.A., Artemyeva A.M., Samatadze T.E., Zoshchuk S.A., Muravenko O.V. Genomic changes in generations of synthetic rapeseed-like allopolyploid grown under selection // Euphytica. 2017. V. 213. P. 217-229.

7. Howell P.M, Marshal D.F, Lydiate D.J. Towards developing intervarietal substitution lines in Brassica napus using marker assisted selection // Genome. 1996. V. 39. P. 348358.

8. Barthes L., Ricroch A. Interspecific chromosomal rearrangements in monosomic addition lines of Allium // Genome. 2001. V. 44. P. 929-935.

DOI 10.18699/GPB2020-06

\section{Изучение коллекции пшеницы мягкой яровой для выявления высокоурожайных источников устойчивых к комплексу болезней}

Апарина В.A. ${ }^{l}$ *, магистрантка; Пискарев B.B. ${ }^{2}$, к.с.-х.н., зав. лаб. генофонда растений; Бойко Н.И. ${ }^{2}$, м.н.с.; Сухомлинов В.Ю. ${ }^{2}$, агроном 1 категории.

${ }^{1}$ ФБОУ ВО Новосибирский ГАУ, Новосибирск, Россия;

${ }^{2}$ СибНИИРС - филиал ИЦиГ СО РАН, Новосибирск, Россия

*e-mail: apari-na.viktoriya@yandex.ru

В результате оценки 158 коллекционных линий пиеницьы мягкой яровой в условиях 2019 года выделены образцы устойчивые к одному или нескольким заболеваниям с урожайностью выше или на уровне стандартов. Ранние сорта - Norm $\left(527,7\right.$ 2/ $\left.\mathrm{M}^{2}\right)$ и Kenуоп $(528,6)$; среднеранние и среднеспелье - Этюд (678,9), Свеча (606,2), CDC Merlin (610,5), Легенда $(660,2)$, Лютесиенс 503 (663,9), Харьковская 22 (527,8), PS 133 (568,9), Aletch $(558,1)$, NIL Thatcher Lr36 (469,3), Геракл (579,7), МИС (543,2), Омская 37 (548,5), Glenlea (465,8), AC Drummond (559,5), Cunnigharn (416,8), среднепоздниеМерцана (658,1), Воевода (686,5), Экада $6(545,7)$, Тулайковская $5(604,2)$, WW 17283 (574,1), Маргарита (558,6), Омская 38 (528,4), Nardo (560,3), Tyлайковская 110 (511,9), Тулайковская золотистая (507,3), Тулайковская 108 $(605,9)$, Rh 66-6 (590,5), Тулайковская $10(580,1)$, Экада 85 (593,2). Для подтверждения урожайных качеств линий необходимо продолжить изучение 
образиов.

Ключевые слова: пшеница мягкая яровая; устойчивость; источник; урожайность; сорт.

\section{Study of a collection of soft spring wheat for finding high-yielding sources resistant to a complex of diseases}

Aparina $V .{ }^{1}$, Piskarev $V .^{2}$, head of laboratory, Boiko $N^{2}$, junior researcher, Sukhomlinov $V .^{2}$, agronomist

${ }^{l}$ Federal State Budgetary Educational Institution of Higher Education "Novosibirsk State Agrarian University", Novosibirsk Russia

${ }^{2}$ SibRIPP\&B - branch ICG SB RAS, Novosibirsk, Russia.

As a result of the evaluation of 158 collection lines of soft spring wheat in the conditions of 2019, samples resistant to one or more diseases with a yield above or at the level of standards were identified. Early varieties - Norm $(527.7 \mathrm{~g}$ / m2) and Kenyon (528.6); middle-early and middle varieties - (678.9), Svecha (606.2), CDC Merlin (610.5), Legenda (660.2), Lutescens 503 (663.9), Kharkovskaya 22 (527.8), PS 133 (568.9), Aletch (558.1), NIL Thatcher Lr36 (469.3), Gerakl (579.7), MIS (543.2), Omskaya 37 (548.5), Glenlea (465.8), AC Drummond (559.5), Cunnigharn (416.8), mid-late varieties - Mertsana (658.1), Voivoda (686.5), Ekada 6 (545.7), Tulaykovskaya 5 (604.2), WW 17283 (574.1), Margarita (558.6), Omsk 38 (528.4), Nardo (560.3), Tulaykovskaya 110 (511.9), Tulaykovskaya Zolotistaya (507.3), Tulaykovskaya 108 (605.9), Rh 66-6 (590.5), Tulaykovskaya 10 (580.1), Ekada 85 (593.2). To confirm the yield qualities of the lines, it is necessary to continue studying the samples.

Пшеница подвержена воздействию большого комплекса фитопатогенов, среди которых возбудители бурой (Puccinia triticina Rob. ex Desm. f. sp. tritici Erikss. et Henn.) ржавчины и септориоза (Septoria tritici Rob. ex Desm.) занимают особое место [1].

Успех селекционной работы определятся правильным подбором исходного материала. Он является важным фактором формирования продуктивности, а также комплекса хозяйственно-ценных признаков современных сортов. Изучение и проработка коллекционного материала различного эколого-географического происхождения расширяет круг важных для селекционного процесса признаков, присущих данной культуре. В том числе образцы отличаются значительным генотипическим потенциалом устойчивости к фитопатогенам, что обусловлено микроэволюционными процессами формирования рассоспецифической устойчивости их генотипов в разных условиях среды.

Целью исследования является оценка урожайности коллекционных образцов яровой мягкой пшеницы, источников известных генов устойчивости к комплексу грибных болезней. 
В изучение включены 158 линий, отобранных из коллекционных образцов пшеницы мягкой яровой, сохраняемых в лаборатории генофонда растений СибНИИРС - филиала ИЦиГ СО РАН, устойчивые к одному или нескольким заболеваниям. Стандартами для групп спелости являлись: ранние - Новосибирская 15, среднеранние - Новосибирская 31 и среднепоздние Сибирская 17. Площадь делянки $2 \mathrm{~m}^{2}$, посев изучаемых образцов без повторений, стандартов в 4-х повторениях.

Предшественник - черный пар. Агротехника - принятая для яровой пшеницы [2]. Посев питомника проводили 10 мая 2019 г. сеялкой ССФК-7.

Оценка элементов продуктивности изучаемых линий пшеницы мягкой яровой проведена по методике ВИР [3], разработанной для изучения новых поступлений коллекционных образцов. В период вегетации растений отмечены фенологические фазы - всходы, колошение, восковая спелость. В фазу восковой спелости растения убраны в снопы и подвергнуты структурному анализу. Оценка поражения линий мягкой яровой пшеницы заболеваниями, распространенными в Западной Сибири, проводили в полевых условиях на естественном инфекционном фоне по методике ВИР [3].

В результате полевой оценки (группа ранних сортов, табл. 1) выделены образцы, с урожайностью выше стандарта (Новосибирская 15 - 437,2 $\left.\Gamma / \mathrm{M}^{2}\right) \operatorname{Norm}(527,7)$, Kenyon $(528,6)$, имеющие устойчивость к бурой ржавчине и септориозу (99 и 7б).

Таблица 1 - Показатели продуктивности и устойчивости образцов пшеницы мягкой яровой (ранние сорта)

\begin{tabular}{|c|c|c|c|c|c|c|}
\hline \multirow[t]{2}{*}{ Сорт } & \multicolumn{2}{|c|}{$\begin{array}{c}\text { Гены } \\
\text { устойчивости* }\end{array}$} & \multirow[t]{2}{*}{$\begin{array}{c}\text { Урожай- } \\
\text { ность, } Г / \mathrm{M}^{2}\end{array}$} & \multirow[t]{2}{*}{$\begin{array}{l}\text { МР**, } \\
\text { балл }\end{array}$} & \multirow[t]{2}{*}{$\begin{array}{l}\text { БР**, } \\
\text { балл }\end{array}$} & \multirow{2}{*}{$\begin{array}{c}\text { Септо- } \\
\text { риоз, } \\
\text { балл }\end{array}$} \\
\hline & $\mathrm{Lr}$ & $\mathrm{Pm}$ & & & & \\
\hline Новосибирская 15 & - & - & 437,2 & 3 & 5 & 5 \\
\hline Norm & $\operatorname{LrX}$ & $P m$ & 527,7 & 5 & 99 & 7 \\
\hline Kenyon & Lr26 & $P m 8$ & 528,6 & 3 & 99 & 7 \\
\hline HCP 05 & & & 78,5 & & & \\
\hline
\end{tabular}

*По литературным данным

**БР - поражение бурой ржавчиной, МР - поражение мучнистой росой.

В результате полевой оценки сортов, отнесенных к группе среднеранних (табл. 2), среди изученных образцов в сравнении со стандартом (Новосибирская $31-525,0$ г/м²) превышения по урожайности выявлены у сортов: Этюд $(678,9)$, Свеча $(606,2)$, CDC Merlin $(610,5)$, Легенда $(660,2)$, Лютесценс $503(663,9$ г/м²). Также выделены сорта с урожайностью на уровне со стандартом: Харьковская $22(527,8)$, PS $133(568,9)$, Aletch $(558,1)$, NIL Thatcher Lr36 (469,3), Геракл $(579,7)$, МИС $(543,2)$, Омская $37(548,5)$, Glenlea $(465,8)$, AC Drummond $(559,5)$, Cunnigharn $(416,8)$. 
Таблица 2 - Показатели продуктивности и устойчивости образцов пшеницы мягкой яровой (среднеранние сорта)

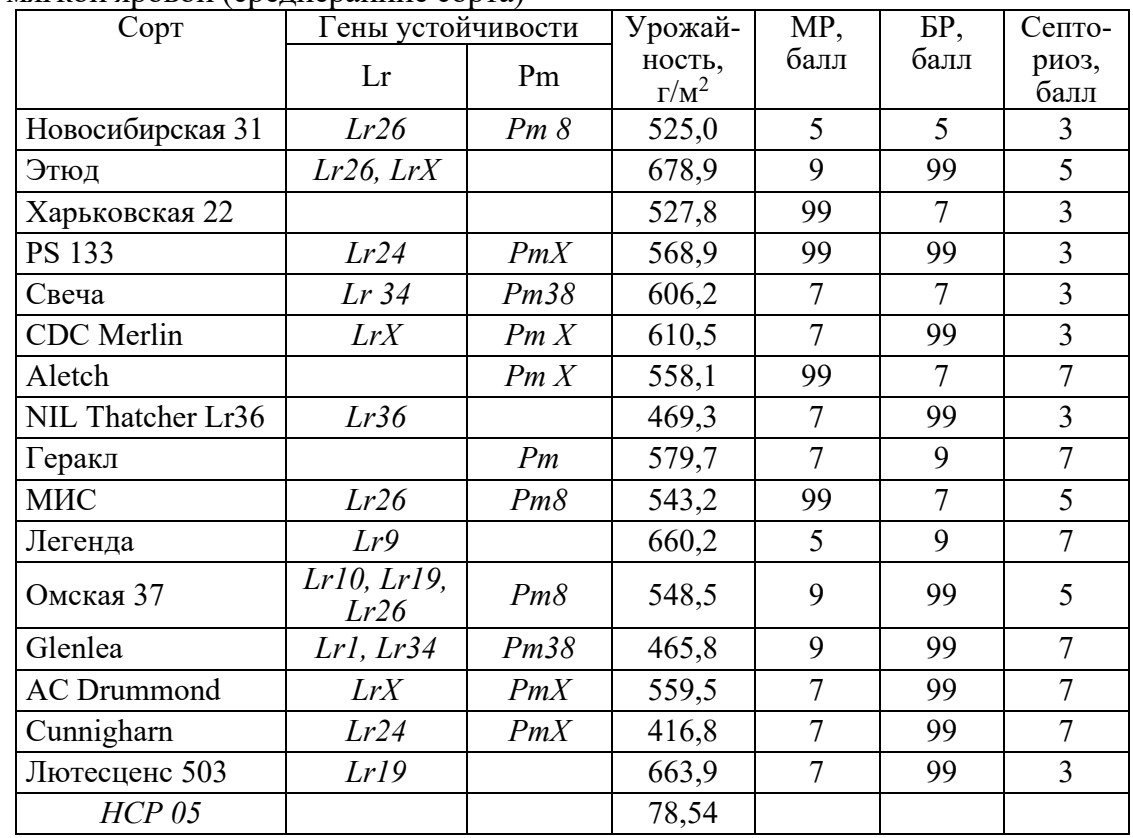

По устойчивости к основным заболеваниям (мучнистая роса, бурая ржавчина и септориоз пшеницы, устойчивость 7-99 баллов):

-комплексная устойчивость: Aletch, Геракл, Glenlea, AC Drummond, Cunnigharn.

-устойчивые к бурой ржавчине и септориозу: Легенда.

-устойчивые к мучнистой росе и бурой ржавчине: Этюд, Харьковская 22, PS 133, Свеча, CDC Merlin, NIL Thatcher Lr36, Мис, Омская 37, Лютесценс 503.

В результате полевой оценки сортов, отнесенных к группе среднепоздних сортов (табл. 3), выделены образцы превысившие по урожайности стандарт

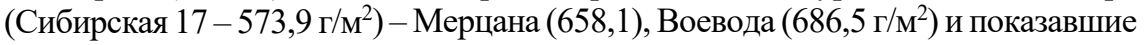
себя на уровне со стандартом: Экада $6(545,7)$, Тулайковская $5(604,2), \mathrm{WW}$ $17283(574,1)$, Маргарита $(558,6)$, Омская $38(528,4), \operatorname{Nardo}(560,3)$, Тулайковская $110(511,9)$, Тулайковская золотистая $(507,3)$, Тулайковская $108(605,9), \mathrm{Rh} 66-6$ $(590,5)$, Тулайковская $10(580,1)$, Экада $85(593,2)$. 
Таблица 3 - Показатели продуктивности и устойчивости образцов пшеницы мягкой яровой (среднепоздние сорта)

\begin{tabular}{|c|c|c|c|c|c|c|}
\hline \multirow[b]{2}{*}{ Сорт } & \multicolumn{2}{|c|}{ Гены устойчивости* } & \multirow{2}{*}{$\begin{array}{c}\text { Урожай- } \\
\text { ность, } \\
\Gamma / \mathrm{M}^{2}\end{array}$} & \multirow{2}{*}{$\begin{array}{l}\text { МР, } \\
\text { балл }\end{array}$} & \multirow{2}{*}{$\begin{array}{l}\text { БР, } \\
\text { балл }\end{array}$} & \multirow{2}{*}{$\begin{array}{c}\text { Септо- } \\
\text { риоз, } \\
\text { балл }\end{array}$} \\
\hline & $\mathrm{Lr}$ & $\mathrm{Pm}$ & & & & \\
\hline Сибирская 17 & $\operatorname{Lr} 9$ & $P m 5 a$ & 573,9 & 5 & 7 & 7 \\
\hline Экада 6 & Lr19 & $P m X$ & 545,7 & 7 & 99 & 7 \\
\hline Тулайковская 5 & Lr6Agi2 & Pm6Agi2 & 604,2 & 99 & 99 & 7 \\
\hline WW 17283 & Lr19 & $P m X$ & 574,1 & 99 & 99 & 7 \\
\hline Маргарита & $\begin{array}{l}\text { Lr49, Lr34, } \\
\text { Lr10 }\end{array}$ & $\operatorname{Pm} 38$ & 558,6 & 9 & 99 & 7 \\
\hline Омская 38 & Lr19, Lr26 & Pm8 & 528,4 & 5 & 9 & 7 \\
\hline Nardo & & $P m X$ & 560,3 & 7 & 7 & 7 \\
\hline Тулайковская 110 & Lr19+Lr6Agi1 & Pm6Agil & 511,9 & 99 & 99 & 7 \\
\hline $\begin{array}{l}\text { Тулайковская } \\
\text { Золотистая }\end{array}$ & Lr6Agi2 & Pm6Agi2 & 507,3 & 99 & 99 & 7 \\
\hline Тулайковская 108 & Lr19+Lr6Agi1 & Pm6Agil & 605,9 & 99 & 99 & 7 \\
\hline Мерцана & $\operatorname{LrX}$ & $P m X$ & 658,1 & 99 & 99 & 7 \\
\hline Rh 66-6 & $\operatorname{LrX}$ & & 590,5 & 5 & 99 & 7 \\
\hline Воевода & $\mathrm{LrBel}$ & PmAg.i & 686,5 & 99 & 99 & 7 \\
\hline Тулайковская 10 & Lr6Agi2 & Pm6Agi2 & 580,1 & 99 & 99 & 7 \\
\hline Экада 85 & $\operatorname{LrX}$ & $P m X$ & 593,2 & 99 & 99 & 5 \\
\hline HCP 05 & & & 78,54 & & & \\
\hline
\end{tabular}

По устойчивости к основным заболеваниям (мучнистая роса, бурая ржавчина и септориоз пшеницы, устойчивость 7-99 баллов):

-комплексная устройчивость: Экада 6, Тулайковская 5, WW 17283, Маргарита, Nardo, Тулайковская 110, Тулайковская золотистая, Тулайковская 108, Мерцана, Воевода, Тулайковская 10.

-устойчивые к бурой ржавчине и септориозу: Омская 38, Rh 66-6.

-устойчивые к мучнистой росе и бурой ржавчине: Экада 85.

\section{Список литературь}

1. Волкова Г.В. и др. Поиск сортообразцов пшеницы с групповой устойчивостью и их практическое использование // Труды по прикладной ботанике, генетике и селекции. - 2009. - Т. 166. - С. 33-41.

2. Доспехов Б.А. Методика полевого опыта (с основами статистической обработки результатов исследований) / Б.А. Доспехов. - 2-е изд., перераб. и доп. - М.: Колос, 1968. - 336 с.

3. Мережко А.Ф. и др. Пополнение, сохранение в живом виде и изучение мировой коллекции пшеницы, эгилопса и тритикале. Методические указания // СПб.: ВИР. $-1999 .-81 \mathrm{c}$. 


\section{Изучение номеров конкурсного сортоиспытания нута по хозяйственно- ценным признакам в сухостепной зоне Алматинской области}

Байтаракова К.Ж., с.н.с.; Кудайбергенов М.С., д.б.н.; Нусипбай К., н.с.; Абилдаева Д.Б., м.н.с.

Казахский научно-исследовательский институт земледелия и растениеводства, п. Алмальгбак, Казахстан.

e-mail: kuralai_baitarakova@mail.ru

Изучены селекиионные номера нута в питомнике конкурсного сортоиспытания. За период исследования были выделены номера, которые по урожайности превзошли стандартный сорт Камила 1255. В 2017 году сорт Cәтті (F02-04) был передан в ГКСИСК на Государственное сортоиспытание.

Ключевые слова: нут, сорт, номер, продуктивность.

The study of samples competitive variety trials of chickpea on economic valuable signs in the dry-steppe zone of Almaty region

Baitarakova K. J., Senior researcher, Kudaibergenov M. S., Doctor of Biological Sciences, Nusipbai K., Researcher, Abildayeva D. B., Junior Researcher. LLP "Kazakh Scientific Research Institute of Agriculture and Plant Growing" (LLP "KazNIIZiR"), Almaty, Kazakhstan

We studied the selection numbers of chickpeas in the nursery of competitive variety testing, in a conditional study and these numbers exceeded the standard variety Kamila 1255. In 2017, they were Satti (F02-04) and transferred to the SACVTAC for State variety testing.

Key words: Chickpeas, variety, number, productivity.

Ценность зерновых бобовых культур определяется, прежде всего, высоким содержанием хорошо усвояемого белка в семенах и других органах $[1,2]$. Важной задачей для Казахстана на сегодня является обеспечение сбалансированного питания людей белковыми продуктами растительного происхождения. Ведутся работы по созданию новых высокоурожайных и конкурентоспособных сортов зернобобовых культур, но в основном привезенные зарубежные сорта не приспособлены к нашим почвенноклиматическим условиям, поэтому мы должны создавать отечественные сорта с высокими хозяйственно-ценными признаками и с высокой урожайностью.

Зерно нута - ценный источник минеральных веществ, витаминов и других биологически ценных веществ. Его семена богаты белком (до 25,8 \%), в них содержится до 8,2 \% жира, до 60 \% крахмала + сахара, 3 \% клетчатки [3- 
6]. Благодаря сбалансированному аминокислотному составу и большому содержанию метионина и триптофана по питательной ценности нут превосходит все другие зернобобовые культуры [7]. Энергетическая ценность нута составляет 329 ккал/100 г массы, что на 26 ккал больше, чем у гороха [8].

Лиманская В.Б., Шектыбаева Г.Х. [9] считают, что нут всегда являлся страховой культурой для Западного Казахстана. Поэтому, поиск новых более урожайных и ценных по комплексу хозяйственно-ценных признаков адаптированных сортов этой культуры в настоящее время является актуальной задачей и требует расширенных научных исследований.

В Западно-Казахстанской области площади посева этой культуры доходили до 3 тыс. га. За последние годы этот показатель варьирует в пределах от 300 до 500 га. С 2017 года планируется увеличение этого показателя до 1 тыс. га.

В условиях сухостепной зоны западного Казахстана, проведено широкое экологическое сортоиспытание сортов нута с целью выявления адаптированных и создания рабочей коллекции исходного материала для селекции. Среди выделенных, наибольший интерес представляют сорта и линии селекции Казахского НИИ земледелия и растениеводства. По комплексу признаков: урожайности, скороспелости, массе 1000 зерен выделены сорта ЕрСултан, Мальхотра, Волгоградский 25, Камила 1255, Икарда 1 и др. [10].

Метеоусловия 2015-2017 гг. были близки к среднемноголетним климатическим показателям, в 2015 году погодные условия были очень подходящими для оценки образцов на засухоустойчивость.

Материалом исследований послужили 19 номеров различного эколого-географического происхождения. 2 номера из Украины, 1 номер из Сирии, 1 номер из Марокко, 1 номер из Германии, 4 номера из Азербайджана и 9 номеров из Казахстана.

Посев поводили в оптимальные для культуры сроки, площадь делянки $25 \mathrm{~m}^{2}$, повторность трехкратная. Стандарт местный сорт Камила 1255 высевался через каждые 2 номера, междурядье 45 см и норма высева 400 тыс. всхожих зерен на 1 га.

Среднюю арифметическую, ее ошибку, дисперсионный анализ и коэффициент вариации определяли по Б.А. Доспехову (1979).

В сухостепной зоне Алматинской области (Карой) из структурного анализа номеров конкурсного сортоиспытания нута по хозяйственно - ценным признакам, выделяются номера, которые характеризуются высоким количеством бобов с растения (30-35 шт.) ТH45-1-01, F97-25/1, F98-30, Высокорослый, F97-121, F97-60, F02-04, F00-21, F97-14, F92-52, с высокой массой семян с растения (31-41 г) F00-21, F02-04, F97-14, F97-60, F92-52, с высокой массой 1000 семян (290-303 г): F97-14, Высокорослый, F02-04, F9760, F98-30 (табл. 1). 
Таблища 1 - Средние значения элементов продуктивности образцов нута конкурсного питомника, 2015-2017 гг.

\begin{tabular}{|c|c|c|c|c|c|c|c|}
\hline $\begin{array}{c}\text { Наименование } \\
\text { образца }\end{array}$ & 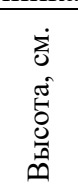 & 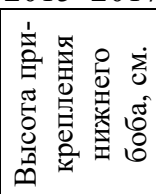 & 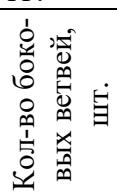 & 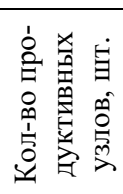 & 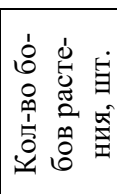 & 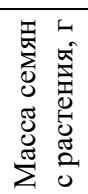 & 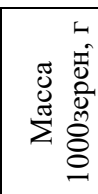 \\
\hline Ст. Камила 1255 & 50,3 & 23,7 & 2,3 & 16,0 & 16,7 & 16,7 & 237 \\
\hline Ezbsen Sponishe & 53,7 & 23,3 & 2,3 & 17,3 & 17,3 & 21,7 & 217 \\
\hline 30-Б & 44,3 & 26,0 & 2,0 & 15,3 & 15,3 & 19,3 & 243 \\
\hline $34-5$ & 47,5 & 27,0 & 2,0 & 12,0 & 12,0 & 14,0 & 260 \\
\hline F97-63 & 48,5 & 28,5 & 2,5 & 15,5 & 19,5 & 20,5 & 260 \\
\hline 13-Б & 42,3 & 23,3 & 2,0 & 12,3 & 12,3 & 12,3 & 263 \\
\hline F97-25/1 & 43,3 & 22,7 & 2,0 & 20,0 & 20,0 & 23,3 & 263 \\
\hline F92-52 & 56,0 & 32,0 & 4,5 & 36,0 & 37,5 & 41,0 & 265 \\
\hline $28-Б$ & 48,0 & 30,0 & 3,0 & 19,7 & 19,7 & 25,3 & 267 \\
\hline F97-121 & 53,7 & 22,0 & 3,7 & 26,0 & 26,0 & 29,0 & 267 \\
\hline F00-21 & 59,0 & 41,5 & 3,5 & 23,5 & 30,0 & 31,0 & 270 \\
\hline $33-5$ & 44,0 & 25,0 & 2,3 & 9,3 & 13,3 & 15,3 & 273 \\
\hline \begin{tabular}{|l|} 
TH45-1-01 \\
\end{tabular} & 49,3 & 29,3 & 2,0 & 15,3 & 20,0 & 21,3 & 277 \\
\hline F03-34-1 & 51,3 & 30,7 & 2,3 & 16,7 & 17,3 & 21,7 & 285 \\
\hline F97-14 & 58,5 & 42,0 & 4,0 & 29,5 & 32,0 & 32,0 & 290 \\
\hline Высокорослый & 50,7 & 32,0 & 1,3 & 24,3 & 24,3 & 26,0 & 297 \\
\hline F02-04 & 53,7 & 27,0 & 3,7 & 28,0 & 28,0 & 32,0 & 303 \\
\hline F97-60 & 55,0 & 30,0 & 4,0 & 27,5 & 27,5 & 36,0 & 300 \\
\hline F98-30 & 49,7 & 24,7 & 3,0 & 23,7 & 24,0 & 26,7 & 303 \\
\hline
\end{tabular}

В сухостепной зоне Алматинской области (Карой) за период 20152017 гг. по сравнению со стандартным сортом Камила 1255 в группе скороспелых и среднеспелых номеров выделено 3 номера, со средней урожайностью по годам 5,$1 ; 7,1 ; 7,9$ ц/га, которые достоверно превосходят по урожайности стандарт Камила 1255 на 1,3-3,0 ц/га (табл. 2).

В группе среднеспелых за 3 года исследований выделено 3 номера, средняя урожайность по годам выделенного образца составила 4,2; 5,2; 7,1 ц/га которые достоверно превосходят по урожайности стандарт Камила 1255 на 1,4 ц/га.

В группе среднепоздних, за 3 года исследований выделено 2 номера, средняя урожайность по годам выделенного образца составила 7,1; 6,2; 7,5 ц/га, которые достоверно превосходят по урожайности стандарт Камила 1255 на 2,2-2,3 ц/га. 
Таблища 2 - Урожайность выделившихся сортов нута питомника конкурсного сортоиспытания 2015-2017 гг.

\begin{tabular}{|c|c|c|c|c|c|c|c|c|c|}
\hline \multirow[b]{3}{*}{ Номер } & \multicolumn{9}{|c|}{ Год исследования } \\
\hline & \multicolumn{2}{|c|}{2015} & \multicolumn{2}{|c|}{2016} & \multicolumn{2}{|c|}{2017} & \multicolumn{3}{|c|}{ за три года } \\
\hline & 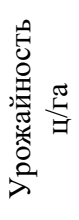 & 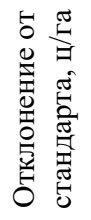 & 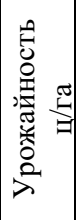 & 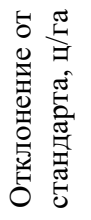 & 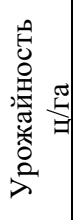 & 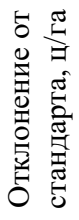 & 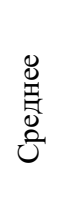 & 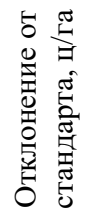 & 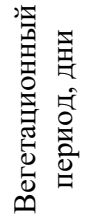 \\
\hline Ст. Камила 1255 & 4,0 & - & 4,2 & - & 6,0 & - & 4,7 & 0,0 & 83 \\
\hline \multicolumn{10}{|c|}{ Раннеспелые и среднеранние образцы (1 группа спелости) } \\
\hline F02-04 & 7,2 & 3,2 & 7,4 & 3,2 & 8,4 & 2,4 & 7,7 & 3,0 & 78 \\
\hline F97-121 & 3,9 & $-0,1$ & 7,0 & 2,8 & 8,2 & 2,2 & 6,3 & 1,6 & 78 \\
\hline TH45-1-01 & 4,1 & 0,1 & 6,8 & 2,6 & 7,1 & 1,1 & 6,0 & 1,3 & 80 \\
\hline \multicolumn{10}{|c|}{ Среднеспелые образцы (2 группа спелости) } \\
\hline $30-5$ & 1,6 & $-2,4$ & 7,3 & 3,1 & 6,7 & 0,7 & 5,2 & 0,5 & 85 \\
\hline Высокорослый & 7,0 & 3,0 & 4,2 & $-0,0$ & 7,2 & 1,2 & 6,1 & 1,4 & 88 \\
\hline Ezbsen Sponishe & 4,0 & $-0,0$ & 4,2 & $-0,0$ & 7,5 & 1,5 & 5,2 & 0,5 & 88 \\
\hline \multicolumn{10}{|c|}{ Среднепоздние образцы (3 группа спелости) } \\
\hline 28-Б & 6,8 & 2,8 & 6,4 & 2,2 & 7,9 & 1,9 & 7,0 & 2,3 & 93 \\
\hline Мальхотра & 7,4 & 3,4 & 6,0 & 1,8 & 7,2 & 1,2 & 6,9 & 2,2 & 93 \\
\hline $\mathrm{HCP}_{095}$ & 1,0 & & 0,65 & & 0,85 & & & & \\
\hline
\end{tabular}

В среднем, по результатам изучения в питомнике конкурсного сортоиспытания в среднеранней ранней группе превышает по урожайности стандартного сорта Камила 1255, номер (F02-04) на 3,0 ц/га и номер (F97-121) на 1,6 ц/га. В среднеспелой группе номер (Высокорослый) на 1,4 ц/га.

В 2017 году передан на ГСИ сорт Сәтті. Урожайность на полуобеспеченной богаре за период 2015-2017 гг. 16,9 ц/га, а на жесткой богаре 7,6 ц/га. Содержание белка в зерне 31,9 \%, содержание масла 12,0 \%. Вегетационный период, наполуобеспеченной богаре, в среднем составил 90-97 дней, а на жесткой богаре в среднем составляет 78-88 дней. Сорт предназначен для возделывания на Юго-Востоке Казахстана и на неполивных землях Западного Казахстана.

\section{Список литературь}

1. Асатуллоев И.А. Исследование биохимического и ферментативного комплекса бобовых культур Таджикистана: автореферат на соискание ученой степени кандидата технических наук. - Москва, 2008. - 21 с.

2. Зотиков В.И. Зернобобовые культуры - источник растительного белка. - Орел: 
ГНУ ВНИИЗБК, 2010. - 268 с.

3. Столяров О.В., Федотов В.А., Демченко Н.И. Нут (Cicer arietinum L.): Монография. - Воронеж: Изд-во Воронежского государственного университета, 2004. - 256 с.

4. Muehlbauer F.J., Tullu A. Cicer arietinum L. NewCROP FactSHEET // http://www.hort.purdue.edu/newcrop/cropfactsheets/Chickpea.html, 1997.

5. Altaf N., Ahmad M.S. Chickpea (Cicer arietinum L.) // Biotechnology in Agriculture and Forestry. Vol. 10. Legumes and Oilseed Crops I. - Berlin Heidelberg: Springer-Verlag, 1990. - P. 100-113.

6. Saxena M.C. Problems and potential of chickpea production in nineties. In Chickpea in the nineties: Proceedings of the second International Workshop on the chickpea Improvement, 4-8 Dec 1989, ICRISAT Center, Patancheru, India, 1990.

7. Булынцев С.В., Балашов А.В. Генетические ресурсы мировых коллекций нута // Вестник РАСХН. - 2010. - №6. - С. 42-45.

8. Мартьянова А.И. Зернобобовые: распространение, закупки, химический состав и ценность // Зерновые культуры. - 2001. - №1. - С. 24-25.

9. Лиманская В.Б., Шектыбаева Г.Х. Результаты конкурсного сортоиспытания сортов нута в засушливых условиях Западно-Казахстанской области // Межд. научнопрак. конф. - 2017. - С. 176-178.

10. Лиманская В.Б. Культура нута для очень континентальных условий Западного Казахстана // Вавилосвкие чтения - 2015: Сборник статей Международной научнопрактической конференции, посвященной 128-й годовщине со дня рождения академика Н.И. Вавилова. - Саратов, 2015. - С. 224-225.

DOI 10.18699/GPB2020-08

\section{Идентификация генов устойчивости к стеблевой ржавчине в интрогрессивнх линиях яровой мягкой пшеницы селекции НИИСХ Юго-Востока с использованием молекулярных маркеров}

Баранова O.A. ${ }^{1}$ к.б.н., в.н.с.; Сибикеев C.H. ${ }^{2}$, Дружин A.E. ${ }^{2}$

${ }^{1}$ ФБНУ «Всероссийский научно-исследовательский институт защчить растений», Санкт-Петербург, Россия;

${ }^{2}$ ФГБНУ «Научно-исследовательский институт сельского хозяйства юговостока» (НИИСХ Юго-Востока), Саратов, Россия.

*e-mail: baranova_oa@mail.ru

В работе проанализированы 73 интрогрессивные линии яровой мягкой пшениць на устойчивость к льсогорской, казанской и омской популяциям стеблевой ржавчины и наличие известных $\mathrm{Sr}$ генов. В проанализированных интрогрессивных линиях идентифицированы гень Sr31/Lr26, Sr25/Lr19, Sr28, Sr22, Sr35, Sr57/Lr34 и Sr38/Lr37. Сочетание генов Sr31+Sr25 было идентифицировано у 6 линий (8,2\%). У семи линий идентифицировано сочетание генов $S r 25+S r 28$, у двух линий - Sr25+Sr35. B трех разных линиях идентифициированы сочетания генов - Sr25+Sr31+Sr57, 
$\operatorname{Sr} 31+\operatorname{Sr} 28+\operatorname{Sr} 38$ u $\operatorname{Sr} 25+\operatorname{Sr} 57+\operatorname{Sr} 38$.

Ключевые слова: яровая мягкая пшеница, интрогрессивные линии, Puccinia graminis f. sp. tritici, $\mathrm{Sr}$ гены.

\section{Identification of the stem rust resistance genes in introgression lines of spring bread wheat of ariser breeding by using molecular markers}

Baranova O.A. ${ }^{1}$, Sibikeev S.N. ${ }^{2}$, Druzhin A.E. ${ }^{2}$

${ }^{1}$ All-Russian Institute of Plant Protection (FSBSI VIZR), St. Petersburg-Pushkin, Russia,baranova_oa@mail.ru. ${ }^{2}$ Agricultural Research Institute for the SouthEast Region (ARISER), Saratov, Russia.

The 73 spring bread wheat introgressive lines have been analyzed for resistance to Lysogorsk, Kazan and Omsk stem rust populations and for the presence of known Sr-genes. Sr31/Lr26, Sr25/Lr19, Sr28, Sr22, Sr35, Sr57/Lr34 and Sr38/Lr37 genes were identified in the analyzed introgressive lines. The combination of Sr31+Sr25 genes was identified in the six lines (8.2\%). The combination of Sr25 + Sr28 genes was identified in seven lines, Sr $25+$ Sr35 in two lines. In the three different lines the combinations - Sr $25+\operatorname{Sr} 31+\operatorname{Sr} 57, \operatorname{Sr} 31+\operatorname{Sr} 28+\operatorname{Sr} 38$ and $\operatorname{Sr} 25+\operatorname{Sr} 57+$ Sr 38 were identified.

Key words: spring bread wheat, introgression lines, Puccinia graminis $f$. sp. tritici, Sr-genes.

В последние годы наблюдается усиление вредоносности стеблевой ржавчины Puccinia graminis f. sp. tritici Eriks. \& Henn на территории Российской Федерации: эпифитотийное развитие болезни отмечалось в 2015-2019 годах в Западной Сибири и Нижнем Поволжье. Сохраняется угроза проникновения в РФ высоковредоносной расы возбудителя стеблевой ржавчины Ug99. В связи с этим большое значение приобретает оценка генетического потенциала селекционного материала пшеницы и идентификация генов устойчивости, эффективных не только против местных популяций патогена, но и против расы Ug99.

Целью нашей работы была оценка интрогрессивных линий пшеницы на устойчивость к стеблевой ржавчине и идентификация эффективных $\mathrm{Sr}$ генов с использованием молекулярных маркеров.

В работе анализировали селекционный материал НИИСХ Юго-Востока (73 интрогрессивных линий). Размножение популяций P. graminis и оценку устойчивости в лабораторных условиях проводили по методикам, принятым в мировой практике [2]. Тип реакции определяли по стандартной шкале [10]. ДНК выделяли из 5-ти дневных проростков с использованием цетилтриметиламмониумбромида (СТАВ) [7]. Разделение продуктов амплификации проводили в $2 \%$ агарозных гелях, окрашенных бромистым эти- 
дием. Положительным контролем служили изогенные линии и сорта с известными $S r$ - генами, негативным контролем - восприимчивый сорт Хакасская. Для идентификации генов устойчивости $(S r 2, S r 22, S r 24, S r 25, S r 26$, $\operatorname{Sr} 28, \operatorname{Sr} 31, \operatorname{Sr} 32, \operatorname{Sr} 35, \operatorname{Sr} 36, \operatorname{Sr} 38$ и $S r 57)$ использовали ДНК маркеры, рекомендованные для маркер вспомогательной селекции (MAS): $S r 2$-csSr2 [4], Sr22 - Xbarc121 [13], Sr24/ Lr24 -Sr24\#12 и Sr24\#50 [6], Sr25/Lr19 - Gb [8], Sr26 - Sr26\#43 [6], Sr28 - wPt-7004-PCR [9], Sr31/Lr26 - Scm9 [12], Sr32 csSr32\#2 [5], Sr35 - Xcfa2170 [14], Sr36 - Xstm773-2 [11], Sr38/Lr37 VENTRIUP-LN2 [1], Sr57/Lr34 - csLV34 [3].

На первом этапе работы 73 линии были оценены на устойчивость к трем популяциям стеблевой ржавчины на стадии проростков в лабораторных условиях. К казанской популяции патогена были устойчивы 32 линии (из них 8 гетерогенны по устойчивости), к лысогорской популяции были устойчивы 25 линий (из них 14 гетерогенны) и к омской популяции P. graminis были устойчивы 54 линии из 73. Только 10 линий $(13,7 \%)$ были устойчивы ко всем, взятым в анализ популяциям патогена.

Из генов, неэффективных к Ug99, но эффективных к местным популяциям стеблевой ржавчины в линиях был идентифицирован ген $\operatorname{Sr} 31$. Для его идентификации был использован маркер scm9, выявляющий ржаную транслокацию 1BL.1RS, несущую комплекс генов устойчивости к стеблевой $S r 31$, бурой $\operatorname{Lr26}$, желтой $\operatorname{Yr} 9$ ржавчинам и мучнистой росе $P m 8$. Данная транслокация (ген $S r 31$ ) была идентифицирована у 7 линий из 73 (9,6 \% образцов). Пять линий, несущих транслокацию 1BL.1RS, были устойчивы ко всем, взятым в анализ, популяциям патогена. Две линии были гетерогенны по данной транслокации. Ген $S r 38$ был идентифицирован в трех линиях с использованием праймеров VENTRIUP-LN2. Из генов, эффективных к $\mathrm{Ug} 99$, практически у всех линий (в 56 линиях), с использованием рекомендованного для маркер вспомогательной селекции маркера $G b$ идентифицирован ген $S r 25$ (76,7 \% линий). В девяти линиях с использованием маркера $w P t-7004-P C R$ был идентифицирован ген $S r 28$, однако данный факт будет подтверждаться с использованием других маркеров. Ген возрастной устойчивости $S r 57 / \operatorname{Lr} 34$ был идентифицирован в 11 линиях. Кроме того, в двух линиях ([Л503/ Sr35] и [Л503/ Sr35*4//Л503]) с помощью маркера Xcfa 2170 было подтверждено наличие $\operatorname{Sr35}$, а в линии [Фаворит/ W3534//Фаворит] с использованием маркера Xbarc121 подтверждено наличие гена $S r 22$. Для идентификации гена возрастной устойчивости $S r 2$ был использован CAPS маркер $c s S r 2$. Продукт амплификации с праймерами $c s S r 2 F / R$ наблюдался практически у всех взятых в анализ образцов. После рестрикции продукта амплификации рестриктазой $B s p H I$, диагностический фрагмент 172 п.о. наблюдали только в контрольных сортах Arthur и Oasis. Несмотря на наличие в родословных интрогрессивных линий доноров генов $S r 24$ и $S r 26$ в образцах эти гены не были идентифицированы, также не были обнаружены 
гены $S r 36$ и $S r 32$. Таким образом, в проанализированных интрогрессивных линиях был в основном идентифицирован ген $S r 25$. Сочетание генов $S r 31+S r 25$ было идентифицировано у 6 линий $(8,2 \%)$. У семи линий идентифицировано сочетание генов $S r 25+S r 28$, у двух линий $-S r 25+S r 35$. В трех разных линиях идентифицированы сочетания генов - Sr25+Sr31+Sr57, $\operatorname{Sr} 31+\operatorname{Sr} 28+\operatorname{Sr} 38$ и $\operatorname{Sr} 25+\operatorname{Sr} 57+\operatorname{Sr} 38$. Гены $\operatorname{Sr} 2, \operatorname{Sr} 24, \operatorname{Sr} 26, \operatorname{Sr} 32$ u $\operatorname{Sr} 36$ в анализируемых линиях обнаружены не были.

Благодарности: Работа выполнена при поддержке гранта РФФИ № 18-016-00170 а.

\section{Список литературы}

1. Helguera M. PCR assays for the Lr37-Yr17-Sr38 cluster of rust resistance genes and their use to develop isogenic hard red spring wheat lines / Helguera M., Khan I.A., Kolmer J., et al. // Crop Science - 2003. - V.43. - P. 1839-1847.

2. Jin, Y. Characterization of seedling infection types and adult plant infection responses of monogenic Sr gene lines to race TTKS of Puccinia graminis f. sp. Tritici / Jin, Y., Singh, R. P., Ward, R. W., et al. // Plant Disease - 2007. - V.91. - P. 1096-1099.

3. Lagudah E.S. Molecular genetic characterization of the Lr34/Yr18 slow rusting resistance gene region in wheat / Lagudah E.S., McFadden H., Singh R.P. et al. // Theor. Appl. Genet. - 2006. - V.114. - P. 21-30.

4. Mago R. An accurate DNA marker assay for stem rust resistance gene $S r 2$ in wheat / Mago R., Simkova, Brown-Guedira H.G., et al. // Theor. Appl. Genet. - 2011. V.122. - P. 735-744. DOI:10.1007/s00122-010-1513-4.

5. Mago R. Development of wheat-Aegilops speltoides recombinants and simple PCR-based markers for $\mathrm{Sr} 32$ and a new stem rust resistance gene on the 2S\#1 chromosome / Mago R., Verlin D., Zhang P., et al. // Theor. Appl. Genet. - 2013. - V.126. - P. 2943-2955.

6. Mago R. Development or PCR markers for the selection of wheat stem rust resistance genes Sr24 and Sr26 in diverse wheat germplasm / Mago R., Bariana H.S., Dundas I.S., et al.// Theor. Appl. Genet. - 2005. - V.111. - P. 496-504.

7. Murray M.G. Rapid isolation of high molecular weight plant DNA / Murray M.G., Thompson W.F. // Nucleic Acids Res. - 1980. - V. 8(19). - P. 4321-4326. DOI:10.1093/nar/8.19.4321.

8. Prins R. AFLP and STS tagging of $\operatorname{Lr} 19$, a gene conferring resistance to leaf rust in wheat / Prins R., Groenewald J. Z., Marais G. F., et al. // Theor. Appl. Genet. - 2001. V.103. - P. 618-624.

9. Rouse M.N.Identification of markers linked to the race Ug99 effective stem rust resistance gene Sr28 in wheat (Triticum aestivum L.) / Rouse MN, Nava IC, Chao S, Anderson JA, Jin Y. // Theoretical and Applied Genetics - 2012. - V.125. - P. 877-885. DOI: $10.1007 / \mathrm{s} 00122-012-1879-6$

10. Stakman E.C.Identification of physiologic races of Puccinia graminis var. tritici / Stakman E.C., Stewart D.M., Loegering W.Q. // United States Department of AgricultureAgricultural Research Service - 1962. - E-617 (rev).

11. Tsilo T.J. Diagnostic microsatellite markers for detection of stem rustresistance gene Sr36 in diverse genetic backgrounds of wheat / Tsilo T.J., Jin Y., Anderson J.A. // Crop Sci. - 2008. - V.48. - P. 253-261.

12. Weng Y. PCR-based markers for detection of different sources of 1AL.1RS and 
1BL.1RS wheat-rye translocations in wheat background / Weng Y., Azhaguvel P., Devkota R.N., Rudd J.C. // Plant Breeding. - 2007. - V.126. - P. 482-486.

13. Yu L.X. Haplotype diversity of stem rust resistance loci in uncharacterized wheat lines / Yu L.X., Liu S., Anderson J.A., Singh R.P., et al. // Mol. Breeding. - 2010. -V. 26. - P. 667-680. DOI: 10.1007/ s11032-010-9403-7

14. Zhang W. Genetic maps of stem rust resistance gene Sr35 in diploid and hexaploid wheat / Zhang W., Olson E., Saintenac C. et al. // Crop Sci. - 2010. - V.50. - P. 24642474. DOI: $10.2135 /$ cropsci2010.04.0202

DOI 10.18699/GPB2020-09

\section{Создание генофонда скороспелых ремонтантных $F_{1}$ гибридов крупноплодной земляники (Fragaria $\times$ ananassa Duch.)}

Батурин С.О., к.б.н., н.с.

ФИЦ ИЦиГ СО РАН; СибФТИ СФНЦА РАН, Новосибирск, Россия. e-mail: SO_baturin@mail.ru

В южной части Западной Сибири у большинства ремонтантных сортов срок созревания ягоды составляет около 30 суток. Нами в экспериментах получены нейтральнодневные $F_{1}$ гибриды № 17/9-15-1 и № 17/9-17-3 с

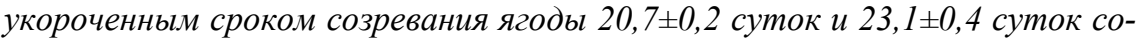
ответственно, а также гибриды с розовой окраской венчика № 16/5-30-5 и

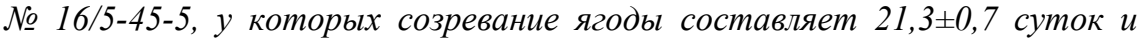

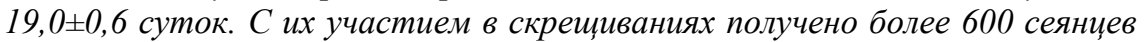
для отбора наиболее эффективных комбинаций скрещуивания для получения скороплодных $F_{1}$ нейтральнодневных гибридов.

Ключевье слова: Fragaria $\times$ ananassa Duch, скороспелость, $F_{1}$ гибриды, генофонд, скрещивания, отбор.

\section{Creation of a gene pool of the fast ripening $F_{1}$ hybrids of garden strawberry (Fragaria $\times$ ananassa Duch.)}

Baturin Sergey Olegovich, Institute of Cytology and Genetics, Siberian Branch of Russian Academy of Sciences, Novosibirsk

In most everbearing strawberry varieties, when grown in the southern part of Western Siberia, the ripening period of the berry is about 30 days. In our experiments, we obtained day neutral $F_{1}$ hybrids №17/9-15-1 and №17/9-17-3 with a shortened berry ripening period of $20.7 \pm 0.2$ days and $23.1 \pm 0.4$ days, respectively, and also pink-flowering hybrids №16/5-30-5 and №16/5-45-5, which have berry ripening of $21.3 \pm 0.7$ days and $19.0 \pm 0.6$ days. We used these hybrids in crosses and got over 600 seedlings to select the most effective cross combinations 
to produce fast ripening day neutral $F_{l}$ hybrids.

Key words: Fragaria $\times$ ananassa Duch, precocity, gene pool, $F_{1}$ hybrid day-neutral strawberries, crosses, selection.

Сорта земляники крупноплодной $($ Fragaria $\times$ ananassa Duch., $2 \mathrm{n}=8 \mathrm{x}=56$ ) c ремонтантным типом цветения и плодоношения становятся в настоящее время все более востребованными как среди сельскохозяйственных производителей плодово-ягодной продукции, так и садоводов-любителей. Популярность таких сортов обусловлена высоким урожаем и возможностью многократного сбора урожая. Ягоды можно собирать уже в первый год вегетации вплоть до установления снежного покрова. В последнее время для ремонтантных сортов активно реализуется принципиально новый подход к селекции, а именно, создание сортов $\mathrm{F}_{1}$ ремонтантной крупноплодной земляники, которые при выращивании из семянок в потомстве сохраняют болееменее однородность по основным биоморфологическим признакам [1-3]. В Сибири сорта $F_{1}$ ремонтантной крупноплодной земляники хотя и пользуются популярностью у садоводов, но их выращивание и эксплуатация ограничивают часто низкая всхожесть семян [4] и растянутые сроки созревания ягоды. Для ремонтантных сортов срок созревания ягоды с момента опыления составляет около 30 дней [5]. Для сибирского региона с коротким вегетационным периодом положительных температур эксплуатация ремонтантных сортов с растянутым сроком созревания ягод становится малоэффективной. Тем не менее, генофонд $F$. $x$ ananassa позволяет отбирать генотипы с укороченным сроком созревания ягоды до 20 дней.

В условиях изменения климата в России и в частности в сибирском регионе $[6,7]$ в сторону увеличения суммы положительных температур становится актуальным создание сортов $F_{1}$ ремонтантных гибридов с укороченным сроком созревания ягоды, позволяющих многократно собирать урожай не только в августе, но и в сентябре и октябре в сибирском регионе.

Цель данной работы - создание генофонда $F_{1}$ ремонтантных скороспелых гибридов для их использования в селекции ремонтантных сортов F. $\times$ ananassa.

В эксперимент включены сорта и гибриды ремонтантной крупноплодной земляники коллекции земляник ФИЦ Института цитологии и генетики СО РАН. Для получения семян были использованы инбридинг, сортолинейные скрещивания, межлинейная гибридизация. Анализ семенного потомства проводили в течение 5 месяцев с июня по октябрь.

В настоящее время известно, что созревание ягод у земляники контролируется как внутренними факторами, такими как фитогормоны, включая этилен, содержанием сахарозы и абсцизовой кислоты (АБК) [8], так и сигналами внешней среды - температура, плотность фотосинтетического фотонного потока и доступность воды. Температура воздуха особенно важна 
для созревания ягод [5]. Недавние исследования механизмов контролясозревания ягоды земляники, обозначили существенную роль специфических белков, регулирующих развитие и созревание ягоды земляники $[9,10]$, что указывает на генетически запрограммированный срок созревания ягоды и дает нам основание для построения направленных скрещиваний с целью отбора скороплодных нейтральнодневных гибридов $\mathrm{F}_{1}$.

Первые $\mathrm{F}_{1}$ гибриды ремонтантной крупноплодной земляники с сокращенным периодом созревания плода нами были получены в рамках экспериментов по отработке технологии семенного воспроизведения нейтральнодневных $F_{1}$ гибридов крупноплодной земляники $[4,11]$. Формирование генофонда скороспелых $\mathrm{F}_{1}$ нейтральнодневных гибридов началось с семенного потомства гибрида № 98/4-17-6 с непрерывным типом цветения и плодоношения, полученного в результате двухступечатых скрещиваний с привлечением геномов сортов Sara и Elin (Швеция) и ремонтантных партеногенетических потомков сорта Комсомолка [12]. В дальнейшем используя инбридинг и сортолинейную гибридизацию были получены серии потомств среди которых провели отбор на сокращенный период созревания ягоды. Таким образом, были получены гибриды с пестичным типом цветков № 17/9-15-1

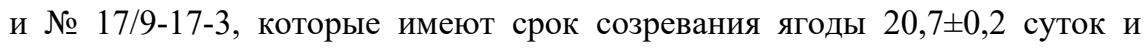
$23,1 \pm 0,4$ суток соответственно, тогда как в южной части Западной Сибири у большинства ремонтантных сортов срок созревания ягоды составляет около 30 суток. Ягоды этих образцов обладают хорошо выраженным ароматом, десертным вкусом, средней плотностью, классической округло-конической формы, равномерно окрашенный в темно-красный цвет. В настоящее время они использованы в качестве материнской формы в скрещиваниях с гибридом № 11/А-1-5 (21,2 0 ,3 суток созревания ягоды) для анализа эффективности комбинации скрещивания и отбора перспективных сеянцев по укороченным срокам созревания среди более чем 400 сеянцев. Кроме того, в эксперименты по выделению скороспелых нейтральнодневных гибридов включили получение гибридов $\mathrm{F}_{1}$ с розовой окраской венчика, которые по современным оценкам являются культурой декоративно-ягодного использования [2, 13]. Гибриды с розовой окраской венчика № 16/5-30-5 и № 16/5-45-5, имеющие срок созревания ягоды $21,3 \pm 0,7$ суток и $19,0 \pm 0,6$ суток соответственно, получены в результате трехступенчатых скрещиваний с использованием первоначально гибрида $\mathrm{F}_{1}$ № $\mathrm{C} 141$ (Нидерланды) с интенсивно розовой окраской венчика. Гибридный фонд сеянцев, полученных с участием гибридов № 16/5-30-5 и № 16/5-45-5, составляет более 200 растений. Таким образом, в настоящее время нами создан и пополняется генофонд скороспелых 
$\mathrm{F}_{1}$ гибридов для оценки эффективности комбинаций скрещивания при разработке технологии получения нейтральнодневных сортов крупноплодной земляники с семенным способом репродукции.

\section{Список литературь}

1. Bentvelsen G.C.M., Bouw E., Veldhuyzen van Zanten J.E. Breeding strawberry (Fragaria $\times$ ananassa Duch.) from seed. Acta Hort. 439 (ISHS), 1997. - P. 149-153.

2. Bentvelsen G.C.M., Bouw E., Breeding strawberry $F_{1}$-hybrids for vitamin $\mathrm{C}$ and sugar content // Proceedings of the fourth international strawberry symposium / Acta Hort. 567 (ISHS). - 2000. - P. 813-814.

3. Hughes B. Developing F1-hybrid seed-propagated dayneutral strawberry cultivars, 2015 // URL: http://www.omafra.gov.on.ca/english/crops/hort/news/allontario/ao0915a2.htm

4. Батурин С.О., Аполинарьева И.К., Петрук В.А. Оценка всхожести семян и сортовой однородности семенного потомства ремонтантных коммерческих сортов крупноплодной земляники // Сибирский вестник сельскохозяйственной науки. - 2010. № 1. - C. 40-45.

5. Perkins-Veazie P. Growth and ripening of strawberry fruit. // Horticultural Reviews: Wiley \& Sons. - 1995. - Vol. 17. - P. 267-297.

6. Паромов В.В., Земцов В.А., Копысов С.Г. Климат Западной Сибири в фазу замедления потепления (1986-2015 гг.) и прогнозирование гидроклиматических ресурсов на 2021-2030 гг. // Известия Томского политехнического университета. - 2017. Т. 328. - № 1. - С. 62-74.

7. Доклад об особенностях климата на территории Российской Федерации за 2018 год. - Москва, 2019. - 79 с.

8. Basson C.E., Groenewald J-H., Kossmann J., Cronje C., Bauer R. Sugar and acidrelated quality attributes and enzyme activities in strawberry fruits: Invertase is the main sucrose hydrolysing enzyme // Food Chemistry. - 2010. - 121. - P. 1156-1162.

9. Han Y., Dang R., Li J., Jiang J., Zhang N., Jia M., Wei L., Li Z., Li B., Jia W. Sucrose nonfermenting1-related proteinkinase2.6, an ortholog of open stomata1, is a negative regulator of strawberry fruit development and ripening // Plant Physiol. - 2015. - Vol. 167. P. 915-930.

10. Jia M, Ding N, Zhang Q, Xing S, Wei L, Zhao Y, Du P, Mao W, Li J, Li B. Jia W. A Feronia-like receptor kinase regulates strawberry (Fragaria $\times$ ananassa) fruit ripeningand quality formation // Front. Plant Sci. 2017. - 8:1099.doi: 10.3389/fpls.2017.01099

11. Аполинарьева И. К., Батурин С.О., Петрук В.А. Фенологические наблюдения в семенных потомствах ремонтантной крупноплодной земляники (Fragaria $\times$ ananassa Duch.) // Сибирский вестник сельскохозяйственной науки, 2013. - № 3. - С. 59-65.

12. Батурин С.О., Сухарева Н.Б., Малецкий С.И. Использование апомиксиса для изучения наследования ремонтантности у Земляники крупноплодной (Fragaria $\times$ ananassa Duch.) // Генетика. - 1995. - Т. 31. - № 10. - С. 1418-1424.

13. Батурин С.О., Хапова С.А. Генетические ресурсы селекции розовоцветковой крупноплодной земляники (Fragaria $\times$ ananassa Duch.) Плодоводство и ягодоводство России. М.: 2016, Т. XXXXIV. - С. 102-106. 


\section{Основные подходы к созданию перспективных сортов яровой мягкой пшеницы для Западной Сибири}

Белан И.А. ${ }^{1 *}$, к.с-х.н., зав. лабораторией; Россеева Л.П. ${ }^{1}$, к.с-х.н., в.н.с.; Блохина Н.П. ${ }^{1}$, с.н.с.; Немченко В.В. ${ }^{2}$, д.с-х.н.; Абакумов С.Н. ${ }^{3}$, зам. директора; Трубачеева Н.В. ${ }^{4}$, к.б.н, н.с.; Першина Л.А. ${ }^{4}$, д.б.н., г.н.с.

${ }^{l}$ ФГБНУ «Омский АНЦ», Омск, Россия;

${ }^{2}$ ООО НЦ «Кургансемена», Курган, Россия;

${ }^{3}$ ФГУП «Опеновское», Тюменская обл., Россия;

${ }^{4}$ ИЦиГ СО РАН, Новосибирск, Россия.

*e-mail: belan_skg@mail.ru

Рассмотрены результаты создания перспективных сортов яровой мягкой пшениџы для Западной Сибири с использованием ряда подходов. Показана эффективность использования в гибридизаиии коммерческих сортов и перспективных линий местной селекции и созданных в других регионах; интрогрессивных линий, носителей генов устойчивости к листостебельным патогенам; аллоплазматических ДГ-линий, сочетающих ичитоплазму культурного ячменя $H$. vulgare и генов устойчивости к биотическим факторам.

Ключевые слова: пшеница, аллоплазматические ДГ-линии, сорта, урожайность, устойчивость.

\section{Main approaches for creating promising varieties of spring bread wheat for Western Siberia}

Belan Igor Aleksandrovich ${ }^{1}$, Rosseeva Ludmila Petrovna ${ }^{l}$, Blokhina, Natalya Pavlovna ${ }^{l}$, Nemchenko Vladimir Vasilyevich ${ }^{2}$, Abakumov Sergey Nikolaevich ${ }^{3}$, Trubacheeva Natalya Victorovna ${ }^{4}$, Pershina Lidiya Aleksandrovna ${ }^{4}$

${ }^{1}$ FGBSI "Omsk ASC", Omsk, Russia;

${ }^{2} S C$ "Kurgansemena", Kurgan, Russia;

${ }^{3}$ FSUE "Openovskoe", Tyumen region, Russia;

${ }^{4}$ IC\&G, SB RAS, Novosibirsk, Russia.

The results of creating promising varieties of springbread wheat for Western Siberia using a number of approaches are considered. The effectiveness of involvement in hybridization when creating source material for breeding commercial varieties and promising lines created in other regions was shown; introgression lines, carriers of genes for resistance to leaf-stem pathogens; alloplasmic DH lines combining the cytoplasm of cultured barley H.vulgare and genes of resistance to biotic factors.

Key words: wheat, alloplasmic DH lines, varieties, productivity, stability. 
Яровая мягкая пшеница - одна из наиболее ценных продовольственных культур, возделываемых на значительных площадях в Западной Сибири. Основные направления селекции на протяжении последних 40 лет были связаны с увеличением урожайности, адаптивности и качества продукции. За эти годы в Госреестр России и Казахстана было включено 29 сортов лаборатории селекции яровой мягкой пшеницы ФГБНУ «Омский АНЦ», в настоящее время допущено к возделыванию 24 сорта лаборатории.

В последние годы, начиная с 2015 по 2019 гг., в Западной Сибири отмечены контрастные погодные условия и эпифитотии листостебельных патогенов. В связи с этим к сортам, обладающим устойчивостью к неблагоприятным биотическим и абиотическим факторам и характеризующимся повышенной урожайностью, проявляется большой интерес, поскольку возделывание таких сортов приводит к уменьшению потерь урожая. Один из подходов для реализации селекционных программ заключается в создании рекомбинантных генотипов, используемых в качестве исходных форм, на основе привлечения в скрещивания линий, выделенных из коммерческих и перспективных сортов, полученных в других регионах. В результате были получены такие сорта как Омская 12, Омская 18, Омская 28, Омская 32, Омская 36 и др.

Другой подход основан на использовании в гибридизации при создании исходного материала интрогрессивных линий, носителей генов устойчивости к листостебельным патогенам. Источниками таких генов в наших работах являются рожь посевная $S$. cereale и дикорастущие сородичи мягкой пшеницы (T. durum, T. dicoccum, T. dicoccoides, Ag. elongatum, Ag. intermedium, T. timopheevii). В процессе создания и проработки селекционного материала проводятся лабораторные и полевые оценки на устойчивость к патогенам бурой и стеблевой ржавчины $[1,2]$, а также контроль за наличием генов устойчивости к грибным патогенам [3].

Кроме того, в качестве исходного материала используются аллоплазматические ДГ-линии мягкой пшеницы, сочетающие цитоплазму культурного ячменя H.vulgare и комплексы генов устойчивости к грибным патогенам. Так, из гибридной популяции, полученной в результате гибридизации (аллоплазматическая линия ДГ-17 // Laj 3302 / Дружина) были выделены перспективные линии яровой мягкой пшеницы, имеющие пшенично-ржаную транслокацию $1 \mathrm{RS} .1 \mathrm{BL}$ (носитель комплекса генов устойчивости Lr26/Sr31/Yr9/Pm8). Три из этих линий Л-311(4), Л-311(5) и Л-311(6) были переданы на ГСИ. По итогам государственного сортоиспытания в 2016 г. среднеспелый сорт Сигма (№ патента РФ 7950) включен в Госреестр РФ по 10 региону. В 2019 г. этот сорт возделывался в Омской области на площади 31024,5 га. В 2019 г. среднепоздний сорт Уралосибирская 2 (№ патента РФ 9568) включен в Госреестр РФ по 9 и 10 регионам. На момент включения сорта в Госреестр РФ площади составили в Омской области 381 га, в Курганской - 500 га. Патент на среднеранний сорт Ишимская 11 (№ патента РФ 
10854) получен в 2020 г. Кроме того, последние два сорта проходят государственное сортоиспытание в Республике Казахстан. Эти сорта характеризуются высокой устойчивостью к стеблевой ржавчине $(И У<0,35)$ и средней к бурой ржавчине (ИУ $0,36 \div 0,65)$. Результаты GISH анализа подтвердили наличие у этих сортов пшенично-ржаной транслокации $1 \mathrm{RS} .1 \mathrm{BL}$, а метод молекулярного анализа показал наличие генов $\operatorname{Lr} 26$ и $\operatorname{Sr} 31$.

В течение пяти лет (2015-2019 гг.) сорта Сигма и Уралосибирская 2 изучались в селекционных питомниках лаборатории селекции яровой мягкой пшеницы ФГБНУ «Омский АНЦ». Стандартом для среднеспелого сорта Сигма служил сорт Дуэт, для среднепозднего сорта Уралосибирская 2 - сорт Серебристая, а для среднераннего сорта Ишимская 11 - сорт Омская 36.

Особенностью этих лет являлось массовое развитие листостебельных заболеваний. Метеорологические условия в годы исследования были контрастны и в полной мере отображали климатические особенности лесостепной зоны Омской области. Благоприятными условиями для возделывания яровой мягкой пшеницы были 2017, 2018 и 2019 гг., два года - 2015 и 2016 были неблагоприятными. В течение вегетационного периода в 2015 г. температурный режим соответствовал среднемноголетней и характеризовался избытком осадков в мае, июне и августе месяцах и недобором в июле, что привело к затягиванию периода колошение восковая спелость, а в 2016 г. температура была выше среднемноголетней, июнь и июль характеризовались избытком, а август - недобором осадков, что привело к короткому периоду колошение - восковая спелость. Такие условия были неблагоприятны как для реализации генетического потенциала сортов по урожайности, так и развитию листостебельных патогенов, однако массовому развитию этих заболеваний способствовало наличие росы на листьях и период ее продолжительности [4].

В среднем в неблагоприятные годы (2015 и 2016 гг.) по урожайности среднеспелый сорт Сигма (2,19 т/га) превзошел на 0,37 т/га сорт стандарт Дуэт (1,82 т/га). Среднепоздний сорт Уралосибирская 2 (2,16 т/га) превзошел сорт стандарт Серебристая (1,51 т/га) на 0,65 т/га, а среднеранний Ишимская $11(4,62$ т/га) - на 0,52 т/га сорт стандарт Омская 36 (4,10 т/га). В благоприятные годы потери урожайности восприимчивых к листостебельным патогенам стандартов были более значительны. Так, урожайность сорта стандарта Дуэт составила 3,45 т/га, что на 0,81 т/га ниже, чем у сорта Сигма (4,26т/га), у сорта стандарта Серебристая $(3,44$ т/га) на 1,05 т/га меньше, чем у сорта Уралосибирская 2 (4,49т/га). Среднеранний сорт Ишимская 11(4,79 т/га) в благоприятные годы превзошел по урожайности на 0,95 т/га сорт Омская 36 (3,84 т/га).

Достоинством сортов Сигма, Уралосибирская 2 и Ишимская 11 являются высокие показатели качества зерна, независимо от условий выращива- 
ния. В неблагоприятные годы масса 1000 зерен у стандартов Дуэт и Серебристая не превышала 26 г., а у сортов Сигма и Уралосибирская 2 значительно выше - 34,7г. и 32,4 г., соответственно. В благоприятные годы разница в массе 1000 зерен была более существенной и равнялась 12,1 г. между сортом Сигма и стандартом Дуэт, а между сортом Уралосибирская 2 и стандартом Серебристая - 11,6 г. По содержанию белка в зерне новые сорта превосходили стандарты Дуэт и Серебристая в неблагоприятные годы на 1,3 и 4,05 $\%$, а в благоприятные $-1,76$ и 2,37 \%, соответственно. Преимуществом новых сортов также является содержание сырой клейковины в зерне, которое превышает 30 \%, независимо от условий выращивания, что соответствует 12 классу. Показатели качества зерна сорта Ишимская 11 по данным ФГУП «Опеновское» за 2012-2014 гг. следующие: натура зерна достигала 741 г/л, масса 1000 зерен - 38,1 г, стекловидность - $51 \%$, содержание сырой клейковины - 30,1 \%, белка - 15,27 \%, сила муки - 314 е.а., валориметр - 81 ед. вал., объем хлеба - $1010 \mathrm{~cm}^{3}$, общая хлебопекарная оценка - 4,3 балла.

Таким образом, благодаря повышенной урожайности в сочетании с высоким уровнем устойчивости к стеблевой ржавчине и хорошими хлебопекарными свойствами новые сорта Сигма, Уралосибирская 2 и Ишимская 11 могут успешно конкурировать с сортами аналогичной группы спелости.

Благодарности: Отдельные разделы работы выполнены при поддержке РФФИ (проект № 20-016-00196).

\section{Список литературы}

1. Белан И.А. Создание сортов мягкой пшеницы устойчивых к грибным заболеваниям для условий Западной Сибири и Урала / Белан И.А., Россеева Л.П., Мешкова Л.В., Блохина Н.П., Першина Л.А., Трубачеева Н.В. // Вестник Алтайского государственного аграрного университета, 2017. - № 1 (147). - С. 5-14.

2. Россеева Л.П. Селекция на устойчивость к стеблевой ржавчине яровой мягкой пшеницы в Западной Сибири / Россеева Л.П., Белан И.А., Мешкова Л.В., Блохина Н.П., Ложникова Л.Ф., Осадчая Т.С., Трубачеева Н.В., Першина Л.А. // Вестник Алтайского государственного аграрного университета, 2017. - № 7 (153). - С. 5-12.

3. Першина Л.А. Аллоплазматические рекомбинантные линии (H. vulgare)T. Aestivum с транслокацией 1RS.1BL: исходные генотипы для создания сортов мягкой пшеницы / Першина Л.А., Л.И. Белова, Трубачеева Н.В., Осадчая Т.С., Шумный В.К., Белан И.А., Россеева Л.П., Немченко В.В., Абакумов С.Н. // Вавиловский журнал генетики и селекции, 2018. - Т. 22. - № 5. - С. 544-552.

4. Першина Л.А. Изучение особенностей андрогенеза в культуре пыльников сортов и перспективной формы яровой мягкой пшеницы западносибирской селекции, различающихся наличием или отсутствием пшенично-чужеродных транслокаций / Першина Л.А., Осадчая Т.С., Бадаева Е.Д., Белан И.А., Россеева Л.П. // Вавиловский журнал генетики и селекции, 2013. - Т. 17. - № 1.- С.40-49. 


\section{Структурно-функциональные особенности новых аллелей гена цветения мягкой пшеницы VRN-B3}

Бережная А.A. ${ }^{* 1,2}$ студент, Киселева А.А. ${ }^{2}$ к.б.н., Салина Е.А. ${ }^{2}$ д.б.н. ${ }^{1}$ Новосибирский государственный университет, Новосибирск, Россия;

${ }^{2}$ Институт иитологии и генетики СО РАН, Новосибирск, Россия.

*e-mail: al.berezhnaya1@gmail.com

Проведено генотипирование коллекции яровой мягкой пшеницы для определения генетического разнообразия по основным детерминантам времени колошения. Выявлено два ранее не описанных мутантных аллеля гена

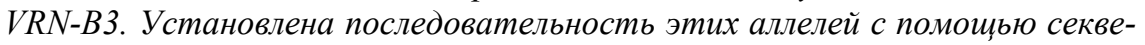
нирования, а также проведена их аннотация.

Ключевые слова: мягкая пшеница, генотипирование, новый аллель, время колошения, VRN-B3.

\section{Functional and structural characterization of new $V R N-B 3$ alleles in hexaploid bread wheat}

Berezhnaya A.A. ${ }^{* 1,2}$, Kiseleva A.A. ${ }^{2}$, Salina E.A. ${ }^{2}$

${ }^{1}$ Novosibirsk State University, Novosibirsk, Russia; ${ }^{2}$ Institute of Cytology and Genetics SB RAS, Novosibirsk, Russia.

Genotyping of common wheat collection was conducted to analyze genetic diversity of the most important wheat heading time regulators. Two previously not described mutant alleles of VRN-B3 gene were sequenced and annotated.

Key words: common wheat, genotyping, new alleles, heading time, VRN-B3.

Время колошения - сложный признак, от которого зависит адаптационная способность растения и его шансы на репродуктивный успех. Одним из ключевых генов, регулирующих этот признак, является $V R N-B 3 . V R N-B 3$ картирован на коротком плече 7В хромосомы, на $1 \mathrm{cM}$ дистальнее маркера ABC158 и на 5 сM проксимальнее микросателлитного маркера GWM569 [3]. На его экспрессию оказывают влияние гены ответа на яровизацию $(V R N-1$ и $V R N-2)$, гены чувствительности к фотопериоду ( $P P D-1)$, гены циркадных ритмов и некоторые другие гены.

Помимо интактного рецессивного аллеля $v r n-B 3$, на данный момент известно 3 мутантных аллеля $V R N-B 3$. Мутации затрагивают промоторную область изучаемого гена и приводят либо к сниженной, либо, напротив, повышенной экспрессии. Аллель Vrn-B3a обуславливает раннее цветение, его экспрессия усилена в результате инсерции ретроэлемента протяженностью 
5300 п.н. в промоторной области (Yan et al., 2006). Аллель Vrn-B3c содержит такую же инсерцию, а также дополнительные делеции 4 п.н. (в ретроэлементе) и 20 п.н. (ранее ретроэлемента), его экспрессия несколько ниже, чем у $V r n-B 3 a$ [1]. Другой аллель Vrn-B3b, содержащий инсерцию 890 п.н. в промоторной области, характеризуется значительным снижением экспрессии, и, таким образом, обуславливает задержку колошения [1].

Следует заметить, все описанные аллели очень редко встречается у культивируемых сортов $[1,2]$. Цель данной работы - выявление новых аллелей гена $V R N-B 3$ и изучение их структурно-функциональной организации.

В исследование были отобраны 93 сорта мягкой пшеницы отечественной селекции, адаптированных к условиям Западной Сибири и Урала, и различающиеся по времени колошения от среднеранних до среднепоздних. Эти образцы были генотипированы с использованием специально разработанных праймеров к гену $V R N-B 3$ для того, чтобы изучить аллельное разнообразие гена в популяции. Было показано, что у некоторых сортов длина ПЦРпродуктов отличается от ожидаемой (больше, чем у интактной последовательности $V r n-B 3$, но не соответствует ни одному известному аллелю этого гена). Обнаруженные варианты гена были отсеквенированы, также была проведена работа по аннотированию этих последовательностей.

Выявлен один сорт с инсерцией 1617 п.н., и 10 сортов с инсерцией 160 п.н. (эти аллели были обозначены как $V R N-B 3 d$ и $V R N-B 3 e$, соответственно). Инсерции расположены за 85 п.н. и 881 п.н. до сайта начала транскрипции (рисунок). На основании последовательностей описанных аллелей разработаны ПЦР маркеры, которые можно использовать для их обнаружения.

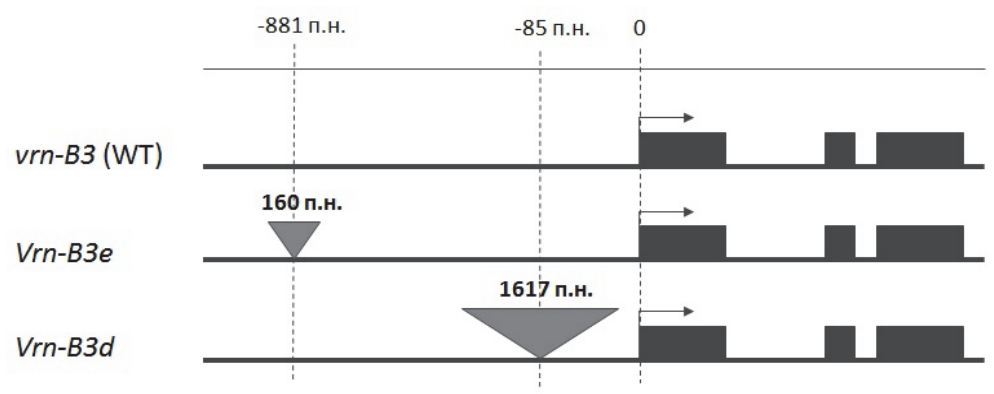

Рисунок. Расположение инсерций в промоторной области гена.

Инсерция аллеля $V R N-B 3 d$ представляет собой ретроэлемент, фланкированный повторяющимися элементами протяженностью 250 п.н., высоко гомологичный неаннотированному ретротранспозону Hordeum vulgare L. Последовательность инсерции $V R N-B 3 e$ демонстрирует высокую гомологию к ряду участков генома пшеницы, на данный момент не аннотированых. 
Таким образом, в ходе данной работы было идентифицировано и описано два новых аллеля гена $V r n-B 3$, в настоящий момент ведутся работы по оценке их фенотипического эффекта.

Благодарности: Данная работа была выполнена при поддержке РФФИ № 20-016-00059.

\section{Список литературы}

1. Chen F. [и др.]. Molecular characterization of vernalization and response genes in bread wheat from the Yellow and Huai Valley of China // BMC Plant Biology. 2013. № 1 (13).

2. Iqbal M., Shahzad A., Ahmed I. Allelic variation at the Vrn-A1, Vrn-B1, Vrn-D1, Vrn-B3 and Ppd-D1a loci of Pakistani spring wheat cultivars // Electronic Journal of Biotechnology. 2011. № 1 (14). C. 1-9.

3. Yan L. [и др.]. The wheat and barley vernalization gene VRN3 is an orthologue of FT // Proceedings of the National Academy of Sciences of the United States of America. 2006. № 51 (103). C. 19581-19586.

DOI 10.18699/GPB2020-12

\section{Скриниг генотипов риса с окрашенным перикарпом на содержание амилозы}

Беркимбай X.A. ${ }^{1,2 *}$, PhD докторант, м.н.с.; Усенбеков Б.Н. ${ }^{2}$, к.б.н., ассои. профессор; Гаркуша С.В. ${ }^{3}$, д.с-х.н.

${ }^{1}$ Казахский национальный аграрный университет, г. Алматы, Казахстан; ${ }^{2}$ Институт биологии и биотехнологии растений, г. Алматы. Казахстан; ${ }^{3}$ Федеральный научный центр риса, г. Краснодар, Россия.

*e-mail:b.horlan@bk.ru

Крахмал является полисахаридом зерновки риса состоящая из большого количества остатков глюкозы, звенья которого соединенные гликозидными связями. Крахмал в рисе представлен в виде смеси двух фракиии полисахаридов - амилозы и амилопектина. Биохимический анализ содержания амилозы $F_{6}-F_{7}$ гибридов с окрашенным перикарпом показал, что содержание амилозы у исследуемых образиов риса колеблется от $0 \%$ до 24,5\%.

Ключевые слова: рис с окрашенным перикарпом, амилоза, восковидный, глютинозный, Wх ген, гибриды.

\section{Screening of rice genotypes with a colored pericarp for amylose}

Berkimbay Kh.A. ${ }^{1,2}$, Ussenbekov B.N. ${ }^{2}$, Garkusha S.V. ${ }^{3}$

${ }^{1}$ Kazakh National Agrarian University, Almaty, Kazakhstan,

${ }^{2}$ Institute of Plant Biology and Biotechnology, Almaty, Kazakhstan, ${ }^{3}$ Federal Scientific Center for Rice, Krasnodar, Russia. 
Starch is a polysaccharide of rice grains consisting of a large number of glucose residues, the units of which are connected by glycosidic bonds. Starch in rice is presented as a mixture of two fractions of polysaccharides - amylose and amylopectin. Biochemical analysis of the content of amylose $F_{6}-F_{7}$ hybrids with colored pericarp showed that the content of amylose in the studied rice samples ranges from 0 to $24.5 \%$.

Key words: rice with colored pericarp, amylose, waxy, glutinous, hybrids.

По биохимическому составу рис бывает обычным и глютинозным. Обычные сорта риса богаты и амилозой (от 8 до 37 \%), и амилопектином, а у глютинозного риса влажное зерно - клейкое и отличается низким содержанием амилозы (>2\%) [1].

По показателю содержания амилозы в зерновке риса различают сорта: высокоамилозные - 25-32 \%, среднеамилозные - 20-25\%, низкоамилозные - 12-20\%, восковые - 1-2 \% и глютинозные - 0 \% [2].

Растение, которое содержит около $20 \%$ амилозы, несет доминантный ген Wx (шаху - восковидный) на 6-й хромосоме, кодирующий фермент синтеза амилозы [3].

Известно, что содержание амилозы варьирует до $6 \%$ для определенного сорта в зависимости от экологических условий [4]. Было обнаружено, что в зависимости от климатических условий произрастания риса содержание амилозы в сортах меняется [5]. Так, прохладные погодные условия в период формирования зерна способствуют повышению содержания амилозы и, наоборот, при повышении температуры в этот период происходит снижение содержания амилозы [6].

Для скрининга по содержанию амилозы были использованы 26 образцов риса, из которых: 18 гибриды поздних поколений и 8 родительские формы (таблица).

Таблица - Классификация образцов риса с окрашенным перикарпом по содержанию амилозы

\begin{tabular}{|c|c|c|}
\hline Генотипы & $\begin{array}{c}\text { Содержа- } \\
\text { ние } \\
\text { амилозы, \% }\end{array}$ & Классификация \\
\hline 1 & 2 & 3 \\
\hline F6 Yir 5815/ Баканасский var.sundensis Koern & 23,7 & среднеамилозные \\
\hline F6 Yir 5815/ Баканасский var.pyrocarpa Alef & 22,1 & среднеамилозные \\
\hline F6 Yir 5815/Пак-Ли var.sundensis Koern & 15,8 & низкоамилозные \\
\hline $\mathrm{F}_{6}$ Yir 5815/Пак-Ли var.subpyrocarpa Gust & 13,9 & низкоамилозные \\
\hline F6 Yir 5815/ Пак Ли var.pyrocarpa Alef & 16 & низкоамилозные \\
\hline $\mathrm{F}_{6}$ Черный рис/Янтарь антоциановой окраской & 10,2 & низкоамилозные \\
\hline $\mathrm{F}_{6}$ Черный рис/Янтарь var.pseudovialonica Vasc & 0,9 & глютинозные \\
\hline $\mathrm{F}_{6}$ Черный рис/Янтарь var.nigrispina Port & 19,6 & низкоамилозные \\
\hline
\end{tabular}




\begin{tabular}{|c|c|c|}
\hline 1 & 2 & 3 \\
\hline $\mathrm{F}_{6}$ Черный рис/Янтарь var.Desvauxii Koern & 19,9 & низкоамилозные \\
\hline F6 Черный рис/Маржан & 22,5 & среднеамилозные \\
\hline $\mathrm{F}_{7}$ Мавр/Курчанка var.pyrocarpa Alef & 13,3 & низкоамилозные \\
\hline F7 Мавр/Баканасский var.Desvauxii Koern & 18,8 & низкоамилозные \\
\hline $\mathrm{F}_{7}$ Черный рис/Баканасский var.para-Gastrol Port & 1,1 & глютинозные \\
\hline $\mathrm{F}_{7}$ Черный рис/Баканасский var.pseudovialonica Vasc & 0,0 & глютинозные \\
\hline F7 Черный рис/Баканасский var.Desvauxii Koern & 0,1 & глютинозные \\
\hline F7 Черный рис/Баканасский var.Eediana Koern & 0,2 & глютинозные \\
\hline ДГ F2 Yir 5815/Маржан var.pyrocarpa Alef & 20,5 & среднеамилозные \\
\hline ДГ F2 Черный рис/Баканасский & 0,4 & глютинозные \\
\hline Yir 5815 & 14,6 & низкоамилозные \\
\hline Баканасский & 24,5 & среднеамилозные \\
\hline Черный рис & 1,4 & глютинозные \\
\hline Пак Ли & 11,1 & низкоамилозные \\
\hline Янтарь & 15,4 & низкоамилозные \\
\hline Маржан & 24,1 & среднеамилозные \\
\hline Мавр & 15,6 & низкоамилозные \\
\hline Курчанка & 18,6 & низкоамилозные \\
\hline
\end{tabular}

По результату анализа выявлено что среди изученных образцов отсутствует высокоамилозные сорта и содержание амилозы колебалась от 0 до $24,5 \%$.

Гибриды $\mathrm{F}_{6}$ Черный рис/Янтарь var. pseudovialonica Vasc, $\mathrm{F}_{7}$ Черный рис/Баканасский var. pseudovialonica Vasc, $\mathrm{F}_{7}$ Черный рис/Баканасский var. Desvauxii Koern, $\mathrm{F}_{7}$ Черный рис/Баканасский var. Eediana Koern и дигаплоид ДГ $\mathrm{F}_{2}$ Черный рис/Баканасский относятся к глютинозным, у которых содержание амилозы колеблется от 0 до $0,9 \%$.

$\mathrm{K}$ восковидной группе относится гибрид $\mathrm{F}_{7}$ Черный рис/Баканасский var.para-Gastrol Port и сорт Черный рис 1,1 и 1,4 \% соответственно.

Гибриды $\mathrm{F}_{6}$ Y ir 5815/Пак-Ли var. sundensis Koern, $\mathrm{F}_{6}$ Y ir 5815/Пак-Ли var. subpyrocarpa Gust, $\mathrm{F}_{6}$ Y ir 5815/Пак Ли var. pyrocarpa Alef, $\mathrm{F}_{6}$ Черный рис/Янтарь ант. окр., $\mathrm{F}_{6}$ Черный рис/Янтарь var.nigrispina Port, $\mathrm{F}_{6}$ Черный рис/ Янтарь var. Desvauxii Koern, $\mathrm{F}_{7}$ Мавр/Курчанка var.pyrocarpa Alef, $\mathrm{F}_{7}$ Мавр/Баканасский var. Desvauxii Koern и сорта Yir 5815, Пак Ли, Янтарь, Мавр, Курчанка относятся к низкоамилозным группам и содержание амилозы варьирует от 10,2 до 19,9\%.

K среднеамилозным группам относятся гибриды $\mathrm{F}_{6}$ Yir 5815/ Баканасский var. sundensis Koern, $\mathrm{F}_{6}$ Yir 5815/Баканасский var. pyrocarpa Alef, $\mathrm{F}_{6}$ Черный рис/Маржан, у которых содержание амилозы колеблется от 22,1 до 23,7 \% и дигаплоид ДГ $\mathrm{F}_{2}$ Y ir 5815/Маржан var. pyrocarpa Alef и сорта Баканасский и Маржан 20,5 \%, 24,5 \% и 24,1 \% соответственно. 
В результате комплексной оценки по биохимическим параметрам образцы риса были классифицированы на 4 группы: 5 глютинозных (содержание амилозы от $0 \%$ до $0,9 \%) ; 2$ восковидных $(1,1-1,4 \%) ; 13$ низкоамилозных (10,2-19,9 \%); 6 среднеамилозных (20,5-24,5 \%) образцов и выделены для дальнейшего отбора.

\section{Список литературь}

1. Sano Y. Differential regulation of waxy gene expression in rice endosperm // Theor. Appl. Genet. - 1984. - V.68. - P. 467-473.

2. Гончарова, Ю.К. О взаимосвязи между эффективностью работы фотосинтетического аппарата, адаптивностью и стабильностью урожайности у различных сортов риса / Ю.К. Гончарова, А.Н. Иванов // Сельскохозяйственная биология. - № 5. - 2006. - С. 92-97.

3. Гончарова, Ю.К. Влияние стрессовых факторов на содержание амилозы в образцах риса отечественной селекции/Ю.К.Гончарова, Е.М.Харитонов, Н.Ю. Бушман, С.А.Верещагина // Вестник РАСХН. - 2013. - № 5. - С. 45-48.

4. Juliano B.O., Pascual C.G. Quality Characteristics of Milled Rice Grown in Different Countries // In IRRI Research Paper Series, 48th International Rice Research Institute. - Los Baños, Philippines, 1980. - P. 25.5

5. Сартбаева И.А., Усенбеков Б.Н., Мамонов Л.К., Зеленский Г.Л., Булатова К.М. Скрининг сортообразцов риса российской и казахстанской селекции на содержание амилозы // Зерновое хозяйство России - 2013. - № 6 (30). - С. 12-16.

6. Chun A., Lee H.J., Hamaker B.R., Janaswamy S. Effects of ripening temperature on starch structure and gelatinization, pasting, and cooking properties in rice (Oryza sativa) // J. Agric. Food Chem. - 2015. - Vol. 63 (12). - P. 3085-3093.

DOI 10.18699/GPB2020-13

\section{Изучение основных параметров устойчивости яровой пшеницы к мучнистой росе}

Бехтольд Н.П. ${ }^{1 *}$, к.с.-х.н., н.с.; Орлова Е.А. ${ }^{1}$, к.с.-х.н., в.н.с.; Пшеничникова Т.А. ${ }^{2}$, к.б.н., зав. сектором генетики качества зерна; Афонников Д.А. ${ }^{2}$, к.б.н., в.н.с.; Зубаирова У.С. ${ }^{2}$, к.б.н., н.с.

${ }^{1}$ Сибирский научно-исследовательский институт растениеводства и селекции - филиал ИЦиГ СО РАН, Новосибирск, Россия;

${ }^{2}$ ФГБНУ Федеральный исследовательский цеентр Институт цитологии и генетики СО РАН, Новосибирск, Россия.

*e-mail: telichkinanina@mail.ru

В 2019 году на фитопатологическом участке СибНИИРС - филиала ИЦиГ СО РАН была проведена оценка сортов яровой пшеницы с различной 
степенью устойчивости к возбудителю заболевания - мучнистой росе. Изучение латентного периода позволило выявить различия между испытуемыми сортами. Первые признаки поражения листьев отмечали на сортах Скала, Сибирская 12, Саратовская 29 и ее изогенных линиях іс-29 HL2, ic-29 б/опуш., іс-29 (ЯП4В), а также на сорте Хаят. Сорта Кеагпеу, Новосибирская 61 и Attila были иммунные к патогену, на них не отмечено признаков заболевания до кониа вегетации растений.

Ключевые слова: яровая пшеница, мучнистая роса, сорт, устойчивость, искусственный фон.

\section{Study of the basic parameters of stability of spring wheat to powdery mildew}

Behtold N.P., candidate of agricultural sciences, researcher, Orlova E.A., candidate of agricultural sciences, leading researcher, Siberian Research Institute of Plant Production and Breeding - Branch of the Institute of Cytology and Genetics, Siberian Branch of the Russian Academy of Sciences, Novosibirsk, Russia Pshenichnikova T.A., Afonnikov D.A., Zubairova U.S., Institute of cytology and genetics SB RAS, Novosibirsk, Russia.

e-mail:Telichkinanina@mail.ru

In 2019, at the phytopathological site of Siberian Research Institute of Plant Production and Breeding - branch of the Institute of Cytology and Genetics $S B R A S$, spring wheat varieties with varying degrees of resistance to the causative agent of the disease - powdery mildew were evaluated. The study of the latent period allowed us to identify differences between the tested varieties. The first signs of leaf damage were noted on Skala, Sibirskaya 12, Saratovskaya 29 varieties and its isogenic lines ic-29 HL2, ic-29 b / opus., Ic-29 (YaP4V), as well as on the Hayat variety. Varieties Kearney, Novosibirsk 61 and Attila were immune to the pathogen; they showed no signs of disease until the end of the plant growing season.

Key words: spring wheat, powdery mildew, variety, resistance, artificial background.

Пшеница - наиболее востребованная продовольственная культура на земном шаре. Однако производство ее зерна лимитировано биотическими и абиотическими стрессами [1]. В условиях Западной Сибири в посевах яровой и озимой пшеницы мучнистая роса является распространенным и вредоносным заболеванием.

Мучнистая роса (возбудитель - облигатный узкоспециализированный паразитический гриб Blumeria graminis) при массовом развитии вызывает недобор урожая 10-15\% и более [2]. Основой успешного проведения профилактических и защитных мероприятий от грибных инфекций пшеницы являются как правильная и своевременная их диагностика, так и скрининг 
устойчивости сортового материала [3].

Цель исследований - оценить на искусственном инфекционном фоне сорта яровой пшеницы с различной степенью устойчивости, а также изогенные линии сорта Саратовская 29, отличающиеся между собой по признаку опушения, к облигатному патогену мучнистой росе (Blumeria graminis (DC) Spee).

Материалы и методика. Полевые опыты закладывали на фитопатологическом участке (изолированный инфекционный питомник), расположенного в пос. Мичуринский, Новосибирской области. Инокуляцию растений проводили методом опрыскивания опытных сортов суспензией изолятов местной популяцией гриба $B$. graminis. Степень поражения растений мучнистой росой оценивали согласно методическим рекомендациям ВНИИФ, учеты проводили каждые 5-7 дней [4].

Для расчета скорости нарастания болезни использовали два метода подсчет образовавшихся пустул и подушечек на листе за промежуток времени и интенсивность поражения растений, выраженная в процентах. Во втором случае рассчитывали площадь под кривой развития болезни (ПКРБ) согласно Методическим рекомендациям «Методы оценки и отбора исходного материала при создании сортов пшеницы устойчивых к бурой ржавчине» $[5,6]$.

Для подсчета пустул мучнистой росы растения маркировали этикетками, а учетные листья отмечали маркером. Количество пустул подсчитывали с момента их появления, через каждые 3-4 дня, до их слияния. Для возбудителя мучнистой росы рассчитывали среднее количество пустул на лист.

Шкала для оценки интенсивности поражения листьев мучнистой росой:

$0-5 \%$ - очень высокая и высокая устойчивость; $10-15 \%$ - устойчивость; $25 \%$ - слабая восприимчивость; 40-65 \% - восприимчивость; 90-100 $\%$ - высокая и очень высокая восприимчивость.

Расчет скорости нарастания болезни выражали площадью под кривой развития болезни (ПКРБ), которую рассчитывали по формуле:

$$
\mathrm{S}=0,5\left(\mathrm{x}_{1}+\mathrm{x}_{2}\right)\left(\mathrm{t}_{2}-\mathrm{t}_{1}\right)+\ldots 0,5\left(\mathrm{x}_{\mathrm{n}-1}+\mathrm{x}_{\mathrm{n}}\right)\left(\mathrm{t}_{\mathrm{n}}-\mathrm{t}_{\mathrm{n}-1}\right), \text { где }
$$

$\mathrm{S}$ - площадь под кривой развития болезни;

$\mathrm{x}_{1}-$ интенсивность развития болезни на момент первого учета, \%;

$\mathrm{x}_{2}-$ интенсивность развития болезни на момент второго учета, $\%$;

$\mathrm{x}_{\mathrm{n}}-$ интенсивность развития болезни на момент последнего учета, \%;

$\left(t_{2}-t_{1}\right)$ - количество дней между вторым и первым учетом;

$\left(t_{n}-t_{n-1}\right)$ - количество дней между последним и предпоследним учетами; $\mathrm{n}$ - количество учетов [5].

Результаты. Продолжительность инкубационного периода определяли по числу дней от момента инокуляции растений до появления на них первых признаков заболевания.

Искусственное заражение мучнистой росой проводили 4 июня, путем 
опрыскивания сортов яровой пшеницы смесью спор патогена. Изучение латентного периода позволило выявить различия между испытуемыми сортами. Первые признаки поражения листьев (единичные подушечки гриба) отмечали 11 июня на сортах Скала, Сибирская 12, Саратовская 29 и ее изогенных линиях ic-29 HL2, ic-29 б/опуш., ic-29 (ЯП4B), а также на сорте Хаят. Для них латентный период составил 7 дней. Для сортов Kadett, Opal, Ботаническая 81, Triso, Bastion, Biggar латентный период составил 10 дней, на них появление единичных подушечек гриба отмечали 14 июня. Самый длинный латентный период был у устойчивого сорта Омега - 17 дней. Сорта Kearney, Новосибирская 61 и Attila были иммунные к патогену, на них не отмечено признаков заболевания до конца вегетации растений.

Подсчет подушечек гриба проводили с 11 по 21 июня, в дальнейшем на восприимчивых сортах отмечали слияние подушечек гриба и интенсивность поражения сортов мучнистой росой оценивали, как процент занятости мицелием гриба поверхности листьев.

Как видно из таблицы устойчивые сорта Омега, Triso, Kadett, Biggar слабо набирали инфекцию, нарастание количества спороносящих подушечек у них шло незначительно, особенно на сортах Омега и Triso. Поражение этих сортов мучнистой росой на 17 июля не превышало $10 \%$.

Таблича - Поражение сортов яровой пшеницы мучнистой росой, \%

\begin{tabular}{|c|c|c|c|c|c|c|c|c|}
\hline \multirow{3}{*}{$\begin{array}{c}\text { Наименование } \\
\text { образца }\end{array}$} & \multicolumn{7}{|c|}{ Поражение мучнистой росой, \% } & \multirow{3}{*}{$\begin{array}{l}\text { ПКРБ, } \\
\text { у.е. }\end{array}$} \\
\hline & \multicolumn{5}{|c|}{ июнь } & \multicolumn{2}{|c|}{ июль } & \\
\hline & 11 & 17 & 19 & 21 & 27 & 09 & 17 & \\
\hline Kearney & 0 & 0 & 0 & 0 & 0 & 0 & 0 & 0 \\
\hline Новосибирская 61 & 0 & 0 & 0 & 0 & 0 & 0 & 0 & 0 \\
\hline Attila & 0 & 0 & 0 & 0 & 0 & 0 & 0 & 0 \\
\hline Омега & 0 & 0 & 0 & 1 & 1 & 1 & 1 & 27 \\
\hline Triso & 0 & 1 & 1 & 1 & 1 & 1 & 1 & 33 \\
\hline Kadett & 0 & 1 & 1 & 3 & 5 & 5 & 5 & 79 \\
\hline Biggar & 1 & 1 & 5 & $5-10$ & 10 & 10 & 10 & 275 \\
\hline Ботаническая 81 & 0 & 5 & 5 & 10 & 10 & 15 & 25 & 410 \\
\hline Bastion & 0 & 1 & 3 & 15 & 15 & $10-15$ & 25 & 425 \\
\hline Хаят & 1 & 5 & 10 & 25 & 25 & 15 & 25 & 618 \\
\hline $\begin{array}{l}\text { ic-29 (ЯП4В) редкое, } \\
\text { короткое опушение }\end{array}$ & 1 & 1 & 3 & 5 & 10 & 10 & 15 & 283 \\
\hline i: C29 без опушения & 1 & 1 & 3 & 5 & 15 & 15 & 25 & 418 \\
\hline $\begin{array}{l}\text { Саратовская } 29 \text { плотное } \\
\text { опушение }\end{array}$ & 1 & 1 & 5 & 25 & 25 & 40 & 65 & 1002 \\
\hline $\begin{array}{l}\text { i:C29 H12 плотное, } \\
\text { удлиненное опушение }\end{array}$ & 1 & 1 & 10 & 10 & 30 & 35 & 45 & 867 \\
\hline Opal & 0 & 10 & 25 & 30 & 45 & 40 & 65 & 1275 \\
\hline Скала & 3 & 10 & 25 & 30 & 45 & 45 & 65 & 1334 \\
\hline Сибирская 12 & 3 & 5 & 15 & 30 & 45 & 45 & 65 & 1294 \\
\hline
\end{tabular}


Не отмечено поражения мучнистой росой на сортах с очень высокой устойчивостью Kearney, Новосибирская 61, Attila. Устойчивостью к патогену обладают также сорта Омега, Triso, Kadett, поражение которых составило от 5 до $10 \%$, расчетная ПКРБ этих сортов составила 27, 33 и 79 у.е.

Несмотря на то, что поражение сортов Ботаническая 81, Bastion и Хаят на 17 июля составило 25 \%, скорость образования подушечек гриба на листе у них различалась. Так у образцов Bastion и Хаят на 14 июня отмечали в среднем по 4 подушечки на лист, а к 21 июня 25,3 и 35,2 соответственно. У сорта Ботаническая 81 нарастание шло от 3 до 18 шт./лист. Интенсивность нарастания поражения растений мучнистой росой, выраженная в процентах, была выше у сорта Хаят. Это подтверждается расчетом площади под кривой развития болезни (ПКРБ), среди слабо восприимчивых сортов ПКРБ у сорта Хаят составила 618 у.е., против 410 и 425 у сортов Ботаническая 81 и Bastion.

Анализ восприимчивости сорта Саратовская 29 и ее изогенных линий к мучнистой росе, позволил установить, что изогенные линии с редким коротким опушением и без него (ic-29 (ЯП4В), i: C29 glabrous) поражались слабее возбудителем, чем Саратовская 29 и изогенная линия i:C29 Hl2, имеющих плотное опушение. Несмотря на то, что первые признаки заболевания отмечали на всех образцах 11 июня, меньше всего интенсивность нарастания гриба было у изогенной линии іс-29 (ЯП4В) - 12,3 пустулы на лист к 21 июня. Поражение этого образца 17 июля не превышало $15 \%$.

Таким образом, среди сортов средневосприимчивой группы (с поражением 25 \%) более высоким уровнем частичной устойчивости обладали образцы Ботаническая 81 и изогенные линии іс-29 (ЯП4В), i: C29 glabrous т.к. у них отмечали медленное нарастание пустул и интенсивность поражения растений (ПКРБ составила 410, 283 и 418 у.е. соответственно).

У восприимчивых сортов Opal, Сибирская 12 и Скала скорость нарастания инфекции была высокой и к 17 июля поражение этих сортов составило $65 \%$.

Расчет площади под кривой развития болезни и индекса устойчивости показал, что сорта Саратовская 29, Opal, Сибирская 12, Скала относятся к группам с низкой устойчивостью и восприимчивые.

Благодарности: Исследование выполнено при финансовой поддержке РФФИ в рамках научного проекта № 17-29-08028.

\section{Список литературы}

1. Лебедева Т.В., Зуев Е.В. Изучение устойчивости к мучнистой росе (Blumeria graminis f. sp. tritici Golov.) сортов мягкой пшеницы (Triticum aestivum L.) // Достижения науки и техники АПК. 2015. Т. 29. № 7. С. 17-19.

2. Санин С.С., Черкашин В.И., Назарова Л.Н. Фитосанитарная экспертиза зерновых культур (болезни растений): рекомендации. М., 2002.

3. Санин С.С., Соколова Е.А., Черкашин В.И., Назарова В.И., Стрижекозин 
Ю.А., Ибрагимов Т.З. Болезни зерновых колосовых культур (рекомендации по проведению фитосанитарного мониторинга). М., 2010.

4. Санин С.С., Неклеса Н.П., Санина А.А., Пахолкова Е.В. Методические рекомендации по созданию инфекционных фонов для иммуногенетических исследований пшеницы / М.: ВНИИФ, 2008. 68 с.

5. Методы оценки и отбора исходного материала при создании сортов пшеницы устойчивых к бурой ржавчине. / Методические рекомендации под редакцией академика Санина С.С. М.: 2012. 93 с.

6. Изучение генетических ресурсов зерновых культур по устойчивости к вредным организмам / Методическое пособие под редакцией Радченко Е.Е. М.: Россельхозакадемия, 2008. 418 с.

DOI 10.18699/GPB2020-14

\section{Crop genebanks - the maintenance of natural resources for future plant breeding}

Börner A. *, Nagel M., Lohwasser U.

Leibniz Institute of Plant Genetics and Crop Plant Research (IPK), Gatersleben, Germany.

*e-mail: boerner@ipk-gatersleben.de

Plant genetic resources for food and agriculture (PGRFA) play a major role for global food security. The most significant and widespread mean of conserving PGRFA is ex situ conservation. Most conserved accessions are kept in specialized facilities known as genebanks maintained by public or private institutions. Worldwide 7.4 million accessions are stored in about 1,750 ex situ genebanks.

Plant ex situ genebank collections comprise seed genebanks, field genebanks as well as in vitro and cryo collections. Species whose seed can be dried, without damage, down to low moisture contents can be conserved in specially designed cold stores. Such "orthodox" seeds can be expected to maintain a high level of vigour and viability for decades. Field genebanks, in vitro and cryo storage are used primarily for species which are either vegetatively propagated or which have non-orthodox seeds that cannot be dried and stored for long periods. In addition, perennial species, for example certain forage species, which produce small quantities of seed, and long-lived plants are also maintained this way. It is estimated that worldwide, less than $10 \%$ of genebank holdings are stored in vivo in the field, and less than $1 \%$ are conserved in vitro/cryo. Clearly, seed storage is the predominant mode of plant genetic resources conservation.

With a total inventory of 150,000 accessions from 3,212 plant species and 776 genera, the 'Federal ex situ Genebank of Germany' in Gatersleben holds one of the most comprehensive collections worldwide. It comprises wild and primitive forms, landraces as well as old and more recent cultivars of mainly cereals but also 
other crops. Starting in the 1920's material was accumulated systematically. Seed storage is managed in large cold chambers at $-18^{\circ} \mathrm{C}$. Seeds are kept in glass jars, covered with bags containing silica gel (active collection) and in aluminum bags under vacuum (base collection).

The maintenance of the collection requires regeneration. Each year between 8 and $10 \%$ of the collection is grown either in the field or in glasshouses. Regeneration becomes necessary when: (1) the quantity of stored seed has dropped below a pre-set threshold, due to supply to users, (2) viability falls below a pre-set threshold, (3) phenotypic evaluations of the accessions need to be conducted or (4) new accessions, which require multiplication and characterization, enter the collection. Regeneration is carried out locally to ensure genetic integrity and to minimize genetic erosion. Voucher specimens, photographs and written documentation are used to monitor the identity of the material. Special attention has to be given to out-pollinating species, which are either multiplied in small glasshouses or in isolation plots in the field.

Since the majority of genebank accessions globally are stored in the form of seed, seed longevity is of particular importance for crop germplasm preservation. At the IPK research was initiated for a range of crops stored in the genebank over decades. Variation between and within crop species was detected.

DOI $10.18699 / \mathrm{GPB} 2020-15$

\section{Генетические механизмы ответа растений на световой стресс: реконструкция генных сетей и эволюционная перспектива}

Бобровских А.В. ${ }^{1}$, м.н.с.; Ермаков А.А. ${ }^{l}$, м.н.с.; Зубаирова У.С. ${ }^{1}$, к.б.н., н.с.; Константинов Д.К. ${ }^{l}$, м.н.с.; Левина А.Б. ${ }^{2}$, студентка; Колодкин А.Н. ${ }^{3,4,5}$, проф.; Хейдари С. ${ }^{6}$; Дорошков А.В. ${ }^{1 *}$, к.б.н., н.с.

${ }^{1}$ ИЦиГ СО РАН, Новосибирск, Россия;

${ }^{2}$ НГУ, Новосибирск, Россия;

${ }^{3}$ Свободный Университет Амстердама, Амстердам, Нидерланды;

${ }^{4}$ Университет Амстердама, Амстердам, Нидерландь;

${ }^{5}$ Люксембургский Центр Системной Биомедицины, Университет Люксембурга, Люксембург;

${ }^{6}$ Мешхедский университет им. Фердовси, Мешхед, Иран.

*e-mail:ad@bionet.nsc.ru

Растения преобразуют энергию солнща в энергию химических связей и поэтому являются фундаментом экосистем и промышленности. Понимание того, как растения контролируют наработку биомассы, как преобразуют энергию солниа и как используют ее для создания органов и тканей 
является не только важной фундаментальной задачей, но и ключевым пунктом для дизайна новых сортов для биотехнологических систем повышенной продуктивностью. В настоящей работе проведена интеграция информации о генах, функиионально аннотированных как участники ответа на повышенную инсоляцию и дифференциально экспрессирующихся в ответ на этот стресс генов по результатам мета - анализа транскриптомных данныхx. Был проведен сравнительный анализ компонентного состава реконструированной генной сети и идентифицированы коровые компоненты сети, представленные у широкого спектра видов иветковых растений, а также компоненты, специфичные для С3 и С4 злаков.

Ключевые слова: абиотический стресс, стрессоустойчивость, световой стресс, сельское хозяйство.

\section{Genetic mechanisms of plan response to light stress: reconstruction of gene networks and evolutional prospects}

Bobrovskih A.V. ${ }^{1}$, Ermakov A.A. ${ }^{1}$, Zubairova U.S. ${ }^{1}$, Konstantinov D.K. ${ }^{l}$, Levina A.B. ${ }^{2}$, Kolodkin A.N. ${ }^{3,4,5}$, Heidari ${ }^{6}{ }^{6}$, Doroshkov A.V. ${ }^{1 *}$

${ }^{1}$ Institute of cytology and genetics SB RAS, Novosibirsk, Russia; ${ }^{2}$ Novosibirsk State University, Novosibirsk, Russia; ${ }^{3} V U$ University Amsterdam, Amsterdam, Netherlands; ${ }^{4}$ University of Amsterdam, Amsterdam, Netherlands; ${ }^{5}$ The University of Luxembourg, Luxembourg Centre for Systems Biomedicine, Luxembourg; ${ }^{6}$ Ferdowsi University of Mashhad, Mashhad, Iran.*ad@bionet.nsc.ru

Plants transform the energy of the sun into the energy of chemical bonds and therefore are the foundation of ecosystems and industry. Understanding how plants control biomass production, how they convert the energy of the sun and how to use it to create organs and tissues is not only an important fundamental task, but also a key point in the design of new varieties for biotechnological systems with increased productivity. In this work, we integrated information on genes functionally annotated as participants in a response to increased insolation and differentially expressed in response to this stress genes based on meta-analysis of transcriptome data. A comparative analysis of the component composition of the reconstructed gene network was carried out and the core components of the network represented in a wide range of flowering plant species, as well as components specific for C3 and C4 cereals, were identified.

Key words: abiotic stress, stress resistance, light stress, agriculture.

Растения - важный энергетический базис как естественных экосистем, так и множества техногенных процессов. Понимание того, как растения контролируют наработку биомассы, как преобразуют энергию солнца и как используют ее для создания органов и тканей является не только важной фундаментальной задачей, но и ключевым пунктом для дизайна новых сортов растений с повышенной продуктивностью. Установлено, что растения 
приспособлены к определенным характеристикам инсоляции и выход за их пределы (например, при дополнительным искусственным освещением растений в теплицах) быстро перестает приносить пропорциональное изменение биомассы. Одним из важнейших ограничений процессов роста и развития при повышенной инсоляции является окислительный стресс фотосинтетических тканей и недостаточная эффективность антиоксидантной системы. Так, в течение дня оптимальные характеристики фотосинтеза злаковых растений, ключевые для накопления биомассы наблюдаются в утренние и вечерние часы, тогда как в середине дня фотосинтетические ткани находятся в состоянии окислительного стресса. Математические модели, как например [1], могут служить инструментом для определения оптимальных характеристик инсоляции для работы ключевых фотозащитных механизмов растений.

Ответ на гиперинсоляцию является комплексным и затрагивает организм на разном уровне - от молекулярного до морфологического и требует системного изучения. Впервые информация о генетических механизмах была систематизирована в обзоре [2]. Авторы приводят обзор молекулярных мишеней ультрафиолетового облучения, кроме того, рассматривая молекулярные механизмы и морфологические изменение растений под действием облучения. Авторы также отмечают многофакторность действия гиперинсоляции на метаболические процессы растения и недостаточную изученность значимости отдельных факторов на устойчивость к ультрафиолетовому излучению.

Гиперинсоляция в разных зонах фотосинтетических тканей активно изучается на кукурузе Zea Mays. В статье [3] приводится анализ тканевых физиологических процессов, связанных с гипероблучением. Авторы отмечают, что гиперинсоляция уменьшает ростовую зону пластинки листа. Анализ RNAseq (GSE95858) показал, что в процесс включены факторы регуляции роста и транскрипты, участвующие в гормон-специфических путях.

Известны отдельные компоненты регуляторной сети ответа на световое облучение на модельном организме арабидопсисе. Например, в статье [4] на Arabidopsis thaliana найден один из ключевых локусов (UVR8), который является эффекторным для транскрипционного фактора НY5. Современное состояние проблемы отражает статья [5]. Обзор рассматривает фоторецептор для UVR8 [6], который активируется в ответ на продолжительное и хроническое облучение; краткосрочный ответ на UV-B излучение вызывается менее специфичными МАР-киназами [7]. Кроме того, в обзоре подробно охарактеризованы морфологические изменения растений, подвергнувшихся гиперинсоляции. В сравнении с контрольными, такие растения имеют более толстые листья, укороченные черешки и стебли, усиленное боковое ветвление и измененные пропорции корня к побегу.

Отмечается, что важную роль в передаче сигнала при ответе на гипе- 
ринсоляцию имеют активные формы кислорода, которые активируют соответствующие пути [8]. Авторы отмечают, что фоновое излучение в ходе нормального метаболизма незначительно влияет на выработку радикалов, однако стимулирует стресс, который проявляется в адаптированном измененном редокс-статусе антиоксидантов [9]. Однако серьезная гиперинсоляция вызывает повышение активных форм кислорода в фотосистемах, детектируемое на разных организмах (листья шпината, листья боба садового, листья риса). В условиях абиотического стресса концентрации активных форм кислорода модулируют активность пероксидаз, которые используют специфические субстраты для борьбы с радикалами [10]. В стрессовых условиях прекращаются ростовые процессы, а при возвращении уровня радикалов в пределы нормы происходит восстановление роста.

В настоящей работе проведен мета анализ транскриптомных данных ответа на гиперинсоляцию с выявлением перспективных генов-кандидатов. Найденные гены были интегрированы с известными генетическими регуляторными компонентами ответа на световой стресс у A. thaliana. Реконструированная генная сеть состоит из 104 известных генов и обогащена 245 новыми генами. Были обнаружены ранее не описанные блоки, связанные с процессингом рибосомальных РНК (16 генов), регуляцией жасмонатного сигнального пути (5), протеосомальным катаболизмом (7), ионным транспортом (10), а также наличие в сети серии глутатион S-трансфераз, которые способны за счет восстановленного глутатиона осуществлять регенерацию липоперекисей в мембранах, снижая последствия окислительного стресса. Прицельное усиление активности антиоксидантной системы является перспективным путем снижения нагрузки на фотосинтетические ткани и, таким образом, увеличения периода эффективной аккумуляции энергии, что позволит сократить период вегетации и сделать возделывание злаковых растений в условиях рискованного земледелия более эффективным.

При помощи подходов сравнительной геномики, мета анализа транскриптомных данных и подходов молекулярной филогении нами были сопоставлены реконструированные и расширенные сети ответа на световой стресс между A. thaliana, Zea mays, Oryza sativa, Hordeum vulgare u Triticum aestivum. Были идентифицированы коровые компоненты сети, представленные у широкого спектра видов цветковых растений, а также компоненты, специфичные для С3 и С4 злаков.

Благодарности: Исследование выполнено при финансовой поддержке РФФИ и Правительства Новосибирской области в рамках научного проекта № 19-44-543021.

\section{Список литературы}

1. Matuszyńska, A., Heidari, S., Jahns, P., Ebenhoeh, O. (2016). A mathematical model of non-photochemical quenching to study short-term light memory in plants. Biochimica et Biophysica Acta (BBA)-Bioenergetics, 1857(12), 1860-1869. 
2. Jansen, M.A., Gaba, V., Greenberg, B.M. (1998). Higher plants and UV-B radiation: balancing damage, repair and acclimation. Trends in plant science, 3(4), 131-135.

3. Fina, J., Casadevall, R., AbdElgawad, H., Prinsen, E., Markakis, M. N., Beemster, G. T., \& Casati, P. (2017). UV-B inhibits leaf growth through changes in growth regulating factors and gibberellin levels. Plant physiology, 174(2), 1110-1126.

4. Brown, B.A., Cloix, C., Jiang, G.H., Kaiserli, E., Herzyk, P., Kliebenstein, D.J., Jenkins, G.I. (2005). A UV-B-specific signaling component orchestrates plant UV protection. Proceedings of the National Academy of Sciences, 102(50), 1822518230.

5. Robson, T.M., Klem, K., Urban, O., \& Jansen, M.A. (2015). Re-interpreting plant morphological responses to UV-B radiation. Plant, cell \& environment, 38(5), 856-866.

6. Rizzini, L., Favory, J. J., Cloix, C., Faggionato, D., O’Hara, A., Kaiserli, E., ... \& Ulm, R. (2011). Perception of UV-B by the Arabidopsis UVR8 protein. Science, 332(6025), 103-106.

7. González Besteiro, M. A., Bartels, S., Albert, A., \& Ulm, R. (2011). Arabidopsis MAP kinase phosphatase 1 and its target MAP kinases 3 and 6 antagonistically determine UV-B stress tolerance, independent of the UVR8 photoreceptor pathway. The Plant Journal, 68(4), 727-737.

8. Hideg, É., Jansen, M. A., \& Strid, Å. (2013). UV-B exposure, ROS, and stress: inseparable companions or loosely linked associates?. Trends in plant science, 18(2), $107-115$.

9. Heuberger, H., Praeger, U., Georgi, M., Schirrmacher, G., Grasmann, J., \& Schnitzler, W.H. (2004, March). Precision stressing by UV-B radiation to improve quality of spinach under protected cultivation. In VII International Symposium on Protected Cultivation in Mild Winter Climates: Production, Pest Management and Global Competition 659 (pp. 201-206).

10. Tenhaken, R. (2015). Cell wall remodeling under abiotic stress. Frontiers in plant science, 5,771 .

DOI 10.18699/GPB2020-16

\section{Реконструкция регуляторных генных сетей ответа на солевой стресс Arabidopsis thaliana и Zea mays}

Бобровских А.В. ${ }^{l}$, м.н.с.; Ермаков А.А. ${ }^{l *}$, м.н.с.; Зубаирова У.С. ${ }^{1}$, к.б.н., н.с.; Константинов Д.К. ${ }^{\text {, }, ~ м . н . с . ; ~ Л е в и н а ~ А . Б . ~}{ }^{2}$, студентка; Дорошков А.В. ${ }^{l}$, к.б.н., H.c.

${ }^{1}$ ИЦиГ СО РАН, Новосибирск, Россия;

${ }^{2}$ НГУ, Новосибирск, Россия;

*e-mail:ermakov@bionet.nsc.ru

Засоление является одним из важнейших абиотических факторов, ограничивающих зоны возделывания сельскохозяйственных культур. Ответ 
растений на засоленость комплексный и его генетическая компонента на данный момент изучена недостаточно. В настоящей работе проведена интеграчия данных, реконструкиия и сопоставление генных сетей между перспективными модельными и селекционно ценными видами растений с иелью выявления генов-кандидатов для селекции и интрогрессии от диких сородичей.

Ключевые слова: абиотический стресс, стрессоустойчивость, засоление, сельское хозяйство, кукуруза, арабидопсис.

\section{Reconstruction of regulatory gene networks of response to salt stress Arabidopsis thaliana and Zea mays}

Bobrovskih A.V., Ermakov A.A., Zubairova U.S., Konstantinov D.K., Levina A.B., Doroshkov A.V.

ICG SB RAS, Novosibirsk, Russia;

Novosibirsk State University, Novosibirsk, Russia.

*e-mail:ermakov@bionet.nsc.ru

Salinization is one of the most important abiotic factors limiting crop cultivation zones. The response of plants to salinity is complex and its genetic component has not been studied sufficiently. In the present work, data integration, reconstruction and comparison of gene networks between promising model and breeding valuable plant species was carried out in order to identify candidate genes for selection and introgression from wild relatives.

Key words: abiotic stress, stress resistance, salinization, agriculture, maize, arabidopsis.

Перед наукой стоят задачи, как увеличения продуктивности культурных растений, так и расширения засеваемых площадей. Этому препятствуют различные факторы, в том числе глобальное изменение климата, возрастающее техногенное давление на культурные растения и необдуманное использование удобрений. Засоление является одним из важнейших абиотических факторов, ограничивающих зоны возделывания сельскохозяйственных культур. Так, известно, что засоленно-солонцовые почвы в Новосибирской области занимают до $50 \%$ от общей площади сельскохозяйственных угодий [1]. В мировых масштабах естественное засоление почв также является общепризнанной проблемой, которая оказывает негативное влияние на продуктивность культурных растений [2], препятствует освоению новых посевных земель и делает непригодными имеющиеся. Техногенное засоление почв представляет собой не меньшую проблему [3]. Решением данной проблемы является рекультивация земель, подвергшихся засолению, и выведение новых форм культурных растений, устойчивых к засолению.

В процессе доместикации растений, как правило, использовали ограниченное число индивидуумов видов-предшественников, а контролируемые 
в процессе отбора признаки обычно были связаны с общей урожайностью, технологическими и вкусовыми качествами $[4,5]$. Результатом такого отбора стало снижение общего генетического разнообразия культурных растений [6-8]. Отбор на максимизацию урожайности в условиях определенной климатической зоны и географического местоположения привел к тому, что полученные сорта часто имеют невысокую устойчивость к любым отклонениям условий окружающей среды от оптимальных, что заметно снижает их продуктивность в стрессовых условиях [9]. Поэтому, перед современными селекционерами и биотехнологами остро стоит задача расширения генофонда, для чего активно используется гибридизация, в т.ч. отдаленная, как способ получения нового селекционного материала.

Известно, что кукуруза (Zea mays L.) слабо устойчива к засолению, тогда как у многих диких сородичей культурных злаков установлена повышенная устойчивость к засоленности. Современные методы селекции с использованием биотехнологических подходов позволяют эффективно переносить ценные хозяйственные признаки из имеющегося генетического материала в культивируемые сорта культурных растений. Таким образом, основной задачей, стоящей перед исследователями сегодня, является поиск генов, реализующих заданные ценные признаки, и получение нового генетического материала для селекционной работы, в т.ч. и среди диких родственных видов, допускающих гибридизацию.

В настоящее время известно, что реакции ответа на солевой стресс можно разделить на специфические и неспецифические. Специфические реакции заключаются в индукции синтеза стрессовых белков, тогда как неспецифические компоненты системы ответа на стресс связаны, прежде всего, с антиоксидантной системой. Физиология специфических реакций достаточно подробно изучена на модельном организме арабидопсисе: поступление ионов $\mathrm{Na}+$ в клетку активирует каскады процессов изменяющие в итоге ионный, водный и гормональный гомеостаз всего растения [10]. Абиотические виды стресса приводят к увеличению концентрации радикалов кислорода, в связи с чем антиоксидантная система защиты, активирующаяся в ответ на широкий спектр стрессов, привлекла к себе пристальное внимание еще два десятилетия назад $[11,12]$. Было выявлено, что компоненты антиоксидантной системы включают серии генов с идентичной молекулярной функцией, но различной клеточной локализацией [13].

Применение системно-биологических подходов для изучения генетических механизмов адаптации с большим числом взаимосвязей представляется наиболее эффективным решением задачи на настоящее время, однако их применение для улучшения культурных растений впервые упомянуто относительно недавно [14]. Сейчас относительно полное понимание функционирование механизма ответа на солевой стресс существует только на примере модельного объекта Arabidopsis thaliana, тогда как для злаков и других 
растений существуют лишь отдельные факты о некоторых генах, которые повышают устойчивость к солевому стрессу. В связи с этим существует необходимость применения подходов системной биологии для интеграции имеющихся разнородных данных для ряда видов, с целью установления механизмов защиты от солевого стресса.

Целью настоящего исследования является интеграция транскриптомных данных по арабидопсису и злакам (Oryza sativa, Zea mays) для описания общих и видоспецифичных компонентов системы ответа на солевой стресс кукурузы Zea mays, как слабоустойчивого к засолению представителя злаковых. Было проведено межвидовое сравнение реконструированных генных сетей, обогащенных транскриптомными данными. С одной стороны, удобной моделью для построения генных сетей является база знаний Arabidopsis thaliana. C другой стороны, выявление ассоциированных генов с солевым стрессом у злаков в ходе транскриптомного анализа позволит также детектировать соответствующих ортологов в геноме арабидопсиса. Следовательно, такой интегративный подход позволит описать наиболее полно генную сеть ответа соответствующих злаков.

В ходе работы был проведен анализ транскриптомных данных для выявления генов-кандидатов у Arabidopsis thaliana. Было выявлено более 3000 дифференциально экспрессирующихся в условиях солевого стресса генов. Была проведена приоритизация и ранжирование генов в данной выборке тремя различными способами, учитывая как достоверность, так и уровень изменения экспрессии гена. В результате было отобрано 1099 генов-кандидатов.

На основании выявленных генов-кандидатов была реконструирована генная сеть с использованием базы данных String (http://string-db.org/, Szklarczyk D. et al., 2016) и списка уже известных генов солевого ответа. Полученная обогащенная генная сеть включает в себя 99 генов, ассоциация которых с ответом на солевой стресс была известна ранее и 268 связанных с ними генов-кандидатов, и регуляцией метаболических процессов (ферменты, транскрипционные факторы, белки-транспортеры, гены фотосистем, антиоксидантные гены).

При помощи подходов сравнительной геномики, мета анализа транскриптомных данных и подходов молекулярной филогении нами были сопоставлены реконструированные и расширенные сети ответа на солевой стресс между A. thaliana, Zea mays, Oryza sativa, Hordeum vulgare u Triticum aestivum.

В результате было выявлен ряд новых генов ответа на солевой стресс, например, гены-регуляторы биосинтеза аминокислот, компоненты рибонуклеопротеидных комплексов, транспортеры азота и калия, белки индуцируемые абсцизовой кислотой, ауксином и этиленом, что свидетельствует в пользу комплексности найденного ответа, а также ряд ферментов редуктаз и 
оксидаз, меняющих окислительно-восстановительный баланс клетки.

Благодарности: Исследование выполнено при финансовой поддержке РФФИ и Правительства Новосибирской области в рамках научного проекта № 19-416-543006.

\section{Список литературы}

1. Панкова Е.И., Конюшкова М.В., Горохова И.Н. О проблеме оценки засоленности почв и методике крупномасштабного цифрового картирования засоленных почв (2017). Экосистемы: экология и динамика.

2. Food and Agriculture: Key to Achieving the 2030, Agenda for Sustainable Development. Job No. I5499, Food and Agriculture Organization of the United Nations,

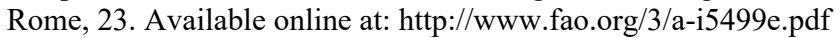

3. Артамонова В.С., Дитц Л.Ю., Елизарова Т.Н., Лютых И.В. (2010). Техногенное засоление почв и их микробиологическая характеристика. Сибирский Экологический Журнал, 3 (2010) 461-470.

4. Hua, L., Wang, D.R., Tan, L.B., Fu, Y.C., Liu, F.X., Xiao, L.T., ... Sun, C.Q. (2015). LABA1, a domestication gene associated with long, barbed awns in wild rice. The Plant Cell, 27, 1875-1888.

5. Konishi, S., Lin, S. Y., Ebana, K., Fukuta, Y., Izawa, T., Sasaki, T. and Yano, M. (2006). A SNP caused the loss of seed shattering during rice domestication. Science, 312, $1392-1396$.

6. Buckler, E.S., Thornsberry, J.M. and Kresovich, S. (2001). Molecular diversity, structure and domestication of grasses. Genetical Research, 77, 213-218.

7. Miller, A.J. and Gross, B.L. (2011). From forest to field: Perennial fruit crop domestication. American Journal of Botany, 98, 1389-1414.

8. Meyer, R.S., DuVal, A.E. and Jensen, H.R. (2012). Patterns and processes in crop domestication: An historical review and quantitative analysis of 203 global food crops. New Phytologist, 196, 29-48.

9. Ramírez, J.I.S., \& Maiti, R. (2016). Research Trends in Abiotic Stress Resistance of Crops. In BioresourceandStressManagement (pp. 131-163). SpringerSingapore.

10. Deinlein, Ulrich et al. 2014. "Plant Salt-Tolerance Mechanisms." Trends in Plant Science 19(6): 371-79.

11. Cazalé, Anne Claire et al. 1999. "MAP Kinase Activation by Hypoosmotic Stress of Tobacco Cell Suspensions: Towards the Oxidative Burst Response?" Plant Journal 19(3): 297-307.;

12. Orozco-Cardenas, Martha, and Clarence A Ryan. 1999. "Hydrogen Peroxide Is Generated Systemically in Plant Leaves by Wounding and Systemin via the Octadecanoid Pathway." Plant Biology 96 (May): 6553-57.

13. Pang CH, Wang BS (2010) Role of ascorbate peroxidase and glutathione reductase in ascorbate-glutathione cycle and stress tolerance in plants.

14. Jogaiah, S., Govind, S. R., \& Tran, L. S. P. (2013). Systems biology-based approaches toward understanding drought tolerance in food crops. Criticalreviewsinbiotechnology, 33 (1), 23-39. 


\section{Характер наследования числа колосков в колосе у сортообразцов пшеницы мягкой яровой}

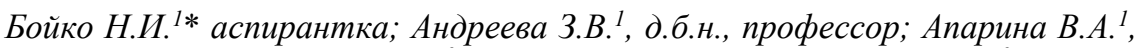
студентка; Сухомлинов В.Ю. ${ }^{2}$, агроном I категории; Пискарев В.В. ${ }^{2}$ к.с.-х.н., зав. лаб. генофонда растений.

${ }^{1}$ Новосибирский государственный аграрный университет, Новосибирск, Российская Федераиия;

${ }^{2}$ Сибирский научно-исследовательский институт растениеводства и селекици - филиал «Федерального исследовательского иентра Институт ицтологии и генетики Сибирского отделения Российской академии наук», Краснообск, Российская Федерачия.

*e-mail:n.bojko@mail.ru

В статье приведены данные о характере наследования числа колосков в колосе, выявлено, что проявление признака детерминируется 1-3 генам с проявлением доминантного и рецессивного эпистаза, а также зависит от условий, сложившихся в годы изучения. За время исследования гибридов $F_{2}$ по комбинациям Энита х Лютесиенс 77, Альбидум 31 х Баганская 51 выявлено различие по двум генам и Тулайковская золотистая х Омская 24 выявлено различие по трем генам.

Ключевые слова: пшеница, число колосков в колосе, характер наследования, эффект генов.

\section{Inheritance spikelet number per spike of spring wheat varieties}

Boyko N.I. ${ }^{1}$ postgraduate,n.bojko@mail.ru, Andreeva Z.V.' , Doctor of Biological Sciences, Professor, Aparina V.A. ${ }^{l}$, student, Sukhomlinov V.YU. ${ }^{2}$, Agronomist of I category, Piskarev V.V. ${ }^{2}$ candidate of agricultural sciences, head of the laboratory of the plant gene pool.

${ }^{I}$ Federal State Budgetary Educational Institution of Higher Education "Novosibirsk State Agrarian University", Novosibirsk Russia,

${ }^{2}$ Siberian Research Institute of Plant Production and Breeding - Branch of Federal State Budget Scientific Institution "The Federal Research Center Institute of Cytology and Genetics of Siberian Branch of the Russian Academy of Sciences".

The article presents data on inheritance spikelet number per spike. It revealed that 1-3 genes with expression of dominant and recessive epistasis determine the expression of a feature, and it depends on the conditions prevailing during the investigation. Difference in two genes was identified in combinations Enita $x$ Lutescens 77, Albidum 31 x Baganskaya 51, and three genes in Tulaykovskaya Zolotistaya $x$ Omskaya 24.

Key words: wheat, spikelet number per spike, inheritance, gene effect. 
Урожайность пшеницы представляет собой сложный признак, формирующийся из элементов структуры урожая, находящихся во взаимосвязи друг с другом. Селекционер может усилить либо ослабить один или несколько признаков для того, чтобы получить их оптимальное сочетание и, как результат, высокую продуктивность. Шелепов В.В. отдает предпочтение при увеличении урожайности числу колосков и зерен в колосе, массе 1000 зерен и зерна с одного растения [1]. Особенностью колоска пшеницы является то, что он содержит более одного зерна, что делает колосок пшеницы самым важным компонентом урожайности зерна [2]. Выявление характера наследования признака позволяет прогнозировать эффективный отбор нужных генотипов.

Цель нашего исследования - определить характер наследования числа колосков в колосе у сортообразцов пшеницы мягкой яровой.

Экспериментальную работу выполняли в 2017-2018 гг. в лесостепи Приобья в СибНИИРС - филиал ИЦиГ СО РАН. Вегетационный период 2017 г. по метеорологическим показателям характеризовался как умеренно увлажненный с повышенной теплообеспеченностью (ГТК =1,63). Метеорологические условия 2018 г. можно охарактеризовать как благоприятные для возделывания пшеницы (ГТК $=1,88)$.

Материалом для исследования служили 6 гибридных популяций, полученные в результате простых парных скрещиваний сортов пшеницы мягкой яровой с контрастной выраженностью признака. Посев проводили в оптимальные сроки, сеялкой РС-2 на глубину 5-6 см. Площадь питания растений $-200 \mathrm{~cm}^{2}$. Количество рядков от одного $\left(\mathrm{F}_{1}\right)$ до шести $\left(\mathrm{F}_{2}\right)$. Повторность 4-кратная. Предшественник - черный пар. Уход за посевами производили вручную (рыхление и прополки) по мере необходимости. Характер наследования количественных признаков определяли по формуле А. Густафссона и И. Дормлинг в процентах [3], а на ее основе определяется характер наследования по шкале, разработанной Р. А. Цильке [4]. Математическую обработку для выявления количества генов контролирующих число колосков в колосе проводили с помощью программы ПолигенА [5] по методике, описанной Костылевым П.И. (2008) [6].

Гибриды $\mathrm{F}_{1}$ в 2017 году характеризовались частичным доминированием родителя с большей выраженностью признака, за исключением комбинации Энита х Лютесценс, по которой наблюдали неполное доминирование родителя с большей выраженностью признака. При этом в 2018 году характер наследования изменялся от неполного доминирования родителя с меньшей выраженностью признака (Тулайковская золотистая х Омская 24) до частичного доминирования родителя с большей выраженностью признака (Лютесценс 77 x Энита, Энита х Лютесценс, Баганская 51 х Альбидум 31), у двух комбинаций изменений не отмечено (Лютесценс 77 x Энита и Баганская 51 x Альбидум 31). 
В целом по опыту родительские формы (табл. 1), которые формируют малое число колосков в колосе (Лютесценс 77, Альбидум 31 и Тулайковская золотистая), имели достоверно меньшее значение показателя, по сравнению с родительскими формами, формировавшими большее число колосков в колосе (Энита, Баганская 51 и Омская 24) за годы изучения. Коэффициент вариации признака по сортам Энита и Лютесценс 77 изменился от незначительной в 2017 году до средней изменчивости в 2018 году, по сорту Альбидум 31 отмечена обратная тенденция.

Таблица 1 - Статистические параметры вариации числа колосков в колосе у родительских форм (Р), Краснообск

\begin{tabular}{|c|c|c|c|c|c|c|c|}
\hline Параметры & Год & $\begin{array}{l}\tilde{\Xi} \\
\stackrel{\Xi}{\Xi}\end{array}$ & 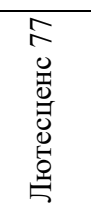 & 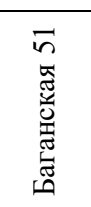 & 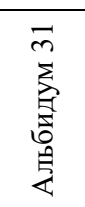 & 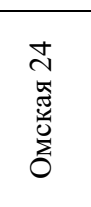 & 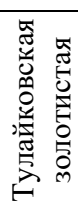 \\
\hline \multirow{2}{*}{ Среднее значение ( $\bar{X})$, шт. } & 2017 & $19,6^{*}$ & $16,2^{*}$ & $20,8^{*}$ & $15,1^{*}$ & $20,9^{*}$ & $15,5^{*}$ \\
\hline & 2018 & $17,5^{*}$ & $14,4^{*}$ & $18,5^{*}$ & $13,7^{*}$ & $20,1^{*}$ & $13,8^{*}$ \\
\hline \multirow{2}{*}{$\begin{array}{l}\text { Среднее квадратическое } \\
\text { отклонение (S) }\end{array}$} & 2017 & 1,6 & 1,1 & 1,6 & 1,6 & 1,5 & 0,2 \\
\hline & 2018 & 2,7 & 2,4 & 1,5 & 1,0 & 1,7 & 0,8 \\
\hline \multirow{2}{*}{ Ошибка выборочной $\left(S_{\bar{x}}\right)$} & 2017 & 0,2 & 0,1 & 0,2 & 0,2 & 0,2 & 0,1 \\
\hline & 2018 & 0,3 & 0,4 & 0,2 & 0,1 & 0,2 & 0,1 \\
\hline \multirow{2}{*}{ Коэффициент вариации, C } & 2017 & 8,0 & 7,0 & 8,0 & 11,0 & 7,0 & 8,0 \\
\hline & 2018 & 15,0 & 16,0 & 8,0 & 8,0 & 8,0 & 6,0 \\
\hline \multirow{2}{*}{$\begin{array}{l}\text { Нижний доверительный ин- } \\
\text { тервал, шт. }\end{array}$} & 2017 & 14,6 & 12,8 & 15,9 & 10,3 & 16,5 & 12,0 \\
\hline & 2018 & 9,5 & 7,3 & 14,0 & 10,6 & 15,1 & 11,3 \\
\hline \multirow{2}{*}{$\begin{array}{l}\text { Верхний доверительный ин- } \\
\text { тервал, шт. }\end{array}$} & 2017 & 24,5 & 19,7 & 25,6 & 19,9 & 25,4 & 19,0 \\
\hline & 2018 & 25,6 & 21,5 & 23,0 & 16,9 & 25,1 & 16,2 \\
\hline
\end{tabular}

По родительским формам Лютесценс 77 и Энита выявлено различие по одному (Лютесценс 77 х Энита в 2017 г.) и двум (Лютесценс 77 х Энита в 2017 и Энита х Лютесценс 77 в 2018 г.) генам (табл. 2). Можно отметить что по комбинациям Лютесценс 77 х Энита и Энита х Лютесценс 77 в 2017 году эффект генов (d) и критерий согласия $\chi^{2}{ }_{\phi}$ были достоверны, при этом в 2018 году эффект генов (d) был достоверен, а критерий согласия $\chi_{\phi}^{2}$ не достоверен. По результатам анализа выявлен доминантный эпистаз $\mathrm{A}>\mathrm{B}=0,5$ (2017 г.) и $\mathrm{A}>\mathrm{B}=0,1$ (2018 г.) (Энита х Лютесценс 77). По комбинации Лютесценс 77 х Энита количество генов изменилось, что можно объяснить влиянием различных генов на признак в зависимости от условий выращивания. Выявлено два (Альбидум 31 х Баганская 51 в 2017 и 2018 гг. и Баганская 51 х Альбидум 31 в 2017 г.) и три (Баганская 51 х Альбидум 31 в 2018 г) гена, контролирующих число колосков в колосе, по которым различаются данные 
родительские формы. В ходе анализа был выявлен доминантный $\mathrm{B}>\mathrm{A}=0,5$ (Альбидум 31 х Баганская 51, 2017 г.) и рецессивный $\mathrm{a}>\mathrm{B}=1,0$ (Альбидум 31 x Баганская 51, 2018 г.), b>A=1,0 (Баганская 51 х Альбидум 31, 2018 г.) эпистаз. Выявлено, что родительские формы Тулайковская золотистая и Омская 24 различаются между собой по трем генам, контролирующим число колосков в колосе. По комбинации Тулайковская золотистая х Омская 24 в 2017 году был выявлен рецессивный эпистаз $\mathrm{a}>\mathrm{B}=1,0, \mathrm{a}>\mathrm{C}=1,0, \mathrm{~b}>\mathrm{A}=1,0$.

Таблица 2 - Результаты гибридологического анализа числа колосков в колосе гибридов $\mathrm{F}_{2}$ пшеницы мягкой яровой, Краснообск

\begin{tabular}{|c|c|c|c|c|}
\hline Комбинация & Год & $\begin{array}{l}\text { Критерий } \\
\text { согласия } \chi^{2} \phi\end{array}$ & $\begin{array}{l}\text { Эффект } \\
\text { генов, d }\end{array}$ & $\begin{array}{l}\text { Число генов, } \\
\text { эпистаз }\end{array}$ \\
\hline \multirow{2}{*}{ Лютесценс 77 x Энита } & 2017 & $3,54 *$ & $\mathrm{~A}=3,32 *$ & 1 \\
\hline & 2018 & 21,53 & $\mathrm{~A}$ и $\mathrm{B}=1,6^{*}$ & 2 \\
\hline \multirow{2}{*}{ Энита х Лютесценс 77} & 2017 & $2,91^{*}$ & $\mathrm{~A}$ и $\mathrm{B}=2,2^{*}$ & $2, \mathrm{~A}>\mathrm{B}=0,5$ \\
\hline & 2018 & 23,41 & А и $\mathrm{B}=1,7^{*}$ & $2, \mathrm{~A}>\mathrm{B}=0,1$ \\
\hline \multirow{2}{*}{ Альбидум 31 х Баганская 51} & 2017 & $2,93^{*}$ & $\mathrm{~A}$ и $\mathrm{B}=3,8^{*}$ & $2, \mathrm{~B}>\mathrm{A}=0,5$ \\
\hline & 2018 & 5,09 & $\mathrm{~A}$ и $\mathrm{B}=2,4^{*}$ & $2, \mathrm{a}>\mathrm{B}=1,0$ \\
\hline \multirow{2}{*}{ Баганская 51 х Альбидум 31} & 2017 & $3,22 *$ & $\mathrm{~A}$ и $\mathrm{B}=2,8^{*}$ & 2 \\
\hline & 2018 & $2,85^{*}$ & $\mathrm{~A}, \mathrm{~B}$ и $\mathrm{C}=1,6^{*}$ & $3, b>A=1,0$ \\
\hline \multirow[t]{2}{*}{$\begin{array}{c}\text { Тулайковская золотистая x } \\
\text { Омская } 24\end{array}$} & 2017 & $3,18^{*}$ & $\mathrm{~A}, \mathrm{~B}$ и $\mathrm{C}=1,8^{*}$ & $\begin{array}{c}3, a>B=1,0 \\
a>C=1,0 \\
b>A=1,0\end{array}$ \\
\hline & 2018 & 20,5 & $\mathrm{~A}, \mathrm{~B}$ и $\mathrm{C}=2,1^{*}$ & 3 \\
\hline \multirow{2}{*}{$\begin{array}{c}\text { Омская } 24 \text { x Тулайковская } \\
\text { золотистая }\end{array}$} & 2017 & $4,30 *$ & $\mathrm{~A}$ и $\mathrm{B}=2,7^{*}$ & 2 \\
\hline & 2018 & 45,57 & $\mathrm{~A}, \mathrm{~B}$ и $\mathrm{C}=2,1^{*}$ & 3 \\
\hline \multicolumn{5}{|c|}{ Примечание: * *ачачение достоверно при $\mathrm{P}>0,05$} \\
\hline
\end{tabular}

\section{Выводы:}

1. характер наследования числа колосков в колосе изменялся в пределах частичного и неполного доминирования родителя с большей и меньшей выраженностью признака;

2. признак «число колосков в колосе», у изученных сортов, контролируется небольшим числом генов (1-3) с проявлением доминантного и рецессивного эпистаза. За два года изучения гибридов второго поколения (20172018 гг.), количество генов, контролирующих проявление признака, по которым различаются сорта, не изменилось по комбинациям Энита х Лютесценс 77, Альбидум 31 х Баганская 51 выявлено различие по двум генам и Тулайковская золотистая х Омская 24 выявлено различие по трем генам.

\section{Список литературы}

1. Шелепов В.В. Пшеница: история, морфология, биология, селекция: монография / В.В. Шелепов [и др.]. - Мироновка: ЗАТ «Мироновская типография», 2009. - 
577 с. - 500 экз. - ISBN 966-7802-52-3.

2. Dixon L.E. TEOSINTE BRANCHED1 regulates inflorescence architecture and development in bread wheat (Triticum aestivum) / L.E. Dixon, J.R. Greenwood, S. Bencivenga, P. Zhang, J. Cockram, G. Mellers, K. Ramm, C. Cavanagh, S.M. Swain, S.A. Boden // Plant Cell - № 3 (30) - 2018. - P. 563-581. doi: 10.1105/tpc.17.00961

3. Gustafsson A. Dominance and over dominance in phytotron analysis of monohybrid barley / A. Gustafsson, I. Dormling // Hereditas - Vol. 70, № 2. - 1972. - P. 185 - 190.

4. Цильке Р.А. Изменчивость и наследование продолжительности периода всходы - колошение у эколого-отдаленных гибридов мягкой яровой пшеницы / Р.А. Цильке, И.В. Кондратьева // Актуальные задачи селекции и семеноводства сельскохозяйственных растений на современном этапе: Доклады и сообщения IX генетикоселекционной школы - Новосибирск, 2005. - С. 195-203.

5. Мережко А.Ф. Система генетического изучения исходного материала для селекции растений: (Метод. указания) / Сост. А.Ф. Мережко. - Л.: ВИР, 1984. - 70 с.

6. Костылев П.И. Генетический анализ в селекции сельскохозяйственных культур / П.И. Костылев, Л.М. Костылева. - Зерноград: ФГОУ ВПО АЧГАА, 2008. - 73 с.

DOI 10.18699/GPB2020-18

\section{Поиск и функциональный анализ генов с циркадным паттерном экспрессии у мягкой пшеницы}

Брагина М.К., м.н.с.; Киселёва А.А., к.б.н., н.с.; Салина Е.А., о.б.н., г.н.с. ИЦиГ СО РАН, Новосибирск, Россия.

e-mail: koltunova@bionet.nsc.ru

Циркадные ритмы регулируют многие аспекты физиологии растений, включая фотосинтез, цвветение, развитие и метаболизм. Поскольку циркадные часы координируют экспрессию ряда ключевых генов, контролируюших важные для сельского хозяйства признаки, основные гены, контролируюшие цииркадные ритмы являются цуентрами важных транскрипциионных сетей. Модификация этих генов может привести к системньм эффектам, которые обеспечат усиление адаптации и положительно повлияют на цельй ряд агрономических признаков. Таким образом, основной темой данной работы является изучение суточных колебаний транскриптома пшеницы, идентификация как основных циикадных генов, так и генов метаболических путей под влиянием суточных ритмов.

Ключевье слова: Triticum aеstivum, цุиркаднье ритмы, экспрессия генов.

\section{Detection and functional analysis of genes with circadian expression pattern in common wheat}

Bragina M.K., Kiseleva A.A., Salina E.A.

Institute of Cytology and Genetics SB RAS, Novosibirsk, Russia. 
Circadian rhythms regulate many aspects of plant physiology, including photosynthesis, flowering, development, and metabolism. Because the circadian clock coordinates the expression of a number of key genes that control traits important to agriculture, the main genes that control circadian rhythms are centers of important transcriptional networks. Modification of these genes can lead to systemic effects that enhance adaptation and positively affect a range of agronomic traits. Thus, the main topic of this work is the study of diurnal fluctuations of the wheat transcriptome, identification of both the main circadian genes and genes of metabolic pathways under the influence of diurnal rhythms.

Key words: Triticum aestivum, circadian rhythms, gene expression.

Циркадные ритмы растений координируют такие физиологические процессы, как рост, переход к цветению, фотосинтез, реакцию на стресс, метаболизм и передачу сигналов фитогормонов при суточных и сезонных изменениях условий окружающей среды [1]. Такая взаимосвязь положительно влияет на рост, развитие растений и их адаптацию. Гены, регулируемые циркадными ритмами, включают в себя гены ассимиляции СО2, накопления/деградации крахмала в листьях и хранения питательных веществ (липидов и жирных кислот) в семенах [2]. Таким образом, большая часть транскриптома растений контролируется циркадными ритмами, которые играют важную роль в суточной регуляции физиологических процессов растений. Транскриптомный анализ циркадных механизмов и их влияния на различные метаболические процессы был проведен для таких растений, как арабидопсис, пекинская капуста и соя [3-5]. Гены центрального осциллятора консервативны, и их взаимодействия очень похожи у разных видов растений, но тем не менее, существуют и видоспецифичные различия. Кроме того, у большинства видов растений гены метаболических путей, на которые влияют циркадные ритмы, очень слабо изучены.

Цель работы. Мягкая пшеница является аллополиплоидом (геном AABBDD), поэтому присутствие гомеологических генов в геноме может оказывать сильное влияние на функционирование и регуляцию циркадных ритмов. Анализ литературы и поиск в базах данных не нашли исследований, изучающих суточную экспрессию транскриптома пшеницы, информация о суточной экспрессии генов и их взаимодействии практически отсутствует. Целью данной работы было исследование суточных осцилляций транскриптома пшеницы, выявление генов различных метаболических путей, находящихся под действием суточных ритмов. Полученные знания в области генетики мягкой пшеницы могут быть использованы в фундаментальных и в прикладных исследованиях, для работ по созданию высокоадаптивных сортов мягкой пшеницы.

Материал и методы. Для идентификации генов, которые демонстрируют ритмичные изменения экспрессии в течение суток, были использованы 
данные транскриптома мягкой пшеницы сорта Chinese Spring, полученные в четырех точках в течение дня $(0,3,9,16$ часов от момента включения света) на стадии трех листьев на 21 день после прорастания. Каждая временная точка была представлена тремя биологическими повторностями. 12 библиотек было получено с использованием набора TruSeq Stranded mRNA LT Sample Prep Kit (Il-lumina). Средний объем полученных в результате одноконцевого секвенирова-ния (75 п.н.) данных на приборе Illumina NextSeq 550 (ИЦиГ СО РАН) составил порядка 35,292,368 (от 25,176,261 до 45,139,550) последовательностей. При этом среднее значение показателя качества Q составило 34.5.

После предварительной обработки и контроля качества данных с использованием утилиты FASTXtoolkit полученные последовательности были карти-рованы на референсный транскриптом пшеницы с использованием программного обеспечения Bowtie. Для количественной оценки транскриптов использовалось программное обеспечение Kallisto v0.42.3 с параметрами по умолчанию. Нормализация обогащенности экспрессии транскриптов выборок выполнена по значению ТРМ (Transcripts per million). Для идентификации генов с циркадным паттерном экспресии была использована программа JTK-CYCLE. Визуализация полученных данных проведена в программе CemiTool. Для проведения функционального анализа обогащения терминами генной онтологии групп ге-нов с различными паттернами суточной экспрессии использованы базы данных REViGO и g:Profiler.

Результаты и обсуждение. Системный анализ транскриптома пшеницы позволил идентифицировать гены, экспрессирующиеся по циркадному типу, и контролируемые ими метаболические пути: биосинтез клеточных аминокислот, фотосинтез, реакция на свет, производство метаболитов и энергии, реакция на абиотический раздражитель, метаболизм соединений азота, углеводный обмен. Было показано, что значительная часть транскриптома находится под контролем суточных ритмов, и экспрессия этих генов может сильно варьировать в зависимости от времени. Мы обнаружили семь характерных паттернов экспрессии, характеризующиеся пиками в разные моменты времени, и описали гены, лежащие в основе этих паттернов. Мы проанализировали обогащение терминов генной онтологии различными паттернами и описали основные метаболические пути в каждой группе.

Благодарности: Исследование выполнено при финансовой поддержке РФФИ в рамках научного проекта № 20-316-80003 мол_эв_а.

\section{Список литературы}

1. Covington M.F. Global transcriptome analysis reveals circadian regulation of key pathways in plant growth and development / M.F. Covington, J.N. Maloof, M. Straume et al. // Genome Biol., 2008, vol. 9, No. 8. 
2. Yakir E. Regulation of output from the plant circadian clock / E. Yakir, D. Hilman, Y. Harir et al. // FEBS J., 2007, vol. 274, no. 2, pp. 335-345.

3. Harmer S.L. Orchestrated transcription of key pathways in Arabidopsis by the circadian clock / S.L. Harmer et al. // Science, 2000, vol. 290, no. 5499, pp. 2110-2113.

4. Chow B.Y., Kay S.A. Global approaches for telling time: omics and the Arabidopsis circadian clock / Semin. Cell Dev. Biol., 2013, vol. 24, no. 5, pp. 383-392.

5. Kim J.A. Transcriptome analysis of diurnal gene expression in Chinese cabbage / J.A. Kim et al. // Genes (Basel), 2019, vol. 10, no. 2, p. 130.

DOI 10.18699/GPB2020-19

\section{Комплекс представителей рода Trollius в биоресурсной коллекции ЦСБС СО РАН: перспективы интродукции и селекции}

Буглова Л.В. ${ }^{1}$, к.б.н., с.н.с.; Васильева О.Ю ${ }^{l}$, д.б.н., в.н.с.; Гусар А.С. ${ }^{2}$, магистрант; Козлова М.B. ${ }^{2}$, магистрант; Морозова A.O. ${ }^{2}$, магистрант.

${ }^{1}$ ФБУН «Центральный сибирский ботанический сад СО РАН» (ФГБУН ЦСБС СО РАН), Новосибирск, Россия;

${ }^{2}$ ФБОУ ВО «Новосибирский государственный аграрный университет» (ФГБОУ ВО НГАУ), Новосибирск, Россия.

e-mail: astro11@rambler.ru

В статье представлены селекционные направления работ с природными видами и формами Trollius, интродуцированными в коллекцию ЦСБС CO РАН. Для T. asiaticus и T. ledebourii установлена довольно строгая аллогамия. Приведен список природных форм. Описано потомство $F_{1}$ от искусственной гибридизации $-T$. europaeus $\times T$. asiaticus, $T$. ledebourii $\times T$. chinensis, достигшее генеративного возраста. Проводится отбор наиболее удачных фенотипических вариантов.

Ключевые слова: Trollius, виды, формы, интродукция, гибридизация.

\section{Complex of trollius forms and species in the bioresource collection of Central Siberian botanical garden Sb Ras: prospects for introduction and selection}

Buglova L.V.' ${ }^{1}$ Vasilieva O.Y. ${ }^{1}$, Gusar A.S. ${ }^{2}$, Kozlova M.V. ${ }^{2}$, Morozova A.O. ${ }^{2}$

${ }^{1}$ Federal State Institution of Science «Central Siberian botanical garden of the Siberian Branch of the Russian Academy of Sciences» (FSIS CSBG SB RAS), Novosibirsk, Russia, e-mail: astro11@rambler.ru

${ }^{2}$ Federal State Educational Institution of Higher Education "Novosibirsk State Agrarian University” (FSEI HE NSAU), Novosibirsk, Russia.

The article presents the selection research with the Trollius natural species and forms, introduced into the collection of the Central Siberian botanical garden 
SB RAS. A strict allogamy is defined for species T. asiaticus and T. ledebourii. The natural plant forms are described. There are descriptions of the artificial hybrids $F_{1}:$ T. europaeus $\times T$. asiaticus and T. ledebourii $\times T$. chinensis that has reached a generative growth phase. The most successful phenotypic characteristics are involved in the selection.

Key words: Trollius, species, forms, introduction, hybridization.

Семейство Ranunculaceae является одним из ведущих по числу родов, виды которого являются высокодекоративными красивоцветущими растениями. Среди лютиковых выделяется род Trollius, представители которого перспективны для интродукции и селекции не только в качестве декоративных растений, но также в качестве лекарственных (противовирусных, антиоксидантных) и медоносных растений [1-4].

Изучение хозяйственно перспективных растений требует мультидисциплинарного подхода, что наиболее эффективно можно выполнить при формировании и использовании биоресурсных научных коллекций.

Основными направлениями изучения растений в таких коллекциях являются: сезонное развитие, онтоморфогенез, репродуктивная биология и генетическая паспортизация [5]. Кроме того, проявление видовых признаков у растений, собранных из разных мест обитания, в однотипных эколого-географических условиях, раскрывает филогенез рода [6-7].

В условиях континентального климата лесостепи Западной Сибири комплекс представителей рода Trollius является частью биоресурсной научной коллекции ЦСБС СО РАН, включает 9 видов, из которых один еще не вступил в генеративный период.

По итогам интродукции 11 видов, только T. lilacinus и T. pumilus выпадают из коллекции. Среди остальных объектов исследований виды T. altaicus, T. riederianus и T. asiaticus отличались наиболее высоким полиморфизмом.

Собранные в различных частях их ареалов в процессе экспедиционных работ природные формы различались по следующим диагностическим признакам: T. europaeus - по длине носиков, T. riederianus - по длине лепестков. Наиболее представлены формы местного вида T. asiaticus, различающиеся по длине носиков, длине и ширине лепестков, срокам начала цветения.

В коллекции имеются 2 природных мутанта с ежегодно воспроизводимыми отклонениями и один садовый ауреовариегатный (пестролистный). На базе имеющегося в биоресурсной коллекции комплекса представителей рода Trollius проводились селекционные работы.

Далее были проведены опыты по учету соотношения авто-аллогамии у T. asiaticus и T. ledebourii с исключением возможности гейтоногамии и искусственная межвидовая гибридизация. Оба вида являются основными генетическими источниками, реализующими в фенотипе высокодекоративный 
околоцветник. Данные по типам опыления приведены в таблице.

Из таблицы видно, что оба вида являются строго аллогамными растениями. При самоопылении образуются единичные семена у обоих видов, не исключено, что они образовались в результате апомиксиса, а не самоопыления. У T. asiaticus большая часть исследованных растений не образует семена при самоопылении, но у нескольких экземпляров отмечено формирование до 7 семян в одном плоде при автогамии. У T. ledebourii наоборот, семена от самоопыления завязывались на всех растениях в количестве 2-4 штук в одном плоде.

Таблица - Количество выполненных семян из одного плода при разных типах опыления

\begin{tabular}{|c|c|c|c|c|}
\hline \multirow{2}{*}{ Вид, год опыления } & \multicolumn{2}{|c|}{ Самоопыление } & \multicolumn{2}{c|}{ Перекрестное опыление } \\
\cline { 2 - 5 } & кол-во плодов & кол-во семян & кол-во плодов & кол-во семян \\
\hline T. ledebourii, 2014 & 2 & 7 & 1 & 141 \\
\hline T. ledebourii, 2017 & 3 & 11 & 6 & 588 \\
\hline T. asiaticus, 2017 & 7 & 22 & 1 & 245 \\
\hline
\end{tabular}

В потомстве, полученном в результате беккроссинга $T$. asiaticus $\times$ (T. asiaticus $\times$ T. europaeus), отобраны крупные растения с мощным стеблем до 110 см высотой в конце цветения, с ярко оранжевыми цветками, бокаловидной формы 5-7 см в диаметре. Форма листьев глубоко-рассеченная, лепестки и чашелистики в числе 20-25, лепестки более ярой окраски, чем чашелистики, около 2 мм шириной, короче чашелистиков, но заметно длиннее лепестков.

Опыты по межвидовой гибридизации включали 4 варианта, в одном из них (T. ledebourii $\times$ T. lilacinus) семена не завязались. Опыление проведено через 2 суток после сбора, по мере ее доставки на территорию ЦСБС.

В потомстве T. europaeus $\times$ T. asiaticus гибриды $F_{1}$ были единообразные. Это крупные растения до 90 см высотой. Цветок морфологически близок к T. apertus - природному виду гибридного происхождения от T. europaeus $\times$ T. asiaticus.

Гибриды T. ledebourii $\times$ T. chinensis представляют собой невысокие растения с прочными стеблями, около 60 см высотой, ниже обоих родителей. Цветок и форма листовок близки к T. ledebourii, носики промежуточной длины 2-3 мм, слабо отогнутые наружу. Экземпляры $F_{1}$ имеют незначительные отличия по длине и степени отгиба носиков.

Гибридное потомство T. ledebourii $\times$ T. altaicus к настоящему времени достигло лишь имматурного онтогенетического состояния.

Все гибридные семена показали хорошую полевую всхожесть.

Таким образом, проведенные интродукционные и селекционные ис- 
следования свидетельствуют о перспективности работ в данном направлении, особенно в связи с тем, что отобранные в природе и полученные в результате гибридизации формы можно поддерживать и размножать вегетативно. Все формы Trollius холодостойки и устойчивы к болезням, что делает их перспективными в регионах с длительным морозным периодом.

\section{Список литературы}

1. Растительные ресурсы СССР. с. Ranunculaceae. Л: Наука, 1985. - С. 82-98.

2. Повыдыш М.Н., Сем. Ranunculaceae / M.Н. Повыдыш, Н.В. Петрова, Л.И. Медведева, Т.А. Орлова // Растительные ресурсы России. Дикорастущие цветковые растения, их компонентный состав и биологическая активность. С-Пб.-М: ТНИ КМК, 2008. - С. 24-67.

3. Wang, S., Growth inhibition and apoptotic effects of total flavonoids from Trollius chinensis on human breast cancer MCF-7 cells / S. Wang, Q. Tian, F.An // Oncology Letters 12(3), 2016. - P.1705-1710.

4. Liu L.J., Anti-inflammatory effect of the compounds from the flowers of Trollius chinensis / L.J. Liu, X.H. Hu, L.N. Guo, R.F. Wang, Q.T. Zhao // Pak J Pharm Sci. 31(5), 2018. - P.1951-1957.

5. Васильева О.Ю. Методические аспекты изучения биоресурсных коллекций редких и хозяйственно ценных растений / О.Ю. Васильева, О.В. Дорогина, И.Н. Кубан, И.Я. Сарлаева, Л.В. Буглова // Садоводство и виноградарство. 4(214), 2018 - С. 12-18. DOI: 10.31676/0235-2591-2018-4-12-18

6. Русанов Ф.Н. Метод родовых комплексов в интродукции растений / Ф.Н. Русанов // Бюл. ГБС АН СССР. Т. 81, 1977. - С. 15-20.

7. Куприянов А.Н. Теория и практика интродукции растений: учебное пособие. - Кемерово: КРЭОО «Ирбис», 2013. - С.160.

DOI $10.18699 /$ GPB2020-20

\section{Селекция озимого рапса для условий лесной зоны}

Воловик В.Т. к.с.-х.н., зав. лабораторией.

ФГБНУ «Федеральный научный иеентр кормопроизводства и агроэкологии им. В.Р. Вильямса», г. Лобня, Россия.

e-mail:vik_volovik@mail.ru

Проведена оценка исходного материала озимого рапса и выделены источники хозяйственно-ценных признаков - зимостойкости, качества и продуктивности. Методом промораживания в климокамере, внутривидовой гибридизации географически отдаленных форм и отбора получены образцы с повышенной зимостойкостью. Использование в скрещчиваниях продуктивного с высокими показателями качества семян родителя позволили получить образцы, сочетающие высокую зимостойкость и качество. В резуль- 
тате созданы сорта озимого рапса с высоким урожаем семян, содержанием жира 44-48\%, низким уровнем глюкозинолатов и отсутствием эруковой кислоты, позволившие расширить ареал воздельвания культуры.

Ключевые слова: озимый рапс, методы селекции, сорта.

\section{Breeding winter oilseed rape for the conditions of the forest zone}

Valentina Timofeevna Volovik

Federal research centre for fodder production and Agroecology in the name of V.R. Williams, Lobnya, Moscow region, Russian Federation.

Evaluated source material of winter rapeseed and sources of economically valuable traits - winterhardiness, quality and productiveness. Method of freezing in climatesure, intraspecific hybridization of geographically distant forms and selection of the obtained samples with increased winter hardiness. The use of productive matings with high-quality seed parent is allowed to obtain samples that combine high winter hardiness and quality. As a result of the varieties of winter canola with productive parent seeds, the fat content of 44-48\%, and a low level of glucosinolates and the absence of erucic acid, which allowed to expand the area of crop cultivation.

Key words: winter rape, breeding methods, varieties.

Озимый рапс (Brassica napus L. var. napus f. biennis (Schübl \& G.Martens) является ценной масличной и кормовой высокобелковой культурой, обладающей высокой продуктивностью зеленой массы и семян; использование в чистом виде и в смеси с викой и злаковыми культурами позволяет создавать зеленый конвейер с ранней весны до поздней осени; семена используются для получения пищевого растительного масла, жмыхов и шротов для животноводства. Культура в условиях лесной зоны рано созревает, уходит от повреждения крестоцветной блошкой и цветоедом, что снижает пестицидную нагрузку на экосистему, хорошо встраивается в севооборот [1-4]. Распространение озимого рапса в стране до начала 21 века сдерживало отсутствие зимостойких двунулевых сортов. Работа по их созданию для условий лесной зоны России проводится с 1994 года [5-6].

Оценка коллекции озимого рапса проведена в соответствии с существующими методиками ВИР и Госкомиссии по сортоиспытанию. В селекции рапса применена внутривидовая гибридизация, отборы: массовый и индивидуально-семенный, метод Педигри, инцухтирование; промораживание проростков, эксплантов и растений в низкотемпературной камере с последующим отбором в полевых условиях. Промораживание растений в фазе розетки проводили по методике ВНИИ масличных культур имени В.С. Пустовойта [7]. Для ускорения селекционного процесса использовали селекционно-тепличный комплекс и одновременное экологическое испытание пер- 
спективного материала; выбраковку селекционного материала по качественным показателям проводили на всех этапах селекции. Определение содержания жира и белка проведено по общепринятым методикам, жирнокислотный состав - с использованием газохроматографического метода, определение глюкозинолатов - тест- палладиевым методом на пламенном фотометре, обработка результатов исследований - методом дисперсионного анализа.

Было установлено, что наивысшей зимостойкостью (85-95 \%) обладали сорта северной эколого-географической группы, средней (70-75\%) западноевропейские и низкой (менее 65 \%) - сорта южных экотипов. Коэффициент вариации зимостойкости за годы изучения составил 0,95 . По признаку зимостойкости выделились Проминь, Тисменецкий (СССР), Jupicu, Status, образцы № 942, 928 (Швеция); Buko, Marinus, Liraston, (Германия); Jet-Nef, Darmor, Tandem (Франция). Сохранность этих образцов после перезимовки в благоприятных условиях была выше средней на 10-15 \%, в неблагоприятных - на 27-44 \%. По продуктивности зеленой массы (235-244 ц/га) выделились образцы Darmor, Tandem, Проминь. Образцы Buko, Liraston, Darmor, Jupicu, Tandem превышали средний стандарт по семенной продуктивности. Существенным недостатком многих образцов было повышенное содержание антипитательных веществ - эруковой кислоты (Buko - 46,4 \%; Darmor - 4,56 \%) и глюкозинолатов. Выделенные образцы были использованы в скрещиваниях для получения нового исходного материала.

Оценка новых образцов проводилась регулярно, по мере их поступления. Среди сортов следующего поколения по признаку зимостойкости выделились образцы Libea, Livius, Lirajet, Wotan, Kronos, Express (Германия), Kasimir (Швеция), Дангал, Света (Украина); Козерог (Белоруссия), Северянин, ВИК 2, Лауреат, Столичный, Оникс (Россия); № 4, 2, 6 (совместно Россия - Германия). Образцы иностранной селекции отличались хорошими биохимическими показателями: высоким содержанием жира, низким уровнем глюкозинолатов, отсутствием эруковой кислоты.

При создании зимостойких сортов озимого рапса одним из результативных методов была гибридизация соответственно подобранных родительских пар с учетом их происхождения. В качестве материнской формы при скрещивании нами использовались более зимостойкие генотипы. В качестве отцовской формы лучшие по качеству и продуктивности сорта и селекционные образцы (часто зарубежной селекции - немецкой, шведской и французской). Для повышения зимостойкости эффективными были повторные скрещивания с высокозимостойкими сортами, а также метод однократного насыщения гибридов первого поколения лучшими по биохимическому составу сортами рапса озимого. От скрещивания географических отдаленных форм возникала трансгрессия по признаку зимостойкости.

В результате проведенной работы создана линейка сортов с периодом весенней вегетации от 86 (Горизонт) до 102 (Гарант) дней, средней урожайностью семян 3,8-4,9 т/га, с перезимовкой 75,1-84,2 \% (табл. 1). 
Таблица 1 - Характеристика сортов озимого рапса селекции ФНЦ «ВИК им. В.Р. Вильямса» (ср. за 5 лет)

\begin{tabular}{|l|c|c|c|c|c|c|}
\hline $\begin{array}{c}\text { Название } \\
\text { сорта }\end{array}$ & $\begin{array}{c}\text { Перезимовка, } \\
\%\end{array}$ & $\begin{array}{c}\text { Урожайность } \\
\text { семян, т/га }\end{array}$ & $\begin{array}{c}\text { Вегетаци- } \\
\text { онный пе-- } \\
\text { риод, дни* }\end{array}$ & $\begin{array}{c}\text { Сбор } \\
\text { жира, } \\
\text { т/гa }\end{array}$ & $\begin{array}{c}\text { Сбор } \\
\text { протеина, } \\
\text { т/га }\end{array}$ & $\begin{array}{c}\text { Регион } \\
\text { допуска }\end{array}$ \\
\hline Северянин & 75,1 & 4,3 & 90 & 1,9 & 1,0 & $3,5,6$ \\
\hline Лауреат & 79,0 & 4,0 & 98 & 1,9 & 0,9 & 3,6 \\
\hline Столичный & 78,2 & 3,8 & 95 & 1,7 & 0,9 & 3,6 \\
\hline Горизонт & 84,2 & 4,5 & 86 & 2,0 & 1,1 & 3 \\
\hline Гарант & 82,3 & 4,9 & 102 & 2,5 & 1,2 & 3,5 \\
\hline Норд & 81,9 & 4,4 & 88 & 2,1 & 1,1 & $3,5,2$ \\
\hline
\end{tabular}

* от весеннего отрастания

Сорта озимого рапса селекции ФНЦ «ВИК им. В.Р. Вильямса» отличаются высоким содержанием сырого жира, варьирование по годам от 44,6 до 50,7 \%. Более высокое содержание жира отмечено у сортов Лауреат, Гарант и Горизонт. Семена всех сортов содержат допустимое количество глюкозинолатов. Сорт Гарант отличается пониженным содержанием глюкозинолатов, что улучшает его питательную ценность при использовании в кормлении животных. В составе жирных кислот всех сортов нашей селекции отсутствует эруковая кислота. Сорт Столичный отличается повышенным содержанием олеиновой кислоты и более низким содержанием линоленовой (табл. 2), что улучшает устойчивость пищевого масла из семян этого сорта к окислению.

Создание новых сортов озимого рапса, отличающихся повышенной зимостойкостью, позволило существенно расширить ареал возделывания культуры. Традиционно озимый рапс возделывался только в 6 и 2 (Калининградская область) регионах. С 2006 года сорта селекции ФНЦ «ВИК им. В.Р. Вильямса» допущены к использованию в 3, 5, 2 и 6 регионах.

Таблища 2 - Биохимический состав семян сортов озимого рапса селекции ФНЦ «ВИК им. В.Р. Вильямса»

\begin{tabular}{|c|c|c|c|c|c|}
\hline \multirow{2}{*}{$\begin{array}{c}\text { Название } \\
\text { сорта }\end{array}$} & \multirow{2}{*}{$\begin{array}{l}\text { Содержание } \\
\text { жира lim, \% }\end{array}$} & \multirow{2}{*}{$\begin{array}{c}\text { Содержание } \\
\text { глюкозинолатов, } \\
\text { мкмоль/г }\end{array}$} & \multicolumn{3}{|c|}{$\begin{array}{c}\text { Содержание } \mathrm{C}_{18} \text { жирных кислот, } \\
\%\end{array}$} \\
\hline & & & $\begin{array}{c}\text { олеино- } \\
\text { вая }\end{array}$ & $\begin{array}{c}\text { линоле- } \\
\text { новая }\end{array}$ & $\begin{array}{c}\text { линолено- } \\
\text { вая }\end{array}$ \\
\hline Северянин & $45,0-49,4$ & 20,0 & 61,96 & 19,40 & 9,74 \\
\hline Лауреат & $46,0-50,7$ & 15,5 & 63,30 & 19,26 & 8,85 \\
\hline Столичный & $44,6-48,0$ & 15,9 & 66,25 & 17,03 & 8,05 \\
\hline Горизонт & $46,9-49,8$ & 16,5 & 61,85 & 19,82 & 10,02 \\
\hline Гарант & $46,3-50,4$ & 14,5 & 64,40 & 17,49 & 8,63 \\
\hline Норд & $45,2-48,0$ & 15,2 & 62,40 & 19,70 & 8,90 \\
\hline
\end{tabular}


Проведенное молекулярно-цитогенетическое исследование сортов рапса с применением GISH с зондами геномной ДНК сурепицы и капусты для разделения геномов и последующим FISH с зондами 45S и $5 \mathrm{~S}$ рДНК, позволило изучить хромосомный полиморфизм А- и С- субгеномов по локализации кластеров рибосомных генов. У зимостойких сортов Норд и Северянин, с более широким районировананием, обнаружено сходство по распределению и размерам выявленных хромосомных маркеров и идентичность сочетаний полиморфных вариантов гомологичных хромосом, несущих локусы 45S и/или 5S рДНК [8-9].

Благодарности: Исследование выполнено в рамках Государственного задания ФНЦ «ВИК им. В.Р. Вильямса» 007-01865-17 при финансовой поддержке РФФИ в рамках научного проекта №18-54-00027 Бел_а.

\section{Список литературы}

1. Гортлевский А.А., Макеев В.А. Озимый рапс. - М.: Россельхозиздат, 1983. - 135 с.

2. Воловик В.Т. Результаты научных исследований по масличным капустным культурам (ГНУ ВИК Россельхозакадемии, этапы 30-летнего пути) // Адаптивное кормопроизводство. - 2012. - №4 (12). - С. 13-24.

3. Золотарев В.Н., Новоселов Ю.К., Рудоман В.М. и др. Рекомендации по возделыванию и использованию вики мохнатой (озимой) на корм и семена. - М.: ФГНУ «Росинформагротех». $-2007 .-46 \mathrm{c}$.

4. Воловик В. Т., Разгуляева Н.В. Итоги селекции сортов озимого рапса для Нечерноземной зоны // Кормопроизводство. - 2011. - № 10. - С. 25-26.

5. Volovik V., Razgulyaeva N. Breeding of winder rapeseed in the Central European Russia // 13th Rapeseed Congress (Prague, June 05-09, 2011). - Prague: Tiskarna V raji s.r.o, 2011. - P. 220.

6. Volovik V.T., Prologova T.V. Breeding Winter Rapeseed for the Temperate Forest Zone // Russian Agricultural Sciences. - 2017. - Vol. 43, No. 3. - PP. 213-218.

7. Бочкарева Э.Б. Методы оценки озимых крестоцветных культур на морозостойкость // Селекция и семеноводство масличных культур. Сб. тр. ВНИИМК. - Краснодар, -1980 . - C. 127-134.

8. Amosova A.V, Zemtsova L.V., Grushetskaya Z.E., Samatadze T.E., Mozgova G.V., Pilyuk Y.E., Volovik V.T., Melnikova N.V., Zelenin A.V., Lemesh V.A., Muravenko O.V. Intraspecific chromosomal and genetic polymorphism in brassica napus 1. detected by cytogenetic and molecular markers // Journal of genetics. - 2014. - Vol. 93, No. 1, april. - PP. 133-143.

9. Земцова Л.В., Амосова А.С., Саматанзе Т.Е., Большева Н.Л., Воловик В.Т., Зеленин А.В., Муравенко О. В. Разделение близкородственных геномов и идентификация хромосом рапса с помощью одновременной флуоресцентной гибридизации in situ геномной гибридизации in situ // Доклады Академии наук. - 2014. - Т. 457. № 3. - С. 356. 


\section{Основные задачи селекции сливы на Алтае}

Гарапов Д.С., н.с.

Федеральный Алтайский научный центр агробиотехнологий, Барнаул, Россия. e-mail:prunus@inbox.ru

В результате многолетней селекиионной работы по повымению адаптивного потенциила сливы на Алтае созданы сорта и элитные формы на основе межвидовой гибридизачии. От скрещчивания сортов и форм алычи с местныли сортами сливы уссурийской получены сорта и перспективные гибриды с плотной мякотью плодов, среднеустойчивые к выпреванию, устойчивые к плодожорке и монилиозу. Показана возможность выделения невыпреваюших клоновых подвоев сливы на основе межвидовых гибридов терна.

Ключевые слова: слива уссурийская, алыча, сорт, терн, межвидовые гибриды, подвой.

\section{The main objects of plum breeding in Altai}

Garapov Denis Sergeevich, Federal Altai Scientific Centre of Agro Biotechnologies, Barnaul, Russia, e-mail: prunus@inbox.ru

Long-term breeding for plum adaptation to Siberian conditions resulted in new cultivars and elites originated from interspecific hybridization. Crossing Prunus cerasifera forms and cvs. with P. ussuriensis local cvs. made it possible to have cultivars and promising hybrids with improved fruit traits (firmness), moderate tolerance to asphyxiation, disease and insect resistance. Non-asphyxiating rootstock for plum can be selected on the basis of P. spinosa interspecific hybrids.

Key words: Ussurian plum, cherry plum, cultivar, blackthorn, interspecific hybrids, rootstock.

В суровых климатических условиях Сибири культура сливы является любительской, как и другие плодовые культуры [1]. Слабое распространение сливы в Западной Сибири, чем в Западной Сибири связано с тем, что в многоснежных районах растения ежегодно повреждаются выпреванием и по разным причинам плодоносят нерегулярно [2]. Но и в более благоприятных климатических зонах Сибири сливовые сады не являются товарными. Отчасти это объясняется дефицитом сортов с соответствующим качеством плодов (транспортабельность, крупноплодность). Такие же требования к сортам предъявляет любительский сектор. Основным направлением в улучшении сортимента сливы в Сибири, как и во всех зонах плодоводства России, является создание продуктивных, адаптированных к местным условиям сортов с высокими товарными качествами плодов [3].

В Алтайском научном центре агробиотехнологий накоплен и изучен 84 
богатый фонд доноров и источников селекционно-значимых признаков $[4,5]$. Встает вопрос их сохранения и рационального использования. В связи с этим, цель настоящей работы - определить задачи селекции сливы на Алтае.

Систематическая работа с культурой сливы на Алтае начата с 1935 г. Работа ведется в двух природно-климатических зонах - среднегорье Алтая (с. Чемал) и лесостепная зона (г. Барнаул). К настоящему времени селекционерами В.С. Путовым, И.А. Пучкиным и М.Н. Матюниным выведены относительно адаптированные сорта [6, 7]. Все они получены на основе сливы уссурийской (Prunus ussuriensis) и являются ее гибридами со сливой китайской (P. salicina). Некоторые сорта представляют собой межвидовые гибриды с участием алычи (P. cerasifera) и сливы американской (P. americana). Несмотря на использование межвидовой гибридизации, основные недостатки, унаследованные от сливы уссурийской (слабая зимостойкость плодовых почек, раннее цветение, неустойчивость к выпреванию), не преодолены. В последние годы отмечен прогресс в выведении устойчивых к выпреванию сортов. Получены первые сибирские сорта гибридной алычи или сливы русской (P. rossica) - Дака, Цыганочка, элитная форма Дудука [7]. Изза недостаточной морозоустойчивости плодовых почек, периодичность плодоношения у них выражена сильнее, чем у китайско-уссурийской сливы. Тем не менее, некоторые формы гибридной алычи по урожайности не уступают лучшим сортам сливы (табл. 1).

Таблица 1 - Урожайность сортообразцов сливы и гибридной алычи в саду первичного изучения, г. Барнаул, посадка осени 2007, 2008 гг., схема $5 \times 2$ м

\begin{tabular}{|c|c|c|c|c|c|c|c|c|}
\hline \multirow{3}{*}{ Сортообразец } & \multicolumn{7}{|c|}{ Урожайность, т/га } & \multirow{3}{*}{$\begin{array}{c}\text { Состояние } \\
\text { к } 2019 \text { г., } \\
\text { балл }\end{array}$} \\
\hline & \multicolumn{7}{|c|}{ Годы } & \\
\hline & 2013 & 2015 & 2016 & 2017 & 2018 & 2019 & $\begin{array}{l}2013- \\
2019\end{array}$ & \\
\hline \multicolumn{9}{|c|}{ Слива } \\
\hline $\begin{array}{l}\text { Алтайская } \\
\text { юбилейная }\end{array}$ & 0,2 & 4,7 & 1,8 & 6,2 & 4,5 & 4,8 & 3,7 & 3,5 \\
\hline Узюк & 2,2 & 8,5 & 6,1 & 2,5 & 1,3 & 5,3 & 4,3 & 3,3 \\
\hline \multicolumn{9}{|c|}{ Гибридная альча } \\
\hline ГА 12-60 & 0,3 & 0,5 & 5,7 & 7,8 & 4,7 & 8,0 & 4,5 & 3,8 \\
\hline Дудука & 0 & 1,8 & 1,4 & 6,0 & 3,3 & 4,5 & 2,8 & 3,1 \\
\hline $\mathrm{HCP}_{05}$ & 0,4 & 2,3 & 3,8 & $\mathrm{~F}_{\phi}<\mathrm{F}_{\mathrm{T}}$ & $\mathrm{F}_{\phi}<\mathrm{F}_{\mathrm{T}}$ & $\mathrm{F}_{\phi}<\mathrm{F}_{\mathrm{T}}$ & $\mathrm{F}_{\phi}<\mathrm{F}_{\mathrm{T}}$ & 0,5 \\
\hline
\end{tabular}

Алыча привлечена в селекцию для создания устойчивых к выпреванию сортов сливы. При скрещиваниях сливы уссурийской с алычой происходит и снижение морозостойкости гибридов. Работа с алычой начиналась с мелкоплодных форм - гибрида II-31 (армянская алыча х слива уссурийская), алычи согдийской (P. sogdiana), алычи Писсарда из барнаульского дендрария. Среди гибридов $\mathrm{F}_{1}$ наибольшую зимостойкость 
и устойчивость к выпреванию показали сеянцы гибридной алычи II-31, в том числе отборная форма ГА 12-60, и сеянцы алычи согдийской. В Барнауле зимостойкие гибриды получены с участием сорта грузинской алычи Красное знамя. Гибриды $\mathrm{F}_{1}$, полученные от свободного опыления алычи Писсарда зимостойкими сортообразцами сливы уссурийской (5-6, Краснощекая, Пониклая и др.), были недостаточно зимостойкими, но выделены крупноплодные формы с высокими вкусовыми (9-269-14, 9-28414) и консервными качествами (9-248-14). При повторном скрещивании гибридов $\mathrm{F}_{1}$ со сливой уссурийской морозостойкость в $\mathrm{F}_{2}$ повысилась, но устойчивость к выпреванию снизилась или осталась на прежнем уровне. Среднезимостойкая форма Дудука получена от скрещивания слабозимостойкого сорта сливы Красномясая с гибридами $\mathrm{F}_{1}$ алыча Писсарда $\times$ слива уссурийская [7].

Для создания сортов с высокими товарными качествами плодов привлечен донор признака плотной (хрящеватой) мякоти плодов - сорт армянской алычи Аштаракская 2. Наиболее зимостойкие формы с участием этого сорта получены от повторного скрещивания гибридов $\mathrm{F}_{1}$ с со сливой уссурийской, где в каждом поколении участвовали высокозимостойкие сорта сливы Желтая Хопты, Катунская, Краснощекая, Пирамидальная, Пониклая. Формы, выделенные среди гибридов $\mathrm{F}_{1}$ (Караташ) и $\mathrm{F}_{2}$ (Ида, Лира), проходят испытание на Шушенском госсортоучастке. Удовлетворительную зимостойкость в Барнауле показала элитная формаОсенняя черная селекции Н.М. Матюнина. В отличие от первых сортов гибридной алычи, у этих форм появились новые признаки - плотная консистенция мякоти, транспортабельность плодов [7]. Не менее важными признаками, приобретенными от алычи, являются устойчивость к плодожорке, к поражению плодов монилиозом и устойчивость к осыпанию плодов (Дака, Цыганочка).

Алыча значительно обогатила алтайский генофонд сливы. При этом задействована лишь небольшая часть кавказского и среднеазиатского генофонда алычи, обладающего значительным полиморфизмом [8], в том числе за счет интрогрессии некоторых генов от микровишни мелкоплодной (P. microcarpa), культурных сортов сливы китайской, персика и абрикоса [9]. Целесообразно скрещивать гибриды с участием различных разновидностей алычи, как между собой, так и с различными сортами сливы [10].

В Чемале созданы гибриды диплоидных слив с терном (P. spinosa), терносливой (P. insititia) и сливой домашней (P. domestica). Полиплоидные сливы привлечены в селекцию за устойчивость к выпреванию, длительный зимний покой плодовых почек и позднее цветение. Объединение геномов полиплоидных и диплоидных видов затруднено, гибриды слабоплодовиты, 
но лучшие из них значительно превосходят исходные виды по адаптивности (табл. 2).

Таблища 2 - Изучение сливы, терносливы и межвидовых гибридов терна в коллекции, г. Барнаул, среднее за 2015-2019 гг.

\begin{tabular}{|c|c|c|c|c|}
\hline Сортообразец & 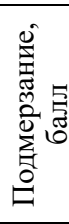 & 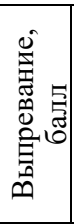 & 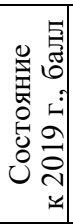 & 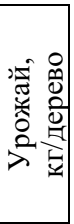 \\
\hline \multicolumn{5}{|l|}{ Слива (посадка осени 2011 г.) } \\
\hline $\begin{array}{l}\text { Алтайская юбилейная } \\
\text { (прививка на штамб невыпревающего подвоя 61-2) }\end{array}$ & 1,0 & 0,3 & 3,7 & 2,6 \\
\hline \multicolumn{5}{|l|}{ Тернослива (посадка осени 2011 г.) } \\
\hline 18-119 (сеянец Терна № 3) & 2,1 & 0,7 & 2,0 & 1,5 \\
\hline \multicolumn{5}{|c|}{$\begin{array}{c}\text { Межвидовые гибриды терна } \\
\text { (прививка весны 2010-2012 гг., посадка осени 2008-2010 гг.) }\end{array}$} \\
\hline 31-60 [16-9 (Тока × терн) × Тернослива хабаровская] & 0,9 & 0,3 & 5,0 & 0 \\
\hline $\begin{array}{l}\text { ТСГ № } 1 \text { [сеянец Терносливы хабаровской } \\
\text { (слива уссурийская × тернослива)] }\end{array}$ & 1,0 & 0,6 & 4,5 & 0 \\
\hline 10-42-00 [Тернослива хабаровская $\times($ Пчелка $\times$ терн $)]$ & 0,8 & 0,2 & 4,5 & 0,1 \\
\hline $\begin{array}{l}\text { 16-1-00 [сеянец гибрида 4-60 } \\
\text { (слива уссурийская × тернослива)] }\end{array}$ & 0,8 & 1,0 & 4,3 & 1,2 \\
\hline Г 12-3 [(слива уссурийская × алыча) $\times$ Тернослива хабаровская] & 1,1 & 0,9 & 4,0 & 0 \\
\hline ГЭС 6-76 [сеянец гибрида № 53 (Сапа × терн крупноплодный)] & 1,5 & 0,6 & 4,0 & 0 \\
\hline
\end{tabular}

В Чемале имеется более 500 сеянцев терновых гибридов в селекционных садах, в Барнауле - 135 сеянцев и 60 сортообразцов в коллекции. Данный фонд межвидовых гибридов терна следует использовать для выделения клоновых подвоев сливы, устойчивых к выпреванию. В Чемале и Барнауле проводится оценка способности терновых гибридов к размножению зелеными черенками. Проблема заключается в том, что терн и тернослива не обладают такой способностью. Донором этого признака является микровишня низкая (P. pumila) и ее гибриды с диплоидными сливами (сливо-вишневые гибриды). Высокую окореняемость черенков имеют и многие сортообразцы типичной алычи [11].

Таким образом, основными задачами по культуре сливы являются:

- сохранение и расширение генофонда донорами и источниками селекционно-значимых признаков;

- создание сортов с повышенной адаптацией (высокая зимостойкость 
плодовых почек, позднее цветение, устойчивость к выпреванию) и высокими товарными качествами плодов (транспортабельность, крупноплодность);

- выделение и создание клоновых подвоев сливы, устойчивых к выпреванию, зимостойких, пригодных для использования в качестве штамбообразователей по принятой технологии выращивания саженцев, совместимые с большинством сортов сливы.

\section{Список литературы}

1. Усенко В.И. Состояние и перспективы развития промышленного садоводства в Сибири // Садоводство и виноградарство. - 2009. - № 5. - С. 17-19.

2. Программа работ селекцентра Научно-исследовательского института садоводства Сибири имени М.А. Лисавенко до 2030 г.: выпуск 3 / Под ред. В.И. Усенко, И.А. Пучкина; ГНУ НИИСС Россельхозакадемии. - Новосибирск: РИЦ СибНСХБ Россельхозакадемии, 2011. - 335 с.

3. Помология. Том ІІІ. Косточковые культуры / под ред. Е.Н. Седова. - Орел: ВНИИСПК, 2008. - 592 с.

4. Каталог паспортов доноров и источников селекционно-значимых признаков северных видов сливы, вишни и черемухи / составители Г.В. Еремин, И.С. Чепинога, О.В. Еремина, ГНУ Крымская ОСС; М.Н. Матюнин, НИИСС; В.С. Симагин, ЦСБС СО РАН; В.П. Царенко, Н.А. Царенко, Дальневосточная ОС ВИР; под ред. Г.В. Еремина. - Крымск: ГНУ Крымская ОСС, 2010. - 100 с.

5. Мочалова О.В. Цитоэмбриология и селекция отдаленных гибридов и полиплоидов косточковых растений на Алтае / О.В. Мочалова, М.Н. Матюнин; РАСХН, Сибирское отделение, НИИСС им. М.А. Лисавенко. - Новосибирск: ГУП РПО СО РАСХН, 2002. - 232 c.

6. Помология. Сибирские сорта плодовых и ягодных культур ХХ столетия / РАСХН, Сиб. отд-ние, ГНУ НИИСС им. М.А. Лисавенко; под общ. ред. И.П. Калининой. - Новосибирск: Юпитер, 2005. - 568 с.

7. Матюнин М.Н. Биологические особенности и селекция косточковых культур в Горном Алтае / М.Н. Матюнин; ФГУП «Горно-Алтайское», Министерство сельского хозяйства Республики Алтай. - Горно-Алтайск, 2016. - 344 с.

8. Horvath A. Genetic diversity and relationships among Prunus cerasifera (cherry plum) clones / A. Horvath, H. Christmann, F. Laigret // Botany. - 2008. - Vol. 86. - P. 3011-3018.

9. Еремин Г.В. Отдаленная гибридизация косточковых плодовых растений / Г.В. Еремин. - М.: Агропромиздат, 1985. - 280 с.

10. Еремин Г.В. Алыча и слива русская // Современные методологические аспекты организации селекционного процесса в садоводстве и виноградарстве / Под общ. ред. акад. РАСХН Г.В. Еремина. - Краснодар: СКЗНИИСиВ, 2012. - С. 346354.

11. Гнездилов Ю.А. Размножение косточковых культур зелеными черенками / Ю.А. Гнездилов, С.В. Симакина // Труды по прикладной ботанике, генетике и селекции / ВИР. - Л., 1976. - Т. 56. - Вып. 2. - С. 68-79. 


\section{SeedCounter - мобильное приложение для массового фенотипирования зерен}

Генаев М.А. ${ }^{1,2,3}$, к.б.н, н.с.; Комылеев Е.Г. ${ }^{1,2 *}$, м.н.с.; Афонников Д.А. ${ }^{1,2,3}$, к.б.н, B.H.C.

${ }^{1}$ ИЦиГ СО РАН, Новосибирск, Россия;

${ }^{2}$ Курчатовский геномный иентр, Новосибирск, Россия;

${ }^{3}$ Новосибирский государственный университет, Новосибирск, Россия;

*e-mail:komyshev@bionet.nsc.ru

Разработано мобильное приложение SeedCounter для массового фенотипирования зерен, которое может быть использовано для массового фенотипирования зерен в условиях где применение для этого специального оборудования затруднено или не представляется возможным. Приложение SeedCounter разработано для операционной системы Android и доступна для бесплатной загрузки и свободного использования. Адрес приложения в Google Play:

https://play.google.com/store/apps/details?id=org. wheatdb.seedcounter

Ключевые слова: анализ изображений, распознавание образов, морфометрия зерен, мобильное приложение.

\section{SeedCounter - mobile application for high throughput grain phenotyping}

Genaev M.A. ${ }^{1,2,3}$, Komyshev E.G. ${ }^{1,2 *}$, Afonnikov D.A. ${ }^{1,2,3}$

${ }^{1} I C G S B$ RAS, Novosibirsk, Russia.

${ }^{2}$ Kurchatov Genomic Center, Novosibirsk, Russia.

${ }^{3}$ Novosibirsk State University, Novosibirsk, Russia.

*e-mail:komyshev@bionet.nsc.ru

In this work, we present a mobile application, SeedCounter, for the Android platform that enables the automated calculation of morphological parameters of grains using mobile devices "in the field" (conditions without computer facilities). The SeedCounter application is available on GooglePlay: https://play.google.com/store/apps/details?id=org. wheatdb.seedcounter

Key words: image analysis, pattern recognition, grains morphometry, mobile application.

Количественному и качественному анализу биологических данных об урожае зерновых предшествует рутинный этап сборки этих данных. При этом измеряются такие параметры зерен как длина, ширина, округлость, цвет, центр массы и т.д., а количество рассматриваемых образцов может 
достигать нескольких тысяч. Данный этап часто выполняется вручную, так как, как правило нет возможности использовать специальное оборудование в “полевых условиях". Обычно такая работа выполняется по следующей схеме: из колоса определенного урожая извлекаются зерна, они располагаются на некой поверхности и производятся замеры с помощью различных инструментов. Сегодня характеристики мобильных устройств, такие как вычислительная мощность, качество оптики и разрешающая способность матрицы, позволяют реализовывать программно-аппаратные инструменты для облегчения выполнения подобных задач. SeedCounter [1] - это мобильное приложение, позволяющее распознавать зерна на листе бумаги и производить автоматическое измерение их характеристик.

Для разработки SeedCounter была выбрана мобильная платформа Android [2], как одна из самых распространенных и открытых операционных систем, для которой доступно большое количество не дорогих, но качественных мобильных устройств. Для обработки изображений полученных с камеры используется библиотека компьютерного зрения OpenCV [3].

Для проведения измерений, необходимо положить лист бумаги формата A4 на ровную поверхность, на бумагу высыпать зерна, навести камеру мобильного устройства на лист бумаги и зафиксировать изображение. Приложение работает по следующей схеме: на полученном изображении распознается лист бумаги, после чего на листе бумаги производится распознавание зерен, а после - их измерение. Полученные данные могут быть сохранены в памяти устройства, а также переданы на сервер для хранения и последующей обработки.

Благодарности: Работа выполнена за счет финансирования Курчатовского геномного центра ИЦиГ СО РАН, соглашение с Министерством Образования и Науки № 075-15-2019-1662.

\section{Список литературь}

1. Komyshev E., Genaev M., Afonnikov D. Evaluation of the SeedCounter, a mobile application for grain phenotyping // Frontiers in plant science. - 2017. - T. 7. - C. 1990.

2. Android: Open-source software stack for a wide range of mobile devices and a corresponding open-source project led by Google. http://www.android.com.

3. OpenCV (Open Source Computer Vision Library): Open source computer vision and machine learning software library. http://opencv.org. 


\section{Генетические ресурсы - первооснова результативной селекции яровой пшеницы в Беларуси}

Гриб С.И., д.с.-х.н., г.н.с.; Маркевич И.М., н.с.; Матыс И.С., к.с.-х.н., зав. отделом генетических ресурсов растений; Буштевич В.Н., к.с.-х.н., зав. лабораторией тритикале; Шабан Е.М., м.н.с.

РУП «Научно-практический центр НАН Беларуси по земледелию», г. Жодино, Республика Беларусь.

e-mail: belgenbank@mail.ru

В статье представлены результаты изучения и использования генофонда в селекиии мягкой яровой пшеницы (Triticum L.). Выявлены генетические источники хозяйственно иенных признаков. Показаны результаты селекичи в Беларуси.

Ключевые слова: генетические ресурсы растений, пшеница мягкая яровая, генбанк, коллекция.

\section{Genetic resources - primary basis for effective spring wheat breeding in Belarus}

Grib S.I., Markevich I.M., Matys I.S., Bushtevich V.N., Shaban E.M., Research and Practical Center of the NAS for Arable Farming, Zhodino, the Republic of Belarus,

*e-mail:belgenbank@mail.ru

The paper presents the results of study and use of gene pool in spring wheat breeding (Triticum L.). Genetic sources of economically important traits are identified. The results of plant breeding in Belarus are stated.

Key words: plant genetic resources, spring wheat, genebank, collection.

Мировые генетические ресурсы растений являются исходным материалом - основой для создания новых высокоурожайных и высокотехнологичных конкурентоспособных сортов $[1,2]$.

С 2000 года в Беларуси в рамках ГП «Генофонд растений» проводится научно-исследовательская работа в области мобилизации, изучения, сохранения и использования генетических ресурсов растений, создан Национальный банк семян генетических ресурсов хозяйственно полезных растений РУП «Научно-практический центр НАН Беларуси по земледелию», Республика Беларусь стала членом ECPGR и AEGIS, налажен обмен генофондом с зарубежными генными банками и международными научными центрами.

Среди коллекций Национального банка семян генетических ресурсов хозяйственно полезных растений РУП « Научно-практический центр НАН 
Беларуси по земледелию» коллекция пшеницы (Triticum L.) самая многочисленная по своему составу - содержит 4278 образцов, из них 2178 образцов яровой пшеницы. Ежегодно коллекция пополняется новыми поступлениями образцов из генных банков мира, отечественных и зарубежных научно-исследовательских учреждений.

Семенная коллекция генетических ресурсов пшеницы яровой (Triticum L.) включает 18 видов (T. aestivum L., T. durum Desf., T. turgidum L., T. spelta L., T. sphaerococcum Percival, T. compactum Host, T. aethiopicum Jakubz., T. carthlicum Nevski, T. ispahanicum Heslot, T. araraticum Jakubz., T. dicoccoides (Körn. ex Asch. \& Graebn.) Schweinf., T. dicoccum Schrank, T. monococcum L., T. polonicum L., T. turanicum Jakubz., T. timopheevii Zhuk., T. militinae Zhuk.et Migusch., T. Sinskajae,), различающихся по степени окультуривания, уровню плоидности и геномному составу, некоторые из видов имеют большое число ботанических разновидностей. Коллекция включает в себя дикие виды, разновидности, формы и культивируемые сорта из 73 стран мира. Преобладающее большинство образцов пшеницы в коллекции по своему происхождению из Европейских стран. Особое внимание уделяется сохранению отечественного генофонда яровой пшеницы, 19 \% образцов в коллекции белорусского происхождения. В коллекционном питомнике пшеницы яровой ежегодно изучается 500-600 образцов, представленных разными агроэкотипами.

Коллекция пшеницы наряду с другими коллекциями Национального банка семян генетических ресурсов хозяйственно полезных растений РУП «Научно-практический центр НАН Беларуси по земледелию» включена в Государственный реестр научных объектов, которые составляют национальное достояние Республики Беларусь (постановление Совета Министров Республики Беларусь от 27.12.2019 г. № 924).

Исследования по изучению коллекционного материала пшеницы яровой (Triticum L.) проводили в 2017-2019 гг. на опытном поле РУП «Научнопрактический центр НАН Беларуси по земледелию». Было изучено 645 образцов яровой пшеницы различного эколого-географического происхождения более чем из 40 стран мира. Образцы для изучения поступили в коллекцию из международных генных банков.

Почва опытных участков дерново-подзолистая легкосуглинистая, характеризуется следующими агрохимическими показателями пахотного слоя: $\mathrm{pH}-5,6-6,1$; содержание подвижного $\mathrm{P}_{2} \mathrm{O}_{5}-175-185$ мг/кг почвы и $\mathrm{K}_{2} \mathrm{O}-$ 230-260 мг/кг. Предшественник - гречиха.

Закладка коллекционного питомника осуществлялась согласно общепринятой методике [3]. Обработка почвы, посев и уход за посевами осуществлялись в соответствии с агротехникой, принятой для возделывания яровой мягкой пшеницы в Беларуси. Фенологические наблюдения и морфологические описания проводились по общепринятым методикам [4]. 
По результатам 3-х летнего изучения коллекции яровой мягкой пшеницы выделены следующие источники хозяйственно ценных признаков: короткостебельности - Yumai 34 (CHN), SW Kronjet (SWE), Mane Nick (ESP), CHRISMAR (FRA), Бухус 10 (IRQ); устойчивости к полеганию Воронежская 20, Экада 109, Набат (Россия), ВАJКА (Польша), Ротре (Швеция), FLAMBAR (Франция), KE HAN 9 и KENBEI-2 (Китай); устойчивости к мучнистой росе - FURIO (Франция), Sparrow (Великобритания), BAJKA (Польша), Pasteur (Нидерланды), Banks (Австралия); скороспелости Tanori F 71 (Мексика), PROSPER (Франция), NORIN 42 (Япония); озерненности колоса - ALFA (Польша), ECHO, BEHERT (Франция), SOPU (Финляндия), Абаа 95 (Ирак), SNØGG II (Норвегия), Corso (Германия), Sv.59433, BATALJ (Швеция); продуктивности колоса - BATALJ, Pompe (Швеция), Рима, Сибаковская Юбилейная (Россия), ALFA (Польша), Janus (германия), Lin Hong 14 (Китай); массы 1000 зерен - Juchi F2000 (Мексика), Подмосковная 10, Экада 109, Сибаковская Юбилейная (Россия), NING CHUN 12, Ken Da 3, YOU YI MAI (Китай), Злата (Украина), Бухус 10, Ашур (Ирак), Јanus (Германия), PRONTO (Франция); урожсайности - Janus (Германия), KE HAN NO.8 (Китай), SKIRNE (Норвегия), Дубравка (Россия); высокобелковости - Тулунская 50 (RUS), Long Fu 8 (CHN), Miana (FRA), Thasos (DEU), Подмосковная 10 (RUS); по комплексу хозяйственно ценных признаков Pompe (Швеция), BAJKA (Польша), BATALJ (Швеция), Janus (Германия), Бухус 10 (IRQ).

За последние 60 лет в Беларуси создано более 20 сортов мягкой яровой пшеницы, включенных в Государственный реестр: Минская, Белорусская 12, Белорусская 80, Виза, Ростань, Дарья, Рассвет, Тома, Сабина, Василиса, Ласка, Любава, Сударыня, Славянка, Монета, Мадонна, Награда, Эврика, Ладья, Каменка, из них 17 сортов за период с 1993 по 2019 гг. Сорта Сударыня, Ладья и Каменка созданы совместно с ФГБНУ «Верхневолжский ФАНЦ» на основе принципа организации экологической селекции. Сорт Дарья входит в число топ-10 наиболее распространенных сортов в Российской Федерации.

Сорта отечественной селекции служат основой комплекса адаптированных к условиям Беларуси хозяйственно-полезных признаков в перспективных программах селекционных работ, в частности: Виза - устойчивости к полеганию, поражению мучнистой росой и септориозом, высокого содержания белка и клейковины; Ростань - устойчивости к поражению мучнистой росой, септориозом и бурой ржавчиной, высокого содержания белка и клейковины; Дарья - высокой продуктивности, устойчивости к полеганию, поражению мучнистой росой, высокого содержания белка и клейковины; Рассвет - устойчивости к полеганию, поражению мучнистой росой, бурой ржавчиной и септориозом, носитель идентифицированных генов устойчивости Pm3d, Pm4b, высокого содержания белка и клейковины; Белорусская 80 
- носитель идентифицированных генов устойчивости pm1, pm2, pm3, pm4, pm5, pm6, pm8, pm16, pm17, pm18, pm19, pm21, pm22, pm23, pm24; Тома высокой продуктивности, устойчивости к полеганию, поражению мучнистой росой и септориозом; Сабина - устойчивости к поражению мучнистой росой и бурой ржавчиной, высокого содержания белка и клейковины; Василиса - устойчивости к мучнистой росе, крупносемянности; Ласка - устойчивости к мучнистой росе; Любава - устойчивости к мучнистой росе, септориозу, высокого качества зерна; Сударыня - устойчивости к мучнистой росе и бурой ржавчине, полеганию, по качеству зерна отнесен к ценным пшеницам; Славянка - ценный по качеству, обладает полевой устойчивостью к мучнистой росе; Монета - среднеранний, крупнозерный, продовольственного использования, устойчив к мучнистой росе; Мадонна - обладает полевой устойчивостью к мучнистой росе, сорт продовольственного использования, крупнозерный; Награда - устойчивый к полеганию, обладает полевой устойчивостью к мучнистой росе, крупнозерный; Эврика - высокоустойчив к мучнистой росе, слабовосприимчив к бурой ржавчине, септориозу и фузариозу колоса, с хорошими хлебопекарными качествами.

Таким образом, коллекция яровой пшеницы, объединившая в себя многообразие местных и селекционных сортов, является первоисточником селекционно ценных признаков для создания новых конкурентоспособных, высокоурожайных сортов. Созданные на этой основе сорта белорусской селекции в свою очередь служат источниками комплекса адаптированных к местным условиям хозяйственно-ценных признаков для дальнейшего повышения потенциала продуктивности, адаптивности и качества зерна мягкой яровой пшеницы в Беларуси.

\section{Список литературы}

1. Вавилов Н.И. Селекция как наука // Теоретические основы селекции. М.: Наука, 1987. С. 7-59.

2. Гриб С.И. Факторы прогресса в селекции яровой пшеницы в Беларуси / С.И. Гриб, Л.В. Кучинская // Проблемы и пути повышения эффективности растениеводства в Беларуси: Мат. межд. науч.-практ. конф. посвящ. 80-летию образования Института земледелия. 29 июня 2007 г. Жодино-Минск, 2007. С. 50-53.

3. Доспехов Б.А. Методика полевого опыта (с основами статистической обработки результатов исследований) / Б.А. Доспехов. - М.: Агропромиздат, 1985. - 351 с.

4. Унифицированный классификатор пшеницы Triticum L. / Ф.И. Привалов, С.И. Гриб, И.С. Матыс, [и др.] / РУП «Научно-практический центр НАН Беларуси по земледелию». - Минск, 2012. - 57c. 


\section{Картирование локусов ответственных за содержание токоферолов в семенах подсолнечника с использованием высокопроизводительного генотипирования}

Губаев Р.Ф. ${ }^{l}$, аспирант; Чернова А.И. ${ }^{1}$, аспирант; Болдырев С.В. ${ }^{l}$, м.н.с.; Мартынова Е.У. ${ }^{1}$, к.б.н., м.н.с.; Коваленко Т.А. ${ }^{2}$, аспирант; Горюнова С.В. ${ }^{l}$, к.б.н., н.с.; Хайтович Ф.Е. ${ }^{l}$, Ph.D., профессор; Демурин Я.Н. ${ }^{2}$, д.б.н., зав. отделом биологических исследований.

${ }^{1}$ Сколковский институт науки и технологий, Москва, Россия;

${ }^{2}$ Всероссийский научно-исследовательский институт масличных культур имени В.С. Пустовойта, Краснодар, Россия.

*e-mail:rim.gubaev@skoltech.ru

Подсолнечник является важнейшей масличной культурой в России. Одним из ключевых фенотипических признаков подсолнечника - служит содержание в масле различных классов токоферолов, которые проявляют антиоксидантную активность, а также активность витамина E. B настоящем исследовании было проведено ассочиативное картирование локусов, сиепленных $c$ содержанием токоферолов $c$ применением современных подходов выскокопроизводительного генотипирования $u$ биоинформатического анализа. Полученная информация будет в дальнейшем использована для создания маркер-опосредованной схемы селекиии по составу токоферолов с использованием полученных маркеров.

Ключевые слова: подсолнечник, картирование локусов количественных признаков, токофероль, маркер-опосредованная селекиия.

\section{Association mapping of loci responsible for tocopherol composition in sunflower seeds using high-throughput genotyping}

Gubaev R.F. ${ }^{1 *}$, Chernova A.I. ${ }^{1}$, Boldyrev S.V. ${ }^{l}$, Martynova E.U. ${ }^{l}$, Kovalenko T.A. ${ }^{2}$, Goryunova S.V. ${ }^{l}$, Khaitovich F.E. ${ }^{l}$, Demurin Y.N. ${ }^{2}$.

${ }^{1}$ Skolkovo Institute of Science and Technology, Moscow, Russia;

${ }^{2}$ Federal scientific center "V.S. Pustovoit All-Russian Research Institute of Oil crops", Krasnodar, Russia.

*e-mail:rim.gubaev@skoltech.ru

Sunflower is the most important oilseed crop in Russia. One of the key phenotypic trait of sunflower is the composition of tocopherols that exhibit antioxidant activity as well as the vitamin E activity. In the present study, mapping of loci associated with the content of tocopherols was carried out using modern approaches of high-throughput genotyping and bioinformatics analysis. The obtained information will be further used to create a marker-assisted selection 
scheme for the tocopherol composition using the obtained markers.

Key words: sunflower, quantitative trait loci mapping, tocopherols, marker-assisted selection.

Подсолнечник - важнейшая масличная культура, один из основных источников растительных жиров в России, СНГ, Турции и многих других странах. Свойства и область применения растительного масла во многом определяется его химическим составом, который отвечает за пищевую ценность масла и его физические характеристики, например скорость окисления, температуру кипения и другие.

Помимо триглицеридов и жирных кислот в состав подсолнечного масла входяттокоферолы - природные антиоксиданты липофильной природы, обладающее активностью жирорастворимого витамина Е. Токоферольный комплекс подсолнечного масла представлен четырьмя различными формами, а именно $\alpha-, \beta-, \gamma$ - и $\delta$-токоферолами. Активность витамина Е убывает в ряду от $\alpha$ - к $\gamma$-токоферолу, в то время как in vitro антиоксидантные свойства, наоборот, возрастают. С одной стороны, токоферолы как природные антиоксиданты определяют окислительную стабильность масла, препятствуя процессам свободнорадикального окисления липидов, и обеспечивая устойчивость к прогорканию. С другой стороны, показано, что умеренное потребление витамина Е оказывает положительное влияние на здоровье человека. Витамин Е благодаря своими антиоксидантными свойствами и способности нейтрализовать свободные радикалы должен обязательно присутствовать в диете. В связи с вышеперечисенным, получение семян с увеличенным содержанием витамина Е (в первую очередь содержание $\alpha$-токоферола) может позволить производить подсолнечное масло с улучшенными питательными свойствами. Увеличение содержания сильных, в антиоксидантном отношении, форм токоферолов ( $\delta$ и $\gamma$-токоферолы) сделает возможным улучшение качества масла семян подсолнечника. Таким образом, одной из перспективных задач в селекции подсолнечника является получение масла с увеличенным содержанием токоферолов и сбалансированным составом токоферольного комплекса.

В представленной работе было проведено ассоциативное картирование локусов количественных признаков на основе данных высокопроизводительного секвенирования сегрегирующих популяций подсолнечника, различающихся по признаку содержания токоферолов с целью поиска локусов, потенциально ответственных за изменчивость профиля токоферолов. Для этого на первом этапе была проведена фенотипическая характеристика $200 \mathrm{~F}_{2}$ потомков растений, контрастных по содержанию токоферолов. В качестве родителей использовали мутантную 
линию (гамма/дельта-токоферольный фенотип) и линию дикого типа (альфатокоферольный фенотип). Для определения содержания токоферолов была использована технология тонкослойной хроматографии с последующей денсиометрией. При этом было определено относительное содержание $\alpha$-, $\beta$-, $\gamma$ - и $\delta$-токоферолов. Для генотипирования был использован подход генотипирования посредством секвенирования (genotyping-by-sequencing, GBS) на высокопроизводительной платформе Illumina. Такой подход позволяет секвенировать лишь выборочные участки генома, ограниченные специфическими сайтами рестрикции и таким образом сэкономить на объеме секвенирования.

В ходе секвенирования были получены риды, соответствующе фрагментам ДНК, риды были отфильтрованы по качеству и выровнены на референсный геном подсолнечника HanXRQ1. Затем с помощью программы GATK были найдены однонуклеотидные генетические полиморфизмы (SNP). В результате анализа данных генотипирования было получено более 6 тысяч SNP, которые были использованы для построения генетической карты высокой плотности. Построение генетической карты было проведено в программе $\mathrm{R} / \mathrm{qtl}$, для этого была использована информация о расположении локусов на физической карте подсолнечника. Полученная карта была использована при поиске локусов, достоверно ассоциированных c содержанием токоферолов с помощью сложного интервального картирования (composite interval mapping, CIM). Также дополнительно была проведена проверка ассоциированных локусов с помощью смешанных регрессионных моделей.

В результате проведенного анализа были обнаружены локусы на хромосоме 8 , достоверно ассоциированные с содержанием $\alpha$-токоферолов. А также локусы, расположенные на хромосомах 1 и 8 и достоверно ассоциированные с содержанием $\beta$-токоферолов. Информация о найденных локусах и маркирующих их SNP будет использована для построения предсказательных моделей содержания токоферолов на основании генотипа и разработки ПЦР-тестов для маркер-опосредованной селекции подсолнечника.

Благодарности: Работа выполнена при финансовой поддержке РФФИ в рамках научного проекта № 20-316-80002. 


\section{Определение содержания стероидных гликоалкалоидов соланина и хаконина в диких видах картофеля методом ВЭЖХ}

Домрачев Д.В. ${ }^{l *}$, м.н.с., Иванова К.А. ${ }^{2}$, Колошина К.A. ${ }^{2}$, Герасимова С.B. ${ }^{2}$ ${ }^{I}$ ФГБУН Новосибирский институт органической химии им. Н.Н. Ворожиова СО РАН, Новосибирск, Россия;

${ }^{2}$ ФИЦ Институт иитологии и генетики СО РАН, Новосибирск, Россия. *e-mail:dmitry@nioch.nsc.ru

Подобраны условия для извлечения из надземной части растения стероидных гликоалкалоидов и количественного определения содержания соланина и хаконина методом ВЭЖХ. С использованием полученной методики охарактеризовано содержание соланина и хаконина в 13 дикорастущих видах картофеля из коллекции ВИР, воспроизведенных в вегетачионных условиях региона.

Ключевые слова: Solanuт, гликоалкалоиды, соланин, хаконин, ВЭЖХ.

\section{Steroidal glycoalkaloids solanine and chaconine determination by HPLC in potato wild species}

Domrachev Dmitry Vasilievich, $N$. N. Vorozhtsov Novosibirsk Institute of Organic Chemistry Of the Siberian Branch of Russian Academy of Science, Novosibirsk, Russia.

The conditions were selected for the extraction of steroidal glycoalkaloids from the aerial part of the plant and the quantitative determination of the content of solanine and chaconine was made by HPLC. Using the obtained method, the content of solanine and chaconine in 13 wild potato species from the VIR collection, reproduced under the growing conditions of the region, was characterized

Key words: Solanum, glycoalkaloids, solanine, chaconin, HPLC.

Одной из важнейших характеристик хозяйственных растений является содержание вторичных метаболитов, в том числе и такого важного класса соединений, как алкалоиды. Для картофеля (Solanum tuberosum) важно контролировать содержание гликоалкалкалоидов соланина и хаконина [1]. Содержание гликоалкалоидов в дикорастущих видах картофеля изучено гораздо меньше. Так, показано, например, что, кроме соланина и хаконина, в диких видах присутствуют и другие гликоалкалоиды [2].

Дикие виды картофеля могут быть введены в селекционную работу для придания полезных признаков, таких как устойчивость к болезням и вредителям [3, 4]. Вместе с тем необходимо контролировать, чтобы вредные признаки, присущие диким видам, как, например, высокое содержание 
гликоалкалоидов, не передались культурным [5].

В нашей работе мы изучали содержание гликоалкалоидов в видах Solanum из коллекции ВИР, воспроизведенных в вегетационных условиях региона: S. demissum Lindl., S. polyadenium Greenm., S. pinnatisectum Dun., S. ehrenbergii Bitt., S. stoloniferum Schlechtd., S. jamesii Torr., S. tarijense Hawkes, S. cardiophyllum Lindl., S. pinnatisectum Dun., S. dolichostigma Buk., S. fendleri A. Gray S. kurtzianum Bitt. et Wittm. Ex Engl, S. chacoense Bitter.

Растения выращивались на полях СибНИИРС (Россия, Новосибирская область) в парнике, обтянутом укрывным материалом, пропускающим свет, влагу и воздух, но задерживающим насекомых и пыльцу других растений. Растения, выращенные in vitro в трех повторностях, высаживали в 12 л ведра с землей «TERRA VITA, питательный грунт универсальный», смешанной в равных пропорциях с естественным грунтом, добытым из-под дерна в березовой роще. Урожай собирали в период сбора урожая культурного картофеля. Надземную часть сушили до воздушно-сухого состояния и измельчали.

Измельченное и высушенное сырье в количестве 0.2-2 грамма экстрагировали 24-48 часов при комнатной температуре. Состав экстрагента: $40 \%$ метанола $+5 \% \mathrm{CH}_{3} \mathrm{COOH}+55 \%$ воды, из полученного экстракта отбирали аликвоту 1 мл, фильтровали через шприц-фильтр пористостью 0,45 мкм и использовали для анализа. Анализ проводился на обращенно-фазовой колонке ZORBAX-SB-C18, элюент 0,1 \% $\mathrm{CF}_{3} \mathrm{COOH}$ (А) и ацетонитрил (B). 0 10 мин $80 \%$ A + $20 \%$ B, 10-20 мин градиент до $100 \%$ В, детектирование на длине волны 205 нм. Калибровка осуществлялась путем анализа стандартных образцов соланина и хаконина (SigmaAldrich).

Наибольшее содержание соланина и хаконина $(25,7$ мг/г воздушносухого сырья (2,57 \% масс)) выявлено в Solanum dolichostigma Buk. Bce прочие образцы содержат гликоалкалоиды в существенно меньших количествах: S. pinnatisectum Dun - 1,8 мг/Г (преимущественно хаконин), S. polyadenium Greenm. - 1,7 мг/г (преимущественно хаконин), S. stoloniferum Schlechtd. - 0.5 мг/г (преимущественно хаконин).

Bсе прочие образцы содержат соланина и хаконина менее $0,5 \mathrm{Mг} / \Gamma$ (типичное для надземной части Solanum tuberosum содержание суммарных гликоалкалоидов), однако содержат, по-видимому, другие гликоалкалоиды.

Благодарности: Работа выполнена при финансовой поддержке гранта РФФИ № 18-316-00068.

\section{Список литературы}

1. Friedman M. Potato glycoalkaloids and metabolites: roles in the plant and in the diet // Journal of Agricultural and Food Chemistry. - 2006. - T. 54. - №. 23. - C. 8655-8681.

2. Friedman M., McDonald G. M., Filadelfi-Keszi M. A. Potato glycoalkaloids: chemistry, analysis, safety, and plant physiology //Critical Reviews in Plant Sciences. 1997. - T. 16. - №. 1. - C. 55-132. 
3. Зотеева Н.М., Зимнох-Гузовска Е. Влияние генотипов картофеля на патогенные свойства Phytophthora infestans //Микология и фитопатология. - 2005. T. 39. - №. 1. - С. 59-65.

4. Чалая Н.А., Бирюкова В.А., Киру С.Д. Новые источники устойчивости к золотистой картофельной нематоде (G. rostochiensis Woll.) из коллекции дикорастущих видов картофеля ВИР //Известия Санкт-Петербургского государственного аграрного университета. - 2012. - №. 26. - С. 45-50.

5. Laurila J. et al. Formation of parental-type and novel glycoalkaloids in somatic hybrids between Solanum brevidens and S. tuberosum //Plant Science. - 1996. - T. 118. №. 2. - C. 145-155.

DOI 10.18699/GPB2020-26

\section{Особенности накопления биофлавоноидов в ягодах интродуцированных сортов винограда на Алтае}

Ериова И.В., к.б.н., доиент, в.н.с., зав. лабораторией индустриальных технологий, отдел «НИИСС», ФГБНУ Федеральный Алтайский научный иуентр агробиотехнологий, г. Барнаул, Россия.

e-mail:inessers@yandex.ru

В статье представлены результаты исследования содержания биофлавоноидов в ягодах интродуцчированных на Алтае сортов винограда. Установлены суммарное содержание флавоноидов и количество отдельных фракций, зависимость этих показателей от метеоусловий года. Выделень сорта - ценные источники биоантиоксидантов.

Ключевые слова: виноград, сорта, ягоды, биофлавоноиды.

The particularities of bioflavonoid accumulation in the berries of grape varieties introduced in the Altai region

Ershova I.V. Federal Altai Scientific Centre of Agro-Biotechnologies, Barnaul, Russia.

The article discusses the results of the research of bioflavonoid content in the fruits of grape varieties introduced in the Altai region. The total content of flavonoids and the number of separate flavonoid fractions is determined, as well as dependence of these values on weather conditions of the year. The varieties that represent a valuable source of bio-antioxidants are also determined.

Key words: grape, varieties, berries, bioflavonoids.

Ягоды винограда, одной из самых распространенных культур в мире, по праву считаются высокоценным лечебным продуктом питания, сырьем 
для химико-фармацевтической и пищевой промышленности. Они служат источником важнейших биологических компонентов - легкоусвояемых сахаров, органических кислот, макро- и микроэлементов, целого комплекса природных биоантиоксидантов, и в первую очередь - биофлавоноидов. Содержание последних является фактором, в значительной степени определяющим биологическую активность ягод винограда и продуктов его переработки, их лечебный эффект, технологические достоинства сортов [1]. Биофлавоноидам присуща, прежде всего, мощная антиоксидантная активность, позволяющая препятствовать аномальным процессам свободно-радикального окисления и защищать, таким образом, живые организмы от многих патологий. Они обладают противовоспалительными, адаптогенными, капилляроукрепляющими, бактерицидными, нейропротекторными и другими ценными свойствами [2].

Виноград представляет большой интерес для промышленного и любительского садоводства Сибири. Поскольку он являет собой южное, теплолюбивое, незимостойкое растение, долгое время культура считалась неперспективной для региона. С точки зрения его выращивания, климатические условия лесостепной зоны Алтайского края характеризуются недостаточным количеством тепла в период вегетации, не всегда благоприятными условиями перезимовки. Однако в этих условиях успешно вызревают раннеспелые европейские сорта, и на сегодняшний день доказана возможность возделывания укрывной культуры винограда на Алтае. Создание его сортимента осуществляется в основном путем интродукции. К настоящему времени в отделе НИИ садоводства Сибири имени М.А. Лисавенко ФГБНУ ФАНЦА (НИИСС) сформирована и поддерживается ампелографическая коллекция, представленная образцами европейско-азиатской, восточно-азиатской, а также - американской групп. Преобладающее большинство - сорта отечественной селекции столового, технического и универсального назначений. Сортоизучение интродуцированных образцов с целью улучшения сортимента осуществляется по многим направлениям, в том числе - исследование антиоксидантного комплекса свежих ягод винограда. Факторами, определяющими его содержание, являются генетические особенности сорта, условия его произрастания, агротехнические приемы возделывания. Данная работа была направлена на изучение содержания биологически активных фенольных соединений (ФС) - биофлавоноидов в плодах сортов винограда коллекции НИИСС в условиях лесостепной зоны Алтайского края с целью выявления высокоценных в этом отношении сортов.

Исследования проводились в 2013-2016 гг. Объектом изучения являлись зрелые ягоды винограда, выращенного в типичных почвенно-климатических условиях лесостепи Алтайского края. Из обширной коллекции были взяты 13 сортов, зарекомендовавших себя положительно в аспекте проявле- 
ния основных хозяйственно-ценных признаков - Агат Донской, Алешенькин, Восторг, Гуна, Космонавт, Кристалл, Московитянин, Память Лазаревского, Платовский, Сувенир Васьковского, Тамбовский белый, Томайский. Контролем служил универсальный сорт Катыр селекции НИИСС, включенный в Государственный реестр и допущенный к использованию по всем зонам возделывания винограда. Определяли суммарное содержание и фракционный состав биофлавоноидов спектрофотометрическими и колориметрическими методами в этанольных экстрактах плодов.

В результате проведенных исследований был выявлен широкий интервал варьирования показателя содержания биофлавоноидов в ягодах винограда различных сортов, свидетельствующий об очень нестабильном характере накопления этой группы биологически активных веществ (БАВ). Сортовые отличия могли быть четырехкратными, что обусловливалось как особенностями сорта, так и метеоусловиями года, наряду с упомянутыми выше факторами. Поскольку, как было установлено, преобладающей фракцией в составе биофлавоноидов винограда является антоциановый комплекс, существенные различия наблюдались, прежде всего, между сортами с разной окраской плодов. В условиях лесостепи Алтайского края суммарное содержание ФС варьировало в пределах 133,5-728,4 мг/100 г сырой массы (коэффициент вариации V - 42 \%), составляя в среднем 337,3 мг/100 г. Наибольшим накоплением биофлавоноидов в ягодах за годы исследований отличился сорт столового назначения с темноокрашенными ягодами Московитянин - 728,4 мг/100 г (селекции ВНИИГиСПР им. И.В. Мичурина). При этом он был довольно стабильным в проявлении признака (V - 13,5 \%), из года в год выделяясь максимальными среди всех сортов значениями показателя, существенно превышающими контрольные. Столовый сорт селекции этого же института Память Лазаревского, в среднем уступая сорту Московитянин в 1,5 раза, также выделился повышенным содержанием ФС - 486,5 мг/100 г. Максимальное значение показателя, установленное для него, составило 518,4 мг/100 г. Характерной чертой сорта явилась гомеостатичность признака (V - 9,0 \%). В группу перспективных вошли сорта столового назначения с темноокрашенными плодами Агат Донской (селекции ВНИИВиВ им. Я.И. Потапенко) и Космонавт (селекции ВНИИГиСПР) с количеством ФС в ягодах, существенно превышающим средний уровень, от 400 до 600 мг/100 г в разные годы исследования (в среднем - 485,9 и 483,4 мг/100 г соответственно). При этом сорта оказались в значительной степени зависимы от метеофакторов периода вегетации ( $\mathrm{V}>22 \%)$. В одном ряду с упомянутыми стоит и сорт универсального назначения селекции нашего института Катыр с высоким содержанием ФС в ягодах и средней изменчивостью признака ( $\mathrm{V}$ - 16,9 \%). Потенциальные возможности сорта лежат в пределах 600 мг/100 г при среднем показателе 491,2 мг/100 г. Следует отметить сорта технического 
назначения Кристалл и Платовский (селекции ВНИИВиВ), а также - универсальный сорт Гуна (Латвия), с уровнем содержания биофлавоноидов в ягодах, близким к среднему (> 300 мг/100 г), превышающем его в отдельные годы.

Наименьшим количеством ФС в ягодах в условиях Алтая характеризовались столовые сорта со светлоокрашенными плодами Алешенькин (Волгоград) и Восторг (селекции ВНИИВиВ) - до 200 мг/100 г.

Для изученных сортов, по данным дисперсионного анализа, была установлена сильная взаимосвязь содержания ФС и метеофакторов вегетационного периода. Уровень биофлавоноидов в ягодах положительно коррелировал с суммой активных температур (САТ) и отрицательно - с гидротермическим коэффициентом (ГТК) и суммой осадков (СО), что вполне объяснимо с точки зрения биологических особенностей культуры. По накоплению ФС наиболее продуктивным для винограда стал 2015 г. (в среднем - 439,9 мг/100 г), наименее - 2013 г. (в среднем - 307,2 мг/100 г). Последний характеризовался аномально повышенной влажностью воздуха (по данным метеостанции НИИСС), чрезмерным выпадением осадков (428,9 мм), низкой САТ $\left(2043,4{ }^{\circ} \mathrm{C}\right)$ и минимальным количеством ясных дней. Величина ГТК составила 1,96. 2015 г. отличился наибольшей теплообеспеченностью, были отмечены высокое значение САТ $\left(2529,0^{\circ} \mathrm{C}\right)$ с превышением ежемесячных среднемноголетних температур на 2-3 градуса, дефицит осадков по сравнению со среднемноголетним уровнем (232,3 мм), низкий ГТК $-0,91$.

Исследование содержания основных фракций биофлавоноидов в ягодах сортового материала винограда показало преобладание комплекса антоцианов - 77 \% состава, что согласуется с литературными данными, 13,6 \% приходится на долю катехинов, 9,4 \% составляют флавонолы. В наибольшем количестве представлены процианидины, диапазон изменчивости показателя 127,0-385,3 мг/100 г. Содержание антоцианов в зависимости от сорта варьирует в пределах 2,8-292,8 мг/100 г, катехинов - 12,9-111 мг/100 г, флавонолов - 12,2-78,0 мг/100 г. Наиболее ярко различия между сортами выражались в содержании антоцианов, что связано с контрастной окраской плодов. Известно, что именно этой группе биофлавоноидов присуща высокая антиоксидантная активность. К выокоантоциановым можно отнести ягоды сортов Катыр, Агат Донской, Московитянин, Космонавт. Значительное количество фракции Р-активного действия - катехинов - содержалось в плодах сортов Память Лазаревского, Космонавт, Тамбовский белый, Агат Донской, Платовский, Катыр, Гуна.

Резюмируя вышесказанное, хотелось бы отметить, что ягоды интродуцированных на Алтай сортов винограда при благоприятных погодных условиях способны в значительных количествах накапливать биологически активные фенольные соединения, что обусловливает их высокую биологическую ценность. В этом отношении сорта не уступают аналогичным из южных и других регионов, а в ряде случаев и превосходят их. Учитывая тот 
факт, что вышеупомянутые сорта отличаются высокой зимостойкостью, хорошей урожайностью, устойчивостью к болезням и вредителям, крупноплодностью, гармоничным вкусом и ароматом, высокой питательной ценностью, их без сомнения можно признать перспективными для возделывания в условиях Сибири.

\section{Список литературы}

1. Ткаченко М.Г., Соловьева Л.М., Зайцев Г.П., Гришин Ю.В., Мосолкова В.Е., Виноградов Б.А. Фенольный состав и антиоксидантная активность виноградных соков и виноматериалов // «Магарач». Виноградарство и виноделие. - 2012. - № 4. - C. 29-31.

2. Гудковский В.А. Антиокислительный комплекс плодов и ягод и его роль в защите живых систем (человек, растение, плод) от окислительного стресса и заболеваний // Основные итоги и перспективы научных исследований ВНИИСС им. И.В. Мичурина (1931-2001 гг.): Сб. науч. трудов. - Тамбов, 2001. - Т. 1. - С. 76-88.

DOI 10.18699/GPB2020-27

\section{Генетические ресурсы нетрадиционных культур в решении проблем экологической и продовольственной безопасности}

Есимбекова M.A. ${ }^{1 *}$, д.б.н., зав. группь генофонда полевых культур; Еспанов А.М. ${ }^{2}$, директор; Жубанышева А.У. ${ }^{3}$, к.с.-х.н., зав. отд. земледелия; Мукин К.Б. ${ }^{l}$, к.с.-х.н., с.н.с. группь генофонда полевых культур.

${ }^{1}$ ТОО «КазНИИЗиР», п. Алмальбак, Казахстан;

${ }^{2}$ ТОО «ПОСГРР», г. Шалкар, Казахстан;

${ }^{3}$ ТОО «Актюбинская СХОС», г. Актобе, Казахстан.

*e-mail: minura.esimbekova@mail.ru

В статье представлены первичные результаты оценки адаптивной способности и хозяйственной ценности коллекиии дикого кумарчика (Agriophyllum squarrosum L.) в условиях пустьни Северного Приаралья Актюбинской области Казахстана. Установлена возможность селекционного улучшения хозяйственно-ценных признаков в целях одомашнивания.

Ключевые слова: кумарчик, коллекиия, хозяйственно-ценные признаки, кормовая и семенная продуктивность.

\section{Genetic resources of non-traditional crops in solving environmental and food security problems}

Yessimbekova M.A.*, Doctor of Biological Sciences, Head groups of the field crops gene pool, “KazRIAPG” LLP, Almalybak, Kazakhstan,; Espanov AM., Director of "PESPGR" LLP, Shalkar, Kazakhstan; Zhubanysheva A.У., Candidate 
of Agricultural Sciences, Head of agriculture department, "Aktobe AES" LLP, Aktobe, Kazakhstan; Mukin K.B., Candidate of Agricultural Sciences, Senior Researcher groups of the field crops gene pool, "KazRIAPG” LLP, Almalybak, Kazakhstan.

*e-mail:minura.esimbekova@mail.ru

The article presents the primary results of assessing the adaptive ability and economic value of the wild sand rice (Agriophyllum squarrosum L.) collection in the desert conditions of the Northern Aral Sea area (Aktobe region of Kazakhstan). The possibility of breeding improvement of economically valuable traits in order to domesticate has been established.

Key words: sand rice, collection, economically valuable traits, fodder and seed productivity.

Продовольственная безопасность является одной из ключевых глобальных проблем этого столетия. Продовольственная система нестабильна в условиях растущего населения Земли, продолжающихся изменений климата и деградации почвы, а также растущего дефицита воды и земли. Оценка поставок продовольствия во всем мире продемонстрировала, что разнообразие видов сельскохозяйственных культур уменьшается и глобальная однородность пищевых продуктов увеличивается за последние 50 лет, что является потенциальной угрозой продовольственной безопасности. Развитие новых видов сельскохозяйственных культур и увеличение их разнообразия будут краеугольным камнем устойчивого и интенсивного производства продовольствия [1].

К мало используемым (нетрадиционным) культурам, требующим широкого изучения, селекции, хорошо налаженного маркетинга и коммерции отнесены 67 видов съедобных растений Казахстана (2-ой Национальный отчет РК о состоянии ГРРПСХ, ФАО, 2007). В рамках выполнения проекта ФАО «Национальный механизм информационного обмена для внедрения Глобального плана действий в Казахстане» выпущен каталог «Дикорастущие полезные растения Казахстана». В каталоге приведена информация по полезным свойствам 1949 видов высших растений. В частности, в каталог включены 5 видов рода Aegilops - Aeg. crassa Boiss., Aeg. cylindrica Host, Aeg. juvenalis (TheIl.) Eig, Aeg. tauschii Coss., Aeg. triuncialis L., обладающие солидным потенциалом использования в улучшении пшеницы, по целевому хозяйственному назначению указанные виды отнесены к группе кормовых [2].

Глобальную экологическую и социально-экономическую проблему для Казахстана представляют песчаные пастбища пустынной зоны Казахстана $(54,6$ млн. га) с низкой урожайностью кормовых трав $(\approx 5$ млн. га в песчаных массивах Актюбинской и Кызылординской областей). Проблема восстановления растительности таких локальных очагов денудации в настоящее время весьма актуальна [3]. Одним из растений пионеров закрепления 
песка признан дикорастущий кумарчик (Agriophyllum L.) - однолетнее травянистое растение семейства Маревых (Chenopodioídeae). Четыре вида кумарчика (Agr. lateriflorum (Lam.) Moq., Agr. latifolium Fisch. et C. A. Mey., Agr. minus Fisch. et C. A. Mey., Agr. pungens (Vahl.) Link) включены в каталог «Дикорастущие полезные растения Казахстана» как пищевые, кормовые и лекарственные. Песчаный вид кумарчика (Agr. Squarrosum L.), является потенциальным кандидатом для использования и одомашнивания. Растения указанного вида представляют большой интерес для введения в культуру с целью создания осенних пастбищ и сенокосных угодий (в 100 кг зеленой массы содержится около 25 корм. ед. и 3,7 кг перевариваемого протеина). Урожайность до 20 ц зеленой массы и 30 кг семян с 1 га. Сухие семена кумарчика, как источник углеводов в системе питания, отсутствующий в традиционной мясной и молочной пище кочевников пустынь Центральной Азии, содержат: $16-17 \%$ белка, 6-10 \% жирного, пищевого и полувысыхающего масла и 60 \% углеводов, главным образом, крахмала, в сумме до 87 \% веществ, отлично усваиваемых организмом. Белковая фракция включает в себя полный спектр незаменимых аминокислот, необходимых в рационе человека. В 100 г этих веществ, употребляемых в качестве пищи, заключается 343 ккал (в пшеничной муке, 344 ккал.). Масло кумарчика по вкусу напоминает подсолнечное, а по составу приближается к кунжутному [4-7]. Таким образом, кумарчик представляет собой новую сельскохозяйственную альтернативу для будущего производства продуктов питания, и для стабилизации песчаных дюн, однако его устойчивость и адаптивная способность остаются в значительной степени неисследованными и плохо изученными.

Исследования проведены в 2015-2017 гг. в условиях пустыни Северного Приаралья Актюбинской области Казахстана. Почвы участка светлокаштановые и бурые, супесчаные, бедные, с содержанием гумуса от 0,7 до $1,6 \%$. Климат резко континентальный. Среднегодовая высота осадков - 155 мм, с колебаниями по годам от 58 до 220 мм. Средняя многолетняя температура воздуха в летние месяцы составляет $22-23^{\circ} \mathrm{C}$ тепла. Максимальная температура воздуха поднимается до $42-45^{\circ} \mathrm{C}$. Материалом исследований служили 30 образцов коллекции дикорастущих образцов кумарчика песчаного Agr. squarrosum (L.) Moq. Наблюдения и учеты проведены согласно методическим указаниям ВНИИР (Санкт-Петербург) [8]. За стандарт принят образец кумарчика вк-15.24 Шалкарского района Актюбинской области.

Усредненная оценка хозяйственно-ценных признаков 30 образцов кумарчика песчаного приведена в таблице. Стратификация и скарификация семян кумарчика значительно повысила их лабораторную всхожесть (до 56 \%, в природе - 1-3\%). Растения в культуре значительно превосходили своих сородичей по высоте и мощности растений $(\geq 70 \mathrm{~cm})$. Уровень кормовой про-

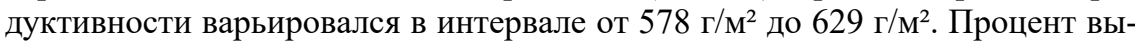
хода сухого вещества в среднем по коллекции составил $29 \%$. 
Таблица - Оценка хозяйственно-ценных признаков 30 образцов кумарчика песчаного Agriophyllum squarrosum (L.) Moq, 2015-2017 гг.

\begin{tabular}{|c|c|c|c|c|c|}
\hline $\begin{array}{c}\text { Всхожесть, } \\
\%\end{array}$ & $\begin{array}{l}\text { Вегетаци- } \\
\text { онный пе- } \\
\text { риод, дни }\end{array}$ & $\begin{array}{c}\text { Высота } \\
\text { растений, } \\
\text { см }\end{array}$ & $\begin{array}{l}\text { Урожай зе- } \\
\text { леной } \\
\text { массы, г/м² }\end{array}$ & $\begin{array}{l}\text { Урожай су- } \\
\text { хого веще- } \\
\text { ства, г/м² }\end{array}$ & $\begin{array}{c}\text { Урожай } \\
\text { семян } \\
\text { (средн.), } \\
\Gamma / \mathrm{M}^{2}\end{array}$ \\
\hline $32-48$ & $113-121$ & $68-79$ & $578-629$ & $170,0-179,7$ & 45,2 \\
\hline
\end{tabular}

Массовая доля листьев колебалась в пределах от 41,7 \% до 44,2 \% от

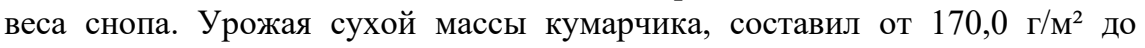
179,7 г/ $\mathrm{M}^{2}$. Семенная продуктивность кумарчика составила в среднем по кол-

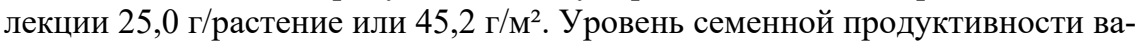
рьировал от 5,38 до 96,5 г/растение. Широкая амплитуда варьирования показателя семенной продуктивности на уровне растений говорит о хороших перспективах селекционной работы по данному признаку. Вес 1000 семян составил от 1,27 до 1,39 г. Отмечается влияние условий выращивания на данный показатель. Выделено 10 источников хозяйственно-ценных признаков, которые можно использовать в фитомелиорационных работах при закреплении деградированных песчаных почв в Западном Казахстане. Будущий скрининг различных экотипов кумарчика будет способствовать дальнейшему улучшению агрономических признаков и одомашниванию кумарчика.

\section{Список литературь}

1. Zhao P., Capella-Gutierrez S., Shi Y., Zhao X., Chen G., Gabaldon T., Ma X. Transcriptomic analysis of a psammophyte food crop, sand rice (Agriophyllum squarrosum) and identification of candidate genes essential for sand dune adaptation // BMC Genomics. 2014. - V. 15 (1):872. - P. 1-14.

2. Грудзинская Л.М., Гемеджиева Н.Г., Есимбекова М.Ф., Мукин К.Б. Дикорастущие полезные растения Казахстана. - Алматы: «Асыл кітап», 2008. - 100 с.

3. Zhubanysheva A.U., Espanov A.M., Esimbekova M.A. Wild-growing sand rice (Agriophyllum L.) in Western Kazakhstan // The Way of Science. - 2018. - № 7 (53). - P. 40-42.

4. Абилденов М.А., Сарсенбин Б.А., Ахметов К.А. Сбор дикорастущих кормовых трав и использование их в селекции // Вестник с.-х. науки Казахстана. - 2007. - №11. -C. $17-18$.

5. Li J., Zhao H., Zhou R., Yun J., Pan C. Growth and physiological rensponses of Agriophyllum squarrosum to sand burial stress // J. Arid Land. - 2015. - V. 7 (1). - P. 94-100.

6. Курочкина Л.Я., Османова Л.Т., Карибаева К.Н. Кормовые растения пустынь Казахстана. - Справочное пособие. - Алма-Ата: Кайнар, 1986. - С. 70.

7. Жуковская Н.Л. Пища кочевников Центральной Азии (к вопросу экологических основ формирования модели питания) // Советская этнография. - 1979. - № 5. C. $65-75$.

8. Иванов А.И., Бухтеева А.В., Шустова З.П., Тихомирова Н.А., Сосков Ю.Д., Синякова А.А., Базылев Э.Я. Изучение коллекции многолетних кормовых растений. - Методические указания. - Л.: ВИР, 1985. - 48 с. 


\section{Исходный материал для селекции сортов ярового ячменя, толерантных к абиотическим стрессам}

Зайцева И.Ю. *, м.н.с., аспирант; Кокина Л.П., к.с.-х.н., с.н.с. Федеральный аграрный научный иенттр Северо-Востока имени Н.В. Рудницкого, г. Киров, Российская Федерачия.

*e-mail: irina-zajjceva30@rambler.ru

Обеспечение устойчивого роста величины и качества урожая сортов ячменя связано с повышением их экологической устойчивости за счет селекиии. Ведущая роль в успешном решении этой задачи принадлежит научнообоснованному подбору генетически разнообразного исходного материала. Проведена оценка 28 коллекционных образиов различного эколого-географического происхождения на устойчивость к засухе и алюмокислому стресс. Для дальнейшей селекиионной работы выделены образиьы: Бионик, Одесский 115, Полярный 14, Новичок, Сябра, NCL 95098, местный сорт из Китая (к2929), Haxby, Rodos, Наран, Казьминский, Bonita, Danuta и 752 A.

Ключевые слова: ячмень, коллекция, корни, засухоустойчивость, алюмоустойчиовсть.

\section{Initial material for breeding spring barley cultivars tolerant to abiotic stresses}

Zaytseva I.Yu., Associate Researcher, Post-graduate ; Kokina L.P., PhD in Agriculture, Senior Researcher; Federal Agricultural Research Center of the NorthEast name N.V. Rudnitsky, Kirov, Russian Federation.

e-mail: irina-zajjceva30@rambler.ru

Sustainable growth in the value and quality of barley's yield is linked to improve its environmental resistance through breeding. A science-based selection of genetically diverse initial material plays a leading role in the success of this task. Twenty-eight collection samples of different ecological-geographical origin were evaluated for resistance to drought and aluminum-acid stress. For further breeding work next samples were selected: Bionic, Odessky 115, Polarny 14, Novichok, Syabra, NCL 95098, local variety from China (k-2929), Haxby, Rodos, Naran, Kazminsky, Bonita, Danuta, and 752A.

Key words: sample, collection, roots, drought resistance, aluminum resistance.

Увеличение урожайности является одной из наиболее важных задач в селекции сельскохозяйственных культур, в том числе и ячменя. Потенциальная возможность сорта дать реальный урожай зависит от уровня устойчивости 
сорта к стрессовым экологическим факторам окружающей среды [2].

В настоящее время к категории наиболее сложных фитоэкологических проблем относится эдафический стресс, обусловленный ионной токсичностью алюминия и марганца, связанных с величиной $\mathrm{pH}$, т.е. почвенной кислотностью [12]. Волго-Вятский регион считается зоной достаточного увлажнения, но для него характерно неравномерное выпадение осадков в течение вегетационного периода, которое ограничивает рост сельскохозяйственных культур и сопровождается значительными потерями урожая [5]. Эти абиотические стрессы нарушают происходящие в растениях физиологические процессы, что ведет к ухудшению качества зерна (семян) и снижению урожайности. В связи с этим обеспечение устойчивого роста величины и качества урожая сельскохозяйственных культур, в том числе ячменя, связано с повышением их экологической устойчивости методами селекции [1].

Цель исследований: изучение генофонда ячменя различного эколого-географического происхождения и выделение источников алюмо- и засухоустойчивости для создания толерантных к абиотическим стрессам высокопродуктивных сортов ячменя, пригодных для эффективного использования в Кировской области.

Материалы и методика. Экспериментальная работа проводилась в ФГБНУ ФАНЦ Северо-Востока (г. Киров). Объектом исследований являлись 28 образцов ярового ячменя различного эколого-географического происхождения. Оценку сортов к эдафическим стрессам проводили согласно методикам лабораторной оценки алюмоустойчивости зерновых культур [6]. Засухоустойчивость ярового ячменя изучали по лабораторной методике ВИР [3].

Результаты. Для прогнозирования отбора форм с высокими адаптивными свойствами необходима оценка по комплексу биологически ценных признаков на разных этапах онтогенеза. Однако большое значение имеет изучение первичной корневой системы и надземных органов, изменчивость которых может характеризовать степень устойчивости популяции, способность ее противостоять неблагоприятным факторам среды $[9,11]$.

Показатель ИДК изменялся от 56,1 \% (Cooper) до 110,3 \% (Haxby). По уровню алюмоустойчивости (по величине ИДК согласно [13]) изучаемые образцы были распределены на две группы: умеренно устойчивые - сорта Crusades, Cooper, Sultan и Filippa и устойчивые - все остальные сорта. У сортов Haxby (ИДК=110,3 \%) и Полярный 14 (ИДК=102,1 \%) был отмечен стимулирующий эффект алюминия на рост корневой системы (ИДК>100 \%), что ранее наблюдалось рядом исследователей $[4,6,12]$. В наших исследованиях не установлено тесной корреляционной взаимосвязи между ИДК и урожайностью сортов в полевых условиях (r=0,052), поэтому в дополнение к этому показателю, как рекомендует [7], использовали еще один - RSR.

Показатель относительного соотношения RSR (изменение показателя 
под влиянием стресса) при оценке устойчивости сортов к повышенному содержанию ионов алюминия изменялся от снижения на 26,8 \% (752А) до увеличения на 49,6 \% (Бионик). Среди изученных сортов по этому показателю выделились Бионик, Mentor, Orthega, NCL 95098, местные сорта из Китая (к2929 и к-2930), Одесский 115, Сябра, Полярный 14, обладавшие также высоким ИДК (табл. 1).

Таблица 1 - Алюмоустойчивые сорта ячменя

\begin{tabular}{|l|c|c|c|c|}
\hline \multicolumn{1}{|c|}{ Сорт } & $\begin{array}{c}\text { Отклоне- } \\
\text { ние ИДК, } \\
\%\end{array}$ & $\begin{array}{c}\text { Относи- } \\
\text { тельная } \\
\text { RSR, \% }\end{array}$ & $\begin{array}{c}\text { Отклонение } \\
\text { RSR, \% }\end{array}$ & $\begin{array}{c}\text { Суммарный } \\
\text { индекс } \\
\text { устойчивости }\end{array}$ \\
\hline Белгородский 100 & 24,2 & 83,7 & 16,3 & 40,5 \\
\hline Новичок & 8,3 & 90,3 & 9,7 & 18,0 \\
\hline Бионик & 14,3 & 149,6 & 49,6 & 63,9 \\
\hline Меntor & 15,1 & 115,5 & 15,5 & 30,6 \\
\hline Danuta & 8,3 & 115,7 & 15,7 & 24,0 \\
\hline NCL 95098 & 3,6 & 108,4 & 8,4 & 12,0 \\
\hline Haxby & 10,3 & 92,8 & 7,2 & 17,5 \\
\hline Местный сорт (к-2929) & 12,6 & 112,7 & 12,7 & 25,3 \\
\hline Местный сорт (к-2930) & 2,3 & 107,5 & 7,5 & 9,8 \\
\hline Одесский 115 & 14,9 & 101,4 & 1,4 & 16,3 \\
\hline Сябра & 11,5 & 102,8 & 2,8 & 14,3 \\
\hline Rодоз & 7,7 & 99,1 & 0,9 & 8,5 \\
\hline Полярный 14 & 2,1 & 103 & 3,0 & 5,1 \\
\hline Наран & 8,2 & 89,2 & 10,8 & 19,0 \\
\hline Казьминский & 5,6 & 89,3 & 10,7 & 16,3 \\
\hline
\end{tabular}

Так как отдельные генотипы используют различные механизмы устойчивости в разной степени, логичнее использовать сразу несколько параметров для оценки уровня устойчивости сорта к стрессовому воздействию. С другой стороны, оценить их вклад в интегральную устойчивость по абсолютным значениям несколько затруднительно, поэтому, согласно [9], нами для принятия решения использовались относительные уровни развития того или иного признака.

Таким образом, на основе выше изложенного из сортов устойчивых к алюмокислому стрессу по обоим показателям (ИДК и RSR) выделялись NCL 95098, местный сорт из Китая (к-2929), Одесский 115, Сябра, Полярный 14. Они обладали наименьшим суммарным индексом устойчивости, а значит и отклонениями ИДК и RSR, поэтому физиологические процессы, протекаю- 
щие в растениях данных сортов при воздействии алюмокислого стресса, более стабильны. Кроме уже перечисленных образцов, к устойчивым можно отнести сорта Новичок, Нaxby, Rodos, Наран и Казьминский, также отличавшихся наименьшим суммарным индексом устойчивости.

По устойчивости к засухе (по способности прорастать в растворе осмотика ПЭГ-600) все изученные сорта разделились на три группы: среднеустойчивые, с устойчивостью выше средней и высокоустойчивые.

Самой высокой всхожестью в стрессовых условиях характеризовался сорт Новичок (91 \%). Также по уровню всхожести к высокоустойчивым к засухе можно отнести сорта Бионик $(84,4 \%)$, Orthega $(81,1 \%)$, Bonita (82,2\%), Ci 11084 (83,3\%), Makbo (80,0\%), Наран (88,8\%). У сортов Crusades (55,6 \%), Sultan (50 \%), Ментор (48,9\%), Mie (48,9\%), характеризующихся, как среднеустойчивые, была самая низкая всхожесть.

При оценке сортов на засухоустойчивость RSR варьировал от снижения на 51,4 \% у сорта Ментор до увеличения на 459,1 \% у сорта Filippa. Наибольшей относительной RSR характеризовались образцы, представленные в таблице 2. Кроме них, по этому параметру выделились сорта Новичок, Crusades, Cooper, Orthega, Danuta, Bonita, местный сорт из Афганистана (к5983), местный сорт из Китая (к-2929), Makbo, Одесский 115, Mie, Rodos, Полярный 14.

Таблица 2 - Сорта с высокой относительной RSR

\begin{tabular}{|l|c|c|}
\hline \multicolumn{1}{|c|}{ Сорт } & Относительная RSR, \% & Отклонение RSR, \% \\
\hline Белгородский 100 & 203,0 & 103,0 \\
\hline Sultan & 223,2 & 123,1 \\
\hline Filippa & 559,1 & 459,1 \\
\hline Ci 11084 Lan & 289,2 & 189,2 \\
\hline Haxby & 406,5 & 306,5 \\
\hline Mестный сорт (к-2930) & 258,0 & 158,0 \\
\hline Сябра & 294,7 & 194,7 \\
\hline Наран & 217,0 & 117,0 \\
\hline Щедрый & 254,4 & 154,4 \\
\hline
\end{tabular}

Среди названных выше образцов наибольшей толерантностью к засухе характеризовались сорта Новичок, Orthega, Bonita, Ci 11084 Lan и Наран, сочетавшие высокую всхожесть и относительную RSR. Однако из этих образцов лишь сорт Bonita имел наименьшее отклонение RSR, что характеризует его как более устойчивого к засухе по сравнению с остальными. Также к засухоустойчивым можно отнести сорта не обладавшие высокой $\mathrm{RSR}$, но имевшие наименьшее отклонение этого показателя и хорошую всхожесть: Бионик, Danuta, 752A, NCL 95098, Одесский 115, Rodos, Казьминский. Одним из наименьших отклонений RSR отличался сорт Mie, но из-за 
низкой всхожести в стрессовых условиях мы не можем отнести его к засухоустойчивым.

Выводы. В качестве исходного материала для создания алюмоустойчивых сортов рекомендуется использовать коллекционные образцы: NCL 95098, местный сорт из Китая (к-2929), Одесский 115, Сябра, Полярный 14, Новичок, Нaxby, Rodos, Наран и Казьминский; для создания засухоустойчивых сортов - Bonita, Бионик, Danuta, 752A, NCL 95098, Одесский 115, Rodos и Казьминский.

\section{Список литературы}

1. Анисимова Н.Н., Ионова Е.В. Элементы структуры урожая сортов ярового ячменя и их вклад в формирование высокой продуктивности растений // Зерновое хозяйство России. Аграрный научный центр «Донской» (Зерноград). 2016. №5. С. 40-43.

2. Баталова Г.А. Овес в Волго-Вятском регионе. - Киров: ООО «Орма», 2013. $288 \mathrm{c}$.

3. Диагностика устойчивости растений к стрессовым воздействиям: методическое руководство / Под ред. Г.В. Удовенко. - Л.: ВИР, 1988. - 227 с.

4. Климашевский, Э.Л. Генетический аспект минерального питания растений. М.: Агропромиздат. 1991. - 420 с.

5. Кокина Л.П., Щенникова И.Н., Зайцева И.Ю. Оценка коллекционных образцов ячменя на устойчивость к осмотическому стрессу // Аграрная наука Евро-Северо-Востока. 2018. №5 (66).

6. Лисицын Е.М. Методика лабораторной оценки алюмоустойчивости зерновых культур // Доклады РАСХН. 2003. №3. С. 5-7.

7. Лисицын Е.М. Показатели развития корневых систем в эдафической селекции ячменя // Зернобобовые и крупяные культуры. 2018. №2 (26).

8. Лисицын Е.M. Физиологические параметры корневых систем в селекции зерновых культур на абиотическую устойчивость // Вестник Марийского государственного университета. Серия «Сельскохозяйственный науки. Экономические науки». 2018. T. 4. № 3. С. 7-44.

9. Пакуль, В. Н. Источники ярового ячменя по засухоустойчивости в условиях лесостепи Западной Сибири / В.Н. Пакуль, С.В. Мартынова, Д.Е. Андросов // Международный научно-исследовательский журнал. 2016. № 2 (44) Часть 3. С. 102-106.

10. Щенникова И.Н., Шуплецова О.Н., Бутакова О.И. Оценка сортов ярового ячменя на кислотоустоустойчивость $\left(\mathrm{A} 1^{+}\right) / /$Генетические ресурсы ржи, ячменя и овса / Труды по прикладной ботанике, генетике и селекции / С-Пб.: ВИР, 2009. Т. 165. С. 179-182.

11. Яковлева О.В., Капешинский А.М. Толерантность ячменя к токсичным ионам алюминия в условиях почвенной культуры // Труды по прикладной ботанике, генетике и селекции. 2011; 168: 54-64.

12. Яковлева О.В. Фитотоксичность ионов алюминия // Труды по прикладной ботанике, генетике и селекции. 2018; 179(3): 315-331.

13. Navacode S., Weidner A., Varshney R.K. Lohwasser U., Scholz U., Roder M.S., Borner A. A genetic analysis of aluminium tolerance in cereais // Agris Conspec Sci. 2010. V. 75. No. 4. P. 191-196. 


\section{Изучение топологии ростковых трубок бурой ржавчины на поверхности листа пшеницы на основе анализа конфокальных 3D-изображений}

Зубаирова У.С. ${ }^{1 *}$, к.б.н., н.с.; Букатич Е.Ю. ${ }^{1}$, м.н.с.; Дорошков А.В. ${ }^{1}$, к.б.н., н.с.; Маловичко Е.С. ${ }^{2}$, студент; Орлова Е.А. ${ }^{3}$, к.с-х.н., в.н.с.; Афонников Д.А. ${ }^{l}$, к.б.н., B.H.C.

${ }^{1}$ ИЦиГ СО РАН, Новосибирск, Россия;

${ }^{2}$ НГУ, Новосибирск, Россия;

${ }^{3}$ СибНИИРС - филиал ИЦиГ СО РАН, Новосибирск, Россия.

*e-mail: ulyanochka@boinet.nsc.ru

Для изучения геометрии ростковых трубок бурой ржавчины (Риссіпіа recondita) на поверхности листа пшениць применен оригинальный подход, основанный на получении и обработке конфокальных $3 D$ изображений зараженных листьев, окрашенных флуоресцентными красителями. В работе проанализирован ряд 3D-изображений для шести сортов мягкой пшеницы и составлено иџфровое описание расположения ростковой трубки на поверхности листа.

Ключевые слова: бурая ржавчина, мягкая пшеница, конфокальная микроскопия, анализ изображений.

\section{Studying the topology of brown rust germination tubes on the wheat leaf surface based on confocal 3d-images analysis}

Zubairova U.S., Institute of cytology and genetics SB RAS, Novosibirsk, Russia, ulyanochka@boinet.nsc.ru;_Bukatich E.Yu., Institute of cytology and genetics SB RAS, Novosibirsk, Russia; Doroshkov A.V., Institute of cytology and genetics SB RAS, Novosibirsk, Russia; Malovichko E.S., Novosibirsk state university, Novosibirsk, Russia; Orlova E.A., Institute of cytology and genetics SB RAS, Novosibirsk, Russia; Afonnikov D.A., Institute of cytology and genetics SB RAS, Novosibirsk, Russia.

To study the topology of germinatin tubes of brown rust (Puccinia recondita) on the surface of a wheat leaf, an original approach based on the receipt and processing of confocal $3 D$ images of infected leaves stained with fluorescent dyes was used. We analyzed a number of $3 D$ images for six varieties of bread wheat and compiled a digital description of the location of the germination tube on the leaf surface.

Key words: brown rust, bread wheat, confocal microscopy, image analysis. 
Бурая ржавчина (Puccinia recondita) поражает листья пшеницы, в результате уменьшается их способность к фотосинтезу, что приводит к снижению урожайности пшеницы. Для изучения патогенеза этого заболевания используется широкий класс методов системной биологии, в том числе и компьютерные модели [1], которые рассматривают взаимодействие патогенрастение как комплексный процесс. Для изучения механизмов патогенеза ржавчинных заболеваний растений используется анализ изображений листьев зараженных зерновых культур, полученных методом конфокальной лазерной сканирующей микроскопии [2].

Для изучения геометрии ростковых трубок бурой ржавчины на поверхности листа пшеницы применен оригинальный подход, основанный на получении и обработке конфокальных 3D изображений зараженных листьев, окрашенных флуоресцентными красителями. Области листа, в которых ожидалось проявление болезни, фиксировались в 4 \% растворе параформальдегида в течение 3 или более часов и затем окрашивались красителями DAPI (SIGMA), Calcofluor White (SIGMA) и Propidium Iodide (SIGMA). Этот набор красителей на фиксированном материале обеспечивает достаточно устойчивую к выгоранию окраску ядер и клеточных стенок для клеток гриба и растения. Полученные препараты затем были отсканированы при помощи микроскопа ZEISS LSM 780 NLO в режиме многокадрового сканирования. Подбор области сканирования проводился исходя из необходимости обеспечить видимость всех клеточных стенок растения и границ ростковых трубок гриба. Обработка и анализ 3D-изображений проводилась с помощью разработанного авторами программного модуля для плагина LSM-W ${ }^{2}$ [3], позволяющего обрабатывать и анализировать конфокальные изображения бурой ржавчины на листьях пшеницы. Основными этапами алгоритма являются: (1) получение информации о градиенте поверхности листа, (2) получении серии изображений: (i) клеточной структуры эпидермиса листа, (ii) поверхности листа с ростковой трубкой, (iii) разметки-сегментации клеточной структуры, (iv) разметки-сегментации морфологических структур гриба (споры, ростковой трубки, аппрессория), (3) сопоставление полученных изображений с целью автоматического извлечения информации о расположении ростковой трубки на поверхности листа.

С помощью разработанного программного модуля проанализирован ряд 3D-изображений для шести сортов мягкой пшеницы и составлено цифровое описание расположения ростковой трубки на поверхности листа.

Благодарности: Исследование выполнено при финансовой поддержке РФФИ в рамках научного проекта № 17-29-08028. В работе использовались вычислительные ресурсы ЦКП «Биоинформатика» при поддержке бюджетного проекта № 0324-2019-0040-С-01. 


\section{Список литературы}

1. Nikolaev S.V., Zubairova U.S., Skolotneva E.S., Orlova E.A., Afonnikov D.A. A system approach to the modeling of fungal infections of the wheat leaf. Vavilovskii Zhurnal Genetiki i Selektsii=Vavilov Journal of Genetics and Breeding. 2019;23(1):100-109. DOI 10.18699/VJ19.468 (in Russian)

2. Solanki, S., Ameen, G., Borowicz, P., Brueggeman, R.S. (2019). Shedding light on penetration of cereal host stomata by wheat stem rust using improved methodology. Scientific reports, 9(1), 1-13.

3. Zubairova, U.S., Verman, P.Y., Oshchepkova, P.A., Elsukova, A.S., Doroshkov, A.V. (2019). LSM-W 2: laser scanning microscopy worker for wheat leaf surface morphology. BMC systems biology, 13 (1), 22.

\section{Влияние предпосевной обработки семян микроэлементами на урожайность сорта сои Жансая в условиях Алматинской области}

Кабылбекова Г.К. *, докторант; Дидоренко С.В., к.б.н., зав. отделом зернобобовых культур; Кудайбергенов М.С., д.б.н., г.н.с. отдела зернобобовых культур; Байтаракова К.Ж., с.н.с. отдела зернобобовых культур.

ТОО «Казахский научно-исследовательский институт земледелия и растениеводства», Алматы, Казахстан

*e-mail: shaiza_68@mail.ru

Изучено влияние предпосевной обработки семян сои растворами микроэлементов Мо и Со. Самое большое отклонение от контроля дала совместная обработка семян азотфиксирующими бактериями и микроэлементами $-8,4$ uุ/2a.

Ключевые слова: соя, микроэлементы, признаки продуктивности, урожайность.

\section{Effect of pre-seeding treatment of seeds with microelements on the yield of the soybaen variety in the conditions of the Almaty region}

Kabylbekova G.K., $2^{\text {nd }}$ year doctoral student shaiza 68@mail.ru, Didorenko S.V., candidate of biological sciences, head of the department of leguminous crop, Kudaibergenov M.S., Doctor of Biological Sciences, Chief Researcher at the Department of Leguminous Crops, Baitarakova K. Zh. - Senior Researcher at the Department of Pulses.

LLP "Kazakh Research Institute of Agriculture and Crop Production", Almaty, Kazakhstan.

The effect of pre-seeding treatment of soybean seeds with solutions of trace elements Mo and Co was studied. The largest deviation from the control was given 
by the joint treatment of seeds with nitrogen-fixing bacteria and microelements $8.4 \mathrm{c} / \mathrm{ha}$.

Key words: soybeans, microelements, signs of productivity, productivity.

Одним из приоритетных направлений развития АПК Казахстана является кормовая база. Не последнее место в этом занимает такая высокобелковая и одновременно масличная культура - соя. Посевные площади под этой культурой увеличиваются не только в странах лидерах ее производства, но и в нашей стране. За последние 10 лет площади возделывания сои в республике увеличены почти в 2,5 раза с 53 тыс. га в 2008 году до 138,9 тыс. га в 2019. Большую часть площадей занимают орошаемые земли Алматинской области (до 90 \%). Средняя урожайность по стране составляет 21-22 ц/га. Назревает необходимость увеличения урожайности этой культуры в производственных масштабах, так как на опытных и демонстрационных участках она достигает 40-45 ц/га при традиционном поливе, а при применении капельного орошения до 60-65 ц/га.

Управление вегетацией растений новых сортов путем использования научно обоснованного севооборота, а также с помощью микроудобрений и стимуляторов роста позволяет добиваться высочайшей рентабельности растениеводства [1].

При «успешной азотфиксации» соя способна накопить до 400 кг/га азота, правда, большую его часть использует само же растение. Однако, по данным различных авторов, после уборки урожая сои в почве для последующих культур остается от 60 до 150 кг азота в составе клубеньков, корневых и пожнивных остатков. О том, что микроэлементы имеют если не прямое, то косвенное влияние на азотфиксацию, написано в любом учебнике по физиологии растений. Одни, например, входят в состав азотфиксирующих ферментов, другие - создают условия для усиления процессов.

Причем многочисленные эксперименты как отечественных, так и зарубежных исследователей свидетельствуют, что совместное применение молибдена и бора дает лучший результат, чем отдельное их использование [2-4].

Кобальт, в свою очередь, повышает содержание леггемоглобин в клубеньках, содержание которого определяет интенсивность их дыхания. При наличии кобальта процесс фиксации азота проходит активно.

Установлено, что рекомендуемые в научной литературе дозировки не оптимальны и требуют корректировки [5].

Традиционно молибден применяют для предпосевной обработки семян (на 1 ц семян сои - 30-50 г молибденово-кислого аммония (50 \% Мо). При внекорневой подкормке в период бутонизации - начала цветения норма внесения составляет до 200 г/га. Кобальт непосредственно участвует в процессах усвоения азота из воздуха, поскольку концентрируется в самых клу- 
беньках, где способствует размножению клубеньковых бактерий. Используется при внекорневой подкормке и внесении непосредственно в грунт $[6,7]$.

Исследованиями Ю.Н. Казачкова [8] было показано, что в случаях применения повышенных доз молибдена (50 и более г/га д.н.) коэффициент усвоения его значительно выше при смачивании семян, нежели при опрыскивании растений.

Минимальная доза молибденовых удобрений, которую необходимо применить для получения семян с достаточным количеством молибдена в семенах следующей репродукции (5 мг/кг и выше) при внесении его методом смачивания исходных семян является доза 50 г/га, а при опрыскивании растений - 200 г/га. При получении обогащенных семян с помощью внекорневой подкормки обычно используют раствор, содержащий 200 г молибдата аммония (гектарная норма) в 500-1000 литрах воды.предварительное обогащение семян сои молибденом, позволяет избежать антагонизма его с серой при совместном внесении удобрений, содержащих эти элементы и достичь дополнительной прибавки урожая зерна сои [9].

В наших исследованиях мы использовали лучший допущенный к производству по Алматинской области сорт сои Жансая. Это среднеспелый сорт с периодом вегетации 120-125 дней.

Полевой опыт заложен 29 апреля 2019 года в предгорной зоне на высоте 740 м над уровнем моря с характерными континентальными климатическими условиями: мягкой и прохладной зимой, прохладной весной, жарким и сухим летом, теплой и сухой осенью. Температурный режим всех месяцев на которых приходилась вегетация сои отличался повышенным фоном по сравнению со среднемноголетними показателями на $1,5-2,5{ }^{\circ} \mathrm{C}$, а распределение осадков оказалось крайне неравномерным. Так самые высокие показатели пришлись на апрель, август и сентябрь. В мае, июне и июле осадков было критически мало по сравнению со среднемноголетними показателями.

За две недели до посева семена сои обрабатывались раствором аммония молибденовокислым 4 водным из расчета 40 г на100 кг семян и кобальт (II) сернокислым 7 водным из расчета 4 г на 100 кг семян. В день посева семена обработаны препаратом, содержащим азотфиксирующие бактерии «Histick», из расчета 400 г на 100 кг семян. Учетная делянка 25 м кв., норма высева семян 500 тыс. шт/га.

Все виды обработок не оказали воздействие на длину вегетационного периода. Все делянки созревали равномерно, и полной спелости достигли 17 сентября. Однако при анализе продуктивности, было выявлено влияние предпосевных обработок микроэлементами на урожайность сои (таблица). 
Таблица - Урожайность сои сорта Жансая при разных видах обработок

\begin{tabular}{|c|c|c|c|c|c|c|}
\hline Вариант опыта & \multicolumn{4}{|c|}{ Валовый сбор с делянки, кг } & \multirow{2}{*}{$\begin{array}{c}\text { Урожай- } \\
\text { ность, } \\
\text { ц/га }\end{array}$} & \multirow{2}{*}{$\begin{array}{c}\text { Отклонение } \\
\text { от кон- } \\
\text { троля, ц/га }\end{array}$} \\
\hline Жансая & 1 пов. & 2 пов. & 3 пов. & среднее & & \\
\hline $\begin{array}{l}\text { Контроль - } \\
\text { без обработок }\end{array}$ & 8,7 & 7,9 & 8,5 & 8,4 & 34,9 & 0,0 \\
\hline $\mathrm{Mo}+\mathrm{Co}$ & 7 & 9,1 & 10,7 & 8,9 & 37,2 & 2,3 \\
\hline Histick & 9,7 & 9,9 & 9,5 & 9,7 & 40,4 & 5,5 \\
\hline Histick $+\mathrm{Mo}+\mathrm{Co}$ & 10 & 10 & 11,2 & 10,4 & 43,3 & 8,4 \\
\hline $\mathrm{HCP}$ & & & & & & 1,5 \\
\hline
\end{tabular}

Все виды обработок оказали положительное влияние на урожайность сои. Даже внесение микроэлементов без иннокуляции повысило урожайность по сравнению с контролем на 2,3 ц/га. Самое большое отклонение от контроля дала совместная обработка семян азотфиксирующими бактериями и микроэлементами $-8,4$ ц/га.

По элементам продуктивности дополнительные обработки повышали завязываемость цветков, что отразилось на повышении количества бобов с растения.

\section{Список литературь}

1. Зотиков В.И., Сидоренко В.С., Бударина Г.А., Голопятов М.Т., Акулов А.С., Семенов С.А., Вилюнов С.Д. Влияние применения препаратов биостим масличный и ультрамагкомби на урожайность новых сортов зернобобовых культур // Научно-производственный журнал «Зернобобовые и крупяные культуры». - 2019. - № 4(32) - С. $4-12$.

2. Чумак А., Довгаюк-Семенюк М. Молибден и соя: возможности и проблемы // Пропозиция. - 2017. - № 2. - С. 60-62.

3. Анспок П.И., Лиениньш Ю.Я. Содержание микроэлементов в почвах и необходимость их применения // Химизация сельского хоз. - 1988. - № 2. - С. 73-75.

4. Новикова Н.Е. Физиологическое обоснование листовой подкормки для оптимизации питания зерновых бобовых культур в онтогенезе растений (обзор) // Научнопроизводственный журнал «Зернобобовые и крупяные культуры». - 2018. - № 1 (25). - C. 60-67.

5. Асокин О.И. Эффективность некорневых подкормок сои молибденом и бором // V международная конференция молодых ученых и специалистов, ВНИИМК, 2009.

6. http://nanit.ua/ materials/753 -vazhnye- mikroelementy -dlya-soi.html

7. Голов В.И., Казачков Ю.Н. Поступление молибдена в растения сои и его последействие при внесении молибденовых удобрений на почвах Дальнего Востока // Агрохимия. - 1973. - № 10. - С. 103-109.

8. Казачков, Ю.Н. Оценка результатов и корректировка применения молибдена под сою // Пути повышения продуктивности растениеводства, кормопроизводства и садоводства на Дальнем Востоке. - Владивосток: ДВО АН СССР, 1987. - С. 49-57.

9. Голов В.И. Антагонизм серы и молибдена в растениях сои и возможности их совместного применения в качестве удобрений // Масличные культуры. Научно-технический бюллетень ВНИИМК. Вып. 2 (151-152), 2012. 


\section{Развитие отрасли растениеводства Новосибирской области в зависимости от природно-сельскохозяйственного зонирования}

Капустянчик С.Ю. ${ }^{1 *}$, к.б.н., с.н.с.; Садохина Т.А. ${ }^{2}$, к.с.-х.н., в.н.с.; Шелковников С.А. ${ }^{3}$, д.э.н., профессор; Петухова М.С. ${ }^{3}$, к.э.н., н.с.; Добрянская С.Л. ${ }^{3}$, к.б.н., доиент.

${ }^{1}$ Сибирский научно-исследовательский институт растениеводства и селекuчи - филиал «ФИЦ Институт иฺитологии и генетики СО РАН», p.n. Краснообск, Россия

${ }^{2}$ Сибирский научно-исследовательский институт кормов Сибирский федеральный научный центр агробиотехнологий Российской академии наук, p.n. Краснообск, Россия

${ }^{3}$ ФГБОУ ВО «Новосибирский государственный аграрный университет», 2. Новосибирск, Россия

*e-mail: kapustyanchik@bionet.nsc.ru

Дана оценка развития отрасли растениеводства Новосибирской области в зависимости от природно-сельскохозяйственного зонирования. Отмечено, что в Западно-Сибирской провинции южно-таежно-лесной зоны имеется заболачивание и переувлажнение почв, в Западно-Сибирской провинции лесостепной зоны - засоленность почв и слабая биологическая мелиорация, в Северо-Предалтайской провинции лесостепной зоны - водная эрозия и сильная расчлененность рельефа, в Западно-Сибирской (Казахстанской) провинции степной зоны - ветровая эрозия и залужение солонцовых почв. Это позволяет сосредоточить ресурсы сельского хозяйства на повышении эффективности производства и качества продукции растениеводства с использованием адаптивно-ландшафтных систем земледелия.

Ключевые слова: растениеводство, адаптивно-ландшафтная система земледелия, адаптивное растениеводство.

\section{The development of crop production in the Novosibirsk region in depending on natural agricultural zoning}

*Kapustyanchik S.Yu. ${ }^{\text {}, ~ C a n d i d a t e ~ o f ~ B i o l o g i c a l ~ S c i e n c e s, ~ S e n i o r ~ R e s e a r c h e r, ~}$ Sadokhina T.A. ${ }^{2}$, Candidate of Agricultural Sciences, Senior Researcher, Shelkovnikov S.A. ${ }^{3}$, Doctor of Economic Sciences, Professor, Petukhova M.S. ${ }^{3}$, Candidate of Economic Sciences, Researcher, Dobryanskaya S.L. ${ }^{3}$, Candidate of Biological Sciences, Associate Professor.

${ }^{1}$ Siberian Research Institute for Plant Industry and Breeding, Branch of the Federal Research Center, Siberian Branch, Russian Academy of Sciences, Krasnoobsk, Russia, 
${ }^{2}$ Siberian Federal Scientific Centre of Agro-BioTechnologies of the Russian Academy of Sciences, Krasnoobsk, Russia,

${ }^{3}$ Federal State Budget Education Institution of Higher Education «Novosibirsk State Agrarian University», Novosibirsk, Russia.

*e-mail:kapustyanchik@bionet.nsc.ru

An assessment of the development of the plant growing industry in the Novosibirsk Region, depending on natural agricultural zoning, was carried out. It was revealed that in the West Siberian province of the southern taiga-forest zone there is a problem of water logging and water logging of soils, in the West Siberian province of the forest-steppe zone with soil salinity and poor biological reclamation, in the North-Pre-Altai province of the forest-steppe zone there is water erosion and strong ruggedness of the relief, in the West Siberian (Kazakhstan) province of the steppe zone - wind erosion and tinned solonetzic soils. This allows you to focus agricultural resources on increase production efficiency and product quality plant growing using adaptive-landscape farming systems.

Key words: crop production, adaptive-landscape farming system, agroecological groups of lands.

Особенность российского растениеводства заключается в острой необходимости ускорения его научно-технологического развития на базе инновационных процессов. Центральное место в растениеводстве занимает селекция, направленная на создание и использование новых сортов и гибридов сельскохозяйственных культур. Выдающимися отечественными селекционными достижениями являются сорта озимой мягкой пшеницы, мягкой яровой пшеницы с повышенной устойчивостью к неблагоприятным факторам среды.

Сибирь занимает важное положение в сельском хозяйстве России. Так, в обеспечении населения продовольствием значительная роль отводится АПК Сибирского федерального округа (СФО). Сельское хозяйство здесь развивается в экстремальных природных условиях, земледельческая территория относится в основном к ареалу пониженной биологической активности, значительная ее часть характеризуется холодным климатом. Биоклиматический потенциал земледельческой зоны в 2-2,5 раза ниже, чем в европейской части России [1].

Одним из крупных сельскохозяйственных регионов в Западной Сибири является Новосибирская область. Сельское хозяйство Новосибирской области развивается в зоне рискованного земледелия, поэтому производство продуктов растениеводства находится в сильной зависимости от погодных условий. Производство зерновых и зернобобовых культур, помимо картофеля и овощей является одним из ведущих направлений данного региона. Поскольку природные условия области ограничивают число и виды возде- 
лываемых культур, определяют высокие затраты на производство сельскохозяйственной продукции, преобладающими культурами в выращивании зерновых являются яровая пшеница, овес и ячмень. Основными зернопроизводящими районами в Новосибирской области являются Краснозерский, Купинский, Чистоозерный, Баганский, Карасукский [2]. На полях области выращивают также рожь, просо, гречиху и сою. Одним из ведущих направлений в растениеводстве Новосибирской области, помимо зернового, является выращивание кормовых и технических культур - злаковые многолетние травы (кострец безостый); бобовые (люцерна, клевер красный) и др. В последние годы проявляется большой интерес к выращиванию рапса, рыжика; ведутся исследовательские работы по таким культурам, как фестулолиум и мискантус.

Цель исследования заключалась в изучении развития отрасли растениеводства Новосибирской области в зависимости от природно-сельскохозяйственного зонирования.

Условия, материалы и методы. Методологической основой исследования послужили методы анализа и метод группировки.

Результаты и обсуждение. В развитии растениеводства Новосибирской области особое место принадлежит селекции, созданию новых сортов и гибридов зерновых, овощных и других культур. За последние годы происходит увеличение посевных площадей, занятых зерновыми, кормовыми и техническими культурами, что приводит к упрощенным системам земледелия (севообороты с короткой ротацией и повторные посевы). Нарушение сроков сортосмены и сортообновления приводит к тому, что сорт не может раскрыть свой биологический потенциал, тем самым снижая качество урожая по Новосибирской области.

Оценивая Новосибирскую область в соответствии с природно-сельскохозяйственным районированием России, выделяют 4 природно-сельскохозяйственные провинции, в которых выделяют агроландшафтные районы с различными природно-климатическими и почвенными условиями:

1) Западно-Сибирская провинция южно-таежной зоны. Сельскохозяйственная освоенность зоны низка. Специализации растениеводства: производство зеленых, сочных и грубых кормов, пивоваренного и фуражного ячменя, продовольственного зерна ржи, овса и льна.

2) Западно-Сибирская провинция лесостепной зоны. Северо-лесостепной Барабинский агроландиафтный район. Специализации растениеводства: производство продовольственного зерна ржи и пшеницы, зеленых, сочных и грубых кормов, фуражного зерна, полевых капустовых на слабопереувлажненных и малосолонцовых землях. Центрально-лесостепной Барабинский агроландиафтный район. Специализация растениеводства: производство фуражного и продовольственного зерна, зеленых, сочных и грубых кормов, полевых капустовых и крупяных культур для малосолонцовых 
земель и производство зеленых и грубых кормов для солонцовых земель. Южно-лесостепной Барабинский агроландшафтный район. Специализация растениеводства: производство фуражного и продовольственного зерна, зеленых, сочных и грубых кормов, полевых капустовых культур для малосолонцовых и частично солонцовых земель.

3) Северо-Предалтайская провинция лесостепной зоны. Северо-лесостепные агроландшафтные районы. Специализация растениеводства -производство фуражного и продовольственного зерна пшеницы, ржи, гороха, овса; зеленых, сочных и грубых кормов, полевых капустовых культур и льна для плакорных земель; на слабоэрозионных землях расширяются площади под многолетними травами, вместо чистого пара вводится почвозащитный; для эрозионных земель - производство кормов из многолетних трав длительного пользования, прерываемого для обновления травостоя посевами покровных зерновых культур или однолетних трав. Лесостепные Приобский и Сузунский агроландшафтные районы. Специализация растениеводства: производство фуражного и продовольственного зерна, зеленых, сочных и грубых кормов, полевых капустовых культур и сои для плакорных, слабоэрозионных и малосолонцовых земель; для эрозионных земель - производство кормов из многолетних трав длительного пользования.

4) Западно-Сибирская (Казахстанская) провинция степной зоны. Почти все пахотные земли потенциально опасные в отношении дефляции и эрозии. Специализация растениеводства для плакорных дефляционно опасных земель - производство фуражного и продовольственного зерна; семеноводство многолетних и однолетних трав; производство крупяных и масличных культур; зеленых, сочных и грубых кормов; для малосолонцовых земель производство фуражного и продовольственного зерна; зеленых, сочных и грубых кормов; масличных культур; для солонцовых земель - кормопроизводство с использованием соле- и солонцоустойчивых многолетних трав и травосмесей [3].

В соответствии с агробиологическими требованиями растений, для каждого района формируется определенный набор культур, разрабатываются севообороты, системы обработки почвы, удобрения, мероприятия по защите растений от сорняков, болезней и вредителей. Поскольку, каждая зона имеет свои почвенно-климатические особенности, возникает необходимость повышения устойчивости культивируемых растений к стрессовым температурам, засухе, кислым и засоленным почвам [4]. Эти задачи решают селекционные центры области, осуществляющие работы по поиску и созданию гендоноров устойчивости растений и созданию сортов с большей агроэкологической адресностью и ресурсовоспроизводящими возможностями.

Выводы. Подводя итог вышесказанному, можно сказать, что направление ресурсов на преодоление вышеназванных проблем в каждой из зон даст возможность снизить уровень дифференциации региона по условиям 
ведения сельскохозяйственного производства. К таким направлениям относят: поддержание почвенного плодородия, агрохимические и мелиоративные мероприятия, применение минеральных удобрений и средств защиты растений, освоение новых технологий выращивания сельскохозяйственных культур, расширение посевных площадей под высокоурожайными сортами и гибридами. Необходимым условием для разработки новых механизмов селекции и семеноводства в области является повышение генетического потенциала растений за счет организации систематического сортообновления и сортосмены, выведения новых районированных высокоурожайных сортов сельскохозяйственных культур, устойчивых к сорнякам, вредителям и болезням, использование в селекции разработок по биохимии, физиологии и генетики. Внедрение новых технологий производства продукции растениеводства в хозяйства Новосибирской области в зависимости от природносельскохозяйственных зон, позволит перейти на адаптивно-интенсивную систему производства растениеводческой продукции и внедрить в практику достижения научно-технического прогресса, способствующие сохранению базовых природных ресурсов.

Благодарности: Исследование выполнено при финансовой поддержке РФФИ и Новосибирской области в рамках научного проекта № 19410-540001.

\section{Список литературы}

1. Донченко А.С., Першукевич П.М. Состояние и стратегия развития сельского хозяйства Сибири / Продовольственное обеспечение Сибири в условиях глобализации мировой экономики: материалы международной научно-практической конференции, посвященной 60-летию создания Сибирского научно-исследовательского института экономики сельского хозяйства, (Новосибирск, 3-4 июня 2015 г.) / ФГБНУ СибНИИЭСХ. - Новосибирск, 2015. - С. 3-16.

2. Зяблицева Я.Ю. Влияние природных условий на размещение зернового производства в районах Кулундинской зоны Новосибирской области / Продовольственное обеспечение Сибири в условиях глобализации мировой экономики: материалы международной научно-практической конференции, посвященной 60-летию создания Сибирского научно-исследовательского института экономики сельского хозяйства, (Новосибирск, 3-4 июня 2015 г.) / ФГБНУ СибНИИЭСХ. - Новосибирск, 2015. - С. 89-92.

3. Адаптивно-ландшафтные системы земледелия Новосибирской области / РАСХН. Сиб. Отд-ние. СибНИИЗХиМ. - Новосибирск, 2002. - 388 с.

4.Жученко А.А. Ресурсный потенциал производства зерна в России (теория и практика). - М.: ООО «Издательство Агрорус», 2004. - 1110 с. 


\section{Достижения по селекции кормовых культур в Сибирском НИИ Кормов СФНЦА РАН за 50 лет}

Камеваров Н.И., д.с.-х.н., академик РАН, директор; Полюдина Р.И., д.с.-х.н., рук. селекционного центра по кормовым культурам; Потапов Д.А., к.с.-х.н., в.н.с.; Гришин В.М., к.с.-х.н., с.н.с.

Сибирский федеральный научный центр агробиотехнологий РАН, Новосибирск, Россия.

e-mail: sibkorma@ngs.ru

В селекиионном иентре СибНИИ кормов СФНЦА РАН создано более 60 сортов по 24 кормовым культурам, в Государственный реестр включен 51 сорт. Впервые в Сибири созданы безэруковые, низкоглюкозинолатные, высокоурожайные сорта ярового рапса СибНИИК 198, СибНИИК 21, Дубравинский скороспельий, Надежный 92 и Сибирский; уникальные скороспелые и высокоурожсайные сорта сои СибНИИК 315, СибНИИК 9, Горинская и кормовых бобов Сибирские; зимостойкие одно- и двуукосные на диплоидной и тетраплоидной основе сорта клевера лугового СибНИИК 10, Родник Сибири, Атлант, Огонек, Памяти Лисицьна, Метеор, Прима; редька масличная Сибирячка.

Ключевые слова: селекиия, яровой рапс, соя, суданская трава, клевер луговой, бобы кормовые, редька масличная.

\section{Progress in forage crops breeding in Siberian Research Institute of Forage Crops SFSCA of The RAS for fifty years}

Kashevarov N.I., Polyudina R.I., Potapov D.A., Grishin V.M., Siberian Federal Scientific Centre of Agro-BioTechnologies of the Russian Academy of Sciences; Novosibirsk, Russian Federation, sibkorma@ngs.ru

As many as sixty cultivars of twenty four fodder crops were developed in a breeding center of Siberian research Institute of forage crops of SFSCA of the RAS. Fifty-one cultivars are included in the State register of breeding achievements. High-yielding canola varieties such as SibNIIK 198, SibNIIK 21, Dubravinsky skorospeliy, Nadezhny 92 and Sibirsky, and unique early-maturing and high-yielding soybean varieties SibNIIK 315, SibNIIK 9, Gorinskaya, fodder beans Sibirskye, and winter-hardy diploid and tetraploid meadow clover varieties SibNIIK 10, Rodnik Sibiri, Atlant, Ogonyok, Pamyati Lisitsyna, Meteor, Prima, and oilseed radish Sibiryachka are created for the first time in Siberia.

Key words: breeding, Brassica napus, Glycine max, Sorghum sudanense, Trifolium pratense, Faba vulgaris, Raphanus sativus var. Oleiformis. 
В 1970 г. решением ВАСХНИЛ был учрежден Сибирский научно-исследовательский институт кормов с отделом селекции и семеноводства, на базе которого в 1977 году был создан Сибирский селекционный центр по кормовым культурам. В его состав в настоящее время входят региональные отделы: Северо-Кулундинский (г. Баган Новосибирской области) и Восточно-Сибирский (с. Михайловка Ужурского района Красноярского края), организованные на базе сельскохозяйственных опытных станций. Это позволяет вести селекцию на адаптивность к условиям лесостепной и степной зон Западной и Восточной Сибири. За годы функционирования селекцентра создано более 60 сортов по 24 кормовым культурам, в Государственный реестр включен 51 сорт.

Первый в СССР сорт ярового panca Восточно-Сибирский был создан на Ужурской СХОС (Восточно-Сибирский отдел СибНИИ кормов) в 1981 г. Из 145 сортов включенных Государственный реестр в 2019 г., 52 - включены по Западно- и Восточно-Сибирскому регионам, среди которых 8 - сибирской селекции. Сорта СибНИИ кормов: СибНИИК 21, СибНИИК 198, Дубравинский скороспелый, Надежный 92, Сибирский [1]. Начатые в СибНИИ кормов в 1987 г. исследования по получению ярового рапса 000-типа с использованием методов отдаленной гибридизации и инбридинга [2] привели к созданию нового высокоурожайного и высокомасличного сорта СибНИИК 32 , который в 2018 г. передан на ГСИ.

В Сибири до 1993 года возделывались местные сорта клевера лугового, районированные еще в 1940-х годах прошлого столетия и селекционные сорта, созданные методом массового отбора. С созданием селекцентра по кормовым культурам взяты на вооружение современные селекционно-генетические методы: гетерозисная селекция, гибридизация, мутагенез и полиплоидия. В СибНИИ кормов создана серия сортов нового поколения пластичных, высокоадаптивных, зимостойкие, высокоурожайные одноукосные и двуукосные на диплоидной и тетраплоидной основе [3].

Применительно к клеверу луговому во ВНИИ кормов разработана селекционная схема эффективного использования метода химического мутагенеза, обеспечивающая создание новых признаков и их закрепления, сокращение сроков селекции на первых этапах в 1,5-2 раза в условиях искусственного климата. Впервые решена сложная проблема селекции клевера лугового на скороспелость, где преодолена генетическая отрицательная корреляционная связь между признаками зимостойкости и скороспелости генотипов клевера лугового [4].

В результате сочетания методов мутагенеза, полиплоидии, гибридизации и отбора в жестких климатических условиях Западной Сибири впервые создан раннеспелый (двуукосный) зимостойкий на тетраплоидной основе сорт Метеор. Урожайность зеленой массы в первом укосе у сорта варьировала от 177 до 520 ц/га, во втором укосе от 105 до 486 ц/га. Максимальная 
урожайность за два укоса у сорта установлена 700 ц/га - $112 \%$ к стандарту СибНИИК 10 (2001 год) [5]. Облиственность в первом укосе у сорта Метеор составляет 36-48 \%, во втором укосе 32-53 \%; у стандарта - 36-44 и 40-49\%.

Сорт Прима раннеспелого типа на диплоидной основе создан совместно с ВНИИ кормов методом гибридизации и отборов. Средняя урожайность зеленой массы за два укоса 388 , сухого вещества 86, семян 3,17 ц/га [6]. Урожайность семян у нового сорта Прима варьировала по годам от 2,76 до 3,92 ц/га, при этом в сравнении с диплоидным стандартом СибНИИК 10 в 2007 и в 2009 была на уровне, а в 2011 году превышение составило 18 \%, а в сравнении с тетраплоидным стандартом Метеор диплоидный сорт Прима превышал по этому показателю на 36-93 \% в среднем на 52 \% (табл. 1). Сорт включен в Госреестр в 2019 г.

Таблица 1 - Урожайность семян клевера лугового растений первого года пользования сорта Прима (конкурсное сортоиспытание), ц/га

\begin{tabular}{|c|c|c|c|c|c|c|}
\hline \multirow{3}{*}{$\begin{array}{c}\text { Год } \\
\text { посева }\end{array}$} & \multicolumn{5}{|c|}{ Урожайность } & \multirow{3}{*}{$\mathrm{HCP}_{05}$} \\
\hline & \multirow{2}{*}{$\begin{array}{l}\text { Метеор, } \\
\text { ст.1 }\end{array}$} & \multirow{2}{*}{$\begin{array}{c}\text { СибНИИК } 10, \\
\text { ст. } 2\end{array}$} & \multicolumn{3}{|c|}{ Прима } & \\
\hline & & & $ц / г а$ & $\begin{array}{c} \pm \mathrm{\kappa} \\
\text { ст. } 1 / \mathrm{c} \text {. } 2 \\
\end{array}$ & $\begin{array}{c}\% \text { к } \\
\text { ст. } 1 / \text { ст. } 2\end{array}$ & \\
\hline 2006 & 1,96 & 2,88 & 2,83 & $0,87 /-0,05$ & $144 / 98$ & 0,44 \\
\hline 2008 & 2,88 & 4,33 & 3,92 & $1,04 /-0,41$ & $136 / 91$ & 0,35 \\
\hline 2010 & 1,43 & 2,34 & 2,76 & $1,33 / 0,42$ & 193/118 & 1,11 \\
\hline Среднее & 2,09 & 3,18 & 3,17 & $1,08 / 0,01$ & $152 / 99$ & - \\
\hline
\end{tabular}

Работа по селекции сои в Сибири была начата в 1950-х годах. Первый сибирский уникальный сорт СибНИИК 315 создан путем отбора, включен в Госреестр РФ с 1991 г. и допущен к использованию в 5 регионах России и Казахстане. В лесостепи Западной Сибири он вызревает за 90-110 дней, дает до 30 ц/га семян с содержанием белка 35-40 \%, масла 17-20 \%. Высокая экологическая пластичность сорта обеспечивает его широкое распространение: в настоящее время он возделывается от Москвы до Иркутска, превосходя по ареалу все другие российские сорта, и пользуется большим спросом. В настоящее время созданы высокоурожайные сорта сои СибНИИК 9 [7] и Горинская. Самая высокая урожайность зерна у этих сортов была установлена в 2017 г., она составила соответственно 33,6 и 29,2 ц/га [8].

Впервые в условиях Сибири в СибНИИ кормов совместно с Алтайским НИИСХ создан сорт кормовых бобов Сибирские. Сорт создан методом индивидуального (трехкратного) отбора из гетерогенной популяции К-2083 (Германия). Он характеризуется урожайностью зеленой массы 300 , сухого вещества -70 , зерна -35 ц/га. Вегетационный период от всходов до уборки на корм - 55 дней, на зерно 91-99 дней [9].

Одними из самых распространенных сортов суданской травы в Си- 
бири являются: Новосибирская 84, Лира, Туран 2, Кулундинская. В Государственном реестре селекционных достижений зарегистрировано 43 сорта суданской травы, их которых 21 районированы по Сибири. Сорта суданской травы, возделываемые в Сибири должны обладать не только высокими хозяйственно ценными признаками продуктивности, но и повышенной устойчивостью к неблагоприятным факторам внешней среды (табл. 2).

Таблииа 2 - Модель сорта суданской травы для возделывания в условиях Сибири

\begin{tabular}{|l|c|}
\hline \multicolumn{1}{|c|}{ Признаки } & Параметры \\
\hline Вегетационный период & $100-110$ дней \\
\hline Урожайность зеленой массы & $250-350$ ц/га \\
\hline Урожайность сухой массы & $40-50$ цга \\
\hline Урожайность семян & $15-20$ ц/га \\
\hline Интенсивность начального роста & средняя или высокая \\
\hline Выравненность по высоте растений и спелости семян & выровненные \\
\hline \multirow{2}{*}{ Устойчивость к заболеваниям } & $\begin{array}{c}\text { средне- и высоко-устой- } \\
\text { чивые }\end{array}$ \\
\hline
\end{tabular}

В СФНЦА РАН селекция суданской травы ведется с 1983 г. За это время было сформировано более десятка сложногибридных и синтетических популяций суданской травы [10]. Создано 5 сортов: Новосибирская 84, Лира, Достык 15 (совместно с ТОО Павлодарским НИИСХ), Карагандинская (совместно с ТОО Карагандинским НИИРС), Ника (совместно с ТОО «Научнопроизводственный центр зернового хозяйства им. Бараева» Республики Казахстан).

В 2018 г. создан новый сорт редьки масличной Сибирячка, урожайность семян составила 14,3 ц/га, на $12 \%$ выше стандарта, урожайность зеленой массы - 371,4 ц/га, что превышало стандарт на 18 \%. Продолжительность вегетационного периода составила 95 дней. Сорт может успешно возделываться во всех земледельческих регионах РФ [11].

Таким образом, за пятьдесят лет исследований достигнуто расширение сибирского генофонда по яровому рапсу, сое, клеверу луговому, суданской траве, кормовым бобам и другим кормовым культурам.

\section{Список литературь}

1. Осипова Г.М., Потапов Д.А. Рапс (Особенности биологии, селекция в условиях Сибири и экологические аспекты использования) / Россельхозакадемия. Сиб. отд-ние. - Новосибирск, 2009. - 132 с.

2. Потапов Д.А. Увеличение биоразнообразия в пределах вида Brassica napus L. при селекции на желтую окраску оболочки семян / Генофонд и селекция растений: мат. VI Междунар. науч.-практ. конф. (4-6 апреля 2018 г., Новосибирск, Россия). Новосибирск, ИЦиГ СО РАН, 2018. - С. 322-327. 
3. Полюдина Р.И. Экологическая селекция клевера лугового для создания сортов с повышенной адаптивностью к отрицательному воздействию температурных факторов среды в условиях Западно-Сибирского региона / Экологическая селекция и семеноводство клевера лугового. - М., 2012. - С. 77-103.

4. Новоселов М.Ю. Селекция клевера лугового. - М., 1999. - С. 183.

5. Полюдина Р.И. Селекционный потенциал клевера лугового в Сибири // Сиб. вестн. с.-х. науки. - 2016, №5. - С. 106-112.

6. Полюдина Р.И. Клевер в Сибири / СФНЦА РАН. - Новосибирск, 2017. $348 \mathrm{c}$.

7. Рожанская О.А., Полюдина Р.И. Особенности селекции сои с использованием методов сомаклональной изменчивости и мутагенеза в условиях Западной Сибири // Сиб. вест. с-х. науки, 2012. - №4. - С. 69-76.

8. Кашеваров Н.И., Полюдина Р.И., Данилов В.П., Потапов Д.А. Сорта кормовых культур в Сибири для импортозамещения АПК РФ // Труды Кубанского государственного аграрного университета. - №3 (59), 2016. - С. 167-176.

9. Кашеваров Н.И., Полюдина Р.И., Полищук А.А., Петров А.Ф., Кашеварова Н.Н. Кормовые бобы Сибирские // Кормопроизводство. - 2008. - №4. - С. 20-21.

10. Кашеваров Н.И., Полюдина Р.И., Балыкина Н.В., Штаус А.П. Суданка в кормопроизводстве Сибири / Под ред. Н.И. Кашеварова. - Новосибирск, 2004. - 224 с.

11. Полюдина Р.И., Потапов Д.А., Харчебников В.В. Новый сорт редьки масличной Сибирячка // Сиб. вестн. с.-х. науки, 2018. - Т. 48 (4). - С. 50-54.

DOI 10.18699/GPB2020-33

\section{Использование расширенной панели молекулярных маркеров на гены устойчивости $(S r 21, S r 23, S r 35, S r 36, S r 38)$ к стеблевой ржавчине на сортах мягкой и твердой пшеницы}

Кельбин В.Н. *, м.н.с.; Сколотнева Е.С., к.б.н., с.н.с.; Морозова Е.В., м.н.с.; Салина Е.А., д.б.н., г.н.с. ИЦиГ СО РАН, Новосибирск, Россия.

*e-mail: kelbin@bionet.nsc.ru

Стеблевая ржавчина пшениць - губительное заболевание, которое представляет реальную угрозу для производства пшенищы во всем мире. $C$ каждым годом возрастает вероятность появления и распространения новых вирулентных рас гриба. В этом исследовании мы провели оценку новой расширенной панели молекулярных маркеров (5 доминатных и кодоминатных маркера) на гены устойчивости к стеблевой ржавчине на 11 сортах мягкой и твердой пшениць в комплексе с фитопатологической оценкой к агрессивной западно-сибирской расе Pисcinia graminis f. sp. tritici.

Ключевые слова: молекулярные маркеры, гены устойчивости, анализ вирулентности, стеблевая ржавчина пшеницы. 


\section{The use of an expanded panel of molecular markers for stem rust resistance genes $(\mathrm{Sr} 21, \mathrm{Sr} 23, \mathrm{Sr} 35, \mathrm{Sr} 36, \mathrm{Sr} 38)$ on soft and durum wheat varieties}

Kelbin Vasily Nikolaevich

Institute of Cytology and Genetics, Siberian Branch of Russian Academy of Sciences, Novosibirsk, Russia.

Wheat stem rust is a fatal disease that poses a real threat to wheat production worldwide. The likelihood of the emergence and spread of new virulent mushroom races increases every year In this study, we evaluated a new expanded panel of molecular markers (5 dominant and codominant markers) for stem rust resistance genes in 11 varieties of soft and durum wheat in combination with a phytopathological assessment of the aggressive West Siberian race Puccinia graminis f. sp. tritici.

Key words: molecular markers, resistance genes, virulence analysis, wheat stem rust.

Стеблевая ржавчина пшеницы, вызываемая грибом Puccinia graminis f. sp. tritici (Pgt) - является серьезным инфекционным заболеванием, которое угрожает посевам пшеницы по всему миру на протяжении веков [2]. Наиболее эффективным, экономичным и экологически чистым способом защиты пшеницы от эпифитотий стеблевой ржавчины является возделывание устойчивых сортов и линий. В этой связи возникает необходимость оценки генетического потенциала существующих коллекций мягкой и твердой яровой пшеницы и идентифицирование генов устойчивости, которые будут эффективны не только против местных популяций патогена, но и против расы Ug99.

Целью работы была оценка разрешающей способности однозначных доминантных и кодоминантных молекулярных маркеров на $\mathrm{Sr}$ гены устойчивости к стеблевой ржавчине у сортов яровой мягкой и твердой пшеницы Оренбургской селекции, с последующим фитопатологическим тестированием сортов на устойчивость к агрессивному монопустульному изоляту стеблевой ржавчины, доминирующему в западно-сибирской популяции Pgt.

Материал и методы. В работе был анализирован селекционный материал, состоящий из (1) 6 сортов яровой мягкой пшеницы: Варяг, Оренбургская 13, Оренбургская 22, Оренбургская 23, Оренбургская юбилейная, Учитель; и (2) 5 сортов яровой твердой пшеницы: Оренбургская 10, Оренбургская 21, Меляна, Оренбургская целинная, Целинница.

Для идентификации генов устойчивости $(\operatorname{Sr} 36, \operatorname{Sr} 38, \operatorname{Sr} 23, \operatorname{Sr} 21$ и $\operatorname{Sr} 35)$ использовали ДНК маркеры, рекомендованные для маркер-вспомогательной селекции (MAS) (табл. 1). 
Таблица 1 - Молекулярные маркеры для генов устойчивости к стеблевой ржавчине

\begin{tabular}{|c|c|c|c|}
\hline Ген & Праймеры & Структура & Ссылка \\
\hline Sr21 & Sr21TRYF5R5 & $\begin{array}{r}\text { 5'-CCTAGAGAAACGGAAGGGACCA-3' } \\
\text { 5'-TGTGAGCTGTTTGCAGAAGTGTG-3' }\end{array}$ & {$[4]$} \\
\hline Sr23 & XTaLr16_RGA266585 & $\begin{array}{r}\text { 5'-GCTGGGATGAGCAATAAC-3' } \\
\text { 5'-GCAACCAACAACATCAGTAG-3' }\end{array}$ & {$[5]$} \\
\hline Sr35 & CNL9 & $\begin{array}{r}\text { 5'-CTCATCAACTGCTTGAGCGAAC-3' } \\
\text { 5'-GTATCTAGCGAACCTCAATCG-3' }\end{array}$ & {$[9]$} \\
\hline Sr36 & Xstm773-2 & $\begin{array}{r}\text { 5'-ATGGTTTGTTGTGTTGTGTGTAGG-3' } \\
\text { 5'-AAACGCCCCAACCACCTCTCTC-3' }\end{array}$ & {$[6]$} \\
\hline Sr38 & VENTRIUP-LN2 & $\begin{array}{r}\text { 5'-AGGGGCTACTGACCAAGGCT-3' } \\
\text { 5'-TGCAGCTACAGCAGTATGTACACAAAA-3' }\end{array}$ & {$[7]$} \\
\hline
\end{tabular}

ДНК выделяли из шестидневных проростков методом Plaschke et al., 1995, с измененными параметрами механической гомогенизации: разрушение спор гриба лизирующим матриксом (керамические шарики диаметром 1 мм) при комнатной температуре в экстракционном буфере на гомогенизаторе FastPrep-24 MP «Biomedicals». Положительными контролями служили изогенные линии и сорта с известными $S r$ генами, негативным контролем восприимчивый сорт Thatcher и Хакасская. Фитопатологическую оценку устойчивости в лаборатории проводили на стадии проростков по стандартным методикам [1].

Результаты и обсуждение. Условия для эффективной амплификации диагностических фрагментов расширенной панели молекулярных маркеров к генам устойчивости $\operatorname{Sr} 21, \operatorname{Sr} 23, \operatorname{Sr} 35, \operatorname{Sr} 36, \operatorname{Sr} 38$, отработанные нами на матрицах положительных контролей (табл. 2.).

Таблица 2 - Расширенная панель молекулярных маркеров с параметрами амплификации и размерами диагностических фрагментов

\begin{tabular}{|l|c|c|c|}
\hline Ген & Праймеры & $\begin{array}{c}\text { Условия амплификации } \\
\text { (Т отжига праймеров) }\end{array}$ & Длина фрагмента \\
\hline Sr21 & Sr21TRYF5R5 & $56^{\circ} \mathrm{C}$ & $\mathrm{R}-951$ п.н. \\
\hline Sr23 & XTaLr16_RGA266585 & $52^{\circ} \mathrm{C}$ & $\mathrm{R}-57$ п.н. \\
\hline Sr35 & NL9 & $61^{\circ} \mathrm{C}$ & $\mathrm{R}-719$ п.н. \\
\hline Sr36 & Xstm773-2 & $55^{\circ} \mathrm{C}$ & $\mathrm{R}-155$ п.н.; $\mathrm{S}-\sim 180$ п.н. \\
\hline Sr38 & VENTRIUP-LN2 & $65^{\circ} \mathrm{C}$ & $\mathrm{R}-259$ п.н. \\
\hline
\end{tabular}

\section{- Идентификация Sr21}

Ген устойчивости к стеблевой ржавчине $S r 21$ обеспечивает эффективную защиту от нескольких pac Pgt, в том числе из группы Ug99. Данный ген впервые идентифицирован у диплоидной пшеницы Triticum monococcum 
[11], а затем перенесен на гексаплоидную пшеницу, где он был картирован на плече хромосомы 2AL. Для гена устойчивости $S r 21$ известен PCR-CAP маркер Sr21TRYF5R5. Обработка ферментом эндонуклеазой рестрикции Nsi I выдает два фрагмента длиной 836 п.н. и 115 п.н. для образцов $T$. monococcum, которые несут восприимчивый гаплотип к $S r 21$, и одну полосу 951 п.н. для образцов, которые несут устойчивый гаплотип. Продемонстрированно отсутствие маркера на транслокацию у исследуемых сортов, что согласуется с их родословной.

\section{- Идентификация $\mathrm{Sr} 23$}

Ген устойчивости к стеблевой ржавчине $S r 23$ расположен на малом плече хромосомы 2B. Для гена устойчивости $S r 23$ известен RGA маркер XTaLr16_RGA266585, который картирован проксимально на 1,2 и 23,8 cM от $\operatorname{Lr} 16$ [5].

\section{- Идентификация Sr35}

Ген устойчивости к стеблевой ржавчине $\operatorname{Sr} 35$ первоначально был перенесен из T. топососсит в гексаплоидную пшеницу [8]. Известно, что фрагмент T. топососсит, содержащий $S r 35$, расположен на плече $3 \mathrm{AL}$ хромосомы в T. aestivum [12]. Для гена устойчивости $\operatorname{Sr} 35$ известен доминатный маркер CNL9, который охватывает локус $\operatorname{Sr} 35$.

\section{- Идентификация Sr36}

Ген устойчивости к стеблевой ржавчине Sr36, получен из $T$. timopheevi, придает устойчивость к расе Ug99. Данный ген картирован на плече хромосомы 2BS мягкой пшеницы. Для гена устойчивости Sr36 известен кодоминантный SSR маркер Xstm773.

\section{- Идентификация Sr38}

Ген устойчивости к стеблевой ржавчине $S r 38$ расположен на длинном хромосомном фрагменте (25-38 cM), который содержит три гена устойчивости к ржавчине ( $\operatorname{rr37}, \operatorname{Yr} 17$ и $S r 38)$, он был перемещен на короткое плечо $T$. ventricosum $2 \mathrm{NS}$ и хромосомой $2 \mathrm{AS}$ мягкой пшеницы [3]. Для верификации гена устойчивости $S r 38$ разработана пара праймеров VENTRIUP-LN2, которые амплифицируют фрагмент в 259 п.н. несущие транслокацию 2NS. Маркер успешно применяется в качестве диагностического [10].

Таким образом, применение расширенной панели маркеров позволило констатировать отсутствие в тестируемом генетическом материале генов устойчивости $\operatorname{Sr} 21, \operatorname{Sr} 23, \mathrm{Sr} 35, \mathrm{Sr} 36, \operatorname{Sr} 38$. Фитопатологическое тестирование материала обнаружило высокую восприимчивость сортов к образцам западно-сибирской популяции стеблевой ржавчины: «3» и «4» балла по шкале инфекционных типов.

Благодарности: Исследование выполнено при финансовой поддержке РФФИ в рамках научного проекта № 19-316-90051 и бюджетным проектом № 0259-2019-0001-С-01. 


\section{Список литературь}

1. Сколотнева Е.С. и др. Расовый состав новосибирской популяции Рuccinia graminis f. sp. tritici // Микология и фитопатология. - 2020. - Т. 54. - №. 1. - С. 49-58.

2. Наумов Н.А., Гешелье Е.Е., Шитикова-Русакова А.А. Ржавчина хлебных злаков в СССР: монографическая сводка. - Сельхозгиз, 1939.

3. Bariana H.S., McIntosh R.A. Cytogenetic studies in wheat. XV. Location of rust resistance genes in VPM1 and their genetic linkage with other disease resistance genes in chromosome 2A // Genome. - 1993. - T. 36. - №. 3. - C. 476-482.

4. Chen $\mathrm{S}$. et al. Identification and characterization of wheat stem rust resistance gene $\mathrm{Sr} 21$ effective against the Ug99 race group at high temperature // PLoS genetics. 2018. - T. 14. - №. 4.

5. Harrison N.R. et al. Using RNA sequencing and in silico subtraction to identify resistance gene analog markers for Lr16 in wheat // The Plant Genome. - 2015. - T. 8. - №. 2.

6. Hayden M.J., Sharp P.J. Sequence-tagged microsatellite profiling (STMP): a rapid technique for developing SSR markers // Nucleic acids research. - 2001. - T. 29. №. 8. - C. e43-e43.

7. Helguera M. et al. PCR assays for the Lr37-Yr17-Sr38 cluster of rust resistance genes and their use to develop isogenic hard red spring wheat lines //Crop Science. - 2003. - T. 43. - №. 5. - C. 1839-1847.

8. McIntosh R.A. et al. Cytogenetical studies in wheat. XIII: Sr 35-a third gene from Triticum monococcum for resistance to Puccinia graminis tritici // Zeitschrift für Pflanzenzüchtung. - 1984. - T. 92. - №. 1. - C. 1-14.

9. Saintenac C. et al. Identification of wheat gene Sr35 that confers resistance to Ug99 stem rust race group // Science. - 2013. - T. 341. - №. 6147. - C. 783-786.

10. Shamanin V. et al. Genetic diversity of spring wheat from Kazakhstan and Russia for resistance to stem rust Ug99 // Euphytica. - 2016. - T. 212. - №. 2. - C. 287-296.

11. The T.T. Chromosome location of genes conditioning stem rust resistance transferred from diploid to hexaploid wheat // Nature New Biology. - 1973. - T. 241. - №. 112. - C. 256-256.

12. Zhang W. et al. Genetic maps of stem rust resistance gene Sr35 in diploid and hexaploid wheat // Crop science. - 2010. - T. 50. - №. 6. - C. 2464-2474.

DOI 10.18699/GPB2020-34

\section{Новые гены-кандидаты, определяющие текстуру зерна у российских сортов мягкой пшеницы}

Киселева А.А. ${ }^{1 *}$, к.б.н., н.с., Леонова И.Н. ${ }^{1}$, Пшеничникова Т.А. ${ }^{1}$, Салина Е.А. ${ }^{l}$ ${ }^{1}$ ФГБНУ «Федеральный исследовательский центр Институт изттологии и генетики Сибирского отделения Российской академии наук» (ИЦиГ СО РАН), г. Новосибирск, Россия.

*e-mail: antkiseleva@bionet.nsc.ru

В ходе данного исследования на материале коллекции яровых сортов мягкой пшеницы отечественной селекиии подтверждена ключевая роль пуроиндолинов в формировании текстуры зерна, а также с использованием 
GWAS вылвлены новые локусы, ассочиированные с признаком. Анализ генов из данных локусов с использованием опубликованной аннотащии генома пиеницы (IWGSC), а также данные экспрессии, позволил предложить несколько генов-кандидатов из состава выявленных локусов. Эти гены вовлечень в метаболизм галактолипидов, углеводов и дефензинов.

Ключевые слова: текстура зерна, твердозерность, пуроиндолины, Triticum aestivum.

\section{New candidate genes determining grain texture in Russian wheat varieties}

Kiseleva A.A., Leonova I.N., Pshenichnikova T.A., Salina E.A.

Institute of Cytology and Genetics, Siberian Branch of Russian Academy of Sciences (IC\&GSBRAS), Novosibirsk, Russia.

e-mail:antkiseleva@bionet.nsc.ru

In this study, using the collection of common spring wheat accessions, we confirmed the key role of puroindolines for the grain texture, and identified new loci associated with the trait using GWAS. Analysis of the genes from these loci using the published annotation of the wheat genome (IWGSC), and the expression data, allowed us to propose several candidate genes from the identified loci. These genes are involved in the metabolism of galactolipids, carbohydrates and defensins.

Key words: grain texture, grain hardness, puroindolines, Triticum aestivum.

Текстура зерна (твердозерность) хлебной пшеницы является ключевым признаком, от которого зависит качество помола и выпечки. Мука из твердозерных сортов пшеницы характеризуется более крупными частицами и большим количеством поврежденных гранул крахмала. Мука такого типа лучше поглощает воду во время образования теста [1].

Ранее было показано, что локус $H a$, расположенный на коротком плече 5D хромосомы, играет решающую роль в структуре эндосперма $[2,3]$. В состав данного локуса входят гены гены puroindoline $a$, puroindoline $b$ и GSP-1 [4]. Также в формирование данного признака вносят вклад puroindoline-like гены, картированные на хромосомах группы 7 [5]. Были выявлены и некоторые другие локусы, но не было предложено никаких конкретных генов, участвующих в организации твердости зерна.

В данной работе мы исследовали генетические детерминанты твердозерности T. aesivum на материале сортов яровой пшеницы отечественной селекции, адаптированных к условиям Урала и Западной Сибири. Для изучения аллельного разнообразия известных генов, обуславливающих твердозерность, использовали аллель-специфическую ПЦР. Результаты генотипирования показали, что $25 \%$ исследованных сортов несут аллель Pina-D $1 k$, ко- 
торый характеризуется отсутствием генов Pina и Pinb (двойной нулевой аллель). Pina-D $1 k$, как известно, имеет наибольшее влияние на твердость зерна по сравнению с другими аллелями Pina и Pinb [6]. Кроме того, он является довольно редким [7].

Для выявления новых локусов мы провели полногеномный анализ ассоциаций с использованием данных высокопроизводительного секвенирования (чип Illumina Wheat $15 \mathrm{~K}$ ) и двухгодичного анализа фенотипа. Всего было обнаружено 26 SNP и Pina-специфичный маркер, которые показали значимую ассоциацию с признаком (P-value $<0,001)$. Аллель Pina-D $1 k$ демонстрировал наиболее сильное влияние на фенотип, подтверждая ключевую роль гена в формировании текстуры эндосперма. Другие значимые локусы располагались на 1B, 3А, 5B, 6A, 6D, 7B и 7D хромосомах. Среди этих локусов наибольший интерес представляют локусы на 5В и 7В хромосомах, поскольку они представлены группами сцепленных маркеров (от 5 до 7) и являются значимыми после поправки на множественное тестирование (FDR $\leq$ $0.05)$. Мы проанализировали гены из состава данного локуса с использованием опубликованной аннотации генома пшеницы (IWGSC), а также опубликованные данные по экспрессии этих генов.

Наиболее вероятными кандидатами являются TraesCS5B02G011700, кодирующий $\alpha$-галактозидазу, TraesCS5B02G010300, кодирующий 1,3- $\beta$ глюкансинтазу, и TraesCS3A01G442500, TraesCS3A01G442700, TraesCS3A01G445500, TraesCS7D02G411700, кодирующие дефензины.

Ген TraesCS5B02G011700 кодирует $\alpha$-галактозидазу, которая участвует в метаболизме DGDG. Ранее уже было показано, что различные липиды могут участвовать в определении текстуры зерна пшеницы [8]. Мы предполагаем, что соотношение галактолипидов MGDG и DGDG может регулировать ассоциацию пуроиндолинов и липидного слоя, контролируя, таким образом, текстуру эндосперма.

Ген TraesCS5B02G010300 кодирует 1,3- $\beta$-глюкансинтазу. В ячмене содержание $(1 \rightarrow 3 ; 1 \rightarrow 4)$ - $\beta$-глюкана в зерне коррелирует с текстурой зерна. Мы полагаем, что у пшеницы данный углевод также может оказывать влияние на твердозерность.

Гены TraesCS3A01G442500, TraesCS3A01G442700, TraesCS3A01G445500 и TraesCS7D02G411700 кодируют дефензины. Эти защитные белки, расположенные в белково-липидном матриксе вокруг крахмальных гранул эндосперма пшеницы, также могут вносить вклад в структуру зерна пшеницы.

Таким образом, в данной работе мы подтвердили комплексную природу текстуры зерна пшеницы и выявили новые гены-кандидаты и метаболические пути, которые могут вносить вклад в формирование признака.

Благодарности: Данная работа выполнена при поддержке Российского Научного Фонда (Проект No. 16-16-00011-P) 


\section{Список литературы}

1. Morris C.F., Rose S.P. Cereal Grain Quality // Crop Science / ed. Kettlewell R.J., Henry P.S. Dordrecht: Springer, 1996. Vol. 38, № 1. P. 3-54.

2. Law C.N. et al. The study of grain protein control in wheat using whole chromosome substitution lines // Seed protein improvement by nuclear technique. 1978. P. 483-502.

3. Morris C.F. Puroindolines: The molecular genetic basis of wheat grain hardness // Plant Mol. Biol. 2002. Vol. 48, № 5-6. P. 633-647.

4. Glenn G., Saunders R. Physical and structural properties of wheat endosperm associated with grain texture // Cereal chemistry. 1990. Vol. 67, № 2. P. 176-182.

5. Wilkinson $\mathrm{M}$. et al. Identification and genetic mapping of variant forms of puroindoline b expressed in developing wheat grain // J. Cereal Sci. Elsevier Ltd, 2008. Vol. 48, № 3. P. 722-728.

6. Takata K. et al. Comparison of five puroindoline alleles on grain hardness and flour properties using near isogenic wheat lines // Breed. Sci. 2010. Vol. 60, № 3. P. 228232.

7. Shaaf S. et al. The grain Hardness locus characterized in a diverse wheat panel (Triticum aestivum L.) adapted to the central part of the Fertile Crescent: genetic diversity, haplotype structure, and phylogeny // Mol. Genet. Genomics. Springer Berlin Heidelberg, 2016. Vol. 291, № 3. P. 1259-1275.

8. Greenblatt G.A., Bettge A.D., Morris C.F. Relationship between endosperm texture and the occurrence of friabilin and bound polar lipids on wheat starch // Cereal Chemistry. 1995. Vol. 72, № 2. P. 172-176.

DOI 10.18699/GPB2020-35

\section{Устойчивость перспективных селекционных линий яровой мягкой пшеницы, созданных в Челябинском НИИ сельского хозяйства, к листовым пятнистостям}

Коваленко Н.M. ${ }^{1 *}$ к.б.н., с.н.с.; Тюнин В.А. ${ }^{2}$, о.с.-х.н., г.н.с.; Кушниренко И.Ю. ${ }^{2}$ к.б.н., в.н.с.; Шрейдер Е.Р. ${ }^{2}$, к.с.-х.н., в.н.с.; Колесова М.А. ${ }^{3}$, к.б.н., в.н.с.; Гультяева Е.И. ${ }^{l}$, д.б.н., в.н.с.

${ }^{1}$ Всероссийский НИИ защчты растений, Санкт-Петербург, Россия;

${ }^{2}$ Челябинский НИИСХ, пос. Тимирязевский, Россия;

${ }^{3}$ ФИЦ Всероссийский институт генетических ресурсов растений им. Н.И. Вавилова, Санкт-Петербург, Россия.

*e-mail:nadyakov@mail.ru

Изучена устойчивость в фазе проростков и взросльх растений у перспективного селекционного материала ЧНИИСХ к листовым пятнистостям - септориозу и пиренофорозу. В лабораторных условиях проведено уточнение видов пятнистостей с использованием метода микрокопирования и питательных сред. Показано, что возбудителем септориоза в условиях Южного Урала в 2019 г. был гриб Parastagonaspora nodorum (=Septoria 
nodorum). Выделены линии устойчивые к одному из видов пятнистостей, $и$ $\kappa$ обоим (Pyrenophora tritici-repentis и P. nodorum).

Ключевые слова: пшенииа, устойчивость, пиренофороз, септориоз, Pyrenophora tritici-repentis, Parastaganospora nodorum, фuтопатогены.

\section{Resistance of improved breeding spring wheat lines developed in Chelyabinsk Scientific Research Institute of Agriculture to foliar blotches}

Kovalenko Nadezhda Mikhailovna ${ }^{1}$, Tyunin Vladimir Alexandrovich ${ }^{2}$, Kushnirenko Igor' Yur'evich ${ }^{2}$, Shreyder Ekaterina Robertovna ${ }^{2}$, Kolesova Maria ${ }^{3}$, Gultyaeva Elena Ivanovna ${ }^{l}$

${ }^{1}$ All-Russian Institute of Plant Protection, Saint-Petersburg, Russia

${ }^{2}$ Chelyabinsk Scientific Research Institute of Agriculture, Timiryazevsky, Russia

${ }^{3}$ VIR, Saint-Petersburg, Russia

Resistance to foliar blotches (tan spot and septoriosis) of improved wheat breeding lines developed in Chelyabinsk Scientific Research Institute of Agriculture was studied at the field and laboratory conditions. In laboratory conditions, identification of caused agent species were refined using the microcopy method and culture media. It was determined that caused agent of septoriosis in the Sourthen Ural in 2019 was fungus Parastagonaspora nodorum (=Septoria nodorum). Lines resistant to tan spot or septoriosis and both these pathogens (Pyrenophora tritici-repentis $u S$. nodorum) were revealed.

Key words: wheat, resistance, tan spot, septoriosis, Pyrenophora triticirepentis, Parastaganospora nodorum, phytopathogens.

Яровая пшеница на Южном Урале - ведущая зерновая культура. В структуре посевных площадей региона она занимает свыше 40 \% (в 2019 г. - 899 тыс. га). Производство зерна на Южном Урале, является неустойчивым, и лимитировано абиотическими и биотическими стрессами [1]. С 1990 годов в ЧНИИСХ проводится целенаправленная селекция на устойчивость к стрессовым факторам с привлечением доноров чужеродных транслокаций и генов устойчивости. В качестве таких источников широко использовались образцы с транслокациями от Aegilops umbellulata и Aegilops speltoides (линии типа «кукушки», созданные И.Г. Одинцовой). В современный период в Челябинском НИИ сельского хозяйства (ЧНИИСХ) широко используются доноры других чужеродных транслокаций от Aegilops speltoides, Agropyron elongatum, Ag. intermedium, Ae. tauschii, Secale sereale и других видов. Создан перспективный селекционный материал, большая часть которого характеризуется устойчивостью к ржавчинным патогенам. Детальные исследования устойчивости данного материала к пятнистостям до настоящего времени не проводились.

Целью исследований являлась характеристика перспективных интрогрессивных линий, полученных в ЧНИИСХ, на устойчивость к листовым 
пятнистостям - септориозу и пиренофорозу.

Объектом исследований служила 61 линия яровой пшеницы. Устойчивость оценивали в полевых условиях на естественном инфекционном фоне и в лабораторных, в фазе проростков.

В полевых условиях учеты пятнистостей в ЧНИИСХ до 2019 г. проводили без разделения их на виды (по общему поражению листовой поверхности пятнами). В текущем году впервые была оценена представленность и значимость двух видов пятнистостей - септориоза и пиренофороза в условиях Южного Урала. Симптомы желтой пятнистости нелегко отделить от септориоза, и даже для специалистов это достаточно проблематично. В связи с этим, в полевых условиях была выполнена визуальная диагностика пятнистостей по симптомам. Для уточнения вида возбудителя с каждого образца были собраны листья с пятнами и изучены в лабораторных условиях.

Результаты изучения устойчивости селекционных линий в полевых $\boldsymbol{y c л о в и я x . ~ П р и ~ в и з у а л ь н о м ~ о с м о т р е ~ в ~ п о л е в ы х ~ у с л о в и я х ~ в ы я в л е н о ~ п р е - ~}$ валирование септориоза. Степень развития его варьировала от 0 до $30 \%$. Симптомов поражения септориозом не выявлено на двух линиях: Лют. 26708 и Ферр. 26577. Линии Лют. 26729, Эритр. 26762, Эритр. 26764, Эритр. 26620 имели поражение менее $1 \%$, что также позволяло отнести их к группе устойчивых. Свыше $50 \%$ других изученных генотипов имели поражение до $5 \%$, a $23 \%$ до 10-15\%. Поражение изучаемых линий пиренофорозом согласно визуальной диагностике было ниже. У 33 \% линий не выявлено симптомов пиренофороза, а у 61 \% пораженность составляла 1-5\%.

Лабораторные исследования по идентификации возбудителей пятнистостей. Всего проанализировано 792 пятна (от 9 до 20 с каждого изучаемого образца). Для определения видов патогенов использовали метод микроскопирования и питательных сред (выделение патогена в чистую культуру) [2]. Показатель частоты колоний грибов был использован в качестве критерия распространения данных возбудителей. Определено, что возбудителем септориоза в условиях Южного Урала в 2019 г. был вид Parastagonaspora nodorum (=Septoria nodorum).

В полевых условиях визуальные симптомы пиренофороза были отмечены на 20 селекционных линиях. С использованием метода питательных сред эти результаты подтвердились для 42 линий.

Из листьев восьми изученных сортообразцов (Эритр. 26724, Эритр. 26725, Эритр. 26735, Эритр. 26751, Эритр. 26764, Ферр. 26773, Ферр. 26536, Барбаросса 26607) на питательной среде выделен возбудитель темно-бурой пятнистости (Bipolaris sorokiniana).

Полученные результаты еще раз свидетельствуют о сложности проведения визуальной диагностики к листовым пятнистостям в полевых условиях.

Лабораторная оценка устойчивости линий пшеницы пятнистоcmя.м. Для оценки устойчивости к септориозу использовали смесь изолятов 
Parastagonaspora nodorum. Концентрация суспензии составляла $1 \times 10^{6}$ спор/мл. Учет развития болезни проводили через 7 суток после инокуляции по семибалльной шкале [3], где 0 - отсутствие симптомов поражения; 1, 2, 3, 4 - поражено 10, 20, 30, 40 \% листовой поверхности, соотвественно; 5 поражено более $50 \%$ листовой поверхности; 6 - гибель листа. Образцы, с баллами 0,1 и 2 относили к высоко устойчивым, 3 и 4 - к средне устойчивыми, 5 и 6 - к восприимчивым.

Большинство изученных линий (87 \%) характеризовались восприимчивостью к септориозу в фазе проростков (тип реакции 5 баллов). Умеренной устойчивостью (баллы 2-4) характеризовались линии Лют. 26708, Лют. 26714, Эритр. 26749, Ферр. 26758, Ферр. 26774, Эритр. 26775, Эритр. 26596, Ферр. 26635 , что согласовывалось с результатами их оценки в полевых условиях.

Для изучения устойчивости интрогрессивных линий к пиренофорозу использовали сборную азиатскую популяцию P. tritici-repentis, включающую штаммы, выделенные из омской и казахстанской популяций. Концентрация суспензии составляла 2-3 × $10^{3}$ конидиоспор/мл. Оценку устойчивости проводили через 6-7 дней после инокуляции по 5-бальной шкале Ламари $[4,2]$. Растения с баллом 1 относили к устойчивым, 2 - к умеренно устойчивым, 3 - к умеренно-восприимчивым, 4-5 - к восприимчивым.

В фазе проростков 40 \% изученных интрогрессивных линий показали умеренно восприимчивый тип реакции $(3 / 3,3 / 2)$ к пиренофорозу; $30 \%$ умеренно устойчивый $(2 / 2,2 / 1,2 / 0)$ и $27 \%$ - устойчивый $(0 / 0,1 / 1,1 / 0)$. К устойчивым в фазе проростков относились линии Эритр. 26677, Ферр. 26691, Эритр. 26701, Лют. 26706, Эритр. 26724, Эритр. 26735, Эритр. 26736, Эритр. 26738, Эритр. 26744, Эритр. 26749, Эритр. 26751, Эритр. 26752, Ферр. 26757, Ферp. 26772 и Ферр. 26577. В большинстве случаев устойчивость образцов в фазе проростков коррелировала с устойчивостью в фазе взрослых растений.

Ранее Л.А. Михайловой и др. (2012) было показано, что линии с транслокацией от Ae. speltoides, несущие ген устойчивости к бурой ржавчине $(\operatorname{LrSp})$, сцепленный с гаметоцидным геном, также устойчивы и к пиренофорозу. В наших исследованиях у линий, несущих эту транслокацию, выявлено варьирование по степени пораженности данными болезнями в полевых и лабораторных условиях. Проведенные исследования позволили уточнить значимость обоих видов пятнистостей на образцах яровой мягкой пшеницы в условиях Южного Урала и выявить линии устойчивые к пятнистостям.

Благодарности: Работа выполнена при поддержке проекта РФФИ № 19-16-00052.

\section{Список литературы}

1. Шрейдер Е.Р. Селекция мягкой яровой пшеницы на устойчивость к бурой ржавчине и урожайность в условиях Южного Урала: автореф. дис. канд. с.-х. наук: 06.01.05. - Челябинск, 2006. - 24c. 
2. Михайлова Л.А, Мироненко Н.В., Коваленко Н.М. Желтая пятнистость пшеницы // Методические указания по изучению популяций возбудителя желтой пятнистости Pyrenophora tritici-repentis и устойчивости сортов. СПб.: ВИЗР, 2012. 56 с.

3. Тырышкин Л.Г., Колесова М. А. Септориоз колоса. Изучение генетических ресурсов зерновых культур по устойчивости к вредным организмам: метод. пособие. M.: PACXH, 2008. C. 185-186.

4. Lamari L, Bernier CC. Evalution of wheat lines and cultivars to tan spot [Perynophora tritici-repentis] based on lesion type. Can. J. Plant Sci.; 1989. 11(1): 49-56.

DOI 10.18699/GPB2020-36

\section{Изучение особенностей культивирования и регенерации iv vitro диких видов картофеля}

Колошина К.А. *, Иванова К.А., Герасимова С.В.

ФГБУН Институт ичитологии и генетики Сибирского отделения Российской академии наук, Новосибирск, Россия.

*e-mail: kristina.koloshina@yandex.ru

Целью данного исследования было изучение прочесса развития растений в культуре in vitro и влияния различных типов питательных сред на прочессы регенерачии дикого картофеля. Данные исследований по оптимальным условиям культивирования іп vitro растений картофеля и способности к регенерачии могут быть использованы для генетических исследований селекционного процесса при создании сортов с улучшенными признаками.

Ключевые слова: картофель, дикие виды, культивирование, регенерация.

\section{Study of the features of cultivation and in vitro regeneration of wild potato species}

Koloshina K. A., Ivanova K. A., Gerasimova S. V. Institute of Cytology and Genetics, SB RAS, Novosibirsk, Russia.

The purpose of this study was to evaluate the process of plant development in culture in vitro and the influence of various types of nutrient media on the regeneration processes of wild potatoes. Research data on optimal conditions for cultivation in vitro plants potato and their ability to regenerate can be used for genetic studies of the selection process when creating varieties with improved characteristics.

Key words: potato, wild species, cultivation, regeneration.

В работе был изучен 31 генотип диких видов картофеля (табл. 1). Культивирование in vitro осуществлялось посредством черенкования с применением питательной среды Мурасиге-Скуга [1]. Растения в асептических 
условиях разрезают по числу междоузлий, а черенки пересаживают в пробирки с питательной средой. Культивируют в течение четырех недель до следующего черенкования. Параметры роста отмечались через 10 и 20 дней после черенкования.

Таблица 1 - Список образцов in vitro коллекции диких видов картофеля

\begin{tabular}{|c|c|c|}
\hline № ח/п & Вид & Номер каталога ВИР \\
\hline 1 & S. verrucosum & 23015 \\
\hline 2 & S. demissum & 15176 \\
\hline 3 & S. stoloniferum & 23652 \\
\hline 4 & S. polyadenium & 24957 \\
\hline 5 & S. pinnatisectum & 24239 \\
\hline 6 & S. ehrenbergii & 24207 \\
\hline 7 & S. pinnatisectum & 4455 \\
\hline 8 & S. pinnatisectum & 4455 \\
\hline 9 & S. pinnatisectum & 4459 \\
\hline 10 & S. pinnatisectum & 4459 \\
\hline 11 & S. pinnatisectum & 21955 \\
\hline 12 & S. stoloniferum & 3326 \\
\hline 13 & S. stoloniferum & 3360 \\
\hline 14 & S. stoloniferum & 3360 \\
\hline 15 & S. stoloniferum & 3554 \\
\hline 16 & S. jamesii & 24923 \\
\hline 17 & S. tarijense & 12637 \\
\hline 18 & S. pinnatisectum & 21955 \\
\hline 19 & S. cardiophyllum & 16828 \\
\hline 20 & S. pinnatisectum & 4459 \\
\hline 21 & S. pinnatisectum & 21955 \\
\hline 22 & S. pinnatisectum & 21955 \\
\hline 23 & S. pinnatisectum & 21955 \\
\hline 24 & S. pinnatisectum & 23569 \\
\hline 25 & S. pinnatisectum & 23569 \\
\hline 27 & S. dolichostigma syn S. chacoence & 7613 \\
\hline 28 & S. commersonii & 21355 \\
\hline 30 & S. fendleri & 18242 \\
\hline 33 & S. chacoense & 19759 \\
\hline 34 & S. chacoense & 22687 \\
\hline 35 & S. demissum & 15175 \\
\hline 36 & S. demissum & 19997 \\
\hline
\end{tabular}


Индукция регенерации осуществлялась в два этапа:

1. Посадка эксплантов в трех повторностях на питательную среду для индуцирования процесса образования каллуса (4,4 г/л MS, 2 мг/л глицина, 0,5 мг/л витамина В6, 1 г/л дрожжевого экстракта, 4 мг/л 2,4-Д, 25 г/л сахарозы и $0,8 \%$ агара, $\mathrm{pH}=5,6$ ). В качестве эксплантов использовали фрагменты междоузлий.

2. Пересадка эксплантов на различные экспериментальные питательные среды для морфогенеза и ризогенеза: (1) 4 г/л MS, 20 г/л сахарозы, 7 г/л агара, 6 мг/л глицина, 0,5 мг/л витамина В6, 2 мг/л 2,4-Д; (2) 2,2 г/л MS, 15 г/л сахарозы, 8 г/л агара, 0,2 мг/л гиббереллиновой кислоты, 0,1 мг/л кинетина; (3) 4,4 г/л MS, 20 г/л сахарозы, 8 г/л агара, 0,03 мг/л НУК, 30 мг/л БАП.

Результаты и обсуждение. При культивировании in vitro в течение 7 10 дней некоторые виды показывают существенную разницу в развитии растений (табл. 2). Высота растений варьируется от 0,63 до 4,27 см. Наибольшая высота растений отмечена у видов S. pinnatisectum (№ 5, 7) 4,1 см и 4,27 см. Также отмечены виды, имеющие наименьшую высоту растений, такие как S. pinnatisectum (№ 11) - 0,97 см и S. commersonii (№ 28) - 0,63 см.

На 10 день культивирования некоторые дикие виды картофеля не образуют корни, например, виды S. pinnatisectum (№ 10, 11) и $S$. commersonii (№ 28). Другие исследуемые виды к этому моменту образуют 1-2 корня.

При выращивании растений на 20 день отмечено, что дикие виды S. pinnatisectum (№ 21, 22) достигают 11,3 см в высоту. Наименьшая высота растений отмечена у видов $S$. commersonii (№ 28) и $S$. polyadenium (№ 4): 1,37 и 2,43 см соответственно.

Наибольшая длина корней отмечена у $S$. chacoense (№ 33), 7,43 см. Наименьшая длина отмечена у вида $S$. tarijense (№ 17) - 0,23 см.

Наибольшее количество корней отмечено у видов $S$. verrucosum (№ 1), S. pinnatisectum (№ 18) и S. dolichostigma (№ 27): 10, 11 и 14 корней соответственно. Развитие 1 корня наблюдается у вида $S$. pinnatisectum $(№ ~ 5,10)$. Вид S. commersonii (№ 28) не образует корней на 20 день культивирования.

Таблица 2 - Морфометрические показатели растений картофеля при культивировании в культуре in vitro

\begin{tabular}{|c|c|c|c|c|c|}
\hline \multirow{2}{*}{$\begin{array}{c}\text { № } \\
\Pi / \Pi\end{array}$} & \multirow{2}{*}{ Вид } & \multicolumn{2}{|c|}{ Высота растений, см } & \multirow{2}{*}{$\begin{array}{c}\text { Длина } \\
\text { корней, см }\end{array}$} & \multirow{2}{*}{$\begin{array}{l}\text { Количество } \\
\text { корней, шт. }\end{array}$} \\
\hline & & 10 дней & 20 дней & & \\
\hline 1 & 2 & 3 & 4 & 5 & 6 \\
\hline 1 & S. verrucosum & 2,60 & 10,90 & 3,70 & 10,3 \\
\hline 2 & S. demissum & 1,47 & 4,60 & 1,23 & 3,7 \\
\hline 3 & S. stoloniferum & 1,63 & 4,97 & 2,13 & 3,0 \\
\hline 4 & S. polyadenium & 1,27 & 2,43 & 1,77 & 3,0 \\
\hline 5 & S. pinnatisectum & 4,10 & 9,40 & 0,73 & 1,3 \\
\hline 6 & S. ehrenbergii & 2,63 & 6,50 & 1,20 & 5,0 \\
\hline 7 & S. pinnatisectum & 4,27 & 6,77 & 6,13 & 3,7 \\
\hline
\end{tabular}




\begin{tabular}{|c|c|c|c|c|c|}
\hline $\mathbf{1}$ & $\mathbf{2}$ & $\mathbf{3}$ & $\mathbf{4}$ & $\mathbf{5}$ & $\mathbf{6}$ \\
\hline 8 & S. pinnatisectum & 1,33 & 4,43 & 4,45 & 3,0 \\
\hline 9 & S. pinnatisectum & 2,70 & 7,13 & 1,67 & 2,3 \\
\hline 10 & S. pinnatisectum & 1,07 & 3,47 & 5,40 & 1,0 \\
\hline 11 & S. pinnatisectum & 0,97 & 4,00 & 2,60 & 2,0 \\
\hline 12 & S. stoloniferum & 2,10 & 7,30 & 3,67 & 4,0 \\
\hline 13 & S. stoloniferum & 2,93 & 11,07 & 1,77 & 4,7 \\
\hline 14 & S. stoloniferum & 3,33 & 10,53 & 3,97 & 5,7 \\
\hline 15 & S. stoloniferum & 3,27 & 9,77 & 3,87 & 5,0 \\
\hline 16 & S. jamesii & 1,35 & 9,12 & 3,56 & 3,8 \\
\hline 17 & S. tarijense & 1,37 & 3,83 & 0,23 & 4,3 \\
\hline 18 & S. pinnatisectum & 2,07 & 9,40 & 3,30 & 10,7 \\
\hline 19 & S. cardiophyllum & 3,33 & 7,33 & 0,83 & 4,0 \\
\hline 20 & S. pinnatisectum & 2,50 & 8,60 & 3,97 & 3,7 \\
\hline 21 & S. pinnatisectum & 2,33 & 11,30 & 6,70 & 3,7 \\
\hline 22 & S. pinnatisectum & 2,47 & 11,30 & 5,80 & 3,7 \\
\hline 23 & S. pinnatisectum & 2,07 & 7,83 & 5,73 & 4,0 \\
\hline 24 & S. pinnatisectum & 1,73 & 6,17 & 5,57 & 2,7 \\
\hline 25 & S. pinnatisectum & 3,10 & 8,20 & 6,27 & 4,0 \\
\hline 27 & S. dolichostigma & 1,20 & 7,63 & 4,47 & 13,7 \\
\hline 28 & S. commersonii & 0,63 & 1,37 & 0,00 & 0,0 \\
\hline 30 & S. fendleri & 1,50 & 10,07 & 7,10 & 5,7 \\
\hline 33 & S. chacoense & 3,43 & 9,80 & 7,43 & 6,7 \\
\hline 34 & S. chacoense & 1,27 & 2,10 & 2,67 & 4,7 \\
\hline 35 & S. demissum & 0,80 & 3,03 & 2,50 & 2,5 \\
\hline 36 & S. demissum & 1,93 & 5,70 & 2,97 & 3,0 \\
\hline & & & & & \\
\hline
\end{tabular}

В процессе индукции регенерации формирование каллуса отмечено у 26 диких видов картофеля. При применении различных питательных сред было отмечено, что наиболее оптимальной питательной средой для регенерации является вторая. При использовании питательной среды № 27 видов образовали побег, 5 видов - корень и 1 вид образовал и побег, и корень (табл. 3 ).

Таблица 3 - Процесс регенерации диких видов картофеля

\begin{tabular}{|c|c|c|c|c|c|}
\hline \multirow{2}{*}{$№$ п/п } & \multirow{2}{*}{ Вид } & \multirow{2}{*}{ Формирова- } & \multicolumn{2}{|c|}{ Регенерация, питательная среда } \\
\cline { 4 - 6 } & & ние каллуса & №1 & №2 & №3 \\
\hline $\mathbf{1}$ & $\mathbf{2}$ & $\mathbf{3}$ & $\mathbf{4}$ & $\mathbf{5}$ & $\mathbf{6}$ \\
\hline 1 & S. verrucosum & + & - & - & - \\
\hline 2 & S. demissum & + & $\mathrm{P}$ & $\mathrm{P}$ & $\mathrm{P}$ \\
\hline 3 & S. stoloniferum & + & - & - & - \\
\hline 4 & S. polyadenium & + & - & $\mathrm{P}$ & $\mathrm{P}$ \\
\hline 5 & S. pinnatisectum & + & - & $\mathrm{K}$ & - \\
\hline 6 & S. ehrenbergii & - & - & - & - \\
\hline 7 & S. pinnatisectum & + & - & $\mathrm{P}$ & $\mathrm{P}$ \\
\hline 8 & S. pinnatisectum & + & - & - & - \\
\hline
\end{tabular}




\begin{tabular}{|c|c|c|c|c|c|}
\hline $\mathbf{1}$ & $\mathbf{2}$ & $\mathbf{3}$ & $\mathbf{4}$ & $\mathbf{5}$ & $\mathbf{6}$ \\
\hline 9 & S. pinnatisectum & - & - & - & - \\
\hline 10 & S. pinnatisectum & + & $\mathrm{P}$ & - & - \\
\hline 11 & S. pinnatisectum & + & - & - & - \\
\hline 12 & S. stoloniferum & + & - & $\mathrm{K}$ & - \\
\hline 13 & S. stoloniferum & + & - & - & - \\
\hline 14 & S. stoloniferum & + & - & - & - \\
\hline 15 & S. stoloniferum & + & - & $\mathrm{K}$ & - \\
\hline 16 & S. jamesii & - & - & - & - \\
\hline 17 & S. tarijense & - & - & - & - \\
\hline 18 & S. pinnatisectum & + & $\mathrm{K}$ & - & $\mathrm{K}$ \\
\hline 19 & S. cardiophyllum & - & - & - & - \\
\hline 20 & S. pinnatisectum & + & - & - & - \\
\hline 21 & S. pinnatisectum & + & - & - & - \\
\hline 22 & S. pinnatisectum & + & $\mathrm{K}$ & $\mathrm{P}$ & - \\
\hline 23 & S. pinnatisectum & + & - & - & - \\
\hline 24 & S. pinnatisectum & + & - & $\mathrm{K}$ & $\mathrm{P}$ \\
\hline 25 & S. pinnatisectum & - & - & - & - \\
\hline 27 & S. dolichostigma & + & $\mathrm{P}$ & $\mathrm{P}$ & $\mathrm{P}$ \\
\hline 28 & S. commersonii & + & - & - & - \\
\hline 30 & S. fendleri & + & - & $\mathrm{P}$ & - \\
\hline 33 & S. chacoense & + & $\mathrm{K}$ & $\mathrm{P}, \mathrm{K}$ & $\mathrm{K}$ \\
\hline 34 & S. chacoense & + & - & $\mathrm{P}$ \\
\hline 35 & S. demissum & + & - & - & - \\
\hline 36 & S. demissum & + & - & - & - \\
\hline
\end{tabular}

+ - наблюдалось формирование каллуса, $P$ - наблюдалось формирование растений регенерантов, $K$-наблюдалось формирование корней без формирования побегов.

Заключение. В ходе исследования был изучен процесс культивирования in vitro растений диких видов картофеля с применением классической питательной среды Мурасиге-Скуга. Наиболее активно в культуре in vitro развиваются виды $S$. pinnatisectum, $S$. dolichostigma, $S$. chacoense, $S$. verrucosum.

Был охарактеризован процесс регенерации диких видов картофеля на различных питательных средах и выделена оптимальная питательная среда для процесса регенерации.

Благодарности: Работа выполнена при поддержке гранта РФФИ № 20-016-00217.

\section{Список литературь}

1. Murashige T. and Skoog F. (1962) A revised medium for rapid growth and bio-assays with tobacco tissue cultures. Physiol Plant. 15(3): 473-497. 


\section{Оценка фасоли зерновой по основным элементам продуктивности}

Колупаев Д.А. *, аспирант; Якубенко О.Е., аспирантка; Паркина О.В., к.с.х.н., доиент

ФГБОУ ВО Новосибирский государственный аграрный университет, Новосибирск, Россия

*e-mail: kolupaevdenis@ngs.ru

Исследования проводились в 2018-2019 г2. на опытном поле УПХ «Сад Мичуринцев» Новосибирского ГАУ. Проведена комплексная оченка образиов фасоли обыкновенной зернового направления по основным элементам продуктивности. Выделены образиы, обладающие высокой урожайностью. Выявлены источники ценных признаков.

Ключевые слова: масса 1000 семян, урожайность, масса семян с растения, число семян в бобе, число семян с растения, фасоль обыкновенная.

\section{Assessment of grain beans by the main elements of productivity}

Kolupaev D. A., post-graduate student of the 1st year; Yakubenko O. E., postgraduate student of the 3rd year; Parkina O.V., Cand. associate Professor of agricultural SciencesNovosibirsk state agrarian University, Novosibirsk, Russia, kolupaevdenis@ngs.ru

The research was conducted in 2018-2019 at the experimental field of the EPF "Michurintsev Garden" of the Novosibirsk state UNIVERSITY. A comprehensive assessment of samples of common beans of the grain direction on the main elements of productivity was carried out. Samples with high yield were selected. Sources of valuable attributes are identified.

Key words: mass of 1000 seeds, yield, mass of seeds from a plant, number of seeds in a bean, number of seeds from a plant, common bean.

Фасоль обыкновенная относится к группе ценных высокобелковых продовольственных культур. По содержанию белка в семенах (от 17 до $32 \%$ ), жиров (от 2 до $3,5 \%$ ) и количеству незаменимых аминокислот превосходит пшеницу. В симбиозе с клубеньковыми бактериями растения фасоли фиксируют атмосферный азот и обогащают им почву, обеспечивая преимущество хорошего предшественника.

В настоящее время фасоль обыкновенная широко распространена в мировом земледелии, ее возделывают более чем в 70 странах в разных почвенно-климатических зонах. Выращивание фасоли в условиях сибирского региона ограничивается отсутствием сортов интенсивного типа и резким континентальным климатом, характеризующимся дефицитом теплообеспеченности в разные годы. В связи с этим актуально комплексное изучение 
лучших европейских и отечественных сортов и выделение источников хозяйственно-ценных признаков в условиях лесостепи Западной Сибири [1].

Цель исследования - комплексная оценка по основным элементам продуктивности.

Объект исследования - 25 образцов Phaseolus vulgaris L. зернового направления различного эколого-географического происхождения. Стандарт - районированный сорт Рубин (группа спелости - среднеранний).

Методика. Фенологические наблюдения проводили согласно методическим указаниям по изучению коллекции зерновых бобовых культур, морфологическое описание - по методическим указаниям по изучению образцов мировой коллекции фасоли $[2,3]$.

Посев в 2018-2019 гг. проводили по схеме 70×6 см, глубина заделки семян - 4 см. Норма высева - 23 шт./м². Площадь делянки $-2,1 \mathrm{~m}^{2}$.

Гидротермический режим вегетационного периода. Гидротермический режим 2018 года характеризовался поздним наступлением прогревания почвы (отклонение 1,5-2 недели) в силу дождливого (209 \% от нормы) и холодного мая (отклонение $4{ }^{\circ} \mathrm{C}$ ), что привело к смещению срока посева, и как следствие, к увеличению вегетационного периода. Это привело к тому, что созревание семян фасоли проходило на фоне пониженных температур, что не позволило в полной мере реализовать свой потенциал продуктивности.

Гидротермический режим 2019 года характеризовался благоприятными гидротермическими условиями для посева. Температурный режим был в пределах нормы, осадков немного больше нормы (117 \% от нормы). Своевременный срок посева семян обеспечивал благоприятные условия второй половины вегетационного периода: небольшое количество осадков (33 $\%$ от нормы) на фоне повышенных температур (отклонение $+2{ }^{\circ} \mathrm{C}$ ), что привело к дружному наступлению биологической спелости у всех образцов.

Результаты исследования. Проведена оценка образцов фасоли обыкновенной по урожайности и основным элементам продуктивности: число семян с растения, число семян в бобе, массе семян с растения, массе 1000 семян.

Таблица - Оценка фасоли обыкновенной по структуре урожая

\begin{tabular}{|c|c|c|c|c|c|c|}
\hline $\begin{array}{l}\text { № } \\
\Pi / \Pi\end{array}$ & Образец & $\begin{array}{c}\text { Число семян } \\
\text { с растения, } \\
\text { шт. }\end{array}$ & $\begin{array}{c}\text { Число } \\
\text { семян в } \\
\text { бобе, шт. }\end{array}$ & $\begin{array}{c}\text { Масса се- } \\
\text { мян с рас- } \\
\text { тений, Г }\end{array}$ & $\begin{array}{c}\text { Macca } \\
1000 \text { ce- } \\
\text { мян, Г }\end{array}$ & $\begin{array}{l}\text { Урожай- } \\
\text { ность, } \\
\text { Г/M² }\end{array}$ \\
\hline 1 & 2 & 3 & 4 & 5 & 6 & 7 \\
\hline 1 & Рубин, st & 34,1 & 3,7 & 14,5 & 433,3 & 264,8 \\
\hline 2 & Золотистая & 43,3 & 3,8 & 17,4 & 383,2 & 248,5 \\
\hline 3 & Пестрая & 32,7 & 3,9 & 12,6 & 400,7 & 191,8 \\
\hline 4 & Красно-пестрая & 23,9 & 4,4 & 11,9 & 535,7 & 243,3 \\
\hline 5 & Bomba & 31,1 & 3,7 & 9,0 & 305,0 & 152,8 \\
\hline 6 & Мотольская белая & 34,0 & 4,0 & 16,3 & 498,7 & 95,9 \\
\hline
\end{tabular}




\begin{tabular}{|c|c|c|c|c|c|c|}
\hline 1 & 2 & 3 & 4 & 5 & 6 & 7 \\
\hline 7 & Пестрая Романово & 25,7 & 3,7 & 11,4 & 463,5 & 205,2 \\
\hline 8 & Canario & 29,2 & 4,3 & 10,0 & 364,3 & 224,7 \\
\hline 9 & Stringless & 27,7 & 4,5 & 9,3 & 336,5 & 96,5 \\
\hline 10 & Мечта хозяйки & 35,9 & 4,9 & 14,7 & 424,3 & 154,5 \\
\hline 11 & Инга & 31,1 & 3,8 & 8,5 & 270,7 & 96,2 \\
\hline 12 & Бийчанка пестрая & 14,5 & 3,4 & 6,3 & 426,1 & 78,6 \\
\hline 13 & Красная шапочка & 17,7 & 2,5 & 10,7 & 527,1 & 82,8 \\
\hline 14 & Зуша белая & 31,6 & 3,7 & 18,1 & 541,0 & 67,9 \\
\hline 15 & Линия № 1 & 22,1 & 2,7 & 7,2 & 554,1 & 76,9 \\
\hline 16 & Veenoorl & 25,6 & 3,9 & 10,7 & 448,2 & 149,1 \\
\hline 17 & Мухранула & 19,5 & 4,1 & 9,5 & 522,9 & 181,9 \\
\hline 18 & Katia & 38,3 & 3,4 & 14,5 & 403,7 & 148,8 \\
\hline 19 & Нерусса & 78,6 & 4,0 & 15,4 & 201,1 & 196,5 \\
\hline 20 & Зуша черная & 59,7 & 3,6 & 15,0 & 253,0 & 280,3 \\
\hline 21 & Лукерья & 53,2 & 3,9 & 17,3 & 370,1 & 264,4 \\
\hline 22 & Creola & 41,6 & 4,0 & 22,4 & 293,3 & 222,9 \\
\hline 23 & Brunot & 26,3 & 4,4 & 9,3 & 326,1 & 140,5 \\
\hline 24 & Зуша пестрая & 21,2 & 3,3 & 13,5 & 684,1 & 94,5 \\
\hline 25 & Оран & 49,2 & 3,5 & 11,5 & 249,5 & 125,1 \\
\hline \multicolumn{2}{|c|}{ Lim } & $14,5 \div 78,6$ & $2,5 \div 4,9$ & $6,3 \div 22,4$ & $201,1 \div 684,1$ & $67,9 \div 280,3$ \\
\hline \multicolumn{2}{|r|}{$\overline{\mathrm{X}}$} & 33,912 & 3,804 & 12,68 & \begin{tabular}{|l|}
408,648 \\
\end{tabular} & \begin{tabular}{|l|}
163,376 \\
\end{tabular} \\
\hline \multicolumn{2}{|r|}{$\delta$} & 14,382 & 0,522 & 3,863 & 116,105 & 67,777 \\
\hline \multicolumn{2}{|r|}{$\mathrm{Cv}, \%$} & $42 \%$ & $14 \%$ & $30 \%$ & $28 \%$ & $41 \%$ \\
\hline
\end{tabular}

Число семян с растения изменялось от минимального усредненного значения у сорта Бийчанка пестрая, равное 15 шт. до максимального усредненного значения 79 шт. у сорта Нерусса. Среднее значение признака составило 34 шт., что на уровне стандарта. Стандартное отклонение по сортам, равно 14,382, коэффициент вариации $42 \%$.

По числу семян в бобе можно выделить образцы с максимально выраженным усредненным значением признака у сортов Мечта хозяйки, Stringless - 5 шт. Наименьшее число завязавшихся семян в бобе отмечено у сорта Красная шапочка и образца Линия № $1-3$ шт. Среднее значение признака составило 4 шт., что является на уровне стандарта. Стандартное отклонение составило 0,522 с коэффициентом вариации, равным 14 \%.

Масса семян с растения имела широкий разброс средних значений от 6,3 г у сорта Бийчанка пестрая до 22,4 г у сорта Creola. Среднее значение признака по образцам составило 12,7 г, что меньше стандарта на 1,8 г. Стандартное отклонение составило 3,863 с коэффициентом вариации, равным 30 \%.

Усредненная масса 1000 семян варьировала от 201,1 г у сорта Нерусса до 684,1 г у сорта Зуша пестрая. Среднее значение признака по изучаемым образцам составило 408,6 г, что меньше стандарта на 24,7 г. Стандартное отклонение составило 116,1 г. Коэффициент вариации равен 28 \%. 
Максимальной усредненной урожайностью обладал сорт Зуша черная, равной 280,3 г; минимальная урожайность, равная 67,9 г выявлена у сорта Зуша белая. Средняя урожайность по образцам составила 163,4 г/м², что меньше стандарта 1,62 раза. Стандартное отклонение составило 67,777 с коэффициентом вариации, равным $41 \%$.

Заключение. В ходе изучения образцов фасоли обыкновенной зернового направления с целью повышения продуктивности были выделены образцы-источники хозяйственно-ценных признаков:

- число семян в бобе: Красно-пестрая, Stringless, Мечта хозяйки, Brunot;

- число семян с растения: сорта Нерусса и Зуша черная;

- масса 1000 семян (с учетом оптимальной массы 1000 семян для механизированного возделывания): Золотистая, Пестрая, Bomba, Пестрая Романово, Canario, Stringless, Мечта хозяйки, Бийчанка пестрая, Veenoorl, Katia, Лукерья, Brunot.

По комплексу хозяйственно-ценных признаков выделился образец Красно-пестрая.

\section{Список литературы}

1. Маракаева Т.В. Сравнительная оценка хозяйственно-ценных признаков фасоли (Phaseolus vulgaris L.) и создание на их основе нового селекционного материала для условий южной лесостепи Западной Сибири: Дис. ... канд. с.-х. наук. - Омск, 2014. $180 \mathrm{c}$.

2. Методические указания по изучению коллекции зерновых бобовых культур. Санкт-Петербург, 1975. - 60 с.

3. Методические указания. Методика проведения испытаний на отличимость, однородность и стабильность (Фасоль обыкновенная Phaseolus vulgaris L.). - М.: 1995. $-14 \mathrm{c}$.

DOI $10.18699 / \mathrm{GPB} 2020-38$

\section{Влияние полиморфных вариантов CAD (EC 1.1.1.195) на устойчивость пшеницы к грибным инфекциям}

Коновалов А.А. ${ }^{1 *}$, д.б.н., с.н.с.; Орлова Е.А. ${ }^{2}$, к.с-х.н., в.н.с.; Карпова Е.В. ${ }^{3}$, к.х.н., с.н.с.; Шундрина И.К. ${ }^{3}$, к.х.н., с.н.с.

${ }^{1}$ Федеральный исследовательский центр Институт ичитологии и генетики Сибирского отделения Российской академии наук, Новосибирск, Россия;

${ }^{2}$ Сибирский научно-исследовательский институт растениеводства и селекиии - филиал ИЦиГ СО РАН, пос. Краснообск, Россия;

${ }^{3}$ Новосибирский институт органической химии им. Н.Н. Ворожиова Сибирского отделения Российской академии наук, Новосибирск, Россия.

*e-mail:konov@bionet.nsc.ru 
Полиморфизм по спектрам CAD (cinnamil alcohol dehydrogenase, deгидрогеназа коричного спирта; EC 1.1.1.195) обнаружен в сортообразиах яровой мягкой пшенищы, различающихся по устойчивости к грибным инфекциям. Получены гибриды между контрастными образцами, потомства $F_{4}$ с различныли генотипами по САD оценивали на устойчивость к бурой ржавчине и мучнистой росе. Генотипы различались по устойчивости, наибольший вклад в устойчивость придает ген $C A D^{\text {im+ }}$. Изучены микроморфологические и химические показатели пораженных и устойчивых растений. Обнаружены различия в содержании компонентов лигнина, повышено содержание компонентов с альдегидными группами.

Ключевые слова: мягкая пшенича, дегидрогеназа коричного спирта, устойчивость, бурая ржавчина, химический состав.

\section{Influence of polymorphic variants of cad (ec 1.1.1.195) on resistance of wheat to fungal infections}

Konovalov A.A ${ }^{1}$., Orlova Ye.A ${ }^{2}$., Karpova Ye.V. ${ }^{3}$, Shundrina I.K. ${ }^{3}$

${ }^{l}$ Institute of Cytology and Genetics, Siberian Branch of Russian Academy of Sciences, Novosibirsk, Russia

${ }^{2}$ Siberian Research Institute of Crop Production and Selection - branch of ICG SB RAS, Krasnoobsk, Novosibirsk region, Russia

${ }^{3}$ N.N. Vorozhtsov Novosibirsk Institute of Organic Chemistry of the Siberian Branch of Russian Academy of Science, Novosibirsk, Russia

konov@bionet.nsc.ru

CAD polymorphism (cinnamil alkohol dehydrogenase, cinnamon alcohol dehydrogenase; EC 1.1.1.195) is found in the cultivars of spring bread wheat, differing on resistance to fungal infections. Hybrids between contrast samples were obtained, $F_{4}$ progeny with different genotypes by CAD were evaluated for resistance to brown rust and powdery mildew. Genotypes varied in resistance, with the $C A D^{\text {im+ }}$ gene giving the greatest contribution to resistance. Micromorphological and chemical indicators of affected and resistant plants have been studied. Differences in the content of lignin components were found, and the content of aldehyde group components was increased.

Key words: bread wheat, cinnamil alkohol dehydrogenase, brown rust, chemical composition.

Защитные реакции растений от грибных инфекций могут быть двух типов: индуцированные патогенной атакой и присутствующие в тканях конститутивно. Последние основаны на структурных особенностях тканей растений и содержании в них тех или иных метаболитов, оказывающих защитное действие. В ряде исследований отмечается участие в защитных механизмах продуктов фенилпропаноидного пути метаболизма - лигнина, лигнанов 
и ароматических гликозидов. В нашем предыдущем исследовании обнаружена связь между устойчивостью растений яровой мягкой пшеницы Triticum aestivum L. к бурой ржавчине (возбудитель Puccinia triticina Erikss.) и содержанием в тканях различных метаболитов и минеральных веществ [1]. В этой работе использованы образцы, полиморфные по изоферментным спектрам CAD (cinnamil alcohol dehydrogenase, дегидрогеназа коричного спирта; EC 1.1.1.195), фермента, катализирующего последнюю реакцию фенилпропаноидного пути. У многих видов растений обнаружен полиморфизм по генам, кодирующим CAD [2]. Влияние генотипов CAD на устойчивость к грибным инфекциям обнаружено на китайских сортах пшеницы [3], а также на двудольных [4-6].

В нашей работе были использованы сортообразцы яровой мягкой пшеницы, полиморфные по спектрам CAD и различающиеся по устойчивости к грибным инфекциям: устойчивый к мучнистой росе и бурой ржавчине сорт яровой пшеницы Новосибирская 61 (СибНИИРС) и три восприимчивых образца: сорт Скала, популяция Хакасская (СІММҮТ 2167) и образец спельты к-53660 из коллекции ВИРа. Гибриды $\mathrm{F}_{1}$ были получены зимой 2017/18 гг. в теплице и высеяны на инфекционном поле весной 2018 года. Зимой 2018/19 гг. получены потомства $\mathrm{F}_{3}$, которые использовались для лабораторной оценки устойчивости к бурой ржавчине, и потомства $\mathrm{F}_{4}$, которые высевались на инфекционном поле летом 2019 г. Тип поражения растений бурой ржавчиной определяли по методике Mains, Jackson (1926) [7]. Генотипы CAD определяли методом гель-электрофореза, обнаружен полиморфизм по трем генам, обозначенным CAD-5A, CAD-5D и CAD-im, всего 8 гомозиготных фенотипов.

Большинство растений $F_{1}$ были устойчивы, потомства $F_{3}$ и $F_{4}$ различались по устойчивости. В таблице приведены данные по потомствам $\mathrm{F}_{3}$. Из полученных данных следует, что ген $\mathrm{CAD}^{\mathrm{im}+}$ вносит наибольший вклад в устойчивость. Данные по $\mathrm{F}_{4}$, полученные летом на инфекционном поле, в основном совпадали с данными по $\mathrm{F}_{3}$. Образцы с генотипами $\mathrm{CAD}^{\mathrm{im}+}$ и $\mathrm{CAD}^{\mathrm{im}-}$ были использованы для анализа микроморфологических и химических показателей тканей. Растения, выращенные на поле, отличаются толщинами клеточных стенок. Для генотипа 9-65 (CAD-im: +/+) средняя толщина клеточной стенки составляет 2,82 мкм, для генотипа 9-1 (CAD-im: -/-) $-1,80$ мкм.

Таблица - Лабораторная оценка устойчивости к бурой ржавчине

\begin{tabular}{|c|c|}
\hline Генотипы CAD & Тип реакции \\
\hline 1 & 2 \\
\hline CAD-5A: +/+ CAD-5D: +/+ CAD-im: $+/+$ & 1 \\
\hline CAD-5A: $-/$-CAD-5D: $-/$ CAD-im: $+/+$ & $0-1$ \\
\hline CAD-5A: +/+CAD-5D: $-/$ CAD-im: $+/+$ & 0 \\
\hline CAD-5A: - /-CAD-5D: $+/+$ CAD-im: $+/+$ & $0-1$ \\
\hline
\end{tabular}




\begin{tabular}{|c|c|}
\hline 1 & $\mathbf{2}$ \\
\hline CAD-5A: +/+ CAD-5D: +/+ CAD-im: $-/-$ & $2-3$ \\
\hline CAD-5A: $-/$ CAD-5D: $-/$ CAD-im: $-/-$ & 3 \\
\hline CAD-5A: +/+ CAD-5D: $-/$ CAD-im: $-/-$ & $1-2$ \\
\hline CAD-5A: $-/$ CAD-5D: +/+ CAD-im: $-/-$ & 2 \\
\hline
\end{tabular}

Препараты диоксанлигнина были изучены методами ИКспектроскопии, протонного магнитного резонанса, ядерного магнитного резонансы по изотопу ${ }^{13} \mathrm{C}$, а также методом 2D-ЯMP. Обнаружено повышенное содержание карбонильных групп у генотипа $\mathrm{CAD}^{\mathrm{im}+}$ (повышенное содержание альдегидных групп). Содержание других структурных фрагментов в образцах примерно одинаково. Также по данным ${ }^{13} \mathrm{C}-Я \mathrm{MP}$ и $2 \mathrm{D}-$ ЯMP обнаружены значительные различия по коричным мономерам лигнина. Можно предположить, что повышенное содержание альдегидов в тканях листа оказывает защитное действие.

Благодарности: Работа поддержана бюджетными проектами № 0324-2019-0039 (ИЦИГ СО РАН) и 0302-2020-0005 (НИОХ СО РАН), а также проектом РФФИ 19-44-540003 р_а.

\section{Список литературы}

1. Коновалов А.А., Шундрина И.К., Карпова Е.В., Ельцов И.В., Орлова Е.А., Гончаров Н.П. Влияние лигнификации и минерализации тканей листа на устойчивость к бурой ржавчине растений мягкой пшеницы. Вавиловский журнал генетики и селекции. 2017;21(6):686-693. DOI 10.18699/VJ17.286

2. Коновалов А.А., Шундрина И.К., Карпова Е.В. Полиморфизм ферментов лигнификации у растений: функциональное значение и прикладные аспекты // Успехи современной биологии. 2015. Т. 135. № 5. С. 496-513.

3. Rong W, Luo M, Shan T, Wei X, Du L, Xu H, Zhang Z. A Wheat Cinnamyl Alcohol Dehydrogenase TaCAD12 Contributes to Host Resistance to the Sharp Eyespot Disease. Front Plant Sci. 2016. November 2016 | Volume 7| Article 1723. eCollection 2016. PMID: 27899932. DOI: 10.3389/fpls.2016.01723

4. Somssich I.E., Wernert P., Kiedrowski S., Hahlbrock K. Arabidopsis thaliana defense-related protein ELI3 is an aromatic alcohol:NADP+ oxidoreductase // Proc. Natl. Acad. Sci. USA. 1996. V. 93. No. 14199-14203. DOI: 10.1073/pnas.93.24.14199

5. Tronchet M., Balagué C., Kroj T., Jouanin L., Roby D. Cinnamyl alcohol dehydrogenases-C and $\mathrm{D}$, key enzymes in lignin biosynthesis, play an essential role in disease resistance in Arabidopsis. Molecular Plant Pathology. 2010;11:83-92. DOI 10.1111/j.13643703. 2009.00578.x.

6. Новаковский Р.О., Повхова Л.В., Краснов Г.С., и др. Семейство генов дегидрогеназ коричного спирта вовлечено в ответ устойчивых и восприимчивых генотипов льна на заражение Fusarium oxysporum . Вавиловский журнал генетики и селекции. 2019;23(7):896-901. DOI 10.18699/VJ19.564

7. Mains E.B., Jackson H.S. Physiological specialization in the leaf rust of wheat, Puccinia triticina Erikss // Phytopathology. 1926. V. 16. P. 89-120. 


\section{Изучение сортов льна (Linum Usitatissimum L.) в условиях Тюменской области}

Королев К.П.*, к.с.-х.н., н.с.; Боме Н.А., д.с.-х.н., зав. кафедрой; Аксенов С.А., студент.

ФГАУ ВО Тюменский государственный университет, г. Тюмень, Россия, *e-mail: corolev.konstantin2016@yandex.ru

В условиях Тюменской области с контрастными почвенно-климатическими условиями подбор сортов льна-долгунца и льна масличного для конкретных агроэкологических зон является актуальной задачей. Впервые выявлены ответные реакиии сортов льна на изменчивость факторов среды. $B$ результате полевого испытания (2017-2019 г2.) нами установлены источники полевой всхожести семян, высоты растений, биологической устойчивости.

Ключевые слова: лен-долгунеи, лен масличный, стабильность, пластичность, полевая всхожесть, высота растений, биологическая устойчивость растений.

\section{Study of flax varieties (Linum Usitatissimum L.) in the Tyumen region}

Korolev K. P., candidate of agricultural sciences, researcher, Bome N. A., doctor of agricultural sciences, head of the Department, Aksenov S. A., student. Tyumen State University, Tyumen, Russia.

*e-mail: corolev.konstantin2016@yandex.ru

In the conditions of the Tyumen region with contrasting soil and climate conditions, the selection of varieties of fiber flax and linseeds for specific agroecological zones is an urgent task. For the first time, responses of flax varieties to the variability of environmental factors were revealed. As a result of the field test (2017-2019), we established the sources of field germination of seeds, plant height, and biological stability.

Key words: fiber flax, linseeds, stability, plasticity, field germination, plant height, biological stability of plants.

В связи с глобальными изменениями климата, все большее внимание отечественных и зарубежных исследователей отводится проблеме экологической устойчивости растений. Лен является культурой важного народнохозяйственного значения, биологический потенциал которого максимально реализуется в оптимальных условиях выращивания. Для условий Сибири сорта должны обладать высокой продуктивностью, качеством, при низком уровне зависимости от факторов среды. В Тюменской области в настоящее время культура льна не имеет широкого распространения, однако наиболее 
развито льноводство было в 70-80 гг. ХX вв. Отсутствие районированныХ сортов, адаптированной технологии выращивания, оказывает негативное влияние на практику возделывания льна, в связи с этим, подбор сортов и последующее расширение посевов льна является актуальным направлением в науке и сельскохозяйственном производстве.

Полевое испытание сортов льна проводили в 2017-2019 гг. на опытном полигоне изучения генетических ресурсов культурных растений биостанции «Озеро Кучак» Института биологии Тюменского государственного университета (Нижнетавдинский район Тюменской области). Объект исследований: сорта льна-долгунца (60 шт.) и льна масличного (40 шт.) различного эколого-географического происхождения. Закладку питомника изучения льна, фенологические учеты и наблюдения проводили в соответствии с

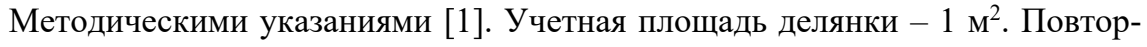
ность опытов трехкратная. Экологическую стабильность и пластичность сортов льна рассчитывали по методу S.A. Eberhart, W.W. Russell [2]. Статистическую обработку данных выполняли по методике, изложенной Б.А. Доспеховым [3]. Достоверность различий сортов и среднего популяционного значения устанавливали согласно критерию Стьюдента при 95\% уровне значимости. Цель исследования - выявить изменчивость сортов льна по полевой всхожести семян, высоте растения, биологической устойчивости при действии факторов среды.

В результате проведенных полевых исследований (2017-2019 гг.) нами выявлены различия сортов по количественным признакам (Рисунок). Установлено, что полевая всхожесть семян большинства из изученных сортов льна-долгунца характеризовалась показателями на 10,0-15,0 \% выше сортов льна масличного. Среднее популяционное значение по годам исследований составило 60,2 \% (лен-долгунец), 50,4 \% (лен масличный). Достоверные различия установлены у сортов льна-долгунца: Томский-16 (72,1 \%), TOCT (72,3 \%), Рубин (71,5 \%), Печерский кряж (71,1 \%), Велижский кряж (70,3 \%), Дукат (70,1 \%), Восход (70,0 \%), Upite-2 (69,2 \%), Honkei 41 $(69,1 \%)$, Маяк (69,9 \%); льна масличного: Северный $(61,9 \%)$, Бирюза $(60,8 \%)$, Исилькульский $(60,7 \%)$, Кустанайский янтарь $(60,0 \%)$, Antares $(59,9 \%)$, Сокол $(59,1 \%)$.

Учитывая, что у льна-долгунца, стебель - хозяйственно-ценная часть растения, выявление источников высокорослости, является одним из основных составляющих при оценке исходного материала. Нами установлены фенотипические различия между сортами по высоте растений, как по годам, так и по сортам. Минимальную высоту растений льна - долгунца выявили в условиях 2019 г. (70,0 см, Hermes; Велижский кряж, 72,0 см), максимальную (Ива, 105,1 см; 104,5 см, Грант) в 2017 г. У льна масличного минимальное значение высоты (39,0 см, Кустанайский янтарь, Ручеек, 38,9 см, Krocus, 37,2 см) в 2018 г.; максимальное проявление признака (Артем, 77,0 см, ВМ- 
620, 75,1 см; Нилин, 74,0 см) зарегистрировали в 2019 г. Среднее популяционное значение составило для генотипов льна-долгунца (92,9 см), льна масличного $(65,0$ см).
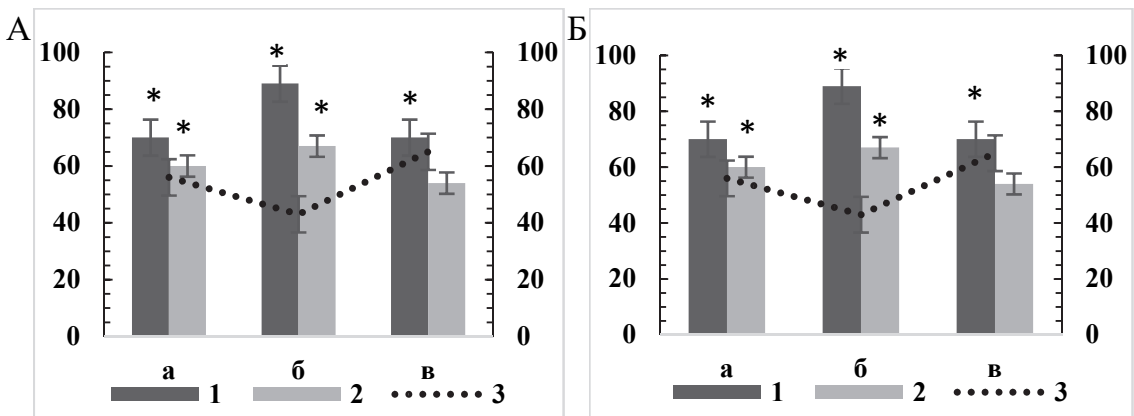

Примечание: * - различия со средним популяционным значением статистически достоверны при $\mathrm{P}<0,05$. Признаки: полевая всхожесть семян, \% (a); высота растения, см (б); биологическая устойчивость растений, \% (в). Лимиты: $\max (1), \min (2)$. Среднее арифметическое (3). По левой оси: среднее арифметическое по лимитам; по правой оси: среднее популяционное значение.

Рисунок. Количественные признаки у сортов льна-долгунца (А) и льна масличного (Б) в условиях полевого опыта (2017-2019 гг.).

В качестве источников высокорослости льна-долгунца, рекомендуем сорта: Alizee (103,8 см), Ива (103,2 см), Глинум (101,4), Дукат (100,5 см), Рубин (99,4 см); Ярок (98,7 см), Восход (97,3 см), Upite-2 (97,2 см).

Биологическая устойчивость растений определяется генотипическими особенностями генотипов, степенью их адаптивности. При этом, необходимо учитывать наличие внутрипопуляционной вариабельности растений и характера изменения амплитуды этого варьирования [4]. У сортов льна-долгунца биологическая устойчивость растений изменялась от $56,42 \%$ (2018 г.) до 84,59 \% (2019 г.); у льна масличного - от 45,34 \% (2018 г.) до 79,48 \% (2017 г.). Высокие значения признака в среднем за 2017-2019 гг. установлены у сортов долгунцового типа (Ярок, 80,51 \%; Дукат 80,44 \%; Alizee, 77,31 \%; Импульс, 75,32 \%, Томич, 70,22 \%; Маяк, 69,39\%; Томский$16,67,33 \%$; Прибой, 66,00 \%; Ikar 332, 66,03 \%); масличного (Северный, $80,41 \%$; McGregor, 77,51 \%; Кустанайский янтарь, 70,38 \%; Исилькульский, 69,52 \%; Бирюза, 68,01 \%; Mikael, 67,41 \%).

Согласно S.A. Eberhart, W.W. Russell, экологическая стабильность определяется $\left(\mathrm{S}^{2} \mathrm{~d}_{\mathrm{i}}\right)$, пластичность $\left(\mathrm{b}_{\mathrm{i}}\right)$. Исследования по льну, с использованием данного метода не многочисленны $[5,6]$. Нами установлена неоднозначность ответных реакции сортов льна на изменение факторов среды. Выделены следующие группы сортов: нестабильные $\left(\mathrm{b}_{\mathrm{i}}<1, \mathrm{~S}^{2} \mathrm{~d}_{\mathrm{i}}=0\right)$; стабильные $\left(\mathrm{b}_{\mathrm{i}}=1, \mathrm{~S}^{2} \mathrm{~d}_{\mathrm{i}}=0\right)$; нестабильные с высокой отзывчивостью в благоприятных 
условиях среды $\left(\mathrm{b}_{\mathrm{i}}>1, \mathrm{~S}^{2} \mathrm{~d}_{\mathrm{i}}=0\right)$.

Таким образом на основе полевого изучении сортов льна - долгунца и льна масличного выявлен адаптивный потенциал сортов по количественным показателям. В результате оценки выявлены источники полевой всхожести семян, биологической устойчивости растений и высоты растения для условий юга Тюменской области.

\section{Список литературь}

1. Методические указания по селекции льна-долгунца / Л.Н. Павлова [и др.]; Всерос. науч.- исслед. ин-т льна. - Торжок [б. и.], 2004.- 44 с.

2. Eberhart, S.A. Stability parameters for comparing varieties / S.A. Eberhart, W.W Russell // Crop Science. - 1966. - Vol. 6, № 1. - P. 36-40.

3. Доспехов, Б.А. Методика полевого опыта (с основами статистической обработки результатов исследований) / Б. А. Доспехов. - Изд. 3-е, перераб. и доп. - М.: Колос, $1972 .-399$ с.

4. Методы определения устойчивости растений: курс лекций / сост. Ю.П. Федулов - Краснодар: КубГАУ, 2015. - 39 с.

5. Полонецкая, Л.М. Идентификация при отборе генотипов льна-долгунца (Linum usitatissimum L.) в различных условиях выращивания / Л.М. Полонецкая, В.3. Богдан, И.А. Голуб // Вес. Нац. акад. Беларусі. Сер. біял. навук. - 2009. - № 2.- С. $22-27$.

6. Королев, К.П. Экологический скрининг коллекционных образцов льна-долгунца в условиях северо-востока Беларуси/ К.П. Королев // «Молодежь в науке»: материалы Межд. молод.- конф., Минск, 18-19 ноября 2014 г. / Нац. акад. наук Беларуси; редкол.: В.В. Казбанов [и др.]. - Минск, 2014. - С. 24.

DOI 10.18699/GPB2020-40

\section{Мировые генетические ресурсы риса и отечественные достижения в селекции на качество зерна}

Коротенко Т.Л. ${ }^{1 *}$, к.с.-х.н., руководитель группь УНУ, с.н.с.; Садовская Л.Л. ${ }^{2}$, зав. справочно-библиографическим отделом, м.н.с.

${ }^{1}$ ФГБНУ ФНЦ риса, г. Краснодар, Россия;

${ }^{2}$ ГПНТБ СО РАН, г. Новосибирск, Россия.

*e-mail: korotenko.tatyan@mail.ru

В статье обобщены данные по изучению в 2014-2019 г2. генетических ресурсов риса отечественной и зарубежной селекции из коллекции ФНЦ риса, которая насчитывает более 7 тыс. образиов из 42 стран мира. Приведены показатели качества зерна традиционных кубанских сортов и достижений ведущих рисосеющих стран, выращенных в Краснодарском крае. Ведется селекиия эксклюзивных сортов на широкий потребительский cпрос.

Ключевые слова: рис, семенная коллекиия, сорт, селекиия, качество зерна. 


\section{Global rice genetic resources and domestic achievements in breeding for grain quality}

Korotenko T.L., FSBSI Federal Research Center for Rice, Krasnodar, Russia Sadovskaya L.L., State Public Scientific Technological Library Siberian Branch of the Russian Academy of Sciences, Novosibirsk, Russia.

The article summarizes the data on studying in 2014-2019 genetic resources of rice of domestic and foreign breeding from the collection of the Federal Scientific Rice Centre, which has more than 7 thousand samples from 42 countries of the world. Grain quality indicators of traditional Kuban varieties and achievements of the leading rice-growing countries grown in the Krasnodar region are presented. Exclusive varieties are selected for wide consumer demand.

Key words: rice, seed collection, variety, breeding, grain quality.

Теплолюбивая культура рис из тропических и субтропических регионов хорошо приспосабливается к разнообразным эколого-географическим условиям выращивания, возделывается в 120 странах на 163 млн. га, в том числе и в самом северном ареале рисосеяния - России. Рис является основным источником энергии и белка для 4,5 миллиардов человек, эта зерновая продовольственная культура дает в год 650 млн тонн зерна (FAO, 2014) $[1,2]$.

В мире насчитывается около 1750 генетических банков растений, где собрано более 420 тыс. зародышевой плазмы риса - незаменимых источников специфических признаков в изменяющихся условиях окружающей среды. Богатое генетическое разнообразие сортов риса в мире обусловлено совокупным воздействием разнообразных агроэкосистем и культурных предпочтений человека [3, 4]. Японским Национальным институтом агробиологических наук собрана коллекция культуры - 44 тыс. образцов; Международный научно-исследовательский институт IRRI (Филиппины) сохраняет самую генетически разнообразную коллекцию риса в мире: 124 тыс. $(O$. sativa), 1651 (O. glaberrima) и 4508 (дикие родственники). Национальный Генный банк Китая насчитывает более 80 тыс.; национальная коллекция США при Министерстве сельского хозяйства (USDA) - более 19 тыс. из 110 стран; Национальный банк генов в Индии (NBPGR) - более 104 тыс. [5, 6]; в России Вавиловская коллекция риса (ВИР, г. Санкт-Петербург) - около 12 тыс. [7], а коллекция ФГБНУ ФНЦ риса (г. Краснодар) - более 7,1 тыс. образцов риса [8].

При этом ученые отмечают, что лишь небольшая часть всей сохраняемой генплазмы риса использована в селекционных программах, фундаментальных и прикладных исследованиях. Эффективность использования генетических ресурсов должна значительно возрасти в будущем производстве риса, так как новые высокоурожайные сорта должны удовлетворять потребностям рынка. Oryza sativa L. - одна из наиболее изучаемых в мире крупяных 
культур с точки зрения качества зерна, этому свидетельствует проведенный в ГПНТБ СО РАН анализ публикационной активности в области «grain rice quality». По данным аналитической системы Scopus за 2009-2018 годы выявлено 2668 документов, значительная часть которых (92 \%) - это журнальные статьи, в аспекте регионального вклада: наибольшее количество публикаций авторов, аффилированных с организациями в Китае (32 \%), Индии (18 \%), США (12 \%). Учитывая рассчитываемые в Scopus показатели CiteScore, SJR, SNIP, выделен научный журнал «Field Crops Research» (Elsevier), при этом самые цитируемые научные работы в области качества риса написаны китайскими исследователями, а также учеными из Филиппин, Нидерландов, Германии, США, Италии и Индии.

Физико-химические свойства крахмала и кулинарные характеристики отличаются у разных генотипов и подвидов риса, а также условия выращивания и окружающая среда значительно влияют на их свойства, что усложняет производство зерна с требуемым качеством. В настоящее время качество зерна риса классифицируется стандартами разных стран на 4-5 типов по его физическим, кулинарным и сенсорным характеристикам. По форме зерна сорта риса делят на округлозерные (japonica) и длиннозерные (indica), внешний вид зерна определяет его цену на рынке, а кулинарные и сенсорные свойства - востребованность и предназначение в зависимости от предпочтений потребителей и национальных особенностей конкретной страны [9]. Широкое распространение любого нового сорта риса на других континентах не гарантировано без понимания потребительских предпочтений по качеству. Потребители риса в Малайзии, Индонезии, Бангладеш и Филиппин предпочитают длинные и тонкие зерна. В ряде стран северной Азии: Японии, Тайвани, Корее едят короткие и толстые рисовые зерна, в Европе больше популярны средние зерна, а в Китае популярен короткозерный рис белый и с пигментированной зерновкой. Хорошо известны в мире европейские элитные сорта Арборио, Бальдо, Карнароли (Италия); американские Bluebonnet, Texas Panta 49, Dawn, Coloro и Nato; среднеазиатские для плова Арпа-Шалы, Узрос 7, Ходжа-Ахмат, Кырмызы, Девзира, Чунгара, Аланга и Лазарь, Амбарбу белый, Дунган-шалы, Маржан, Ару, Тогускен; дальневосточные Кендзо, Дихроа 213, Сантахезский 52. В мире популярны и востребованы экзотические сорта: Жасмин, индийский ароматный Басмати, египетский Камолино, тибетский дикий черный рис с приятным ореховым вкусом, итальянский Nerone rice - эксклюзивный сорт черного риса с особенным ароматом сандалового дерева.

В коллекции УНУ «ФНЦ риса» (Краснодар) собрана генплазма Oryza s. L двух подвидов indica и japonica из 42 стран, 8 эколого-географических групп. По технологическим и биохимическим признакам качества изучено за пятилетний период более 600 образцов. Форма зерновки $(1 / \mathrm{b})$ образцов коллекции, варьирующая от 1,3 до 4,1 и крупность зерна (масса 1000 зерен 
от 16,3 до 43 граммов) отражают фенотипическое разнообразие мирового культурного сортимента (табл. 1).

Таблица 1 - Диапазон варьирования признаков у генотипов коллекции «ФНЦ риса»

\begin{tabular}{|l|c|l|c|}
\hline Наименование признака & Min-max & Наименование признака & Min-max \\
\hline Высота растений & $36-150$ см & Длина зерновки & $3,1-9,4$ мм \\
\hline Длина метелки & $7,5-28,0$ см & Форма зерновки $(1 / \mathrm{b})$ & $1,5-4,1$ \\
\hline Плотность метелки & $1,4-21$ шт./см & Пленчатость зерна & $15,1-24,0 \%$ \\
\hline Число колоск. на метелке & $23,3-326,3$ шт. & Общий выход крупы & $60,0-74,0 \%$ \\
\hline Масса зерна с метелки & $0,5-8,1$ г & Содержание амилозы & $1,2-31,8 \%$ \\
\hline Масса 1000 зерен & $16,3-43,1$ г & Содержание белка в зерне & $2,35-11,9 \%$ \\
\hline
\end{tabular}

С использованием генетического разнообразия селекционерами «ВНИИ риса» создано более 100 сортов риса, районировано 68, в Госреестре охраняемых сортов РФ на 2019 г. включено 45 сортов, в том числе 8 эксклюзивных: глютинозный Вита, краснозерные Марс, Рыжик, Рубин, чернозерные Южная ночь, Гагат, Мавр, ароматный Аромир и длиннозерные Ласточка, Злата, Шарм, Австрал. В нашей стране производство риса неуклонно растет от 30-40 ц/га в 1996-2000 гг. до 60-65 ц/га в 2015-2018 гг. за счет создания поколения новых сортов с потенциалом урожайности до 8-10 т/га, что позволяет полностью обеспечить население страны всеми видами крупы риса отечественного производства [10]. В таблице 2 приведена сравнительная характеристика кубанских и сортов ведущих рисосеющих стран.

Таблица 2 - Характеристика сортов риса российской и мировой селекции по качеству зерна из коллекции ФНЦ риса

\begin{tabular}{|c|c|c|c|c|c|c|c|c|}
\hline \multirow{2}{*}{$\begin{array}{c}\text { Номер } \\
\text { по } \\
\text { каталогу }\end{array}$} & \multirow[b]{2}{*}{$\begin{array}{c}\text { Наименование } \\
\text { сорта }\end{array}$} & \multirow[b]{2}{*}{ Страна } & \multirow{2}{*}{$\begin{array}{c}\text { Мacca } \\
1000 \text { зе- } \\
\text { рен, Г }\end{array}$} & \multirow{2}{*}{$\begin{array}{c}\text { Пленч } \\
\text { а- } \\
\text { тость, } \\
\%\end{array}$} & \multirow{2}{*}{$\begin{array}{c}\text { Стекло- } \\
\text { вид- } \\
\text { ность, } \\
\%\end{array}$} & \multirow[b]{2}{*}{$1 / b$} & \multicolumn{2}{|c|}{$\begin{array}{c}\text { Выход } \\
\text { крупы, \% }\end{array}$} \\
\hline & & & & & & & $\begin{array}{c}\text { об- } \\
\text { щий }\end{array}$ & $\begin{array}{l}\text { доля } \\
\text { цел. } \\
\text { ядра }\end{array}$ \\
\hline 1 & 2 & 3 & 4 & 5 & 6 & 7 & 8 & 9 \\
\hline 04062 & Рапан & Россия & 26,4 & 17,8 & 91,0 & 2,0 & 70,4 & 92,1 \\
\hline 04431 & Виктория & Россия & 27,8 & 18,5 & 93,0 & 1,9 & 70,1 & 90,2 \\
\hline 04220 & Сонет & Россия & 24,1 & 17,6 & 89,0 & 2,1 & 73,5 & 90,9 \\
\hline 04490 & Олимп & Россия & 23,4 & 16,4 & 92,0 & 2,1 & 70,7 & 92,1 \\
\hline 04335 & Флагман & Россия & 28,7 & 17,7 & 95,0 & 2,1 & 74,0 & 98,1 \\
\hline 04802 & Партнер & Россия & 27,1 & 19,7 & 97,0 & 2,4 & 71,2 & 91,2 \\
\hline 04789 & Титан & Россия & 34,0 & 17,5 & 84,0 & 2,4 & 69,8 & 66,8 \\
\hline 04668 & Фаворит & Россия & 29,6 & 18,4 & 91,0 & 2,2 & 69,3 & 93,1 \\
\hline 04489 & Австрал & Россия & 23,5 & 19,4 & 94,0 & 3,4 & 68,6 & 83,7 \\
\hline 04889 & Яхонт & Россия & 28,3 & 17,4 & 91,0 & 2,2 & 73,0 & 86,2 \\
\hline
\end{tabular}




\begin{tabular}{|c|c|c|c|c|c|c|c|c|}
\hline 1 & 2 & 3 & 4 & 5 & 6 & 7 & 8 & 9 \\
\hline 04973 & Юбилейный 85 & Россия & 28,2 & 20,8 & 95,0 & 1,9 & 72,0 & 93,0 \\
\hline 04882 & 3лата & Россия & 24,0 & 21,4 & 89,0 & 3,3 & 65,7 & 75,6 \\
\hline 04468 & Maratelli & Франция & 29,2 & 19,3 & 61,0 & 1,9 & 70,8 & 91,0 \\
\hline 04632 & Османчик & Турция & 30,9 & 17,2 & 83,0 & 2,1 & 72,3 & 91,0 \\
\hline $86-07$ & NEGIS & Турция & 34,3 & 17,3 & 88,0 & 2,3 & 71,8 & 62,7 \\
\hline 04703 & Roxani & Греция & 35.9 & 22.6 & 77,0 & 2.4 & 65.0 & 89.7 \\
\hline 04840 & Cammeo & Италия & 34,0 & 17,8 & 75,0 & 2,4 & 65,2 & 93,0 \\
\hline 04495 & Gisa 178 & Египет & 18,9 & 21,2 & 96,0 & 2,1 & 72,7 & 99,0 \\
\hline $160-12$ & WAB 96-1-1 & Африка & 24,0 & 17,6 & 65,0 & 2,3 & 72,6 & 62,0 \\
\hline 04479 & Geumobyeo & Корея & 25,2 & 19,2 & 98,0 & 1,8 & 73,4 & 95,0 \\
\hline 04697 & Fuku-Juki & Япония & 24,1 & 18,9 & 87,0 & 1,7 & 71,3 & 97,7 \\
\hline 151-09 & WJ 17 & Вьетнам & 22,9 & 20,8 & 89,0 & 2,1 & 69,2 & 94,8 \\
\hline 168-09 & TreaonWAB 99-17 & Вьетнам & 31,6 & 20,2 & 90,0 & 2,8 & 69,4 & 91,0 \\
\hline $157-12$ & SADRI & Иран & 20,9 & 21,2 & 84,0 & 3,2 & 69,0 & 53,0 \\
\hline $105-15$ & IRRI 142 & Филиппины & 21,9 & 17,6 & 88,0 & 1,8 & 72,0 & 97,5 \\
\hline $255-08$ & ПВ-1 Kirkpinar & Филиппины & 35,3 & 17,0 & 68,0 & 2,3 & 72,2 & 44,6 \\
\hline $247-11$ & Ganzaoxian 49 & Китай & 21,8 & 20,3 & 94,0 & 3,2 & 68,9 & 89,3 \\
\hline 234-09 & Ji sheng 202 & Китай & 22,5 & 20,5 & 90,0 & 1,9 & 70,8 & 94,0 \\
\hline $99-12$ & DULAR & Индия & 21,3 & 23,0 & 83,0 & 2,6 & 68,4 & 85,7 \\
\hline $03-82$ & Dedalo & США & 23,7 & 19,2 & 98,0 & 3,2 & 71,0 & 92,1 \\
\hline $03-25$ & Пак-5 & Мадагаскар & 32,4 & 20,7 & 74,0 & 2,2 & 66,3 & 67,8 \\
\hline $97-12$ & CUIABANA & Бразилия & 20,6 & 23,0 & 76,0 & 2,7 & 66,7 & 72,6 \\
\hline 04395 & Мадина & Казахстан & 36,3 & 18,5 & 82,0 & 2,5 & 66,3 & 87,2 \\
\hline 03325 & Амбарбу белый & Азерб-ан & 26,8 & 19,0 & 56,0 & 2,1 & 68,0 & 68,8 \\
\hline 03324 & Челяй & Азерб-ан & 35,9 & 18,3 & 59,0 & 2,1 & 68,5 & 87,8 \\
\hline 03782 & Талмас 2 & Узбекистан & 24,4 & 18,8 & 82,0 & 2,2 & 71,9 & 94,2 \\
\hline $\mathrm{HCP}_{05}$ & & & 1,7 & 0,6 & 2,6 & & 1,2 & 3,1 \\
\hline
\end{tabular}

Возделываемые в Краснодарском крае высокоурожайные сорта риса не уступают по качеству зерна зарубежным, при этом современная селекция ведется на иммунитет, увеличение крупности зерна и создание эксклюзивных сортов на широкий потребительский спрос.

\section{Список литературы}

1. www.fao.org/publications, http://www.un.org/rus$\underline{\text { sian/news/story.asp?NewsID }=21022 \# . \text { WCdtkC2LSM8 }}$

2. Agrama, H.A. Genetic structure associated with diversity and geographic distribution in the USDA rice world collection / H.A. Agrama, W. Yan, M. Jia, R. Fjellstrom, A.M. McClung / Nat. Sci. -V. 2. - 2010. - Is. 4. - P. 247-291.

3. Жученко, А.А. Адаптивное растениеводство (эколого-генетические основы) / А.А. Жученко. - Т. 2 - 2009. - 1098 с.

4. Chang, T.T. The Conservation and use of Rice Genetic Resources / T.T. Chang, C.R. Adair, T.H. Johnston // Advances in Agronomy. - V. 35. - 1982. - P. 37-91. 
5. Bhaskar, C. Genetic and Genomic Resources for Grain Cereals Improvement / Bhaskar C. Patra, Soham Ray, Umakanta Ngangkham, Trilochan Mohapatra. - 1: Rice, 2016. - P. 1-80.

6. Kehu, Li. Genotypic diversity and environmental stability of starch physicochemical properties in the USDA rice mini-core collection / Kehu Li, Jinsong Bao, Harold Corke, Mei Sun // Food Chemistry. -V. 221. - 2017. - P. 1186-1196.

7. С.М. Алексанян, Стратегия взаимодействия генбанков мира в условиях глобализации / Труды по прикладной ботанике, генетике и селекции. - Т. 164. - СПб.: ВИР, 2007. - С. 11-33.

8. Коротенко, Т.Л. Взаимосвязь биологических, биохимических и технологических признаков качества генплазмы коллекции риса / Т.Л. Коротенко, СС. Чижикова, Р.А. Пустовалов Р.А. / Бюллетень Государственного Никитского ботанического сада, 2019. - № 133. - С. 174-181.

9. Туманьян, Н.Г. Классификация сортов риса генетической коллекции на основе агрегированного интегрального показателя качества зерна / Н.Г. Туманьян, Т.Б. Кумейко, Г.Л. Зеленский и др.// Политематический сетевой электронный научный журнал Кубанского государственного аграрного университета. - 2015. - №114. - С. $1580-1591$.

10. Харитонов Е.М. Экологические аспекты селекционно-генетических исследований по рису / Е.М. Харитонов, Ю.К. Гончарова / Вестник Орловского государственного аграрного университета. - 2017. - № 3 (66). - С. 47-55.

DOI 10.18699/GPB2020-41

\section{Получение голозерных линий ячменя после направленной модификации гена $\mathrm{Nud}$ методом CRISPR/Cas}

Короткова A.M. ${ }^{1}$, Колосовская Е.B. ${ }^{1}$, Герасимова С.В. ${ }^{l}$, Кукоева T.В. ${ }^{1}$, Хлесткина $E . K^{1,2}$

${ }^{1}$ ИЦиГ СО РАН, Новосибирск, Россия;

${ }^{2}$ ВИР, Санкт Петербург, Россия

*e-mail: korotkova@bionet.nsc.ru

Ген Nид ячменя кодирует транскрипционныци фактор, ответственный за образование липидного слоя на поверхности зерна, который, при созревании, приводит к прилипанию иветковых чешуй к зерновке и формированию, таким образом, свойства пленчатости зерна. После проведения направленной модификации генома ячменя сорта Golden promise методом CRISPR/Cas nо гену Nud был получен ряд мутантов поколения T0, семена которых были голозерными. В результате отбора в трех поколениях были выделены три голозерные линии растений с гомозиготными мутациями в гене Nud: две линии несут делецчии (-1 п.н.) и (-3 п.н.), одна линия содержит однонуклеотидную инсерциию (+1 n.н.).

Ключевые слова: CRISPR/Cas, ячмень, Nud, геномное редактирование, пленчатость, голозерность. 


\section{Development of naked barley lines after targeted modification of the $\mathrm{Nud}$ gene using gRNA/CAS9 system}

Korotkova A.M. ${ }^{l}$, Kolosovskaya E.V. ${ }^{1}$, Gerasimova S.V. ${ }^{l}$, Kukoeva T.V. ${ }^{l}$, Khlestkina E.K. ${ }^{1,2}$

${ }^{1}$ ICG SB RAS, Novosibirsk, Russia; ${ }^{2} V I R$, St. Petersburg, Russia.

korotkova@bionet.nsc.ru

The Nud gene in barley encodes the transcription factor responsible for the formation of the lipid layer on the surface of the grain, which leads to the adhesion of lemma and palea to the pericarp and the formation of hulled phenotype. After a targeted modification of the barley genome using RNA-guided endonuclease Cas 9 , a number of T0 primary regenerated plants with mutations in the Nud gene were obtained. As a result of selection in three generations, three naked barley lines with homozygous mutations in the Nud gene were developed: two lines carry deletions $(-1$ bp and $-3 \mathrm{bp})$, one line contains a single nucleotide insertion $(+1 \mathrm{bp})$. ked barley.

Key words: CRISPR/Cas, barley, Nud, genome editing, hulled barley, na-

Методы геномного редактирования растений бурно развиваются в последние годы [1], однако работ по редактированию ячменя не много, что обусловлено сложностью редактирования геномов однодольных растений [2].

С помощью двух разных направляющих РНК (Nud45 и Nud50) методом модификации генома с использованием РНК-направленной нуклеазы Cas9 были получены растения Т0 с различными мутациями в гене Nud ячменя. В случае использования нРНК Nud45 мутации в целевом гене сопровождались мутациями в нецелевых локусах: гене HvWinl и двух безымянных генах, расположенных на хромосомах 6Н и 7Н [3]. Модификация проводилась на сорте Golden promise. Всего в популяции первичных регенерантов Т0 было получено 99 растений, среди которых встречались и гетерозиготы по мутациям в гене $N u d$, и дикий тип, и растения с биаллельной мутацией (два аллеля гена $N u d$ содержат разные типы мутаций).

Для получения второго поколения Т1 были отобраны интересующие нас генотипы для перевода их в гомозиготное состояние, были посеяны семена 9 растений из каждой группы первичных регенерантов (Nud45 и Nud50). В том числе была выделена линия, несущая исходный вариант гена $\mathrm{Nud}$, качестве контрольной группы. Растения поколения T1 были проверены на наличие генов Cas9 направляющей РНК, среди растений, не несущих данные гены, выделены три нетрансгенные линии с мутациями в гене $\mathrm{Nud}(-3$ п.н., -1 п.н., +1 п.н.) и без мутаций в нецелевых локусах. Две выделенные линии содержат мутации со сдвигом рамки считывания, и одна линия мутацию без сдвига рамки считывания. Все три линии растений несут в себе свойство голозерности - чешуи не прилипают к зерну и легко обмолачиваются. Голозерность является важным селекционным признаком, который 
сложно получить с помощью обычных селекционных методов без ухудшения исходных характеристик сорта.

Растения отобранных линий были высажены в теплице в количестве 10-13 растений на линию. Из каждого растения была выделена геномная ДНК, при помощи секвенирования было подтверждено единообразие последовательностей гена $N u d$ в каждой линии. Отсутствие трансгенности было подтверждено при помощи ПЦР-теста. Проведен сноповой анализ и сравнение с контролем. Результаты находятся в стадии обработки.

В результате работы получены три устойчивые нетрансгенные голозерные линии ячменя сорта Golden promise с разными мутациями в гене $N u d$.

Благодарности: Исследование выполнено за счет гранта Российского научного фонда (проект № 16-14-00086).

\section{Список литературы}

1. Korotkova A.M. Current achievements in modifying crop genes using CRISPR/Cas system / A.M. Korotkova, S.V.Gerasimova, E.K. Khlestkina. // Vavilov journal of genetics and breeding -2019. - 23(1). - C. 29-37.

2. Gerasimova S.V. Genome editing system CRISPR/CAS9 and peculiarities of its application in monocots / S.V. Gerasimova, E.K. Khlestkina, A.V. Kochetov, V.K. Shumny // Russ. J. Plant Physiol - 2017. - Vol. 64, № 2. - C. 141-155.

3. Gerasimova S. Conversion of hulled into naked barley by Cas endonucleasemediated knockout of the NUD gene / S. Gerasimova, C. Hertig, A. Korotkova, E. Kolosovskaya, I. Otto, S. Hiekel, A. Kochetov, E. Khlestkina, J. Kumlehn // BMC Plant Biology -2020 . - in press.

DOI 10.18699/GPB2020-42

\section{Поиск и анализ гена-кандидата признака остистости мягкой пшеницы Triticum Aestivum L.}

Куваева Д.Д. ${ }^{1,2}$, студентка, Щербань А.Б. ${ }^{2}$, д.б.н., с.н.с.

${ }^{1}$ Новосибирский государственный университет, Новосибирск, Россия;

${ }^{2}$ Федеральный исследовательский центр Институт цุитологии и генетики СО РАН, Новосибирск, Россия

*e-mail: diana.kuvaeva@gmail.com

Проведен анализ первичной структуры генов-кандидатов, контролируюших проявление признака остистости в составе В1 локуса 5 А хромосомы у остистых и безостых форм пшеницы. В результате было установлено, что ген C2H2Znfin является наиболее вероятным кандидатом генаингибитора признака остистости мягкой пшеницы Triticum aestivum L. Комбинации специфических для рецессивного и доминантного аллелей этого гена праймеров показали точные результаты на выборке остистых и безостых форм.

Ключевые слова: пшеницуа, остистость, ген, локализация. 


\section{Search and analysis of the candidate gene associated with awn length in soft wheat Triticum aestivum L.}

Kuvaeva Diana Dmitrievna ${ }^{1,2}$, student Shcherban Andrey Borisovich ${ }^{2}$, Doctor of Biological Sciences, senior researcher ${ }^{1}$ Novosibirsk state University, Novosibirsk, Russia; ${ }^{2}$ Federal research center Institute of Cytology and Genetics of SB RAS, Novosibirsk, Russia.

The analysis of the primary structure of candidate genes that control the manifestation of the sign of awning in the composition of the B1 locus of the $5 \mathrm{~A}$ chromosome in awned and awnless forms of wheat was carried out. As a result, it was found that the C2H2Znfin gene is the most likely candidate for the inhibitor of the sign of awning in soft wheat Triticum aestivum L. Combinations of primers specific for the recessive and dominant alleles of this gene showed accurate results on a sample of awned and awnless forms.

Key words: wheat, awn, gene, localization.

Изучение мягкой пшеницы Triticum aestivum L. диктуется ее важностью как одной из основных продовольственных культур и обусловлено в значительной степени запросами селекции. Установление генов, контролирующих проявление остистости, может быть использовано для изучения генетического разнообразия мягкой пшеницы по этому признаку и последующего отбора форм с повышенной продуктивностью на фоне меняющихся условий внешней среды [1]. Целью данного исследования был поиск генакандидата признака остистости и сопоставление его структуры у остистых и безостых форм пшеницы.

Объектами нашего исследования были выбраны шесть сортов мягкой пшеницы Triticum aestivum L. (Любава 5, Синтетик, Элемент 22, Стар +, Зауральская, Саратовская 29) и девять линий мягкой пшеницы Triticum aestivum L. (K1731, 5219, 6535, 15014, 20546, 62501, 24724, Скифянка, MV VEKNI). Материалы для исследования были взяты из коллекции лаборатории молекулярной генетики и цитогенетики растений ИЦиГ СО РАН.

На первом этапе выполнения данной работы мы выделяли геномную ДНК из растительного материала [2] и с помощью спектрофотометра определяли концентрацию выделенной ДНК. Проверку качества выделенной ДНК осуществляли электрофорезом в агарозном геле. В соответствии с данными спектрофотометрии и полученными электрофореграммами производилось разбавление образцов ДНК для выравнивания их концентраций.

Следующим этапом нашего исследования был анализ потенциальных генов кандидатов, контролирующих остистость. Было подобрано несколько пар специфических праймеров (таблица) к промоторному и кодирующему районам двух генов, находящихся в составе исследуемого локуса и кодирующих транскрипционный фактор C2H2Zincfinger (C2H2Znfin) и фермент фосфатидилсерин-декарбоксилазу $(P h s)$. 
Таблица - Праймеры, использованные в работе

\begin{tabular}{|c|c|c|c|c|}
\hline Праймер & Последовательность нуклеотидов (5’ $\left.\rightarrow 3^{\prime}\right)$ & Size & Часть гена & $\mathrm{Tm},{ }^{\circ} \mathrm{C}$ \\
\hline $\begin{array}{c}\text { B1for } \\
\text { (прямой) }\end{array}$ & ATAAACTCCCACATAATTACTCCG & 24 & Промотор & 51 \\
\hline $\begin{array}{c}\text { b1for } \\
\text { (прямой) }\end{array}$ & ATAAАCTCCCACATAATTACTCCC & 24 & Промотор & 52 \\
\hline $\begin{array}{l}\text { ZfinC2H2f } \\
\text { (прямой) }\end{array}$ & GTTGTGTTGTGACAAGGGCTG & 21 & Промотор & 57 \\
\hline $\begin{array}{l}\text { ZfinC2H2r } \\
\text { (обратный) }\end{array}$ & CTACTGCATGTCCTTAGTGCCT & 22 & $\begin{array}{c}\text { 3'-некодиру- } \\
\text { ющая }\end{array}$ & 57 \\
\hline $\begin{array}{c}\mathrm{ZnfF} \\
\text { (прямой) }\end{array}$ & GGTTGGTCATATCAACCATGAC & 23 & Промотор & 59 \\
\hline $\begin{array}{c}\text { ZnfR } \\
\text { (обратный) }\end{array}$ & ATCGAGCCCCTCTTCCATCTCC & 22 & Кодирующая & 61 \\
\hline $\begin{array}{c}\text { Phserf } \\
\text { (прямой) }\end{array}$ & GGCAAGCATCTTGGGCTGTCC & 21 & Кодирующая & 61 \\
\hline $\begin{array}{c}\text { Phserr } \\
\text { (обратный) }\end{array}$ & GCCGGGCAGAAGGAACTTGC & 20 & Кодирующая & 62 \\
\hline
\end{tabular}

В результате в обоих случаях не было выявлено никаких различий между сортами по длине продуктов ПЦР (рис. 1, 2).

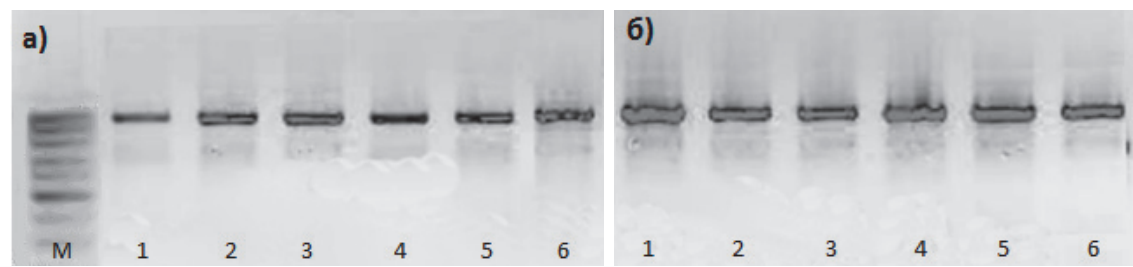

Рис. 1. Электрофореграмма продуктов амплификации для гена C2H2Znfin: a) кодирующий район; праймеры: ZfinC2H2f/ZfinC2H2r; б) промоторный район; праймеры: $\mathrm{ZnfF} / \mathrm{ZnfR}$

Выборка сортов 1-6: Любава 5, Синтетик, Элемент 22 (остистые); Стар +, Зауральская, Саратовская 29 (безостые). М - маркер 100 bp Ladder

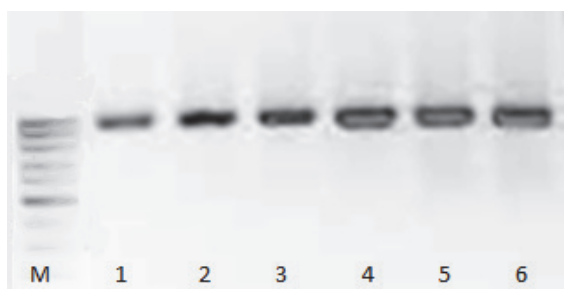

Рис. 2. Электрофореграмма продуктов амплификации для гена Phs: кодирующий район; праймеры: Phserf/Phserr

Выборка сортов 1-6: Любава 5, Синтетик, Элемент 22 (остистые); Стар +, Зауральская, Саратовская 29 (безостые). М - маркер $100 \mathrm{bp} \mathrm{Ladder}$ 
Этот результат указывает на отсутствие крупных изменений (делеций или инсерций) в составе этих генов у безостых сортов относительно остистых. Однако эти изменения могут представлять собой точковые мутации, не выявляемые с помощью электрофореза. Для поиска таких мутаций нами было проведено секвенирование ПЦР-продуктов, представляющих различные участки анализируемых генов из локуса остистости. Как оказалось, кодирующие участки того и другого гена у остистых и безостых сортов не отличаются по первичной структуре.

Вместе с тем в промоторном участке гена C2H2Znfin были выявлены 6 SNP [3]. Сравнение данного гена у остистых и безостых сортов в базе данных 10 сортов выявило точно такие же SNP.

Таким образом, именно данный ген представляется наиболее вероятным кандидатом для гена-ингибитора остистости B1. Для проверки этого предположения нами были сконструированы 2 комбинации специфических для рецессивного и доминантного аллелей этого гена ( $b 1$ и $B 1$ соответственно) праймеров (табл. 1), фланкирующих промоторный участок, при этом прямой праймер в каждой комбинации содержал на 3'- конце сдвоенные SNP.

Далее эти комбинации проверили на выборке остистых и безостых сортов (рис. 3).

a)

$\begin{array}{llllllll}M & 1 & 2 & 3 & 4 & 5 & 6 & 7\end{array}$
6)

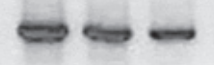

Рис. 3. Электрофореграмма продуктов амплификации: а) с праймерами для рецессивного аллеля blfor/ZnfR; наличие продукта для остистых форм; б) с праймерами для доминантного аллеля B1for/ZnfR; наличие продукта для безостых форм.

Выборка сортов: 1 - сорт Любава 5; 2 - сорт Синтетик; 3 - сорт Элемент 22; 4 - сорт Стар +; 5 - сорт Зауральская; 6 - сорт Саратовская 29; 7 - сорт Chinese spring. M маркер 100 bp Ladder

Видно, что каждая комбинация маркирует соответствующий аллель анализируемого гена. В качестве положительного контроля рецессивного аллеля взят сорт Chinese Spring, содержащий этот аллель [4].

Таким образом, было установлено, что ген C2H2Znfin является наиболее вероятным кандидатом гена-ингибитора признака остистости мягкой пшеницы Triticum aestivum L. Комбинации специфических для рецессивного и доминантного аллелей этого гена праймеров показали точные результаты на выборке остистых и безостых форм. 
Благодарности: Исследование было выполнено за счет средств Курчатовского геномного центра (075-15-2019-1662).

\section{Список литературы}

1. Yoshioka M., Iehisa J.C.M., Ohno R., Kimura T., Enoki H., Nishimura S., Nasuda S., Takumi S. Three dominant awnless genes in common wheat: Fine mapping, interaction and contribution to diversity in awn shape and length. Plos one, 2017.

2. Великов В.А. Молекулярная биология. Практическое руководство: Учеб. пособие для студ. биол. фак. - Саратов: Издательство «Саратовский источник», 2013. - 84 с.: ил.

3. Wang D., Yu K., Jin D., Sun L., Chu J., Wu W., Xin P., Li X., Sun J., Yang W., Zhan K., Zhang A., Liu D. ALI-1, candidate gene of B1 locus, is associated with awn length and grain weight in common wheat. BioRxiv, 2019.

4. Sourdille P., Cadalen T., Gay G., Gill B., Bernard M. Molecular and physical mapping of genes affecting awning in wheat. Plant Breed, 2002. 121: 320-324 c.

DOI 10.18699/GPB2020-43

\section{Разработка генетико-селекционного подхода для получения новых сортов ячменя с повышенным содержанием антоцианов в зерне}

Кукоева T.B. ${ }^{1 *}$, ст. лаборант-исследователь; Стрыгина К.B. ${ }^{2}$, с.н.с.; Глаголева А.Ю. ${ }^{l}$ аспирант, м.н.с.; Григорьев Ю.Н. ${ }^{3}$, с.н.с.; Шоева О.Ю. ${ }^{l}$, с.н.с., зав. сектором; Хлесткина Е.К. ${ }^{1,2}$, в.н.с., директор ВИР.

${ }^{I}$ ФИЦ Институт ичитологии и генетики СО РАН (ИЦиГ СО РАН), Новосибирск, Россия;

${ }^{2}$ Всероссийский институт генетических ресурсов растений имени Н.И. Вавилова (ВИР), Санкт-Петербург, Россия; ${ }^{3}$ СибНИИРС - филиал ИЦиГ СО РАН, Новосибирск, Россия.

*e-mail:kukoeva@bionet.nsc.ru

Необходимость создания исходного материала и сортов ячменя с повышенным содержанием антоцианов для функиионального питания становиться все более ошутимой как для России в целом, так и для Сибирского региона в частности. В предложенной работе на основе знаний о молекулярно-генетических механизмах формирования признаков антоциановой пигментации у ячменя были разработаны и реализуются на практике оптимальные схемы получения новых сортов с повышенным содержанием антоцианов в зерне.

Ключевые слова: Hordeum vulgare, маркер-ориентированная селекция, перикарп, алейрон, фиолетовое зерно, голубое зерно. 


\section{Development of a genetic-breeding approach for obtaining new varieties of barley with an increased content of anthocyanins in grain}

Kukoeva T.V., Senior Laboratory Assistant Researcher, FRC Institute of Cytology and Genetics SB RAS, Novosibirsk, Lavrentjev ave., 10. *e-mail:kukoeva@bionet.nsc.ru

The necessity of creation of source material and varieties of barley with a high content of anthocyanins for functional nutrition is becoming more and more tangible for Russia as a whole and for the Siberian region in particular. In the proposed work, on the basis of knowledge about the molecular-genetic mechanisms of the anthocyanin pigmentation formation in barley, optimal schemes for breeding new varieties with a high content of anthocyanins in grain were developed and put into practice.

Key words: Hordeum vulgare, marker-assisted breeding, pericarp, aleurone, purple grain, blue grain.

Помимо важных функций, выполняемых флавоноидными соединениями в жизни растений, связанных с регуляцией роста и развития, а также адаптацией к стрессу, показана функциональная активность этих соединений для здоровья человека. С потреблением флавоноидных пигментов антоцианов связывают уменьшение риска возникновения сердечно-сосудистых заболеваний, диабета рака, а также возрастных нейродегенеративных заболеваний [1]. В связи с этим в последнее время в мире наблюдается повышенный интерес к созданию новых сортов культурных растений, обогащенных антоциановыми соединениями, в том числе зерна злаков.

У ячменя антоцианы могут присутствовать в вегетативных органах, таких как листовые пластинки, листовые влагалище, ушки листового влагалища, стебель, ости, жилки колосковой чешуи и основание растения, а также в зерне, придавая ему фиолетовую и голубую окраски [2]. К настоящему времени выделены нуклеотидные последовательности регуляторных генов Ant1 (картирован в коротком плече хромосомы 7Н) и Ant2 (2HL), контролирующих фиолетовую окраску зерна ячменя, обусловленную накоплением антоцианов в перикарпе, и генов $H v M p c 2$ (4HL), HvMyc2 (4HL), HvWD40 (6HL), определяющих голубую окраску зерна за счет накопления антоцианов в алейроновом слое [2]. На основании выделенных нуклеотидных последовательностей этих генов были разработаны диагностические ДНК-маркеры, позволяющие уже во втором поколении $\left(\mathrm{F}_{2}\right)$ отбирать гомозиготные по соответствующим генам растения (таблица). 
Таблиия - ДНК-маркеры, используемые для отбора гомозиготных гибридов по генам Ant1, Ant2, $\mathrm{HvMyc2}$

\begin{tabular}{|c|c|c|c|c|c|}
\hline Ген & $\begin{array}{c}\text { Длина ПЦР- } \\
\text { продукта, } \\
\text { п.н. }\end{array}$ & $\begin{array}{c}\text { Структура } \\
\text { прямого праймера } \\
(5, \rightarrow 3 \text { ') }\end{array}$ & $\begin{array}{c}\text { Структура } \\
\text { обратного праймера } \\
\left(5^{\prime} \rightarrow 3^{\prime}\right)\end{array}$ & $\begin{array}{c}\mathrm{T} \\
\text { отжига } \\
\left({ }^{\circ} \mathrm{C}\right)\end{array}$ & 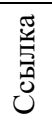 \\
\hline Ant1 & $455 / 488$ & gcggcttgatttgtttcata & tttaaatggcgaggtaaggt & 55 & [3] \\
\hline Ant2 & $268 / 447$ & gccgtgtgtttccttagtt & cgagccaacaacaagcgagac & 55 & [4] \\
\hline$H v M y c 2$ & $610-611^{*}$ & caagtaggtccgaaggctct & cgggcactttacctccaaca & 60 & [5] \\
\hline
\end{tabular}

* полученный ПЦР-продукт обрабатывался эндонуклеазой рестрикции Bsel I и детектировался полиморфизм рестрикционных фрагментов.

Для создания исходного селекционного материала ячменя в качестве материнских форм нами были выбраны районированные сибирские сорта Ворсинский 2 , Алей, Танай, а в качестве отцовских форм - почти-изогенные линии сорта Bowman 'Intence blue aleurone' (BA) и 'Purple lemma and pericarp' (PLP) из коллекции NordGen (www.nordgen.org), являющиеся донорами доминантных аллелей генов $H v M y c 2$ и Ant1/Ant2 соответственно.

C помощью CAPS-маркера, разработанного к гену $H v M y c 2$, в поколении $\mathrm{F}_{2}$ были отобраны гомозиготные по этому гену растения: из 83 гибридов Ворсинский 2 x ВА было отобрано 31 растение, из 72 гибридов Танай х ВА 25 , из 56 гибридов Алей х ВА - 29 растений. Эти растения будут подвергнуты 5-6 кратному возвратному скрещиванию и маркер-контролируемому отбору гомозиготных растений.

Для получения образцов с фиолетовой окраской зерна необходимо наличие доминантных аллелей двух генов - Ant1 и Ant2. Поскольку ген Ant1 имеет плейотропный эффект и определяет как окраску зерна, так и листового влагалища, выбор оптимальной схемы отбора зависит от наличия и интенсивности антоциановой окраски листового влагалища у сорта-реципиента. Если исходный генотип имеет окраску листового влагалища, тогда отбор с помощью ДНК-маркеров можно вести лишь по гену Ant2. Если исходный генотип не имеет окраски листового влагалища, тогда отбор с помощью ДНК-маркеров необходимо вести по двум генам - Ant1 и Ant2. В качестве морфологического маркера доминантного аллеля гена Ant1 можно использовать признак окраски листового влагалища.

Для выбора оптимальной схемы отбора нами было исследовано содержание антоцианов в листовом влагалище у 30 сортов сибирской селекции, в качестве контроля была взята почти изогенная линия ВА, у которой содержание антоцианов, оцененное с помощью спектрофотометра при длин волны 530 нм, было самое высокое и для растений, растущих в поле и в теплице, составляло 1.72 и 4.87 оптических единиц соответственно. Содержание антоцианов у сибирских сортов варьировало от 0.12 до 2.50 оптических 
единиц, при этом наблюдались количественные различия у сортов в зависимости от условий произрастания. Сорта, взятые нами в селекционный процесс в качестве материнских форм (Танай, Алей, Ворсинский2), имели низкое и среднее содержание антоцианов во влагалищном листе. На основе гибридов $\mathrm{F}_{1}$, были получены растения поколения $\mathrm{F}_{2}$, среди которых был проведен отбор растений с окрашенным стеблем. С помощью SNP-маркеров к генам Ant1 и Ant2 были отобраны гомозиготные растения: из 64 гибридов Танай x PLP - 14, из 43 гибридов Алей х PLP - 5, из 49 гибридов Ворсинский 2 x PLP - 7 гомозиготных растений. Все эти растения будут в дальнейшем подвергнуты 5-6 кратному возвратному скрещиванию и маркер-контролируемому отбору гомозиготных растений. Нами также были выбраны в качестве сортов-реципиентов сорта Golden Promise, Биом, Красноярский 1, характеризующиеся средним и высоким содержанием антоцианов в листовом влагалище. Они были скрещены с линией 18 , имеющей генотип antlant1Ant2Ant2 [6]. Так как доминантный аллель гена Ant1 присутствует у исходных сортов, селекция фиолетовозерных генотипов на их основе возможна с использованием ДНК-маркера только к гену Ant2. Насколько интенсивной будет окраска зерновки в зависимости от окраски листового влагалища исходного сорта, можно будет оценить на стадии гибридов поколения $\mathrm{F}_{2}$.

Используя все новые методы селекции, а так же накопленную информацию о генах, контролирующие процесс биосинтеза флавоноидов, мы можем упростить и сократить процесс получения новых сортов с повышенным содержание антоцианов в зерновке.

Благодарности: Работа выполнена при поддержке гранта РФФИ № 19-016-00140.

\section{Список литературь}

1. Тараховский Ю.С., Ким Ю.А., Абдрасилов Б.С., Музафаров Е.Н. Флавоноиды: биохимия, биофизика, медицина. Пущино: Synchrobook, 2013.

2. Шоева О.Ю., Стрыгина К.В., Хлесткина Е.К. Гены, контролирующие синтез флавоноидных и меланиновых пигментов ячменя // Вавиловский журнал генетики и селекции. 2018; 22 (3). 333-342 c.

3. Shoeva O.Y., Kukoeva T.V., Börner A., Khlestkina E.K. 2015. Barley Ant1 is a homolog of maize $C l$ and its product is part of the regulatory machinery governing anthocyanin synthesis in the leaf sheath // Plant Breeding. V. 134. - P. 400-405.

4. Shoeva O.Y., Mock H.P., Kukoeva T.V., Börner A., Khlestkina E.K. Regulation of the flavonoid biosynthesis pathway genes in purple and black grains of Hordeum vulgare. PloS one. 2016; 11 (10).

5. Strygina K.V., Börner A., Khlestkina E.K. Identification and characterization of regulatory network components for anthocyanin synthesis in barley aleurone // BMC Plant Biology 2017, 17 (Suppl 1):184.

6. Gordeeva E.I., Glagoleva AY, Kukoeva TV, Khlestkina EK, Shoeva OY. 2019. Purple-grained barley (Hordeum vulgare L.): marker-assisted development of NILs for investigating peculiarities of the anthocyanin biosynthesis regulatory network // BMC Plant Biology. 19 (Suppl 1): 52. 


\section{Оценка на устойчивость казахстанских образцов пшеницы к патогену Pyrenophora Tritici-repentis}

Кумарбаева M.T. ${ }^{1,2 *}$, м.н.с., РhD докторант; Кохметова А.M. ${ }^{1,2}$, д.б.н., профессор; Коваленко Н.М. ${ }^{3}$, к.б.н., с.н.с.

${ }^{1}$ Казахский Наџиональный Аграрный Университет, Алматы, Казахстан; ${ }^{2}$ Институт Биологии и Биотехнологии Растений, Алматы, Казахстан; ${ }^{3}$ Всероссийский научно-исследовательский институт защить растений, Санкт-Петербург, Россия.

*e-mail:madina_kumar90@mail.ru

Pyrenophora tritici-repentis является важным листовым заболеванием пшеницы. Целью исследований является в лабораторных условиях идентифицировать и отобрать перспективные линии пшеницы устойчивых $\kappa$ пиренофорозу P. tritici-repentis. В качестве объектов исследований была создана коллекиия включающая перспективные линии и сорта казахстанской селекиии. В результате исследований было отобрано 17 перспективных линий и 5 казахстанских сортов (Dana, Daulet, Diana, Dinara, Krasnovodopadskaya 210), включаюшие устойчивость к Ptr ToxA и Pt. ToxB, а также полевую устойчивость. Отобранный перспективный материал используется в программах селекции пшеницы, на повышение устойчивости к пиренофорозу.

Ключевые слова: пшений, популяция Pуrenophora tritici-repentis, устойчивость, пиренофороз.

\section{Assessment of the resistance of Kazakh wheat samples to the pathogen Pyrenophora tritici-repentis}

Kumarbayeva Madina Talgarovna, ${ }^{1,2}$, Kokhmetova Alma Myrzabekovna, ${ }^{1,2}$, Kovalenko Nadezhda Mikhailovna ${ }^{3}$.

${ }^{1}$ Kazakh National Agrarian University, Almaty, Republic of Kazakhstan, madina_kumar90@mail.ru

${ }^{2}$ Institute of Plant Biology and Biotechnology, Almaty, Republic of Kazakhstan, ${ }^{3}$ All-Russian Research Institute of Plant Protection, Saint-Petersburg, Russia

Pyrenophora tritici-repentis of wheat is an important leaf disease of wheat. The aim of the research is to identify and select promising lines of wheat resistant to tan spot P. tritici-repentis in the laboratory. As objects of research, a collection was created that includes promising lines and cultivars of Kazakh selection. As a result of the research, 17 promising lines and 5 Kazakh cultivars (Dana, Daulet, Diana, Dinara, Krasnovodopadskaya 210) were selected, including resistance to PTR ToxA and PTR ToxB and field resistance. Selected a promising material used in breeding programs of wheat to increase resistance to tan spot. 
Key words: wheat, population of Pyrenophora tritici-repentis, isolates, resistance, tan spot.

В последнее годы в последствии измениения климата, минимальной обработкти почвы и нарушения севооборатов приводит к видовым изменениям возбудителей особо ценных сельскохозяйственных культур. Пиренофороз встречается на пшенице и некоторых дикорастущих злаках (Agropyron, Bromus, Agrostis, Avena, Hordeum, Lollium, Festuca, Setaria, Stipa и другие) [1]. На ржи и ячмене отмечается редко, овес к P. tritici-repentis устойчив. В период вегетации возбудитель распространяется конидиями воздушно-капельным путем. Зимует гриб возбудителя на пожнивных остатках, семенах. На перезимовавших листьях и стеблях образуется сумчатая стадия возбудителя в черных псевдотециях. Осуществляют заражение растений весной и являются дополнительным источником инфекции. В исследованиях Л. Ламари с соавторами, отмечали два симптома, связанные с пиренофорозом, таких как некроз и хлороз. Некротические пятна окрашиваются в желто-коричневый цвет, тогда как хлоротичные пятка появляются в результате постепенного пожелтения ткани [2]. Изоляты P. tritici-repentis охарактерезованы по их способности вызывать некрозы и (или) хлорозы. Lamari и Bernier (1989a) классифицировали 4 патотипа гриба Ptr: nec ${ }^{+} \mathrm{chl}^{+}$вызывает некроз и хлороз; nec $^{+} \mathrm{chl}^{-}-$вызывает только некроз; nec $\mathrm{chl}^{+}$вызывает только хлороз; nec $\mathrm{chl}^{-}-$не вызывает ни некроз, ни хлороз [3]. Кроме листьев порожает стебли пшеницы, в последствии образуются серокоричневые и темно-бурые полоски. В 2016 году А. Кохметова с соавторами изучила расовый состав и вирулентность изолятов P. tritici-repentis в Казахстане и на Северо-Кавказском регионе России. Показано что в Казахстане, доминирующими являются расы 1 и 8 , раса 8 обнаружена впервые в Казахстане [4].

Исследования проводили на коллекции из 93 образцов мягкой пшеницы Triticum aestivum, включающей перспективные линии и сорта казахстанской селекции. Наиболее подходящий метод лабораторной оценки устойчивости к пиренофорозу является инокуляция отрезков листьев, помещенных в раствор бензимидазола [1]. Оценку на устойчивость проводили на стадии пяти листьев, растения выращивали на смоченной вате в кюветах (рисунок). Отрезки 10-дневных проростков пшеницы длиной 3-4 см раскладывают на стекло, заранее обернутое фильтровальной бумагой, смоченной $0,004 \%$ водным раствором бензимидазола. Для приготовления суспензии споры гриба собираем шпателем с поверхности питательной среды, добавляем детергент Твин-80 (0,0001 \%), затем суспензию фильтруем через металлическое ситечко для отделения фрагментов мицелия. Инокуляция отрезков листьев проведена способом опрыскивания суспензией конидий из пульверизатора. Для инокуляции была использована суспензия с концентрацией 3-5 тыс. спор конидиеспор на мл. Кюветы с инфекционным материалом 
плотно обертываем полиэтиленовой пленкой и выдерживаем в течение 24 часов в темноте. После суток темноты кювету помещаем в светоустановку с флуоресцентными лампами ЛБ-40 при температуре $22-24{ }^{\circ} \mathrm{C}$. Оценку реакции проростков на устойчивость к пиренофорозу суспензией $P$. triticirepentis проводили на седьмые сутки по разработанной шкале Михайловой и др. [1]. Результаты лабораторной оценки на устойчивость к пиренофорозу приведены в таблице.

Таблица - Лабораторная оценка казахстанских образцов на устойчивость к P. tritici-repentis

\begin{tabular}{|c|c|c|c|c|c|}
\hline $\begin{array}{l}\text { Название } \\
\text { образцов }\end{array}$ & $\begin{array}{c}\text { Оценка } \\
\text { устойчивости } \\
\text { на ТохА Ка- } \\
\text { захстанская } \\
\text { популяция } \\
\end{array}$ & $\begin{array}{c}\text { Фенотип } \\
\text { устойчивост } \\
\text { и пшеницы }\end{array}$ & $\begin{array}{c}\text { Оценка } \\
\text { устойчивости } \\
\text { на ТохВ Гре- } \\
\text { ческая попу- } \\
\text { ляция } \\
\end{array}$ & $\begin{array}{c}\text { Фенотип } \\
\text { устойчив } \\
\text { ости } \\
\text { пшеницы }\end{array}$ & $\begin{array}{c}\text { Полевая } \\
\text { оценка к } \\
\text { PTR, } \\
2019\end{array}$ \\
\hline GF_1_CP & $1 / 1$ & $\mathrm{R}$ & $1 / 0$ & $\mathrm{R}$ & 10 \\
\hline GF_5_CP & $1 / 1$ & $\mathrm{R}$ & $1 / 1$ & $\mathrm{R}$ & 5 \\
\hline GF 7 CP & $1 / 1$ & $\mathrm{R}$ & $0 / 1$ & $\mathrm{R}$ & 5 \\
\hline GF $11 \mathrm{CP}$ & $1 / 1$ & $\mathrm{R}$ & $1 / 1$ & $\mathrm{R}$ & 5 \\
\hline GF_13_CP & $1 / 1$ & $\mathrm{R}$ & $1 / 1$ & $\mathrm{R}$ & 10 \\
\hline GF 23_CP & $1 / 0$ & $\mathrm{R}$ & $1 / 0$ & $\mathrm{R}$ & 0 \\
\hline $10204 \_1$ KSI & $2 / 1$ & MR & $1 / 1$ & $\mathrm{R}$ & 0 \\
\hline 10204_2_KSI & $2 / 1$ & MR & $2 / 2$ & MR & 0 \\
\hline 10204_3_KSI & $1 / 1$ & $\mathrm{R}$ & $1 / 1$ & $\mathrm{R}$ & 0 \\
\hline $102051 \mathrm{KSI}$ & $1 / 2$ & MR & $1 / 1$ & $\mathrm{R}$ & 5 \\
\hline 102052 KSI & $1 / 2$ & MR & $1 / 1$ & $\mathrm{R}$ & 5 \\
\hline 601 SP2 & $1 / 1$ & $\mathrm{R}$ & $1 / 2$ & MR & 5 \\
\hline 620 SP2 & $1 / 1$ & $\mathrm{R}$ & $1 / 1$ & $\mathrm{R}$ & 5 \\
\hline 621_SP2 & $1 / 1$ & $\mathrm{R}$ & $2 / 2$ & MR & 10 \\
\hline 624_SP2 & $1 / 0$ & $\mathrm{R}$ & $1 / 2$ & MR & 10 \\
\hline 630_SP2 & $1 / 0$ & $\mathrm{R}$ & $2 / 0$ & MR & 0 \\
\hline 640_SP2 & $1 / 0$ & $\mathrm{R}$ & $1 / 1$ & $\mathrm{R}$ & 0 \\
\hline Dana & $2 / 2$ & MR & $1 / 2$ & MR & 5 \\
\hline Daulet & $1 / 2$ & MR & $1 / 2$ & MR & 0 \\
\hline Diana & $2 / 2$ & MR & $1 / 2$ & MR & 5 \\
\hline Dinara & $2 / 1$ & MR & $1 / 1$ & $\mathrm{R}$ & 5 \\
\hline $\begin{array}{l}\text { Krasnovodopadska } \\
\text { ya } 210\end{array}$ & $1 / 1$ & $\mathrm{R}$ & $1 / 1$ & $\mathrm{R}$ & 5 \\
\hline
\end{tabular}

Примечание: над чертой - балл развития некроза, под чертой - балл развития хлороза.

В лабораторных условиях (ВИЗР, СПб, Россия) была проведена инокуляция и оценка 93 образцов пшеницы из казахстанской коллекции. Заражение было проведено популяцией из коллекции ВИЗР (казахстанская популяция Ptr ToxA и греческая популяция Ptr ToxB). По результатам оценка устойчивости на Ptr ToxA казахстанскую популяцию было выделено 18 перспективных линий (19,35 \%) устойчивых (R) с оценкой $1 / 0,1 / 1.39$ образцов (42 \%) показали среднеустойчивую реакцию (MR) с оценкой по некроз/хлорозу 1/2, 2/1, 2/2. 
Восприимчивый тип реакции (MS) с оценкой $3 / 2,3 / 3,3 / 4$ было отмечено у 34 образцов, что составляет 36,55 \% от общего числа изученного материала. Два образца показали высокую восприимчивость (HS) с оценкой по некроз/хлорозу 4/4 (610_SP2, 615_SP2). В результаты оценки на греческую популяцию Ptr ToxB выявлено 39 образцов (42 \%) с устойчивым типом реакции (R). Среднеустойчивый тип реакции (MR) было установлено у 40 образцов, что составляет 43 \%. Двенадцать перспективных линии проявили себя как средневосприимчивыми (MS) с типом реакции 2/3. При оценке на устойчивость к $P \operatorname{tr} T$ oxB восприимчивый тип (S) реакции с оценкой $3 / 3$ проявили два образца (GF_4_CP, 639_SP2).

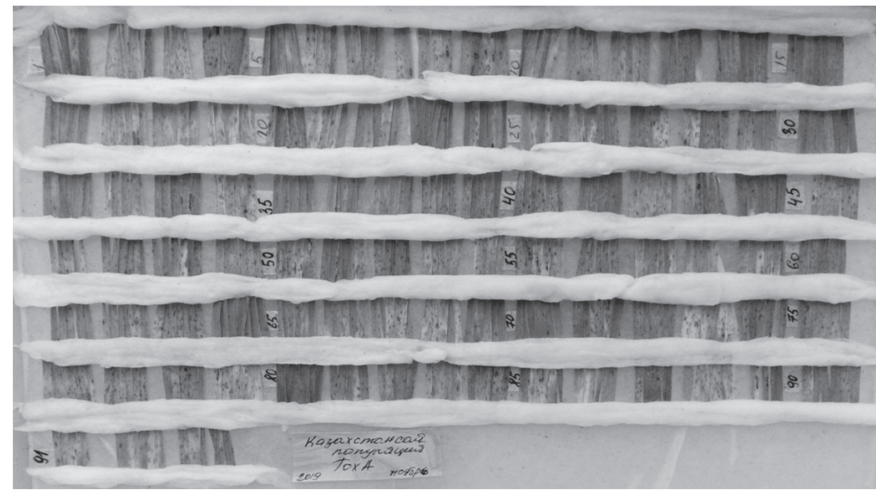

Рисунок. Оценка образцов пшеницы на устойчивость к Ptr ToxA (Казахстанская популяция изолятов).

В результате оценки на устойчивость к Ptr ToxA и Ptr ToxВ было выделено 17 перспективных линий и 5 казахстанских сортов (Dana, Daulet, Diana, Dinara, Krasnovodopadskaya 210) с устойчивым типом реакции на две популяции P. tritici-repentis. Также эти образцы показали высокую фитопатологическую устойчивость в 2019 году к пиренофорозу на естественном инфекционном фоне (п. Алмалыбак, Алматинская область, Казахстан) (таблица 1). Рекомендуется дальнейшее исследование отобранного материала на наличие генов устойчивости Р. tritici-repentis.

\section{Список литературы}

1. Михайлова Л.А., Мироненко Н.В., Коваленко Н.М. Желтая пятнистость пшеницы. Методические указания по изучению популяций возбудителя желтой пятнистости Pyrenophora tritici-repentis и устойчивости сортов. ВИЗР, Санкт-Петербург, $2012,64 \mathrm{c}$.

2. Lamari L., Bernier C.C. Genetics of tan necrosis and extensive chlorosis in tan spot of wheat caused by Pyrenophora tritici-repentis // Phytopathology, 1991, 81, p.1092-1095. 
3. Lamari L., Bernier C.C. Toxin of Pyrenophora tritici-repentis: host specificity, significance in desease and inheritance of host-reaction // Phytopathology, 1989, 79, p.740-744.

4. Кохметова А.М., Кремнева О.Ю., Кейшилов Ж.С., Султанова Н. Ж. Расовый состав и вирулентность изолятов Pyrenophora tritici-repentis в Северо-кавказском регионе России и Республике Казахстан // Eurasian Journal of Applied Biotechnology. 2016. №3. С.57-66.

DOI 10.18699/GPB2020-45

\section{Рост и развитие гибридов астильбы в лесостепи Алтайского края}

Куранда Ю.В., м.н.с.

ФГБНУ Федеральный Алтайский научный цуентр агробиотехнологий, г. Барнаул, Россия.

*e-mail: margo.22@mail.ru

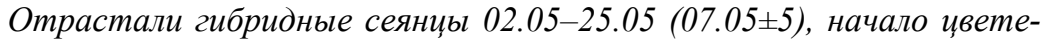

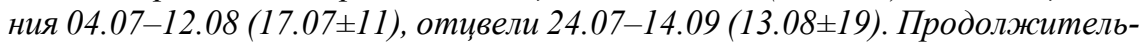
ность ияветения была 12-45 (27士10 дней). Высота гибридов составила 20,0-

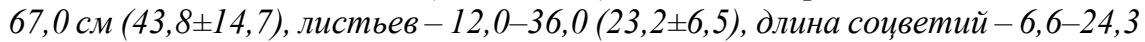

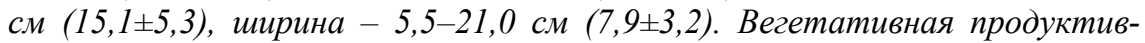
ность популяции сеянцев составила 4-35 (16士8) розеток листьев, генеративная - 1-29 (8土7) ияветоносов.

Ключевье слова: астильба, гибриды, фенология, морфология, продуктивность.

\section{Growth and development of Astilba hybrids in the forest-steppe of the Altai territory}

Kuranda, Yu., Junior researcher, Federal state scientific institution of FANZA, Department NIISS Barnaul, Russia.margo.22@mail.ru

Hybrid seedlings grew on 02.05-25.05 (07.05 \pm 5$)$, the beginning of flowering on 07.07-12.08 (17.07 \pm 11$)$ faded on 07.24-14.09 (13.08 \pm 19$)$. The duration of flowering was 12-45 (27 \pm 10 days). The height of the hybrids was 20.0-

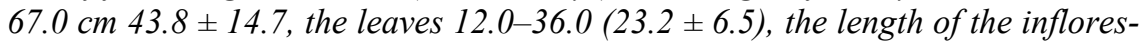
cences was 6.6-24.3 cm (15.1 \pm 5.3$)$, width $-5.5-21.0 \mathrm{~cm}$ (7.9 \pm 3.2$)$. The vegetative productivity of the seedling population was 4-35 (16 \pm 8$)$ rosettes of leaves, generative - 1-29 (8 \pm 7) peduncles.

Key words: astilba, hybrids, phenology, morphology, productivity.

Астильба (Astilbe Buch-Наm.) - род многолетних травянистых растений, популярных в ландшафтной архитектуре. Введена в культуру во II по- 
ловине XIX века [1]. Первым селекционером был Э. Лемуан (1823-1911), затем Г. Арендс и другие, в настоящее время селекция ведется на Украине и Голландии, создано 200-250 сортов [2]. На Алтае интродукцию начали И.В. Верещагина и 3.В. Долганова; здесь важно создание местного ассортимента растений [3]. Хорошая всхожесть семян и разнообразное по фенологии и морфологии потомство открывает большие возможности для селекции культуры [5].

Цель исследований - оценить возможности роста и развития гибридных сеянцев астильбы в условиях лесостепной зоны Алтая.

Исследования проведены в 2019 г., объектами исследования служили 26 сеянцев от свободного опыления, высаженные в коллекционный питомник в 2017 г. Сбор семян - X.2013 г., посев IV.2014 г., наблюдения - по Методике ГСИ [4], анализ погодных условий по данным метеостанции НИИСС.

Результаты. Вегетационный период 2019 г. был наиболее теплый, слабо увлажненный, ГТК - 0,9. Первая декада апреля была теплее нормы на $3,7^{\circ} \mathrm{C}$, во II и III декадах температура была в пределах многолетнего значения, снежный покров сошел 17 апреля. Массовое отрастание сеянцев наблюдалось в I декаде мая 05.05 \pm 5 (02.05-25.05), единичные сеянцы - только в II-III декаде (табл. 1). Весенние заморозки 2-5.05 $\left(-5{ }^{\circ} \mathrm{C}\right), 16.05\left(-4{ }^{\circ} \mathrm{C}\right)$ и $27.05\left(-2,2{ }^{\circ} \mathrm{C}\right)$ вызвали гибель надземной части, включая отрастающие цветоносы. Поэтому рано зацветающие материнские растения сортов Deutchland, Ellie, а также Brautschleier в 2019 г. образовали только единичные, не достигающие нормальных размеров соцветия, как и черенки сорта Superba.

Таблица 1 - Фенологическое развитие гибридов астильбы

\begin{tabular}{|c|c|c|c|c|}
\hline \multirow{2}{*}{$\begin{array}{c}\text { Материнский сорт, } \\
\text { гибрид }\end{array}$} & \multirow{2}{*}{$\begin{array}{c}\text { Дата отрас- } \\
\text { тания } \\
\end{array}$} & \multicolumn{3}{|c|}{ Цветение, дата } \\
\hline & & начало & окончание & период, дни \\
\hline 1 & 2 & 3 & 4 & 5 \\
\hline Brautschleier & $27.04 \pm 6$ & $05.07 \pm 6$ & $30.07 \pm 9$ & $23 \pm 3$ \\
\hline $01-14-03$ & 10.05 & 08.07 & 26.07 & 18 \\
\hline 01-14-09 & 06.05 & 21.07 & 08.08 & 18 \\
\hline 01-14-10 & 10.05 & 15.07 & 08.08 & 24 \\
\hline 01-14-11 & 25.05 & 15.07 & 08.08 & 24 \\
\hline Deutchland & $29.04 \pm 6$ & $27.06 \pm 6$ & $17.07 \pm 7$ & $20 \pm 1$ \\
\hline $02-14-01$ & 03.05 & 04.07 & 24.07 & 20 \\
\hline $02-14-02$ & 02.05 & 06.07 & 26.07 & 20 \\
\hline $02-14-03$ & 02.05 & 05.07 & 26.07 & 21 \\
\hline 02-14-04 & 03.05 & 05.07 & 26.07 & 21 \\
\hline $02-14-06$ & 06.05 & 08.07 & 28.07 & 20 \\
\hline 02-14-08 & 12.05 & 08.07 & 24.07 & 16 \\
\hline 02-14-09 & 05.05 & 05.07 & 24.07 & 19 \\
\hline $02-14-12$ & 06.05 & 06.07 & 26.07 & 20 \\
\hline
\end{tabular}




\begin{tabular}{|l|c|c|c|c|}
\hline \multicolumn{1}{|c|}{$\mathbf{2}$} & $\mathbf{3}$ & $\mathbf{4}$ & $\mathbf{5}$ \\
\hline $02-14-13$ & 07.05 & 07.07 & 28.07 & 21 \\
\hline Ellie & $28.04 \pm 8$ & $05.07 \pm 7$ & $28.07 \pm 6$ & $23 \pm 3$ \\
\hline \multirow{2}{*}{$04-14-02$} & 06.05 & 26.07 & 07.08 & 12 \\
\cline { 3 - 5 } & & 12.08 & 10.09 & 29 \\
\hline Superba & $27.04 \pm 7$ & $18.07 \pm 4$ & $23.08 \pm 8$ & $35 \pm 4$ \\
\hline $05-14-01$ & 03.05 & 26.07 & 26.08 & 31 \\
\hline $05-14-02$ & 03.05 & 02.08 & 09.09 & 38 \\
\hline $05-14-03$ & 13.05 & 07.08 & 14.09 & 38 \\
\hline $05-14-04$ & 03.05 & 26.07 & 09.09 & 45 \\
\hline $05-14-05$ & 02.05 & 26.07 & 09.09 & 45 \\
\hline $05-14-06$ & 02.05 & 26.07 & 09.09 & 45 \\
\hline $05-14-07$ & 03.05 & 26.07 & 09.09 & 45 \\
\hline Bronzelaub & $27.04 \pm 9$ & 29.06 & 24.07 & 25 \\
\hline $06-14-01$ & 02.05 & 24.07 & 26.08 & 33 \\
\hline $06-14-02$ & 02.05 & 15.07 & 10.08 & 26 \\
\hline $06-14-05$ & 03.05 & 15.07 & 05.08 & 21 \\
\hline $06-14-06$ & 03.05 & 20.07 & 12.08 & 23 \\
\hline $06-14-08$ & 05.05 & 24.07 & 18.08 & 25 \\
\hline min-max & $\mathbf{0 2 . 0 5 - 2 5 . 0 5}$ & $\mathbf{0 4 . 0 7 - 1 2 . 0 8}$ & $\mathbf{2 4 . 0 7 - 1 4 . 0 9}$ & $\mathbf{1 2 - 4 5}$ \\
\hline сpeднеe $\pm \boldsymbol{\sigma}$ & $\mathbf{0 5 . 0 5} \pm \mathbf{5}$ & $\mathbf{1 7 . 0 7} \pm \mathbf{1 1}$ & $\mathbf{1 3 . 0 8} \pm \mathbf{1 9}$ & $\mathbf{2 7} \pm \mathbf{1 0}$ \\
\hline
\end{tabular}

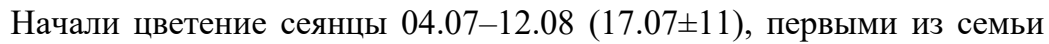
Deutchland (04.07-08.07) близко к материнскому сорту (05.07), который в 2013-2015 гг. зацветал на 8 дней раньше. Вторыми зацвели гибриды Brautschleier (08.07-15.07) близко к родительской форме - 12.07 (01-14-09 на 9 дней позже), которая в 2013-2015 гг. цвела на 7 дней раньше. Затем начал цветение гибрид Ellie (26.07) - через 6 дней после материнского сорта (20.07 в 2019 г.) и спустя 5 дней после окончания цветения первых соцветий (07.08), зацвел вторично (12.08) на 23 дня позже материнского растения (цветение проходило в два этапа - см. табл. 1). Цветение сеянцев Bronzelaub началось 15.07-24.07, на 7-16 дней после материнского сорта (08.07), Superba - 26.07 близко к родительской форме (гибриды 05-14-02 и 05-14-03, соответственно 02.08 и 07.08$)$.

Окончание цветения отмечалось 24.07-14.09 (13.08 \pm 19$)$. Первыми отцвели гибриды Deutchland (24.07-28.07) и Brautschleier (26.07-08.08) вместе с материнскими сортами (24.07 и 05.08 соответственно). Затем Bronzelaub 05.08-26.08, гибрид 06-14-05 в одно время с родительской формой (05.08), остальные - на 5-19 дней позже. Сеянцы сорта Superba заканчивали цветение в I-II декаде сентября, 05-14-01 в августе (26.08). Длительность цветения $12-45$ дней $(27 \pm 10)$, наименьшая - у сеянцев Brautschleier 18-24 и Deutchland 16-21 день. В среднем по годам сорт Bronzelaub цвел около 25 дней, в 2019 
г. - 28, гибрид 06-14-01 дольше его на 5 дней, остальные на 2-7 дней меньше. Длительно цвели сеянцы Superba (31-45 дней) и имели очень приятный аромат. Во влажном 2013 г. сорт Superba цвел 39 дней, засушливом 2015 г. - 31 день.

Высота сеянцев 20-67 см $(43,8 \pm 14,7)$, листьев 12-36 см $(23,2 \pm 6,5)$ : сорта Brautschleier - 40-52 см, Deutchland - 20-49 см, что на 9-21 см и 3422 см соответственно ниже материнских сортов (гибрид 02-14-12 - на уровне). Сеянцы Ellie и Superba достигли высоты материнского растения (табл. 2), или ниже его на 9-13 см (05-14-03 - на 44). Сорт Bronzelaub в 2019 г. достиг 70 см, гибриды ниже его на 10-28 см.

Таблища 2 - Морфологическое развитие гибридов астильбы

\begin{tabular}{|l|c|c|c|c|c|c|}
\hline \multirow{2}{*}{$\begin{array}{c}\text { Материнский } \\
\text { сорт, гибрид }\end{array}$} & \multicolumn{2}{|c|}{ Высота, см } & \multicolumn{2}{c|}{ Соцветие, см } & \multicolumn{2}{c|}{ Число, шт.* } \\
\cline { 2 - 7 } \multicolumn{1}{c|}{ растений } & листьев & длина & ширина & розеток & $\begin{array}{c}\text { соцве- } \\
\text { тий }\end{array}$ \\
\hline Brautschleier & $\mathbf{2}$ & $\mathbf{3}$ & $\mathbf{4}$ & $\mathbf{5}$ & $\mathbf{6}$ & 7 \\
\hline $01-14-03$ & 40 & $27,9 \pm 6,9$ & $32,3 \pm 12$ & $20,4 \pm 6,8$ & 22 & 20 \\
\hline $01-14-09$ & - & 12 & - & - & 14 & 9 \\
\hline $01-14-10$ & 50 & 20 & 23,0 & 10,0 & 6 & 1 \\
\hline $01-14-11$ & 52 & 27 & 20,0 & 21,0 & 30 & 23 \\
\hline Deutchland & $54,4 \pm 4,2$ & $38,1 \pm 1,0$ & $21,6 \pm 5,5$ & $8,8 \pm 1,1$ & 31 & 22 \\
\hline $02-14-01$ & 32 & 19 & 7,8 & 9,6 & 22 & 10 \\
\hline $02-14-02$ & 27 & 21 & 10,5 & 5,5 & 14 & 2 \\
\hline $02-14-03$ & 32 & 18 & 11,3 & 11,3 & 16 & 4 \\
\hline $02-14-04$ & 25 & 19 & 8,9 & 6,6 & 15 & 2 \\
\hline $02-14-06$ & 20 & 14 & 6,6 & 5,6 & 17 & 3 \\
\hline $02-14-08$ & 27 & 20 & 8,0 & 8,0 & 25 & 1 \\
\hline $02-14-09$ & 26 & 22 & 11,0 & 8,7 & 16 & 4 \\
\hline $02-14-12$ & 49 & 23 & 14,0 & 8,5 & 26 & 4 \\
\hline $02-14-13$ & 22 & 13 & 8,5 & 7,5 & 9 & 2 \\
\hline Ellie & $37,0 \pm 6,1$ & $15,7 \pm 4,7$ & $17,0 \pm 3,3$ & $9,2 \pm 5,1$ & 7 & 5 \\
\hline $04-14-02$ & 36 & 16 & 12,3 & 7,6 & 9 & 3 \\
\hline Superba & $78,7 \pm 13,0$ & $33,9 \pm 8,3$ & $35,6 \pm 9,2$ & $9,0 \pm 1,0$ & 12 & 9 \\
\hline $05-14-01$ & 52 & 36 & 14,6 & 6,0 & 8 & 4 \\
\hline $05-14-02$ & 56 & 33 & 19,6 & 5,8 & 15 & 7 \\
\hline $05-14-03$ & 34 & 17 & 18,5 & 6,0 & 4 & 2 \\
\hline $05-14-04$ & 64 & 25 & 22,2 & 6,2 & 10 & 9 \\
\hline $05-14-05$ & 67 & 30 & 24,3 & 6,6 & 7 & 3 \\
\hline $05-14-06$ & 55 & 25 & 18,5 & 6,0 & 9 & 3 \\
\hline $05-14-07$ & 65 & 30 & 19,8 & 6,0 & 10 & 9 \\
\hline Bronzelaub & 77,7 & $35,8 \pm 13,4$ & 26,8 & 12,6 & 13 & 14 \\
\hline & & & & & & \\
\hline
\end{tabular}




\begin{tabular}{|c|c|c|c|c|c|c|}
\hline $\mathbf{1}$ & $\mathbf{2}$ & $\mathbf{3}$ & $\mathbf{4}$ & $\mathbf{5}$ & $\mathbf{6}$ & $\mathbf{7}$ \\
\hline $06-14-01$ & 52 & 30 & 12,4 & 7,0 & 35 & 29 \\
\hline $06-14-02$ & 49 & 24 & 16,4 & 6,6 & 19 & 7 \\
\hline $06-14-05$ & 60 & 30 & 20,6 & 9,4 & 18 & 14 \\
\hline $06-14-06$ & 42 & 23 & 14,6 & 8,2 & 21 & 19 \\
\hline $06-14-08$ & 60 & 33 & 18,4 & 6,6 & 19 & 14 \\
\hline min-max & $20-67$ & $12-36$ & $6,6-24,3$ & $5,5-21,0$ & $4-35$ & $1-29$ \\
\hline среднее $\pm \boldsymbol{\sigma}$ & $43,8 \pm 14,7$ & $23,2 \pm 6,5$ & $15,1 \pm 5,3$ & $7,9 \pm 3,2$ & $16 \pm 8$ & $8 \pm 7$ \\
\hline
\end{tabular}

* примечание: максимальное значение у материнских сортов за 2013-2015 гг.

Длина соцветий не достигала размеров материнского сорта и составила от 6,6 до 24,3 см $(15,1 \pm 5,3)$, ширина от 5,5 до 21,0 см $(7,9 \pm 3,2)$. Продук-

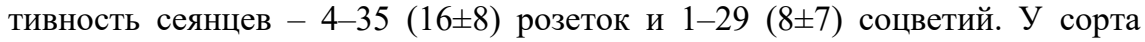
Bronzelaub она высокая - 8-35 розеток и 7-29 соцветий. Гибрид 06-14-01 наиболее продуктивный (35 и 29 соответственно). Сеянец Brautschleier 0114-11 имеет 30 розеток и 23 соцветия (второй по продуктивности), у остальных на 8-16 розеток меньше, чем у материнского сорта (данные по сеянцам не полные вследствии усыхания надземной части). В семье Deutchland гибриды 02-14-01, 02-14-08 и 02-14-12 имеют свыше 25 розеток, 02-14-03 - менее 9, остальные 14-17. Количество соцветий 1-4, (что связано с обмерзанием надземной части), максимум (10) - у гибрида 02-14-01. Сеянец Ellie хорошо разрастается, гибриды Superba 05-14-02, 05-14-04 и 05-14-07 имеют 10-15 розеток и 7-9 цветоносов - они лидеры по продуктивности в семье, остальные - 4-9 розеток листьев и 2-4 соцветия, что на 3-8 и 5-7 соответственно меньше, чем у материнского сорта.

По итогам изучения роста и развития можно сделать выводы:

1. Зацветают сеянцы 04.07-12.08, в ранние сроки Deutchland, Brautschleier - близко к материнскому сорту, Bronzelaub - на 7-16 дней позже, Ellie - на 6, поздние - Superba - с материнским сортом, а два сеянца на 15-20 дней позднее.

2. Цветение продолжается 12-45 дней: кратковременное Brautschleier и Deutchland, среднее - у гибридов Bronzelaub (один дольше родительской формы), длительное - Superba.

3. Высота гибридов варьировала от 20 до 67 см, длина соцветий от 6,6 до 24,3, ширина - от 5,5 до 21,0 см, что меньше растений материнских сортов. Вегетативная продуктивность 4-35 розеток, генеративная - 1-29 соцветий. Сеянцы Bronzelaub лидируют по вегетативной и генеративной продуктивности, Deutchland - только по вегетативной. Продуктивность сеянцев Superba и Brautschleier на уровне, либо ниже родительской формы (01-14-11 выше).

\section{Список литературь}

1. Иевиня С.О., Лусиня М.А. Астильбы. Интродукция в Латвийской ССР. - Рига: 
Зинанте, 1975. - $120 \mathrm{c.}$

2. Кабанов А.В. Проблемы охранения генофонда декоративных растений на примере коллекции рода Astilbe Buch-Ham в отделе декоративных растений ГБС РАН. // Цветоводство: традиции и современность: матер. VI Межд. науч. конф. / Отв. ред. А.С. Демидов. - Белгород: ИД «Белгород» НИУ «БелГУ», 2013 г. - С. 271-274.

3. Верещагина И.В. Культура цветочных растений в Алтайском крае. - Барнаул: Алтайское книж. изд-во, 1968. - 143 с.

4. Методика государственного сортоиспытания сельскохозяйственных культур: декоративные культуры. М.: Изд-во Мин-ва сел. хоз-ва РСФСР, 1968. Вып. 6. - С. $56-89$.

5. Куранда Ю.В. Возможность семенного размножения и первичная оценка сеянцев Astilbe Buch-Ham. от свободного опыления сортов. // Проблемы промышленной ботаники индустриально развитых регионов. / Отв. ред. Куприянов А.Н. Кемерово: ФИЦ УУХ СО РАН, 2018 г. - С. 72-74.

DOI 10.18699/GPB2020-46

\section{Генетическое разнообразие и биохимическая ценность культур Raphanus L. коллекции ВИР}

Курина А.Б. м.н.с., Соловьева А.Е. к.б.н., с.н.с., Артемьева А.М. к.с.-х.н., в.н.с. ФГБНУ «Федеральный исследовательский центр Всероссийский институт генетических ресурсов растений им. Н.И. Вавилова (ВИР)», г. Санкт-Петербург, Россия.

e-mail: nastya_n11@mail.ru

Изучение генофонда культур Raphanus L. имеет большое значение в вопросах оценки исходного материала и выявления источников хозяйственно-ценных признаков для селекции. Это связано с недостаточной изученностью физиологической реакции образцов различных сортотипов на условия выращиввания, биохимических особенностей, пределов изменчивости признаков селекционного интереса, экологической пластичности, адаптационных возможностей, устойчивости к абиотическим и биотическим стрессам. Изучение разнообразия культур Raphanus L. коллекции ВИР позволит всесторонне оценить коллекцию, описать новые формы и сортотипь, выявить биологические закономерности формирования фотосинтетического аппарата, урожая, устойчивости к биотическим и абиотическим стрессорам. В результате исследований оценен в контрастных условиях выращивания диапазон проявления признаков интереса, их стабильность/лабильность, определень эколого-географические группь и сортотипь, которые содержат источники ценных признаков, выделены образцы с высоким адаптационным потенциалом. 
Ключевые слова: Raphanus L., генетическое разнообразие, изменчивость, признаки.

\section{Genetic diversity and biochemical value of VIR collections of the Raphanus L.}

A.B. Kurina, A.E. Soloveva, A.M. Artemyeva

Federal Research Centre N.I. Vavilov Institute of Plant Genetic Resources (VIR), Russia, Saint-Petersburg

e-mail:nastya_n11@mail.ru

The study of the diversity of plants of the genus Raphanus L. is of great importance in assessing the source material and identifying sources of economically valuable traits for breeding. This is connect to insufficient study of the physiological response of samples of various types to growing conditions, biochemical characteristics, the limits of variability of traits of breeding interest, ecological sustainability, adaptive ability and resistance to abiotic and biotic stresses. The study of the diversity of VIR collection of plants of the genus Raphanus L. will make it possible to comprehensively evaluate the collection, describe new forms and varieties, and find the biological patterns of photosynthetic apparatus formation, productivity, and resistance to biotic and abiotic stressors. As the results of our study, the range of manifestation and stability of traits of interest during grows in contrast growing conditions was detected. Several ecologo-geographical groups, types of varieties and samples from the small radish collection, with high adaptive potential, were identified. They can be used like the sources of valuable traits for the future breeding programs.

Key words: Raphanus L., genetic diversity, variability, traits.

Род Raphanus L. включает в себя 10 видов, из которых возделываются только четыре: R. sativus L. (редис, редька), R. landra Mor. (редька листовая), $R$. indicus Sinsk. (редька индийская), $R$. caudatus L.(редька змеевидная) [1].

Редька и редис (Raphanus sativus L.) являются корнеплодными растениями, выращиваемыми и потребляемыми во всем мире. В настоящее время различают три крупные изолированные географические группы редьки и редиса - европейскую, китайскую и японскую. Каждая группа имеет разновидности и сортотипы, различающиеся по комплексу морфологических, фенологических, биохимических и хозяйственно-ценных признаков.

Редька индийская ( $R$. indicus Sinsk.) и змеевидная ( $R$. caudatus L.) являются малораспространенными видами и редко используются в качестве источника пищи. Данные культуры популярны в странах Южной Азии. Редька индийская и змеевидная не образуют съедобного корнеплода, в пищу употребляются стручки [1].

Редька листовая (R. landra Mor.) является дикорастущей и распространена в странах Западного Средиземноморья. Растения не формируют съе- 
добного корня, но формируют много листовой массы, которую можно употреблять в пищу [1].

В целом культуры Raphanus L. содержат углеводы, сахара, пищевые волокна, различные водорастворимые витамины $\left(\mathrm{B}_{1}, \mathrm{~B}_{2}, \mathrm{~B}_{3}, \mathrm{~B}_{5}, \mathrm{~B}_{6}, \mathrm{~B}_{9}\right.$ и $\left.\mathrm{C}\right)$ и минералы (кальций, железо, магний, марганец, цинк, калий и фосфор) [2]. Кроме того, они содержат уникальные биоактивные соединения, которые недавно были признаны потенциально полезными для здоровья человека [35]. Фармакологическая активность культур Raphanus L. является результатом многих важных химических компонентов, в том числе флавоноидов, антоцианов, фенольных соединений, гликозидов, витаминов, горчичных и эфирных масел [6-8]. Эффективное использование культур Raphanus L. отмечено при сердечно-сосудистых заболеваниях, диабете, раке и других желудочных заболеваниях. Сообщалось также, что они являются очень эффективным гепатозащитным средством. Было установлено, что различные части, такие как листья, корни, семена, обладают антиоксидантными свойствами [9-15].

Таким образом, изучению генофонда Raphanus L. и созданию исходного материала по основным направлениям селекции культур: разные группы спелости, масса, форма и окраска корнеплода, оптимальное соотношение массы корнеплода к общей массе растения (выше 60 \%), устойчивость к раннему стеблеванию, неопушенный цельный лист, компактная листовая розетка, высокие вкусовые качества и ценный биохимический состав, - необходимо отводить большую роль, учитывая, что вопросы оценки исходного материала и выявления источников хозяйственно-ценных признаков для селекции данных культур разработаны недостаточно. Недостаточно изучена физиологическая реакция образцов различных сортотипов на условия выращивания, биохимические особенности, пределы изменчивости признаков селекционного интереса, экологическая пластичность, адаптационные возможности, устойчивость к абиотическим и биотическим стрессам.

Мировая коллекция ВИР культур Raphanus L. включает 2810 образцов, из которых: редиса - 1600, редьки - 1200, других видов - 10 образцов, поступивших из 75 стран мира.

В настоящее время в ВИР активно ведется всестороннее исследование коллекции Raphanus L. За последние годы изучено 155 образцов редиса, 155 - редьки, 5 - редьки змеевидной $(R$. caudatus L.) и 3 - редьки листовой $(R$. landra Mor.) различного эколого-географического происхождения и ботанической принадлежности по морфологическим, фенологическим, биохимическим и хозяйственно ценным признакам в условиях открытого и защищенного (зимняя остекленная и весенняя поликарбонатная теплица) грунта и в условиях интенсивной светокультуры.

В результате выявлено, что пределы изменчивости морфологических признаков, а также признаков продуктивности, скороспелости у культур 
Raphanus L. достаточно велики (таблица).

Таблица - Изменчивость количественных признаков листового аппарата и корнеплода редьки и редиса в среднем за 2016-2018 гг.

\begin{tabular}{|c|c|c|c|c|c|c|c|c|}
\hline \multirow{2}{*}{ Признак } & \multicolumn{4}{|c|}{ Редька } & \multicolumn{5}{|c|}{ Редис } \\
\cline { 2 - 10 } & $\mathrm{X}_{\mathrm{cp}}$ & $\mathrm{X}_{\min }$ & $\mathrm{X}_{\max }$ & $\begin{array}{c}\text { Cv, } \\
\%\end{array}$ & $\mathrm{X}_{\mathrm{cp}}$ & $\mathrm{X}_{\min }$ & $\mathrm{X}_{\max }$ & $\begin{array}{c}\mathrm{Cv} \\
\%\end{array}$ \\
\hline $\begin{array}{c}\text { Вегетационный период, } \\
\text { дни }\end{array}$ & 50,82 & 32,00 & 88,00 & 27,44 & 27,3 & 18,0 & 51,0 & 22,7 \\
\hline Высота розетки, см & 25,38 & 13,30 & 42,60 & 21,94 & 20,07 & 10,40 & 33,60 & 18,89 \\
\hline Диаметр розетки, см & 29,07 & 15,00 & 44,80 & 14,63 & 16,25 & 9,38 & 25,18 & 17,04 \\
\hline Длина листа, см & 14,56 & 7,50 & 25,70 & 19,99 & 11,14 & 6,29 & 18,40 & 17,19 \\
\hline Ширина листа, см & 9,65 & 5,50 & 13,30 & 14,07 & 7,21 & 3,86 & 12,40 & 18,66 \\
\hline $\begin{array}{c}\text { Площадь листовой по- } \\
\text { верхности, см }\end{array}$ & 1336,99 & 344,70 & 3999,14 & 41,65 & 431,19 & 135,43 & 1140,06 & 32,93 \\
\hline Длина корнеплода, см & 14,17 & 3,50 & 37,10 & 45,08 & 4,53 & 1,67 & 13,50 & 44,67 \\
\hline Диаметр корнеплода, см & 5,75 & 2,69 & 10,14 & 21,88 & 2,55 & 0,86 & 4,40 & 19,29 \\
\hline Индекс корнеплода & 2,69 & 0,73 & 8,56 & 58,96 & 1,94 & 0,66 & 8,00 & 60,72 \\
\hline Масса растения, г & 416,37 & 53,60 & 1050,00 & 46,34 & 34,07 & 11,42 & 75,70 & 34,71 \\
\hline Масса корнеплода, г & 271,18 & 35,80 & 723,00 & 51,13 & 18,02 & 6,25 & 41,50 & 33,34 \\
\hline Доля корнеплода, \% & 66,39 & 13,19 & 92,78 & 21,35 & 53,83 & 25,00 & 89,13 & 14,59 \\
\hline
\end{tabular}

В результате биохимических исследований было идентифицировано 134 показателя химического состава, из них: органических кислот - 23, сахаров - 15, фенольных соединений - 10, свободных аминокислот - 26 , жирных кислот -17 , спиртов - 14 и ряд вторичных метаболитов - 29. Размах вариации содержания каждого из изученных биохимических соединений был очень велик.

Изучение видового и сортового разнообразия Raphanus L. по биохимическим признакам качества позволило выявить пределы изменчивости по содержанию массы сухих веществ, сахаров, аскорбиновой кислоты, органических кислот, фенольных соединений, свободных аминокислот, жирных кислот и спиртов. Например, у редиса амплитуда изменчивости составляла: массы сухих веществ - от 4 до $8 \%$, аскорбиновой кислоты - от 19 до 44 мг $/ 100$ г, сахаров от $0,16 \%$ до 5,45\%, суммы органических кислот от $0,18 \%$ до 1,72 \%, фенольных соединений - от 7 до 793 мг/100 г, свободных аминокислот - от 9 до 516 мг/100 г, свободных жирных кислот - от 8 до 669 мг/100 г, спиртов - от 14 до 4768 мг/100 г. У редьки масса сухих веществ варьировала от 5 до $13 \%$, аскорбиновой кислоты - от 39 до 85 мг/100 г, сахаров от $0,1 \%$ до $1,93 \%$, суммы органических кислот от $0,01 \%$ до $0,74 \%$, фенольных соединений от 0,6 до 103 мг/100 г, свободных аминокислот от 3 до 102 мг/100 г, свободных жирных кислот от 2 до 54 мг/100 г, спиртов от 1 до 763 мг/100 г. 
У редиса выделены источники устойчивости к раннему стеблеванию в условиях длинного дня, пониженных и повышенных температур, исследована стабильность и пластичность образцов различных сортотипов и выделен материал с высоким адаптационным потенциалом среди образцов сортотипов Розово-красный округлый и Красный округлый. Выделены источники устойчивости редьки к раннему стеблеванию при весеннем посеве, образцы с высокой продуктивностью, высоким содержанием аскорбиновой кислоты и сахаров, слабо поражающиеся личинками капустной мухи.

В результате исследований оценен в контрастных условиях выращивания диапазон проявления признаков интереса, их стабильность/лабильность, определены эколого-географические группы и сортотипы, которые содержат источники ценных признаков, выделены образцы с высоким адаптационным потенциалом.

Благодарности: Работа выполнена в рамках выполнения государственного задания № 0662-2019-003 «Генетические ресурсы овощных и бахчевых культур мировой коллекции ВИР: эффективные пути расширения разнообразия, раскрытия закономерностей наследственной изменчивости, использования адаптивного потенциала».

\section{Список литературы}

1. Шебалина М.А., Сазонова Л.В. Корнеплодные растения // Культурная флора СССР. Т. 18. - Л.: Агропромиздат, ЛО, 1985. - С. 156-324.

2. Khattak K.F. Nutrient composition, phenolic content and free radical scavenging activity of some uncommon vegetables of Pakistan. - Pak. J. Pharm. Sci. 2011, 24, 277-283.

3. Malik M.S., Riley M.B., Norsworthy J.K., Bridges W. Jr. Variation of glucosinolates in wild radish (Raphanus raphanistrum) accessions. - J. Agric. Food Chem. 2010, 58, 11626-11632.

4. Ishida M., Kakizaki T., Morimitsu Y., Ohara T., Hatakeyama K., Yoshiaki H., Kohori J., Nishio T. Novel glucosinolate composition lacking 4-methylthio-3-butenyl glucosinolate in japanese white radish (Raphanus sativus L.). - Theor. Appl. Genet. 2015, 128, 2037-2046.

5. Baenas N., Piegholdt S., Schloesser A., Moreno D.A., Garcia-Viguera C., Rimbach G., Wagner A.E. Metabolic activity of radish sprouts derived isothiocyanates in drosophila melanogaster. - Int. J. Mol. Sci. 2016, 17, 251.

6. Brunetti C., Di Ferdinando, M. Fini, A. Pollastri, S. Tattini Flavonoids as antioxidants and developmental regulators: relative significance in plants and humans. - Int. J. Mol. Sci 14, 2013, 3540-55.

7. Nakabayashi R. et al. Enhancement of oxidative and drought tolerance in Arabidopsis by overaccumulation of antioxidant flavonoids. - Plant J 77, 2014, 367-79.

8. Gutierrez E. et al. Transcriptomics, Targeted Metabolomics and Gene Expression of Blackberry Leaves and Fruits Indicate Flavonoid Metabolic Flux from Leaf to Red Fruit. - Front. Plant Sci 8, 2017, 472.

9. Lugasi A., Dworschak E., Blazovics A., Kery A. Antioxidant and free radical scavenging properties of squeezed juice from black radish (Raphanus sativus L. var 
niger) root. - Phytotherapy research. 12 (7), 1998, 502-506.

10. Papi A., Orlandi M., Bartolini G., Barillari J., Iori R., Paolini M., Ferroni F., Grazia Fumo M., Pedulli G.F., Valgimigli L. Cytotoxic and antioxidant activity of 4methylthio-3-butenyl isothiocyanate from Raphanus sativus L. (Kaiware Daikon) sprouts. - Journal of agricultural and food chemistry. 56 (3), 2008, 875-883.

11. Barillari J., Cervellati R., Costa S., Guerra M.C., Speroni E., Utan A., Iori R. Antioxidant and choleretic properties of Raphanus sativus L. sprout (Kaiware Daikon) extract. - Journal of agricultural and food chemistry. 54 (26), 2006, 9773-9778.

12. Beevi S. S., Narasu M.L., Gowda B.B. Polyphenolics profile, antioxidant and radical scavenging activity of leaves and stem of Raphanus sativus L. - Plant foods for human nutrition. 65 (1), 2010, 8-17.

13. Takaya Y., Kondo Y., Furukawa T., Niwa, M. Antioxidant constituents of radish sprout (kaiware daikon), Raphanus sativus L. - Journal of agricultural and food chemistry. 51 (27), 2003, 8061-8066.

14. Vanitha Reddy P., Desai S., Ahmed F., Urooj A. Antioxidant properties and stability of Raphanus sativus extracts. - Journal of Pharmacy Research. 3 (3, Cop), 2010, 658-661.

15. Wu S., Gao Q., Zhao P., Gao Y., Xi Y., Wang X., Liang Y., Shi H., Ma, Y. Sulforaphane produces antidepressant-and anxiolytic-like effects in adult mice. $-\mathrm{Be}$ havioural brain research. 301, 2016, 55-62.

DOI 10.18699/GPB2020-47

\section{Современное состояние генофонда рода седум (Sedum L.) в НИИСС имени М.А. Лисавенко}

Ларина О.В., к.с.-х.н., н.с.

Федеральный Алтайский научный иентр агробиотехнологий, Барнаул, Россия e-mail:olia.sadovod@yandex.ru

В НИИСС имени М.А. Лисавенко коллекция рода Sedum L. включает 14 видов, 2 формы и 7 сортов. Представлены сведения о сроках, продолжительности иветения 23 объектов исследования в условиях лесостепной зоны Алтайского края. Перспективные образиы с высокими показателями декоративности и устойчивости рекомендованы для использования в озеленении региона.

Ключевые слова: интродукиия, седум, толстянковые, декоративность, перспективность, адаптивность.

\section{Current state of the gene pool Sedum L.} at the NIISS named after M.A. Lisavenko

Larina O.V.

Federal Altai Scientific Centre of Agro-BioTechnologies, Barnaul, Russia.

At the NIISS named after M.A. Lisavenko collection of the genus Sedum L. 
includes 14 species, 2 forms and 7 varieties. Provides information on the composition of the collection. Wintering, dates, and duration of flowering of 23 objects of researchthe in the forest-steppe zone of the Altai Territory are estimated. Promising samples with high decorative and sustainability indicators are recommended for use in landscaping the region.

Key words: introduction, sedum, Crassulaceae, decorativeness, perspective, wintering.

Алтайский край - это регион, характеризующимся суровой зимой и коротким жарким летом. Многие цветочные интродуценты не могут здесь успешно расти и цвести. Растения из рода седум (Sedum L.) - это многолетние или двулетние красивоцветущие, декоративнолиственные растения. Они перспективны для зеленого строительства из-за высокодекоративных внешних качеств, легкости размножения и высокого адаптивного потенциала $[1,2]$.

Начало работы с представителями рода седум в НИИСС имени М.А. Лисавенко положила З.И. Лучник. Ее работу продолжила И.В. Верещагина. Ею были изучены 7 видов. Из них рекомендованы для основной культуры - с. Эверса, гибридный, едкий; для выращивания с зимним укрытием - уссурийский, видный, ложный [3]. В настоящий момент генофонд рода седум в коллекции поддерживается автором статьи и по возможности пополняется новыми высокодекоративными видами и сортами.

Цель исследований: сохранение генофонда, пополнение новыми видами сортами рода седум; изучение их роста и развития, зимостойкости, декоративных качеств в условиях интродукции в лесостепи Алтайского края.

Место проведения, методика, объекты исследований. Исследования проводили в отделе «НИИСС» имени М.А. Лисавенко ФГБНУ ФАНЦА, расположенном в г. Барнауле. Город находится в лесостепной зоне Алтайского края. Климат региона резкоконтинентальный. Весной наблюдаются весенние возвраты холодов, а осенью - ранние заморозки. Посадки находятся на открытом солнечном участке без искусственного орошения.

Наблюдений проводятся по «Методике ГСИ...» для декоративных культур [4], а также методике Карписоновой [5]. Продуктивность цветения оцениваем по 5-бальной шкале, где 5 баллов - высшая, а 1 балл - низшая оценка. В статье приведены средние данные за 4 года (2016-2019 гг.).

Объекты исследований. Коллекции седумов НИИСС насчитывает 14 видов, 2 формы, 7 сортов (табл. 1). Некоторые находятся в коллекции, но наблюдения за ними на современном этапе не проводятся. Они были изучены И.В. Верещагиной, были даны рекомендации по ним [3]. Наблюдения проводятся у 6 видов, 2 форм и 7 сортов. Сорта с. видного, а также с. Эверса относятся к группе очитники (Hylotelephium), остальные - к группе очиток (Sedum). Два вида занесены в Красную книгу - с. гибридный (Красные книги 
России и Среднего Урала), с. едкий (Красная книга Мурманской области).

Таблица 1 - Генофонд рода седум в НИИСС

\begin{tabular}{|c|c|c|c|}
\hline \multicolumn{2}{|c|}{ Наблюдаемые объекты } & \multicolumn{2}{|c|}{ Место обитания вида в природе } \\
\hline 1 & 2 & 3 & 4 \\
\hline Седум белый & Sedum album $\mathrm{L}$. & $\begin{array}{l}\text { Запад. Евр., Мал. } \\
\text { Азия, Кавказ } \\
\end{array}$ & $\begin{array}{l}\text { каменистые } \\
\text { места }\end{array}$ \\
\hline $\begin{array}{l}\text { Седум видный } \\
\text { Matrona }\end{array}$ & $\begin{array}{l}\text { Hylotelephium spectabile (Bo- } \\
\text { reau) H. Ohba Matrona }\end{array}$ & \multirow{4}{*}{$\begin{array}{c}\text { северо-вост. Ки- } \\
\text { тай, Кавказ, Ки- } \\
\text { тай, Япония, } \\
\text { Монголии, Даль- } \\
\text { ний Восток, Си- } \\
\text { бирь }\end{array}$} & \multirow{4}{*}{$\begin{array}{c}\text { смешанные и } \\
\text { сосновые } \\
\text { леса, опушки, } \\
\text { луга }\end{array}$} \\
\hline $\begin{array}{l}\text { Седум видный } \\
\text { Осенняя радость }\end{array}$ & $\begin{array}{l}\text { H. spectabile (Boreau) H. } \\
\text { Ohba Autumn Joy }\end{array}$ & & \\
\hline $\begin{array}{l}\text { Седум видный } \\
\text { Red Imperator }\end{array}$ & $\begin{array}{l}\text { H. spectabile (Boreau) H. } \\
\text { Ohba Red Imperator }\end{array}$ & & \\
\hline $\begin{array}{l}\text { Седум видный } \\
\text { Star Dast }\end{array}$ & $\begin{array}{l}\text { H. spectabile (Boreau) H. } \\
\text { Ohba Star Dast }\end{array}$ & & \\
\hline С. гибридный & Sedum hybridum L. & \multirow{2}{*}{$\begin{array}{c}\text { Сибирь, Урал, } \\
\text { Средняя Азия, } \\
\text { Монголия }\end{array}$} & \multirow{2}{*}{$\begin{array}{l}\text { степи, каме- } \\
\text { нистые } \\
\text { склоны, раз- } \\
\text { режен. леса, } \\
\text { вырубки } \\
\end{array}$} \\
\hline $\begin{array}{c}\text { Седум гибридный } \\
\text { Хеnox }\end{array}$ & Sedum hybridum L. Xenox & & \\
\hline Седум едкий & Sedum acre L. & $\begin{array}{c}\text { Европ. ч. России, } \\
\text { юг Сибири, Ма- } \\
\text { лая Азия, Сев. } \\
\text { Африка }\end{array}$ & $\begin{array}{l}\text { открытые } \\
\text { песчаные ме- } \\
\text { ста }\end{array}$ \\
\hline Седум испанский & Sedum hispanicum L. & $\begin{array}{c}\text { Западная Европа, } \\
\text { Крым, Кавказ, } \\
\text { Малая Азия }\end{array}$ & $\begin{array}{l}\text { каменистые } \\
\text { склоны }\end{array}$ \\
\hline $\begin{array}{l}\text { C. камчатский с бе- } \\
\text { лой каймой }\end{array}$ & Sedum kamtschaticum Fisch. & $\begin{array}{c}\text { Дальний Восток, } \\
\text { Корея, Япония, } \\
\text { Северо-Восточ- } \\
\text { ный Китай }\end{array}$ & $\begin{array}{l}\text { каменистые } \\
\text { склоны }\end{array}$ \\
\hline Седум ложный & Sedum spirium M. Bieb. & \multirow{4}{*}{$\begin{array}{c}\text { Кавказ, Турция, } \\
\text { Иран }\end{array}$} & \multirow{4}{*}{$\begin{array}{c}\text { скальные } \\
\text { склоны, суб- } \\
\text { альпийские } \\
\text { луга }\end{array}$} \\
\hline $\begin{array}{l}\text { Седум ложный ро- } \\
\text { зовый }\end{array}$ & $\begin{array}{c}\begin{array}{c}\text { Sedum spirium M. Bieb. f. } \\
\text { rosea }\end{array} \\
\end{array}$ & & \\
\hline $\begin{array}{l}\text { Седум ложный Tri- } \\
\text { color } \\
\end{array}$ & $\begin{array}{l}\text { Sedum spirium M. Bieb. Tri- } \\
\text { color }\end{array}$ & & \\
\hline $\begin{array}{l}\text { Седум ложный } \\
\text { Roseum }\end{array}$ & $\begin{array}{c}\text { Sedum spirium M. Bieb. } \\
\text { Roseum }\end{array}$ & & \\
\hline $\begin{array}{l}\text { Седум Максимо- } \\
\text { вича }\end{array}$ & $\begin{array}{l}\text { Sedum macsimovicha (Regel) } \\
\text { S.B. Gontch. }\end{array}$ & Приморье & $\begin{array}{l}\text { скальные } \\
\text { склоны }\end{array}$ \\
\hline $\begin{array}{c}\text { Седум Мидден- } \\
\text { дорфа }\end{array}$ & $\begin{array}{l}\text { Sedum Middendorfiana } \\
\text { (Maxim.) Grulich }\end{array}$ & $\begin{array}{c}\text { Восточная Си- } \\
\text { бирь, Дальний } \\
\text { Восток, Северо- } \\
\text { Восточный Ки- } \\
\text { тай, Корея }\end{array}$ & $\begin{array}{c}\text { трещины } \\
\text { скал, щебни- } \\
\text { стые склоны, } \\
\text { скалы } \\
\end{array}$ \\
\hline Седум отогнутый & Sedum reflexum $\mathrm{L}$. & Западная Европа & $\begin{array}{l}\text { песч. места, } \\
\text { скалы }\end{array}$ \\
\hline
\end{tabular}




\begin{tabular}{|c|c|c|c|}
\hline 1 & 2 & 3 & 4 \\
\hline Седум пурпурный & $\begin{array}{l}\text { Sedum purpureum }(\mathrm{L} .) \\
\text { Schultes }\end{array}$ & $\begin{array}{l}\text { Европа, Сибирь, } \\
\text { Дальний Восток }\end{array}$ & $\begin{array}{c}\text { каменистые и } \\
\text { глинистые } \\
\text { почвы }\end{array}$ \\
\hline Седум тоненький & Sedum tenellum M. Bieb. & $\begin{array}{l}\text { Кавказ, Иран, } \\
\text { Турция }\end{array}$ & $\begin{array}{c}\text { щебнистые } \\
\text { скалы, каме- } \\
\text { нистые места }\end{array}$ \\
\hline $\begin{array}{c}\text { Седум } \\
\text { шестигранный }\end{array}$ & Sedum sexangulare L. & Западная Европа & $\begin{array}{l}\text { сухие песча- } \\
\text { ные, камени- } \\
\text { стые почвы }\end{array}$ \\
\hline Седум Эверса & $\begin{array}{l}\text { Hylotelephium Ewersii } \\
\text { (Ledeb.) H. Ohba }\end{array}$ & $\begin{array}{l}\text { Юг Сиб., Алтай, } \\
\text { Ср. Азия, Сев. } \\
\text { Индия, Монго- } \\
\text { лия, Зап. Китай }\end{array}$ & $\begin{array}{c}\text { галечники, } \\
\text { прирусл. } \\
\text { пески кам. } \\
\text { склоны, }\end{array}$ \\
\hline
\end{tabular}

Результаты. Род седум (Sedum L.) относится к семейству Толстянковые (Crassulaceae DC.) и насчитывает от 280 до 650 видов (в зависимости от классификации), распространенных главным образом в умеренных и горных районах Северного полушария. Седумы в коллекции НИИСС разнообразны по своим характеристикам. По окраске листьев выделены группы: с зеленой окраской листвы (3 сорта с. видного, гибридный, едкий, испанский, Максимовича, Миддендорфа, отогнутый, тоненький, шестигранный); с пурпурной (видный Matrona, пурпурный); с сизой (Эверса); с пестрой (камчатский, ложный Tricolor).

Отрастание большинства седумов проходит в II половине апреля (табл. 2). Сорта с. видного Matrona и Star Dast отрастают в мае. Через 10-15 дней после отрастания седумы уже обладают декоративным эффектом. Больше половины образцов (57 \%) - это растения, зацветающие в июне. Цветение начинается с середины июня. Наиболее раннее цветение у с. Миддендорфа - 14.06. Седум ложный Tricolor относиться к среднему сроку цветения - 04.07. Остальные виды и сорта относятся к позднему сроку цветения. Начало зацветания у них приходится на август - сентябрь. Наиболее позднее цветение у с. гибридного Star Dast - 25.09 (табл. 2).

Большинство образцов (12) имеют высокий балл (4-5) и длительный период цветения (от 27 до 47 дней), что говорит об их успешной интродукции (табл. 2). Особенно выделяются следующие образцы, имеющие высокий балл и длительную продолжительность цветения: седум видный Осенняя радость, с. видный Matrona, с. камчатский, с. ложный белый, с. ложный Roseum. Седум гибридный Xenox, сорта с. видного Red Imperator и Star Dast проявляют плохую адаптацию в условиях лесостепной зоны Алтайского края; имеют низкий балл продуктивности (1-2) и короткую продолжительность (7-15 дней) цветения.

В коллекции имеются образцы с белыми, желтыми, розовыми и пурпурными цветами (табл. 2). 
Таблица 2 - Характеристика объектов исследований, среднее 2014-2019 гг.

\begin{tabular}{|c|c|c|c|c|c|}
\hline \multirow{2}{*}{ Объекты исследований } & \multicolumn{2}{|c|}{ Начало } & \multirow{2}{*}{ 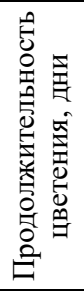 } & \multirow{2}{*}{ 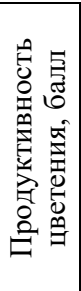 } & \multirow{2}{*}{$\begin{array}{l}\text { Окраска } \\
\text { цветков }\end{array}$} \\
\hline & отрастания & цветения & & & \\
\hline Седум гибридный Xenox & 25.04 & $*$ & - & - & - \\
\hline Седум видный Осенняя радость & 29.04 & 24.08 & 45 & 5 & розовая \\
\hline Седум видный Matrona & 05.05 & 28.08 & 42 & 4 & розовая \\
\hline Седум видный Red Imperator & 28.04 & 26.08 & 15 & 1 & пурпурная \\
\hline Седум видный Star Dast & 03.05 & 25.09 & 7 & 2 & белая \\
\hline Седум испанский & 20.04 & 07.06 & 47 & 3 & желтая \\
\hline Седум камчатский & 22.04 & 27.06 & 40 & 4 & желтая \\
\hline Седум ложный белый & 17.04 & 28.06 & 37 & 5 & белая \\
\hline Седум ложный розовый & 22.04 & 26.06 & 29 & 5 & розовая \\
\hline Седум ложный Roseum & 19.04 & 30.06 & 41 & 5 & пурпурная \\
\hline Седум ложный Tricolor & 24.04 & 04.07 & 35 & 3 & розовая \\
\hline Седум Максимовича & 20.04 & 16.06 & 29 & 5 & желтая \\
\hline Седум Миддендорфа & 19.04 & 14.06 & 26 & 5 & желтая \\
\hline Седум пурпуровый & 30.04 & 09.08 & 40 & 4 & пурпурная \\
\hline Седум шестигранный & 22.04 & 21.06 & 33 & 4 & желтая \\
\hline
\end{tabular}

* - не имел цветения во все годы исследований

Выводы. Генофонд рода седум в НИИСС составляет 14 видов, 2 формы и 7 сортов. Имеющиеся в коллекции образцы разнообразны по фенологическим и биометрическим параметрам (окраска цветков, габитус куста, форма листьев, время цветения). Большинство из них (12) имеют высокие показатели адаптивности (зимостойкость, разрастание кустов, регулярное цветение), декоративности в условиях интродукции. Особенно выделены седум видный Осенняя радость, с. видный Matrona, с. камчатский, с. ложный белый, с. ложный Roseum. Седум гибридный Хеnox, сорта с. видного Red Imperator и Star Dast показывают низкую адаптацию.

\section{Список литературь}

1. Касынкина О.М. Возможности использования селена для декоративных особенностей очитка // Аграрная наука - сельскому: сборник материалов XIII Международной научно-практической конференции: в 2 кн. (15-16 февраля 2018 г) ФГБОУ ВО «Алтайский государственный аграрный университет». - 2018. - С. 47-48. 
2. Орлова О.Н., Сорокопудова О.А. Виды очитковых (Crassulaceae) для озеленения города Белгорода / Научные ведомости Белгородского государственного университета. - Серия: Естественные науки. - 2010. - Т. 9. - С. 45-48.

3. Верещагина И.В., Долганова 3.В. Зимующие многолетники, рекомендуемые для Алтайского края. Методические рекомендации. / Сиб. отд-ние ВАСХНИЛ, НИИСС. - Новосибирск. - 1985. - 36 с.

4. Методика государственного испытания сельскохозяйственных культур: Декоративные культуры. - М.: Колос, 1968. - Вып 6. - 223 с.

5. Карписонова Р.А. Травянистые растения широколиственных лесов. - М.: «Наука», 1985. - С. 56-62.

\section{Изменчивость шишек и семян клонов сосны кедровой сибирской (Pinus sibirica Du Tour) в Краснообске}

Лихенко Н.Н.*, к.с.-х.н., в.н.с.; Чудная А.П., агроном 1 категории; Капко Т.Н., м.н.с.

Сибирский научно-исследовательский институт растениеводства и селекиии - филиал ИЦиГ СО РАН, Новосибирск, Россия.

*e-mail: lihenko.n@yandex.ru

Приведены данные, характеризующие размеры шишек и семян клонов плюсовых деревьев сосны кедровой сибирской, произрастающих на территории дендропарка СибНИИРС - филиала ИЦиГ СО РАН. По совокупности признаков клонов выделился № 96, поскольку на нем формировались наиболее крупные и полнозернистые шишки с наибольшим выходом семян по массе (19,9 г) и массе 1000 семян (256,7 г).

Ключевые слова: сосна кедровая сибирская, клон, иишка.

\section{Variability of cones and seeds at clones of Siberian cedar pine in Krasnoobsk}

Likhenko N.N. *, Chudnaya A.P., Kapko T.N.

SibRIPP\&B - branch ICG SB RAS, Novosibirsk, Russia.

*e-mail: lihenko.n@yandex.ru

The data characterizing the sizes of cones and seeds of clones of plus trees of Siberian cedar pine, which are grows in the arboretum of SibRIPP\&B-branch ICG SB RAS, are provided. According to the totality of features, clone No. 96 stood out. It formed the largest and most full-grain cones with the highest seed yield by weight (19.9 g) and 1000 seeds $(256.7 \mathrm{~g})$.

Key words: Siberian cedar pine, clone, cone.

Сосна кедровая сибирская - это одна из наиболее значимых в хозяйственном отношении орехоплодных хвойных пород, представляющей интерес в качестве источника ценной древесины и продуктов пищевого и технического 
назначения. Кроме того, кедр сибирский отличается высокой декоративностью. Особый интерес представляют его семена - кедровые орехи, содержащие порядка 60 \% жира, богатые витаминами и отличающиеся очень высокой пищевой ценностью и усвояемостью [1]. Известно, что несколько хороших урожаев семян кедра сибирского полностью окупают стоимость его древесины [2]. В связи с чем особый интерес представляет его выращивание в культуре и изучение с целью отбора на семенную продуктивность.

Исследования проведены в условиях дендропарка СибНИИРС - филиала ИЦиГ СО РАН, в клоновом архиве, при создании которого были использованы привои с плюсовых деревьев кедра сибирского (Pinus sibirica Du Tour), отобранные и аттестованные в Колыванском лесхозе Новосибирской области. Клоновый архив был заложен весной 1990 г. на площади 1 га с размещением по садовому типу для обеспечения перекрестного опыления. 147 растений расположены рядами с запада на восток, поперек господствующих ветров высажена лесозащитная полоса из сосны обыкновенной (Pinus sylvestris L.).

В ходе эксперимента у 13 клонов сосны кедровой сибирской было изучено плодоношение в урожайный год. Сбор зрелых шишек проведен 1 сентября 2019 г. Раздельно собранные образцы пронумерованы в соответствии номеру клона. Просушены при комнатной температуре и влажности в течение двух месяцев. Собранный материал позволил провести анализ количественных параметров шишек и семян (длина шишек, диаметр в средней части, масса шишек, количество семян в шишке, масса семян в шишке). Крупность шишек определяли в соответствии с классификацией, предложенной Л.Ф. Правдиным [3]: крупные - более 8 см, средние - 6-8 см, мелкие - менее 6 см. Геометрическая форма была определена инструментально с использованием коэффициента формы (по отношению ширины к длине): коэффициент менее 0,80 - шишки цилиндрические, 0,81-0,90 - яйцевидные, более 0,90 - округлые. По числу семян в шишках делятся на многосемянные (120 шт. и более) и малосемянные (50 шт. и менее) [4]. За основу брали шишку, сформированную у кедра сибирского в таежных условиях, длиной от 5 до 13 см, диаметром от 4 до 8 см [5], весом от 50 до 58 г, с массой 1000 шт. семян в пределах 200-250 г [6]. Для оценки уровня изменчивости количественных признаков использовали шкалу, разработанную С.А. Мамаевым [7].

Целью настоящей работы послужил морфометрический анализ шишек и семян 29-летних клонов Pinus sibirica Du Tour, произрастающих в дендропарке СибНИИРС - филиала ИЦиГ СО РАН.

В результате исследования биометрических показателей шишек и семян клонов сосны кедровой сибирской (таблица) установлено, что средняя

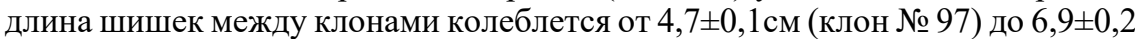
см (клон № 96). Уровень изменчивости длины шишек в клонах преимущественно низкий (CV 6,4-13,6 \%) (таблица). В соответствии с классификацией, предложенной Л.Ф. Правдиным [3], шишки формируются от мелких до средних размеров. Диаметр шишки колеблется от 3,6 0,1 см (клон № 24) до $4,7 \pm 0,1$ см (клоны №№ 96, 111), уровень изменчивости в пределах нижней нормы варьирования. Форма шишек зависит от отношения ее ширины к 
длине [4]. Шишки исследуемых образцов имеют преимущественно цилиндрическую форму. Клон № 97 имеет яйцевидную форму шишек. Средняя масса шишек клона № 96 (48,3 33,2 г) превышает весовые параметры шишек по всем клонам от 1,3 до 2,4 раза. С увеличением линейных размеров шишки увеличивается количество семян и масса семян. По числу семян выделяются

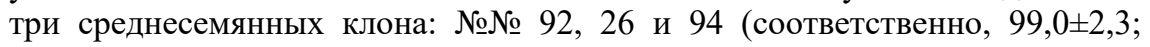
$99,9 \pm 3,2$ и $111,4 \pm 4,3$ шт. при среднем уровне варьирования), по массе семян

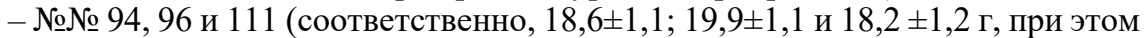
уровень изменчивости признака был повышенный). Масса 1000 шт. определяет качество семян, показывает запас питательных веществ, всхожесть, пищевую ценность. Показатели массы 1000 семян интродуцированных клонов кедра сибирского в исследуемом урожайном 2019 г. варьировали от $200,7 \pm 2,9$ г (клон № 97) до 256,7 $\pm 5,7$ г (клон № 96), что близко к показателям естественного ареала $[5,6]$.

Распределение семян в шишке по категориям (рисунок) характеризуется наличием нормальных семян (полнозернистых), недоразвитых, дефектных, прекративших свое развитие на различных стадиях. Причины дефективности могут быть различны. Среди исследуемых клонов только у № 89 доля недоразвитых семян составила $64,4 \%$, дефектных $-5,7 \%$. Наибольшее число нормальных семян в шишке (70,6 $\pm 3,9$ шт.) наблюдалось у клона № 96, полнозернистость (доля выполненных семян в шишке) составила 73,9 \%.

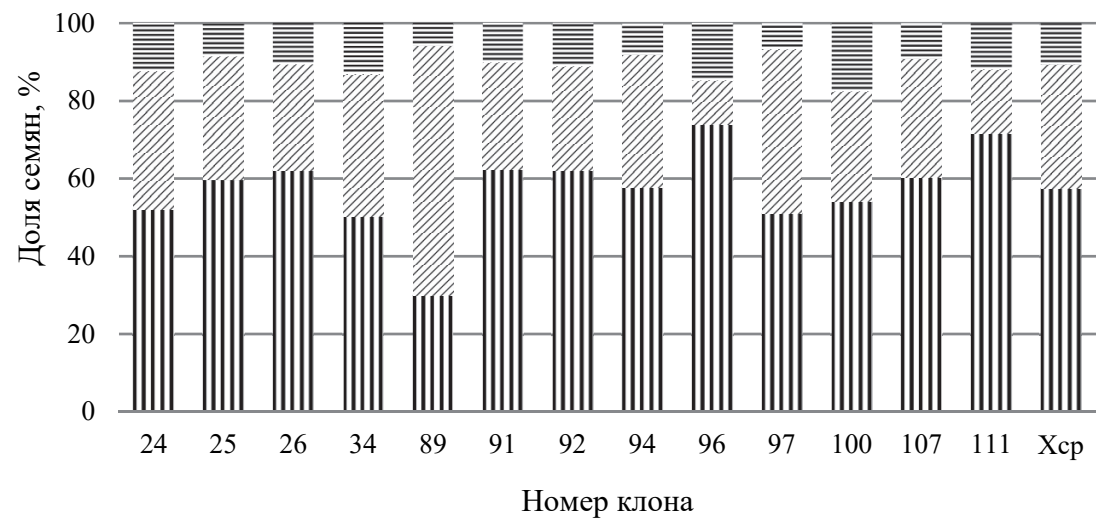

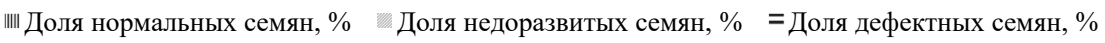

Рисунок - Распределение семян в шишке по категориям: нормальные (нормально развитые оплодотворенные семяпочки); недоразвитые (неоплодотворенные семяпочки и погибшие до оплодотворения); дефектные (пустые, гнилые, беззародышевые) [6]. 


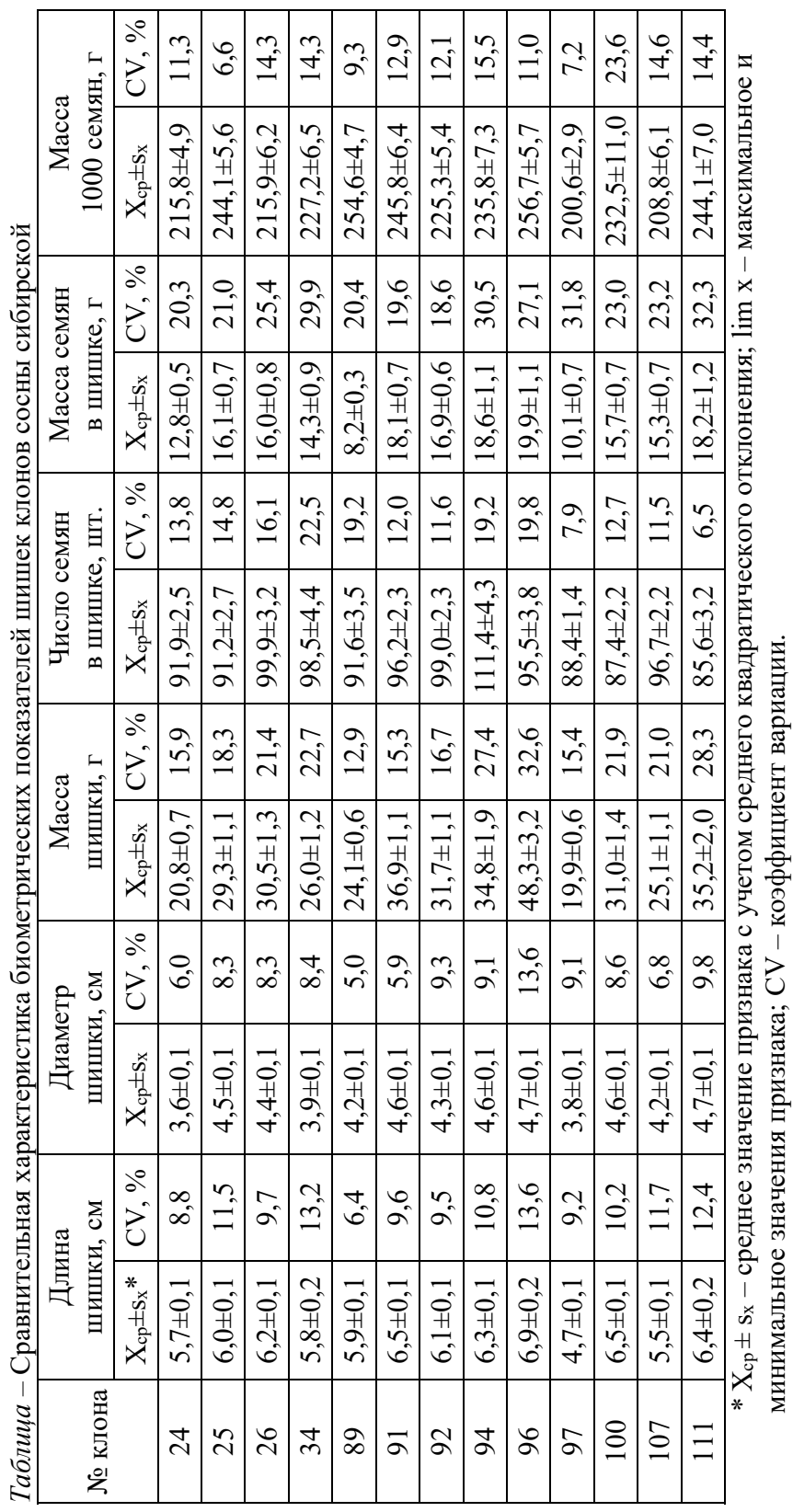


Заключение. В ходе изучения 13 интродукцированных клонов Pinus sibirica Du Tour установлено, что они формируют шишки и семена с размерами, близкими к средним показателям, характерным для естественных условий. По результатам оценки элементов продуктивности установлено, что в качестве наиболее привлекательных образцов можно отметить клоны: № 96 по длине и ширине шишки (6,9 и 4,7 см), по массе шишки (48,3 г), по массе семян в шишке (19,9 г), по массе 1000 семян (256,7 г), и № 94 - по числу зерен в шишке (111,4 шт.), по массе семян в шишке $(18,6$ г). По совокупности признаков среди исследованных клонов выделился № 96, поскольку на нем формировались наиболее крупные и полнозернистые шишки с наибольшим выходом семян по массе и массе 1000 шт. Таким образом, его можно считать наиболее пригодным для дальнейшего изучения в селекции, а также для сбора прививочного материала с целью создания прививочной плантации сосны сибирской кедровой.

Благодарности: Работа поддержана бюджетным проектом ИЦиГ СО PAH № 0324-2019-0039-C-01.

\section{Список литературы}

1. Ефремов А.А. Перспективы малотоннажной переработки кедровых орехов в продукты пищевого и технического назначения / А.А. Ефремов // Химия растительного сырья. - 1998. - № 3. - С. 83-86.

2. Земляной, А.И. О создании постоянной семенной базы кедра сибирского в Ханты-Мансийском округе (ХМАО - Юрга) / А.И. Земляной, В.И. Барановский // Лесное хозяйство. - 2008. - № 5. - С. 34-35.

3. Правдин Л.Ф. Селекция и семеноводство кедра сибирского / Л.Ф. Правдин // Плодоношение кедра сибирского в Восточной Сибири. М.: АН СССР, 1963. - С. 5-21.

4. Братилова Н.П. Биология и формовое разнообразие сосны кедровой сибирской / Н.П. Братилова, Р.Н. Матвеева, О.Ф. Буторова // Экопотенциал. - 2014. - №1. C. $120-127$.

5. Бех И.А. Сибирское чудо-дерево / И.А. Бех, И.В. Таран // Новосибирск: Наука, 1979. - 126 c.

6. Некрасова, Т.П. Биологические основы семеношения кедра сибирского / Т.П. Некрасова. - Новосибирск, 1972. - 273 с.

7. Мамаев С.А. Формы внутривидовой изменчивости древесных растений / С.А. Мамаев. - М.: Наука, 1973. -284 с. 


\section{Оценка возможности применения SRAP-маркеров для ДНК- идентификации российских сортов люцерны}

Мавлютов Ю.М.*, м.н.с. аспирант; Шамустакимова А.О., н.с.; Клименко И.А., к.с.-х.н., с.н.с. ФНЦ «ВИК им. В.Р. Вильямса», г. Лобня, Россия *e-mail: yulian92@mail.ru

Изучалась возможность использования SRAP-маркеров для идентификации сортов лючерны отечественной селекции. Результаты исследований показали, что данная маркерная техника пригодна для выявления межсортовых различий на генетическом уровне.

Ключевые слова: геном, люиерна, SRAP-маркеры, полиморфизм ДНК, генетическое разнообразие.

\section{Estimation of the possibility to use SRAP-markers for DNA-identification of Russian alfalfa cultivars}

Mavlyutov Y.M.*, Shamustakimova A.O., Klimenko I. A.

Federal Williams Research Center of Forage Production \& Agroecology, Lobnya, Russia.*e-mail: yulian92@mail.ru

The results of using SRAP-markers for identification of Russian alfalfa cultivars are presented in this study. It was found that this marker system is suitable for evaluation the differences between the analyzed cultivars.

Key words: genome, alfalfa, SRAP-markers, DNA-polymorphism, genetic diversity.

Люцерна является ценной кормовой культурой, широко используемой в качестве источника дешевого растительного белка и энергии для всех видов скота и птицы. Ее применяют в виде зеленого корма, как сырье для приготовления силоса, сенажа и травяной муки [1], включают в состав травосмесей с целью обогащения почвы биологическим азотом и активации микробиологических процессов. Биологические и хозяйственно-ценные особенности этой культуры обусловили создание системы современных сортов, обладающих высокой продуктивностью, долголетием, устойчивостью к болезням и вредителям [2].

До настоящего времени российские сорта люцерны различают только по морфологическим признакам. Выгодно отличаются от классических подходов методы ДНК-идентификации. Они не требуют фенотипического проявления признака, могут применяться на любой стадии развития растений и существенно сокращают затраты труда и времени на выявление межвидовых 
и межсортовых различий. Для оценки генетического разнообразия используют различные молекулярные маркерные системы, каждая из которых имеет свои преимущества и недостатки [3]. Простым и эффективным является метод, основанный на использовании SRAP-маркеров (Sequence-related amplified polymorphism) для амплификации интрон-экзонных областей генома, или открытых рамок считывания (Open reading Frame, ORF) исследуемых организмов. Вариабельность продуктов ПЦР достигается за счет обратного праймера, нацеленного на некодирующую область генома, обладающую низкой консервативностью. Использование SRAP-маркеров при оценке генетического разнообразия позволяет получить надежные и воспроизводимые результаты [4, 5].

Целью нашего исследования являлась оценка SRAP-маркерной системы, как инструмента для выявления различий между сортами люцерны отечественной селекции.

Материалы, методы и условия проведения исследований. Объектом исследования служили 18 сортов и образцов люцерны, относящиеся к разным видам (табл. 1).

Таблица 1 - Перечень исследуемых сортов люцерны

\begin{tabular}{|c|l|l|}
\hline №№ & \multicolumn{1}{|c|}{ Наименование сорта } & \multicolumn{1}{c|}{ Вид } \\
\hline 1 & Луговая 67 & Medicago varia Mart. \\
\hline 2 & Вега 87 & Medicago varia Mart. \\
\hline 3 & Лада & Medicago varia Mart. \\
\hline 4 & Агния & Medicago varia Mart. \\
\hline 5 & Тамбовчанка & Medicago sativa L. \\
\hline 6 & Камелия & Medicago varia Mart. \\
\hline 7 & Воронежская & Medicago varia Mart. \\
\hline 8 & Влада & Medicago varia Mart. \\
\hline 9 & Селена & Medicago varia Mart. \\
\hline 10 & Таисия & Medicago varia Mart. \\
\hline 11 & Мира & Medicago lupulina L. \\
\hline 12 & Вела & Medicago varia Mart. \\
\hline 13 & Сарга & Medicago varia Mart. \\
\hline 14 & Пастбищная 88 & Medicago varia Mart. \\
\hline 15 & Сортообразец А2 & Medicago varia Mart. \\
\hline 16 & Узень & Medicago sativa L. \\
\hline 17 & Находка & Medicago varia Mart. \\
\hline 18 & Благодать & Medicago varia Mart. \\
\hline
\end{tabular}

Для выделения ДНК использовали 7-дневные проростки и коммерческий набор реагентов «ДНК-ЭКСТРАН-3» от компании «Синтол» (Россия).

Реакционная смесь объемом 25 мкл содержала 10x Taq Turbo buffer, 50x dNTP mix, 2U Taq-ДНК полимеразы, а также по 0,2 мкМ каждого праймера и 20 нг ДНК. Амплификация проходила на приборе «Bio-Rad iCycler, 
USA» в соответствии с условиями, предложенными Li и Quiros [4] с внесением некоторых модификаций. Детекция результатов ПЦР проводилась путем электрофореза в 1,6 \% агарозном геле. Для оценки размера продуктов амплификации использовали молекулярный маркер $1 \mathrm{~kb}$ DNA Ladder («Евроген», Россия).

Результаты и обсуждение. Для генотипирования 18 сортов и образцов люцерны использовали 25 комбинаций из одиночных SRAP-праймеров (табл. 2), синтез которых осуществлен в компании «Евроген» на основе информации, полученной из источников литературы [6].

Таблица 2 - Нуклеотидные последовательности SRAP - праймеров, использованных для выявления полиморфных локусов

\begin{tabular}{|c|c|c|c|}
\hline $\begin{array}{c}\text { Прямые } \\
\text { праймеры } \\
(\mathrm{F})\end{array}$ & $\begin{array}{c}\text { Последовательность } \\
\left(5^{\prime} \rightarrow 3^{\prime}\right)\end{array}$ & $\begin{array}{c}\text { Обратные } \\
\text { праймеры } \\
(\mathrm{R})\end{array}$ & $\begin{array}{c}\text { Последовательность } \\
\left(5^{\prime} \rightarrow 3^{\prime}\right)\end{array}$ \\
\hline F9 & GTAGCACAAGCCGGACC & R9 & GACTGCGTACGAATTTCA \\
\hline F13 & CGAATCTTAGCCGGCAC & R7 & GACTGCGTACGAATTGAG \\
\hline Me4 & CGAATCTTAGCCGGAAT & Em2 & GACTGCGTACGAATTCGG \\
\hline F10 & GTAGCACAAGCCGGAAG & R14 & CGCACGTCCGTAATTAAC \\
\hline F11 & CGAATCTTAGCCGGATA & R8 & GACACCGTACGAATTGAC \\
\hline
\end{tabular}

По результатам ПЦР-анализа отобраны 7 информативных комбинаций, позволяющих выявить ДНК-полиморфизм исследуемых сортов (табл. 3).

Таблица 3 - Результаты оценки ДНК-полиморфизма сортов люцерны с использованием SRAP-маркеров

\begin{tabular}{|c|c|c|c|c|}
\hline $\begin{array}{c}\text { Комбина- } \\
\text { ция прай- } \\
\text { меров }\end{array}$ & $\begin{array}{c}\text { Общее коли- } \\
\text { чество ПЦР- } \\
\text { продуктов }\end{array}$ & $\begin{array}{c}\text { Размер ПЦР- } \\
\text { продуктов, п. н. }\end{array}$ & $\begin{array}{c}\text { Количество по- } \\
\text { пиморфных } \\
\text { ПЦР-продуктов }\end{array}$ & $\begin{array}{c}\% \\
\text { полиморфизма }\end{array}$ \\
\hline F9-R9 & 25 & $105-490$ & 7 & 28 \\
\hline F9-R8 & 14 & $125-385$ & 3 & 21 \\
\hline F13-Em2 & 9 & $125-235$ & 3 & 33 \\
\hline F10-R7 & 16 & $165-708$ & 6 & 38 \\
\hline F10-R8 & 27 & $145-708$ & 8 & 30 \\
\hline F13-R9 & 20 & $60-485$ & 5 & 25 \\
\hline F13-R7 & 18 & $50-305$ & 9 & 50 \\
\hline
\end{tabular}

С использованием информативных SRAP-праймеров удалось выявить 129 ПЦР-продуктов, из которых 41 оказался полиморфным. При этом длина ПЦР-продуктов варьировала от 50 до 708 пар нуклеотидов.

Сорт Мира (Medicago lupulina L.) выделялся среди других образцов наличием уникальных фрагментов амплификации со всеми испытанными комбинациями праймеров. В качестве примера на рисунке представлена электрофореграмма ПЦР-продуктов, полученных с использованием прай- 
мерной пары F10-R7 (белой стрелкой обозначен ампликон 275 п.н., отличающий его от остальных сортов). С этой же комбинацией праймеров обнаружен специфический ампликон для сорта Селена в 316 п.н. (обозначен черной стрелкой).

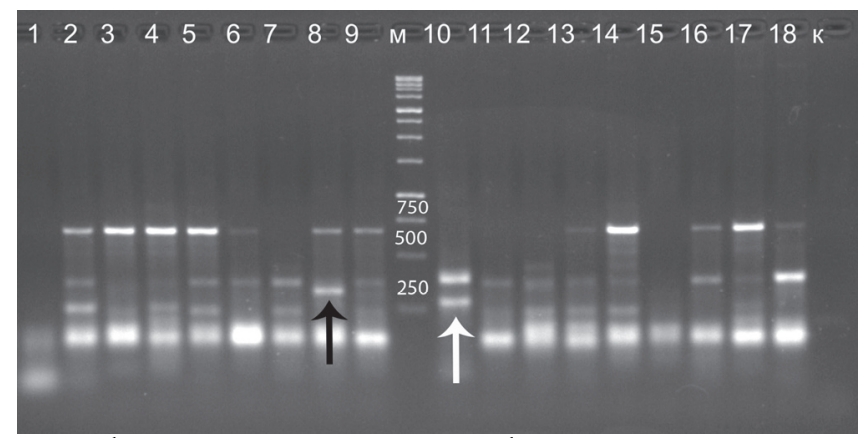

Рисунок. Электрофореграмма продуктов амплификации ДНК сортов люцерны с комбинацией SRAP-праймеров F10-R7, где лунки 1-18 сорта: Вега 87, Лада, Агния, Тамбовчанка, Камелия, Воронежская, Влада, Селена, Таисия, Мира, Вела, Сарга, Пастбищная 88, сортообразец А2, Луговая 67, Узень, Находка, Благодать, к - контроль $\left(\mathrm{H}_{2} \mathrm{O}\right)$, м - маркер молекулярного веса $1 \mathrm{~kb}$ DNA Ladder.

По результатам проведенного исследования можно сделать вывод о пригодности ПЦР-техники на основе SRAP-маркеров для оценки различий между российскими сортами и видами люцерны. Способность SRAPмаркеров амплифицировать кодирующие последовательности в геноме открывает возможности для идентификации локусов, связанных с хозяйственно-ценными признаками [4].

\section{Список литературь}

1. Писковацкий Ю.М. и др. Агротехника возделывания сортов люцерны селекции ВНИИ кормов им. ВР Вильямса на семенные и кормовые цели. - 2008. - С. 3-15.

2. Косолапов В.М. и др. Актуальные направления селекции и использование люцерны в кормопроизводстве. - 2014. - С. 4-6.

3. Хлесткина Е.К. Молекулярные маркеры в генетических исследованиях и в селекции // Вавиловский журнал генетики и селекции. - 2015. - Т. 17. - №. 4/2. - С. 1044-1054.

4. Li G., Quiros C.F. Sequence-related amplified polymorphism (SRAP), a new marker system based on a simple PCR reaction: its application to mapping and gene tagging in Brassica // Theoretical and applied genetics. - 2001. - T. 103. - №. 2-3. - C. 455-461.

5. Robarts D.W.H., Wolfe A.D. Sequence-related amplified polymorphism (SRAP) markers: A potential resource for studies in plant molecular biology1//Applications in plant sciences. - 2014. - T. 2. - №. 7. - C. 1400017.

6. Rhouma H.B. et al. Assessment of the genetic variation in alfalfa genotypes using SRAP markers for breeding purposes // Chilean journal of agricultural research. - 2017. T. 77. - №. 4. - C. 332-339. 


\section{Генофонд и селекция абрикоса в Среднем Приамурье}

Михайличенко О.А., с.н.с.; Юдаева Н.В., м.н.с ФГБУН Хабаровский Федеральный исследовательский иентр Дальневосточного отделения Российской академии наук, Дальневосточный научно-исследовательский институт сельского хозяйства, Хабаровск, Россия. e-mail:lab_plod@mail.ru

Объектами исследований абрикоса являются созданные сорта и формы дальневосточной селекиии, и их гибриды. Детальное изучение биологических и хозяйственно - ценных признаков позволяет оценить их селекиионною значимость в процессе получения новых сортов. Задача селекиионной работы с абрикосом состоит в создании новых сортов, сочетающих в себе высокие хозяйственно - ценные признаки, а также устойчивость к биотическим и абиотическим стрессорам Среднего Приамурья

Ключевые слова: селекиия, абрикос, сортоизучение, гибридизачия, биотические и абиотические стрессоры.

\section{Genepound and apricot selection in the Middle Amur}

Mikhailichenko O.A, Senior Researcher, Yudaeva N.V., Junior Researcher, Federal State Budgetary Institution Khabarovsk Federal Research Center of the Far Eastern Branch of the Russian Academy of Sciences, Far Eastern Agricultural Research Institute Khabarovsk, Russia,Lab_plod@mail.ru

The objects of apricot research are the created varieties and forms of Far Eastern selection, and their hybrids. A detailed study of biological and economically valuable traits allows us to evaluate their breeding importance in the process of obtaining new varieties. The task of breeding work with apricot is to create new varieties that combine high economically valuable traits, as well as resistance to biotic and abiotic stressors of the Middle Amur Region

Key words: selection, apricot, variety study, hybridization, biotic and abiotic stressors.

В дикорастущем состоянии и культуре род абрикоса представлен восьмью видами: абрикос обыкновенный (A. vulgaris), абрикос сибирский (A. sibirica), абрикос маньчжурский (A. manshurica), абрикос Давида (A. davidi$a n a)$, абрикос Ансу (A. ansu), абрикос Муме (A. тите), абрикос тибетский (A. noloserieca) и абрикос волосистоплодный или черный (A. dasyearpa).

Северо-восточная Азия является центром происхождения и одним из древнейших очагов формообразования абрикоса. Здесь в результате совместного произрастания и естественной гибридизации абрикоса обыкновенного с северными видами - маньчжурским, сибирским, Давида - возникли наиболее 
зимостойкие формы, которые послужили исходным материалом для создания культурных сортов абрикоса на Дальнем Востоке [1].

Формирование культурного сортимента абрикоса на Дальнем Востоке началось в 20-х годах прошлого века, но проводилось это на уровне садоводов-любителей. Планомерная работа с абрикосом была развернута в ДВ НИИСХ в 1938 году [2]. Основное ее направление - выведение высокозимостойких и урожайных сортов с товарными плодами хороших вкусовых качеств разных сроков созревания. Работа по созданию местного сортимента абрикоса осуществлялась несколькими путями:

- отбор ценных форм среди сеянцев от свободного опыления восточноазиатской и европейской групп сортов;

- межсортовые скрещивания сортов восточноазиатской группы;

- скрещивание сортов из восточноазиатской группы с европейскими и среднеазиатскими сортами;

- межродовые скрещивания - дальневосточные сливы + восточноазиатские абрикосы.

За истекшие более чем 80 лет произведен большой объем скрещиваний. Селекционерами Г.Т. Казьминым, В.А. Марусичем и Е.Ф. Королевой получено более 20 культурных сортов, среди которых Хабаровский, Академик, Серафим, Ранний Марусича, Подарок БАМу, Петр Комаров и другие [3]. Они до сих пор составляют основу сортимента для Дальнего Востока (табл. 1).

Таблица 1 - Характеристика основных сортов абрикоса, лаборатория плодоводства ДВ НИИСХ

\begin{tabular}{|l|c|c|c|c|c|c|}
\hline \multicolumn{1}{|c|}{ Сорт } & $\begin{array}{c}\text { Скороплод- } \\
\text { ность, год }\end{array}$ & $\begin{array}{c}\text { Сила ро- } \\
\text { ста, м }\end{array}$ & $\begin{array}{c}\text { Сроки со- } \\
\text { зревания }\end{array}$ & $\begin{array}{c}\text { Поражение } \\
\text { болезнями, } \\
\text { балл }\end{array}$ & $\begin{array}{c}\text { Зимостой- } \\
\text { кость }\end{array}$ & $\begin{array}{c}\text { ностай- } \\
\text { ц/га }\end{array}$ \\
\hline Академик & 4 & 4,7 & $5-15.08$ & 2,2 & средняя & 151,8 \\
\hline Амур & 5 & 4,5 & $10-15.08$ & 2,0 & высокая & 133,6 \\
\hline Гритиказ & 4 & 4,7 & $10-15.08$ & 1,0 & высокая & 148,5 \\
\hline Казмар & 4 & 2,9 & $12-19.08$ & 1,5 & высокая & 149,3 \\
\hline Подарок БАМу & 3 & 3,1 & $19.07-5.08$ & 1,0 & высокая & 138,8 \\
\hline Титан & 4 & 3,2 & $4-11.08$ & 1,5 & высокая & 150.9 \\
\hline Хабаровский & 4 & 4,8 & $25.07-5.08$ & 1,5 & высокая & 149,7 \\
\hline
\end{tabular}

Наряду с устойчивостью к неблагоприятным факторам среды, высокой урожайностью, большое значение для сорта абрикоса имеют такие показатели, как масса плода, вес косточки и их соотношение, характер вкуса ядра косточки, что важно учитывать при переработке плодов.

Плоды большинства сортов относятся к крупноплодным. На фоне всех сортов выделяется сорт Академик со средней массой плода 40,5 г (табл. 2). 
Таблица 2 - Технические показатели плодов сортов абрикоса селекции ДВ НИИСХ

\begin{tabular}{|l|c|c|c|c|}
\hline \multirow{2}{*}{ Сорт } & \multicolumn{3}{|c|}{ Показатели плода } & \multirow{2}{*}{$\begin{array}{c}\text { Вкус ядра } \\
\text { косточки }\end{array}$} \\
\cline { 2 - 4 } & $\begin{array}{c}\text { Средняя масса } \\
\text { плодов, г }\end{array}$ & $\begin{array}{c}\text { Макс. масса } \\
\text { плодов, г }\end{array}$ & $\begin{array}{c}\text { Диаметр в двух } \\
\text { плоскостях, мм }\end{array}$ & сладкий \\
\hline Академик & 40.5 & 55,3 & $42 / 37$ & горький \\
\hline Амур & 26,2 & 39,1 & $39 / 38$ & сладкий \\
\hline Гритиказ & 25,8 & 41,0 & $39 / 40$ & сладкий \\
\hline Казмар & 26,0 & 36.0 & $40 / 41$ & сладкий \\
\hline Подарок БАМу & 30,7 & 39,2 & $40 / 39$ & сладкий \\
\hline Титан & 33,2 & 40,5 & $41 / 35$ & сладкий \\
\hline Хабаровский & 31,2 & 45,2 & $40 / 34$ & \\
\hline
\end{tabular}

Объектами исследований абрикоса являются созданные сорта и формы дальневосточной селекции, и их гибриды. Детальное изучение биологических и хозяйственно - ценных признаков позволяет оценить их селекционною значимость в процессе получения новых сортов. Главная роль в селекции принадлежит целенаправленному подбору исходных родительских форм при выведении новых сортов с заданными биологическими и хозяйственно ценными свойствами [4]. Для того, чтобы получить высокозимостойкий сорт абрикоса, необходимо, чтобы исходные родительские сорта, от которых происходят сеянцы, обладали прежде всего высокой устойчивостью к биотическим и абиотическим стрессорам Среднего Приамурья, в сочетании с урожайностью и качественными товарными плодами, компактностью деревьев для использования в садах интенсивного типа. Задачу можно решить путем создания и накопления гибридного материала с целью дальнейшего его использования в селекции и гибридизации лучших по отдельным признакам сеянцев с сортами улучшителями или друг с другом [5]. Наиболее эффективным методом при работе по селекции абрикоса мы считаем метод аналитической селекции, массовый отбор сеянцев, полученных от свободного опыления.

Лучшим подвоем для дальневосточных сортов абрикоса, по нашему мнению, является - абрикос маньчжурский. Абрикос маньчжурский характеризуется высокой зимостойкостью и очень коротким периодом покоя, который наступает в связи с резким похолоданием в осенне-зимний период. В условиях муссонного климата Дальнего Востока, где в течение зимы удерживается низкая температура без оттепелей, не наблюдается подмерзания почек и цветков от возвратных весенних заморозков. Не бывает и подопревания коры у корневой шейки.

За последние четыре года генофонд абрикоса лаборатории плодоводства ДВ НИИСХ пополнился тремя новыми сортами по своим характеристикам отвечающим современным требованиям к абрикосу для Дальневосточного региона. 
Гритиказ - Сорт включен в Госреестр по Дальневосточному (12) региону. Патент № 9979, 23.01.2019 г. Универсальный, позднего срока созревания.

Дерево большое, с раскидистой кроной средней густоты. В плодоношение вступает на 5-ый год. Плоды плоской формы, с красноватой покровной окраской, средней массой 25,8 г. Кожица слабо опушена. Мякоть желтая, волокнистая, кисло-сладкого вкуса. Дегустационная оценка - 4,5 балла. В плодах содержится: сухих веществ $11,1 \%$, сахара $8,5 \%$, кислоты $1,8 \%$, витамина С 7,7 мг/\%. Средняя урожайность - 148 ц/га. Зимостойкость высокая.

Казмар - В 2019 году сорт предан на Государственное сортоиспытание. Универсальный, позднего срока созревания. Дерево средних размеров с разряженной кроной. В плодоношение сорт вступает на третий год. Форма плода плоская, средний вес плодов 26 г, (максимальный 36 г), окраска плода желто - оранжевая, вкус кисло-сладкий. Дегустационная оценка - 4,7 балла. В плодах содержится: сухих веществ $11,3 \%$, сахара $8,7 \%$, кислоты $1,8 \%$, витамина С 7,7 мг/\%. Средняя урожайность - 149,3 ц/га. Зимостойкость высокая.

Титан - 2016 году сорт предан на Государственное сортоиспытание. Универсальный, среднего срока созревания. Дерево средней силы роста, крона густая, округло-вытянутая. В плодоношение вступает на третий год. Средняя масса плода 33,2 г, (максимальная 40,5 г). Форма округлая. Окраска плода желтая, покровная красноватая. Мякоть нежная, оранжевая от кожицы, сочная, освежающая, приятного кисло-сладкого вкуса. Дегустационная оценка - 4,8 балла. В плодах содержится: сухих веществ 10,1 \%, сахара 9,1 $\%$, кислоты $1,8 \%$, витамина С 7,7 мг/\%. Средняя урожайность - 150,9 ц/га. Зимостойкость сорта высокая.

\section{Список литературы}

1. Асеева, Т.А. Энциклопедия садоводства Приамурья / Т.А. Асеева, О.А. Михайличенко, Е.С. Тихомирова - Хабаровск: изд-во Тихоокеанского гос. ун-та, 2015. -243 с.

2. Казьмин Г.Т. Дальневосточный абрикос / Г. Т. Казьмин, В. А. Марусич. - 2-е изд., перераб. и доп. - Хабаровск: Кн. изд-во, 1989. - 157 с.

3. Царенко, В.П. История садоводства на Дальнем Востоке / В.П. Царенко, Н.А. Царенко. - Владивосток: Морской гос. ун-т, 2017. - 300 с.

4. Исаев, С.И. Современные методы селекции плодовых и ягодных культур / С.И. Исаев. - Москва: «Знания», 1979. - 302 с.

5. Матюнин, М.Н. Биологические особенности и селекция косточковых культур в Горном Алтае / М.Н. Матюнин. - Новосибирск: 2016. - 344 с. 


\title{
Разработка информационной системы для описания наблюдений за фенотипическими признаками сельскохозяйственных растений
}

\author{
Молодияов B.B., cm.nреп., НГУ, г. Новосибирск, Россия, vv@fen.nsu.ru \\ Афонников Д.А. *, к.б.н., в.н.с., ИЦиГ СО РАН, г. Новосибирск, Россия \\ *e-mail:ada@bionet.nsc.ru
}

Разработана компьютерная система 'Observer', которая позволяет осуществлять сбор данных по селекиионно-генетическим экспериментам, полученных, прежде всего, в результате полевого мониторинга посевов. Ее структура позволяет гибким образом формировать описание признаков растений и мест проведения эксперимента, учитывать условия среды и даты проведения измерений.

Ключевые слова: селекичонно-генетический эксперимент, фенотипирование растений, полевые наблюдения, база данных.

\section{Information system for collecting and storing phenotypic observation in crop plants}

Molodtsov V.V., senior lecturer, NSU, Novosibirsk, Russia,vv@fen.nsu.ru Afonnikov D.A., kand.biol.sci., leading researcher, ICG SB RAS, Novosibirsk, Russia,ada@bionet.nsc.ru

The information system 'Observer' developed for collection and storing of the data for breeding experiment, mostly from field observations. The structure of the system allows to describe wide range of plant phenotypic traits, locations, environment anв measurement time.

Key words: breeding experiment, plant phenotyping, field observations, database.

Современные селекционно-генетические эксперименты по созданию новых сортов и гибридов сельскохозяйственных растений опираются на использование информации как о генотипах растений, так и их фенотипов, а также условиях окружающей среды [1]. Данные наблюдений за растениями могут быть использованы для моделирования урожая с использованием современных математических и численных методов [2]. Фенотипические данные разнообразны, могут описывать десятки характеристик растений и измеряются в течение всей вегетации. Для селекционера измерения этих признаков происходят в полевых условиях и заносятся в полевой журнал наблюдений. Ведение таких журналов рутинная и трудоемкая процедура. В этой связи, создание технологий эффективного сбора данных о полевых наблюдениях и фенотипических признаках растений является актуальной задачей. 
Для решения этой задачи в работе была разработана база данных “Observer” для хранения информации о фенотипических признаках растений, измеренных в процессе вегетации.

Данная система в качестве объекта исследований использует делянку растений, для которой определены географические координаты и название месторасположения. Для делянки определена структура данных “Эксперимент”, которая хранит информацию об измерении различных фенотипических характеристик растений, включая фенологические данные, характеристики урожайности, степень повреждения растений патогенами и вредителями (рис.1).

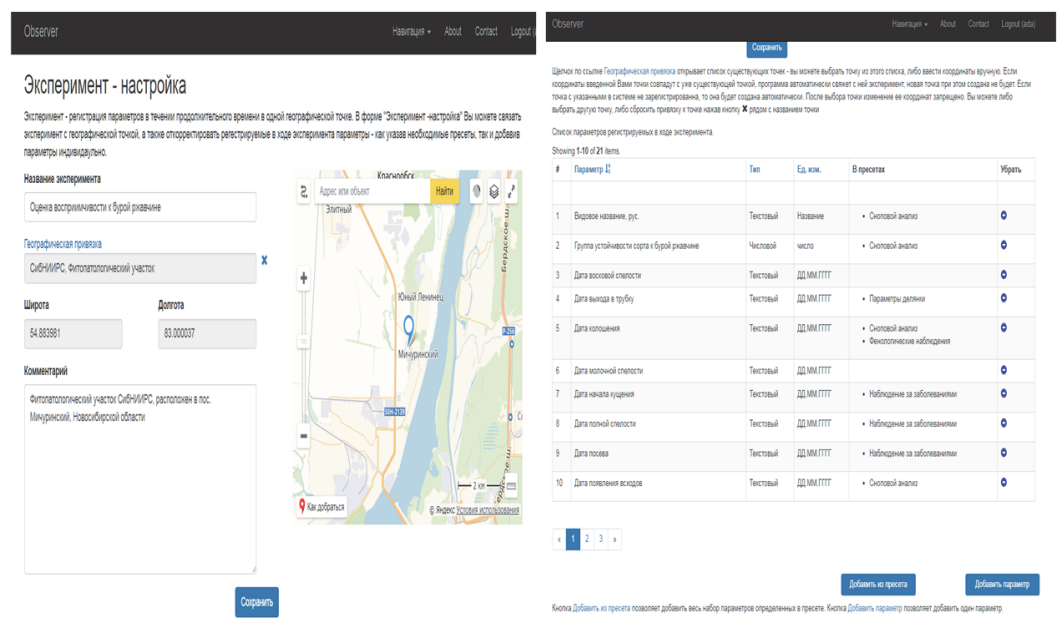

Рисунок 1. Настройка эксперимента: слева представлена страница создания эксперимента; справа - страница формирования параметров растений.

Наблюдения над растениями в эксперименте характеризуются датой, набором параметров, а также их значениями. Для эксперимента определяется заранее заданный набор параметров, каждый из которых задан следующими характеристиками: название, тип (числовой или текстовый), единицей измерения. Для параметра также определяется его принадлежность к блоку параметров, несколько параметров могут быть объединены в блок. Один параметр может находиться в нескольких блоках. Такая группировка параметров является удобной для описания групп фенотипических, генетических признаков и признаков окружения. Например, в текущей версии базы данных мы определили блок параметров, который характеризует воздействие патогена на растение и реакцию растения (рис. 2): группа устойчивости сорта к бурой 
ржавчине; индекс устойчивости к бурой ржавчине; латентный период поражения бурой ржавчиной; патотип патогена; поражение листовой пластинки бурой ржавчиной; тип реакции на бурую ржавчину; уровень устойчивости к бурой ржавчине; устойчивость сорта к бурой ржавчине.

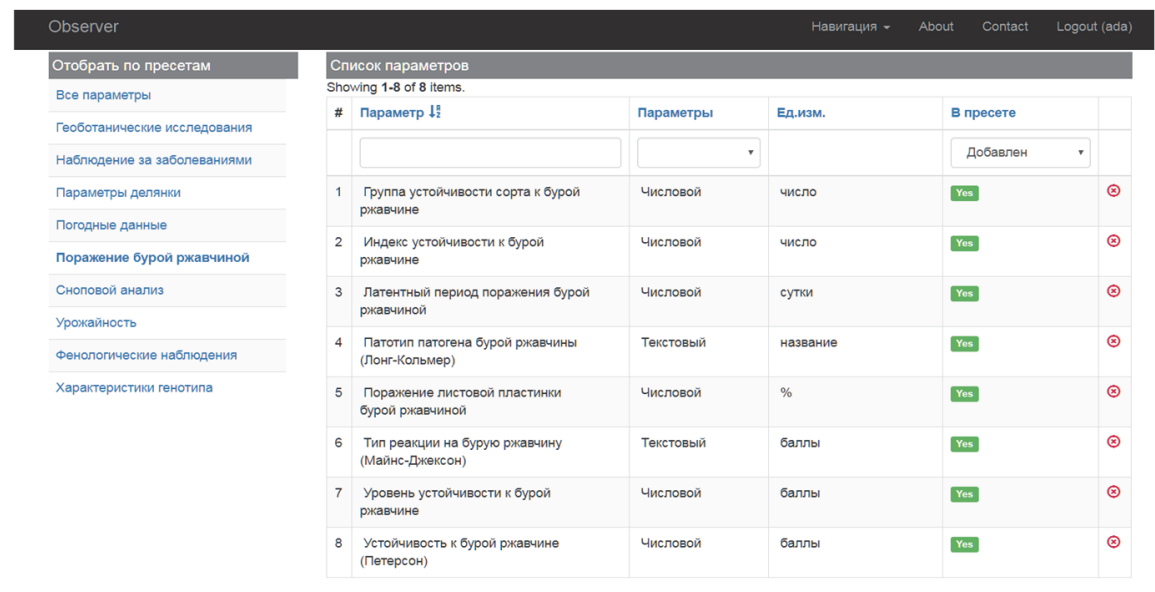

Щелчок по флажку "В пресете" изменит статус.

Рисунок 2. Набор параметров, характеризующие взаимодействия патоген-хозяин для бурой ржавчины (P. triticina) и пшеницы в системе сбора и хранения данных.

Большое разнообразие фенотипических характеристик, проведение экспериментов в разных лабораториях и географических точках обуславливают актуальность стандартизации описания фенотипических параметров растения, условий среды и селекционно-генетического эксперимента. Для решения данной проблемы мы использовали дополнительное описание фенотипических признаков растений, представленных в виде онтологий, структурированных и контролируемых словарей биологических терминов [3]. Описания онтологий взяты на сайте pecypca CropOntology (www.cropontology.org).

В системе также реализована возможность интеграции фенотипических данных с результатами метеонаблюдений, которые могут быть получены через Web c ближайшей к месту проведения эксперимента метеостанции.

Разработанная система позволяет автоматизировать сбор информации о результатах наблюдений и оценки фенотипических параметров в процессе выполнения селекционно-генетических экспериментов.

Благодарности: Работа выполнена при поддержке РФФИ (проект № 17-29-08028). При создании базы данных и информационной системы использовались вычислительные ресурсы ЦКП «Биоинформатика» при поддержке бюджетного проекта №0324-2019-0040-С-01. 


\section{Список литературь}

1. Афонников Д.А. и др. Методы высокопроизводительного фенотипирования растений для массовых селекционно-генетических экспериментов // Генетика. -2016. - T. 52. - №. 7. - C. 788-803.

2. Brisson N. et al. An overview of the crop model STICS. // Eur. J. Agron. 2003. - V. 18 - № 3-4 - P. 309-332.

3. Shrestha R. et al. Bridging the phenotypic and genetic data useful for integrated breeding through a data annotation using the Crop Ontology developed by the crop communities of practice //Frontiers in physiology. - 2012. - T. 3. - C. 326.

DOI 10.18699/GPB2020-52

\section{Межсортовая хромосомная изменчивость рапса}

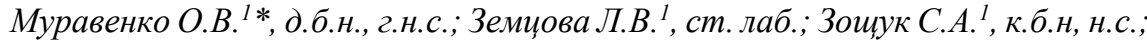
Воловик B.T. ${ }^{2}$, к.с.-х.н., зав.отд.; Юркевич O.Ю. ${ }^{1}$, к.б.н, н.с.; Саматадзе T.E. ${ }^{l}$, к.б.н, н.с.; Амосова А.B. ${ }^{l}$, к.б.н, с.н.с.

${ }^{I}$ ФБУУН Институт молекулярной биологии им. В.А. Энгельгардта РАН, Москва, Российская Федерачия;

${ }^{2}$ ФГБНУ Федеральный научный иентр кормопроизводства и агроэкологии им. В.Р. Вильямса, Московская область, г. Лобня, Российская Федерация. *e-mail:olgmur1@yandex.ru

Впервые исследована хромосомная изменчивость у сортов рапса, произрастающих в районах рискованного земледелия. Анализ структуры кариотипов и хромосомного распределения $45 S$ и $5 S$ рДНК выявил наличие полиморфных вариантов хромосом по локализации и числу этих маркеров в $A$ - $u$ C-субгеномах рапса. Наиболее часто такие полиморфные варианты наблюдались на 1, 3 и 4 парах гомологичных хромосом А-субгенома. В кариотипах растений некоторых сортов выявлен гетероморфизм гомологов, который также чаще обнаруживался на хромосомах А-субгенома. Наши результать указывают на повыленный уровень хромосомного полиморфизма в озимых сортах рапса, по сравнению с яровыми.

Ключевые слова: Brassica napus ssp. oleifera (DC.) Metzg., кариотип, FISH, хромосомный полиморфизм.

\section{Chromosomal variability in rapeseed varieties}

Muravenko O.V. ${ }^{1}$, Zemtsova L.V. ${ }^{1}$, Zoshchuk S.A. ${ }^{l}$, Yurkevich O.Yu. ${ }^{l}$, Volovik V.T. ${ }^{2}$, Samatadze T.E. ${ }^{1}$, Amosova A.V. ${ }^{1}$

${ }^{1}$ Engelhardt Institute of Molecular Biology, Russian Academy of Sciences, Moscow, Russian Federation E-mail olgmur1@yandex.ru

${ }^{2}$ Federal Williams Research Center of Forage Production and Agroecology, Lobnya, Moscow region, Russian Federation. 
For the first time, chromosomal variability in rapeseed varieties cultivated in risk farming areas was investigated. Analysis of the karyotype structure and also chromosomal distribution of $45 S$ and $5 S$ rDNA revealed variability in number and localization of these chromosomal markers in rapeseed $A$ and $C$ subgenomes. Polymorphic variants were more often detected in 1, 3 and 4 chromosome pairs of the A subgenome. In plant karyotypes of several varieties, chromosome heteromorphism (more often in the A subgenome) was observed. Our findings indicated the increased level of chromosomal polymorphism in winter rapeseed varieties compared to spring ones.

Key words: Brassica napus ssp oleifera (DC.) Metzg., karyotype, FISH, chromosomal polymorphism.

Геном естественного амфидиплоида рапса масличного (Brassica napus ssp. oleifera (DC.) Metzg.) содержит в своем составе два субгенома А и C [1]. Известно, что для представителей семейства капустных (Brassicaceae) характерна внутривидовая изменчивость числа сайтов рибосомных генов в кариотипах. Виды, которые содержат А-геном в своем хромосомном наборе, такие как B. rapa, B. juncea и B. napus, демонстрируют высокий уровень полиморфизма по количеству и хромосомной локализации сайтов рДНК. Причем локусы, несущие предположительно неактивные гены рибосомной РНК, особенно склонны к полиморфизму [2, 3]. Показано, что вариация числа копий и экспрессии рибосомных генов связана с функциональным проявлением множества различных генов, ассоциированных с разными признаками, в том числе с холодоустойчивостью $[4,5]$.

Рапс является источником пищевого масла, полноценного корма для скота и сырья для биотоплива. Это достаточно теплолюбивая культура и для успешного ее выращивания в районах рискованного земледелия важно наличие сортов устойчивых к низким температурам [6]. Различают яровую и озимую формы рапса. Для озимых сортов устойчивость и адаптивная способность к низким температура особенно важна. Одним из показателей, отражающих устойчивость к абиотическому стрессу, считается полиморфизм по числу кластеров рибосомных генов [7,8]. FISH-анализ выявил на хромосомах рапса значительное количество полиморфных сайтов рибосомных генов $[2,3,9]$. Вместе с тем, внури- и межсортовой полиморфизм рапса по локализации кластеров рибосомных генов до сих пор изучен мало и, из-за сложности идентификации хромосом, не всегда корректно [3, 9]. Нами проведено исследование внутри- и межсортового полиморфизма по локализации кластеров 45S рДНК и 5S рДНК у сортов рапса, выведенных для выращивания в средней полосе, которая относится к регионам рискованного земледелия.

Материальы и методы. Материалом для исследования послужили семена 17 сортов рапса, полученные из ФГБНУ ФНЦ кормопроизводства и агроэкологии им. В.Р. Вильямса (г. Москва, Россия) и РУП НПЦ по земледелию НАН Беларуси (г. Жодино, Беларусь). Среди них 9 озимых и 8 яровых 
сортов. Приготовление хромосомных препаратов, процедуру FISH с зондами $45 \mathrm{~S}$ и $5 \mathrm{~S}$ рДНК а также анализ хромосом проводили по разработанным нами ранее методикам [3, 10, 11].

Результаты и обсуждение. Кариотип рапса состоит из 9 пар хромосом С-субгенома и 10 пар хромосом А-субгенома, которые характеризуются небольшими размерами, бедным рисунком С-бэндинга [12]. После процедуры FISH хромосомы рапса дифференциально окрашиваются DAPI, и получаемый рисунок похож на рисунок С-окраски, что позволяет использовать его для идентификации хромосом $[11,13]$. Используя ранее разработанную цитологическую номенклатуру хромосом рапса [11], основанную на размеpax хромосом, центромерном индексе, рисунке DAPI-дифференциального окрашивания и локализации кластеров рибосомных генов, были изучены кариотипы 17 сортов рапса, районированных в регионе с умеренным и умеренно-континентальным климатом. Как правило, в кариотипах образцов рапса кластеры $45 \mathrm{~S}$ рДНК наблюдаются на 7 парах хромосом (7С и 8С, 1А $5 \mathrm{~A})$ а кластеры $5 \mathrm{~S}$ рДНК на 6 парах хромосом (4С, 1A, 3A, 4A, 5А и 10A). Из них, на 4 парах хромосом А-субгенома (1А, 3A, 4A и 5A) 45S и 5S рДНК обычно расположены совместно. Это согласуется с результатами других авторов о высоком полиморфизме хромосом А-генома по локализации кластеров рибосомных генов $[2,3,11]$. В некоторых сортах наблюдается отсутствие сигналов гибридизации обеих последовательностей $45 \mathrm{~S}$ или $5 \mathrm{~S}$ рДНК на $4 \mathrm{~A}$ хромосоме. У этой пары хромосом наиболее часто наблюдается гетероморфизм гомологов. В целом, число хромосом с кластерами $45 \mathrm{~S}$ рДНК в кариотипах разных сортов рапса варьирует и составляет 12, 13 или 14, а число хромосом с кластерами 5S рДНК менялось от 10 до 12.

При этом, больше полиморфных вариантов гомологичных хромосом и их гетероморфных сочетаний характерно для озимых сортов по сравнению с яровыми, хотя количество кластеров $45 \mathrm{~S}$ и $5 \mathrm{~S}$ рДНК может быть одинаковым. Например, у озимого сорта Ветразь выявлен дополнительный вариант хромосомы $3 \mathrm{C}$ с локализацией $5 \mathrm{~S}$ рДНК в длинном плече и два варианта хромосомы 4A, которые могут сочетаться как в одинаковых вариантах, так и в разных. У озимого сорта Северянин обнаружен гетероморфизм хромосомы $4 \mathrm{~A}$ по наличию кластеров $45 \mathrm{~S}$ и $5 \mathrm{~S}$ рДНК, а у ярового сорта Викрос обнаружен гетероморфизм гомологов хромосомы 4А по наличию кластера $5 \mathrm{~S}$ рДНК. Таким образом, результаты проведенного исследования указывают на возможную адаптивную значимость хромосомного полиморфизма по количеству и распределению сайтов рибосомных генов, что ранее отмечалось у рапса и других видов растений $[2,3,6,7,14,15]$.

Заключение. В результате проведенного сравнительного молекулярноцитогенетического исследования выявлен полиморфизм по числу и распределению сайтов рибосомных генов на хромосомах сортов рапса, имеющих разные селекционные истории, с учетом ярового или озимого типа развития. 
Выявленный полиморфизм важен для характеристики сорта и может использоваться для идентификации отдельных хромосом. На основе предложенного цитогенетического анализа в дальнейшем возможен отбор перспективных селекционных образцов для выведения новых сортов рапса с улучшенными характеристиками устойчивости к неблагоприятным условиям в регионах рискованного земледелия.

Благодарности: Работа поддержана РФФИ (проект № 18-54-0027), а также в рамках Программы фундаментальных исследований государственных академий наук на 2013-2020 годы (тема № 0120136 3824).

\section{Список литературы}

1. U N. Genome-analysis in Brassica with special reference to the experimental formation of B. napus and peculiar mode of fertilization // Japanese Journal of Botany. 1935. Vol. 7. P. 389-453

2. Hasterok R, Wolny E, Hosiawa M, et al. Comparative analysis of rDNA distribution in chromosomes of various species of Brassicaceae // Annals of Botany. 2006. V. 97. P. 205-216.

3. Amosova A. V., Zemtsova L. V., Grushetskaya Z. E. et al. Intraspecific chromosomal and genetic polymorphism in Brassica napus L. detected by cytogenetic and molecular markers // Journal of Genetics. 2014. V. 93. P. 133-143.

4. Hasi Yu, Xiangfeng Kong, Huan Huang et al. STCH4/REIL2 Confers Cold Stress Tolerance in Arabidopsis by Promoting rRNA Processing and CBF Protein Translation // Cell Reports. 2020. V. 30. P. 229-242.

5. Bo Li, Karl A.G. Kremling, Penghao Wu et al. Coregulation of ribosomal RNA with hundreds of genes contributes to phenotypic variation // Genome Res. 2018. V. 28. P. $1555-1565$.

6. Воловик В. Т. Качество семян рапса перспективных сортов селекции ГНУ ВИК Россельхозакадемии // Материалы Всероссийской научно-практической конференции по кормопроизводству. Казань. - 2011. - С. 71-75.

7. Bogunić F., Siljak-Yakovlev S., Muratović E., Ballian D. Different karyotype patterns among allopatric Pinus nigra (Pinaceae) populations revealed by molecular cytogenetics // Plant Biol. 2011. V. 13. P. 194-200.

8. Scaldaferro MA, da Cruz MV, Cecchini NM, Moscone EA. FISH and AgNor mapping of the 45S and 5S rRNA genes in wild and cultivated species of Capsicum (Solananceae) // Genome. 2016. V. 59. P. 95-113.

9. Snowdon R. J., Friedrich T., Friedt W., Kohler W. Identifying the chromosomes of the A- and C-genome diploid Brassica species B. rapa (syn. campestris) and B. oleracea in their amphidiploid B. napus // Theor. Appl. Genet. 2002. Vol. 104. P. 533-538.

10. Muravenko O. V., Yurkevich O. Yu., Bolsheva N. L. et al. Comparison of genomes of eight species of sections Linum and Adenolinum from the genus Linum based on chromosome banding, molecular markers and RAPD analysis // Genetika. 2009. V. 135. № 2. P.245-255.

11. Amosova, A. V., Zemtsova, L. V., Yurkevich et al. Genomic changes in generations of synthetic rapeseed-like allopolyploid grown under selection // Euphytica. 2017. V. 213. P. 217-229.

12. Olin-Fatih M. and Heneen W. K. C-banded karyotypes of Brassica campestris, B. oleracea and B. napus. // Genome. 1992. Vol. 35. P. 583-589. 
13. Xiong Z. and Pires J. C. Karyotype and identification of all homoeologous chromosomes of allopolyploid Brassica napus and its diploid progenitors // Genetics. 2011. Vol. 187. P. 37-49.

14. Pedrosa-Harand A., de Almeida C.C., Mosiolek M. et al. Extensive ribosomal DNA amplification during Andean common bean (Phaseolus vulgaris L.) evolution // Theor. Appl. Genet. 2006. V.112. P. 924-933.

15. Long Q., Rabanal F.A., Meng D. et al. 2013. Massive genomic variation and strong selection in Arabidopsis thaliana lines from Sweden. Nat Genet 45: 884-890.

DOI 10.18699/GPB2020-53

\section{Оценка полиморфизма ампелографической коллекции по реакци сортов на изменение агроклиматических показателей}

Новикова Л.Ю. ${ }^{l *}$, д.с.-х.н., в.н.с., и.о. зав. отд. автоматизированных информационных систем генетических ресурсов растений; Наумова Л.Г. ${ }^{2}$, к.с.-х.н., в.н.с. лаборатории ампелографии.

${ }^{1}$ ФБНУ «ФИЦ Всероссийский институт генетических ресурсов растений им. Н.И. Вавилова», Санкт-Петербург, Россия;

${ }^{2}$ ВНИИ виноградарства и виноделия имени Я.И. Потапенко - филиал ФГБНУ ФРАНЦ, г. Новочеркасск, Россия.

*e-mail: l.novikova@vir.nw.ru

В условиях изменения климата важное значение приобретает анализ скоростей реакичи сортов винограда на изменения агроклиматических характеристик. На основе спецификаций ранее построенных регрессионных уравнений «среднего сорта» винограда рассчитаны коэффициченты регрессии для 292 сортов Донской ампелографической коллекции. Полученные скорости реакции на изменения агроклиматических факторов сравнили у групп сортов различного направления использования, таксономического происхождения, срока созревания с помощьью критерия Краскела-Уоллиса. Показано, что наибольшими скоростями характеризовались межвидовые гибриды с V. labrusca L. и V. amurensis Rupr., что связано с их чувствительностью к зимним и весенним температурам, и более поздние сорта.

Ключевые слова: ампелографическая коллекция, изменения климата, регрессионная модель, скорость реакции.

\section{Assessment of the ampelographic collection polymorphism}

based on the varieties reaction to changes in agroclimatic parameters

Novikova Liubov, Dr. Sci. in Agricul., leading researcher of the Department of automated information systems, Federal State Budgetary Scientific Institution «Federal Research Center the N.I. Vavilov All-Russian Institute of Plant Genetic Resources» (VIR), St.-Petersburg, Russia; Naumova Lyudmila, Cand. Agr.Sci., 
leading researcher of the Laboratory of ampelography, Federal State Budget Scientific Institution "Research Institute of Viticulture and Winemaking named after Ya.I. Potapenko», Novocherkassk, Russia.

In conditions of climate change, it is important to analyze the reaction rates of grape varieties to changes in agro-climatic characteristics. The regression coefficients for 292 varieties of the Don ampelographic collection were calculated based on the specifications of the previously constructed regression equations for the "average variety" of grape. The obtained reaction rates to changes in agroclimatic factors were compared in groups of varieties of different direction of use, taxonomic origin, and maturation period using the Kruskal-Wallis ANOVA by Ranks. It is shown that the highest speeds had the interspecific hybrids with $V$. labrusca L. and V. amurensis Rupr., due to their sensitivity to winter and spring temperatures; and later varieties.

Key words: ampelographic collection, climate change, regression model, reaction rate.

Научной основой программы адаптации виноградарства к текущим и ожидаемым климатическим изменениям является создание фенотипических баз данных генетических ресурсов винограда $[1,2]$, оценка трендов в динамике хозяйственно-ценных признаков сортов $[2,3]$, их моделирование и прогнозирование $[4,5]$. Нами ранее были построены агрометеорологические модели основных хозяйственно ценных признаков винограда [6-8]. Модели построены в разностях $[8,9]$ для приведения временных рядов наблюдений к стационарному виду. Показано, что межгодовая вариабельность продолжительности продукционного периода винограда определяется двумя агроклиматическими переменными: суммой температур выше $20^{\circ} \mathrm{C}$ и продолжительностью весеннего периода с температурами $10-15{ }^{\circ} \mathrm{C}$ [8]. Урожайность зависит от суммы эффективных температур выше $20{ }^{\circ} \mathrm{C}$ прошлого сезона, минимальной температурой зимы и продолжительностью весеннего периода с температурами $10-20{ }^{\circ} \mathrm{C}[6]$. Сахаристость и кислотность зависят от ГТК за период с температурами выше $15{ }^{\circ} \mathrm{C}$ [8]. Процент распустившихся глазков укрывных сортов зависит от минимальной температуры зимы и осадков июля предыдущего сезона; неукрывных - числа суток с температурами ниже минус $20{ }^{\circ} \mathrm{C}$ и осадков июля [7]. Анализ полиморфизма ампелографической коллекции показал, что основными дифференцирующими факторами являются направление использования, таксономическое происхождение и срок созревания сорта. Исследованные характеристики имеют у разных групп долговременные тренды одного знака, хотя их значения отличаются [10].

Задачей исследования является расчет и сравнительный анализ скорости реакции на изменение выделенных в комплексе моделей агроклиматических факторов для сортов разного направления использования, таксономического происхождения, сроков созревания. 
Объект и метод. Материалом для исследования послужила база данных наблюдений 1981-2017 гг. за 292 сортами винограда Донской ампелографической коллекции. Выборка состоит из 162 сортов технического и 130 столового направления использования. Представлены 4 группы сортов по таксономическому происхождению: 179 сортов Vitis vinifera L. (обозначаемые далее V), 20 сортов - межвидовые гибриды $V$. vinifera L. x V. labrusca L. (L), $37-V$. vinifera L. x V. amurensis Rupr. (A), 56 - гибриды с несколькими американскими видами (U). Представлены 7 групп сортов по срокам созревания. Для каждого сорта рассчитаны 9 коэффициентов регрессии на выявленные моделями агроклиматические факторы. Коэффициенты регрессии представляют собой скорости реакции хозяйственно ценных признаков сортов на изменения агроклиматических факторов. В сравнительном анализе использованы параметры сортов, имеющих не менее 5 лет измерений признака. Параметризация осуществлена в компьютерной программе VITIS TIME SERIES (Свидетельство о государственной регистрации программы для ЭВМ № 2019664805), разработанной нами для решения типовых задач агрометеорологического моделирования и прогнозирования хозяйственно ценных признаков винограда. Исследована достоверность различий параметров сортов контрастных групп непараметрическим критерием Краскела-Уоллиса (Kruskal-Wallis ANOVA by Ranks) в пакете Statistica 13.3.

Результат. Сорта столового (T) и технического (W) направления использования различались по скорости реакции продолжительности продукционного периода на рост сумм температур выше $20{ }^{\circ} \mathrm{C}(\mathrm{p}=0.004$; Т-минус 0.005 сут. $/{ }^{\circ} \mathrm{C} ; \mathrm{W}$ - минус 0.011 сут. $\left./{ }^{\circ} \mathrm{C}\right)$ и сокращение продолжительности весеннего периода с температурами $10-20{ }^{\circ} \mathrm{C}(\mathrm{p}=0.024 ; \mathrm{T}-0.211 ; \mathrm{W}-0.282)$, а также реакцией кислотности на рост ГТК 15 ( $\mathrm{p}=0.020 ; \mathrm{T}-2.403$ г/дм $3 / \mathrm{eд}$.; W3.027 г/дм $3 /$ ед.), скорости роста процента перезимовавших глазков на рост минимальной температуры зимы $(\mathrm{p}=0.000)$. Более сильная реакция технических сортов связана, возможно, с более поздними сроками их созревания по сравнению со столовыми (см. далее).

У сортов разного таксономического происхождения достоверно различалась скорость увеличения продолжительности продукционного периода в зависимости от роста продолжительности весеннего периода с температурой $10-15^{\circ} \mathrm{C}(\mathrm{p}=0.005)$. Группа гибридов с $V$. labrusca имела более высокую скорость реакции на рост температуры весны, чем остальные сорта, наименее реагировали сорта $V$. vinifera (средние скорости по группам, в порядке убывания: L-0.689; U-0.278; A-0.239; V-0.194 сут./ $\left.{ }^{\circ} \mathrm{C}\right)$. Это согласуется с выявленным нами фактом [10], что у группы гибридов с V. labrusca отмечен наибольший тренд к сокращению продукционного периода. Скорость роста урожайности в зависимости от роста минимальной температуры зимы $(\mathrm{p}=0.000)$ была наибольшей у гибридов с V. amurensis и c V. labrusca (L-0.481; 
A-0.293; V-0.110; U-0.103; кг $/$ куст $\left./{ }^{\circ} \mathrm{C}\right)$. Вероятно, это связано с тем, что в основном это морозостойкие сорта [11], зависящие от условий перезимовки и активно развивающиеся при низких температурах весны. Таким образом, по скорости реакции на изменения агроклиматических переменных выделились группы межвидовых гибридов с V. labrusca $u$ V. amurensis, контрастных с сортами $V$. vinifera.

У сортов разных сроков созревания скорость сокращения продолжительности вегетации при росте $\Sigma \mathrm{T}_{20}(\mathrm{p}=0.011)$ была наибольшей у более поздних групп (ранне-средние -0.15; средне-поздние -0.009; средние -0.008; сверхранние -0.007 ; ранние -0.004 ; очень ранние -0.002 сут. $\left.{ }^{\circ} \mathrm{C}\right)$. С ростом продолжительности вегетации наблюдается достоверное $(\mathrm{p}=0.000)$ усиление реакции кислотности на снижение ГТК 15 (сверхранние сорта 1.207 ; очень ранние 1.520; ранние 1.653 , ранне-средние 2.816 ; средние 3.184 ; средне-поздние 3.751 г/дм³/ед). По нашим наблюдениям, кислотность положительно коррелирует с продолжительностью продукционного периода [10].

Таким образом, наблюдался ряд достоверных отличий в скорости реакции групп сортов винограда различного направления использования, таксономического происхождения, срока созревания на изменения агроклиматических показателей. Наибольшими скоростями характеризовались межвидовые гибриды с $V$. labrusca $u$ V. amurensis, что связано с их чувствительностью к зимним и весенним температурам, и сорта более позднего срока созревания.

Благодарности: Работа выполнена при поддержке гранта РФФИ №18-016-00213.

\section{Список литературы}

1. Hausmann L., Maul E., Ganesch A., Kecke S., Töpfer R. The Vitis International Variety Catalogue and the European Vitis Database. INTEGRAPE 2019. Data Integration as a key step for future grapevine. Book of Abstracts Chania, Greece 25-28 March, 2019. 9. [Electronic resource] http://www.integrape.eu/images/pdf/CA17111-integrape2019.pdf.

2. Choudhury A., Jones J. Crop yield prediction using time series models. Journal of Economics and Economic Education Research. - 2014. - 15(3). - pp.53-67.

3. Jones G. Climate, Grapes, and Wine: Structure and Suitability in a Changing Climate // Acta Hort. 2012. - 931. - pp.19-28.

4. Molitor D., Junl J., Evers D., Hoffmann L., Beyer M. A high-resolution cumulative degree day-based model to simulate phonological development of grapevine // Am. J. Enol. Vitic. - 2014. - Vol. 65:1. - pp. 72-80.

5. Quenol H., Grosset M., Barbeau G., K.van Leeuwen, Hofmann M., Foss Ch., Irimia L., Rochard J., Boulanger J.-Ph., Tissot C., Mirand K. Adaptation of viticulture to climate change: high resolution observation of adaptation scenario for viticulture // Bull. de l'OIV. - 2014. - N1001-1002-1003 : Vol. 87. - pp. 385-406.

6. Наумова Л.Г., Новикова Л.Ю. Анализ тенденций изменений урожайности сортов винограда коллекции ВНИИВиВ им.Я.И. Потапенко // Виноделие и виноградарство. - 2014. - № 5. - С. $44-49$.

7. Новикова Л.Ю., Наумова Л.Г. Регрессионный анализ зимостойкости сортов 
винограда Донской ампелографической коллекции им. Я.И. Потапенко // Магарач. Виноградарство и виноделие. - 2018. - № 4. - С. 59-61.

8. Наумова Л.Г., Новикова Л.Ю. Использование метода последовательных разностей при создании агрометеорологических регрессионных моделей многолетних данных // Плодоводство и ягодоводство России. - 2018. - Т. 55. -С. 133 137. DOI 10.31676/2073-4948-2018-55-133-137.

9. Елисеева И.И., Курышева С.В., Костеева Т.В., Пантина И.В., Михайлов Б.А., Нерадовская Ю.В., Штрое Г.Г., Бартелс К., Рыбкина Л.Р. Эконометрика. М., 2007.

10. Novikova L.Yu., Naumova L.G. Structuring ampelographic collections by phenotypic characteristics and comparing the reaction of grape varieties to climate change // Vavilovskii Zhurnal Genetiki i Selektsii = Vavilov Journal of Genetics and Breeding. 2019. - 23(6). - C.772-779. - DOI 10.18699/VJ19.551.

11. Негруль А.М. Очерк семейства виноградных и его главных видов с их краткой хозяйственной характеристикой. Ампелография СССР. - Т.1. - М., 1946. C. 45-133.

DOI 10.18699/GPB2020-54

\section{Продуктивность и качество зерна у раннеспелых сортов мягкой яровой пшеницы в Северном Зауралье}

Новохатин В.В. *, к.с.-х.н., в.н.с.; Шеломенцева Т.В., н.с. НИИСХ Северного Зауралья - филиал ТюмНЦ СО РАН, г. Тюмень. *e-mail:vnovokhatin@bk.ru

Показаны сортовые различия по урожайности и основным технологическим показателям зерна. Выявлены сопряженные связи продуктивности с ее составляюшими, показателями качества зерна, поражаемостью патогенами и прорастанием зерна в колосе в предуборочный период. По урожайности и технологическим показателям зерна выделились сорта: Гренада, Тулунская 12, Тюменская 25, Ирень, Аделина, Новосибирская 31.

Ключевые слова: мягкая яровая пшеница, сорт, Урожайность, масса 1000 зерен, натура, протеин, клейковина.

\section{Productivity and quality of grain in early mature varieties of soft spring wheat in the northern Trans-Ural}

Novokhatin V.V., candidate of agricultural sciences, leading researcher, TV Shelomentseva, ns NIISH North-Urals - a branch of the Tyumen Scientific Center of the SB RAS, Tyumen, Russia.

*e-mail:vnovokhatin@bk.ru

Varietal differences in yield and main technological indicators of grain are 
shown. The interconnected relationships of productivity with its components, indicators of grain quality, pathogen susceptibility and sprouting of grain in the ear in the pre-harvest period were revealed. In terms of productivity and technological indicators of grain, the following varieties were distinguished: Grenada, Tulunskaya 12, Tyumen 25, Zlatozar and Adeline.

Key words: spring soft wheat, cultivar, yield, mass of 1000 grains, nature, protein, gluten.

Формирование урожая мягкой яровой пшеницы происходит под влиянием сильно варьирующих, в основном, не регулируемых факторов среды и сильно зависит от лим-факторов, проявление которых неравнозначно по годам [1]. Одним из основных является ограниченный период вегетации [2]. Установлено, что между урожайностью и длиной вегетационного периода корреляция высокая в засушливые годы, несколько ниже она в оптимальные по увлажнению годы и отсутствует в холодные годы [3]. Увеличение урожайности приводит к уменьшению содержания клейковины и белка, и увеличению массы 1000 зерен [4]. Крупность зерна является сортовым признаком [5-7] и одним из основных в формировании урожайности $[8,9]$. При этом селекция на крупнозерность более эффективна, чем на озерненность колоса [10]. Белковый комплекс зерно-клейковина - это косвенный показатель содержания белка. Эти признаки, а также показатель качества зерна, наряду с сортовыми особенностями [5] в сильной степени зависит от климатических условий [5] и в значительной степени - от технологии выращивания [6]. Прорастание зерна в колосе в предуборочный период, отрицательно влияет на продовольственные и семенные свойства зерна и семян [11]. Стекловидность зерна связана с его твердозерностью, содержанием белка и клейковины и является показателем мукомольных свойств зерна [5]. Поэтому увеличение урожайности и улучшение качества зерна, наряду с улучшением технологий возделывания, возможно только за счет новых, создаваемых сортов.

Исследования проводились в 2016-2019 гг. на опытном поле НИИСХ Северного Зауралья (г. Тюмень) в коллекционном питомнике «Музей», где из 60 распространенных (1929-2018 гг.) в регионе сортов - 19 раннеспелые.

Почва - темно-серая лесная, тяжелосуглинистая: $\mathrm{Ph}=6,0$; содержание гумуса - 3,5 \%; $\mathrm{NO}_{3}-4,2-5,2 ; \mathrm{P}_{2} \mathrm{O}_{5}-22,2-24,1 ; \mathrm{K}_{2} \mathrm{O}-18,7-22,0$ мг 100 г почвы. Предшественник - черный, удобренный $\mathrm{N}_{30} \mathrm{P}_{45} \mathrm{~K}_{30}$ кг д.в./га, пар. Посев сеялкой СКС-6-10, на делянках 5 м², повторность трехкратная, с нормой высева 650 всх.

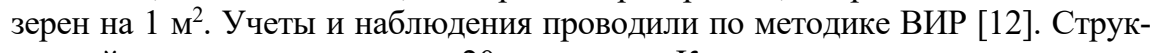
турный анализ проводился по 20 растениям. Качество зерна определялось по методическим указаниям оценки качества зерна [13] по следующим параметрам: масса 1000 зерен - ГОСТ 10842-76; стекловидность - ГОСТ-10987-76; натура (микронатура - ГОСТ-10840-64, микропурка $\left(10 \mathrm{~cm}^{3}\right)$ - конструкция 
СибНИИСхоза; содержание и качество клейковины - ГОСТ-13586.1-68. Математическую и статистическую обработку проводили по компьютерной программе О.Д. Сорокина [14].

Климатические условия были различными. Так, 2016 год был засушливым. При норме осадков за вегетацию 244 мм, их выпало 61 \%. Сумма температур $>10{ }^{\circ} \mathrm{C}$ составила $2163{ }^{\circ} \mathrm{C}$, при норме $1844{ }^{\circ} \mathrm{C}$. Прохладным и влажным характеризовался 2018 год, когда осадков за май-август выпало 307 мм, что на $26 \%$ выше нормы. Сумма активных температур - $1824{ }^{\circ} \mathrm{C}$, что ниже нормы. Увлажненным был 2019 год, с прохладной температурой в начале вегетации и в первой половине августа. По климатическим характеристикам, близким к среднемноголетним был 2019 год.

Результаты. В Северном Зауралье за период с 1929 по 2019 гг. получили распространение 60 сортов мягкой яровой пшеницы, из них раннеспелых - 19 (табл. 1). Среди последних - 10 сортов (со звездочками) зарегистрированы Госкомиссией. В большинстве своем они довольно хорошо адаптированы к местным агроклиматическим условиям. Однако возделывание культуры сильно зависит от проявления лим-факторов, одним из которых является ограниченный период вегетации. В условиях ограниченного периода вегетации Северного Зауралья у пшеницы отмечается направленно отрицательная, слабая сопряженность продуктивности с периодом «всходы-восковая» спелость (r=$0,211 \ldots-0,218)$ (табл. 2). Это является одним из объяснений отсутствия здесь в производстве позднеспелых сортов.

Высота растений - это важный хозяйственный показатель обуславливающий устойчивость к полеганию. Стебель является одним из основных признаков участвующих в фотосинтезе растений. Сопряженность продуктивности и высоты растений разнонаправленная. Она отрицательная в увлажненные годы $(\mathrm{r}=-0,418)$ и положительно выраженная $(\mathrm{r}=0,372)$ в засушливые годы. Оптимальная высота растений - 85-100 см. Устойчивость к полеганию во многом обусловлена диаметром второго нижнего междоузлия, которое положительно коррелирует с продуктивностью (r=0,471 ...0,501) (табл. 2). Отмечается положительная корреляция продуктивности $\mathrm{c}$ устойчивостью к полеганию $(\mathrm{r}=0,512 \ldots 0,548)$. Сопряженность урожайности с продуктивной кустистостью разнонаправленная $(\mathrm{r}=0,244 \ldots-0,408)$. В засушливых условиях она слабо положительная, а в различные по увлажненности годы - отрицательная. Поэтому урожай в регионе формируется за счет продуктивности главного колоса, на долю которого приходится до 70 \% урожайности. Следует отметить, что более урожайными являются сорта с выраженной плотностью колоса $(\mathrm{r}=0,368 . .0,826)$, у которых на 10 см стержня (расчетное) приходится 20-22 колоска. 


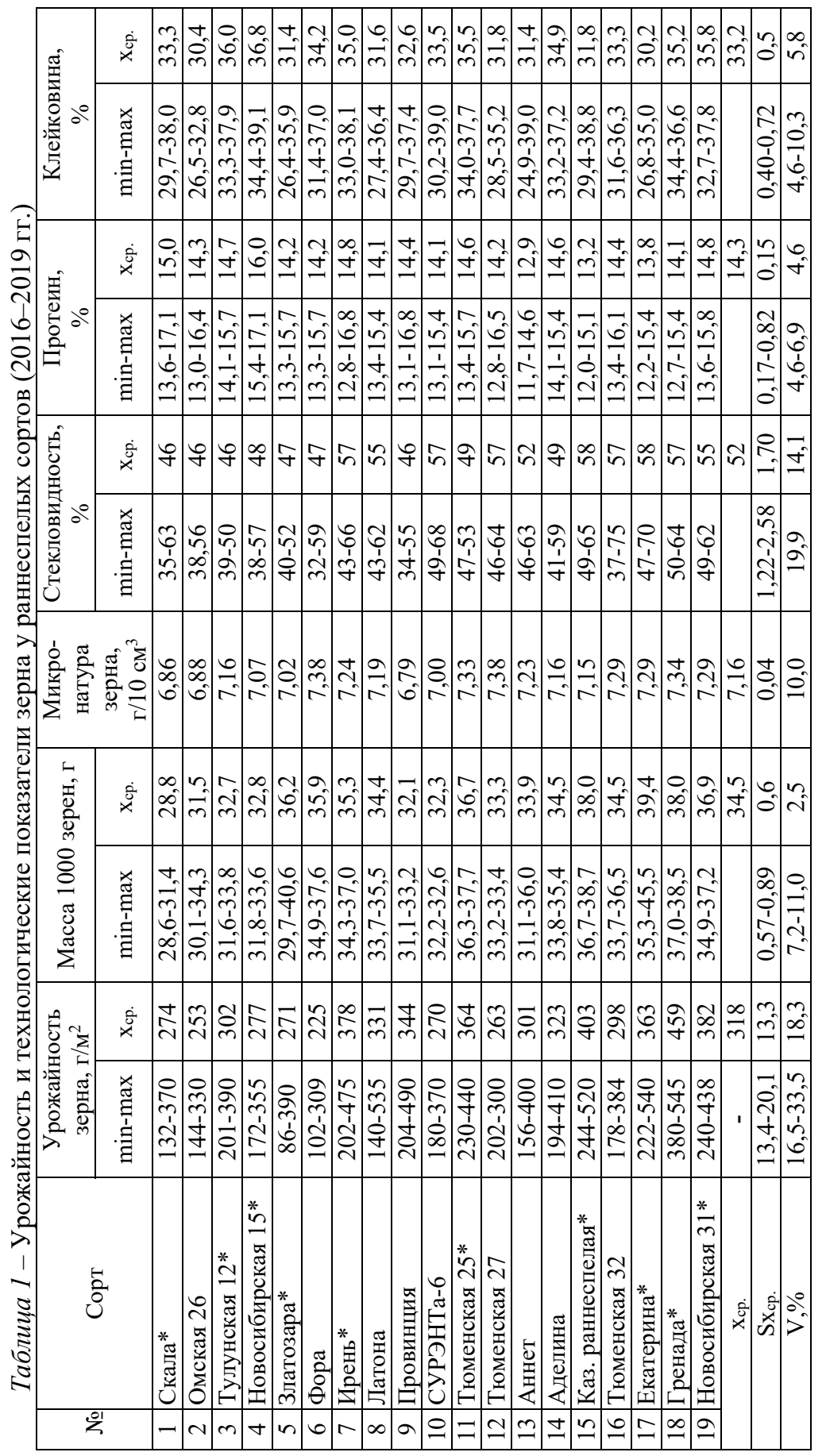


В контрастных условиях урожайность сортов, по годам, сильно варьирует $\left(16,5-33,5 \% ; x_{\mathrm{cp}}=18,3 \%\right)$ и колеблется от 86 до 545 г $/ \mathrm{M}^{2}$, при средней по опыту -318 г/м² и варьировании - 13,3 \% (табл. 1). Среди изученных сортов

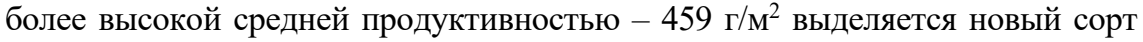
Гренада, у которого как минимальное $\left(380\right.$ г/ $\left.\mathrm{M}^{2}\right)$, так и максимальное $\left(545 \Gamma / \mathrm{M}^{2}\right)$ ее значения довольно высокие. При этом следует отметить, что в засушливом 2016 году, когда отмечена наименьшая урожайность, сорт по продуктивности значительно превысил все изучаемые генотипы. В провокационных условиях только Гренада обладает выносливостью к ржавчинным грибам и септориозу. Благодаря ускоренному прохождению формирования и налива зерна, сорта: Новосибирская 15, Провинция и Фора, имеют меньший тип поражения патогенами - 2 и процент поражения - 20-30 \%. Остальные сорта сильно поражаются названными грибами (3-4/60-80 \%). Корреляция между урожайностью и поражаемостью патогенами стабильно отрицательная $(\mathrm{r}=-0,304 \ldots-0,404)$ (табл. 2). В формировании урожайности масса 1000 зерен имеет большее значение $(\mathrm{r}=0,600 \ldots 0,701)$, чем озерненность колоса $(\mathrm{r}=0,342 \ldots 0,432)$. Между этими основными признаками продуктивности корреляция положительная $(\mathrm{r}=0,283 \ldots-0,413)$. Это позволяет, в разумных пределах, повышать их у вновь создаваемых сортов. При этом следует учитывать, что при меньшем варьировании абсолютной массы зерна $\left(7,2-11 \%\right.$; $\mathrm{x}_{\mathrm{cp}}=7,5 \%$ \% - выражающей ее консервативность, отбор в селекции на увеличение этого признака более эффективен, чем отбор на повышение озерненности колоса.

Таблица 2 - Корреляционные связи урожайности с признаками продуктивности, качества зерна и иммунитета

\begin{tabular}{|l|c|l|c|}
\hline \multicolumn{1}{|c|}{ Признак } & \multicolumn{1}{c|}{$\mathrm{r} \div \mathrm{r}$} & \multicolumn{1}{c|}{ Признак } & $\mathrm{r} \div \mathrm{r}$ \\
\hline всходы-восковая спелость & $-0,211 \div-0,218$ & масса зерна с колоса & $0,655 \div 0,750$ \\
\hline высота растений & $-0,418 \div 0,372$ & натура зерна & $0,464 \div 0,582$ \\
\hline диаметр II м.-узл. & $0,471 \div 0,501$ & протеин & $-0,359 \div-0,598$ \\
\hline полегание & $0,512 \div 0,548$ & клейковина & $-0,377 \div-0,539$ \\
\hline продукт кустистость & $0,244 \div-0,408$ & ИДК & $-0,328 \div-0,540$ \\
\hline плотность колоса & $0,368 \div 0,826$ & бурая ржавчина & $-0,377 \div-0,441$ \\
\hline масса 1000 зерен & $0,600 \div 0,701$ & септориоз & $-0,240 \div-0,251$ \\
\hline озерненность колоса & $0,342 \div 0,432$ & пыльная головня & $-0,304 \div-0,334$ \\
\hline прорастание зерна & $-0,312 \div-0,570$ & \\
\hline \multicolumn{4}{|c|}{$\mathrm{R} \geq 0,404$} \\
\hline
\end{tabular}

По массе 1000 зерен все изучаемые сорта крупнозерные. При этом несколько меньше абсолютная масса зерна у №№ 1-4, 9-10 ( $\mathrm{x}_{\mathrm{cp}}=30,2-32,8$ г) (табл. 1), более крупное оно у Гренады, Екатерины и Казахстанской раннеспелой $\left(\mathrm{x}_{\mathrm{cp}}=38,0-39,4\right.$ г). В благоприятных условиях крупным зерном выделяются Златозара $(40,6$ г) и Екатерина $(45,5$ г).

Натура зерна является одним из маркерных показателей его качества. 
Этот признак довольно стабильный ( $\mathrm{V}=2,5$ \%). Меньшей величиной микронатуры зерна характеризуются: Скала, Омская 26, Новосибирская 15, Златозара, Провинция, СУРЭНТа-6 (6,86-7,02 г/см³) (табл. 1), что следует учитывать при включении их в селекционные программы.

Стекловидность зерна, характеризующая его твердозерность и, в какой-то мере, белковость, проявилась в опыте в среднем на $52 \%$, несколько выше она (57-58 \%) у №№ 7, 10, 12, 15-18 (табл. 1). Следует отметить довольно выраженное варьирование признака - 10,0-19,9 \% ( $\mathrm{x}_{\mathrm{cp} .=14,1 \%) .}$ Наибольшая стекловидность отмечена в 2019 году у Екатерины и Тюменской $32(70-75 \%)$.

Среднее содержание протеина в зерне - 14,3 \%, с колебанием по сортам - 12,9-16,0 \%, большее у Новосибирской 15 и меньшее у Аннет. В благоприятных условиях максимальным проявлением признака выделяются: №№ $1,2,4,7,9,12$ (16,4-17,1 \%). Узким отношение между хорошим минимальным и максимальным проявлением протеина характеризуются: Тулунская $12(14,1-15,7 \%)$, Новосибирская $15(15,4-17,1)$ и Аделина $(14,1-15,4$ $\%)$, что повышает их селекционную значимость.

Клейковина - как белковый комплекс зерна является косвенным показателем протеина, что подтверждается стабильно высокой по годам положительной их сопряженностью $(\mathrm{r}=0,863 \ldots 0,878)$. Поэтому их проявление по годам имеет схожую изменчивость. Варьирование клейковины у сортов довольно значительное по годам - от 24,9 \% до 39,1 \% (табл. 1 ). При этом сильнее она проявилась в более благоприятных условиях 2019 года, а меньше в 2016 году. Большей средней величиной признака выделяются: Тулунская 12, Ирень, Тюменская 25, Аделина, Гренада и Новосибирская 31 (34,9-36,8 \%). У них же большая величина минимального проявления содержания клейковины - 33,0-34,4 \% и довольно высокое максимальное - 36,6-39,1 \%. Эту особенность, названных сортов, следует учитывать при включении их в селекционные программы, направленные на повышение качества зерна.

Показатель отношения содержания клейковины к протеину у сортов изменяется от 2,12 до 2,56. Более высокие значения показателя у №№ 3,6 , $11,15,18,19$ (2,41-2,50). При хорошем содержании протеина $(14,0-15,0 \%)$ и высоком - клейковины (35,0-36,8 \%) он косвенно оценивает хорошие хлебопекарные качества генотипов. Среди отмеченных сортов три - в списке сильных: Тулунская 12, Казахстанская раннеспелая, Новосибирская 31 и два в списке ценных - Тюменская 25, Гренада.

В данном наборе сортов только Новосибирская 15 и Златозара показали первую группу качества клейковины (73 ед. ИДК). В пределах 78-80 ед. ИДК у Екатерины, Казахстанской раннеспелой, Тюменской 32, Гренады. Все остальные сорта однозначно формируют вторую крепкую клейковину.

Заключение. Высота растений отрицательно коррелирует с продуктивностью во влажные годы и положительно - в засушливые, что характерно и 
для продуктивной кустистости. Высокой средней урожайностью выделяется Гренада. Крупнозерность характерна для Златозары и Екатерины. Повышенным содержанием протеина выделяются: Тулунская 12, Новосибирская 15, Аделина и клейковины - они же, а также - Ирень, Тюменская 25 и Новосибирская 31. Выделенные сорта представляют производственную ценностью и рекомендуются для использования, в качестве исходного материала, в селекции на повышение продуктивности и качества зерна.

\section{Список литературы}

1. Драгавцев В.А., Генетика признаков продуктивности яровых пшениц в Западной Сибири / В.А. Драгавцев, Р.А. Цильке, Б.Г. Рейтер, Б.А. Воробьев, А.Г. Дубровская, Н.И. Коробейноков, В.В. Новохатин, В.П. Максименко, А.Г. Бабакишиев, В.Г. Илющенко, Н.А. Калашник, Ю.П. Зуйков, А.М. Федотов - Новосибирск: Наука, 1982. $-230 \mathrm{c}$.

2. Новохатин В.В. Селекция яровой мягкой пшеницы в Северном Зауралье / В.В. Новохатин // Научные результаты агропромышленному производству. Сб. науч. тр. - Курган: Зауралье, 2004. - С. 214-218.

3. Мовчан В.К. Морфологические особенности и продуктивность яровой пшеницы в зоне Северного Казахстана / В.К. Мовчан // Селекция и семеноводство полевых культур. - М.: Колос, 1974. - С. 121-184.

4. Ведров Н.Г. Яровая пщеница в Восточной Сибири / Н.Г. Ведров - Красноярск: КрасГАУ, 1998. - 312 с.

5. Козьмина Н.П. Зерно / Н.П. Козьмина - М.: Колос, 1969. - 368 с.

6. Коданев И.М. Повышение качества зерна / Коданев И.М. - М.: «Колос», 1976. - C. $225-236$.

7. Шеломенцева Т.В. Изучение исходного материала мягкой яровой пшеницы для селекции на продуктивность / Т.В. Шеломенцева // Генофонд и селекция растений. Материалы IV Международной научно-практической конференции 04-06.04.2018 г. - Новосибирск, 2018. - С. 454-459.

8. Кузьмин В.П. Селекция и семеноводство зерновых культур в Целинном крае Казахстана / Кузьмин В.П. - М. - Целиноград: Колос, 1965. - 199 с.

9. Кумаков В.А. Физиология яровой пшеницы / В.А. Кумаков - М.: Колос, 1980. $-207 \mathrm{c}$.

10. Воробьев В.Ф. О связи урожайности с элементами структуры урожая / В.Ф. Воробьев // Селекция и семеноводство, 1972. № 5. - С. 25-27.

11. Новохатин В.В. Устойчивость яровой мягкой пшеницы к предуборочному прорастанию зерна / Новохатин В.В. // Тюменское обеспечение агропромышленного комплекса «Тюменской области». - Новосибирск, 2003. - С. 152-172.

12. Методические указания по изучению мировой коллекции пшеницы. Под. Ред. В.Ф. Дорофеева. Л.: ВАСХНИЛ, 1977. 177 с.

13. Методические указания по оценке качества зерна. М.: ВАСХНИЛ,1977. 177 с.

14. Сорокин О.Д. Прикладная статистика на компьютере. - Краснообск: ГУП РПО СО РАСХН. 2004. -162 c. 


\section{Прививка томата (Solanum licopersicum L.) на картофель (Solanum tuberosum L.)}

Партоев К., д.с.-х.н., профессор

Институт ботаники, физиологии и генетики растений АН Республики Таджикистан, Таджикистан, г. Душанбе.

e-mail:pkurbonali@mail.ru

Опыт по проведению прививки томата на картофель осуществлен на экспериментальном участке Института ботаники, физиологии и генетики растений Академии наук Республики Таджикистан на высоте 840 м над уровнем моря. Исходным материалом для опыта служили растения картофеля сорта Paшт (Solanum tuberosum L.), у которого клубни имеют красную окраску и томаты сорта Волгоградский-5/95 (Solanum licopersicum L.). Растения картофеля и томата вместе были посажены в железный сосуд, заполненный почвой и перепревшим навозом (соотношение 3:1). Для проведения прививки стебля растений повреждали на высоте 10 см от почвы при помощи лезвия в длину 8-10 см и поврежденные части стеблей двух растений соединили друг с другом и замотали тонкой пленкой. После 15 дней, когда образовался каллус, лезвием вырезали ниже от места прививки стебель растений томата, то есть отделяли стебель томата от корней, а сверху от места прививки срезали стебель растения картофеля. Было образовано растение, состоящее из картофеля и томата. Установлено об изменение качественного признака-окраски клубней картофеля под воздействием донора - растений томата.

Ключевые слова: картофель, томаты, прививка, окраска клубней, Таджикистан.

\section{Grafting of tomato (Solanum licopersicum L.) on potatoes (Solanum tuberosum L.)}

Partoev Kurbonali, Institute of Botany, Plants Physiology and Genetics of AS of the Republic of Tajikistan; 734017, Tajikistan, Dushanbe, Karamov St., 27. Email:pkurbonali@mail.ru

Experiment on carrying out an grafting of tomato on potatoes is carried out on the experimental site of Institute of Botany, Plants Physiology and Genetics of Academy of Sciences of the Republic of Tajikistan at the height of $840 \mathrm{~m}$ above sea level. As initial material for experiences served grade potatoes plants Rasht (Solanum tuberosum L.), at which tubers have red coloring and tomatoes of a grade Volgograd-5/95 (Solanum licopersicum L.). Plants of potatoes and a tomato were together planted in the iron vessel filled with the soil and the retorting manure (a ratio 3:1).

For carrying out grafting of a plant of a tomato on potatoes the following 
method of an inoculation was used. Stalks of a plant of potatoes and a tomato damaged at the height of $10 \mathrm{~cm}$ from the soil by means of an edge in length of 8$10 \mathrm{~cm}$ and the damaged parts of stalks of two plants connected with each other and rolled up a thin film. After 15 days when it was formed callus, an edge cut out below from the place of an inoculation a stalk of plants of a tomato, that is separated a tomato stalk from roots, and from above from the place of an inoculation cut off potatoes plant stalk. In experience it is established about change of qualitative sign-colorings of tubers of potatoes under the influence of the donor - tomato plants.

Key words: potato, tomato, grafting, coloring of tubers, Tajikistan.

Прививка - один из способов вегетативного размножения плодовых растений, и она основана на изменении характера питания - обмена веществ между двумя или несколькими прививаемыми формами [5]. Проведенные эксперименты на основе прививки двух сортов табака и анализа РНК и ДНК клетки установлено, что каждая из этих клеток действительно содержит все четыре гена, и все они работают (транскрибируются, то есть используются в качестве матрицы для синтеза РНК) $[5,6]$. Анализ пластидных и ядерных генетических маркеров показал, что в генетическом обмене участвовала только пластидная, но не ядерная ДНК. Из клеточных культур, содержащих смешанный генетический материал двух сортов табака, удалось вырастить взрослые растения, способные к половому размножению. Из их семян выросли растения с теми же признаками, что и у гибридных родителей. Это означало, что новая комбинация признаков, полученная в результате генетического обмена между клетками привоя и подвоя, действительно может стать наследственной, а, следовательно, «вегетативная гибридизация» всетаки возможна, по крайней мере в лабораторных условиях $[5,6]$. В настоящее время горизонтальному переносу генов (ГПГ) уделяется все больше внимания, как процессу, имеющему биологическое значение в формировании эволюционной истории с начала жизни на Земле $[1,2,4]$. По сообщениям [3] еще в 1978 году в Генетическом институте в Германии был получен межродовой гибрид - помитофель, и о результатах на Генетическом конгрессе в Москве докладывали по соматической гибридизации отдаленных видов. Был показан гибрид помитофель - с миниклубнями - в «корешках» и маленькими помидорами - в «вершках». В результате слияния протопластов томата и картофеля был получен гибрид (помитофель), но он был далек от идеала. Однако растения с неулучшенным фотосинтезом не могут работать на «два фронта» и для формирования полноценного урожая томатов и клубней гибрида необходимо удвоить активность фотосинтетического аппарата [3]. Для изучения этого процесса нами были проведены этих полевых опытов. Опыт по проведению прививки томата на картофель был проведен в июне 2019 года на опытном участке Института ботаники, физиологии и ге- 
нетики растений Академии наук Республики Таджикистан. Исходным материалом для опытов служили растения картофеля сорта Рашт (Solanum tuberosum L.), у которого клубни имеют красную окраску и томаты сорта Волгоградский-5/95 (Solanum licopersicum L.). Растения картофеля и томата вместе были посажены в железный сосуд, заполненный почвой и перепревшим навозом (соотношение 3:1). Для проведения прививки растения томата на картофель был использован следующий метод прививки. Стебли растения картофеля и томата повреждали на высоте 10 см от почвы при помощи лезвия в длину 8-10 см и поврежденные части стеблей двух растений соединили друг с другом и замотали тонкой пленкой. После 15 дней, когда образовался каллус, лезвием вырезали ниже от места прививки стебель растений томата, то есть отделяли стебель томата от корней, а сверху от места прививки срезали стебель растения картофеля.

Таким образом, подвоем служило растение картофеля, а привоем томаты и было образовано растение, состоящее из картофеля и томата. В течение вегетации прививших растений картофеля и томата подкармливали аммиачной селитрой из расчета приблизительно 2 г на сосуд и систематический поливали.

В конце вегетации из привоя (томаты) нами были собраны четыре штуки созревших плодов томата (весом всего 100 г), а также из подвоя (картофеля) - три клубня картофеля (весом всего 120 г) (рисунок).
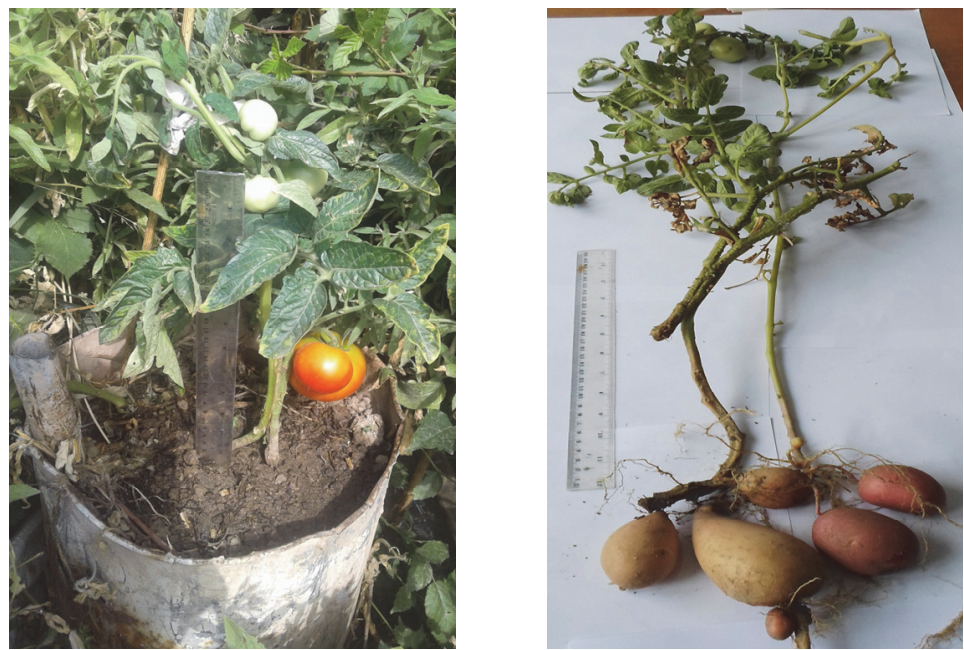

Рисунок. Привитые растения картофеля и томата в железном сосуде с плодами томата (слева) и клубнями картофеля, образовавшимися на привитом стебле картофеля с бледно-розовой окраской (справа - $\mathrm{C}_{1}-$ первая клоновая репродукция), а также красные клубни, сформировавшиеся от глазков клубня с бледно-розовой окраской ( $\mathrm{C}_{2}-$ вторая клоновая репродукция). 
Необходимо отметить, что под влиянием донора-привоя (растение томаты) клубни картофеля сорта Рашт, имеющие красную окраску, приобрели бледно-розовую $\left(\mathrm{C}_{1}\right)$, а вкус плодов томата также был более сладким, чем обычные (без прививки) плоды томата. Однако от клубня с бледно-розовой окраской, от вторичного зарастания проросло новое растение $\left(\mathrm{C}_{2}\right)$, и оно сформировало клубни с красной окраской, что видно на фото (справа).

Таким образом, в условиях Гиссарской долины Таджикистана, на экспериментальном участке Института ботаники, физиологии и генетики растений АН Республики Таджикистан, расположенном на высоте 840 м над уровнем моря, впервые осуществлена прививка картофеля и томата. В результате этого опыта получена необходимая научная информация об изменении качественного признака - окраски клубней картофеля под воздействием донора - растений томата. Однако генетическая и физиологическая природа этого явления пока не установлена. Необходимо отметить, что в предыдущих наших опытах при проведении прививки топинамбура на подсолнечник, картофеля на баклажаны, также нами было обнаружено изменение ряда качественных и количественных признаков растений подвоя и привоя, что необходимо в будущем проведение дальнейших экспериментов в этом направлении.

\section{Список литературь}

1. Марков А.В. Горизонтальный перенос генов и эволюция / А.В. Марков // http://evolbiol.ru/lgt2008/lgt2008.htm.

2. Матвеева Т.В. Роль горизонтального переноса генов в эволюции высших растений / Т.В. Матвеева // Международной конференции «125 лет прикладной ботаники в России». 2-28 ноября 2019 г. - Санкт-Петербург, Россия, 2019. - 160 с.

3. Насыров Ю.С. Факел познания. Москва / Ю.С. Насыров // «Колос», 1994. - 111 с.

4. Шестаков С.В. Роль горизонтального переноса генов в эволюции. / С.В. Шестаков // Горный Алтай, стационар "Денисова Пещера". Электронная публикация. http://evolbiol.ru/shestakov.htm

5. Rusk N. (2009) «Grafting as a potent molecular tool», Nature Methods 6, 484 http://www.nature.com/nmeth/journal/v6/n7/full/nmeth0709-484.html

6. Sandra Stegemann, Ralph Bock. Exchange of Genetic Material Between Cells in Plant Tissue Grafts // Science. 2009. V. 324. P. 649-651. 


\section{Мировые генетические ресурсы Phaseolus vulgaris L., их мобилизация, изучение и рациональное использование для решения селекционных задач в Республике Беларусь}

Пашкевич А.М., аспирант, зав. сектором бобовых овощңных культур; Чайковский А.И., директор; Досина-Дубешко Е.С., зам. директора по научной работе; Медведь Н.В., лаборант сектора бобовых овощных культур. РУП «Институт овощеводства», аг. Самохваловичи, Республика Беларусь. e-mail: 375298516620@mail.ru

Современная селекция должна обладать мобильностью в решении актуальных практических задач. Для этого в каждом селекционном учреждении необходимо иметь в наличии разнообразный исходный материал, который служит источником, как отдельных признаков, так и их разнообразных сочетаний. Расширение генетической основы сортообразцов является мощным инструментом увеличения продуктивности и адаптивности овощных культур.

Ключевые слова: генетическая коллекция, фасоль обыкновенная, генбанк, образеи.

\section{World genetic resources of Phaseolus vulgaris L., their mobilization, study and rational use for solving breeding problems in the Republic of Belarus}

Pashkevich M. A., graduate student, head sector of leguminous vegetable crops, Tchaikovsky A. I., director; Dosina-Dubeshko E. S., deputy director for scientific work; Medved N. V., laboratory assistant of the sector of leguminous vegetable crops. RUP "Institute of vegetable growing", ag. Samokhvalovichi, Republic of Belarus, e-mail: 375298516620@mail.ru.

Modern selection should have mobility in solving actual practical problems. To do this, each breeding institution must have a variety of source material, which serves as a source of both individual traits and their various combinations. Expanding the genetic basis of varieties is a powerful tool for increasing the productivity and adaptability of vegetable crops.

Key words: genetic collection, common bean, genbank, sample.

Фасоль - ценная высокобелковая культура, имеющая многостороннее использование и занимающая первое место в мировом земледелии среди пищевых бобовых, употребляемых человеком. Сочетание высококачественного белка с сахаром, минеральными веществами и витаминами, а также высокая калорийность придают фасоли особую ценность как пищевому и лечебному продукту [1]. Также установлено, что 1 га, засеянный фасолью, про- 
изводит 123 кг белка по сравнению с 3-4 кг белка от мясного скота, на одинаковом количестве земли [2]. Фасоль возделывают более чем в 70 странах, расположенных в различных почвенно-климатических зонах.

За 7000-8000 лет фасоль обыкновенная (Phaseolus vulgaris L.) претерпела целый ряд изменений от дикой лианы, растущей в горной местности Центральной Америки и Анд, до главного продовольственного бобового растения, за счет эволюционных сил - мутаций, миграций, генетического дрейфа, - а также за счет длительного одомашнивания. В процессе доместикации у фасоли изменился характер роста стебля, уменьшился период покоя семян, увеличился размер бобов и семян, изменилась чувствительность к фотопериоду, увеличилась урожайность и др. Длительное параллельное одомашнивание фасоли в двух зонах - Центральная Америка (равнинный тип) и область Анд (высокогорный тип) - сформировало две группы культурных форм $P$. vulgaris L., которые различаются по морфологическим, биометрическим и биохимическим признакам. В дальнейшем фасоль распространилась из центров своего происхождения по всему Американскому континенту, на кораблях первооткрывателей - в Европу, видоизменяясь под действием естественного и искусственного отбора, адаптируясь к новым условиям произрастания, она дошла до Азии. Постепенно, проходя через различные регионы мира, $P$. vulgaris L. вернулась в места своего происхождения в совершенно другом виде, насыщая местные популяции и сорта новыми признаками и свойствами.

Современная доступность генетических ресурсов, а также развитие методов манипуляции генетическим материалом сделали возможным получение новых сочетаний признаков и свойств растений фасоли, благодаря чему генетическое разнообразии ее культурного генофонда продолжает увеличиваться. Практически в любой развитой стране мира национальные генетические банки растений, коллекции университетов и научно-исследовательских учреждений содержат некоторое количество образцов фасоли обыкновенной. Наиболее обширные и разнообразные коллекции P. vulgaris L. собраны в России, Колумбии, США, Канаде, странах Европы: Франции, Германии, Нидерландах, Украине, Молдове, Болгарии, Польше, Швеции, Беларуси и др.

Наиболее обширная информация о мировом генофонде фасоли аккумулирована IPGRI, содержащая контактную информацию об организациях, поддерживающих и хранящих коллекции, образцов фасоли, о типах коллекций, минимальные паспортные данные образцов.

Информация о коллекциях фасоли, сосредоточенных в Европе, располагается в Европейской Базе Данных Фасоли, которая была организована по инициативе Европейской совместной программы по объединению генетических ресурсов сельскохозяйственных растений (ECP/GR) в 1995 г. База данных содержит паспортные данные более 38 тыс. образцов, представленных 
двадцатью двумя европейскими участниками.

Значительные генетические ресурсы фасоли сосредоточены во Всероссийском институте генетических ресурсов растений имени Н.И. Вавилова.

Информацию более чем о 26 тыс. образцах фасоли можно получить посредством поисковой системы NPGS/GRIN, которая предоставляет данные о генетических ресурсах, сосредоточенных в США под управлением USDA (Департамент по сельскому хозяйству США). В коллекции представлено более 1 тыс. диких форм фасоли, включая 126 образцов Phaseolus vulgaris var. aborigineus (Burkart) Baudet.

Обширная коллекция фасоли собрана в СIAТ (Центр по изучению тропических растений, Колумбия): более 36 тыс. образцов из 110 стран, включая около 2 тыс. диких видов и форм.

Собранная нами коллекция генетических ресурсов фасоли представлена ex-situ, состоящая из 302 улучшенных сортов, 30 мутантных образцов (получены воздействием таких мутагенов, как $\operatorname{Co}^{60}$ и неодимовый лазер), 131 гибридных образцов (межсортовые и мутантные гибриды 1-3 поколения), 26 местных образцов, или «народных сортов». Основным критерием включения образца в коллекцию является его достаточная семенная продуктивность, позволяющая поддерживать образец в коллекции и создавать запас семян для обмена или передачи заинтересованным исследователям. В коллекции представлены образцы из 28 стран, овощного, зернового и универсального назначения.

Пополнение нами генетической коллекции ведется за счет обмена с селекционными центрами, генетическими банками, научно-исследова-тельскими институтами, сбора у местного населения в регионах традиционного приусадебного выращивания фасоли. Изучение коллекционных образцов $P$. vulgaris L. осуществляется в полевых условиях по общепринятым методикам, предусматривающее оценку по комплексу морфологических, биологических и хозяйственно-ценных признаков, а также по адаптивной способности и экологической стабильности. Посредством молекулярного маркирования мы выявляем наличие генов устойчивости у образцов к антракнозу фасоли. Проводимая работа позволяет получать ценную информацию о накопленной коллекции и конкретных коллекционных образцах, обеспечивает возможность эффективного отбора исходных образцов для гибридизации. Итогом нашей работы является включение в Государственный реестр сортов и древесно-кустарниковых пород 3 сортов фасоли овощного направления использования и сорта универсального назначения, за последние 15 лет.

Собранная коллекция фасоли относится к коллекциям с краткосрочным хранением семян. Высушенные семена хранятся в стеклянных банках для обеспечения минимального контакта с окружающей средой. Банки снабжены этикеткой с достаточной для идентификации образца информацией, 
содержащей коллекционный и наименование образца и год последней закладки семян на хранение. Во избежание потери образца пересев семян с одновременным контролем характерных для него признаков осуществляется не реже, чем раз в пять лет. Такая динамика размножения и возобновления запаса семян коллекционных образцов позволяет постоянно иметь в наличии не менее 500-1000 г всхожих семян, что вполне достаточно для проведения запланированных исследовательских работ, обмена или односторонней передачи заинтересованным исследователям.

Данные о коллекционных образцах (паспортные данные, данные полевых и лабораторных исследований) хранятся в электронном виде, организованном в систему связанных баз данных, а также на бумажном носителе. Электронная система документирования нами создана для обеспечения нужд пользователей коллекции и управления данными об образцах. Она включает продолжительный ряд сведений от момента поступления образца вплоть до его использования, который организован в виде компьютерных файлов. Кроме того, имеется база фотографических изображений вегетирующих растений, их цветков, бобов в различной стадии развития, семян.

\section{Список литературы}

1. Пашкевич А.М. и др. Оценка коллекционных сортообразцов фасоли овощной по хозяйственным и биолого-морфологическим признакам / А.М. Пашкевич [и др.] // Овощеводство: сб. науч. ст. - Минск, 2015. - Т. 23. - С. 139-143.

2. Phaseolus bean: Post-harvest operations. Organisation: Centro Internacional de Agricultura Tropical (CIAT). Author: A.L. Jones. Edited by AGSI/FAO: Danilo Mejia (Technical), Beverly Lewis (Language \& Style). [Электронный ресурс]. - Режим доступа: http: // www.fao.org/3/a-av015e.pdf. - Дата доступа: 29.02.2018.

DOI 10.18699/GPB2020-57

\section{Наследование генов-маркеров к митохондриальной ДНК у аллоплазматических линий $T$. dicoccum $\mathbf{x}$ T. aestivum}

Перфильев P.H. ${ }^{1 *}$, студент, Щербань А.Б. ${ }^{2}$, д.б.н., с.н.с. Салина Е.А. ${ }^{2}$, д.б.н., 2.H.c.

${ }^{1}$ Новосибирский государственный аграрный университет, Новосибирск, Россия;

${ }^{2}$ Федеральный исследовательский цеентр институт цчитологии и генетики СО РАН, Новосибирск, Россия.

*e-mail: pervf.1999@gmail.com

С помощью молекулярных маркеров митохондриальных генов проанализированы аллоплазматические линии пщеницы, содержащчие ядерный ге- 
ном гексаплоидной пшенищы T. аеstivuт на фоне цитоплазмы тетраплоидной пшеницы T.dicoccuт. У линии D-N-05 маркеры генов rps 19 и orf256 соответствовали родительскому виду T.дісоссит. Секвенирование продукта ПЦР orf 256 подтвердила наследуемость митохондриального генома указанной линии от T.dicocсит. Остальные линии проявляли спектры ПЦР и CAPSмаркеров, соответствующие виду T. аеstivuт, что указывает на вытеснение митохондриального генома T. dicoсcит в процессе беккроссирования с гексаплоидной пшеницей, за исключением линии D-N-05. Последняя линия является перспективной в плане изучения механизмов восстановления фертильности у гибридов с ичтоолазматической мужской стерильностью.

Ключевые слова: аллоплазматические линии, T. dicoccuт, ПЦР, CAPSмаркер, ЦМС, мягкая пшенииа.

\section{Inhearitance of marker genes to mitochondrial DNA in alloplasmic lines of $T$. dicoccum $x T$. aestivum}

Perfilev R.N., student, Novosibirsk Agriculture State University, Novosibirsk, Russia e-mail: pervf.1999@gmail.com

Shcherban A. B., d. b. s., s. r., Federal Research Center Institute of Cytology and Genetics SB RAS, Novosibirsk, Russia

Salina E.A., d. b. s., c. r., Federal Research Center Institute of Cytology and Genetics SB RAS, Novosibirsk, Russia

Using molecular markers of mitochondrial genes, alloplasmic lines of wheat containing the nuclear genome of hecasploid wheat T. aestivum against the background of the cytoplasm of tetraploid wheat T. dicoccum were analyzed. In the D-N-05 line, the markers of the rps 19 and orf256 genes corresponded to the parent species of T. dicoccum. Sequencing of the PCR product orf 256 confirmed the heritability of the mitochondrial genome of the specified line from T. dicoccum. The remaining lines showed PCR and CAPS marker spectra corresponding to the type T. aestivum, indicating the displacement of the mitochondrial genome of $T$. dicoccum in the process of backcrossing with hexaploid wheat, with the exception of the D-N-05 line. The latter line is promising in terms of studying the mechanisms of restoring fertility in hybrids with cytoplasmic male sterility.

Key words: alloplasmic lines, T.dicoccum, CAPS marker, PCR, CMS, wheat.

Важным объектом для селекции, а также для изучения механизмов межвидовой гибридизации являются аллоплазматические линии, полученные в результате объединения ядра и цитоплазмы от разных видов. Зачастую у таких линий происходит конфликт ядра и цитоплазмы, в результате которого наблюдается цитоплазматическая мужская стерильность (ЦМС). Ключевая роль в формировании ЦМС принадлежит митохондриям и данный феномен ассоциирован с различными маркерами, в частности, с химерной рам- 
кой считывания orf256 вблизи гена coxl [1]. Случаи восстановления фертильности у аллоплазматических линий связывают с действием особых генов - восстановителей фертильности, которые у пшеницы, однако, до сих пор не были идентифицированы. Основная цель настоящей работы заключалась в идентификации родительских типов митохондриального генома у фертильных аллоплазматических линий между различными видами пшеницы.

Материал и методы. Материалом послужили 7-дневные проростки 10 аллопламзматических линий пшеницы. Линии получены, в Институте биологии и биотехнологии растений МОН Казахстана, профессором Н.А. Хайленко в результате многолетнего отбора (F12) из гибридного потомства (F3BC2) T. dicoccum Schuebl. var. Araratum (Host.) х $\overparen{T}$ T. aestivum L. (Мироновксая 808) [2].

ДНК выделяли из 7-дневных проростков согласно стандартной методике с бисульфитом натрия. В качестве маркеров генов митохондриальной ДНК использовали следующие комбинации праймеров (условия ПЦР даны в соответствующих статьях): 1) orf256f: ggaagggaaccaatcaagtcacc; orf256r: gatcctgctcgtaaaggctcag [3]; 2) rps19f: tgctccgtactcatttacaatgg; rps19r: atagggtcttcgtctccgtg [4]. В случаe orf256 продукты ПЦР обрабатывали рестрикционной эндонуклеазой Taq I (Сибэнзим, Новосибирск) с последующим электрофорезом (CAPS- маркер).

Продукты ПЦР разделяли в $2 \%$ агарозном геле с добавлением этидиум бромида. Гель фотографировали с помощью GelDoc XR (BioRad, England). Продукт ПЦР orf256 вырезали из геля, очищали с помощью кита (QIAGEN, Germany) и секвенировали с использованием bigdye terminator v3.1 cycle sequencing kit (Applied Biosystems, USA). Анализ продуктов секвенирования проводили в Центре коллективного пользования «Геномика» $\mathrm{CO}$ PAH.

Результаты и обсуждение. На рис. 1 представлен результат электрофореза обработанных рестриктазой Taq I продуктов ПЦР, полученных с помощью праймеров orf256f/r. Видно, что спектр рестрикции линии D-N-05 наиболее соответствует спектру родительского вида $T$. dicoccum, тогда как у остальных линий картина рестрикции соответствует типу T. aestivum.

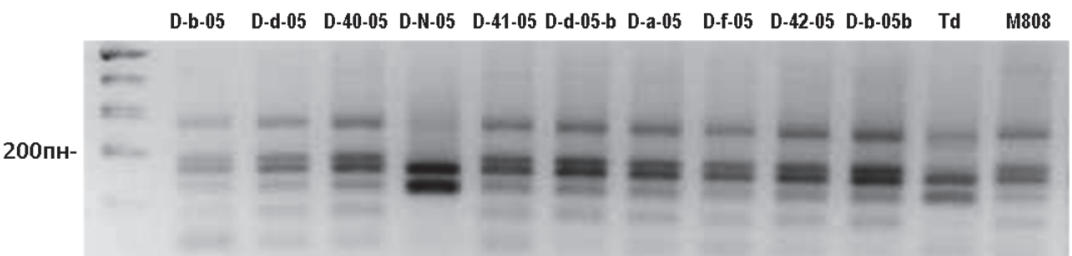

Рисунок 1. CAPS - маркер с праймерами orf256f/r. 
В ходе анализа первичной структуры продуктов амплификации с праймерами orf256f $/$, результат удалось получить только у линии D-N-05, при этом нуклеотидная последовательность этой линии соответствует митДНК T. timopheevii (АР013106) и ЦМС- линии T. timopheevii (†) х T. aestivum (X56186).

Результаты по маркеру rps 19 (Рис. 2), в свою очередь, согласуются с результатами на Рис. 1, а именно: продукт ПЦР линии D-N-05 по длине (111 пн) соответствует T. dicoccum, а также T. timopheevii (АР013106) и ЦМС- линии T. timopheevii () х T. aestivum (X56186). У остальных линий длина фрагмента соответствует виду T. aestivum.

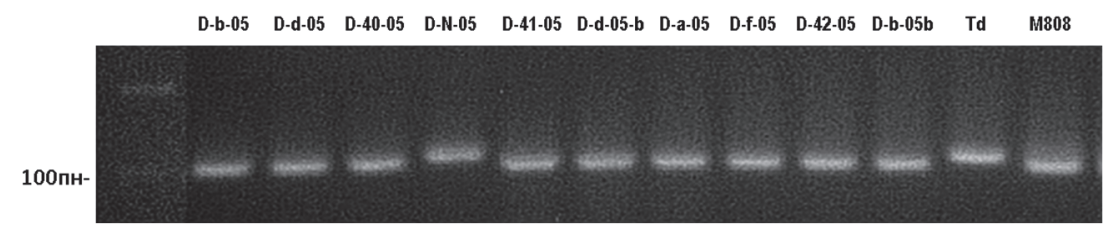

Рисунок 2. Результат электрофореза продуктов ПЦР с праймерами rps19f/r.

Таким образом, полученные результаты свидетельствуют о наследовании типа митохондриальной ДНК мужского родителя (T. aestivum) у большинства исследованных линий (гомоплазмия), за исключением линии D-N05 , у которой выявлено преобладание типа митохондрий материнского вида $T$. dicoccum. В дальнейшем планируется идентифицировать гены- восстановители фертильности в составе ядерного генома у этой линии.

Благодарности: Работа выполнена при поддержке гранта Минобрнауки № 0324-2019-0039-С-01.

\section{Список литературы}

1. Hedgcoth C. A chimeric open reading frame associated with cytoplasmic male sterility in alloplasmic wheat with Triticum timopheevii mitochondria is present in several Triticum and Aegilops species, barley, and rye / Hedgcoth C., El-Shehawi A. M., Wei P., Clarkson M., Tamalis D. // Curr. Genet. - 2002. - Vol. 41. - P. 357-365.

2. Terletskaya N.V. Drought Stress Tolerance and Photosynthetic Activity of Alloplasmic Lines T. dicoccum x T. aestivum. / Terletskaya N.V., Shcherban A.B., Nesterov M.A., Perfil'ev R. N. et al. // Int. J. Mol. Sci. - 2020 - V. 21, № 9 - 3356.

3. El-Shehawi, A.M.Genetic Fingerprinting of Wheat and Its Progenitors by Mitochondrial Gene orf256./ El-Shehawi, A.M.; Fahmi, A.I.; Sayed, S.M.; Elseehy, M.M. // Biomolecules 2012. 2. - P. 228-239.

4. Noyszewski A.K. Mitochondrial sequence diversity among alloplasmic and euplasmic triticum species. Doctoral dissertation, North Dakota State University, Fargo, 2013. 


\section{Особенности предселекции в работе с интрогрессивными аллоплазматическими ДГ-линиями мягкой пшеницы}

Першина Л.А. ${ }^{1 *}$, ә.б.н., г.н.с.; Трубачеева Н.В. ${ }^{1}$, к.б.н., н.с.; Белан И.А. ${ }^{2}$, к.с.х.н., зав. лаб.; Россеева Л.П. ${ }^{2}$, к.с.-х.н., в.н.с.

${ }^{1}$ ИЦиГ СО РАН, Новосибирск, Россия;

${ }^{2}$ ФГБНУ «Омский ФНЦ», Омск, Россия.

*e-mail:pershina@bionet.nsc.ru

В работе с аллоплазматическими интрогрессивными ДГ-линиями, которые планируется включать в селекционный процесс, показана необходимость их предселекиионного изучения. На этом этапе необходим отбор ииитогенетически стабильных 42-хромосомных ДГ-линий с высоким уровнем фертильности, молекулярный анализ для подтверждения наличия иеелевых генов и сохранения стабильности ядерно-циитоплазматических взаимодействий. Кроме того, важен учет и запланированное использование генетически идентичных ДГ-линий, сформированных из андрогенных растений, развившихся в составе кластеров (семейств).

Ключевые слова: ДГ-линии, аллоплазматические линии, предселекция, пшеница.

\section{Features of pre-breeding in work with alloplasmic introgression DH-lines of bread wheat}

Pershina Lidiya Aleksandrovna ${ }^{I}$, Trubacheeva Natalia Victorovna ${ }^{I}$, Belan Igor Aleksandrovich ${ }^{2}$, Rosseva Ludmila Petrovna ${ }^{2}$.

${ }^{1}$ Institute of Cytology and Genetics SB RAS, Novosibirsk, Russia

${ }^{2}$ Siberian Research Institute of Agriculture, Russian Academy of Agricultural Sciences, Omsk, Russia

In work with alloplasmic introgression DH lines, which are planned to be included in the breeding, the need for their pre-breeding study is shown. At this stage, it is necessary to select cytogenetically stable 42-chromosomal DH lines with a high level of fertility, molecular analysis to confirm the presence of target genes and maintain the stability of nuclear-cytoplasmic interactions. In addition, the accounting and planned use of genetically identical DH lines formed from androgenic plants that have developed as part of clusters (families) is important.

Key words: DH-lines, alloplasmic lines, pre-breeding, wheat.

Технологии получения удвоенных гаплоидных (ДГ) линий широко используются при выполнении генетических исследований и в селекции многих культурных растений. ДГ-линии создаются в течение одного года. 
Такие линии являются гомозиготными и могут быть быстро проанализированы в повторных испытаниях. Это значительно ускоряет отбор генотипов с желаемыми признаками в процессе развития растений, особенно в сочетании с использованием молекулярных маркеров [1].

Ранее в наших работах была показана возможность и целесообразность включения интрогрессивных ДГ-линий мягкой пшеницы, полученных на основе аллоплазматических линий (H. vulgare)-T. aestivum, в качестве исходного материала в селекционный процесс при создании новых сортов яровой мягкой пшеницы [2]. Аллоплазматические линии - это генотипы, сочетающие ядерный геном одного вида, а цитоплазму другого. Их образование происходит в результате повторяющихся возвратных скрещиваний отдаленных гибридов с отцовским видом [3]. При замещении цитоплазмы нарушаются взаимодействия между ядром и органельными геномами, что обуславливает новые ядерно-цитоплазматические взаимодействия, которые могут вызвать эпигенетические модификации ядерных генов [4]. В связи с этим аллоплазматические линии с восстановленной фертильностью рассматривают в качестве дополнительного источника биоразнообразия культурных растений [5].

ДГ-линии на основе интрогрессивных аллоплазматических линий $(H$. vulgare)-T. aestivum в наших работах получали с использованием метода культивирования пыльников [6]. Источниками для формирования ДГ-линий служили андрогенные растения со спонтанно удвоенным числом хромосом $(2 \mathrm{n}=42)$ и проявившие фертильность. В зависимости от генотипов частота развития растений с удвоенным числом хромосом наблюдалась от 18 до 45 $\%$. Установлено, что эффективность использования андрогенных растений для формирования ДГ-линий в работе с аллоплазматическими интрогрессивными генотипами, развившимися в культуре пыльников, может быть связана со следующими ограничениями: образованием большого числа нежизнеспособных хлорофилл-дефектных проростков; развитием анеуплоидов среди зеленых проростков; утратой целевых генов; формированием кластеров генетически идентичных проростков. В связи с этим включению ДГ-линий в селекционный процесс должен предшествовать комплекс предселекционного изучения. В нашей работе предусмотрено формирование каждой ДГ-линии из семян одного колоса, независимо от того, было это одиночное растение, или кластер растений. При первичном размножении ДГ-линий в теплице оценивается уровень цитогенетической стабильности; уровень фертильности; выполняется молекулярный анализ с целью выявления генов устойчивости к грибным патогенам, интрогрессированных в геном растений, использованных в качестве доноров пыльников; на основе результатов анализа состояния маркерных последовательностей митохондриальной и хлоропластной ДНК определяется уровень стабильности ядерно-цитоплазматиче- 
ской совместимости; по проявлению фенотипических признаков и результатам структурного анализа оцениваются ДГ-линии, сформированные из семян сестринских андрогенных растений, развившихся потенциально в одних семействах. В летний период в условиях Новосибирска на поле или изолированных участках на естественном фоне оценивается устойчивость к листостебельным патогенам; устойчивость к полеганию; уровень фертильности. В результате отбора ДГ-линий, как сформированных от единичных андрогенных растений, так и от растений, развившихся в семействах, выявляются наиболее перспективные для селекции.

Выделены аллоплазматические интрогрессивные ДГ-линии, которые характеризуются высокой сортообразующей способностью. В результате их гибридизации как между собой, так и с перспективными линиями, выделенными из коммерческих сортов, получено многообразие гибридных форм, включенных в селекционный процесс. Разрабатывается стратегия оптимального использования в селекции сестринских ДГ-линий, характеризующихся высокой продуктивностью, качеством зерна и устойчивостью к биотическим факторам.

Благодарности: Основные разделы работы выполнены при поддержке РФФИ (проект № 20-016-00196).

\section{Список литературы}

1. Germana M.A. Gametic embryogenesis and haploid technology as valuable support to plant breeding / M.A. Germana // Plant Cell Rep. -2011 . - P. 839-857.

2. Першина Л.А. Аллоплазматические рекомбинантные линии (H. vulgare)T. Aestivum с транслокацией 1RS.1BL: исходные генотипы для создания сортов мягкой пшеницы / Л.А.Першина, Л.И. Белова, Н.В.Трубачеева, Т.С. Осадчая, В.К. Шумный, И.А. Белан, Л.П. Россеева, В.В. Немченко, С.Н. Абакумов // Вавиловский журнал генетики и селекции, 2018. - С.544-552.

3. Tsunewaki K. Plasmon analysis as the counterpart of genome analysis $/ \mathrm{K}$. Tsunewaki// Methods of genome analysis in plant - Ed. Jauhar P.P. Boca Raton, New York, London, Tokyo: CRC Press, 1996. - P. 271-299.

4. Noyszewski A.K, Ghavami F., Alnemer L.M., Soltani A., Gu Y.Q., Huo N., Meinhardt S., Kianian P.M., Kianian S.F. Accelerated evolution of the mitochondrial genome in an alloplasmic line of durum wheat /A.K. Noyszewski, F. Ghavami, L.M. Alnemer, A. Soltani, Y.Q.Gu, N. Huo, S. Meinhardt, P.M.Kianian, S.F. Kianian // BMC genomics 2014. - P.1-16.

5. Liu C.G., Wu Y. W., Hou H., Zhang C., Zhang Y., McIntosh R.A. Value and utilization of alloplasmic common wheats with Aegilops crassa cytoplasm / C.G. Liu, Y.W. Wu., H. Hou, C. Zhang, Y. Zhang, R.A.McIntosh // Plant Breeding - 2008. - P. 407-410.

6. Осадчая Т.С., Першина Л.А., Трубачеева Н.В., Белан И.А, Россеева Л.П., Девяткина Э.П. Способность к андрогенезу эуплазматических линий мягкой пшеницы и аллоплазматических рекомбинантных линий (H. vulgare)-T. aestivum с транслокациями 1RS.1BL и 7DL-7Ai и получение дигаплоидных линий / Т.С. Осадчая, Л.А. Першина, Н.В. Трубачеева, И.А. Белан, Л.П. Россеева, Э.П. Девяткина // Вавиловский журнал генетики и селекции - 2014. - С. 650-659. 


\section{Длительная устойчивость пшеницы к бурой ржавчине с традиционной и молекулярной точек зрения}

Плотникова Л.Я.*, профессор; Пожерукова В.Е., н.с. Омский государственный аграрный университет, г. Омск, Россия. *e-mail: lplotnikova2010@yandex.ru

Представлена информация о проявлении комплекса механизмов длительной устойчивости к бурой ржавчине иммунных видов злаков и интрогрессивных линий пшениць с Lr-генами. Несовместимость гриба Pиссіпіа triticina Erikss. с видами-нехозяевами проявляется на нескольких стадиях патогенеза. Отмечено нарушение формирования структур гриба на поверхности и внутри листьев, которое часто происходило до или без накопления активных форм кислорода (АФК) и проявления реакиии СВЧ. Чужеродные гены Lr9, Lr19, Lr23 контролируют эффекты, аналогичные отдельным защиттным механизмам нехозяев. Ген Lr34 имеет плейотропный эффект и определяет ингибирование патогена на поверхности и в тканях растений. Результаты рассмотрены с традиционной и молекулярно-генетической точек зрения.

Ключевые слова: длительная устойчивость, Pисcinia triticina, видынехозяева, интрогрессивные линии, защитные механизмы.

\section{Durable resistance of wheat to leaf rust from traditional and molecular point of view}

Plotnikova L.Ya., Pozherukova V.E.

Omsk State Agrarian University, Omsk, Russia

Information about the durable resistance mechanisms of immune cereal species and introgressive wheat lines with Lr-genes to leaf rustis presented. The incompatibility of the fungus Puccinia triticina Erikss. with non-hosts is appeared at several pathogenesis stages. The suppression of surface and intraleaf fungal structures formation is often occurred before or without accumulation of reactive oxygen species (ROS) and the hypersensitive reaction. The alien genes $\operatorname{Lr} 9, \operatorname{Lr} 19$, and Lr23 effect similar to some non-host species defense mechanisms. Lr34 has a pleiotropic effect and determined the pathogen inhibition on the surface and in plant tissues. The results are considered from the traditional and molecular genetic points of view.

Key words: durable resistance, Puccinia triticina, non-host species, introgressive lines, defense mechanisms.

Производство растительной продукции в значительной мере ограничивается развитием болезней. Во второй половине XX в. в мире была повсеместно распространена бурая ржавчина, вызываемая биотрофным грибом 
Puccinia triticina Erikss. Однако в 1998-2011 гг. в Африке и в Европе появились и стали быстро распространяться агрессивные расы возбудителей стеблевой и желтой ржавчины пшеницы. В 2015 г. сильная вспышка стеблевой ржавчины произошла на юге Западной Сибири и в Северном Казахстане [1]. В связи с усилением вредоносности комплекса ржавчинных болезней активизировался интерес к изучению механизмов устойчивости видов-нехозяев, а также действию генов, длительно защищающих сорта.

В XX в. в фитоиммунологии сложилось представление об участии патогенов и растений в установлении совместимых взаимодействий. Специализированные грибы воспринимают свойства растений в качестве стимулов для формирования инфекционных структур [2]. Гены устойчивости растений кодируют рецепторы, обеспечивающие узнавание метаболитов патогена (элиситоров). При узнавании элиситоров происходит быстрое накопление активных форм кислорода (АФК) - окислительный взрыв, и запускается комплекс защитных реакций. Для преодоления сортовой устойчивости патоген должен утратить элиситоры или приобрести супрессоры защитных реакций [3].

Позже на основании результатов молекулярно-генетических исследований была сформулирована новая концепция иммунитета растений. Предполагается, что растения имеют двухуровневую защиту, У видов-нехозяев запускается первый уровень неспецифических защитных ответов РТI (РAMP-triggered immunity) после узнавания поверхностными рецепторами консервативных паттернов непатогенных микроорганизмов (MAMPs), молекул, связанных с патогенными свойствами (PAMPs), и продуктов разложения растений (DAMPs). После преодоления PTI запускается второй уровень защиты, связанный с узнаванием специфических эффекторов - ETI (EffectorTriggered Immunity), определяющий сортовую устойчивость [4].

Патосистема «P. triticina - виды семейства Роасеае» представляет удобную модель для изучения механизмов устойчивости к ржавчинным болезням, поскольку в XX в. шла активная микроэволюция гриба, и для защиты пшеницы в сорта вводили гены различных видов злаков. Для исследования проблем длительной устойчивости к $P$. triticina нами был использован набор иммунных злаков разных родов (просо посевное Panicum miliaceum L., овес Avena sativa L., ячмень Hordeum sativum L., пырей удлиненный Agropyron elongatum (Host) Beuv., пшеница Тимофеева Triticum timopheevii Zhuk.), пшенично-пырейные гибриды (ППГ), линии сорта Тэтчер (Tc $L r)$ с чужеродными генами устойчивости. Гены Lr9 (от Aegilops umbelllulata), Lr19 (Ag. elongatum), Lr23 (T. turgidum) и возрастной $L r 34$ интенсивно использовались в мировой селекции и длительно сохраняли эффект в большинстве регионов мира, при условии научно-обоснованного использования защищенных ими сортов.

На восприимчивых растениях мягкой пшеницы T. aestivum патоген последовательно формирует набор специализированных инфекционных структур на поверхности (ростковые трубки, аппрессории на устьицах) и в 
ткани листьев (инфекционные гифы, гаустории в клетках растения, спорогенные клетки). На нехозяевах развитие $P$. triticina ингибировалось на разных этапах (таблица). На просе отмечено подавление образования аппрессориев и проникновения в ткани. На иммунных растениях овса, ячменя и пырея удлиненного образование аппрессориев было подавлено в меньшей степени, но образовавшиеся аппрессории погибали при попытке проникновении в устьица после окислительного взрыва. Образование АФК показывает, что узнавание гриба нехозяевами происходило до внедрения в ткани. На наборе пшенично-пырейных гибридов установлено, что взаимодействие отдельных растений с грибом было аналогично с родительским образцом пырея Ag. elongatum, на других гибель гриба происходила после внедрения в единичные мезофилльные клетки и сопровождалась накоплением АФК и реакцией СВЧ. В некоторых ППГ было подавлено формирование гаусторий, необходимых для питания патогена, но без признаков защитных реакций. При взаимодействии P. triticina с образцами T. timopheevii установлены все перечисленные варианты, но преобладало подавление формирования гаусторий, что, вероятно, приводило к гибели гриба от голодания [5].

Таблица - Особенности развития инфекционных структур $P$. triticina и проявление защитных механизмов иммунных видов, пшенично-пырейных гибридов и линий мягкой пшеницы

\begin{tabular}{|c|c|c|c|c|c|c|}
\hline \multirow[b]{2}{*}{$\begin{array}{l}\text { Вид, } \\
\text { гибрид, } \\
\text { линия }\end{array}$} & \multicolumn{5}{|c|}{ Нарушение развития патогена* } & \multirow[b]{2}{*}{$\begin{array}{c}\text { Проявление защитных } \\
\text { реакций }\end{array}$} \\
\hline & 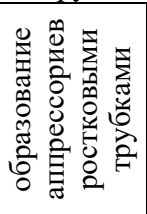 & 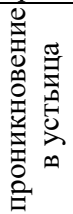 & 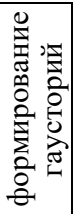 & 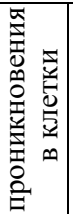 & 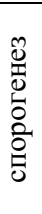 & \\
\hline Panicum miliaceum & +++ & + & - & - & - & - \\
\hline Avena sativa & ++ & ++ & - & - & - & АФК на устьицах \\
\hline Hordeum sativum & ++ & ++ & - & - & - & \langle\rangle$\rangle$ \\
\hline Agropyron elongatum & ++ & ++ & - & - & - & $\langle »\rangle$ \\
\hline $\begin{array}{l}\text { ППГ } \\
\text { (разные гибриды) }\end{array}$ & $\begin{array}{l}++ \\
++\end{array}$ & $\begin{array}{c}++ \\
+\end{array}$ & +++ & $\bar{r}+$ & $\begin{array}{l}- \\
-\end{array}$ & $\begin{array}{c}\text { АФК на устьицах, } \\
\text { АФК на устьицах и } \\
\text { в мезофилльных клетках, } \\
\text { СВЧ } \\
-\end{array}$ \\
\hline Triticum timopheevii & + & + & +++ & + & + & $\begin{array}{c}\text { АФК на устьицах и в ме- } \\
\text { зофилльных клетках, } \\
\text { СВЧ, отложения каллозы } \\
\text { и лигнина }\end{array}$ \\
\hline TcLr9 & ++ & ++ & - & - & - & АФК на устьицах \\
\hline TcLr19 & ++ & ++ & - & - & - & \langle\rangle$\rangle$ \\
\hline $\operatorname{Tc} L r 23$ & - & - & ++++ & - & + & $\begin{array}{c}\text { Отложения каллозы и } \\
\text { лигнина }\end{array}$ \\
\hline TcLr34/Sr57/Yr18/Pm38 & ++ & ++ & ++ & - & + & $\begin{array}{l}\text { АФК на устьицах, отло- } \\
\text { жения каллозы и лигнина }\end{array}$ \\
\hline
\end{tabular}

*Примечание: «-» - эффект отсутствует, «++++» - сильный эффект. 
Взаимодействие патогена с интрогрессивными линиями $\operatorname{Tc} L r 9 u$ TcLr19 было аналогично результатам развития на овсе, ячмене и пырее удлиненном. На линии Tc $L r 23$ обнаружено подавление формирования гаусторий, подобное действию отдельных ППГ и растений T. timopheevii. Эти результаты показывают, что чужеродные гены могут контролировать проявления несовместимости, характерные для нехозяев. Особый интерес представляет действие гена Lr34, входящего в сложную транслокацию Lr34/Sr57/Yr18/Pm38. На взрослых растениях TcLr34 отмечен плейотропный негативный эффект: ингибирование развития аппрессориев, окислительный взрыв на устьицах, нарушение образования гаусторий у отдельных колоний и частичное подавление спорогенеза.

Таким образом, показан набор механизмов, обеспечивающий длительную устойчивость к бурой ржавчине иммунных видов и интрогрессивных линий пшеницы. Несовместимость $P$. triticina с растениями в значительной степени проявлялась до окислительного взрыва, свидетельствующего об узнавании патогена. Вероятно нарушение стимуляции образования инфекционных структур гриба иммунными растениями. Полученная информация в определенной степени противоречит концепции существования двухуровневой защиты PTI- и ЕTI-типов, которая преимущественно основана на активных реакциях, развивающиеся после узнавания MAMPs, PAMPs, DAMPs.

Полученные данные о системе механизмов устойчивости иммунных видов и интрогрессивных линий представляют интерес для определения стратегии защиты мягкой пшеницы от ржавчинных болезней и выявления источников потенциальной длительной устойчивости.

\section{Список литературы}

1. Shamanin V.[et al.]. Genetic diversity of spring wheat from Kazakhstan and Russia for resistance to stem rust Ug99 / V. Shamanin, E. Salina, R. Wanyera [et al.] // Euphytica, 2016. - Vol. 212 - P. 287-296.

2. Hahn M. Characterization of in planta induced rust genes isolated from a haustoriumspecific cDNA library / M. Hahn, K. Mendgen // Mol. Plant-Microbe Interact., 1997. Vol.10. - P. 427-437.

3. Boller T. Perception and Transduction of Elicitor Signals in Host-Pathogen Interactions / T. Boller, N.T. Keen // Mechanisms of Resistance to Plant Diseases. - Dordrecht: Kluwer, 2000. - P. $189-230$.

4. Gill U.S. [et al.]. Host Versus Nonhost Resistance: Distinct Wars with Similar Arsenals / U.S. Gill, S. Lee, K.S. Mysore // Phytopathology, 2015. - Vol. 105. - N. 5. - P. 580586. 


\section{Взаимосвязь между размерами корневой системы и генетическим статусом локуса Vrn-1 у мягкой пшеницы (Triticum aestivum L.)}

Пшеничникова Т.А. ${ }^{*}$, к.б.н., зав. сектором генетики качества зерна, Симонов А.В., к.б.н., н.с., Морозова Е.В., м.н.с., Смирнова О.Г., к.б.н., с.н.с. ФГБНУ «Федеральный исследовательский центр Институт цитологии и генетики Сибирского отделения Российской академии наук».

*e-mail:wheatpsh@bionet.nsc.ru

Архитектура корневой системы определяет укоренение растения, эффективное поглощение питательных веществ и воды из почвы и взаимодействие с биомом почвы. В данной работе у пшеницы (Triticum aеstivum L.) была изучена взаимосвязь между аллельным состоянием локуса Vrn-1 и длиной и весом корней. Было обнаружено, что присутствие доминантных аллелей генов Vrn-A1 и Vrn-B1 аналогично действию длительной яровизации. При этом происходит уменьшение размеров корневой системы одновременно с сокращением периода до иветения. Наибольший эффект оказывает ген Vrn-A1.

Ключевые слова: Triticum aеstivum, интрогрессия, длина и вес корней, моносомный анализ; локус Vrn-1.

\section{Relationship between the size of the root system and the genetic status of lo- cus Vrn-1 in bread wheat (Triticum aestivum L.)}

Pshenichnikova T.A., Simonov A.V., Morozova E.V., Smirnova O.G. Institute of Cytology and Genetics, Siberian Branch of Russian Academy of Sciences, Novosibirsk, Russia

E-mail:wheatpsh@bionet.nsc.ru

Root architecture determines the rooting of the plant, the effective absorption of nutrients and water from the soil and the interaction with the soil biome. In this work, the relationship between the allelic state of the Vrn-1 locus and the length and weight of the roots was studied in wheat (Triticum aestivum L.). It was found that the presence of dominant alleles of the Vrn-Al and Vrn-BI genes is similar to the effect of prolonged vernalization. In this case, a reduction in the size of the root system occurs simultaneously with a reduction in the period before flowering. The Vrn-Al gene has the greatest effect.

Key words: Triticum aestivum, introgression, root weight and length, monosomic analysis; Vrn-1 locus.

Корни - это основной орган растительного организма, формирующийся на первых этапах его развития. Архитектура корневой системы опре- 
деляет укоренение растения, эффективное поглощение питательных веществ и воды из почвы и взаимодействие с биомом почвы. Хорошо развитая мелкая корневая система способна улавливать влагу даже при небольших дождях, а длинные корни способны достигать нижних, более увлажненных горизонтов почвы. Эти свойства особенно важны в условиях засухи, которые в настоящее время представляют наиболее серьезную угрозу климату во всем мире.

Исследования по генетическому контролю корневой системы у хлебной пшеницы (Triticum aestivum L.) значительно отстают от аналогичных исследований по рису и кукурузе и ограничены поиском QTL в различных популяциях [1-3]. Локусы, идентифицированные в этих исследованиях, были локализованы на хромосомах практически всех гомеологических групп, что говорит о сложном генетическом контроле данного признака. В недавнем исследовании было обнаружено, что локус $V r n-1$ участвует в генетическом контроле роста корня и определяет такие фенотипические особенности, как угол и длина корня [4]. В данной работе с помощью моносомного анализа у пшеницы была изучена взаимосвязь между аллельным состоянием локуса $V r n-1$ и длиной и весом корней. В качестве генетического материала послужила озимая интрогрессированная линия (IL) 5D-5, полученная ранее на основе замещенной линии Чайниз Спринг (Синтетик 6x 5D). Донором хромосомы является озимый синтетик гибридного происхождения (T. dicoccoides $\times$ Ae. tauschii, AABBDD). Также был изучен набор из 8 сортов и линий различного состава по генам локуса Vrn-1. Растения изучались в условиях теплицы, в условиях гидропонного выращивания. Моносомные популяции $\mathrm{F}_{2}$ по хромосомам 5A, 5B и 5D были получены на основе соответствующих моносомных линий ярового сорта Саратовская 29 (С29). По 130 растений было изучено в каждой популяции по длине и весу корней. Во втором эксперименте у каждого из сортов и линий было изучено по 12 растений. Длину корней (см) измеряли после извлечения из искусственного грунта, вес корней (г) - после полного высушивания на воздухе.

Таблица 1 - Среднее число дней до цветения, длина корня и его вес у гибридов $\mathrm{F}_{2}$ между моносомными линиями по хромосомам 5A, 5B и 5D ярового сорта С29 и интрогрессированной линией (IL) 5D-5

\begin{tabular}{|c|c|c|c|}
\hline Генотипы & $\begin{array}{c}\text { Дни } \\
\text { до цветения }\end{array}$ & $\begin{array}{c}\text { Длина } \\
\text { корней, см }\end{array}$ & $\begin{array}{c}\text { Вес } \\
\text { корней, г }\end{array}$ \\
\hline 1 & 2 & 3 & 4 \\
\hline $\mathrm{C} 29(V r n-A 1 ; V r n-B 1 ; v r n-D 1)$ & 36,1 & 22,1 & 0,103 \\
\hline $\begin{array}{l}\text { IL 5D-5 (vrn-Al; vrn-Bl; vrn-Dl) } \\
\text { яровизация } 30 \text { дней }\end{array}$ & 49,3 & 30,2 & 1,04 \\
\hline $\begin{array}{l}\text { IL 5D-5 (vrn-Al; vrn-Bl; vrn-Dl) } \\
\text { яровизация } 60 \text { дней }\end{array}$ & 37,0 & 22,8 & 0,090 \\
\hline $\begin{array}{l}\mathrm{F}_{2} \text { моно } 5 \mathrm{~A} \text { C } 29 \times \text { IL } 5 \mathrm{D}-5 \\
(v r n-A 1 ; V r n-B 1 ; v r n-D 1)\end{array}$ & $47,4 * * *$ & $28,4 * * *$ & $0,437 * * *$ \\
\hline
\end{tabular}




\begin{tabular}{|l|c|c|c|}
\hline \multicolumn{1}{|c|}{$\mathbf{1}$} & $\mathbf{2}$ & $\mathbf{3}$ & $\mathbf{4}$ \\
\hline $\begin{array}{l}\text { F2 моно 5B C29 x IL 5D-5 } \\
(\text { Vrn-A1; vrn-B1; vrn-D1) }\end{array}$ & 37,3 & $24,9^{*}$ & $0,278^{* * *}$ \\
\hline $\begin{array}{l}\text { F } 2 \text { моно 5D C29 x IL 5D-5 } \\
(\text { Vrn-A1; Vrn-B1; vrn-D } 1)\end{array}$ & 36,2 & 23,4 & $0,138^{* *}$ \\
\hline
\end{tabular}

$\mathrm{P}<0,05 ; * * \mathrm{P}<0,01 ; * * * \mathrm{P}<0,001$ по сравнению с С29 (критерий Стьюдента)

В таблице 1 представлены средние данные о размере корневой системы в моносомных популяциях сорта С29. При 60-дневной яровизации было обнаружено примерно равное значение трех признаков между озимой линией 5D-5 и яровым сортом S29. В моносомной популяции по хромосоме 5 А большинство растений лишены наиболее эффективного доминантного аллеля гена Vrn-Al сорта С29. Вариабельность по дате цветения определяют аллели генов $V r n-B 1$ и $V r n-D 1$. В этом случае цветение в популяции происходило на 10 дней позже по сравнению с C29, а длина и вес корней были самыми большими. В моносомных популяциях по хромосомам 5B и 5D, где присутствует ген $V r n-A 1$, среднее число дней до цветения было приблизительно равно С29. В моносомной популяции по хромосоме 5В длина и вес корней были значительно выше, чем у реципиентного сорта. Корни были на 2,8 см длиннее и весили в 2,7 раза больше. В моносомной популяции по хромосоме 5D длина корней была такой же, как и у C29, тогда вес был в 1,3 раза выше. Таким образом, присутствие доминантных аллелей генов Vrn-Al и Vrn$B 1$ аналогично действию длительной яровизации на линию 5D-5: происходит уменьшение размеров корневой системы одновременно с сокращением периода до цветения. При этом наибольший эффект оказывает ген Vrn-A1. Сходный эффект мы наблюдали среди 8 сортов и линий пшеницы - носителей различных комбинаций аллелей локуса $\operatorname{Vrn}-1$ (табл. 2).

Таблица 2 - Среднее значение числа дней до цветения, длины и веса корней у генотипов с различной комбинацией генов локуса $V r n-1$

\begin{tabular}{|c|c|c|c|}
\hline Генотипы & $\begin{array}{c}\text { Дни до } \\
\text { цветения }\end{array}$ & $\begin{array}{c}\text { Длина кор- } \\
\text { ней, см }\end{array}$ & $\begin{array}{l}\text { Вес кор- } \\
\text { ней, г }\end{array}$ \\
\hline $\mathrm{C} 29(V r n-A 1 ; V r n-B 1 ; v r n-D 1)$ & 40,2 & 22,1 & 0,32 \\
\hline Янецкис Пробат (Vrn-A1; Vrn-B1; vrn-D1) & 43,7 & 25,8 & 0,40 \\
\hline Новосибирская 67 (Vrn-A1; Vrn-B1; vrn-D1) & 41,3 & 25,8 & 0,30 \\
\hline Диамант $2(V r n-A 1 ; V r n-B 1 ; v r n-D 1)$ & 42,6 & 21,8 & 0,23 \\
\hline $\begin{array}{l}\text { Линия } 821 \text { (с интрогрессиями от } \\
\text { T. timopheevii, на основе C29) }\end{array}$ & 42,5 & 32,0 & 0,76 \\
\hline Мильтурум 553 (vrn-A1; Vrn-B1; vrn-D1) & 46,9 & 28,6 & 1,18 \\
\hline Дуванка $501($ vrn-A1; Vrn-B1; vrn-Dl) & 50,8 & 29,7 & 0,80 \\
\hline Синтетик 6x (vrn-A1; vrn-B1; vrn-D1)* & $45,5^{*}$ & 30,2 & 1,22 \\
\hline Чайниз Спринг (vrn-A1; vrn-B1; Vrn-Dl) & 47,4 & 26,9 & 1,1 \\
\hline
\end{tabular}

* - при яровизации 30 дней 
Среди 8 генотипов только один - озимый. Даже после 30-дневной яровизации он имел наибольшую длину и вес корней. Средняя продолжительность периода «посев-цветение» четырех яровых генотипов - носителей гена $V r n-A 1$ была достоверно ниже, чем у четырех последних $(\mathrm{t}=3.50 ; \mathrm{P}<0,01)$. Генотипы, у которых этот ген отсутствовал, но присутствовал ген Vrn-B1, имели достоверно более длинные корни $(\mathrm{t}=3.50 ; \mathrm{P}<0,01)$ и имели более высокий вес корней $(\mathrm{t}=3.50 ; \mathrm{P}<0,01)$. Линия 821 с интрогрессиями от тетраплоидного вида T. timopheevii, достоверно не отличалась по дате цветения от родительского сорта С29. Однако она, также, как и генотипы - носители гена $V r n-B 1$, имела достоверно более длинные корни и более высокий вес корней. По ранее полученным данным, линия несет интрогрессию в хромосоме $5 \mathrm{~A}$ [5]. Возможно, линия 821 унаследовала новый аллель гена $V r n-1$, который не столь значительно уменьшает размеры корней. Наши данные совпадают с данными австралийских ученых, которые считают, что именно этот ген мягкой пшеницы среди трех генов локуса $V r n-1$ оказывает наибольшее влияние на развитие корневой системы корня [4].

Благодарности: Работа поддержана грантом РФФИ № 19-416-540001 и соглашением р-94 (от 21.06.2019) с Новосибирской областью. Растения выращивались в ЦКП ЛИВР ИЦиГ СО РАН, бюджетный проект №0324-20190039-С-001. Выражаем благодарность Н.М. Ковалевой за техническое сопровождение эксперимента.

\section{Список литературы}

1. Kabir M.R., Liu G., Guan P., Wang F., Khan A.A., Ni Zh., Yao Y., Hu Z.H., Xin V., Peng H., Sun Q. Mapping QTLs associated with root traits using two different populations in wheat (Triticum aestivum L. // Euphytica. 2015. V.206. P.175-190.

2. Ehdaie B., Mohammadi S.A., Nouraein M. QTLs for root traits at mid-tillering and for root and shoot traits at maturity in a RIL population of spring bread wheat grown under well-watered conditions // Euphytica, 2016. V.211. P.17-38.

3. Liu P., Jin Y., Liu J., Liu C., Yao H., Luo F., Guo Z., Xia X., He Z. Genome-wide association mapping of root system architecture traits in common wheat (Triticum aestivum L.) // Euphytica. 2019. V.215. P.121.

4. Voss-Fels K.P., Hannah Robinson H., Mudge S.R., Richard C., Newman S., Wittkop B. et al. VERNALIZATION1 modulates root system architecture in wheat and barley // Molecular Plant. 2018. V.11. P.226-229.

5. Leonova I.N., Kalinina N.P., Budashkina E.B., Röder M.S., Salina E.A. Comparative molecular and genetic analysis of Triticum aestivum $\times$ Triticum timopheevii hybrid lines resistant to leaf rust // Proc. 11th EWAC Conf., Novosibirsk, 2001. 


\section{Устойчивость местных форм овса из Кавказского региона к обыкновенной злаковой тле}

Радченко Е.Е.*, д.б.н., г.н.с.; Чумаков М.А., к.б.н., м.н.с.; Лоскутов И.Г., д.б.н., г.н.с.

Федеральный исследовательский иентр Всероссийский институт генетических ресурсов растений имени Н.И. Вавилова, С.-Петербург, Россия.

*e-mail: eugene_radchenko@rambler.ru

Изучили устойчивость 124 местных образиов овса из стран Кавказа (Армения, Азербайджан, Грузия), а также из Северного Кавказа РФ (Дагестан, Ингушетия, Северная Осетия, Кабардино-Балкария) к краснодарской популяции обыкновенной злаковой тли. Выделили 5 устойчивых форм; 25 образиов гетерогенны по изученному признаку. Наиболее высокий уровень устойчивости выявлен у образиов к-7081 (Кабардино-Балкария) и к-9113 (Северная Осетия). Эти образиы защищеены аллелями генов устойчивости, отличаюшимися от идентифицированных ранее Grb1 и Grb3.

Ключевые слова: овес, Schizaphis graminum, устойчивость, селекиия растений.

\section{Greenbug resistance in oat landraces from Caucasus}

Radchenko E.E., Chumakov M.A., Loskutov I.G.

Federal Research Center the N.I. Vavilov All-Russian Institute of Plant Genetic Resources, St. Petersburg, Russia

e-mail: eugene_radchenko@rambler.ru

One hundred and twenty-four landraces from the Caucasian countries (Armenia, Azerbaijan, Georgia), as well as from the Northern Caucasus region of the Russian Federation (Dagestan, Ingushetia, North Ossetia, Kabardino-Balkaria), were assessed for greenbug resistance. The Krasnodar insect population was used in the experiments. We identified 5 resistant forms; 25 accessions are heterogeneous according to the studied trait. The highest level of resistance was found in accessions k-7081 (Kabardino-Balkaria) and k-9113 (North Ossetia). These accessions are protected by alleles of resistance genes which differ from the earlier identified Grb1 and Grb3.

Key words: oat, Schizaphis graminum, resistance, plant breeding.

Обыкновенная злаковая тля Schizaphis graminum Rondani - опасный вредитель овса и других зерновых культур на юге России. Селекция устойчивых сортов - радикальный и экологически безопасный способ борьбы с насекомым. Дифференциальное взаимодействие $S$. graminum с растениями-хозяевами обусловливает необходимость поиска новых доноров устойчивости. 
Литературные сведения об устойчивости овса к $S$. graminum скудны. Устойчивость образца Russian 77 к биотипу А тли контролируется доминантным геном [4]. Линии PI 186270 (Аргентина) и CI 1580 (Шотландия) имеют по одному доминантному гену устойчивости (Grb1 и Grb2 соответственно) к биотипу C; линия CI 4888 (Италия) защищена доминантным геном устойчивости Grb3 к биотипу тли В [3]. Ген Grb2 эффективен также к биотипам Е [9], I [5] и, лишь отчасти, к F - Н [6, 7].

Изучили устойчивость к $S$. graminum 371 образца овса из стран Азии и Дальнего Востока РФ и выделили 95 гетерогенных форм. Отобрали 7 устойчивых линий и показали, что эти формы защищены разными аллелями генов устойчивости, которые отличаются от гена Grb3 [8]. В результате оценки 191 образца овса из Армении, Азербайджана, Грузии и Дагестана выделили образец к-4308 с высокой устойчивостью к тле и 38 гетерогенных форм [2].

Результаты исследований свидетельствуют о высокой частоте устойчивых к вредителю форм среди коллекционного материала овса из Кавказа. Цель настоящей работы - завершить изучение наследственного разнообразия овса из кавказского региона по устойчивости к насекомому.

В лабораторных опытах оценили устойчивость к S. graminum 124 местных образцов овса из стран Кавказа (Армения, Азербайджан, Грузия), а также из Северного Кавказа РФ. Кроме того, тестировали образцы с генами устойчивости Grb1 (к-13903, PI 186270, Аргентина) и Grb3 (к-13902, CI 4888, Италия). Использовали краснодарскую (Кубанская опытная станция ВИР) популяцию тли и выделенные из нее клоны.

$S$. graminum некротизирует растительную ткань в месте питания, что позволяет тестировать поврежденность растений. Опытные образцы и неустойчивый контроль (сорт Borrus) высевали рядами в кюветы с почвой. В фазу двух листьев на растения стряхивали насекомых. При гибели контроля определяли поврежденность растений по шкале от 0 (нет повреждений) до 10. Растения с баллами 1-4 относили к устойчивым, 9-10-к восприимчивым [1].

Клоны с различными фенотипами вирулентности (“тест-клоны”) использовали для идентификации генов устойчивости у выделенных форм овса. Если хотя бы один клон, авирулентный к тестеру данного гена устойчивости, повреждает изучаемый сорт, это означает, что сорт не имеет функционального аллеля данного гена. Опытные образцы, тестеры двух $G r b$-генов и восприимчивый контроль высевали в сосуды с почвой в круговом порядке и закрывали изоляторами. В фазе 2-х листьев всходы заселяли тлями одного клона и при гибели контроля оценивали поврежденность растений по шкале.

Выявили 5 устойчивых форм; 25 образцов гетерогенны по изученному признаку. Наиболее высокий уровень устойчивости (1-4 балла) выявлен у образцов к-7081 (Кабардино-Балкария) и к-9113 из Северной Осетии 
(табл. 1). Поврежденность растений образцов к-4818, к-4839 (Армения) и к10107 (Азербайджан) варьировала в более широких пределах (2-6 баллов), а ряда других образцов - от 2 до 10 баллов. Значительная изменчивость признака может обусловливаться проявлением генов с низкой экспрессивностью и/или присутствием в популяции фитофага клонов с различной вирулентностью к изученным формам.

Таблица 1 - Образцы местного овса, выделившиеся по устойчивости к S. graminum

\begin{tabular}{|c|c|c|c|c|c|c|}
\hline \multirow{2}{*}{$\begin{array}{c}\text { Номер } \\
\text { по } \\
\text { ката- } \\
\text { логу } \\
\text { ВИР }\end{array}$} & \multirow[t]{2}{*}{ Разновидность } & \multirow[t]{2}{*}{ Происхождение } & \multirow[t]{2}{*}{$\begin{array}{l}\text { Оценено } \\
\text { растений }\end{array}$} & \multicolumn{3}{|c|}{$\begin{array}{c}\text { Распределение расте- } \\
\text { ний по баллам повре- } \\
\text { жденности, \% }\end{array}$} \\
\hline & & & & $1-4$ & $5-8$ & 9,10 \\
\hline 4046 & aristata & Грузия & 41 & 9,8 & 63,4 & 26,8 \\
\hline 4178 & aristata & Армения & 36 & 25,0 & 2,8 & 72,2 \\
\hline 4511 & mutica, aristata & Грузия & 39 & 23,1 & 23,1 & 53,8 \\
\hline 4818 & aristata & Армения & 20 & 70,0 & 30,0 & - \\
\hline 4839 & aristata & Армения & 21 & 52,3 & 47,6 & - \\
\hline 4858 & aristata, montana & Азербайджан & 34 & 11,8 & 11,8 & 76,4 \\
\hline 6531 & aristata & Ингушетия & 47 & 29,8 & 29,8 & 40,4 \\
\hline 7040 & aristata & Дагестан & 40 & 42,5 & 37,5 & 20,0 \\
\hline 7041 & aristata & Дагестан & 38 & 10,5 & 26,3 & 63,2 \\
\hline 7049 & brunnea, setosa & Северная Осетия & 37 & 35,1 & 56,8 & 8,1 \\
\hline 7062 & aristata, mutica & Северная Осетия & 39 & 23,1 & 17,9 & 59,0 \\
\hline 7065 & aristata, mutica & Северная Осетия & 38 & 36,8 & 44,8 & 18,4 \\
\hline 7072 & aristata & Кабардино-Балкария & 35 & 11,4 & 8,6 & 80,0 \\
\hline 7075 & aristata, mutica & Кабардино-Балкария & 39 & 28,2 & 23,1 & 48,7 \\
\hline 7077 & aristata, mutica & Кабардино-Балкария & 33 & 45,5 & 51,5 & 3,0 \\
\hline 7079 & aristata, mutica & Кабардино-Балкария & 36 & 30,6 & 36,1 & 33,3 \\
\hline 7080 & aristata, mutica & Кабардино-Балкария & 45 & 37,8 & 57,8 & 4,4 \\
\hline 7081 & aristata, mutica & Кабардино-Балкария & 20 & 100 & - & - \\
\hline 8329 & mutica & Дагестан & 28 & 21,4 & 7,2 & 71,4 \\
\hline 9109 & $\begin{array}{l}\text { aristata, mutica, } \\
\text { aurea }\end{array}$ & Кабардино-Балкария & 34 & 20,6 & 23,5 & 55,9 \\
\hline 9113 & mutica, aristata & Северная Осетия & 23 & 100 & - & - \\
\hline 9114 & mutica, aristata & Северная Осетия & 30 & 50,0 & 33,3 & 16,7 \\
\hline 9116 & mutica, aristata & Кабардино-Балкария & 30 & 43,3 & 50,0 & 6,7 \\
\hline 9117 & aristata, mutica & Кабардино-Балкария & 31 & 12,9 & 54,8 & 32,3 \\
\hline 10107 & mutica & Азербайджан & 22 & 40,9 & 59,1 & - \\
\hline 10398 & mutica & Грузия & 34 & 32,3 & 32,3 & 35,4 \\
\hline 10399 & aristata, mutica & Дагестан & 36 & 11,1 & 2,8 & 86,1 \\
\hline 10429 & aristata, brunnea & Дагестан & 30 & 3,3 & - & 96,7 \\
\hline 10907 & cinerea & Азербайджан & 34 & 29,4 & 23,5 & 47,1 \\
\hline 12373 & mutica & Грузия & 37 & 24,3 & 73,0 & 2,7 \\
\hline 11840 & Borrus (контроль) & Германия & 165 & - & - & 100 \\
\hline
\end{tabular}


Наибольшее число генотипов (9, или 40,9 \% от числа изученных), у которых поврежденность устойчивых компонентов не превышала четырех баллов, выделено среди образцов из Кабардино-Балкарии. Встречаемость устойчивых форм высока среди образцов овса из Азербайджана: 3 из семи изученных образцов $(42,9 \%)$ несут отчетливо проявляющиеся гены устойчивости, затем следуют образцы из Армении (37,5 \%), Грузии (23,5 \%), Ингушетии (25\%), Дагестана (16,1\%) и Северной Осетии (14,3\%).

Оценили устойчивость образцов к-7081 и к-9113, а также линий с генами Grb1 и Grb3, к десяти клонам тли. При заселении растений наиболее «информативными» клонами, вирулентными к линиям овса из Италии и Аргентины, наблюдали устойчивость образцов из Северного Кавказа (табл. 2), то есть эти формы защищены аллелями генов устойчивости, нетождественными $G r b 1$ и $G r b 3$. На различие генетического контроля устойчивости к $S$. graminum у выделенных форм и линии к-13902 указывает и взаимодействие образцов с клонами, имеющими фенотип вирулентности 2.

Таблица 2 - Устойчивость образцов овса к клонам S. graminum

\begin{tabular}{|l|l|c|c|c|}
\hline \multirow{2}{*}{ Образец } & \multirow{2}{*}{ Происхождение } & \multicolumn{3}{|c|}{ Тест-клоны S. graminum } \\
\cline { 3 - 5 } & & 1 & 2 & 3 \\
\hline к-7081 & Кабардино-Балкария & $\mathrm{R}^{*}$ & $\mathrm{R}$ & $\mathrm{R}$ \\
\hline к-9113 & Северная Осетия & $\mathrm{R}$ & $\mathrm{R}$ & $\mathrm{R}$ \\
\hline к-13902 (СI 4888) & Италия & $\mathrm{R}$ & $\mathrm{S}$ & $\mathrm{S}$ \\
\hline к-13903 (РІ 186270) & Аргентина & $\mathrm{R}$ & $\mathrm{R}$ & $\mathrm{S}$ \\
\hline
\end{tabular}

* $\mathrm{R}$ - устойчивость образца; $\mathrm{S}$ - восприимчивость.

Результаты наших экспериментов продемонстрировали высокую (до $43 \%$ частоту устойчивых к обыкновенной злаковой тле образцов среди местных форм овса из кавказского региона. Выделили 5 резистентных форм, среди которых наиболее высоким уровнем устойчивости характеризуются к7081 (Кабардино-Балкария) и к-9113 (Северная Осетия). Эти образцы защищены аллелями генов, отличающимися от идентифицированных ранее Grb1 и Grb3. Выделили также 26 гетерогенных образцов, которые после отбора по устойчивости могут быть использованы в селекции на иммунитет.

Благодарности: Исследование выполнено при поддержке РФФИ (грант № 20-016-00048) и бюджетного проекта № 0662-2019-0006.

\section{Список литературы}

1. Радченко Е. Е. Злаковые тли // В кн.: Изучение генетических ресурсов зерновых культур по устойчивости к вредным организмам. Методическое пособие. М.: Россельхозакадемия, 2008. - С. 214-257.

2. Радченко Е.Е., Чумаков М.А., Лоскутов И.Г. Устойчивость образцов овса из Дагестана и стран Кавказа к обыкновенной злаковой тле // Труды по прикладной ботанике, генетике и селекции. - 2019. - Т. 180. - № 3. - С. 106-109. DOI: 10.30901/2227- 
8834-2019-3-106-109

3. Boozaya-Angoon D., Starks K.J., Edwards L.H., Pass H. Inheritance of resistance in oats to two biotypes of the greenbug // Environm. Entomol. - 1981. - V . 10. - № 4. - P. 557-559. DOI: 10.1093/ee/10.4.557

4. Gardenhire J.H. Inheritance of greenbug resistance in oats // Crop Sci. - 1964. V. 4. - № 4. - P. 443. DOI:10.2135/cropsci1964.0011183X000400040041x

5. Harvey T.L., Kofoid K.D., Martin T.J., Sloderbeck P.E. A new greenbug virulent to E-biotype resistant sorghum // Crop Sci. - 1991. - V. 31. - № 6. - P. 1689-1691. DOI: 10.2135/cropsci1991.0011183X003100060062x

6. Kindler S.D., Spomer S.M. Biotypic status of six greenbug (Homoptera: Aphididae) isolates // Environ. Entomol. - 1986. - V. 15. - № 3. - P. 567-572. DOI: 10.1093/ee/15.3.567

7. Puterka G.J., Peters D.C., Kerns D.L., Slosser J.E., Bush L., Worrall D.W., McNew R.W. Designation of two new greenbug (Homoptera: Aphididae) biotypes G and H // J. Econ. Entomol. - 1988. - V. 81. - № 6. - P. 1754-1759. DOI: 10.1093/jee/81.6.1754

8. Radchenko E.E., Kuznetsova T.L., Chumakov M.A., Loskutov I.G. Greenbug (Schizaphis graminum) resistance in oat (Avena spp.) landraces from Asia // Genetic Res. Crop Evol. - 2018. - V. 65. - № 2. - P. 571-576. DOI: 10.1007/s10722-017-0554-9

9. Starks K.J., Burton R.L., Merkle O.G. Greenbugs (Homoptera: Aphididae) plant resistance in small grains and sorghum to biotype E // J. Econ. Entomol. - 1983. - V. 76. № 4. - P. 877-880. DOI: 10.1093/jee/76.4.877

\section{Разнообразие генофонда дикорастущих видов секции Petota Dumort. рода Solanum L. для современной селекции картофеля}

Рогозина Е.В. *1, Чалая Н.A. ${ }^{1}$, Кузнеияова M.A. ${ }^{2}$, Бекетова М.П. ${ }^{3}$, Хавкин Э.Е. ${ }^{3}$

${ }^{1}$ Федеральный исследовательский центр Всероссийский институт генетических ресурсов растений им. Н.И. Вавилова (ВИР), Санкт-Петербург, Россия,

${ }^{2}$ Всероссийский научно-исследовательский институт фитопатологии, Московская область, Б. Вяземы, Россия,

3 Всероссийский научно-исследовательский институт сельскохозяйственной биотехнологии, Москва, Россия.

*e-mail: erogozina@vir.nw.ru

В коллекции ВИР выделены образцы диких клубнеобразующих видов Sоlaпuт L. и межвидовых гибридов - источники устойчивости картофеля к фиmофторозу (Phytophthora infestans (Mont.) de Bary), Y вирусу картофеля (YВK), золотистой картофельной нематоде nатотипа Rol (Globodera rostochiensis (Wollenweber) Behrens). Методом ПЦР с помощью ДНКммаркеров генов R1, R3a, R3b, RB/Rpi-blb1, Rpi-vnt1, Rysto, Ryadg, Rychc, H1, Gro1-4 проведен скрининг этой коллекции генотипов картофеля. Структурные гомологи генов устойчи- 
вости обнаружены у широкого круга дикорастущих родичей картофеля. Выявлены клоны межвидовых гибридов, перспективные для использования в селекчии, в том числе с использованием технологии маркер-опосредованного отбора.

Ключевые слова: R гены, фитофтороз, Y вирус картофеля, золотистая нематоде, ДНК маркеры.

\title{
Diversity of genepool of wild solanum species (section Petota Dumort.) currently employed in potato breeding
}

\author{
E.V. Rogozina ${ }^{1}$, N.A. Chalayal, M.A. Kuznetsova ${ }^{2}$, M.P. Beketova ${ }^{3}$, E. Khavkin ${ }^{3}$ \\ ${ }^{1}$ N.I. Vavilov All-Russian Institute of Plant Genetic Resources (VIR), St. Peters- \\ burg, Russia, \\ ${ }^{2}$ All-Russia Research Institute of Phytopathology, Moscow Province, Russia, \\ ${ }^{3}$ All-Russian Research Institute of Agricultural Biotechnology, Moscow, Russia. \\ e-mail:erogozina@vir.nw.ru
}

Numerous accessions of wild tuber-bearing Solanum L. species and interspecific potato hybrids maintained in VIR collection manifest wide diversity of potato germplasm prospective as the sources of resistance to late blight (the causal agent Phytophthora infestans (Mont.) De Bary), Y potato virus (YBK) and golden potato nematode. PCR screening with PCR using DNA markers for the R1, R3a, R3b, RB / Rpi-blb1, Rpi-vnt1, Rysto, Ryadg, Rychc, H1, Grol-4 genes has revealed the structural homologues of resistance genes in a wide range of wild potato relatives. The highlighted clones of interspecific hybrids are hopeful for deploying in current breeding based on the marker-assisted selection.

Key words: R-genes, late blight, Y-potato virus, golden nematode, DNA markers.

Картофелеводство принадлежит к ведущим отраслям сельского хозяйства Российской Федерации. Одним из основных факторов экологически чистого производства картофеля является возделывание сортов, устойчивых к вредоносным организмам, что позволяет минимизировать применение химических средств защиты. Для современной селекции картофеля в России весьма актуально создание новых сортов, обладающих комплексом желаемых хозяйственно ценных признаков, на основе сложных межвидовых гибридов, в родословной которых присутствуют сразу несколько дикорастущих видов картофеля - источники ценных генов $[1,2]$. Использование нового типа селекционных источников и доноров на основе сложных межвидовых гибридов с широким спектром устойчивости к болезням, в том числе к различным расам одного патогена, позволяет оперативно реагировать на быстрые изменения в составе популяций патогенов. Такой подход называют упреждающей селекцией $[3,4]$. 
Разнообразие генофонда дикорастущих сородичей картофеля - видов секции Petota Dumort. рода Solanum L. представляет широкий спектр отсутствующих у культурного картофеля признаков устойчивости к болезням и вредителям. В сравнении с другими сельскохозяйственными культурами, картофель располагает наибольшим разнообразием дикорастущих сородичей, по разным оценкам от 110 [5] до 196 видов [6], в коллекции ВИР представлено более 100 дикорастущих видов картофеля. Перспективы использования дикорастущих клубненосных Solanum spp. в селекции во многом определяются их совместимостью с культурным картофелем при скрещивании и характером наследования целевых признаков. Молекулярно-генетическая характеристика целевых генов у дикорастущих видов и межвидовых гибридов картофеля и создание на основе этих генов маркеров целевых признаков позволит значительно ускорить процесс их переноса от дикорастущих сородичей в культурный картофель.

Источники устойчивости к возбудителям экономически значимых болезней картофеля выделены среди образцов дикорастущих клубненосных Solanum spp. и межвидовых гибридов в коллекции ВИР, сохраняются в виде клонов в полевом генбанке ВИР (Санкт-Петербург, Пушкин). Впервые в мировой практике нами проведены координированные фитопатологические исследования и ДНК анализ клоновых растений, представляющих разнообразие генофонда видов секции Petota Dumort. рода Solanum L. B этой работе использованы ДНК-маркеры генов устойчивости к фитофторозу (Phytophthora infestans (Mont.) de Bary) (Rpi - Resistance to P. infestans - генов) $R 1, R 3 a, R 3 b, R B / R p i-b l b 1, R p i-b l b 2, R p i$-vnt 1 , генов устойчивости к Ү вирусу картофеля (YBK) $R y_{s t o}, R y_{a d g}, R y_{c h c} u$ генов устойчивости к золотистой картофельной нематоде патотипа Ro1 (Globodera rostochiensis (Wollenweber) Behrens). H1, Grol-4. Идентифицированы образцы диких видов и межвидовые гибриды картофеля, устойчивые к возбудителям этих болезней и несущие ДНК маркеры генов устойчивости, в том числе генов, различающихся по специфичности к расам патогена.

Обнаружены различия в распространении и частоте встречаемости ДНК маркеров Rpi генов у представителей клубненосных Solanum spp. SCAR маркеры Rpi генов выявлены у широкого круга дикорастущих видов, представляющих мексиканский и андийский центры происхождения культурных растений. У растений североамериканских видов серий Bulbocastana $(S$. bulbocastanum Dun.), Cardiophylla (S. cardiophyllum Lindl.), Demissa (S. brachycarpum Corr., S.hougasii Corr.), Longipedicellata (S. stoloniferum Schlechtd.) обнаружены маркеры генов $R 1, R 3 a, R 3 b, R B / R p i-b l b 1$. У южноамериканских видов серий Simpliciora ( $S$. simplicifolium Bitt.) и Tarijensia (S. berthaultii Hawkes) также обнаружены маркеры генов $R 1, R 3 a$. Структурные гомологи генов Rpi-blb2 u Rpi-vntl обнаружены у представителей южноамериканских видов S. alandiae Card. и S. okadae Hawkes et Hjerting [7]. 
Менее распространены в клоновой коллекции диких видов картофеля источники устойчивости к ҮВК. Образцы с экстремальной устойчивостью и сочетанием маркеров YES3-3A + YES3-3В гена $R y_{s t o}$ выявлены среди образцов $S$. stoloniferum и близкородственных (той же серии Longipedicellata) видов $S$. polytrichon Rydb. и S. papita Rydb., а также у вида S.cardiophyllum. У одного клона $S$. stoloniferum обнаружена комбинация маркеров RYSC3+RYSC4 гена $R y_{a d g}$. Скрининг 170 генотипов $S$. chacoense Bitt., контрастных по реакции на инфицирование YBK, выявил маркер Ry186 гена $R y_{\text {chc }}$ лишь у единичных генотипов, при этом присутствие маркера не было связано с признаком устойчивости.

У нематодоустойчивых образцов южноамериканских диких видов картофеля серий Tuberosa (S. alandiae, $S$. × doddsii Corr., S. famatinae Bitt., $S$. kurtzianum Bitt. et Wittm., S. leptophyes Bitt., S. sparsipilum (Bitt) Juz. et Buk.) и Yungasensia (S. yungasense Hawkes) обнаружен маркер Gro1-4-1 гена Gro14. Маркер TG689, ассоциированный с геном H1 и распространённый у сортов картофеля российской селекции [8], у нематодоустойчивых образцов диких видов отсутствовал.

Особый интерес для практической селекции представляют межвидовые гибриды картофеля, с групповой устойчивостью к болезням, у которых выявлены ДНК маркеры соответствующих Rpi генов. Более 60 клонов межвидовых гибридов с комплексом хозяйственно ценных признаков, устойчивые к фитофторозу, YВК и золотистой картофельной нематоде и несущие ДНК маркеры $R p i$ генов, генов $R y_{s t o}$ и $R y_{a d g}$, а также гена $H 1$, рекомендованы как родительские формы для создания конкурентоспособных отечественных сортов картофеля [9].

Благодарности: Работа поддержана грантом РФФИ № 18-016-00138.

\section{Список литературы}

1. Рогозина Е.В., Хавкин Э.Е. Межвидовые гибриды картофеля как доноры долговременной устойчивости к патогенам. Вавиловский журнал генетики и селекции. 2017. 21(1): 30-41. DOI 10.18699/VJ17.221

2. Симаков Е. А. и др. Использование генетических ресурсов картофеля для повышения эффективности селекции. Труды по прикл. бот., ген. и сел. 2017. 177(2):113-121.

3. Фадина О.А. и др. Упреждающая селекция: использование молекулярных маркеров при создании доноров устойчивости картофеля (Solanum tuberosum L.) к фитофторозу на основе сложных межвидовых гибридов. Сельскохозяйственная биология. 2017.52(1):84-94.

4. McIntosh, R.A., Brown, G.N. Anticipatory breeding for resistance to rust diseases in wheat. Annu. Rev. Phytol. 1997. 35:311-326. doi: 10.1146/annurev.phyto.35.1.311

5. Spooner D., Salas A. Structure, biosystematics and genetic resources. Handbook of Potato, Production, Improvement and Postharvest Management. Eds. J. Gopal, S.M.P. Khurana. N.Y.: Haworth Press, 2006;1-39. 
6. Hijmans R.J. et al., 2002. Atlas of Wild Potatoes. IPGRI, Rome.

7. Muratova (Fadina) O.A. et al. South American species Solanum alandiae Card. and S.okadae Hawkes et Hjerting as potential sources of genes for potato late blight resistance. Труды по прикл. бот., ген. и сел. 2020. 181(1):73-83.

8. Клименко Н.С. и др. Маркер-опосредованная селекция отечественных сортов картофеля с маркерами генов устойчивости к золотистой картофельной нематоде (патотип Ro1). Труды по прикл. бот., ген. и сел. 2017. 178(4): 66-75.

9. Рогозина Е.В. и др. Каталог мировой коллекции картофеля ВИР. Картофель. Межвидовые гибриды картофеля устойчивые к возбудителям болезней. Вып. 833. СПб. ВИР. 2018.

DOI 10.18699/GPB2020-63

\section{Разработка маркеров, контролирующих устойчивость ярового ячменя к патогену Cochliobolus sativus, на основе ассоциативного картирования}

Розанова И.В. ${ }^{1,3 *}$, Лашина H.M. ${ }^{2}$, Ефимов B.M. ${ }^{3}$, Афанасенко O.C. ${ }^{2}$, Хлесткина E.K. ${ }^{1,3}$

${ }^{1}$ Федеральный исследовательский центр Всероссийский институт генетических ресурсов растений им. Н.И. Вавилова (ВИР), Санкт-Петербург, Россия;

${ }^{2}$ Всероссийский научно-исследовательский институт защчитьл растений, Санкт-Петербург, Россия;

${ }^{3}$ Федеральный исследовательский центр институт циттологии и генетики СО РАН, Новосибирск, Россия.

*e-mail:bykova@bionet.nsc.ru

Несовершенный гриб, патоген Cochliobolus sativus - (Bipolaris sorokiniana (anamorph) (Sacc) Shoemaker) это один из наиболее широко распространенных патогенов, вызывающий различные болезни, в числе которых темно-бурая пятнистость и корневые гнили. Определение генетических локусов, ассоцичрованных с устойчивостью ячменя к этим болезням, важно для разработки диагностических ДНК-маркеров для селекции устойчивых сортов ячменя. Целью настоящей работы является выявление генетических локусов, ассоциированные с устойчивостью как проростков, так и взросльх растений ячменя к изолятам C. sativus на основе оценки Сибирской коллекции ярового ячменя.

Ключевые слова: Hordium vulgare, QTL, Cochliobolus sativus.

The marker development that controlling the resistance of spring barley to Cochliobolus sativus pathogen using association mapping approach

Rozanova I.V. ${ }^{* 1,2}$, Lashina N.M ${ }^{3}$, Efimov V.M. ${ }^{2}$ Afanasenko O.S. ${ }^{3}$, Khlestkina E.K. ${ }^{1,2}$ 
${ }^{1}$ Federal Research Center N.I. Vavilov All-Russian Institute of Plant Genetic Resources (VIR); ${ }^{2}$ Federal Resaech Center Institute of Cytology and Genetics SB RAS, Novosibirsk, Russia; ${ }^{3}$ All-Russian Research Institute for Plant Protection, St. Petersburg, Russia.

*e-mail: bykova@bionet.nsc.ru

The fungal pathogen Cochliobolus sativus - (Bipolaris sorokiniana (anamorph) (Sacc) Shoemaker) is one of the most worldwide pathogen which causes such diseases as spot blotch and root rot of barley. Identification of genetic loci associated with resistance to $C$. sativus is of importance for future marker-assisted selection. The goal of the current study was to identify loci conferring both for seedling and for adult plants resistance to different isolates of $C$. sativus pathogen in the Siberian spring barley core collection.

Селекционные программы по созданию новых сортов злаковых растений ориентированы на сохранение урожая и экологичности его получения. Одним из компонентов этих программ является выведение сортов злаковых, устойчивых к болезням. В конце прошлого века благодаря появлению и быстрому развитию технологий секвенирования и молекулярного картирования появились подходы, основанные на применении ДНК-маркеров в селекции. Маркер-ориентированная селекция (МOC) позволяет ускорять и удешевлять процесс получения сорта путем более быстрого и эффективного отбора нужных генотипов среди селекционных гибридов. Геномная селекция позволяет оценивать потенциал вклада небольших по эффективности QTL. ДНК-маркеры перспективны в создании сортов с долгосрочной устойчивостью, так как их использование дает возможность комбинировать гены устойчивости в одном генотипе, обеспечивая тем самым эффективную защиту против широкого спектра изолятов с различной вирулентностью $[1,2]$. МОС с использованием маркеров, генов устойчивости растений к болезням, широко используются в Европе, США, Канаде и Австралии. Применение этого подхода является актуальным и для России. Одной из основных болезней ячменя, наносящих серьезный урон урожаю во всех регионах его культивирования, является темно-бурая пятнистость (вызываемая аскомицетом Cochliobolus sativus, анаморфа Bipolaris sorokiniana). Эпифитотии пятнистостей ячменя случаются раз в 5-10 лет. Снижение урожайности сортов ячменя восприимчивых к этим болезням во время эпифитотии составляют от 20 до 40 \% $[1,3]$. Патоген C.sativus вызывает не только темно-бурую пятнистость, но так же и корневые гнили. При серьезном поражении корневыми гнилями результатом является укорочение колоса, самого растения и уменьшение зерна, что также приводит к снижению урожайности. Потери урожая могут достигать $80 \%$ [4].

В настоящее время для выявления генетических маркеров, ассоции- 
рованных с устойчивостью используют два подхода: анализ двуродительских картирующих популяций и анализ коллекций с помощью полногеномного анализа ассоциаций (GWAS). QTL анализ 12 двуродительских картирующих популяций выявил ранее ряд локусов, связанных с устойчивостью к темно-бурой пятнистости на всех хромосомах ячменя [3, 5-9]. Ассоциативное картирование локусов, отвечающих за данный признак, также успешно использовалось для выявления новых локусов в коллекциях образцов ячменя различного происхождения [10-14]. Данных по картированию локусов устойчивости к корневым гнилям не обнаружено. Отечественный генофонд, в подобных исследованиях практически не был задействован. В связи с этим целью настоящей работы было выявление генетические маркеры как ювенильной устойчивости, так и взрослых растений к темно-бурой пятнистости, и к корневым гнилям на основе ассоциативного картирования с использованием Сибирской коллекции ярового ячменя.

Экспериментальная часть. В 2017 году было проведено высокопроизводительное SNP-генотипирование 94 отобранных сортов и линий ячменя Сибирской коллекции по технологии 50,000 Иллюмина iSeect SNP анализа в компании Traitgenetics GmbH (Gatersleben, Germany) по 44,040 SNP маркерам. Из 44 тыс. SNP около 39 тыс. были полиморфными, из них для полногеномного анализа ассоциаций использовались 62 \% наиболее информативных [15].

Оценку устойчивости проростков к возбудителям темно-бурой пятнистости проводили с помощью трех изолятов C. sativus различного происхождения: Ch3, Kr2 и O18.2. Так же оценку устойчивости к взрослым растениям проводили с помощью изолята $\mathrm{Ch} 3$. Оценку устойчивости к проросткам к корневым гнилям проводили с помощью изолята О18.2.

Результаты исследования. Согласно литературным данным не было выявлено значимой корреляции между корневыми гнилями и темно-бурой пятнистостью листьев [16-17].

В данной работе корреляция показателей между устойчивостью к корневым гнилям и устойчивостью к темнобурой пятнистости колеблется в районе от 0,221452 до 0,2813. Такое значение говорит о слабой корреляции между устойчивостью к двум болезням. Корреляция между показателями устойчивости к различным изолятам для проростков была достаточно высокой (от 0,609647 до 0,729975). Корреляция между устойчивостью проростковой стадии и стадии взрослых растений оказалась слабее: взрослые растения были инфицированы изолятом Ch3 и корреляция между показателями для проростков инфицированных с Ch3 и взрослыми растениями составила 0,5688.

Выявлены 7 участков генома, ассоциированные с проростковой устойчивостью ячменя к темно-бурой пятнистости. Только 1 значимый SNP на 5 хромосоме был ассоциирован с устойчивостью взрослых растений. Значимых SNP к корневым гнилям выявлено не было. 
По полученным данным 12 значимых SNP (на 1, на 3 , на 5 и на 7 хромосомах) были конвертированы в KASP маркеры. Для подтверждения или опровержения KASP маркеры исследовались на независимой выборке, состоявшей из 22 сортов, контрастных по устойчивости к темно-бурой пятнистости (11 устойчивых и 11 восприимчивых сортов). Устойчивые/Вос-приимчивые сорта были получены из ВИЗР. По данным KASP генотипирования 6 маркеров, расположенные на 3 хромосоме были подтверждены на независимой выборке и их можно исследовать дальше как потенциальные диагностические маркеры для выявления сортов устойчивых к темно-бурой пятнистости.

Полученные маркеры могут быть использованы для отбора селекционного материала, несущего нужные аллели в локусах устойчивости к темно-бурой пятнистости. 14-00086).

Благодарности: Работа выполнена при поддержке РНФ (грант № 16-

\section{Список литературы}

1. Shjerve R.A., Faris J D., Brueggeman R.S., Yan C., Zhu Y., Vaidehi Koladia V., Friesen T.L. Evaluation of a Pyrenophora teres f. teres mapping population reveals multiple independent interactions with a region of barley chromosome $6 \mathrm{H}$. Fungal Genetics and Biology 70 (2014) 104-112.

2. Islamovic E., Bregitzer P., Friesen T. L. Barley 4H QTL confers NFNB resistance to a global set of P. teres f. teres isolates //Molecular Breeding. - 2017. - T. 37. - №. 3. C. 29.Steffenson BJ, Hayes PM, Kleinhofs A. Genetics of seedling and adult plant resistance to net blotch (Pyrenophora teres f. teres) and spot blotch (Cochliobolus sativus) in barley. Theor Appl Genet. 1996;92:552-8.

3. Afanasenko OS, Koziakov AV, Hedlay PE, Lashina NM, Anisimova AV, Manninen O, Jalli M, Potokina EK. Mapping of the loci controlling the resistance to Pyrenophora teres F. teres and Cochliobolus sativus in two double haploid barley populations. Russ. J. Genet. Appl. Res. 2015;5:242-53.

4. Piening L., Orr D. Effects of crop rotation on common root rot of barley. Canadian Journal of Plant Pathology. 1988;10(1):61-65.

5. Steffenson B.J., Hayes P.M., Kleinhofs A. Genetics of seedling and adult plant resistance to net blotch (Pyrenophora teres $\mathrm{f}$. teres) and spot blotch (Cochliobolus sativus) in barley. Theor Appl Genet. 1996;92:552-8.

6. Bilgic H, Steffenson B, Hayes P. Comprehensive genetic analyses reveal differential expression of spot blotch resistance in four populations of barley. Theor Appl Genet. 2005;111:1238-50.

7. Bovill J, Lehmensiek A, Sutherland MW, Platz GJ, Usher T, Franckowiak J, Mace E. Mapping spot blotch resistance genes in four barley populations. Mol Breed. 2010;26:653-66.

8. Grewal TS, Rossnagel BG, Scoles GJ. Mapping quantative trait loci associated with spot blotch and net blotch resistance in a doubled-haploid barley population. Mol Breed. 2012;30:267-79.

9. Haas M, Menke J, Chao S, Steffenson BJ. Mapping quantitative trait loci conferring resistance to a widely virulent isolate of Cochliobolus sativus in wild barley accession 
PI 466423. Theor Appl Genet. 2016;129:1831-42.

10. Roy JK, Smith KP, Muehlbauer GJ, Chao S, Close TJ, Steffenson BJ. Association mapping of spot blotch resistance in wild barley. Mol Breeding. 2010;26:243-56.

11. Zhou H, Steffenson BJ. Genome-wide association mapping reveals genetic architecture of durable spot blotch resistance in US barley breeding germplasm. Mol Breed. 2013;32:139-54.

12. Berger GL, Liu S, Hall MD, Brooks WS, Chao S, Muehlbauer GJ, Baik BK, Steffenson B, Griffey CA. Marker-trait associations in Virginia Tech winter barley identified using genome-wide mapping. Theor Appl Genet. 2013;126:693-710.

13. Gutiérrez L, Berberian N, Capettini F, Falcioni E, Fros D, Germán S, Hayes PM, Huerta-Espino J, Herrera S, Pereyra S, Pérez C, Sandoval-Islas S, Singh R, Castro A. Genome-wide association mapping identifies disease-resistance QTLs in barley germplasm from Latin America. In: Zhang G, Li C, Liu X, editors. Advance in barley sciences. Proceedings of 11th international barley genetics symposium; 2013. p. 209-15.

14. Wang R, Leng Y, Ali S, Wang M, Zhong S. Genome-wide association mapping of spot blotch resistance to three different pathotypes of Cochliobolus sativus in the USDA barley core collection. Mol Breed. 2017;37:44.

15. Bykova I.V., Lashina N.M., Efimov V.M., Afanasenko O.S., Khlestkina, E.K. Identification of $50 \mathrm{~K}$ Illumina-chip SNPs associated with resistance to spot blotch in barley.BMC plant biology, 2017;17(2):250.

16. Kutcher H.R., Bailey K.L., Rossnagel B.G., Legge W.G. Heritability of common root rot and spot blotch resistance in barley. Canadian journal of plant pathology, 1994;16(4):287-294.

17. Almgren I., Gustafsson M., Lindgren H., Liljeroth E. Interaction between root and leaf disease development in barley cultivars after inoculation with different isolates of Bipolaris sorokiniana. Journal of Phytopathology,1999;147(6):331-337.

DOI 10.18699/GPB2020-64

\section{Молекулярно-генетический полиморфизм возбудителя листовой ржавчины на твердой пшенице в Казахстане}

Рсалиев А.С. ${ }^{*}$, к.с.-х.н., зав. лаб.; Шайдаюк Е.Л. ${ }^{2}$, м.н.с.; Кохметова А.М. ${ }^{3}$, д.б.н., зав. лаб.; Гультяева Е.И. ${ }^{2}$, о.б.н., в.н.с.

${ }^{1}$ Научно-исследовательский институт проблем биологической безопасности, Гвардейский, Казахстан;

${ }^{2}$ Всероссийский НИИ зашиты растений, Санкт-Петербург, Россия;

${ }^{3}$ Институт биологии и биотехнологии растений, Алмать, Казахстан, *e-mail: aralbek@mail.ru

Изучена вирулентность и полиморфизм микросателлитных локусов у изолятов Риссіпіа triticina, выделенных с яровой твердой пшеницыь, вырашиваемой в Южном Казахстане в 2018 и 2019 га. Выявлены различия в виру- 
лентности между изолятами из Северного Казахстана и проанализированными в настоящей работе. Сходство между северо-казахстанскими и южно-казахстанскими популячиями по микросателлитным локусам было существенно выше (Nei_d=0,013; Fst=0.03). Показано существование единой популяции возбудителя листовой ржавчины на твердой пшенице в Казахстане.

Ключевые слова: Pиссіпіа triticina, Triticum durum, вирулентность, микросателлитные маркеры.

\section{Molecular genetic polymorphism of leaf rust pathogen on durum wheat in Kazakhstan}

Rsaliyev A.S. ${ }^{1}$, Shaydayuk E.L. ${ }^{2}$, Kokhmetova A.M. ${ }^{3}$, Gultyaeva E.I. ${ }^{2}$

${ }^{1}$ Research Institute for Biological Safety Problems, Gvardeiskiy, Zhambylskaya Oblast, Kazakhstan; ${ }^{2}$ All-Russian Institute of Plant Protection, Saint-Petersburg, Russia; ${ }^{3}$ Institute of Plant Biology and Biotechnology, Almaty, Kazakhstan

The isolates of Puccinia triticina isolated from spring durum wheat grown in 2018 and 2019 years in Southern Kazakhstan region were studied for virulence and polymorphism of microsatellite loci. Diversity of virulence within Northern Kazakhstan isolates were evolved and analysed in this study. Similarity between the Northern Kazakhstani and Southern Kazakhstani population by microsatellite loci were higher (Nei_d=0.013; Fst=0.03). Single population of leaf rust pathogen on durum wheat was revealed in Kazakhstan.

Key words: Puccinia triticina, Triticum durum, virulence, microsatellite markers.

Листовая ржавчина, вызываемая биотрофным грибом Puccinia triticina Erikss. - распространенное и значимое заболевание твердой пшеницы (Triticum durum Desf) [1]. Во всем мире одной из причин массового развития этой болезни является возделывание восприимчивых сортов пшеницы и появление новых вирулентных рас гриба. Следовательно, в 2001 году в штате Мексики Сонора появилась новая раса листовой ржавчины, которая отличилась высокой вирулентностью к сортам твердой пшеницы. В результате эпифитотии данной расы многие сорта твердой пшеницы в течение двух-трех лет потеряли устойчивость к листовой ржавчине [2]. Позже, в 2003 году раса P. triticina появилась на посевах твердой пшеницы юге Калифорнии (США), молекулярное исследование которой показало ее идентичность с расой из Мексики [2]. Недавно охарактеризованы вирулентности популяций $P$. triticina на твердой пшенице в России. Проведенный анализ выявил существенные различия в составе патогена на твердой пшенице по сравнению с ранее изученными популяциями патогена на мягкой пшенице, в частности изоляты с твердой пшеницы имели достоверно меньшее число аллелей вирулентности [4]. 
В Казахстане наиболее значимые популяционные исследования листовой ржавчины на твердой пшенице были выполнены в 2005-2007 гг. В указанный период проанализировано 98 монопустульных изолята гриба, из них идентифицировано 12 рас $P$. triticina. Гены устойчивости $\operatorname{Lr} 9, \operatorname{Lr} 19, \operatorname{Lr} 23$, $L r 24$ u Lr25 были устойчивыми ко всем расам, выделенных с сортов твердой пшеницы [5]. Однако в республике очень слабое внимание уделяется генотипированию изолятов $P$. triticina с использованием молекулярных маркеров. Ограниченные исследования по изучению вирулентности и молекулярного полиморфизма были выполнены в 2014 году в Северном Казахстане. В этих исследованиях было проведено сравнение образцов популяций $P$. triticina на твердой и мягкой пшенице. Выявлено существенное отличие в составе популяций P. triticina на твердой и мягкой пшенице по вирулентности и фенотипическому составу в Северном Казахстане [6].

Целью данной работы являлось изучение популяций P. triticina, coбранных на твердой пшенице в Южном Казахстане, по вирулентности и SSR-маркерам.

Для выполнения экспериментов были использованы образцы листьев твердой пшеницы, пораженных листовой ржавчиной, собранные во время фитосанитарного мониторинга из южных регионов Казахстана в 2018-2019 гг. Анализ вирулентности P. triticina проводили с использованием 37 изогенных линий Thatcher и сортов с $L r$ генами устойчивости. Выделение и размножение монопустульных изолятов осуществили с использованием 10-14дневных проростков восприимчивых сортов твердой и мягкой пшеницы. В отдельных случаях для получения монопустульных изолятов использовали методику отрезков листьев [7]. Учет типа реакции проводили через 10-12 дней после заражения по шкале E.B. Mains и H.S. Jackson [8]. Определение фенотипов проводили с использованием $20 \mathrm{Tc} L r$-линий $[9,10]$. Выделение ДНК из спорового материала гриба проводили согласно методике Justesen et al. [11]. Для деструкции спор использовали гомогенизатор FastPrep®-24. B молекулярных исследованиях использовали 11 SSR-маркеров: PtSSR13, PtSSR50, PtSSR55, PtSSR61, PtSSR68, PtSSR91, PtSSR92, PtSSR151A, PtSSR152, PtSSR158, RB8, RB26) [12, 13].

Амплификацю проводили с использованием термоциклера С1000 BioRad. Генетический анализатор ABI Prism 3500 XL (ABI-Hitachi, Япония) использовали для проведения SSR анализа. Определение размера аллелей проводили с использованием программы STR and Analysis Software.

В 2018-2019 гг. изучена вирулентность 30 изолятов $P$. triticina. Bce изоляты были авирулентными к линиям с генами $L r 2 a, L r 2 b, L r 2 c, L r 9, \operatorname{Lr} 15$, Lr16, Lr17, Lr19, Lr24, Lr28, Lr29, Lr41, Lr45, Lr47, Lr51, Lr52, Lr53 и вирулентными к Lr1, Lr3a, Lr3bg, Lr3ka, Lr11, Lr14a, Lr14b, Lr18, Lr23, Lr26, Lr30, Lr32, Lr33, Lr34, Lr48, Lr49, Lr64. Варьирование по вирулентности от- 
мечено на линиях TcLr20 и TcLr44. Два фенотипа MCRKG и MCRKH определены в казахстанской популяции P. triticina. Среднее число аллелей вирулентности в изученных образцах популяции составило 10,4. Значения индексов внутрипопуляционного разнообразия (Нея, Шеннона, Космана) для казахстанской популяции на $T$. durum были низкими $(\mathrm{Hs}=0,02 ; \mathrm{Sh}=0,22$; $\mathrm{KBm}=0,04)$, и указывали на низкий полиморфизм.

Разнообразие казахстанской популяции по микросателлитным локусам было существенно выше. В ней выявлено 4 SSR генотипа (с частотой $50 \%, 25 \%, 12 \%, 12 \%$, соответственно). Среднее число аллелей на локус (Na) составило 1,3; число эффективных аллелей - 1,2; Индекс Шеннона (I) 0.19. Уровень наблюдаемой гетерозиготности был выше уровня ожидаемой, что подтверждается отрицательными значениями индекса фиксации.

В данных исследованиях выявлены различия в вирулентности между изолятами из Северного Казахстана (2014 г.) [6] и проанализированными в настоящей работе. Различия могли быть вызваны использованием разных методик при проведении анализа вирулентности. В 2014 году был использован метод отрезков листьев [7], а в 2018-2019 гг. более точный метод инокуляции живых растений.

Сходство между северо-казахстанскими и южно-казахстанскими популяциями по микросателлитным локусам было существенно выше (Nei_d=0,013; Fst=0.03). Общие SSR генотипы выявлены в обеих популяциях, что указывает на генный поток между этими популяциями. Высокое сходство между северо- и южно-казахстанскими изолятами указывает на существование единой популяции P. triticina на твердой пшенице в Казахстане.

Благодарности: Данные исследования частично поддержаны Министерством сельского хозяйства Республики Казахстан в рамках программноцелевого финансирования на 2018-2020 гг. (ИРН BR0649329).

\section{Список литературы}

1. Gultyaeva E. Evaluation of resistance of spring durum wheat germplasm from Russia and Kazakhstan to fungal foliar pathogens / E. Gultyaeva, V. Yusov, M. Rosova, P. Malchikov, E. Shayayuk, N. Kovalenko, R. Wanyera, A. Morgounov, G. Yskakova, A. Rsaliyev // Cereal research communications, 2020. https://doi.org/10.1007/s42976-019-00009-9

2. Singh R.P. Occurrence and impact of a new leaf rust race on durum wheat in northwestern Mexico from 2001 to 2003 / R.P. Singh, J. Huerta-Espino, W. Pfeiffer, P. FigueroaLopes // Plant Diseases, 2004. - V. 88. - P. 703-708.

3. Ordonez M. Genetic diversity of a world-wide collection of Puccinia triticiana from durum wheat using simple sequence repeat markers and rdna sequence. (Abstr.) / M. Ordonez, J. Kolmer, L. Szabo // Phytopathology. - 2005. - V. 95. - P. 78.

4. Шайдаюк Е.Л. Характеристика вирулентности возбудителя бурой ржавчины на сортах озимой твердой пшеницы в условиях Ростовской области / Е.Л. Шайдаюк, Е.И. Гультяева, Н.В. Шишкин, Т.Г. Дерова, Д.Р. Яковлева, Н.П. Иличкина // Зерновое хозяйство России, 2019. № 1 (61). - С. 56-61.

5. Рсалиев А.С. Устойчивость сортообразцов яровой твердой пшеницы (Triticum 
durum Desf) к ржавчинным болезням. // Автореферат .... канд. с.-х. наук. - Алмалыбак: Казахский НИИ земледелия и растениеводства, 2009. - 26 с.

6. Гультяева, Е.И. Структура популяций Puccinia triticina Erikss. на мягкой и твердой пшенице / Е.И. Гультяева, А.К. Ахметова, Е.Л. Шайдаюк, М.К. Аристова // Земледелие и селекция сельскохозяйственных растений на современном этапе. Сборник докладов международной научно-практической конференции, посвященной 60-летию НПЦ зернового хозяйства им. А.И. Бараева, 2016 - С. 309-313.

7. Михайлова Л.А. Методы исследований структуры популяции возбудителя бурой ржавчины пшеницы / Л.А. Михайлова, Е.И. Гультяева, Н.В. Мироненко // Сборник методических рекомендаций по защите растений. - Санкт-Петербург: ВИЗР, 1998. - C. 105-126.

8. Mains, E.B. Physiologic specialization in the leaf rust of wheat; Puccinia triticina Erikss. / E.B. Mains, H.S. Jackson // Phytopathol. - 1926. - V.16. - P. 89-120.

9. Long, D.L. A North American system of nomenclature for Puccinia recondita f. sp. tritici / D.L. Long, J.A. Kolmer // Phytopathology. - 1989. - V. 79(5). - P. 525-529.

10. Гультяева Е.И. Генетическая дифференциация Puccinia triticina Erikss. по микросателлитным локусам на территории России / Е.И. Гультяева, М.К. Аристова, Е.Л. Шайдаюк, Н.В. Мироненко, И.А. Казарцев, А. Ахметова, Е. Косман // Генетика. 2017. №. 9. - C. 1053-1060.

11. Justesen, A.F. The recent history of Puccinia striiformis f. sp. tritici in Denmark as revealed by disease incidence and AFLP markers / A.F. Justesen, C.J. Ridout, M.S. Hovmøller // Plant Pathology. - 2002. - V. 51 (1). - P. 13-23.

12. Szabo, L. S. Development of simple sequence repeat markers for the plant pathogenic rust fungus Puccinia triticina / L.S. Szabo, J.A. Kolmer // Mol.Ecol. Notes. - 2007. - V. 7 (4). - P. 708-710.

13. Duan, $\mathrm{X}$. Isolation of 12 microsatellite loci, using an enrichment protocol, in the phytopathogenic fungus Puccinia triticina / X. Duan, J. Enjalbert, D. Vautrin, C. Solignac, T. Giraud // Mol. Ecol. Notes. - 2013. - V. 3 (1). - P. 65-67.

DOI 10.18699/GPB2020-65

\section{Оценка цитогенетической стабильности гибридных растений хлопчатника и их беккроссных потомств с замещениями отдельных хромосом}

Санамьян М.Ф. *, о.б.н., г.н.с. лаб. генетики хлопчатника; Бобохужаев Ш.У., докторант.

Национальный университет Узбекистана, Ташкент, Узбекистан.

*e-mail: sanam_marina@rambler.ru

Изучали мейоз на стадии метафаза I и спорад у гибридных анеуплоидов хлопчатника с замещеенем отдельных хромосом или их плеч. Выявили невысокий уровень нарушений в мейозе. Беккроссирование анеуплоидных гибридов с исходныли линиями привело к снижению мейотического индекса и 
фертильности пыльцы с увеличением числа беккроссов у гибридных анеуплоидных растений в некоторых комбинациях скрещиваний.

Ключевые слова: G. hirsutum, хромосом-замещенные гибриды, циитогенетический анализ.

\section{Evaluation of the cytogenetic stability of hybrid plants of the cotton and their backcross progenies with substitutions of separate chromosomes}

Sanamyan M.F. Doctor of Biological Sciences, chief scientist Cotton Genetics Laboratories, National University of Uzbekistan, Tashkent, Uzbekistan, sanam_marina@rambler.ru

Bobokhujaev Sh.U. PhD student, National University of Uzbekistan, Tashkent, Uzbekistan

We studied meiosis at the metaphase I stage and sporada in hybrid cotton aneuploids with the substitution of individual chromosomes or their arms. It revealed a low level of disturbance in meiosis. Backcrossing aneuploid hybrids with initial lines led to a decrease in the meiotic index and pollen fertility with an increase in the number of backcrosses in hybrid aneuploid plants in some crosses.

Key words: G. hirsutum, chromosome-substitution hybrids, cytogenetic analysis.

Хлопчатник вида $G$. barbadense L. обладает такими свойствами волокна, которые значительно превышают наиболее широко культивируемые сорта вида G. hirsutum L. Попытки перенести гены, ответственные за качество волокна от G. barbadense L. в геном G. hirsutum L. методами обычной межвидовой гибридизации затруднены из-за стерильности и нарушений при расщеплении. Хотя у хлопчатника G. hirsutum L. не получены полные серии анеуплоидных линий, в США проводятся исследования по созданию хромосом-замещенных линий с чужеродными хромосомами. В результате было выяснено, что линии с чужеродными замещениями по хромосомам 2, 6, 16, 18 и отдельным плечам хромосом 5sh, 22Lo и 22sh имели значительное улучшение \% волокна; тогда как линии с замещением по хромосоме 25 - имели сниженный микронейр и увеличенную крепость волокна $[1,2]$.

Материалом для исследований служили моносомные и монотелодисомные линии хлопчатника из Цитогенетической коллекции хлопчатника вида G. hirsutum L. Национального университета Узбекистана [3]. Ранее была проведена унифицированная идентификация унивалентных хромосом у части моносомных линий коллекции с помощью молекулярных SSR-маркеров [4] и тестерных транслокационных линий с идентифицированными хромосомами [5]. Для создания замещенных линий, моносомные 
линии скрещивались с линией Pima 3-79 вида G. barbadense L., затем в гибридных потомствах выделялись межвидовые моносомные гибриды $\mathrm{F}_{1} \mathrm{c}$ замещениями хромосом, которые беккроссировались с исходными моносомными линиями, служившими рекуррентными родителями.

Сравнительный анализ коньюгации хромосом у 29 гибридных моносомиков $F_{1}$ с замещением хромосомы $2,4,6,7$ и 18 , полученных от скрещиваний 14 моносомных линий с линией донором - Pima 3-79 обнаружил нормальную для моносомиков хлопчатника коньюгацию хромосом с формированием 25 бивалентов и одного унивалента разного размера во всех изученных МКП в 12 гибридных семьях, тогда как в одной комбинации скрещивания ( $\mathrm{F}_{1}$ Mo34 х Pima 3-79) один моносомик с замещением хромосомы 6 выделялся присутствием дополнительных унивалентов, а в другой комбинации ( $\mathrm{F}_{1} \mathrm{Mo} 95$ x Pima 3-79) моносомик с замещением по той же хромосоме отличался присутствием одного квадривалента. Четыре гибридных монотелодисомика с замещением отдельных плеч хромосомы 6 и 11, полученные от скрещиваний двух монотелодисомных линий, характеризовались присутствием гетероморфных бивалентов наряду с нормальными закрытыми бивалентами. Анализ стадии спорад микроспор, проведенный у анеуплоидных гибридных растений $\mathrm{F}_{1}$, с замещениями отдельных хромосом или их плеч обнаружил высокий мейотический индекс (от 94,32 $\pm 0,74$ до 99,93 $\pm 0,07$ ) и небольшое число тетрад с микроядрами (от 0,02 $\pm 0,02$ до $1,18 \pm 0,31 \%$ ), что указало на высокую мейотическую стабильность этих гибридных форм. Сравнительный анализ фертильности пыльцы выявил некоторые различия. Так, моносомные гибриды внутри семьи с замещением хромосомы 2 и двух семей с замещением хромосомы 4 имели сходные высокие показатели фертильности пыльцы, тогда как моносомные гибриды внутри других семей с замещением хромосомы 4 ( $\mathrm{F}_{1} \mathrm{Mo} 7 \mathrm{x}$ Pima 3-79, $\mathrm{F}_{1}$ Mo59 х Pima 3-79, $\mathrm{F}_{1}$ Mo60 x Pima 3-79), с замещением хромосомы 6 ( $\mathrm{F}_{1}$ Mo34 x Pima 3-79), а также монотелодисомные гибриды с замещением отдельных плеч хромосомы 6 или 11 ( $\mathrm{F}_{1}$ Telo12 x Pima 3-79 и $\mathrm{F}_{1}$ Тело21 х Pima 3-79) имели различия в фертильности пыльцы, которые были существенными (от 71,34 $\pm 1,28$ у моносомного гибрида $\mathrm{F}_{1} \mathrm{Mo92}$ х Pima 3-79 до 93,12 $\pm 1,35$ \% у моносомного гибрида $\mathrm{F}_{1}$ Mo67xPima 3-79), что также указало на существование специфических различий в фертильности пыльцы у моносомных гибридных растений с замещениями отдельных хромосом.

Сравнительный анализ коньюгации хромосом у 14 гибридных моносомиков $\mathrm{F}_{1} \mathrm{BC}_{1}$ с замещением хромосомы 4, 6, 7 и 18, полученных от беккроссирования четырех моносомных линий, выявил нормальную для моносомиков хлопчатника коньюгацию хромосом с присутствием 25 бивалентов и одного унивалента разного размера. Однако наличие открытых бивалентов у одного моносомного гибрида в варианте $\mathrm{F}_{1} \mathrm{BC}_{1}\left(\mathrm{Mo} 75 \mathrm{x} \mathrm{F}_{1} 104_{2}\right)$, наряду с закрытыми бивалентами, указало на нарушения в коньюгации хромосом. 
Изучение коньюгации хромосом у четырех монотелодисомных гибридов с замещением отдельных плеч хромосомы 6 или 11 обнаружило гетероморфные биваленты, которые подтвердили нехватку одного из плеч этих хромосом. Анализ стадии спорад, проведенный у 13 моносомных растений $\mathrm{F}_{1} \mathrm{BC}_{1}$ с замещением хромосомы 4, 6, 7 и 18 обнаружил высокий мейотический индекс (от $89,89 \pm 1,17$ до $98,99 \pm 0,20)$ и небольшое число тетрад с микроядрами (от $0,05 \pm 0,03$ до $1,34 \pm 0,47 \%$ ). Однако два монотелодисомных гибрида в семье $\mathrm{F}_{1} \mathrm{BC}_{1}$ (Тело21 $\left.\mathrm{x} \quad \mathrm{F}_{1} 100_{1}\right)$ хотя и характеризовались высоким мейотическим индексом (до 92,34 $\pm 1,14$ ), но выделялись увеличением числа

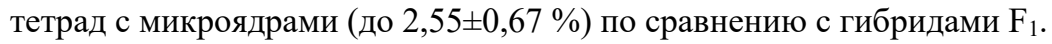

Различия в фертильности пыльцы в различных семьях $\mathrm{F}_{1} \mathrm{BC}_{1}$ были существенными (от 67,27 $\pm 1,45 \%$ у моносомика $\mathrm{F}_{1} \mathrm{BC}_{1}\left(\mathrm{Mo60}\right.$ х $\left.\mathrm{F}_{1} 694_{5}\right)$ до $95,72 \pm 0,91 \%$ у моносомика $\mathrm{F}_{1} \mathrm{BC}_{1}\left(\mathrm{Mo}_{4} \times \mathrm{F}_{1} 529_{16}\right)$ ), что подтвердило существование специфических различий в фертильности пыльцы у гибридных растений с замещением хромосом. Один монотелодисомный гибрид $\mathrm{F}_{1} \mathrm{BC}_{1} \mathrm{c}$ замещением плеча хромосомы 6 характеризовался небольшим снижением фертильности пыльцы (до 85,65 1,37 \%).

Анализ беккроссных потомств $\mathrm{F}_{1} \mathrm{BC}_{2}$, полученных от скрещиваний моносомных и монотелодисомных гибридов $\mathrm{F}_{1} \mathrm{BC}_{1}$ с реккурентными родителями, обнаружил гибридные моносомики $\mathrm{F}_{1} \mathrm{BC}_{2}$ только в 10 гибридных вариантах, поскольку в четырех вариантах моносомные гибриды определить не удалось, из-за сниженной скрещиваемости и небольшого числа гибридных растений в семьях, а также редкого воспроизводства моносомных цитотипов в потомстве. Изучение конъюгации хромосом на стадии метафазаI мейоза у гибридных моносомных форм $\mathrm{F}_{1} \mathrm{BC}_{2}$ с замещением хромосомы 4 , 6, 7 и 18 выявило коньюгацию хромосом с формированием 25 бивалентов и одного унивалента. Анализ стадии спорад микроспор, проведенный у моносомных гибридов $\mathrm{F}_{1} \mathrm{BC}_{2}$, обнаружил высокий мейотический индекс (от $92,27 \pm 0,60$ до $98,04 \pm 0,46$ ) и небольшое число тетрад с микроядрами (от $0,22 \pm 0,15$ до $1,31 \pm 0,41 \%$ ) у большинства изученных растений, за исключением одного гибридного моносомика в варианте $\mathrm{F}_{1} \mathrm{BC}_{2}\left(\mathrm{Mo} 34 \mathrm{x} \mathrm{F}_{1} \mathrm{BC}_{1} 293_{3}\right)$, который выделялся снижением мейотического индекса (до 83,66 $\pm 0,62)$ и существенным увеличением числа тетрад с микроядрами (до 9,23 $\pm 0,77$ \%), причем все другие типы микроспор этого растения также характеризовались присутствием от одного до четырех микроядер, что свидетельствовало о нерегулярности расхождения унивалентов в анафазе мейоза и формировании численно несбалансированных гамет. Анализ фертильности пыльцы, проведенный только в пяти вариантах скрещиваний $\mathrm{F}_{1} \mathrm{BC}_{2}$, обнаружил снижение фертильности пыльцы у растений трех вариантов скрещиваний (до $70,09 \pm 1,57 \%)$.

Сравнительный анализ фертильности пыльцы, проведенный между моносомными гибридами $\mathrm{F}_{1}$ и моносомными беккроссными гибридами 
$\mathrm{F}_{1} \mathrm{BC}_{1}$ и $\mathrm{F}_{1} \mathrm{BC}_{2}$, указал на частичное снижение фертильности пыльцы у гибридных моносомных растений с замещениями отдельных хромосом с увеличением числа беккроссов.

\section{Список литературы}

1. Saha S., J.Wu., J.N. Jenkins, J.C. McCarty, Jr., O.A. Gutierrez, D.M. Stelly, R.G. Percy, and D.A. Raska. Effect of Chromosome Substitutions from Gossypium barbadense L. 3-79 into G. hirsutum L. TM-1 on Agronomic and Fiber Traits // The Journal of Cotton Science. 2004. V. 8. P 162-169.

2. Saha S., Jenkins J. N., WU J., McCarty J. C. and Stelly D. M. Genetic analysis of agronomic and fibre traits using four interspecific chromosome substitution lines in cotton // Plant Breeding. 2008. V. 127. P. 612-618.

3. Sanamyan M.F., Petlyakova J., Rakhmatullina E.M., Sharipova E. World Cotton Germplasm Resources. Chapter 10. "Cytogenetic Collection of Uzbekistan". Intech. - Croatia. - 2014. P. 247- 287.

4. Санамьян М.Ф., Бобохужаев Ш.У., Макамов А.Х., Ачилов С.Г., Абдурахмонов И.Ю. Создание новой серии анеуплоидных линий у хлопчатника (Gossypium hirsutum L.) с идентификацией нехваток отдельных хромосом с помощью транслокационных и SSR-маркеров // Вавиловский журнал генетики и селекции. 2016. - T.20. №5. C.643-652.

5. Санамьян М.Ф., Бобохужаев Ш.У. Идентификация унивалентных хромосом у моносомных линий хлопчатника Gossypium hirsutum L. с помощью цитогенетических маркеров // Вавиловский журнал генетики и селекции. 2019. Т.23. - №7. - С. 836-845.

DOI 10.18699/GPB2020-66

\section{Влияние стимуляторов роста на содержание хлорофилла “a” и "b" и каротиноидов в листьях пшеницы}

Сатторов Б.Н.*, Сафаров Х.Р., Партоев К.

Институт ботаники, физиологии и генетики растений АН Республики Таджикистан, Душанбе

*e-mail: baca6600@mail.ru

В лаборатории генетики и селекции растений Института ботаники, физиологии и генетики растений Академии наук Республики Таджикистан проведены опыты по выявлению действия стимуляторов на содержание хлорофиллов «а», «б» и каротиноидов на ростки четырех сортов пшеницьы. В опьтте изучены ростки сортов пшениць, проросшие в следующих варианmax: 1. Контроль (вода); 2. Водньий раствор стимулятора Узхитан; 3.Водныии раствор ЭРА; 4. Водный раствор Узхитан+ЭРА. Через 10 дней подсчитали количество проросших семян, длины ростков и корней растений по вариантам опыта, а также определили количество хлорофиллов “ $a$ ” $u$ " $b$ " $u$ 
каротиноидов в ростках четырех сортов пшеницьг. Установлено положительного эффекта стимуляторов роста Узхитан и ЭРА на образование количество хлорофиллов «а», «б» и каротиноидов у ростков пшенищы в лабораторных условиях.

Ключевые слова: пшеница, стимуляторы, ЭРА, Узхитан, хлорофилл «а» $и$ «б», каротиноиды, Таджикистан.

\section{Influence of growth factors on the maintenance of the chlorophyll of "a", "b" and of carotinoids in wheat leaves}

Sattorov Bakhtovar Norasovich, Safarov Kholmakhmad Rajabovich, Partoev Kurbonali, Institute of Botany, Plants Physiology and Genetics of AS of the Republic of Tajikistan; 734017, Tajikistan, Dushanbe, Karamov St., 27.

e-mail:baca6600@mail.ru

In laboratory of plant genetics and breeding of Institute of Botany, Physiology and Genetics of Plants of Academy of Sciences of the Republic of Tajikistan are made experiments on identification action of stimulators on the maintenance of a chlorophyll " $a$ ", " $b$ " and carotinoids on sprouts of four grades of wheat. In experience sprouts of the grades of wheat which sprouted in the following options are studied: 1. Control (water); 2. Water solution of a stimulator Uzkhitan; 3. Water ERA solution; 4. Water solution Uzkhitan + ERA. In 10 days counted quantity of the sprouted seeds, lengths of sprouts and roots of plants by experience options and also defined quantity of a chlorophyll of " $a$ ", " $b$ " and carotinoids in sprouts of four grades of wheat. Uzkhitan and the ERA on education the quantity of a chlorophyll " $a$ ", " $b$ " and carotinoids at wheat sprouts in vitro is established positive effect of growth factors.

Key words: wheat, stimulators, ERA, Uzkhitan, chlorophyll " $a$ ", "b" and, carotinoids, Tajikistan.

В настоящее время в разных странах мира учеными ведутся исследования по выявлению влияния разных органических соединений на рост и развитие, а также на продуктивность растений. В частности, ряд ученых сообщают, что такие стимуляторы, как ЭРА, Гель, Узхитан и другие оказывают положительное влияние на ряд морфологических признаков и на продуктивность растений $[1,3,4]$. Установлено, что под влиянием различных препаратов наблюдается усиление роста и развития зерновых и других культур $[2,5,6]$.

В связи, с этим перед нами стояла цель - изучить влияние стимуляторов на содержание хлорофиллов “a” и “b”, а также количество каротиноидов в ростках четырех сортов пшеницы (Краснодарский, Сурхаки махалли, Джагер и Сомони). Нами изучено влияние водных растворов стимуляторов ЭРА (Москва) и Узхитан (Ташкент) на содержание хлорофиллов «а», «б» и каротиноидов в ростках пшеницы. 
Опыты проводились в лабораторных условиях в лаборатории генетики и селекции растений Института ботаники, физиологии и генетики растений Академии наук Республики Таджикистан. Для этого брали по 30 шт. семян сортов пшеницы (в трех кратной повторности, по 10 шт. зерно в каждой повторности) и проращивали в чашках Петри, на дне которых были размещены салфетки. В опыте были испытаны следующее варианты: 1. Контроль (вода); 2. Водный раствор стимулятора Узхитан; 3. Водный раствор ЭРА; 4. Водный раствор Узхитан+ЭРА. Через 10 дней подсчитали количество проросших семян, длины ростков и корней растений по вариантам опыта, а также определяли количество хлорофиллов "a" и “b” и каротиноидов в ростках четырех сортов пшеницы.

Результаты этих экспериментов приведены в таблице и на рисунке. Данные таблицы и рисунка свидетельствуют о положительном влияним стимуляторов на содержание хлорофиллов «а», «б» и каротиноидов в ростках сортов пшеницы.

Таблица - Содержание хлорофилла и каротиноидов в листьях сортов пшеницы

\begin{tabular}{|c|c|c|c|c|c|}
\hline Сорт & Варианты опыта & $\begin{array}{l}\text { Хл-а, Мг/г } \\
\text { сыр. масс. }\end{array}$ & $\begin{array}{l}\text { Хл-b, Мг/г } \\
\text { сыр. масс. }\end{array}$ & $\begin{array}{c}\text { Хл-а+b, Мг/г } \\
\text { сыр.масс. }\end{array}$ & \begin{tabular}{|} 
Сумма каро- \\
тиноидов, \\
Мг Г вес сыр \\
\end{tabular} \\
\hline \multirow{4}{*}{ 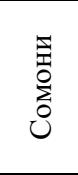 } & Контроль & 0,893 & 0,673 & 1,566 & 0,372 \\
\hline & Узхитан & 1,018 & 0,777 & 1,795 & 0,564 \\
\hline & ЭРА & 0,877 & 0,775 & 1,652 & 0,448 \\
\hline & ЭРА+Узхитан & 1,087 & 0,680 & 1,767 & 0,413 \\
\hline \multirow{4}{*}{ 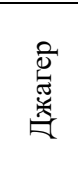 } & Контроль & 0,990 & 0,678 & 1,668 & 0,372 \\
\hline & Узхитан & 1,238 & 0,761 & 1,999 & 0,451 \\
\hline & ЭPA & 0,948 & 0,722 & 1,67 & 0,505 \\
\hline & ЭРА+Узхитан & 1,058 & 0,760 & 1,818 & 0,406 \\
\hline \multirow{4}{*}{ 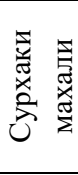 } & Контроль & 0,958 & 0,741 & 1,699 & 0,455 \\
\hline & Узхитан & 1,013 & 0,717 & 1,730 & 0,357 \\
\hline & ЭРА & 0,848 & 0,750 & 1,598 & 0,317 \\
\hline & ЭРА+Узхитан & 1,063 & 0,741 & 1,804 & 0,438 \\
\hline \multirow{5}{*}{ 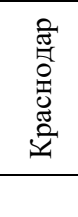 } & Контроль & 0,825 & 0,584 & 1,409 & 0,359 \\
\hline & Узхитан & 0,989 & 0,604 & 1,593 & 0,440 \\
\hline & ЭРA & 1,016 & 0,616 & 1,632 & 0,437 \\
\hline & ЭРА+Узхитан & 1,051 & 0,609 & 1,660 & 0,445 \\
\hline & $\mathrm{HCP}_{05}$ & $\mathbf{0 , 0 7}$ & 0,03 & 0,10 & 0,04 \\
\hline
\end{tabular}

Как видно из таблицы у всех сортов пшеницы в зависимости от их 
генотипической особенности, стимуляторы ЭРА и Узхитан вызывают увеличение количества хлорофиллов «а» и «б», а также каротиноидов в их ростках по сравнению с контролем. Особенно на увеличение количества хлорофиллов и каротиноидов положительно влияет стимулятор Узхитан по сравнению с контролем и стимулятором ЭРА (рисунок). По сравнению с контролем, также на увеличение количества хлорофиллов и каротиноидов положительно влияет и вариант ЭРА+Узхитан. Однако стимулятор ЭРА по сравнению с вариантами Узхитан и ЭРА+Узхитан сравнительно слабо влияет на формирование количество хлорофиллов «а», «б» и каротиноидов в ростках у сортов пшеницы.

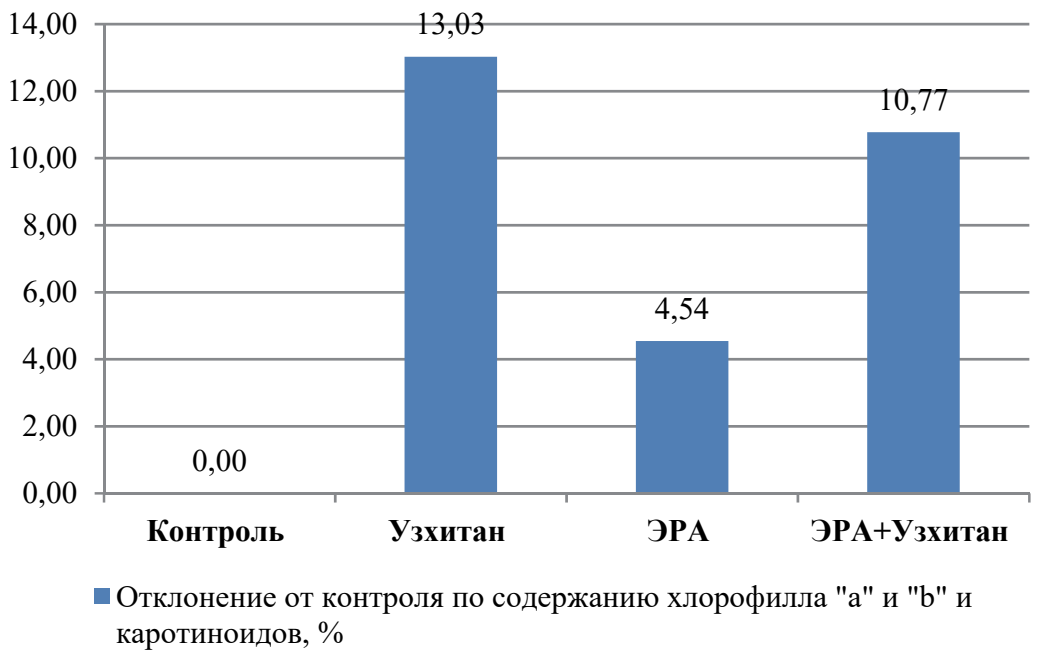

Рисунок. Влияние стимуляторов на формирование количество хлорофиллов «а», «б» и каротиноидов в ростках сортов пшеницы по равнению с контроля, \%.

Таким образом, можно отметить, что в лабораторных условиях стимуляторы Узхитан и ЭРА положительно влияют на образования количество хлорофиллов «а», «б» и каротиноидов в ростках сортов пшеницы по сравнению с контроля.

\section{Список литературы}

1. Астанакулов Е.Т. Влияние стимуляторов роста на урожайность и качество картофеля // Е.Т. Астанакулов // Химизация с.х. 1991, № 7, с.79-81.

2. Куликов С.Н., Алимова А.К., Захарова Н.Г., Немцев С.В., Варламов В.П. Препараты агрохит и триходермин против болезней картофеля. Прикладная биохимия и микробиология. 2006, Т. 42, № 1. - с. 86-92. 
3. Куликов С.Н., Тюрин Ю .А., Долбин Д.А. и др. Роль структуры в биологической активности хитозина // Вестник Казанского технологического университета, 2007, № 6. - С. 10-15.

4. Марупов А. Экологические чистые технологии защиты хлопчатника от вертициллезного вилта в Узбекистане. Ташкент - 2003. - 246 с.

5. Рашидова Д.К. Применение биологически активных полимеров на хлопчатнике. - Ташкент, 2015. - 132 с.

6. Соколова Е.А., Байданова Е.А. Влияние фиторегуляторов на количество зерен в колосе. Материалы седьмой международной конференции. Санкт-Петербург-Репино, 15-18 сентября 2003 г. - С.114-116.

DOI 10.18699/GPB2020-67

\section{Изменчивость качественных параметров волокна у гибридов хлопчатника географически отдаленного происхождения}

Сейтназарова T. *, м.н.с., Эгамбердиева С.А., д.с.-х.н., с.н.с. Научно-исследовательский институт селекиии, семеноводства и агротехнологии вырашивания хлопка, Ташкентская область, Узбекистан. *e-mail: s.tillahon@mail.ru

Изучень длина, удельная разрывная нагрузка, микронейр и расчетная прочность пряжи у гибридов $F_{2}-F_{3}$ хлопчатника, полученных в результате географически отдаленной гибридизаџии в условиях Ташкентской области. Выделены комплексно-ценные комбиначии по качеству волокна.

Ключевые слова: Gossypium hirsutum L., гибрид, верхняя полусредняя длина, микронейр, удельная разрывная нагрузка волокна, SCI.

\section{Variability of qualitative fiber parameters in hybrids of geographically remote origin.}

Seytnazarova Tillakhon Elmuratovna, Cotton breeding, seed production and agricultural technology research institute, 111218 Tashkent, Uzbekistan.

The length, spinning consistency index, micronaire, and the calculated strength of yarn in cotton hybrids F2-F3 obtained as a result of geographically distant hybridization in the conditions of the Tashkent region were studied. Complex-valuable combinations of fiber quality are highlighted.

Key words: Gossypium hirsutum L., hybrid, length, micronaire, SCI.

Сорта хлопчатника должны обладать комплексом хозяйственно-ценных признаков и удовлетворять по качеству волокна быстроразвивающуюся 
текстильную промышленность. Источниками улучшения генетической основы возделываемых сортов хлопчатника являются, как известно, генофонд диких видов, рудеральных форм, обладающие донорскими свойствами по устойчивости к вертициллезу, качеству волокна и другим признакам $[1,3]$.

Полученные ранее интрогрессивные линии Л-Т - $\mathrm{F}_{15} \mathrm{BC}_{4}(G$. hirsutum L., сорт C-4727 x G. trilobum Skovsted) х C-4727, Л-Ю - $\mathrm{F}_{11} \mathrm{BC}_{3}$ (G. hirsutum L., copт Delkott 277x G. hirsutum ssp. yucatanense) х Л-77, линия Л-578 производная от Л-Т служили материнскими формами [4]. В качестве отцовских форм были взяты сорта из США и Австралии. Статистическая обработка данных проводилась методом дисперсионного анализа по Б.А. Доспехову. Анализы качества волокна проводили на приборе HVI. Цель исследования изучить изменчивость признаков качества волокна у гибридов второго и третьего поколения, полученных от скрещивания географически отдаленных форм хлопчатника.

Наиболее важными характеристиками волокна являются длина, микронейр и удельная разрывная нагрузка волокна [5]. Длина волокна из всех качественных признаков имеет наибольшее значение в определении его технологической ценности. Для характеристики этого показателя на приборе HVI (High Volume Instrument) принят параметр «верхняя полусредняя длина». По верхней полусредней длине определяют тип и код волокна, определяющих цену на волокно.

Анализ гибридов $F_{2}$ по длине волокна показал, что при скрещивании линий и сортов с различным происхождением в ряде комбинаций выщепляются формы с длинным волокном. Например, высокие средние значения признака наблюдались в комбинациях $\mathrm{F}_{2}$ Л-578 х S-6082 (1,28 дюйм), $\mathrm{F}_{2}$ Л578 x S-489 (1,27 дюйм), F Л-Т х S-6003 (1,26 дюйм), F Л-Ю х S-6596 (1,25 дюйм), $\mathrm{F}_{2}$ Л-578 x S-6593 (1,23 дюйм) (табл. 1). Наибольший коэффициент вариации по длине волокна наблюдался в комбинациях $\mathrm{F}_{2}$ Л-Т х S-2515 ( $C v$ 7,5 \%), , $\mathrm{F}_{2}$ Л-Ю x S-6082 (Cv 6,0 \%), $\mathrm{F}_{2}$ Л-Ю x S-6593 (Cv 6,1 \%).

Таблица 1 - Изменчивость параметров качества волокна у гибридов $\mathrm{F}_{2}$

\begin{tabular}{|c|c|c|c|c|c|c|c|c|c|}
\hline $\begin{array}{l}\text { Гибридные } \\
\text { комбинации }\end{array}$ & $\mathrm{n}$ & Len & $C v, \%$ & Mic & $C v, \%$ & Str & $C v, \%$ & SCI & $C v, \%$ \\
\hline 1 & 2 & 3 & 4 & 5 & 6 & 7 & 8 & 9 & 10 \\
\hline $\mathrm{F}_{2} Л-578 \mathrm{x} \mathrm{S}-6003$ & 63 & 1,23 & 3,0 & 4,6 & 6,5 & 38,5 & 11,7 & 169,5 & 10,3 \\
\hline $\mathrm{F}_{2}$ Л-Т x S-6003 & 72 & 1,26 & 4,3 & 4,2 & 10,2 & 39,7 & 4,9 & 182,2 & 7,2 \\
\hline $\mathrm{F}_{2} Л-Ю \times$ × S-6003 & 48 & 1,23 & 2,2 & 3,9 & 3,6 & 38,3 & 3,8 & 176,9 & 0,8 \\
\hline $\mathrm{F}_{2} Л-578 \times \mathrm{S}-2515$ & 61 & 1,22 & 4,1 & 4,3 & 6,7 & 36,0 & 5,8 & 162,8 & 6,9 \\
\hline $\mathrm{F}_{2} Л-\mathrm{T}$ x S-2515 & 62 & 1,21 & 7,5 & 4,2 & 6,4 & 39,8 & 7,4 & 173,1 & 10,0 \\
\hline $\mathrm{F}_{2} Л-Ю \times$ x S-2515 & 48 & 1,23 & 4,1 & 4,3 & 10,7 & 35,8 & 11,1 & 166,6 & 10,1 \\
\hline $\mathrm{F}_{2}$ Л-578 x S-6082 & 62 & 1,28 & 0,7 & 4,5 & 8,8 & 40,3 & 1,1 & 171,3 & 9,3 \\
\hline $\mathrm{F}_{2}$ Л-Т x S-6082 & 35 & 1,14 & 5,3 & 4,6 & 8,9 & 37,3 & 5,2 & 171,5 & 0,9 \\
\hline F2Л-Ю × S-6082 & 66 & 1,19 & 6,0 & 4,3 & 9,6 & 36,7 & 13,5 & 166,4 & 12,4 \\
\hline $\mathrm{F}_{2} Л-578 \times$ S-489 & 71 & 1,27 & 4,9 & 4,1 & 8,7 & 33,7 & 3,6 & 169,6 & 7,1 \\
\hline
\end{tabular}




\begin{tabular}{|c|c|c|c|c|c|c|c|c|c|}
\hline 1 & 2 & 3 & 4 & 5 & 6 & 7 & 8 & 9 & 10 \\
\hline $\mathrm{F}_{2}$ Л-T x S-489 & 65 & 1,19 & 4,2 & 4,1 & 10,0 & 33,0 & 7,8 & 158,5 & 9,5 \\
\hline $\mathrm{F}_{2} Л-Ю \times \mathrm{S}-489$ & 52 & 1,16 & 0,6 & 4,0 & 3,5 & 31,9 & 0,4 & 150,8 & 1,4 \\
\hline $\mathrm{F}_{2} Л-578 \times \mathrm{S}-6593$ & 64 & 1,23 & 5,2 & 3,9 & 11,7 & 34,2 & 6,2 & 169,7 & 7,5 \\
\hline $\mathrm{F}_{2} Л-\mathrm{T}$ x S-6593 & 62 & 1,21 & 5,2 & 4,0 & 7,5 & 34,0 & 3,7 & 167,4 & 5,9 \\
\hline $\mathrm{F}_{2} Л-Ю \times$ S-6593 & 65 & 1,18 & 6,1 & 4,0 & 4,6 & 33,6 & 2,9 & 158,4 & 4,2 \\
\hline $\mathrm{F}_{2} Л-578 \times \mathrm{S}-6596$ & 74 & 1,22 & 3,7 & 4,4 & 8,2 & 34,2 & 6,1 & 159,9 & 7,5 \\
\hline $\mathrm{F}_{2} Л-\mathrm{T} \times \mathrm{S}-6596$ & 64 & 1,22 & 3,4 & 4,1 & 9,7 & 35,4 & 9,5 & 168,8 & 10,6 \\
\hline $\mathrm{F}_{2} Л-Ю$ x S-6596 & 73 & 1,25 & 2,7 & 4,0 & 5,4 & 35,4 & 3,6 & 171,7 & 2,7 \\
\hline St. Наманган-77 & 34 & 1,15 & 1,7 & 4,4 & 3,1 & 31,2 & 2,1 & 145,8 & 1,9 \\
\hline St. C-6524 & 37 & 1,17 & 2,1 & 4,3 & 2,8 & 39,9 & 2,4 & 175,3 & 2,6 \\
\hline
\end{tabular}

Микронейр - показатель, характеризующий тонину и зрелость хлопкового волокна. Для I и II сортов хлопкового волокна допустимый диапазон $3,5-4,9$ мк/дюйм. Ниже 3,5 волокно считается незрелым, в нем мало целлюлозы. Выше 4,9 - перезрелое, грубое. Допустимый диапазон микронейра для упландов без каких-либо штрафных санкций цены от 3,5 до 4,9, с диапазоном премиум 3,7 до 4,2 (Bradow и Davidonis, 2000) [6].

В наших опытах микронейр волокна в большинстве комбинаций соответствовал характеристике «среднее волокно» и составил от 4,0 до 4,6 мкг/дюйм. В комбинациях $\mathrm{F}_{2} Л-Ю$ х S-6003 и $\mathrm{F}_{2} Л-578$ х S-6593 средний показатель микронейра равнялся 3,9 , что соответствует характеристике «тонкое волокно». Наибольшая вариабельность признака проявилась в комбина-

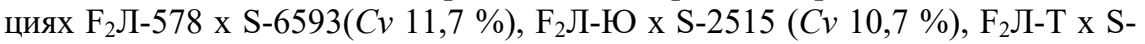
6003 ( $C v 10,2 \%)$ и $\mathrm{F}_{2} Л-\mathrm{T}$ x S-489 (Cv 10,0 \%). Таким образом, взятые нами в скрещивания интрогрессивные линии, а также линии производные от них являются донорами хорошего качества волокна.

Удельная разрывная нагрузка является одним из основных показателей, используемых для характеристики качества волокна и обозначает наибольшее усилие, выдерживаемое волокном до разрыва, выражается в гс/текс (грамм-силе на текс) [5].

У изученных комбинаций удельная разрывная нагрузка значительно превосходила стандартные сорта и колебалась в пределах от 31,9 до 40,3 гс\текс, что соответствует классу «очень крепкое волокно». Высокие показатели удельной разрывной нагрузки волокна отмечены в комбинациях $\mathrm{F}_{2}$ Л578 х Л-6082 - 40,2 гс/текс и F Л-Т х S-2515 - 39.8 гс/текс. Наибольший коэффициент вариации наблюдался в комбинациях $\mathrm{F}_{2}$ Л-Ю х S-6082 (Cv 13,5 $\%), \mathrm{F}_{2} Л-578 \mathrm{x}$ S-6003(Cv 11,7 \%) и $\mathrm{F}_{2}$ Л-Ю x S-2515(Cv 11,1 \%).

Расчетная прочность пряжи (SCI) - это расчет для прогнозирования общего качества и прядильности хлопкового волокна. Уравнение множественной регрессии может предоставить ценную информацию для прогнозирования прочности пряжи и потенциала вращения. 
В уравнении регрессии используется большинство отдельных результатов измерений HVI для расчета SCI. Этот индекс может быть использован для упрощения системы категорий, используемой при оценке хлопко-волокна. Как правило, чем выше индекс, тем выше прочность пряжи и тем лучше общие прядильные качества волокна [7]. Показатель SCI варьировал от 150,8 у F 2 Л-Ю х S-489 до 182.2 у комбинации $\mathrm{F}_{2} Л-\mathrm{T}$ х S-6003.

В результате браковки из 18 комбинаций $\mathrm{F}_{2}$ нами были отобраны 14. В третьем поколении у изученных гибридных комбинаций длина волокна была в пределах 1,18-1,28 дюйма, исключением стали две гибридные комбинации $\mathrm{F}_{3}$ Л-578 x S-6593 и F 3 Л-T х S-6596, длина волокна которых составила 1,12 и 1,15 дюйма соответственно (табл. 2). Наибольшая длина была характерна гибридам $\mathrm{F}_{3}$ Л-578 x S-489 - 1,28 дюйма, $\mathrm{F}_{3}$ Л-578 x S-6082 - 1,27 дюйма и $\mathrm{F}_{3}$ Л-Т x S-6593 - 1,26 дюйма. Эти данные свидетельствуют о высокой донорской способности по длине волокна интрогрессивной линии Л-Т, полученной с участием G. trilobum Skovsted, а также линии Л-578, производной от нее.

Таблица 2 - Изменчивость параметров качества волокна у гибридов $\mathrm{F}_{3}$

\begin{tabular}{|c|c|c|c|c|c|c|c|c|c|}
\hline $\begin{array}{l}\text { Гибридные } \\
\text { комбинации }\end{array}$ & $\mathrm{n}$ & Len & $\begin{array}{l}C v, \\
\%\end{array}$ & Mic & $\begin{array}{l}C v, \\
\%\end{array}$ & Str & $\begin{array}{l}C v, \\
\%\end{array}$ & SCI & $\begin{array}{l}C v, \\
\%\end{array}$ \\
\hline $\mathrm{F}_{3}$ Л-578xЛ-6003 & 44 & 1,21 & 2,6 & 4,5 & 6,3 & 35,1 & 4,9 & 163,8 & 8,5 \\
\hline $\mathrm{F}_{3}$ Л-T x S -6003 & 68 & 1,24 & 4,7 & 4,1 & 4,4 & 34,5 & 4,9 & 172,6 & 7,2 \\
\hline FЗЛ-578 xS-2515 & 56 & 1,24 & 2,4 & 4,2 & 8,5 & 33,2 & 5,5 & 179,4 & 5,5 \\
\hline $\mathrm{F}_{3}$ Л-Т x S -2515 & 60 & 1,21 & 5,2 & 4,5 & 3,8 & 35,0 & 5,3 & 161,8 & 4,8 \\
\hline $\mathrm{F}_{3}$ Л-578 xS-6082 & 57 & 1,27 & 0,6 & 4,6 & 2,8 & 38,0 & 6,1 & 177,2 & 3,1 \\
\hline $\mathrm{F}_{3}$ Л-Ю × S -6082 & 38 & 1,22 & 3,9 & 4,6 & 9,5 & 35,2 & 4,3 & 159,3 & 11,2 \\
\hline F3Л-578 x S-489 & 57 & 1,28 & 7,1 & 4,2 & 7,2 & 34,3 & 4,0 & 158,9 & 5,5 \\
\hline FЗЛ-Т x S-489 & 67 & 1,18 & 4,4 & 4,7 & 5,3 & 31,6 & 9,3 & 149,8 & 8,0 \\
\hline F3Л-578 xS-6593 & 67 & 1,12 & 0,8 & 4,5 & 3,3 & 32,2 & 3,4 & 156,3 & 3,6 \\
\hline F & 51 & 1,26 & 1,9 & 3,9 & 5,2 & 34,4 & 3,2 & 163,7 & 3,4 \\
\hline $\mathrm{F}_{3}$ Л-Ю х S-6593 & 91 & 1,21 & 0,8 & 4,4 & 2,2 & 34,5 & 2,3 & 157,2 & 1,6 \\
\hline F Л 578 xS-6596 & 72 & 1,20 & 5,1 & 4,8 & 7,4 & 32,7 & 2,4 & 142,1 & 6,2 \\
\hline F3Л-Т х S-6596 & 44 & 1,15 & 2,8 & 4,7 & 3,0 & 33,5 & 2,6 & 146,5 & 6,7 \\
\hline $\mathrm{F}_{3} Л-Ю \times$ × S-6596 & 68 & 1,18 & 2,7 & 4,4 & 4,0 & 33,1 & 4,3 & 154,7 & 9,4 \\
\hline St. Наманган-77 & 24 & 1,11 & 1,2 & 4,5 & 2,3 & 30,7 & 1,6 & 127,1 & 2,6 \\
\hline St. C-6524 & 35 & 1,13 & 1,3 & 4,3 & 2,1 & 35,1 & 1,9 & 157,9 & 3,2 \\
\hline
\end{tabular}

Максимальный микронейр волокна 4,8 мкг/дюйм наблюдался в гибридной комбинации $\mathrm{F}_{3}$ Л-578 x S-6596, у гибридов $\mathrm{F}_{3}$ Л-Т х S-489 и F $Л-Т$ х S-6596 4,7 мкг/дюйм. У остальных комбинаций данный показатель располагался в оптимальном промежутке 3,9-4,6 мкг/дюйм. Самое крепкое волокно отмечено у гибридной комбинации $\mathrm{F}_{3}$ Л-578 x Л-6082 - 38 гс/текс. Удельная 
разрывная нагрузка у остальных изученных гибридов соответствовала характеристике «очень высокая разрывная нагрузка волокна» (т.е. выше выше 31 гс/текс) и колебалась от 31,6 до 35,2 гс/ текс.

Показатель расчетной прочности пряжи был наименьшим у $\mathrm{F}_{3}$ Л-578 x S-6596 - 142,1. Наибольший показатель наблюдался у F 3 Л-578 x S-2515 179,4. Среди гибридов встречаются рекомбинанты с индексом прочности пряжи 180-190.Отмечено, что прядильные качества в большей степени зависят от удельной разрывной нагрузки волокна.Полученные данные позволяют выделить комплексно-ценные комбинации по качеству волокна.

\section{Список литературы}

1. Алиходжаева С.С., Мунасов Х., Муратов У.М. Дикие и рудеральные формы хлопчатника вида Gossypium hirsutum L. / С.С. Алиходжаева, Х. Мунасов, У.М. Муратов // Ташкент: Университет, 1992. - 60 с.

2. Доспехов В.А. Методика полевого опыта / В.А. Доспехов // М.: Колос, 1979. $-416 \mathrm{c.}$

3. Лемешев Н. Мировой фонд на службу хлопководства / Н. Лемешев // Хлопководство. 1984 - № 6. - С. 40-42.

4. Семенихина Л.В., Гуревич Л.И., Эгамбердиев А.Э. Проявление контрастных признаков у гибридов хлопчатника $\mathrm{F}_{1}$ и амфидиплоидов $\mathrm{K}_{1}, \mathrm{~K} 2$ G. hirsutum L. х G. trilobum Skovst. / Л.В. Семенихина, Л.И. Гуревич, А.Э. Эгамбердиев // Генетика. 1979. - Т. 15. - № 11. - С. 2013-2016.

5. Устюгин В.Е., Максудов И.Т., Урунов Н.Д. Волокно хлопковое. Технические условия / В.Е. Устюгин, И.Т. Максудов, Н.Д. Урунов // Ташкент: Изд. «Сифат», 1999. $-31 \mathrm{c}$.

6. Bradow, J.M., G.H. Davidonis. Quantitation of fiber quality and the cotton production-processing interface: a physiologist's perspective [electronic resource] / J.M.Bradow, Davidonis G.H. // Journal of cotton science (Online) Journal of cotton science 2000. 4: 34-64.

7. Abhijit Majumdar, Prabal Kumar Majumdar*, Bijon Sarka Selecting cotton bales by spinning consistency index and micronaire using artificial newral networks.AUTEX Research Journal, Vol. 4, No1, March 2004.

DOI 10.18699/GPB2020-68

\section{Изучение структуры популяции гриба бурой ржавчины пшеницы в лесостепи Приобья Новосибирской области в 2017-2019 гг.}

Сочалова Л.П., с.н.с.; Пискарев В.В. *, зав. лабораторией; Бойко Н.И., м.н.с. Сибирский научно-исследовательский институт растениеводства и селекции - филиал Федерального исследовательского центра «Институт циитологии и генетики Сибирского отделения РАН», п. Краснообск, Россия. *еmail: piskaryov_v@mail.ru

По результатам мониторинга популящии Р. recondita на территории 
Новосибирского Приобья в 2017-2019 г2. отмечено снижение частот вирулентности к гену Lr9 (om 51,0\% до 28,1 \%) и резкое нарастание к Lr14b (om 41,9\%. до 95,8\%). В местной популящии гриба установлено большое разнообразие физиологических (14) - 6, 10, 12, 20, 57, 60, 77, 107, 117, 122, 144, 149, 152, 176 и фенотипических рас (27) - THT, THK, THJ, TGT, TGK, TCJ, TQT, TQP, TQS, TLJ, TLR, TRT, BBJ, MBK, KHT, PLK, PHK, PGF, PGT, RQT, SBT, SCK, SGL, SGM, SHT, JQH, FHD. Фенотипь TQ, TL и PL поражали линию Thatcher с геном Lr9, а TH, PH, KH - Thatcher Lr26. В 2017 и 2019 г2. $в$ популящии присутствовал фенотип TRT, вирулентный к двум эти генам.

Ключевые слова: пшеница, бурая ржавчина, популяиия, вирулентность, раса, ген.

\section{Studying the structure of the fungi population of brown wheat rust in the forest steppe of the Ob region of the Novosibirsk region in 2017-2019}

Sochalova L.P., Senior Researcher, Piskarev V.V., Head of Laboratory, Boyko N.I., Junior Researcher

Siberian Research Institute of Plant Growing and Breeding - the branch of the "Federal Research Center the Institution of Cytology and Genetics of the Siberian Branch of the Russian Academy of Sciences"

e-mail:piskaryov_v@mail.ru

According to the results of monitoring the population $P$. recondita in the territory of the Novosibirsk Ob region in 2017-2019, a decrease in the virulence frequencies for the Lr9 gene (from $51.0 \%$ to $28.1 \%$ ) and a sharp increase in Lr14b (from $41.9 \%$ to $95.8 \%$ ). In the local population of the fungus established a wide variety of physiological (14) - 6, 10, 12, 20, 57, 60, 77, 107, 117, 122, 144, 149, 152, 176 and phenotypic races (27) - THT, THK, THJ, TGT, TGK, TCJ, TQT, TQP, TQS, TLJ, TLR, TRT, BBJ, MBK, KHT, PLK, PHK, PGF, PGT, RQT, SBT, $S C K, S G L, S G M, S H T, J Q H, F H D$. Phenotypes TQ, TL and PL damage the Thatcher line with the Lr9 gene, and TH, PH, KH - Thatcher Lr26. In 2017 and 2019 TRT phenotype was present in the population, which was virulent to these two genes.

Key words: wheat, brown rust, population, virulence, race, gene.

Эволюция популяции ржавчинного паразита Puccinia recondita Rob ex Desm. f. sp. tritici протекает сопряженно с эволюцией растения-хозяина во времени и пространстве, в результате которой происходит изменение их генетического состава [1].

С середины 1960-х гг. на территории Западной Сибири в популяции $P$. recondita доминирует 77 раса и ее биотипы [2]. В период 1970-1996-х гг. в популяции гриба Новосибирской области также встречались 117 и 184 [3], а в 2010 и 2011 гг. - 144 [4] расы. Популяция гриба Новосибирской области отличалась от популяции Омской области наименьшим количеством этих 
pac: $5(20,117,144,184)$ и $11(6,10,20,57,61,62,107,121,149,172,184)[5]$ соответственно.

Цель нашего исследования - изучение структуры популяции гриба P. recondita f. tritici в условиях лесостепи Приобья Новосибирской области для выявления источников эффективных генов устойчивости пшеницы к заболеванию.

Условия, материал и методы. Эксперименты проводили в 20172019 гг. в Сибирском НИИ растениеводства и селекции - филиал ИЦиГ СО РАН. В лаборатории по методикам $[6,7]$ исследовали динамику частот вирулентности (табл. 1) 84-х моноклонов паразита по 19-и Lr-линиям Thatcher (табл. 1) и 7-и генотипам пшеницы с известными генами устойчивости Добрыня (Lr19), Челяба 75 (LrSp), Тулайковская 10 (Lr6Agi2), Agent (Lr24), CS2A/2M ( $L r 28)$, KS90WGRC10 (Lr41(39)). Инфекции гриба (популяцию, моноклоны) возобновляли и культивировали на восприимчивом сорте Скала (st). Тип реакции на заражение учитывали на 8 день по шкале Mains и Jackson (1926) [8], где 0-2 балла - устойчивость, 3-4 - восприимчивость; 1-3 (х) относили к восприимчивым.

Физиологические расы (табл. 2) определяли на наборе сортов-дифференциаторов по Johnston и Browder (1966) [9] Фенотипы рас устанавливали по системе Long и Kolmer (1989) по 3 основным наборам моногенных Lrлиний: 1 - Lr1, Lr2a, Lr2c, Lr3a; 2 - Lr9, Lr16, Lr24, Lr26; 3 - Lr3ka, Lr11, $\operatorname{Lr17}, \operatorname{Lr} 30$ [10]. Их дополняли 8 линий Thatcher с генами Lr19, Lr20, Lr14a, Lr18; Lr2b, Lr3bg, Lr14b, Lr15.

Результаты и обсуждение. В 2017-2019 гг. при анализе моноклонов уредопопуляции P. recondita собранной на полях СибНИИРС-филиал ИЦиГ СО РАН выявлена широкая дифференциация частот вирулентности (табл. 1) к Lr-генам устойчивости пшеницы: в среднем от 36,1 \% к $L r 26$ до 94,7 \% к Lrl. Высокое содержание частот вирулентности ежегодно в местной популяции относилось к генам Lr1, Lr2a, Lr2b, Lr2c, Lr3a, Lr3bg, Lr3ka, Lr11, $\operatorname{Lr} 14 a, \operatorname{Lr} 14 b, \operatorname{Lr} 15, \operatorname{Lr} 16, \operatorname{Lr} 17, \operatorname{Lr} 18, \operatorname{Lr} 20$ и $\operatorname{Lr} 30$ (в среднем от 73,0 до 94,7 $\%)$. Максимальное количество частот вирулентности (100\%) в местной популяции бурой ржавчины выявлено в 2018 г. к генам $\operatorname{Lrl}, \operatorname{Lr} 17$ и $\operatorname{Lr} 30$.

Таблица 1 - Динамика частот вирулентности (\%) популяции P. recondita в лесостепи Приобья НСО в период 2017-2019 гг.

\begin{tabular}{|c|c|c|c|c|c|c|c|c|c|}
\hline \multirow[t]{2}{*}{ Ген } & \multicolumn{4}{|c|}{ \% вирулентных клонов } & \multirow[t]{2}{*}{ Ген } & \multicolumn{4}{|c|}{ \% вирулентных клонов } \\
\hline & 2017 & 2018 & 2019 & среднее & & 2017 & 2018 & 2019 & среднее \\
\hline 1 & 2 & 3 & 4 & 5 & 6 & 7 & 8 & 9 & 10 \\
\hline Lrl & 90,4 & 100 & 93,8 & 94,7 & Lr14a & 94,2 & 85,7 & 96,9 & 92,3 \\
\hline$L r 2 a$ & 96,9 & 85,7 & 90,6 & 91,1 & $L r 14 b$ & 41,9 & 95,8 & 81,3 & 73,0 \\
\hline$L r 2 b$ & 93,3 & 90,5 & 87,5 & 90,4 & $\operatorname{Lr} 15$ & 93,8 & 93,8 & 93,8 & 93,8 \\
\hline$L r 2 c$ & 92,2 & 90,5 & 96,9 & 93,2 & Lr16 & 86,5 & 95,2 & 84,4 & 88,7 \\
\hline$L r 3 a$ & 88,2 & 71,4 & 84,4 & 81,4 & $\operatorname{Lr} 17$ & 88,5 & 100 & 87,5 & 92,0 \\
\hline
\end{tabular}




\begin{tabular}{|l|c|c|c|c|c|c|c|c|c|}
\hline \multicolumn{1}{|c|}{} & $\mathbf{2}$ & $\mathbf{3}$ & $\mathbf{4}$ & $\mathbf{5}$ & $\mathbf{6}$ & $\mathbf{7}$ & $\mathbf{8}$ & $\mathbf{9}$ & $\mathbf{1 0}$ \\
\hline Lr3bg & 93,3 & 93,3 & 84,4 & 90,4 & $\operatorname{Lr} 18$ & 88,2 & 88,2 & 84,4 & 86,9 \\
\hline Lr3ka & 86,3 & 81,0 & 68,8 & 78,7 & $L r 20$ & 89,2 & 95,2 & 68,8 & 84,4 \\
\hline Lr9 & 51,0 & 33,3 & 28,1 & 37,5 & Lr26 & 31,4 & 14,3 & 62,5 & 36,1 \\
\hline Lr11 & 90,2 & 66,7 & 71,9 & 76,3 & $L r 30$ & 90,2 & $\mathbf{1 0 0}$ & 65,6 & 85,3 \\
\hline
\end{tabular}

В сравнении с 2017 г. в 2018 и 2019 гг. в популяции происходило снижение частот вирулентности к гену $\operatorname{Lr} 9(51,0 \%, 33,3$ \% и $28,1 \%$ соответственно). Напротив, в популяции отмечено резкое нарастание вирулентности к гену $\operatorname{Lr} 14 b$ (42,0 \% в 2017 г., 95,8 и 81,3 \% в 2018-2019 гг.). Тогда как к гену $L r 26$ содержание частот вирулентности по годам исследования варьировало от $31,4 \%$ в 2017 г., 14,3 \% в 2018 г. и 62,5\% в 2019 г., соответственно.

По результатам мониторинга популяции $P$. rec. нами не обнаружены изоляты вирулентные к генам Lr19, Lr24, Lr25, Lr28, Lr41, Lr6Agi2 и LrSp. Во всех случаях заражения отрезков листьев источников этих генов моноинфекциям гриба их реакция была авирулентная (R).

В популяции было установлено 14 физиологических рас $(6,10,12,20$, $57,60,77,107,117,122,144,149,152$ и 176), лидировала 77 раса и ее биотипы: от 57,8 \% в 2017 г. до 91,0 \% в 2019 г. (табл. 2). Доля дополнительных pac, соответственно, в популяции составляла от 42,2 до $9,0 \%$.

Из дополнительных рас ежесезонно в местной структуре гриба встречалась 122 , по двум годам - 10, 20, 57, 144, 152, однократно - $6,12,60,107$, 149, 176 и 117 из ранее встречающихся (в 1976-1996 гг.), но не была обнаружена 184. Очевидно, с потеплением климата на территории Западной и Восточной Сибири (с 2012 г.) в популяции P. rec. вновь стали отселектироваться ранее отработанные расы, что подтверждают и другие исследователи: в Красноярском крае выявлены 117 и 184 [11], в Омской обл. - 184 [12].

Таблица 2 - Расовый состав популяции $P$. recondita в лесостепи Приобья НСО, 2017-2019 гг.

\begin{tabular}{|c|c|c|c|c|c|c|c|c|c|c|c|c|c|c|c|}
\hline год & \multicolumn{10}{|c|}{ расы } & всего \\
\hline 2017 & 77 & - & - & - & 20 & 57 & & 107 & - & 122 & 144 & - & 152 & 176 & 8 \\
\hline 2018 & 77 & - & 10 & 12 & 20 & - & 60 & - & - & 122 & 144 & 149 & - & - & 8 \\
\hline 2019 & 77 & 6 & 10 & - & - & 57 & & - & 117 & 122 & - & - & 152 & - & 7 \\
\hline
\end{tabular}

В структуре популяции гриба определено 27 фенотипов рас: ТНТ, THK, THJ, TGT, TGK, TCJ, TQT, TQP, TQS, TLJ, TLR, TRT, BBJ, MBK, KHT, PLK, PHK, PGF, PGT, RQT, SBT, SCK, SGL, SGM, SHT, JQH, FHD, все авирулентные к генам Lr19, Lr24, Lr25, Lr28, Lr41(39), Lr6Agi2 и LrAe.sp. Фенотипы TQ, TL и PL поражали линию Thatcher с геном $L r 9$, а фенотипы TH, PH, КН - с геном Lr26. В 2017 и 2019 гг. в местной популяции присутствовал фенотип TRT, вирулентный к двум этим генам. 
Выводы. В 2017-2019 гг. в лесостепи Приобья НСО в генетическом составе популяции $P$. recondita не выявлено клонов вирулентных к генам устойчивости пшеницы $\operatorname{Lr} 19, \operatorname{Lr} 24, \operatorname{Lr} 25, \operatorname{Lr} 28, \operatorname{Lr} 41(39), \operatorname{Lr6Agi2}$ и LrAe.sp.

В структуре популяции $P$. recondita установлено 14 физиологических pac $(6,10,12,20,57,60,77,107,117,122,144,149,152,176)$ и 27 фенотипических. Фенотипы TQ, TL и PL поражали линию Thatcher с геном $\operatorname{Lr} 9$, a TH, $\mathrm{PH}, \mathrm{KH}-\mathrm{c}$ геном

Lr26. В 2017 и 2019 гг. в популяции присутствовал фенотип TRT, вирулентный к двум эти генам.

Благодарности: Экспериментальная работа выполнена при поддержке бюджетного проекта ИЦиГ СО РАН № 0324-2019-0039-С-01. Обработка и оформление результатов выполнены при финансовой поддержке гранта РФФИ 20-016-00093 А.

\section{Список литературы}

1. Prasad P., Bhardwaj S. C., Gangwar O. P., Kumar S., Khan H., Kumar S., Rawal H. C. and Sharma T. R. Population differentiation of wheat leaf rust fungus Puccinia triticina in South Asia. Current Science. 2017. vol. 112, \#10. p. 2073-2084. DOI: $10.18520 / \mathrm{cs} / \mathrm{v} 112 / \mathrm{i} 10 / 2073-2084$

2. Одинцова И.Г. Связь между популяциями возбудителя бурой ржавчины пшеницы на территории СССР и ее значение для селекции / И.Г. Одинцова, Л.Ф. Шеломова, А.А. Алманов, Х.О. Пеуша // Проблемы использования генофонда в селекции растений на иммунитет к болезням и вредителям: сб. науч. тр. по прикл. бот., ген. и сел. - Л.: ВИР, 1987. Т. 110. - С. 12-18.

3. Христов Ю.А. Расовая и генетическая характеристика популяции бурой ржавчины пшеницы / Ю.А. Христов, Т.В. Штайнерт // Генофонд сельскохозяйственных культур для селекции устойчивых сортов. - Новосибирск: РАСХН. Сиб. отд. СибНИИРС, 1999. - С.105-109.

4. Сочалова Л.П. Генетическая устойчивость сортов яровой пшеницы к облигатно-аэрогенным заболеваниям в условиях лесостепи Приобья: каталог сортов-доноров генов устойчивости / Л.П. Сочалова, И.Е. Лихенко // Новосибирск: ГНУ СибНИИРС, 2011. $-27 \mathrm{c}$.

5. Мешкова Л.В. Генетико-популяционная характеристика возбудителя бурой ржавчины Сибири за 1968-1979 годы / Л.В. Мешкова, Б.Г. Рейтер // Актуальные вопросы генетики и селекции растений. - Новосибирск, 1980. - С. 257.

6. Михайлова Л.А. Лабораторные методы культивирования возбудителя бурой ржавчины пшеницы / Л.А. Михайлова, К.В. Квитко // Микология и фитопатология. Л., 1970. Т. 4, №. 3. - С. 269-270.

7. Методические указания по изучению изменчивости популяций фитопатогенных грибов / М.М. Левитин, Л.А. Михайлова, О.С. Афанасенко // Л.: ВИЗР, 1981. - 55 с.

8. Mains E.B. Physiologic specialization in leaf of wheat Puccinia triticina Erikss / E.B. Mains, H.S. Jackson // Phytopathology, 1926. V.16, 1. P. - 89-120.

9. Johnston C.O. Seventh revision of physiologic races of Puccinia recondita f. sp. Trilici / C.O. Johnston, E.B. Browder // Plant Disease reporter, 1966. V. 50, №10. P. 756-760.

10. Long D.L. A North American system of nomenclature for Puccinia recondita f. sp. 
trilici / D.L. Long, J.A. Kolmer // Phytopathology, 1989. V. 79, №5. - P. 525-529.

11. Мешкова Л.В. Физиологическая специализация возбудителя бурой ржавчины в Красноярском крае / Л.В. Мешкова, Л.П. Россеева, А.Б. Сидоров, Т.С. Зверовская, О.Б Сабаева, И.Б. Белан // Вестник Красноярский ГАУ, 2019. №1. - С. 29-36.

12. Мешкова Л.В. Вирулентность природной популяции возбудителя бурой ржавчины пшеницы в Омской области / Л.В. Мешкова, Л.П. Россеева, Т.С. Зверовская, О.Б Сабаева, И.Б. Белан // Успехи современного естествознания, 2018. № 11(2). - С. 279-283.

DOI 10.18699/GPB2020-69

\section{Отбор с помощью молекулярных маркеров линий яровой мягкой пшеницы с ранним сроком колошения}

Стасюк А.И. *, м.н.с.; Киселева А.А., к.б.н., н.с.; Салина Е.А. б.б.н., г.н.с. ФГБНУ «Федеральный исследовательский центр Институт циитологии и генетики СО РАН», Новосибирск, Россия.

*e-mail: stasyuk@bionet.nsc.ru

Проведен ПЦР-анализ генов Ppd-D1, Vrn-A1, Vrn-B1, Vrn-D1, Vrn-B3 c использованием аллель-специффичных праймеров у гибридов яровой мягкой пшеницы поколения $F_{2}$, полученных от скрещчивания сорта Обская 2 с сортом Тулун 15. По аллельному составу генов Vrn-1, Ppd-1 и Vrn-B3 гибридные растения были распределены на 4 гаплотипа. Проведена оченка продолжительности периода всходы-колочение каждого гаплотипа в поколениях $F_{3-}$ 4. Установлено, что наиболее ранний срок колошения имеют растения с аллельным составом Ppd-D1a, Vrn-Ala, Vrn-B1c, vrn-D1, Vrn-B3a. Полученные результаты могут быть использованы в маркер-ориентированной селекции для отбора генотипов, наиболее оптимальных для тех или иньх условий воздельввания.

Ключевые слова: яровая мягкая пшеница, маркер-ориентированный отбор, срок колошения.

\section{Selection of spring wheat lines with early heading date using the molecular markers}

Stasyuk A.I., Kiseleva A.A., Salina E.A. Federal Research Center Institute of Cytology and Genetics SB RAS, Novosibirsk, Russia, e-mail: stasyuk@bionet.nsc.ru

PCR analysis of the genes Ppd-D1, Vrn-A1, Vrn-B1, Vrn-D1, Vrn-B3 was carried out with allele-specific primers in $F_{2}$ spring hybrids of bread wheat obtained from hybridization of Obskaya 2 with Tulun 15 varieties. Hybrid plants 
were divided into 4 haplotypes based on a combination of alleles of the Ppd-1, Vrn-1 and Vrn-B3 genes. The estimation of the period from germination to heading in each haplotype in $F_{3-4}$ generations was carried out. It was established that the plants with allelic composition Ppd-D1a, Vrn-Ala, Vrn-B1c, vrn-D1, Vrn-B3a have the earliest heading date. The results can be used for marker-assisted selection of genotypes most appropriate for different growing conditions.

Key words: spring bred wheat, marker-assisted selection, heading date

Создание сортов мягкой пшеницы адаптированных к определенным условиям окружающей среды является одной из главных задач селекции этой культуры. Значительным фактором при этом, являются сроки наступления колошения, которые контролируются генами реакции на яровизацию - Vrn, и генами, определяющими чувствительность к фотопериоду - Ppd. Аллельные вариации этих генов приводят к различным срокам колошения $[1,2]$. Применение маркер-ориентированной селекции позволяет в короткие сроки отобрать растения с заданным аллельным составом генов, контролирующих сроки наступления колошения. Целью данной работы было определение сроков колошения у растений отобранных с помощью молекулярных маркеров и выявление генотипов с ранним сроком колошения.

Материалы и методы. Материалом для исследования послужили потомства $F_{2-4}$, полученные от скрещивания яровых сортов мягкой пшеницы Тулун 15 и Обская 2. У растений поколения $\mathrm{F}_{2}$ был проведен ПЦР-анализ аллельного состава генов Vrn-1 и Ppd-1 с помощью аллель-специфичных праймеров описанных в работе [3]. Идентификацию аллелей гена $V r n-B 3$ проводили с использованием праймеров описанных в работе [4].

Для оценки периода всходы-колошение растения поколений $\mathrm{F}_{3-4}$ и родительские сорта выращивали на экспериментальном поле в 2018-2019 гг. (Новосибирская обл., п. Краснообск). Статистическую обработку данных проводили с помощью пакета программ Statistica 10.0 («StatSoft, Inc.», CША).

Результаты. Нами ранее при анализе генов Vrn и $P p d$ у сибирских сортов яровой мягкой пшеницы был выделен раннеспелый сорт Тулун 15 , несущий доминантный аллель $P p d-D 1 a$, обуславливающий нечувствительность к фотопериоду [3]. Кроме того, этот сорт содержит доминантный аллель $V r n-B 3 a$, детерминирующий переход растения к раннему цветению. Сорт Тулун 15 был скрещен со среднеранним сортом Обская 2. Во втором поколении было получено 84 потомка, которые были генотипированы с помощью праймеров к генам Vrn-1, Ppd-D1 и Vrn-B3. По результатам анализа было отобрано 34 растения, у которых эти гены были в гомозиготном состоянии. Все гибриды, также, как и оба родительских сорта, содержали аллели $V r n-A 1 a, V r n-B 1 c$ и vrn-Dl и отличались только аллелями генов Ppd-Dl и $V r n-B 3$. По аллельному составу отобранные растения были распределены на 4 гаплотипа (табл. 1). 
Таблища 1 - Аллельные комбинации генов Ppd-D1, Vrn-A1, Vrn-B1, Vrn-D1 и $V r n-\mathrm{B} 3$ у гибридов $\mathrm{F}_{2}$ и у родительских сортов

\begin{tabular}{|c|c|c|c|c|c|c|}
\hline Гаплотип & $P p d-D 1$ & $V r n-A 1$ & $V r n-B 1$ & $V r n-D 1$ & $V r n-B 3$ & $\begin{array}{c}\text { Количество } \\
\text { растений, шт }\end{array}$ \\
\hline 1 & $P p d-D 1 a$ & $V r n-A 1 a$ & $V r n-B 1 c$ & $v r n-D 1$ & $V r n-B 3 a$ & 12 \\
\hline 2 & $P p d-D 1 a$ & $V r n-A 1 a$ & $V r n-B 1 c$ & $v r n-D 1$ & $V r n-B 3 b$ & 6 \\
\hline 3 & $P p d-D 1 b$ & $V r n-A 1 a$ & $V r n-B 1 c$ & $v r n-D 1$ & $V r n-B 3 a$ & 9 \\
\hline 4 & $P p d-D 1 b$ & $V r n-A 1 a$ & $V r n-B 1 c$ & $v r n-D 1$ & $V r n-B 3 b$ & 7 \\
\hline Обская 2 & $P p d-D 1 b$ & $V r n-A 1 a$ & $V r n-B 1 c$ & $v r n-D 1$ & $V r n-B 3 b$ & - \\
\hline Тулун 15 & $P p d-D 1 a$ & $V r n-A 1 a$ & $V r n-B 1 c$ & $v r n-D 1$ & $V r n-B 3 a$ & - \\
\hline
\end{tabular}

Доминантный аллель $P p d-D 1 a$ был обнаружен у 18 растений, остальные 16 растений содержали рецессивный аллель $P p d-D 1 b$, обуславливающий чувствительность к длине светового дня. Аллель $V r n-B 3 a$, присутствовал у 21 растения, 13 растений несли рецессивный аллель $V r n-B 3 b$.

Оценка периода всходы-колошение показала, все генотипы, за исключением сорта Тулун 15, в 2019 году выколашивались позже на 4-5 суток по сравнению с 2018 годом (рис. 1). Сроки колошения у сорта Тулун 15 значительно не отличались по двум годам и составили 37,5 и 37,1 суток в 2018 и 2019 годах соответственно. Значительно позже других генотипов наблюдалось колошение у сорта Обская 2 и составило 42,9 в 2018 и 49,8 суток в 2019 годах. Среди гибридов раньше всех выколашивались растения из гаплотипа 1 , содержащие аллели нечувствительности к фотопериоду (Ppd-Dla) и инициации раннего колошения $(V r n-B 3 a)-34,5$ и 39 суток в 2018 и 2019 годах соответственно. Стоит отметить, что растения из гаплотипа 1 в 2018 году выколосились на 3 суток раньше, чем сорт Тулун 15 с таким же аллельным составом генов Vrn и $P p d$. Однако в 2019 году колошение растений из того же гаплотипа наступило позже на 1,9 суток по сравнению с сортом Тулун 15.

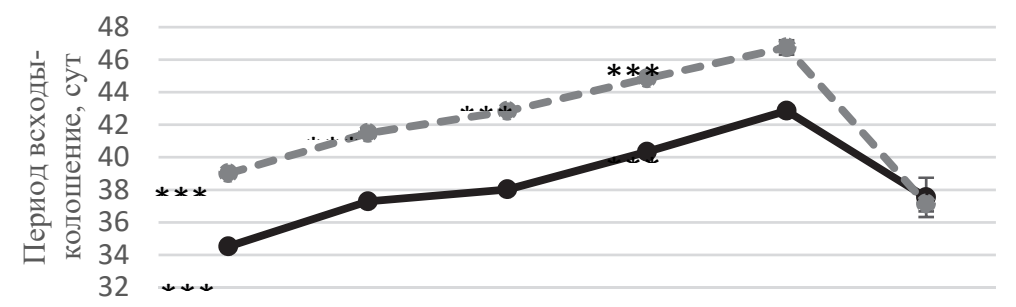

Гаплотип1Гаплотип2ГаплотипЗГаплотип4 Обская 2 Тулун 15

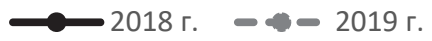

Рис. 1. Продолжительность периода от всходов до колошения у растений F3-4, полученных от скрещивания Обская $2 \times$ Тулун 15 . ** - достоверные отличия гаплотипов от родительских сортов при $\mathrm{p}<0,001$. 
Колошение растений из гаплотипа 2, характеризующихся наличием доминантного аллеля Ppd-Dla и рецессивного аллеля $V r n-B 3 b$, наступило позже чем у гаплотипа 1 на 2,8 суток в 2018 и на 2,5 - в 2019 годах. При этом, при сравнении с сортом Тулун 15 в 2018 году достоверных отличий выявлено не было, а в 2019 году колошение у гаплотипа 2 наступило на 4,4 суток позже. Период от всходов до колошения у пшеницы из Гаплотипа 3 , содержащего рецессивный аллель $P p d-D 1 b$ и доминантный аллель $V r n-B 3 a$, был больше чем у гаплотипов 1 и 2 и в 2018 и 2019 годах соответственно составил 38 и 42,8 суток. При сравнении с родительским сортом Тулун 15 в 2018 году значительных отличий не выявлено, а в 2019 году гаплотип 3 отличался более поздним колошением - на 5,7 суток. Наиболее позднее колошение среди гибридов было отмечено у растений из гаплотипа $4-40,3$ суток в 2018 году и 44,9 суток в 2019 году. Гаплотип 4 так же, как и сорт Обская 2, содержит рецессивные аллели $P p d-D 1 b$ и $V r n-B 3 b$, но при этом выколашивался раньше на 2,6 и 1,9 суток в 2018 и 2019 годах соответственно. При сравнении с сортом Тулун 15 у гаплотипа 4 период всходы-колошение был больше на 2,8 в 2018 и на 7,8 суток в 2019 годах.

Таким образом, полученные результаты позволяют сделать вывод, что доминантные аллели Ppd-Dla и Vrn-B3a оказывают существенное влияние на сроки колошения яровой мягкой пшеницы. Для отбора растений с наиболее ранним сроком колошения целесообразно отбирать генотипы, которые в сочетании с аллелями Vrn-Ala, Vrn-B1c, vrn-D1 содержат доминантные аллели Ppd-Dla и Vrn-B3a.

Благодарности: Исследование выполнено при финансовой поддержке РФФИ в рамках научного проекта № 20-016-00059.

\section{Список литературы}

1. Потокина, Е.К., Кошкин В.А., Алексеева Е.А., Матвиенко И.И., Филобок В.А., Беспалова Л.А. Комбинация аллелей генов Ppd и Vrn определяет сроки колошения у сортов мягкой пшеницы. Вавиловский журнал генетики и селекции. -2012. - T. 16. - P. 77-86.

2. Kiss T, Balla K, Veisz O, Láng L, Bedő Z, Griffiths S, et al. Allele frequencies in the $V R N-A 1, V R N-B 1$ and $V R N-D 1$ vernalization response and $P P D-B 1$ and $P P D-D 1$ photoperiod sensitivity genes, and their effects on heading in a diverse set of wheat cultivars (Triticum aestivum L.). Mol Breed. 2014; 34: 297-310.

3. Likhenko, I.E. Study of allelic composition of Vrn-1 and Ppd-1 genes in earlyripening and middle-early varieties of spring soft wheat in Siberia / I.E. Likhenko, A.I. Stasyuk, A.B. Shcherban' // Rus. J. Genet. Applied Research. 2015. - V. 5. - P. 198-207. DOI: $10.1134 /$ S2079059715030107.

4. Yan, L., D. Fu, C. Li, A. Blechl, G. Tranquilli, M. Bonafede, A. Sanchez, M. Valarik, S. Yasuda, and J. Dubcovsky. 2006. The wheat and barley vernalization gene VRN3 is an orthologue of FT. Proc. Natl. Acad. Sci. USA 103:19581-19586. 


\section{Системная оценка устойчивости сортов яровой пшеницы к корневым гнилям}

Торопова Е.Ю. ${ }^{\text {, }}$ д.б.н., профессор каф. защчиты растений; Сухомлинов В.Ю. ${ }^{1}$ аспирант; Пискарев В.В. ${ }^{2}$, к.с.-х.н., зав. лабораторией генофонда растений. ${ }^{I}$ ФГБОУ ВО Новосибирский государственный аграрнылй университет, Новосибирск, Россия,

${ }^{2}$ Сибирский научно-исследовательский институт растениеводства и селекиии - филиал Федерального исследовательского иентра «Институт ичитологии и генетики Сибирского отделения РАН», п. Краснообск, Россия. e-mail:89139148962@yandex.ru; icelizard@inbox.ru; piskaryov_v@mail.ru

Системная оценка устойчивости растений яровой пшенищы к корневым гнилям включает следуюшие аспекты: оценку поражения растений не менее 2 раз за вегетацию дифферениированно по органам, учет этиологии болезни, определение напряженности инфекиионного фона почвы и влияния на него сорта, учет повреждения растений пшеницы внутристеблевыми фитофагами, провоцирующими усиление патогенеза корневых гнилей.

Ключевые слова: сорт, пшеница, корневая гниль, фитопатоген, ризосфера, фитофаг.

\section{System assessment of spring wheat varieties resistance to root rots}

Toropova E.Yu., Doctor of Biological Sciences, Professor, Department of Plant Protection, Novosibirsk State Agrarian University, Novosibirsk, Russia, 89139148962@yandex.ru;

Sukhomlinov V.Yu., graduate student, Novosibirsk State Agrarian University, Novosibirsk,Russia,icelizard@inbox.ru

Piskarev V.V., Candidate of Agricultural Sciences, Head of the Laboratory of Plant Gene Pool, Siberian Research Institute of Plant Growing and Breeding the branch of the "Federal Research Center the Institution of Cytology and Genetics of the Siberian Branch of the Russian Academy of Sciences", piskaryov_v@mail.ru

A systematic assessment of the spring wheat plants resistance to root rot includes the following aspects: assessment of plant damage at least 2 times per vegetation differentially according to organs, taking into account the etiology of the disease, determining the intensity of the soil infectious background and the influence of the variety on it through the intensity of pathogens sporulation, studying the effect of varieties' root secretions that stimulate the reproduction of antagonists and determine the rhizosphere suppressiveness against root rot pathogens, taking into account damage to wheat plants by intra stem pests provoking 
strengthening the root rot pathogenesis.

Key words: variety, wheat, root rot, plant pathogen, rhizosphere, pest.

Ежегодный недобор урожая яровой пшеницы в России из-за поражения корневыми гнилями оценивается в 30-50 \% при одновременном снижении содержания клейковины и качества муки [1]. Ситуацию осложняет, несмотря на активный поиск, отсутствие устойчивых к корневым гнилям сортов [2-4]. Для повышения эффективности практической селекции яровой пшеницы на устойчивость к корневым гнилям необходимо реализовывать системный подход, предусматривающий анализ болезни, как результат реализации фитопатогенами их фундаментальных экологических ниш и функционирования паразитарной системы «растение - паразит», взаимодействующей с комплексом природных и антропогенных факторов [5]. В ходе практической селекции выявляются значительные колебания пораженности сортов корневыми гнилями, которые требуют анализа и объяснения с позиций фитопатологии и эпифитотиологии.

Результаты оценки пораженности коллекции сортов ВИР (исключая сорта Новосибирская 15, Обская 2, Сибирская 17, Зауралочка) в конце вегетации яровой пшеницы показаны в таблице 1.

Таблица 1 - Развитие корневой гнили сортов яровой пшеницы по годам в конце вегетации, \%

\begin{tabular}{|c|c|c|c|}
\hline \multirow{2}{*}{$\begin{array}{c}\text { № } \\
\Pi / \Pi \\
\end{array}$} & \multirow[t]{2}{*}{ Сорт } & \multicolumn{2}{|c|}{ Индекс развития болезни, \% } \\
\hline & & 2018 & 2019 \\
\hline 1 & Новосибирская 15 & $40,6 \pm 4,12$ & $44,8 \pm 5,26$ \\
\hline 2 & Зауралочка & $33,1 \pm 3,92$ & $35,0 \pm 3,93$ \\
\hline 3 & Quarna & $32,0 \pm 3,65$ & $48,8 \pm 5,96$ \\
\hline 4 & Руслада & $35,6 \pm 4,0$ & $44,8 \pm 5,86$ \\
\hline 5 & ЛТ 3 & $37,2 \pm 4,21$ & $46,1 \pm 4,92$ \\
\hline 6 & Обская 2 & $34,4 \pm 3,65$ & $43,6 \pm 5,03$ \\
\hline 7 & Сибирская 17 & $25,5 \pm 2,96$ & $41,1 \pm 12,1$ \\
\hline 8 & Remus & $36,7 \pm 3,95$ & $38,5 \pm 3,82$ \\
\hline 9 & Тобольская & $34,7 \pm 3,90$ & $40,0 \pm 4,68$ \\
\hline 10 & K65839 & $43,1 \pm 5,02$ & $61,9 \pm 4,36$ \\
\hline 11 & Manu & $29,4 \pm 3,62$ & $55,0 \pm 10,35$ \\
\hline 12 & Тулайковская Надежда & $33,6 \pm 3,45$ & $45,0 \pm 4,89$ \\
\hline & реднее по сортам & $34,7 \pm 4,06$ & $45,4 \pm 7,85$ \\
\hline
\end{tabular}

Данные таблицы свидетельствуют о значительных различиях в уровне пораженности сортов яровой пшеницы корневыми гнилями по годам. Общий рост развития болезни в 2019 году в среднем по сортам составил 10,7 \%, причем самой большой разница по годам была у сортов Сибирская 17 
$(15,6 \%)$, Quarna (16,8 \%), K65839 (18,8 \%) и Manu (25,6 \%). Напротив, у сортов Remus и Зауралочка отклонения развития корневых гнилей были в пределах статистической ошибки.

Для объяснения различий пораженности сортов и объективной оценки наиболее перспективные для дальнейшей селекции форм, нами был проведен анализ динамики корневых гнилей по вегетации. Оказалось, что на фазе полных всходов, когда происходит массовое заражение растений фитопатогенами и корневые гнили наиболее вредоносны, соотношение в пораженности сортов и их органов было совершенно иным (табл. 2).

Таблица 2 - Развитие корневой гнили сортов яровой пшеницы по органам в начале вегетации, \%

\begin{tabular}{|c|c|c|c|c|}
\hline № п/п & Сорт & Корни & $\begin{array}{c}\text { Основание } \\
\text { растения }\end{array}$ & Среднее \\
\hline 1 & Новосибирская 15 & 7,1 & 9,1 & 8,1 \\
\hline 2 & Зауралочка & 14,8 & 17,2 & 16,0 \\
\hline 3 & Quагnа & 21,0 & 15,4 & 18,2 \\
\hline 4 & Руслада & 13,0 & 14,0 & 13,5 \\
\hline 5 & ЛТ 3 & 14,7 & 21,3 & 18,0 \\
\hline 6 & Обская 2 & 25,8 & 30,1 & 28,0 \\
\hline 7 & Сибирская 17 & 10,8 & 28,3 & 19,4 \\
\hline 8 & Rетия & 22,6 & 28,0 & 25,3 \\
\hline 9 & Тобольская & 21,8 & 25,6 & 23,7 \\
\hline 10 & К65839 & 30,1 & 40,1 & 35,1 \\
\hline 11 & Мапи & 7,0 & 7,4 & 7,2 \\
\hline 12 & Тулайковская Надежда & 23,6 & 24,2 & 23,9 \\
\hline & НСР & 3,26 & 4,01 & 4,12 \\
\hline
\end{tabular}

Данные таблицы свидетельствуют, что в начале вегетации разница в пораженности сортов достигла 4,9 раз, тогда как в конце ее - только 1,8 раз. В начале вегетации максимальную устойчивость проявили сорта Новосибирская 15 и Manu, а в конце - Зауралочка и Remus. Обращает на себя внимание различие в пораженности подземных (корни) и околоземных (основание растения) органов некоторых сортов. Так, у сорта Quarna корни были поражены сильнее оснований, а у большинства сортов - наоборот, причем у сорта Сибирская 17, разница по органам достигла 2,8 раз. Эти данные могут иметь несколько объяснений, требующих дополнительных исследований. Так, передача фитопатогенов с семенами сортов обусловливает сильное поражение первичных корней [6]. Основания растений сильнее поражаются корневыми гнилями при их повреждении злаковыми мухами, особенно яровой и шведской ячменной. Анализ поврежденности стеблей сортов яровой пшеницы внутристеблевыми вредителями показал, что различия достигали трех раз и коэффициент корреляции развития корневой гнили оснований 
стеблей и их поврежденности злаковыми мухами составил 0,896 $\pm 0,129$ $(\mathrm{P}<0,01)$. У сорта Сибирская 17 разница в пораженности оснований растений корневыми гнилями по повторностям (делянкам) достигала 4 раз и была обусловлена неравномерным повреждением растений насекомыми. Становится очевидным, что непринятие во внимание наличия и распределения вредителей ведет к ошибочным оценкам сортов в ходе селекции. Следует обратить внимание и на прямую вредоносность злаковых мух, особенно яровой мухи, уничтожающей главный побег растений.

При оценке устойчивости сортов к корневым гнилям следует контролировать инфекционный фон фитопатогенов в почве и учитывать различия в этиологии заболевания по сортам. Колебания естественного инфекционного фона по селекционным участкам может достигать нескольких раз, а гидротермические стрессы в период вегетации могут влиять на пораженность корневыми гнилями разных по засухоустойчивости сортов [7]. Ранее проведенными исследованиями было установлено дифференцированное проявление устойчивости сортов яровой пшеницы к гельминтоспориозной и фузариозной гнилям [4]. Сорта по-разному воздействовали на численность фитопатогенов в ризосферной почве, коэффициент размножения за вегетацию микромицета Bipolaris sorokiniana - возбудителя гельминтоспориозной корневой гнили - колебался по сортам от 1,2 до 4,3, а жизнеспособность конидий в ризосфере сортов отрицательно коррелировала с интенсивностью их размножения на прикорневых листьях.

Благодарности: Исследование выполнено при финансовой поддержке РФФИ в рамках научного проекта № 20-016-00079.

\section{Список литературы}

1. Зональные системы защиты яровой пшеницы от сорняков, болезней и вредителей / Долженко В.И., Власенко Н.Г., Власенко А.Н. [и др.] - Новосибирск. 2014. 124 с.

2. Schroeder K.L., Paulitz T.C. Root Diseases of Wheat and Barley During the Transition from Conventional Tillage to Direct Seeding / K.L. Schroeder, T.C. Paulitz // Plant Disease. 2006. P. 1247-1253.

3. Торопова Е.Ю. Роль сорта в контроле обыкновенной корневой гнили яровой пшеницы / Е.Ю. Торопова, М.С. Соколов / Агрохимия. 2018. № 11. С. 48-59.

4. Торопова Е.Ю. Поиск сортов яровой пшеницы с групповой устойчивостью к фузариозно-гельминтоспориозным корневым гнилям / Е.Ю. Торопова, В.В. Пискарев, В.Ю. Сухомлинов // Агрохимия. 2019. № 11. С. 57-62.

5. Vorobyeva I.G. On the Issue of Ecological Niches of Plant Pathogens in Western Siberia / I.G. Vorobyeva, E.Yu. Toropova // Contemporary Problems of Ecology. 2019. Vol. 12. No. 6. pp. 667-674. Pleiades Publishing, Ltd., 2019.

6. Фитосанитарная диагностика агроэкосистем / В.А. Чулкина, Е.Ю. Торопова, Г.Я. Стецов [и др.] / Учебно-практическое пособие. Барнаул. 2017. 210 с.

7. Toropova E. Yu. Development of Soil-Borne Infections in Spring Wheat and Barley as Influenced by Hydrothermal Stress in the Forest-Steppe Conditions of Western Siberia and the Urals / E. Yu. Toropova, A. P. Glinushkin, M. P. Selyuk, O. A. Kazakova, A. V. Ovsyankina // Russian Agricultural Sciences. 2018. № 44(3). P.241-244. 


\section{Источники скороспелости для селекции овса и ячменя в Северном Зауралье}

Фомина М.Н. ${ }^{*}$, к.с.-х.н., в.н.С.; Иванова Ю.С., к.с.-х.н., н.с.; Пай О.А., н.с.; Брагин Н. А., н.с.; Белоусов С. А., м.н.с.

НИИСХ Северного Зауралья - филиал ФИЦ ТюмНЦ СО РАН, г. Тюмень, РФ. *e-mail: maria_f72@mail.ru

В условиях северной лесостепи Тюменской области в 2015-2019 г2. в коллекиионном питомнике было изучено 202 образиа ярового овса и 172 образиа ярового ячменя различного эколого-географического происхождения. Выявлена их селекционная ценность для регионов Зауралья и Сибири и выделены источники хозяйственно-ценных признаков для создания новых сортов овса и ячменя. В результате изучения коллекции определена группа образиов с коротким периодом вегетации, которые могут быть использованы в селекиии на скороспелость. Для создания скороспельх сортов овса могут быть использованы: Борот, Пенал, Скакор (Ленинградская обл.); Буланый (Московская область); Anak (Швеция); Ехро (Австрия) и другие; ячменя Первочелинник (Оренбургская область), Танай (Новосибирская область). Жулдус (Казахстан) и другие.

Ключевые слова: источники, исходный материал, образеи, скороспелость, селекиия.

\section{Sources of materiality for selection of oat and barley in the Northern Trans-Ural}

Fomina Maria Nikolaevna, Ivanova Julia Semenovna, Pay Olga Alekseevna, Bragin Nikolai Alexandrovich, Belousov Sergey Alexandrovich. Scientific Research Institute of Agriculture for Northern Trans-Ural Region - Branch of Tyumen Scientific Centre SB RAS, Moskowskiy, Tyumen district, Tyumen region, Russia.

In the conditions of the northern forest-steppe of the Tyumen region in 2015-2019. 202 samples of spring oats and 172 samples of spring barley of various ecological and geographical origin were studied in the collection nursery. Their breeding value for the regions of the Trans-Urals and Siberia was revealed and sources of economically valuable traits for creating new varieties of oats and barley were identified. As a result of studying the collection, a group of samples with a short growing season was identified that can be used in breeding for early maturity. To create precocious varieties of oats, the following can be used: Borot, Penal, Skakor (Leningrad Region); Bulany (Moscow region); Anak (Sweden); Expo (Austria) and others; barley - Pervotselinnik (Orenburg region), Tanay (Novosibirsk region). Zhuldus (Kazakhstan) and others.

Key words: sources, source material, sample, precocity, selection. 
Вегетационный период - одно из важнейших биологических свойств любой сельскохозяйственной культуры. Он является показателем пригодности сорта для возделывания в той или иной зоне и определяется как наследственными особенностями сорта, так и совокупностью внешних условий, в которых происходит их развитие $[1,2]$. Продолжительность периода вегетации напрямую связана с урожаем зерна [3], его качеством и посевными свойствами.

Создание скороспелых сортов актуально для большинства сельскохозяйственных зон Российской Федерации $[4,5]$. Вегетационный период у скороспелых образцов значительно короче по сравнению с позднеспелыми, однако они обладают меньшей вегетативной массой и потенциальной продуктивностью метелки [6].

Характерной особенностью погодных условий сибирских регионов (в т.ч. и Северного Зауралья) является короткий безморозный период. В связи с этим в числе первоочередных задач - проблема скороспелости, так как это одно из условий получения гарантированных урожаев [7].

Исследования проводились в 2015-2019 гг. на опытном поле НИИСХ Северного Зауралья - филиал ФИЦ ТюмНЦ СО РАН (северная лесостепь). Почва - серая лесная, тяжелосуглинистая. Для овса предшественник яровая пшеница, для ячменя - чистый пар.

Объектами исследования послужили 202 образца ярового овса и 172 образца ярового ячменя, полученных из ФИЦ «Всероссийский институт генетических ресурсов растений им. Н.И. Вавилова (ВИР). В качестве стандартов использовались сорта, возделываемые в регионе: Талисман (овес), Абалак (ячмень).

Метеорологические условия в северной лесостепи Тюменской области 2015-2019 гг. отличались нестабильностью по обеспеченности растений теплом и влагой.

Погода весенне-летнего периода в 2015 г. характеризовалась значительным выпадением осадков при высоких среднесуточных температурах в мае-июне и низких - в июле-августе $(Г T К=1,46)$. В 2016 г. май был теплым и сухим, июнь - в пределах нормы, жарким, с периодическим выпадение осадков, был июль. Сухой и жаркой погодой характеризовался август. ГТК за май-август составил 0,69 . Погодные условия вегетационного периода в 2017 г. отличались избыточным увлажнением и недостатком тепла в июне и июле. Незначительное количество осадков и высокие среднесуточные температуры в августе обеспечили своевременное созревание хлебов $(Г T К=1,48)$. Период вегетации 2018 года характеризовался как увлажненный $(\Gamma Т К=1,68)$. Сумма активных температур за вегетацию составила $1824^{\circ} \mathrm{C}$ (норма - 1844 $\left.{ }^{\circ} \mathrm{C}\right)$. В 2019 г. май был теплый и увлажненный $(\Gamma T К=1,04)$. Недостаток тепла и избыточное увлажнение отмечалось в июне $(Г Т К=1,74)$. Июль и август были теплыми и влажными (ГТК соответственно 1,81 и 1,51). Сумма активных 
температур за вегетацию составила $-1906^{\circ} \mathrm{C}$.

Оценка коллекционных образцов и фенологические наблюдения проводили согласно общепринятым методикам [7-9].

Статистическая обработка данных по методике полевого опыта [10] с использованием пакета прикладных программ Microsoft Excel и «Snedekor» [11].

Распределение сортов различного эколого-географического происхождения проводилось на основе изменчивости анализируемого признака в зависимости от метеорологических условий в годы исследований. Набор изучаемых коллекционных образцов сильно различался продолжительностью вегетационного периода. В целом за годы исследований период вегетации у образцов овса варьировал от 65 (Illinois 62-1535, США, 2015 г.) до 84 суток (местный, Румыния, 2015 г.); у образцов ячменя - от 63 (Танай, Новосибирская обл., 2018 г.) до 81 суток (Cerbinetta, Германия; Себастьян, Чехия и др., 2017 г.).

В коллекции овса доля среднеранних сортов составила 12,9 \%, среднеспелых $-55,4 \%$, среднепоздних - 32,2\%. В коллекции ячменя среднеранние образцы составили 20,9\%, среднеспелые - 48,3\%, среднепоздние - 30,8 \%.

В результате проведенных исследований выделена группа образцов овса с периодом вегетации 68 - 70 суток (при продолжительности вегетационного периода у стандарта Талисман 75 суток) и ячменя - периодом вегетации 66 - 68 суток (при продолжительности вегетационного периода у стандарта Абалак 70 суток). В качестве источников скороспелости у овса могут быть использованы: Борот, Пенал, Скакор (Ленинградская обл.); Буланый (Московская область); Anak (Швеция); Ехро (Австрия); Neklan (Чехия), Zvolen (Словакия), ряд образцов американского, китайского и австралийского происхождения; у ячменя - Первоцелинник (Оренбургская область), Танай (Новосибирская область). Жулдус (Казахстан) и другие (табл. 1).

Таблица 1 - Источники скороспелости овса и ячменя в условиях Северного Зауралья, 2015-2019 гг.

\begin{tabular}{|c|c|c|c|c|}
\hline \multirow{2}{*}{$\begin{array}{c}\text { № } \\
\text { каталога } \\
\text { ВИР }\end{array}$} & \multirow[b]{2}{*}{ Сорт } & \multirow[b]{2}{*}{ Страна-оригинатор } & \multicolumn{2}{|c|}{ Период вегетации, сут. } \\
\hline & & & Среднее & $\begin{array}{c}\text { Размах } \\
\text { варьирования }\end{array}$ \\
\hline 1 & 2 & 3 & 4 & 5 \\
\hline \multicolumn{5}{|c|}{ Овес яровой } \\
\hline & Талисман (St) & Тюменская обл. & 75 & $74-76$ \\
\hline 14858 & Борот & Ленинградская обл. & 68 & $68-69$ \\
\hline 15313 & Пенал & Ленинградская обл. & 69 & $66-72$ \\
\hline 15312 & Скакор & Ленинградская обл. & 70 & $67-72$ \\
\hline 15277 & Буланый & Московская обл. & 70 & $68-72$ \\
\hline 15237 & Anak & Швеция & 70 & $66-73$ \\
\hline 14936 & Neklan & Чехия & 68 & $67-69$ \\
\hline 15080 & Expo & Австрия & 70 & $69-70$ \\
\hline 15135 & Zvolen & Словакия & 69 & $66-72$ \\
\hline
\end{tabular}




\begin{tabular}{|c|c|c|c|c|}
\hline 1 & 2 & 3 & 4 & 5 \\
\hline 15307 & Ajay & США & 68 & $67-69$ \\
\hline 15306 & Y 201-150-8-19 & США & 68 & $67-69$ \\
\hline 15267 & INO 9201 & США & 68 & $67-68$ \\
\hline 15265 & SD 790400 & США & 69 & $68-69$ \\
\hline 15256 & PA 7836-61 & США & 70 & $67-72$ \\
\hline 15258 & PA 7836-2701 & США & 68 & $66-70$ \\
\hline 15090 & MF 9224-164 (г) & США & 70 & $67-73$ \\
\hline 15089 & MF 9224-106 (г) & США & 70 & $67-73$ \\
\hline 15228 & MF 9714-35 & США & 69 & $66-72$ \\
\hline 15033 & PI 244467 & Бразилия & 69 & $68-69$ \\
\hline 14922 & Y 5 & Китай & 69 & $66-73$ \\
\hline 14851 & Numbat & Австралия & 69 & $66-72$ \\
\hline \multicolumn{5}{|c|}{ Ячмень яровой } \\
\hline & Абалак (St) & Тюменская обл. & 70 & $67-74$ \\
\hline 31272 & ДЛ А-14 & Ленинградская обл. & 68 & $67-71$ \\
\hline 30977 & Омский 96 & Омская обл. & 67 & 64-68 \\
\hline \multirow[t]{3}{*}{30895} & Первоцелинник & Оренбургская обл. & 67 & $66-72$ \\
\hline & Танай & Новосибирская обл. & 67 & $63-69$ \\
\hline & Жулдус & Казахстан & 66 & 64-69 \\
\hline 30916 & Pasadena & Германия & 68 & $65-72$ \\
\hline 30943 & Amulet & Чехия & 66 & $64-69$ \\
\hline
\end{tabular}

Большая часть раннеспелых образцов уступала по урожайности стандартным сортам. Особый интерес представляли номера, сочетающие короткий период вегетации с высокой продуктивностью. Выделена группа сортов овса, созревающих на 4-7 суток раньше стандарта (Талисман) и превышающих его по урожайности на 3,8-15,6 \%. Это: Камбулинский (Ленинградская область); КСИ 466/01 (Ульяновская обасть): Новосибирский 2 (Новосибирская область), Vendelin (Словакия) и другие (табл. 2).

Таблица 2 - Источники высокой продуктивности овса с коротким периодом вегетации в условиях Северного Зауралья, 2015-2019 гг.

\begin{tabular}{|c|c|c|c|c|c|c|}
\hline \multirow{2}{*}{$\begin{array}{c}\text { № } \\
\text { каталога } \\
\text { ВИР }\end{array}$} & \multirow[t]{2}{*}{ Сорт } & \multirow{2}{*}{ Страна-оригинатор } & \multicolumn{2}{|c|}{$\begin{array}{c}\text { Период веге- } \\
\text { тации, сут. }\end{array}$} & \multicolumn{2}{|c|}{$\begin{array}{c}\text { Урожайность, } \\
\Gamma / \mathrm{M}^{2}\end{array}$} \\
\hline & & & $\ddot{x}$ & $\mathrm{R}$ & $\ddot{\mathrm{x}}$ & $\mathrm{R}$ \\
\hline & Талисман (St) & Тюменская обл. & 75 & $74-76$ & 470,4 & $409,7-572,0$ \\
\hline 13911 & Камбулинский & Ленинградская обл, & 71 & $69-73$ & 497,0 & $450,0-544,0$ \\
\hline 15319 & Нарпс & Лениградская обл. & 70 & $69-72$ & 488,5 & $445,0-532,0$ \\
\hline 15328 & КСИ 466/01 & Ульяновская обл. & 70 & $68-72$ & 520,5 & $465,0-576,0$ \\
\hline & Новосиборский 2 & Новосибирская обл. & 69 & $68-71$ & 492,6 & $395,0-578,7$ \\
\hline 15191 & Vendelin & Словакия & 68 & $66-71$ & 496,5 & $465,0-528,0$ \\
\hline 14971 & Illinois $62-1535$ & США & 69 & $65-73$ & 478,3 & $436,0-510,0$ \\
\hline 15261 & PA 7836-9938 & США & 68 & $67-69$ & 544,0 & $528,0-560,0$ \\
\hline 14842 & Wandering & Австралия & 71 & $68-73$ & 531,1 & $475,3-570,0$ \\
\hline
\end{tabular}


Среди коллекционных образцов ячменя большой интерес в этом плане представляли: Тандем (Кировская область), Зенит (Тюменская область), Ача (Новосибирская область) (табл. 3).

Таблица 3 - Высокопродуктивные источники скороспелости ячменя ярового в зоне северной лесостепи Тюменской области, 2016-2019 г.

\begin{tabular}{|c|c|c|c|}
\hline Сорт & Происхождение & $\begin{array}{c}\text { Период вегета- } \\
\text { ции, сутки }\end{array}$ & $\begin{array}{c}\text { Урожайность, } \\
\Gamma / \mathrm{M}^{2} \\
\end{array}$ \\
\hline Абалак (St) & Тюменская область & 70 & 626,0 \\
\hline Тандем & Кировская область & 68 & 679,0 \\
\hline Зенит & Тюменская область & 67 & 628,0 \\
\hline Ача & Новосибирская область & 68 & 623,0 \\
\hline
\end{tabular}

В результате проведенных исследований выделены перспективные источники для создания скороспелых сортов овса и ячменя в Северном Зауралье.

\section{Список литературы}

1. Вавилов Н.И. Значение межвидовой и межродовой гибридизации в селекции и эволюции / Н.И. Вавилов // Избр. тр. - М.; Л., 1960. - Т.2. - С. 444-460.

2. Вавилов Н.И. Избранные сочинения. Генетика и селекция / Н.И. Вавилов. - М.: Колос, 1966. - с. 559.

3. Боме А.Я. Изменчивости вегетационного периода и некоторых элементов продуктивности у коллекционных образцов Avena L. в различных условиях среды / Боме А.Я., Лоскутов И.Г., Боме Н.А. // Тр. по прикл. бот., ген. и сел. / Всерос. науч.-ислед. ин-т растениеводства им. Вавилова. - Санкт-Петербург, 2009. - Т.166. - С. 493-498.

4. Сартакова С.В. Испытание коллекции овса в Кемеровской области / С.В. Сартакова, Н.Н. Чуманова, В.Н. Солдатов // Тр. по прикл. бот., ген. и сел. - СПб.: ВИР, 2006. - T. 162. - C. 119-123.

5. Батакова О.Б. Некоторые итоги по изучению длины вегетационного периода в условиях Архангельской области / О.Б. Батакова // Тр. по прикл. бот., ген. и сел. СПб.: ВИР, 2009. Т. 165. - С. 169-173.

6. Смирнова, Л.О. Генетическое разнообразие овса по фотопериодической чувствительности и скороспелости: авореф. дис. канд. биол. наук / Л.О. Смирнова. - С.Петербург, 2011. - 13 с.

7. Заушинцена А.В. Генетические источники для реализации основных направлений селекции ячменя в Сибири / А.В. Заушинцина // Труды по прикл. бот., ген. и сел. СПб.: ВИР, 2011. -Т. 168. - С. 101-104.

8. Методические указания по изучению мировой коллекции ячменя и овса. - Л., 1981. - c. 32 .

9. Методические указания по изучению и сохранению мировой коллекции ячменя и овса. - С-Петербург, 2012. - с. 63.

10. Методика государственного сортоиспытания сельскохозяйственных культур. - М.: Наука, 1989. - с. 194.

11. Доспехов Б.А. Методика полевого опыта. - М.: Колос - 1985. - 381 с.

12. Сорокин О.Д. Прикладная статистика на компьютере / О.Д. Сорокин. - Новосибирск, 2004. - 162 с. 


\section{Устойчивость образцов яровой твердой пшеницы КАСИБ к возбудителю желтой ржавчины}

Шайдаюк Е.Л. *, м.н.с.; Гультяева Е.И., д.б.н., в.н.с. Всероссийский НИИ защиты растений, Санкт-Петербург, Россия. *e-mail: eshaydayuk@bk.ru

Изучена проростковая устойчивость к возбудителю желтой ржавчины у 25 образиов яровой твердой пшеницы, полученных из КазахстанскоСибирской сети улучшения яровой пшенищы (КАСИБ). Выделены образиы устойчивые к популяциям возбудителя желтой ржавчины широкого географического происхождения.

Ключевые слова: Pиссіпіа striiformis, Triticum durum, устойчивость, Yr-гены.

\section{Resistance of common spring wheat samples to yelow rust}

Shaydayuk Ekaterina L'vovna, Gultyaeva Elena Ivanovna, All-Russian Institute of Plant Protection, Saint-Petersburg, Russia eshaydayuk@bk.ru

Resistance to yellow rust causative agent was studied in 25 samples of spring durum wheat obtained from the Kazakhstan-Siberian Network for Wheat Improvement (KASIB) at the seedling stage. Samples resistant to geographically distant yellow rust populations have been revealed.

Key words: Puccinia striiformis, Triticum durum, resistance, Yr-genes.

Желтая ржавчина (возбудитель Puccinia striiformis Westend. f. sp. tritici) относится к группе потенциально опасных болезней пшеницы в России. До 2000-х годов она представляла значимость только в предгорных районах Северного Кавказа. В современный период зоны распространения заболевания существенно расширились. Практически ежегодно заболевание отмечается в посевах озимой пшеницы в Северо-Кавказском регионе [1] и периодически в центрально-европейской части и на Северо-Западе России [2]. В 2018-2019 гг. желтая ржавчина встречалась на посевах яровой мягкой и твердой пшеницы в Омской области, а в 2019 году была отмечена в Новосибирской (устное сообщение Пискарев В.В., СибНИИРС - филиал ИЦиГ CO РAH).

Проявляется заболевание в виде лимонно-желтых урединиопустул, расположенных вдоль жилок листа. При сильном развитии болезни могут быть поражены колосковые чешуи. Данный вид ржавчины считается более вредоносным, по сравнению с бурой и стеблевой. В связи с этим, в совре- 
менный период ей уделяется особое внимание во всем мире. Высокая миграционная способность $P$. striiformis обуславливает распространение спор на длительные расстояния [3]. Justesen с соавторами [4] доказали возможность миграции спор патогена по всей территории Западной Европы. Аналогичные сведения получены для других регионов мира (США, Китай Северная и Южная Африка).

Возбудитель желтой ржавчины в современный период успешно адаптировался к высоким температурам, в связи с чем, ареал ее существенно расширился. У новых рас отмечено сокращение латентного периода, повышенная спорообразующая способность и агрессивность, по сравнению с расами P. striiformis, отмечаемыми до 2000 годов [5].

Высокий эволюционный потенциал возбудителя желтой ржавчины предопределяет проведение опережающей селекции на устойчивость к данному патогену. Целью работы являлась оценка ювенильной устойчивости линий яровой твердой пшеницы КАСИБ-2019 к популяциям P. striiformis широкого географического происхождения.

Материалом исследований служили 25 образцов яровой твердой пшеницы, переданных из Казахстанско-Сибирской сети улучшения яровой пшеницы (КАСИБ) в 2019 году. Для инокуляции использовали 12-14 дневные растения, которые опрыскивали водной суспензией урединиоспор с добавлением детергента Твин-80. Для инокуляции использовали географически отдаленные популяции P. striiformis, которые были получены с мягкой пшеницы в Северо-Кавказском (Краснодарский край) (СК), Западно-Сибирском (Новосибирская обл.) (ЗС) и Северо-Западном (Ленинградская обл.) (СЗ) регионах. В Ленинградской области листья с урединиопустулами были также собраны и на твердой пшенице. Все популяции были размножены в лабораторных условиях и охарактеризованы по вирулентности к линиям Avocet c генами устойчивости к желтой ржавчине $(\mathrm{Yr})$. Концентрация спор в суспензии составляла $1 \times 10^{6}$ спор/мл. После инокуляции растения плотно закрывали полиэтиленовым каркасом для создания влажной камеры и переносили в камеру искусственного климата Versatille Environmental Test Chamber MLR352H («SANYO Electric Co., Ltd.», Япония), где выдерживали в темноте при температуре $10{ }^{\circ} \mathrm{C}$ в течение 16 часов. Далее каркасы снимали, и растения инкубировали на свету в течение 16 часов при температуре $16^{\circ} \mathrm{C}$ и влажности $70 \%$, и затем в течение 8 часов в темноте при температуре $10{ }^{\circ} \mathrm{C}$ и влажности $75 \%$. Учет типа реакции проводили на 18-20 день после заражения с использованием шкалы McNeal с соавторами (1971) [6], где 0 - отсутствие симптомов; 1 - некротические следы; 2 - некротические пятна без урединиопустул; 3-4 - слабо спорулирующие урединиопустулы, окруженные некрозами и хлорозами; 5-6 - умеренно спорулирующие урединиопустулы с зоной хлороза и некроза; 7-8 - спорулирующие урединиопустулы с хлорозом; 9 - обильно спорулирующие пустулы без хлороза. Растения с баллами 
0-6 относили к устойчивым, с баллами 7-9 к восприимчивым [7].

С использованием молекулярных маркеров провели идентификацию генов $\quad Y r 9$ (SCM9), $\quad \operatorname{Yr} 17$ (маркер Ventriup/LN2) и $\quad Y r 18$ (csLV34) (https://maswheat.ucdavis.edu).

При инокуляции популяциями широкого географического происхождения устойчивость (тип реакции от 0 до 6 балла) ко всем из них выявлена у шести (24 \%) образцов твердой пшеницы: Р-1409, Сояна, Сеймур 17, Гордеиформе 1790, Гордеиформе 910 и Линия Д-2165 (таблица). Семь образцов $(28 \%)$ показали устойчивость ко всем популяциям с мягкой пшеницы (СК, 3С, С3), но были восприимчивы к ленинградской популяции с твердой пшеницы. К ним относились сорта Янтарная 60, Серке, Меляна, Безенчукская 139 и линии 69-08-2, Гордеиформе 895, Гордеиформе 924. Сорта Гордея, Целинная и линия 2021д-1 были устойчивы к краснодарской и новосибирской популяциям P. striiformis и восприимчивы к северо-западным с твердой и мягкой пшеницы.

Выявлены различия в типе реакции при инокуляции образцов твердой пшеницы популяциями патогена с твердой и мягкой пшеницы. Инокулюм с твердой пшеницы был более вирулентным для твердой пшеницы, чем с мягкой. Только пять образцов твердой пшеницы (20\%) показали умеренно устойчивый тип реакции (балл 5-6) при инокуляции ленинградской популяцией с твердой пшеницы. При заражении ленинградской популяцией патогена с мягкой пшеницы количество устойчивых было существенно выше (13 образцов, $52 \%)$.

Таблица - Устойчивость образцов яровой твердой пшеницы к возбудителю желтой ржавчины в фазе проростков

\begin{tabular}{|c|c|c|c|c|c|c|}
\hline \multirow{2}{*}{$\begin{array}{l}\text { № } \\
\text { п/п }\end{array}$} & \multirow{2}{*}{$\begin{array}{l}\text { Название } \\
\text { сорта/линии }\end{array}$} & \multirow{2}{*}{ Оригинатор } & \multicolumn{4}{|c|}{$\begin{array}{c}\text { Тип реакции к популяциям } \\
\text { P. striiformis в фазе проростков }\end{array}$} \\
\hline & & & СК & $3 \mathrm{C}$ & $\begin{array}{c}\mathrm{C} 3 \mathrm{c} \\
\text { T.aestivum } \\
\end{array}$ & $\begin{array}{c}\mathrm{C} 3 \mathrm{c} \\
\text { T.durum }\end{array}$ \\
\hline 1 & 2 & 3 & 4 & 5 & 6 & 7 \\
\hline 1 & P-1409 & $\begin{array}{l}\text { Актюбинская } \\
\text { СХОС }\end{array}$ & $1-2$ & 0 & 0 & 5 \\
\hline 2 & Сояна & - & $0-1$ & 0 & 0 & $5-6$ \\
\hline 3 & Янтарная 60 & - & 1 & 0 & 0 & 8 \\
\hline 4 & Сеймур 17 & КазНИИЗиР & 5 & 0 & $5-6$ & 6 \\
\hline 5 & Серке & - & 5 & 0 & $0-1$ & $6-7$ \\
\hline 6 & Линия 69-08-2 & $\begin{array}{l}\text { НПЦЗХ им. } \\
\text { А.И.Бараева }\end{array}$ & 2 & 0 & 0 & $6-7$ \\
\hline 7 & Линия 250-06-14 & - & $6-7$ & $7-8$ & $6-7$ & 7 \\
\hline 8 & Костанайская 15 & $\begin{array}{c}\text { Карабалыкская } \\
\text { СХОС }\end{array}$ & $6-7$ & 7 & 7 & 7 \\
\hline 9 & Гордеиформе 1790 & - & 1 & 0 & 0 & 5 \\
\hline 10 & Линия №9 & - & $6-7$ & $7-8$ & 7 & $6-7$ \\
\hline
\end{tabular}




\begin{tabular}{|c|l|c|c|c|c|c|}
\hline $\mathbf{1}$ & \multicolumn{1}{|c|}{$\mathbf{3}$} & $\mathbf{4}$ & $\mathbf{5}$ & $\mathbf{6}$ & $\mathbf{7}$ \\
\hline 11 & Гордеиформе 895 & $\begin{array}{c}\text { Алтайский } \\
\text { НИИСХ }\end{array}$ & 1 & 0 & 0 & $6-7$ \\
\hline 12 & Гордеиформе 910 & - & 0 & 0 & 0 & $5-6$ \\
\hline 13 & Гордеиформе 924 & - & 0 & 0 & 0 & $7-8$ \\
\hline 14 & Гордеиформе 08-25-2 & СибНИИСХ & $6-7$ & 7 & 7 & 7 \\
\hline 15 & Гордеиформе 08-67-1 & - & 7 & $6-7$ & 7 & 7 \\
\hline 16 & Гордеиформе 08-107-5 & - & 8 & $6-7$ & 7 & 7 \\
\hline 17 & Линия 1693д-71 & $\begin{array}{c}\text { Самарский } \\
\text { НИИСХ }\end{array}$ & $6-7$ & $6-7$ & 7 & 7 \\
\hline 18 & Линия 1970д-5 & - & 7 & $7-8$ & 7 & 7 \\
\hline 19 & Линия 2021д-1 & - & 3 & $1-2$ & 7 & $6-7$ \\
\hline 20 & Гордеиформе 1591-21 & - & 7 & $6-7$ & 7 & $7-8$ \\
\hline 21 & Линия Д-2165 & $\begin{array}{c}\text { НИИСХ Юго- } \\
\text { Востока }\end{array}$ & 4 & 0 & $1-2$ & $5-6$ \\
\hline 22 & Гордея & Оренбургский & 3 & $1-2$ & 7 & 7 \\
\hline 23 & Целинная & - & $3-4$ & 0 & 7 & 7 \\
\hline 24 & Меляна & - & 3 & 0 & 0 & 7 \\
\hline 25 & Безенчукская 139 & Стандарт & 5 & 0 & 0 & $6-7$ \\
\hline
\end{tabular}

С использованием молекулярных маркеров у изучаемых образцов твердой пшеницы не выявлено генов $\operatorname{Yr} 9$, $\operatorname{Yr} 17$ и $\operatorname{Yr} 18$. Полученные данные молекулярного тестирования согласуются с фитопатологическим тестом. Используемые в данной работе популяции были вирулентны к линиям с генами $\operatorname{Yr} 9$ и $\operatorname{Yr} 18$ и авирулентны к $\operatorname{Yr} 17$ (тип реакции 0).

Варьирование типа реакции у образцов твердой пшеницы к используемым популяциям возбудителя желтой ржавчины указывает на расоспецифический тип их устойчивости, а также различия патогена по вирулентности в географически отдаленных регионах (Западной Сибири, Северном Кавказе и Северо-Западе). Полученные сведения следует учитывать в селекции на устойчивость твердой пшеницы к болезням.

19-76-30005.

Благодарности: Работа выполнена при поддержке проекта РНФ №

\section{Список литературы}

1. Волкова Г.В. Желтая ржавчина пшеницы на Кубани / Г.В. Волкова, Л.Н. Шуляковская, О.А. Кудинова, И.П.Матвеева // Защита и карантин растений. 2018. - №4. - С.22.

2. Гультяева Е.И. Болезни зерновых культур и рапса в Северо-западном регионе в 2016 г / Е.И. Гультяева, Е.Л. Гасич, М.М. Левитин, И.В. Маслова, О.А. Колесникова, М.П. Вусатюк, Е.Л. Шайдаюк, М.М. Гомжина, Н.П. Шипилова / Защита и карантин растений. - 2017. - №4. - С. 27-29.

3. Chen, W. Wheat stripe (yellow) rust caused by Puccinia striiformis f. sp. tritici / W.Chen, C. Wellings, X. Chen, Z. Kang, T. Liu / Molecular Plant Pathology. - 2014. - V. 
15(5). - P. 433-446. DOI: 10.1111/mpp.12116.

4. Justesen, A.F. The recent history of Puccinia striiformis f. sp. tritici in Denmark as revealed by disease incidence and AFLP markers / A.F. Justesen, C.J. Ridout, M.S. Hovmøller // Plant Pathology. - 2002. - V. 51. - P. 13-23.

5. Milus, E.A. Evidence for increased aggressiveness in a recent widespread strain of Puccinia striiformis f. sp. tritici causing stripe rust of wheat / E.A. Milus, K. Kristensen, , \& M.S. Hovmøller / Phytopathology. - 2009. - V. 99(1). - P. 89-94. DOI: 10.1094/PHYTO-99-1-0089).

6. McNeal F. H. A uniform system for recording and processing cereal research data / F. H. McNeal, C. F Konzak, E. P. Smith, W. S. Tate, T. S. Russell / U.S. Dept. Agric., Agric. Res. Serv, 1971. - ARS 34-121. - 42 pp.

7. McIntosh, R.A. Catalogue of gene symbols for wheat: 2005 supplement R.A. McIntosh1, K.M. Devos2, J. Dubcovsky3, W.J. Rogers4, C.F. Morris5, R. Appels6, and O.D. Anderson. - 2005. Режим доступа:

https://shigen.nig.ac.jp/wheat/komugi/genes/macgene/supplement2005.pdf

DOI 10.18699/GPB2020-73

\section{Создание исходного материала для селекции в Омском ГАУ с использованием синтетической пшеницы}

Шаманин В.П. ${ }^{{ }^{*}}$, д.с.-х.н., профессор; Потоикая И.В. ${ }^{l}$, к.с.-х.н., доиент; Шепелев С.С. ${ }^{1}$, к.с.-х.н., зав. лаб.; Чурсин А.С. ${ }^{1}$, зав. лаб.; Пожерукова В.Е. к.б.н., н.с.; Гладких М.С. ${ }^{1}$, к.с.-х.н., н.с., Моргунов А.И. ${ }^{2}$ к.с.-х.н., адьюнктпреподаватель.

${ }^{1}$ ФГБОУ ВО Омский ГАУ, Омск, Россия,

${ }^{2}$ Университет штата Вашингтон, Пулман, США.

*e-mail:vp.shamanin@omgau.org

Проведена фенотипическая оценка исходного материала яровой мягкой пшеницы, полученного на основе гексаплоидной синтетической пиеницы с геномом Aegilops tauschii селекции CIMMYT в условиях южной лесостепи Западной Сибири. Показана селекционная ценность линий с генетическим материалом синтетической пшеницы для повышения урожайности и качества зерна сортов пиеницы.

Ключевые слова: синтетическая пшеница, признаки продуктивности растения, качество зерна, КАSP-маркеры.

\section{Creation of initial material for breeding in Omsk SAU on the basis of synthetic wheat}

Shamanin Vladimir Petrovich ${ }^{1}$, Pototskaya Inna Vladimirovna ${ }^{l}$, Shepelev Sergey Sergeevich $^{l}$, Chursin Aleksandr Sergeevich ${ }^{l}$, Pozherukova Violetta Evgenievna ${ }^{l}$, Gladkih Marina Sergeevna ${ }^{l}$, Morgunov Alexey Ivanovich ${ }^{2}$ 
${ }^{1}$ Omsk State Agrarian University, Omsk, Russia,

${ }^{2}$ Washington State University, Pullman, USA.

A phenotypic and genotypic assessments of the initial material of spring bread wheat obtained on the basis of hexaploid synthetic wheat with the genome of Aegilops tauschii from CIMMYT under conditions of the southern forest-steppe of Western Siberia were carried out. The breeding value of lines with the genetic material of synthetic wheat for increasing of wheat varieties yield and grain quality was shown.

Key words: synthetic wheat, traits of plant productivity, grain quality, KASP-markers.

Первые попытки интродукции генетического материала в геном мягкой пшеницы от диких сородичей были предприняты в 1940-х гг. в Японии и США [7, 8]. Вид Ae. tauschii широко используется в селекционных программах мягкой пшеницы во многих странах мира для расширения генотипического потенциала сортов пшеницы по устойчивости к биотическим и абиотическим стрессовым факторам. В 1980-х гг. в СІММҮТ стартовал проект по созданию синтетической пшеницы с геномом Ae. tauschii и к настоящему моменту получено более 1524 синтетических форм, которые вовлечены в гибридизацию с коммерческими сортами пшеницы, и имеют большую селекционную ценность как генетический ресурс новых аллелей генов [5]. В Омском ГАУ, начиная с 2016 г. в рамках реализации проекта РНФ, ведется работа по изучению набора 124 синтетических линий с геномом $A e$. tauschii селекции CIMМYТ и университета Киото $[1,2,6]$.

Цель исследований - фенотипирование и генотипирование линий, полученных на основе синтетической пшеницы, в условиях южной лесостепи Западной Сибири.

Материал и методы исследований. На опытном поле Омского ГАУ в 2016-2018 гг. изучены 124 синтетические линии селекции СІММҮТ и университета Киото (Япония), созданные в результате гибридизации сортов твердой пшеницы с образцами Ae. tauschii различного эколого-географического происхождения (Иран, Дагестан, Азербайджан, Туркменистан, Кыргызстан, Индия).

В 2019 г. в СП-1 изучено 147 линий $\mathrm{F}_{4}$, полученных методом индивидуального отбора из гибридных популяций от скрещивания сортов пшеницы с синтетическими линиями селекции СІММҮТ. Посев питомника СП-1 проводили вручную рендомизированными блоками с группой стандартов Памяти Азиева, Дуэт, Элемент 22 в 3-х кратной повторности. Генотипирование синтетиков и линий яровой пшеницы осуществляли в «LGC Genomics (Beликобритания) с использованием 42 KASP-маркеров, в том числе 12 маркеров, сцепленных с генами, контролирующими размер и массу зерновки. 
Результаты. По результатам фенотипирования 2016-2018 гг. синтетических линий по комплексу хозяйственно-ценных признаков сформированы 2 набора линий: яровые синтетические формы - 48 линий и озимые 14 линий. Отбор селекционного материала с помощью КАSP-маркеров позволяет повысить точность отбора нужных генотипов и открывает новые возможности в маркер-ориентированной селекции для экономии времени и средств на создание новых сортов [3, 4].

Фенотипирование и генотипирование синтетических линий, а также полученного на их основе исходного материала, осуществлялось в соответствии, с указанной ниже схемой (рисунок). В 2016 г. проведены рекогносцировочные скрещивания яровых синтетических линий с реестровыми сортами Памяти Азиева и ОмГАУ 90, получено более 30 гибридных популяций, из которых путем индивидуального отбора выделено 207 линий, изученных в СП-1. Данные линии в 2018 г. были генотипированы с использованием 42 KASP-маркеров в лаборатории LGC-genomics.

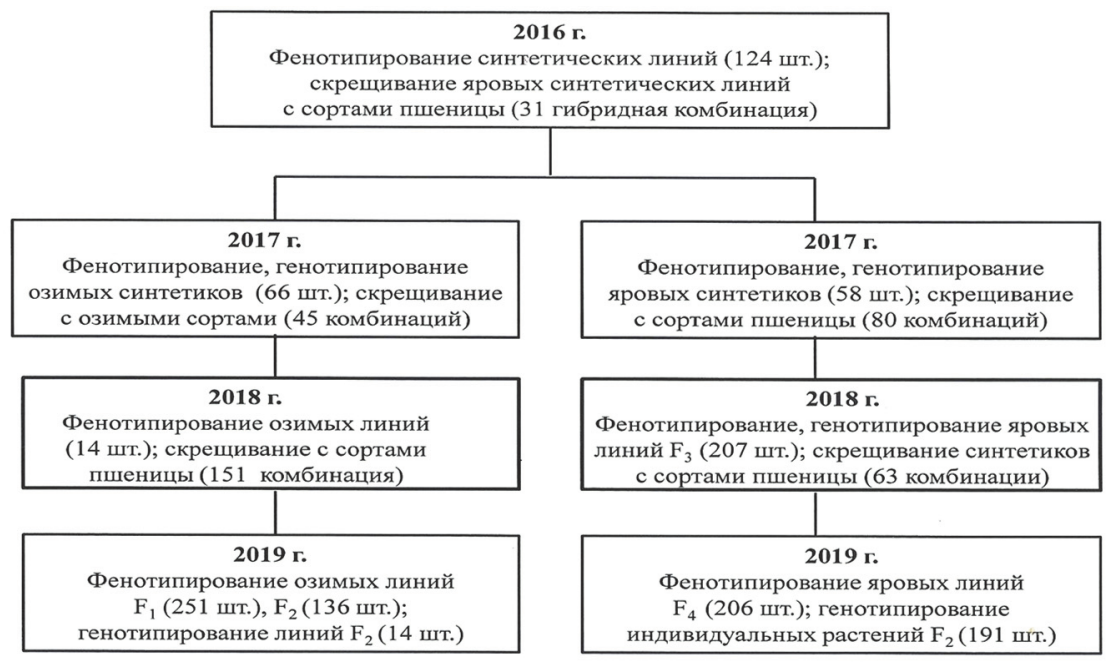

Рисунок. Скрещивания синтетических линий с сортами пшеницы, движение гибридных популяций в селекционном процессе, генотипирование селекционных линий.

В 2019 г. в питомнике СП-1 изучено 147 линий $\mathrm{F}_{4}$, полученных от скрещивания синтетической пшеницы селекции СІММYТ с реестровыми сортами яровой пшеницы Памяти Азиева и ОмГАУ 90 (таблица). Отдельные гибридные комбинации представляют интерес в качестве исходного материала в селекции на повышение урожайности, в частности, Aisberg/ Ae.sq.(369) // ОмГАУ 90, Ukr-Od.1530.94 / Ae.sq.(1027) // Памяти Азиева. 
Выделены линии данных комбинаций по основным компонентам продуктивности растений: числу колосков главного колоса - №9-4 UkrOd.1530.94 / Ae.sq.(1027) // Памяти Азиева (21,5 шт.); числу зерен главного колоса - №9-4 Ukr-Od.1530.94 / Ae.sq.(1027) // Памяти Азиева (56,1 шт.); числу зерен с растения №1-20 Ukr-Od.1530.94 / Ae.sq.(310) // ОмГАУ 90 (84,1 шт.); массе главного колоса - №9-4 Ukr-Od.1530.94 / Ae.sq.(1027) // Памяти Азиева (3,31 г); массе зерна растения - №8-23 Aisberg/ Ae.sq.(369) // ОмГАУ 90 (2,77 г); продуктивности растений - №8-31 Aisberg/ Ae.sq.(369) // ОмГАУ 90 (77,6 г/п.м), №8-34 Aisberg/ Ae.sq.(369) // ОмГАУ 90 (73,1 г/п.м), №9-1 Ukr-Od.1530.94 / Ae.sq.(1027) // Памяти Азиева (74,6 г/п.м).

Таблица - Линии яровой мягкой пшеницы, созданные с участием синтетических форм, СП-1, 2019 г. (в среднем на гибридную комбинацию)

\begin{tabular}{|c|c|c|c|c|c|c|c|}
\hline $\begin{array}{c}\text { № } \\
\Pi / \Pi\end{array}$ & 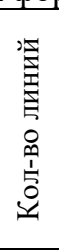 & Гибридная комбинация & 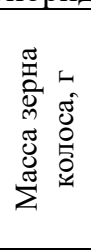 & 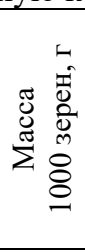 & 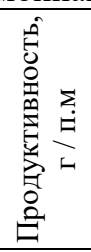 & $\begin{array}{l}d^{0} \\
\text { aे } \\
0 \\
5 \\
0\end{array}$ & 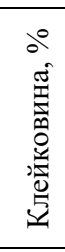 \\
\hline \multicolumn{3}{|c|}{ Памяти Азиева, среднеранний стандарт } & 1,23 & 31,4 & 31,5 & 15,3 & 27,9 \\
\hline \multicolumn{3}{|c|}{ Дуэт, среднеспелый стандарт } & 0,99 & 24,1 & 29,2 & 15,6 & 28,0 \\
\hline \multicolumn{3}{|c|}{ Элемент 22, среднепоздний стандарт } & 2,37 & 37,7 & $\mathbf{5 1 , 5}$ & 17,2 & $\mathbf{3 3 , 9}$ \\
\hline \multicolumn{3}{|c|}{ ОмГАУ 90} & 1,47 & 27,7 & 31,8 & 14,9 & 25,9 \\
\hline 1 & & $\begin{array}{l}\text { Ukr-Od.1530.94 / Ae.sq.(310) // } \\
\text { ОмГАУ } 90\end{array}$ & 1,49 & 29,5 & 33,2 & 15,6 & 28,2 \\
\hline 2 & & $\begin{array}{l}\text { Ukr-Od.1530.94 /Ae.sq.(392) // } \\
\text { ОмГАУ } 90\end{array}$ & 1,51 & 34,1 & 35,2 & 16,3 & 30,1 \\
\hline 3 & & $\begin{array}{l}\text { Aisberg/ Ae.sq.(511)// } \\
\text { Памяти Азиева }\end{array}$ & 1,22 & 33,3 & 29,8 & 15,0 & 27,8 \\
\hline 4 & 5 & Aisberg / Ae.sq.(511) // ОмГАУ 90 & 1,24 & 35,5 & 31,3 & 17,0 & 30,8 \\
\hline 5 & & Aisberg/Ae.sq.(369) // ОмГАУ 90 & 2,02 & 36,8 & 55,1 & 16,9 & 32,4 \\
\hline 6 & 19 & $\begin{array}{l}\text { Ukr-Od.1530.94 / } \\
\text { Ae.sq.(1027)// ОмГАУ } 90\end{array}$ & 1,52 & 33,1 & 36,5 & 16,4 & 30,8 \\
\hline 7 & 5 & Pandur / Ae.sq.(223) // ОмГАУ 90 & 1,51 & 34,7 & 39,1 & 16,4 & 30,3 \\
\hline 8 & 18 & $\begin{array}{l}\text { Ukr-Od.1530.94 / } \\
\text { Ae.sq. (1027) // Памяти Азиева }\end{array}$ & 1,71 & 35,7 & 42,4 & 16,1 & 30,9 \\
\hline 9 & 10 & $\begin{array}{l}\text { Ukr-Od.1530.94 / } \\
\text { Ae.sq.(458) // Памяти Азиева }\end{array}$ & 1,52 & 37,9 & 40,0 & 16,7 & 32,5 \\
\hline 10 & 10 & $\begin{array}{l}\text { Ukr-Od.1530.94 / } \\
\text { Ae.sq.(458) // ОмГАУ } 90\end{array}$ & 1,27 & 33,2 & 33,1 & 16,8 & 32,3 \\
\hline 11 & 10 & $\begin{array}{l}\text { Pandur / Ae.sq.(409) // } \\
\text { Памяти Азиева }\end{array}$ & 1,12 & 32,2 & 29,2 & 15,9 & 29,9 \\
\hline 12 & 9 & Pandur / Ae.sq.(409) // ОмГАУ 90 & 0,89 & 32,4 & 25,0 & 14,9 & 27,5 \\
\hline 13 & & $\begin{array}{l}\text { Aisberg / Ae.sq.(369) // Demir /3/ } \\
\text { ОмГАУ } 90\end{array}$ & 1,47 & 37,6 & 37,5 & 16,2 & 30,9 \\
\hline
\end{tabular}


Данные линии существенно превышали по продуктивности стандарт Элемент 22 (51,5 г/п.м). Линии, полученные путем гибридизации с синтетической пшеницей, имеют большое селекционное значение как источники для улучшения качества зерна яровой пшеницы. По содержанию белка и клейковины в зерне выделены линии гибридных комбинаций Ukr-Od.1530.94 / Ae.sq.(458) // Памяти Азиева - 16,7 и 32,5\% соответственно, №13-6 UkrOd.1530.94 / Ae.sq.(458) // ОмГАУ 90 - 16,8 и 32,3\%.

Для ускорения селекционного процесса и повышения эффективности отбора нужных генотипов линии, полученные на основе синтетической пшеницы, генотипированы с использованием 42 KASP-маркеров. Например, ген $T a G S-D 1$, контролирующий размер и массу зерновки, был идентифицирован у 74,4\% синтетических линий СІММYТ и 88,9 \% линий японских синтетиков, доля сортов-носителей данного гена из России и Казахстана в питомнике ОмонГАИ составила 34,7 \%. У линий $\mathrm{F}_{4}$ №8-23, №8-31, №8-34 гибридной комбинации Aisberg/ Ae.sq.(369) // ОмГАУ 90, выделенных по продуктивности растений, данный ген присутствует в генотипе, тогда как у стандартов (кроме Памяти Азиева) и ОмГАУ 90 ген TaGS-D1 не идентифицирован. Лучшие линии с генетическим материалом синтетической пшеницы переданы в контрольный питомник для дальнейшего изучения.

В заключении следует отметить, что с использованием синтетических гексаплоидов пшеницы с геномом Ae. tauschii создан ценный исходный материал, на основе генотипирования которого KASP-маркерами выявлены источники новых аллелей генов для расширения генофонда пшеницы и ускорения селекционного процесса выведения сортов яровой мягкой пшеницы с высокой урожайностью и качеством зерна.

Благодарности: Данное исследование проведено при финансовой поддержке РНФ (проект № 16-16-10005).

\section{Список литературь}

1. Оценка линий синтетической пшеницы (Triticum durum/Aegilops tauschii) по вегетационному периоду и устойчивости к болезням / В.П. Шаманин [и др.] // Вавиловский журнал генетики и селекции. - 2017. - 21(3). - С. 347-353.

2. Морфометрические параметры корневой системы и продуктивность растений у синтетических линий яровой мягкой пшеницы в условиях Западной Сибири в связи с засухоустойчивостью / В.П. Шаманин [и др.] // Сельскохозяйственная биология. 2018. - T.53. - № 3. - С. 587-597.

3. Хлесткина Е.К. Молекулярные маркеры в генетических исследованиях и в селекции / Е.К. Хлесткина // Вавиловский журнал генетики и селекции. - 2013. - Т. 14. - № 4/2. - C. 1044-1054.

4. Evaluation and haplotype analysis of elite synthetic hexaploid wheat lines for resistance to hessian fly / G.T. Yu [et al.] // Crop Sci. - 2012. - V. - 52. - P. 752-763.

5. Genetic contribution of synthetic hexaploid wheat to CIMMYT's spring bread wheat breeding germplasm: scientific reports / U. Rosyara [et al.]. - 2019. - V. 9. - P. 12355. 
6. Genetic diversity and population structure analysis of synthetic and bread wheat accessions in Western Siberia / M. Bhatta [et al.] // Journal of applied genetics. - 2019. - V. 60 (3-4), P. 283-289.

7. Kihara H. Discovery of the DD analyser, one of the ancestors of Triticum vulgare / H. Kihara // Agric. Hort. - 1944. - V.19. - P. 889-890.

8. McFadden, E.S., Sears, E.R. The artificial synthesis of Triticum spelta / E.S. McFadden, E.R. Sears // Rec. Genet. Soc. Am. - 1944. - V.13. - P. 26-27.

\section{Молекулярно-генетические основы для направленной селекции на содержание полифенольных соединений в зерне ячменя}

Шоева О.Ю. ${ }^{1 *}$, к.б.н., с.н.с., Стрыгина К.В. ${ }^{2}$, Глаголева А.Ю. ${ }^{1}$, Гордеева Е.И. ${ }^{1}$, Вихорев А.В. ${ }^{1}$, Кукоева T.В. ${ }^{1}$, Хлесткина Е.К. ${ }^{1,2}$

${ }^{1}$ Института циитологии и генетики СО РАН (ИЦиГ СО РАН), Новосибирск, Россия,

${ }^{2}$ Всероссийского института генетических ресурсов растений имени Н.И. Вавилова (ВИР), Санкт-Петербург, Россия.

*e-mailolesya_ter@bionet.nsc.ru

Состав и количество полифенольных соединений в зерне ячменя определяют его изелевое использование. Направленное создание новых сортов с заданными паттернами полифенольных соединений невозможно без знаний об их синтезе и его генетической регуляция. В представленной работе были идентифицированы гень, контролирующие биосинтез антоциановых пигментов и проантоцианидинов в зерне ячменя и установлены особенности их функционирования. Полученные данные используются в селекции на содержание и состав полифенольных соединений в зерне ячменя.

Ключевые слова: Hordeum vulgare, антоцианы, проантоциианидины, меланинь функциональное питание, пивоварение, маркер-ориентированная селекция.

\section{Molecular-genetic basis for directed breeding for polyphenol content in barley grain}

Shoeva O.Yu., Senior Researcher, the FRC Institute of Cytology and Genetics SB RAS, Novosibirsk, Lavrentjeva ave., 10,*e-mail: olesya_ter@bionet.nsc.ru

The content and composition of polyphenolic compounds in barley grain determines its objective application. The targeted creation of new varieties of barley with given patterns of polyphenolic compounds is impossible without knowledge of their synthesis and its regulation. In the presented study, the regulatory genes that control synthesis of anthocyanin pigments and proanthocyanidins in barley grain 
were identified, and the features of their functioning were established. The data obtained are used in breeding for the content of polyphenolic compounds in barley grain.

Keywords: Hordeum vulgare, anthocyanidins, proanthocyanidins, melanins, functional food, brewing, marker-assisted breeding.

К полифенольным соединениям растений относятся гидролизуемые танины, меланины, и фенилпропаноиды (флавоноиды, лигнин, конденсированные танины). Они выполняют важные функции у растений: регулируют их рост и развитие, играют защитную роль при различных типах стресса, участвуют в поддержании состояния покоя семян [1]. В зерне ячменя (Hordeum vulgare L.) могут синтезироваться различные группы полифенольных соединений (см. рисунок).

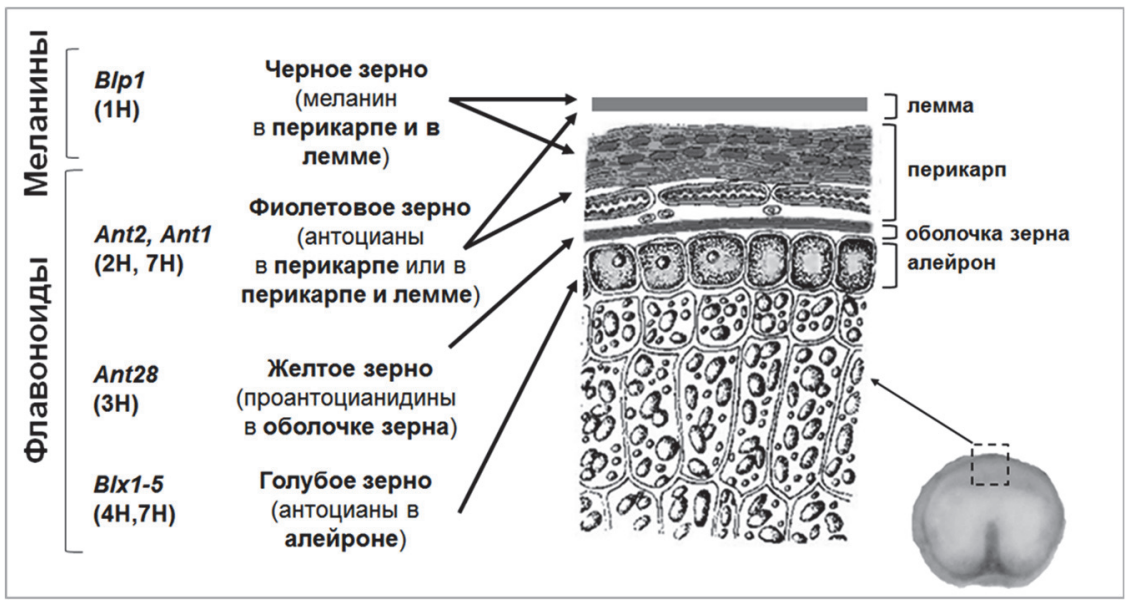

Рисунок. Гены, контролирующие синтез полифенольных соединений в различных частях зерновки ячменя, и их хромосомная локализация. Полифенольные соединения, определяющие окраску зерна, и их локализация в частях зерновки указаны в скобках.

Их состав и количество имеют важное практическое значение и определяют целевое использование зерна. Антоциановые пигменты, которые могут синтезироваться в перикарпе (под контролем генов Ant1 и Ant2) и алейроновом слое зерна (Blxl-5), придавая ему фиолетовую и голубую окраски, соответственно, являются перспективными компонентами функционального питания [2]. Полимерные флавоноидные соединения проантоцианидины (Ant28) синтезируются в оболочке зерна ячменя, при окислении определяя красно-коричневую его окраску. Данные соединения вызывают колло- 
идное помутнение пива при хранении, являясь нежелательными в пивоваренных сортах ячменя [3]. Меланины (Blpl) могут накаливаться в цветковых чешуях и в перикарпе. Данный тип пигментов рассматривается в качестве сырья для получения антиоксидантов, противостарителей, ингибиторов радикальных реакций, сорбентов, биостимуляторов [4,5]. Для направленного создания новых сортов ячменя с заданными паттернами полифенольных соединений в зерне необходимы знания о генетическом контроле их синтеза и его регуляции.

Целью исследования являлось определение молекулярных функций генов, определяющих тканеспецифическое накопление флавоноидных пигментов в зерне ячменя. В работе использовались полученные с помощью радиационного и химического мутагенеза безантоциановые и/или безпроантоцианидиновые Ant (anthocyanin-less) мутантные [6] и почти-изогенные линии ячменя, содержание различные аллели регуляторных генов, контролирующих синтез антоцианов [7].

На основе данных сравнительного картирования, а также транскрипционного анализа структурных генов, кодирующих ферменты биосинтеза антоцианов, было показано, что локус Ant1 (картирован на хромосоме 7HS) кодирует транскрипционный фактор (ТФ) семейства MYB, необходимый для активации экспрессии структурных генов в листовом влагалище растений ячменя [8]; ген Ant2 (2HL) кодирует ТФ типа bHLH, необходим совместно с Ant1 для активации биосинтеза антоцианов в перикарпе зерна $[9,10]$. Локус Ant13 ко-локализуется с геном $W D 40$ в длинном плече хромосомы 6HL и участвует в активации транскрипции структурных генов в листовом влагалище и в зерне ячменя, где он принимает участие в синтезе антоцианов и проантоцианидинов, соответственно. У мутантов ant13 были выявлены однонуклеотидные нонсенс и миссенс мутации в нуклеотидных последовательностях данного гена. Выявленные мутации позволяют разработать молекулярные маркеры к нефункциональным аллелям гена $W D 40$ и использовать их в селекции на отсутствие проантоцианидинов в зерне.

Секвенирование генов-кандидатов для локусов Ant1 и Ant2 у почти изогенных линий, отличающихся окраской перикарпа, выявило различия в промоторных областях этих генов, которые предположительно связаны с различной их функциональной активностью в окрашенном и неокрашенном зерне. Выявленные отличия были использованы для разработки диагностических маркеров для с создания почти-изогенных линий ячменя с различными комбинациями доминантных и рецессивных аллей этих генов [10]. Анализ экспрессии структурных генов в полученных линиях показал, что транскрипция структурного гена $A n s$, кодирующего антоцианидинсинтазу (ANS), зависит от наличия доминантных аллелей как Ant1, так и Ant2. Поскольку анализ безантоциановых мутантов показал, что локусы Ant1, Ant2 и Ant5 совместно 
контролируют реакцию превращения лейкоантоцианидинов в антоцианидины, катализируемую ANS [6], ген Ans был предложен в качестве гена-кандидата для локуса Ant5. Секвенирование гена Ans у мутантов ant5 и их родительских сортов выявило SNP, вызывающие стоп-кодоны и аминокислотные замены, нарушающие функционирование белка. С помощью полученных линий также были установлены регуляторные взаимоотношения между генами Ant1 и Ant2 по типу регуляторной петли с положительной обратной связью.

Используя полученные данные о генах, контролирующих биосинтез флавоноидов, и отличиях между доминантными и рецессивными аллелями этих генов мы можем направленно создавать новые сорта с заданными паттернами антоциановых и проантоцианидиновых соединений в зерновках ячменя.

Благодарности: Работа выполнена в рамках проекта КГЦ № 075-152019-1662, при частичной поддержке гранта РФФИ №19-016-00140 и Visby Scholarship Program №25896/2018.

\section{Список литературы}

1. Khlestkina E.K. The adaptive role of flavonoids: emphasis on cereals // Cereal Research Communication. 2013;41:185-198.

2. Calderaro A., Barreca D., Bellocco E., Smeriglio A., Trombetta D., Laganà G. Colored phytonutrients: role and applications in the functional foods of anthocyanins. Phytonutrients in food: From traditional to rational usage. Eds. S. M. Nabavi, I. Suntar, D. Barreca, H. Khan. Woodhead Publishing, 2020:177-195.

3. von Wettstein D. From analysis of mutants to genetic engineering // Annual Review of Plant Biology. 2007;58:1-19.

4. Gracheva N.V., Zheltobryukhov V.F. Sorbtion properties of sunflower husk melanins // Pharmaceutical Chemistry Journal. 2019;53(4):337-341.

5. Kablov V.F., Novopoltseva O.M., Gracheva N.V., Zheltobryukhov V.F., Dao P.K. Prospects of application of melanins as antiaging agents in elastomer compositions // Vietnam Journal of Chemistry. 2019;57(2):255-260.

6. Jende-Strid B. Genetic control of flavonoid biosynthesis in barley // Hereditas. 1993;119:187-204.

7. Druka et al. 2011.

8. Shoeva O.Y., Kukoeva T.V., Börner A., Khlestkina E.K. Barley Ant1 is a homolog of maize $C 1$ and its product is part of the regulatory machinery governing anthocyanin synthesis in the leaf sheath // Plant Breeding. 2015; 134:400-405.

9. Shoeva O.Y., Mock H.P., Kukoeva T.V., Börner A., Khlestkina E.K. Regulation of the flavonoid biosynthesis pathway genes in purple and black grains of Hordeum vulgare. PloS one. 2016;11(10).

10. Gordeeva E.I., Glagoleva AY, Kukoeva TV, Khlestkina EK, Shoeva OY. 2019. Purple-grained barley (Hordeum vulgare L.): marker-assisted development of NILs for investigating peculiarities of the anthocyanin biosynthesis regulatory network // BMC Plant Biology. 19(Suppl 1):52. 


\section{Фитопатологический скрининг сортообразцов озимой пшеницы по возрастной устойчивости к основным грибным болезням}

Ыскакова Г.Ш.*, РhD-докторант, м.н.с., Молдажанова Р.А., магистр, м.н.с., Мауленбай А.Д., магистр, м.н.с., Рсалиев А.С., к.с.-х.н., заведуюший лабораторией.

Научно-исследовательский институт проблем биологической безопасности, Гвардейский, Казахстан

*e-mail: y_gulbahar@mail.ru

В 2019 году на искусственном инфекиионном фоне видов ржавчины и на естественном фоне желтой пятнистости листьев охарактеризованы 481 сорта, образцы и линии пшенищы Казахстана, ближнего и дальнего зарубежья. По результатам фитопатологической оценки среди сортообразиов пшеницы отобраны источники полевой устойчивости к основным грибным болезням. Выявлено 145 источников озимой пшеницы с высокой устойчивостью к возбудителю желтой ржавчины, 253 - листовой ржавчины, 171 - стеблевой ржсавчины, 71 -желтой пятнистости листьев.

Ключевые слова: пшеница, сортообразиьы, грибные болезни, устойчивость, восприимчивость.

\section{Phytopatological screening of winter wheat varieties in adult plant resistance to major fungi diseases}

Yskakova G.Sh., PhD-student, junior researcher, Moldazhananova R.A., M.S., junior researcher, Maulenbay A.D., M.S., junior researcher, Rsaliyev A.S., PhD, head of laboratory Research Institute for Biological Safety Problems, Gvardeiskiy,ZZhambylskaya Oblast, Kazakhstan.E-mail:y_gulbahar@mail.ru

In 2019, 481 varieties, samples and wheat lines from Kazakhstan and abroad were characterized on an artificial infectious background of rust types and on a natural background of tan spot. Sources of resistance to the main fungal diseases were selected according to the results of phytopathological assessment among the varieties of wheat. Study demonstrated overall 145 sources of winter wheat with resistance to the causative agent of yellow rust, 253 - leaf rust, 171 stem rust, and 71 - tan spot.

Key words: wheat, varietal samples, fungal diseases, resistance, susceptibility.

В Казахстане на посевах озимой пшеницы ежегодно развивается не одна, а комплекс болезней, вызывающих значительные потери урожая. 
Среди болезней пшеницы наиболее распространенными и вредоносными являются виды ржавчины и пятнистости листьев. Они относятся к особо опасным болезням, создающим большой риск для продовольственной безопасности республики. Многие допущенные к использованию в Казахстане сорта озимой пшеницы восприимчивы к указанным патогенам $[1,2]$. Скрининг генофонда пшеницы к грибным болезням создает предпосылки для выведения и внедрения в производство новых болезнеустойчивых сортов пшеницы, которые являются основой интенсификации сельского хозяйства. В связи с этим выявление сортов озимой пшеницы с высокой устойчивостью к болезням является весьма актуальной задачей, имеющей не только научную, но и практическую значимость в селекции пшеницы.

Целью данной работы являлось фитопатологический скрининг сортообразцов озимой пшеницы по возрастной устойчивости к основным грибным болезням.

В 2019 году на искусственном инфекционном фоне видов ржавчины и на естественном фоне желтой пятнистости листьев охарактеризованы 481 линии, сорта и образцы пшеницы Казахстана, ближнего и дальнего зарубежья. Полевые опыты заложены в полевом орошаемом участке НИИПББ. Для накопления и распространения инфекции в питомнике, между ярусами, посеяли восприимчивые сорта-спредеры, в качестве которых служили Morocco и Богарная 56. Весной, в фазе кущения, посевы озимой пшеницы заражали урединиоспорами видов ржавчины. Для заражяения использовали только местную популяцию грибов, либо смесь изолятов с определенной вирулентностью. Инфекционный материал на растения наносили методом опрыскивания водной суспензией спор с 0,001 \% Твин 80 [3]. Учет пораженности растений проводили в период максимального развития заболеваний на восприимчивых контрольных сортах пшеницы. Степень поражения ржавчинными болезнями (в \%) оценивали по шкале R.F. Peterson и др. [4]. Степень устойчивости и восприимчивости образцов пшеницы к пятнистости листьев устанавливали по шкале Saari, Prescott [5].

В 2019 году на экспериментальном полевом участке изучены устойчивости 68 коммерческих сортов озимой пшеницы Центральной Азии и Закавказья (ЦАЗ), 20 элитных и 80 перспективных линий, а также зарубежные питомники IWWYT-IR (208 образцов) и IWWYT-SA (105) к трем видам ржавчины и желтой пятнистости. На основе анализа полученных данных, сортобразцы озимой пшеницы сгруппированы по степени поражения болезнями (рисунок). 

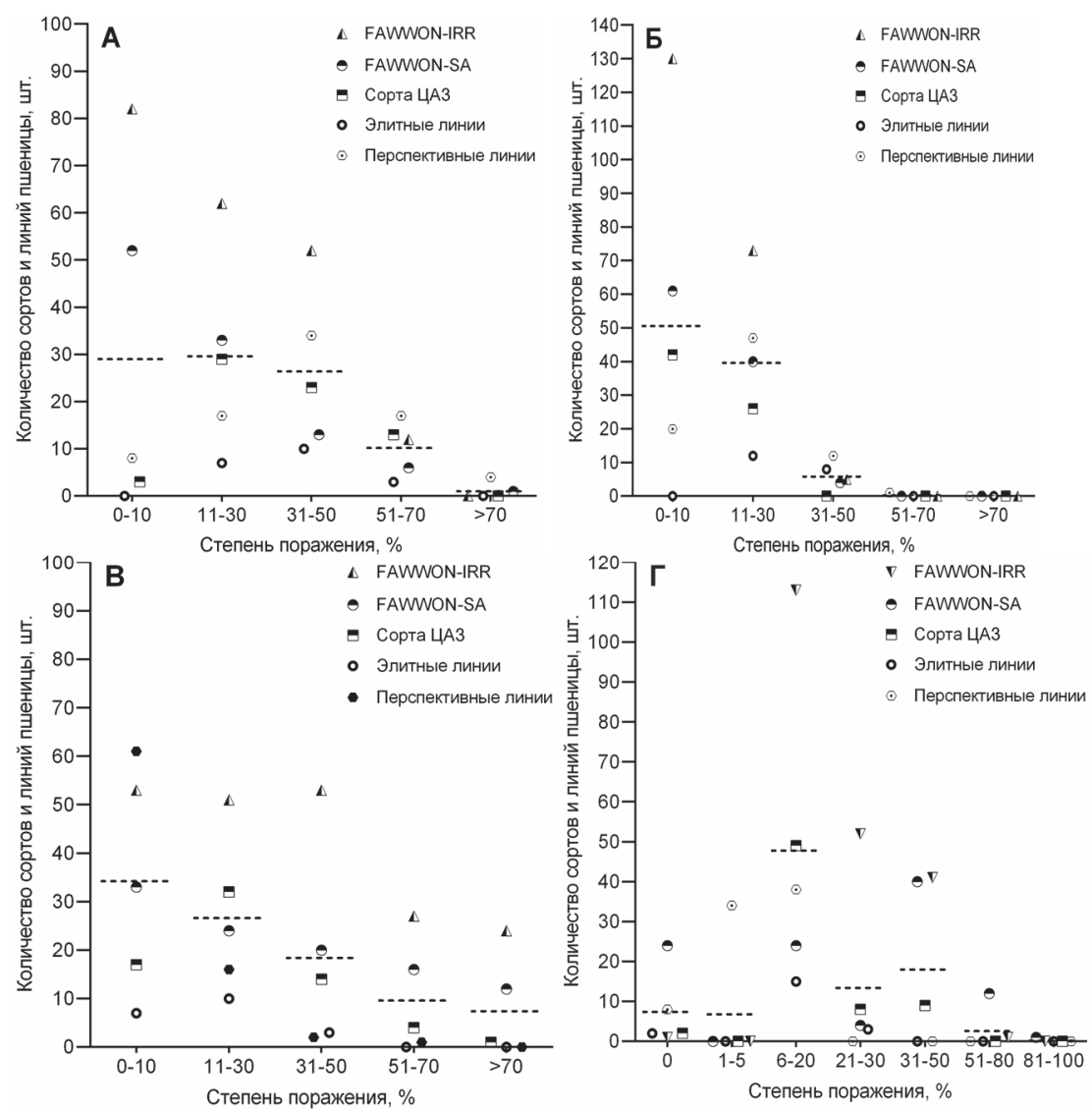

Распределение сортообразцов озимой пшеницы по степени поражения желтой (А), листовой (Б), стеблевой ржавчиной (В) и желтой пятнистости (Г)

Погодные условия вегетационного сезона 2019 года складывались благоприятно для развития желтой ржавчины, в связи, с чем патоген развивался в сильной степени в изученных питомниках озимой пшеницы. К желтой ржавчине высокую устойчивость показывают всего 145 сортообразцов (30,1 \% от числа испытанных), остальные характеризуются разным уровнем устойчивости и восприимчивости (рисунок, А). Максимальная доля устойчивых к патогену образцов озимой пшеницы в изученной выборке приходилась на зарубежные образцы в питомниках FAWWON-IRR (82) и FAWWONSA (52).

В 2019 году листовая ржавчина на озимой пшенице проявилась 
поздно, и ее развитие было в слабой степени. Первые пустулы гриба выявлены на изученных материалах только в фазе колошения. В зависимости от питомников и сортовых особенностей поражение листовой ржавчиной листьев среднего и верхнего ярусов в период налива зерна колебалось от 0-5 до 20-60\%. При этом во всех изученных питомниках только 30 образцов были восприимчивыми, а остальные оказались устойчивыми и умеренно устойчивыми к болезни (рисунок, Б).

Оценка устойчивости озимой пшеницы к возбудителю стеблевой ржавчины в 2019 году показала, что более 35 \% (171 образец) из них проявляют устойчивость, когда растения находятся во взрослом состоянии. Сравнительно слабое развитие патогена отмечено на элитных и перспективных линиях озимой пшеницы (рисунок, В).

Установлено, что большинство изученных селекционных материалов озимой пшеницы поражаются в средней и сильной степени желтой пятнистости. В полевых условиях всего обнаружено 37 сортообразцов озимой пшеницы с иммунной реакцией к желтой пятнистости. Результаты оценки показали высокую устойчивость 34 образцов с поражением до 5 \% (рисунок, Г).

Таким образом, в 2019 году дана характеристика сортов, образцов и линий озимой мягкой пшеницы (в общей сложности 481) по возрастной устойчивости к основным грибным болезням. На основе анализа полевых данных отобран всего 171 источник озимой пшеницы с устойчивостью к возбудителю стеблевой ржавчины, 145 - желтой ржавчины, 253 - листовой ржавчины и 71 - желтой пятнистости.

Благодарности: Работа была выполнена при финансовой поддержке Министерства сельского хозяйства Республики Казахстан в рамках программно-целевого финансирования на 2018-2020 гг. (ИРН BR06249329).

\section{Список литературь}

1. Койшыбаев М. Болезни пшеницы. - Анкара: ФАО, 2018. - 365 с.

2. Рсалиев А.С. Выявление доноров устойчивости мягкой пшеницы к желтой ржавчине / А.С. Рсалиев, Г.Ш. Ыскакова, Н.Т. Амирханова, Ж.У. Пахратдинова // Вестник КазНУ, серия биологическая, 2015. №3 (65). - С.150-160.

3. Гешеле Э.Э. Методы заражения растений и учета его результатов в селекции / Э.Э. Гешеле // Основы фитопатологической оценки в селекции растений. Москва: Колос, 1978. - С.129-159.

4. Peterson R.F. A diagrammatic scale for estimating rust intensity on leaves and stems of cereals / R.F. Peterson, A.B. Campbell, A.E. Hannah // Canad. J. Res., 1948. V.26. - P.496-500.

5. Saari, E.E. A scale for appraising the foliar intensity of wheat diseases / E.E. Saari, J.M. Prescott // Plant Dis.Rep., 1975. - V.59. - P. 377-380. 


\section{Оценка адаптивности перспективных образцов фасоли овощной в условиях Лесостепи Приобья}

Якубенко О.Е.*, преподаватель, Паркина О.В., к.с.-х.н., доцент; Плотников К.О., студент.

ФГБОУ ВО Новосибирский ГАУ, г. Новосибирск, Россия

*e-mail: o.e.yakubenko@yandex.ru

Оиенка адаптивного потенциала сортов является актуальным направлением в области селекции. Главным условием для создания высококачественного сорта является сочетание в нем экологической пластичности и продуктивности. При этом большое внимание уделяется параметрам, оказывающим влияние на потенцииальную урожайность сорта. На кафедре селекиии, генетики и лесоводства ФГБОУ ВО Новосибирский ГАУ проведена многолетняя оценка (2017-2019 г2.) перспективных линий фасоли овошной.Выделены генотипы культуры, которые сочетают высокую продуктивность со средовой устойчивостью.

Ключевые слова: фасоль обыкновенная, адаптивность, коэффичиент регрессии, селекционная цеенность генотипа, экологическая пластичность, лесостепь Приобья.

\section{The appraisement of adaptive ability of perspective lines of common bean in the conditions of the Western Siberia}

Yakubenko O.E., Parkina O.V., Plotnikov K.O.

Novosibirsk State Agrarian University, Novosibirsk, Russia.

*e-mail: o.e.yakubenko@yandex.ru

The evaluation of adaptive ability of varieties is an actual direction in selection. The main condition for creating a high-quality variety is a combina-tion of ecological plasticity and productivity. At the same time, much attention is paid to the parameters that affect the potential yield of the variety. On the basis Department of Selection, Genetics and Forestry, Novosibirsk State Agrar-ian University (2017-2019), long-term evaluation of perspective lines of green bean. As a result of the study genotypes of the crop, combining high productivi-ty and environmental resistance, were selected.

Key words: common bean, adaptability, regression coefficient, the breeding value of the genotype, environmental plasticity, Western Siberia. 
Фасоль обыкновенная овощного направления обладает высокими вкусовыми и диетическими свойствами, широко используется в кулинарии. Для России фасоль, выращиваемая на зеленую лопатку, является относительно новой культурой. Незначительное распространение связано с недостаточным набором экологически пластичных сортов. Для создания адаптивных, высокопродуктивных образцов необходимо при подборе родительских пар отдавать предпочтение генотипам с высокой селекционной ценностью.

Методы целенаправленного выведения высокоадаптивных сортов и сортов интенсивного типа к настоящему времени недостаточно разработаны. Обычно учитывают норму реакции генотипа, которая является наследственной. Высокоадаптивные сорта могут быть использованы в производственных условиях повсеместно, а сорта интенсивного типа лучшие результаты смогут показать в хозяйствах с высоким уровнем культуры земледелия.

В настоящее время в ассортименте овощных культур более распространены сорта высоко- и среднеадаптивные. Их ценность заключается в том, что эти образцы более устойчивые к экологическим изменениям среды, но не отличаются высокой урожайностью. Для отбора интересующих селекционера форм, прибегают к изучению такого показателя, как селекционная ценность генотипа. В этом случае равное значение придается продуктивности и стабильности.

На базе УПХ «Сад Мичуринцев» Новосибирского ГАУ был проведен опыт по изучению адаптивного потенциала селекционных линий фасоли овощного направления в 2017-2019 годах [4].

Цель исследования - оценить адаптивность перспективных линий фасоли овощной в условиях лесостепи Приобья.

Фенологические и морфологические наблюдения проводили в соответствие с принятыми методиками ВИР [2, 3]. Один из эффективных методов по оценке адаптивности генотипов разработан А.В. Кильчевским и Л.В. Хотылевой (1985). Согласно этому методу реакцию сорта характеризуют общая адаптивная способность (ОАС) - среднее значение признака в различных условиях выращивания и специфическая адаптивная способность (САС) - отклонение от ОАС в определенной среде. Введен комплексный показатель селекционной ценности генотипа (СЦГ), позволяющий выделить генотипы, сочетающие высокую продуктивность со средовой устойчивостью [1].

Уровень урожайности служит главным критерием экономической целесообразности возделывания сорта. Создание сорта с высоким генетическим потенциалом продуктивности не гарантирует получение высоких урожаев при его возделывании.

По признаку урожайность зеленых бобов в 2017-2019 года изучено 9 генотипов перспективных форм фасоли овощного направления. Стандартом выступает сорт сибирской селекции Солнышко, отличающийся высокими показателями продуктивности и адаптивности. 
Коэффициент регрессии позволяет определить к какому типу относится изучаемый образец. При значении параметра больше единицы форма относится к интенсивному типу, которая характеризуется высокой отзывчивостью и пластичностью. Значение коэффициента меньше нуля или приближенное к нулю позволяет сделать вывод о низкой адаптивности сорта к изменениям окружающей среды и отнести его к нейтральному типу. Изучаемые линии по признаку урожайность имеют коэффициент регрессии отрицательный или приближенный к нулю, что позволяет нам отнести формы к нейтральному типу (таблица).

Таблица - Оценка адаптивности линий фасоли овощной по признаку урожайность зеленых бобов

\begin{tabular}{|l|l|c|c|c|c|c|c|}
\hline$№$ п/п & Сорт & $\mathrm{Xi}$, кг/M & bi & OACi & CACi & Sgi, \% & СЦГі \\
\hline 1 & Солнышко - стандарт & $1,9 \pm 0,5$ & $-2,12$ & 0,2 & 0,04 & 2,1 & 1,78 \\
\hline 2 & F24 & $1,5 \pm 0,2$ & $-1,01$ & $-0,2$ & 0,15 & 9,8 & 0,96 \\
\hline 3 & F27 & $2,3 \pm 0,1$ & $-1,88$ & 0,5 & 0,10 & 4,3 & 1,92 \\
\hline 4 & F29/1 & $1,5 \pm 0,4$ & $-0,35$ & $-0,3$ & 0,30 & 20,2 & 0,36 \\
\hline 5 & F29/2 & $1,9 \pm 0,6$ & $-0,06$ & 0,1 & 0,34 & 18,4 & 0,56 \\
\hline 6 & F29/3 & $1,9 \pm 0,2$ & $-1,20$ & 0,1 & 0,15 & 8,1 & 1,29 \\
\hline 7 & F29/4 & $1,5 \pm 0,3$ & $-0,43$ & $-0,3$ & 0,21 & 14,4 & 0,67 \\
\hline 8 & F30 & $1,5 \pm 0,6$ & 0,33 & $-0,3$ & 0,34 & 23,4 & 0,16 \\
\hline 9 & F171/1 & $2,1 \pm 0,6$ & $-0,27$ & 0,3 & 0,41 & 19,6 & 0,53 \\
\hline 10 & F171/2 & $1,7 \pm 0,4$ & $-0,62$ & $-0,1$ & 0,19 & 11,4 & 0,94 \\
\hline
\end{tabular}

Примечание: $\mathrm{Xi}$ - среднее значение признака, кг/м2; bi - коэффициент регрессии; $\mathrm{CACi} \mathrm{-} \mathrm{специфическая} \mathrm{адаптивная} \mathrm{способность;} \mathrm{Sgi} \mathrm{-} \mathrm{относительная} \mathrm{стабильность}$ генотипа; СЦГі - селекционная ценность генотипа.

Относительная стабильность генотипа (Sgi) выступает важным параметром при селекции культур на адаптивность. Она является составляющей характеристики селекционно ценных генотипов, сочетающих высокую потенциальную продуктивность и экологическую устойчивость. При значении Sqi $<10 \%$ уровень экологической изменчивости признака незначительный, от 10 до $20 \%$ - средний и выше $20 \%$ - значительный. Высоким уровнем экологической изменчивости обладали линии F30 (23,4 \%) и F29/1 (20,2 \%).

Лучшим для зоны будет являться образец, в генотипе которого сочетаются высокие показатели параметров изучаемого признака, а также ОАСi и СЦГі. Наибольшими показателями по изучаемым параметрам обладала линия F27. Среди изученных линий по показателю СЦГі выделились формы F27 $(1,92)$, F29/3 $(1,29)$ и F24 $(0,96)$.

Оценка стабильности форм, проведенная на основе сумм отклонений урожайности изучаемых линий, показала, что чем ниже максимальная урожайность, тем выше стабильность генотипа (рисунок). 


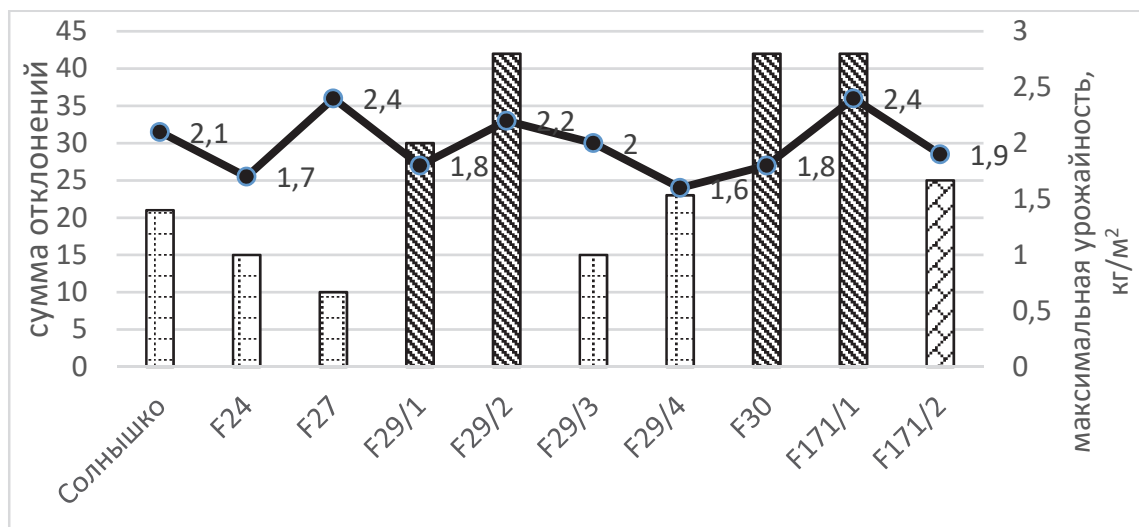

Рисунок. Оценка стабильности генотипов по урожайности и суммам отклонений (2017-2019 гг.).

Для производства интерес представляют генотипы, сочетающие высокий уровень продуктивности и стабильности. Наиболее оптимальными значениями по параметрам обладают перспективные линии F27, F29/3, F24.

Многолетняя оценка 9 перспективных линий фасоли овощной показала, что, в основном образцы существенно отличаются между собой по степени реакции на изменение условий выращивания.

Среди перспективных форм, выделены 3 генотипа (F27, F29/3, F24), сочетающие высокую продуктивность со средовой устойчивостью, которые гарантированно обеспечивают стабильную урожайность и высокое качество продукции.

\section{Список литературь}

1. Кильчевский А.В. Генетико-экологические основы селекции растений / А.В. Кильчевский / Вестник ВОГиС. - Беларусь, 2005. - №4 (9). - С. 518-526.

2. Методические указания. Коллекция мировых генетических ресурсов зерновых бобовых ВИР: пополнение, сохранение и изучение (под ред. Вишняковой М.А.). СПб.: ООП «Копи-Р. Групп», $-2010-142$ с.

3. Методические указаниям по изучению образцов мировой коллекции фасоли СПб, 1987. - 60 с.

4. Якубенко О.Е. Перспективные генотипы фасоли овощной / О.Е. Якубенко, О.В. Паркина // Актуальные проблемы агропромышленного комплекса: Сборник трудов научно-практической конференции преподавателей, аспирантов, магистрантов и студентов Новосибирского государственного аграрного университета. - ИЦ «Золотой колос». - 2018. - С. 56-59. 


\section{Авторский указатель}

Börner A. 59

Lohwasser U. 59

Nagel M. 59

Абакумов С.Н. 45

Абдуллаев Р.А. 6

Абекова А.М. 9

Абилдаева Д.Б. 33

Абугалиева А.И. 14

Адонина И.Г. 21

Аксенов С.А. 151

Амосова А.В. 25, 204

Андреева 3.В. 69

Апарина В.А. 28, 69

Артемьева А.М. 178

Афанасенко О.С. 249

Афонников Д.А. 54, 89, 113, 201

Байтаракова К.Ж. 33, 115

Баранова О.А. 37

Батурин С.O. 41

Бекетова М.П. 245

Белан И.А. 45, 230

Белоусов С.А. 282

Бережная А.А. 49

Беркимбай Х.А. 51

Берсимбаева Г.Х. 9

Бехтольд Н.П. 54

Блохина Н.П. 45

Бобохужаев Ш.У. 257

Бобровских А.В. 60, 64

Бойко Н.И. 28, 69, 269

Болдырев С.В. 95

Боме Н.А. 151

Брагин Н.А. 282

Брагина М.К. 73

Буглова Л.В. 76

Букатич Е.Ю. 113

Буштевич В.Н. 91

Васильева О.Ю. 76
Вихорев А.В. 296

Воловик В.Т. 79, 204

Гарапов Д.С. 84

Гаркуша С.В. 51

Генаев М.А. 89

Герасимова С.В. 98, 139, 159

Глаголева А.Ю. 165, 296

Гладких М.С. 291

Гордеева Е.И. 296

Горюнова С.В. 95

Гриб С.И. 91

Григорьев Ю.Н. 165

Гришин В.М. 124

Губаев Р.Ф. 95

Гультяева Е.И. 135, 253, 287

Гусар A.C. 76

Гуськова Н. И. 25

Демурин Я.Н. 95

Дидоренко С.В. 115

Добрянская С.Л 119

Домрачев Д.В. 98

Дорошков А.В. 60, 64, 113

Досина-Дубешко Е.С. 223

Дружин А.Е. 37

Ержебаева Р.С. 9

Ермаков А.А. 60, 64

Ершова И.В. 100

Есимбекова М.А. 104

Еспанов А.М. 104

Ефимов В.М. 249

Жубанышева А.У. 1034

Зайцева И.Ю. 108

Земцова Л.В. 25, 204

Зорина М.В. 21

Зощук С.A. 25, 204

Зубаирова У.С. 54, 60, 64, 113
Иванова К.А. 98, 139

Иванова Ю.С. 282

Кабылбекова Г.К. 115

Капко Т.Н. 188

Капустянчик С.Ю. 119

Карпова Е.В. 147

Кашеваров Н.И. 124

Кельбин В.Н. 128

Киселева А.А. 49, 73, 132, 274

Клименко И.А. 193

Коваленко Н.М. 135, 169

Коваленко Т.А. 95

Кожахметов К.К. 14

Козлова М.В. 76

Кокина Л.П. 108

Колесова М.А. 135

Колодкин А.Н. 60

Колосовская Е.В. 159

Колошина К.А. 98, 139

Колупаев Д.А. 144

Комышев Е.Г. 89

Коновалов А.А. 147

Коновалова Г.С. 6

Константинов Д.К. 60, 64

Королев К.П. 151

Коротенко Т.Л. 154

Короткова А.М. 159

Косарева И.А. 6

Кохметова А.М. 169, 253

Куваева Д.Д. 161

Кудайбергенов М.С. 33, 115

Кузнецова М.А. 245

Кукоева Т.В. 159, 165, 296

Кумарбаева М.Т. 169

Куранда Ю.В. 173

Курина А.Б. 178

Кушниренко И.Ю. 135

Ларина О.В. 183

Лашина Н.М. 249

Левина А.Б. 60, 64 
Леонова И.Н. 132

Лихенко Н.Н. 188

Лоскутов И.Г. 241

Мавлютов Ю.М. 193

Маловичко Е.С. 113

Маркевич И.М. 91

Мартынова Е.У. 95

Матыс И.С. 91

Мауленбай А.Д. 300

Медведь Н.В. 223

Мехдиева С.П. 21

Михайличенко О.А. 197

Молдажанова Р.А. 300

Молодцов В.В. 201

Моргунов А.И. 291

Морозова А.О. 76

Морозова Е.В. 128, 237

Мукин К.Б. 104

Муравенко О.В. 25, 204

Наумова Л.Г. 208

Немченко В.В. 45

Новикова Л.Ю. 208

Новохатин В.В. 212

Нусипбай К. 33

Орлова Е.А. 54, 113, 147

Пай О.А. 282

Паркина О.В. 144, 304

Партоев К. 219, 261

Пашкевич А.М. 223

Перфильев Р.Н. 226

Першина Л.А. 45, 230

Петухова М.С. 119

Пискарев В.В. 28, 69, 269, 278

Плотников К.О. 304
Плотникова Л.Я. 233

Пожерукова В.Е. 233, 291

Полюдина Р.И. 124

Потапов Д.А. 124

Потоцкая И.В. 291

Пшеничникова Т.А. 54, 132,237

Радченко Е.Е. 6, 241

Рогозина Е.В. 245

Розанова И.В. 249

Россеева Л.П. 45, 230

Рсалиев А.С. 253, 300

Садовская Л.Л. 154

Садохина Т.А. 119

Салина Е.А. 21, 49,73, 128, $132,226,274$

Саматадзе Т.Е. 25, 204

Санамьян М.Ф. 257

Сатторов Б.Н. 261

Сафаров Х.P. 261

Сейтназарова Т. 265

Сибикеев С.Н. 37

Симонов А.В. 237

Сколотнева Е.С. 128

Смирнова О.Г. 237

Соловьева А.Е. 178

Сочалова Л.П. 269

Стасюк А.И. 274

Стрыгина К.В. 165,296

Сухомлинов В.Ю. 28, 69, 278

Торопова Е.Ю. 278

Трубачеева Н.В. 45, 230

Тюнин В.А. 135

Усенбеков Б.Н. 51
Фомина М.Н. 282

Хавкин Э.Е. 245

Хайтович Ф.Е. 95

Хейдари С. 60

Хлесткина Е.К. 159, 165, 249, 296

Чайковский А.И. 223

Чалая Н.А. 245

Чернова А.И. 95

Чудная А.П. 188

Чумаков М.А. 241

Чурсин А.С. 291

Шабан Е.М. 91

Шайдаюк Е.Л. 253, 287

Шаманин В.П. 291

Шамустакимова А.О. 193

Шелковников С.А. 119

Шеломенцева Т.В. 212

Шепелев С.С. 291

Шоева О.Ю. 165, 296

Шрейдер Е.P. 135

Шундрина И.К. 147

Щербань А.Б. 161, 226

Ыскакова Г.Ш. 300

Эгамбердиева С.А. 265

Юдаева Н.В. 197

Юркевич О.Ю. 25, 204

Яковлева О.В. 6

Якубенко O.Е. 144, 304 


\section{Содержание}

Абдуллаев Р.А., Яковлева О.В., Косарева И.А., Коновалова Г.С., Радченко E.E. Комплексная устойчивость образцов ячменя из Эфиопии к биотическим и абиотическим стрессорам $\ldots \ldots \ldots \ldots \ldots \ldots \ldots \ldots$

Абекова А.М., Ержебаева Р.С., Берсимбаева Г.Х. Оценка образцов свеклы на хладостойкость . . . . . . . . . . . . . . . . . . . 9

Абугалиева А.И., Кожахметов К.К. Характеристика синтетических и диких форм пшеницы в яровом и озимом варианте: 1. Морфология

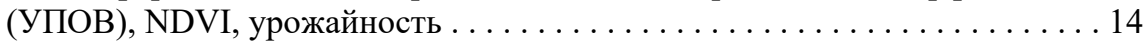

Адонина И.Г., Зорина М.В., Мехдиева С.П., Салина Е.А. Кариотипические особенности гибридных форм гексаплоидной пшеницы с вавилоидным типом ветвлением колоса $\ldots \ldots \ldots \ldots \ldots \ldots \ldots \ldots \ldots \ldots \ldots . \ldots \ldots$

Амосова А.В., Земчова Л. В., Зомук С.А., Гуськова Н. И., Юркевич О.Ю., Саматадзе T.E., Муравенко О.В. Хромосомная изменчивость в поколениях ЭМС-мутантных линий ярового рапса $\ldots \ldots \ldots \ldots \ldots \ldots \ldots \ldots \ldots \ldots \ldots \ldots$

Апарина В.А., Пискарев В.В., Бойко Н.И., Сухомлинов В.Ю. Изучение коллекции пшеницы мягкой яровой для выявления высокоурожайных источников устойчивых к комплексу болезней . . . . . . . . . . . 28

Байтаракова К.Ж., Кудайбергенов М.С., Нусипбай К., Абилдаева Д.Б. Изучение номеров конкурсного сортоиспытания нута по хозяйственноценным признакам в сухостепной зоне Алматинской области . . . . . . . . 33

Баранова О.А., Сибикеев С.Н., Дружин А.Е. Идентификация генов устойчивости к стеблевой ржавчине в интрогрессивных линиях яровой мягкой пшеницы селекции НИИСХ Юго-Востока с использованием молекулярных маркеров . . . . . . . . . . . . . . . . . . . . . 37

Батурин С.О. Создание генофонда скороспелых ремонтантных $\mathrm{F}_{1}$ гибридов крупноплодной земляники (Fragaria $\times$ ananassa Duch.) . . . . . . 44

Белан И.А., Россеева Л.П., Блохина Н.П., Немченко В.В., Абакумов С.Н., Трубачеева Н.В., Першина Л.А. Основные подходы к созданию перспективных сортов яровой мягкой пшеницы для Западной Сибири . . . . . . . . 45

Бережная А.А., Киселева А.А., Салина Е.А. Структурно-функциональные особенности новых аллелей гена цветения мягкой пшеницы Vrn-B3 . . 49

Беркимбай Х.А., Усенбеков Б.Н., Гаркуша С.В. Скриниг генотипов риса с окрашенным перикарпом на содержание амилозы . . . . . . . . . . . 51 
Бехтольд Н.П., Орлова Е.А., Пшеничникова Т.А., Афонников Д.А., Зубаирова У.С. Изучение основных параметров устойчивости яровой пше-

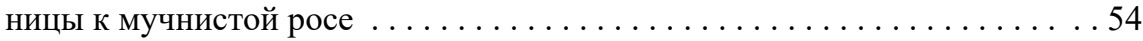

Börner A., Nagel M., Lohwasser U. Crop genebanks - the maintenance of natural resources for future plant breeding

Бобровских АВ., Ермаков А.А., Зубаирова У.С., Константинов Д.К., Левина А.Б., Колодкин А.Н., Хейдари С., Дорошков А.В. Генетические механизмы ответа растений на световой стресс: реконструкция генных сетей и эволюционная перспектива $\ldots \ldots \ldots \ldots \ldots \ldots \ldots \ldots \ldots \ldots \ldots \ldots \ldots \ldots \ldots$

Бобровских А.В., Ермаков А.А., Зубаирова У.С., Константинов Д.К., Левина А.Б., Дорошков А.В. Реконструкция регуляторных генных сетей ответа на солевой стресс Arabidopsis thaliana и Zea mays . . . . . . . . . . 64

Бойко Н.И., Андреева 3.В., Апарина В.А., Сухомлинов В.Ю., Пискарев В.В. Характер наследования числа колосков в колосе у сортообразцов пшеницы мягкой яровой . . . . . . . . . . . . . . . . . . . . . . . 69

Брагина М.К, Килелева А.А., Салина Е.А. Поиск и функциональный анализ генов с циркадным паттерном экспрессии у мягкой пшеницы . . . . . . . 73

Буглова Л.В., Васильева О.Ю., Гусар А.С., Козлова М.В., Морозова А.О. Комплекс представителей рода Trollius в биоресурсной коллекции ЦСБС СО РАН: перспективы интродукции и селекции . . . . . . . . . . . 76

Воловик В.T. Селекция озимого рапса для условий лесной зоны . . . . . . 79

Гарапов Д.С. Основные задачи селекции сливы на Алтае . . . . . . . . . . . 84

Генаев М.А., Комышев Е.Г., Афонников Д.А. SeedCounter - мобильное приложение для массового фенотипирования зерен . . . . . . . . . . . 89

Гриб С.И., Маркевич И.М., Матыс И.С., Буштевич В.Н., Шабан Е.М. Генетические ресурсы - первооснова результативной селекции яровой пшеницы в Беларуси . . . . . . . . . . . . . . . . . . . . . . . .91

Губаев Р.Ф., Чернова А.И., Болдырев С.В., Мартынова Е.У., Коваленко Т.А., Горюнова С.В., Хайтович Ф.Е., Демурин Я.Н. Картирование локусов ответственных за содержание токоферолов в семенах подсолнечника с использованием высокопроизводительного генотипирования . . . . . . . . . 95

Домрачев Д.В., Иванова К.А., Колошина К.А., Герасимова С.В. Определение содержания стероидных гликоалкалоидов соланина и хаконина в диких видах картофеля методом ВЭЖХ . . . . . . . . . . . . . 98 
Ершова И.В. Особенности накопления биофлавоноидов в ягодах интродуцированных сортов винограда на Алтае . . . . . . . . . . . . . . . 100

Есимбекова М.А., Еспанов А.М., Жубанышева А.У., Мукин К.Б. Генетические ресурсы нетрадиционных культур в решении проблем экологической и продовольственной безопасности . . . . . . . . . . . . . . . 104

Зайцева И.Ю., Кокина Л.П. Исходный материал для селекции сортов ярового ячменя, толерантных к абиотическим стрессам . . . . . . . . . 108

Зубаирова У.С., Букатич Е.Ю., Дорошков А.В., Маловичко Е.С., Орлова Е.А., Афонников Д.А. Изучение топологии ростковых трубок бурой ржавчины на поверхности листа пшеницы на основе анализа конфо-

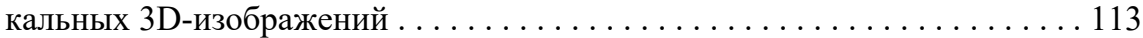

Кабылбекова Г.К., Дидоренко С.В., Кудайбергенов М.С., Байтаракова К.Ж. Влияние предпосевной обработки семян микроэлементами на урожайность сорта сои Жансая в условиях Алматинской области . . . . . . . . . 115

Капустянчик С.Ю., Садохина Т.А., Шелковников С.А., Петухова М.С., Добрянская С.Л. Развитие отрасли растениеводства Новосибирской области в зависимости от природно - сельскохозяйственного зонирования

Камеваров Н.И., Полюдина Р.И., Потапов Д.А., Гришин В.М. Достижения по селекции кормовых культур в Сибирском НИИ кормов СФНЦА РАН за 50 лет . . . . . . . . . . . . . . . . . . . . 124

Кельбин В.Н., Сколотнева Е.С., Морозова Е.В., Салина Е.А. Использование расширенной панели молекулярных маркеров на гены устойчивости (SR21, SR23, SR35, SR36, SR38) к стеблевой ржавчине на сортах

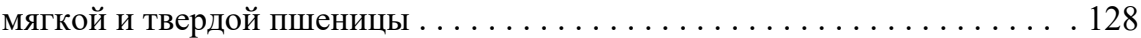

Киселева А.А., Леонова И.Н., Пшеничникова Т.А., Салина Е.А. Новые гены-кандидаты, определяющие текстуру зерна у российских сортов мягкой пшеницы . . . . . . . . . . . . . . . . . . . . . . . . . . . . . . 132

Коваленко Н.М., Тюнин В.А., Кушниренко И.Ю., Шрейдер Е.Р., Колесова М.А., Гультяева Е.И. Устойчивость перспективных селекционных линий яровой мягкой пшеницы, созданных в Челябинском НИИ сельского хозяйства, к листовым пятнистостям . . . . . . . . . . . 135

Колошина К.А., Иванова К.А., Герасимова С.В. Изучение особенностей культивирования и регенерации in vitro диких видов картофеля . . . . . . 139 Колупаев Д.А., Якубенко О.Е., Паркина О.В. Оценка фасоли зерновой по основным элементам продуктивности . . . . . . . . . . . . . . . . . 144 
Коновалов А.А., Орлова Е.А., Карпова Е.В., Шундрина И.К. Влияние полиморфных вариантов CAD (EC 1.1.1.195) на устойчивость пшеницы к грибным инфекциям .

Королев К.П., Боме Н.А., Аксенов C.А. Изучение сортов льна (Linum Usitatissimum L.) в условиях Тюменской области .

Коротенко Т.Л., Садовская Л.Л. Мировые генетические ресурсы риса и отечественные достижения в селекции на качество зерна. . . . . . . . . . 154

Короткова А.М., Колосовская Е.В., Герасимова С.В., Кукоева Т.В., Хлесткина E.K. Получение голозерных линий ячменя после направленной модификации гена Nud методом CRISPR/Cas . . . . . . . . . . . . . . 159

Куваева Д.Д., Щербань А.Б. Поиск и анализ гена-кандидата признака остистости мягкой пшеницы Triticum aestivum L. . . . . . . . . . . . . . . 161

Кукоева Т.В., Стрыгина К.В., Глаголева А.Ю., Григорьев Ю.Н., Шоева О.Ю., Хлесткина Е.К. Разработка генетико-селекционного подхода для получения новых сортов ячменя с повышенным содержанием анто-

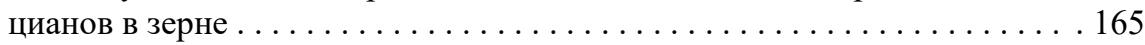

Кумарбаева М.T., Кохметова А.М., Коваленко Н.М. Оценка на устойчивость казахстанских образцов пшеницы к патогену Pyrenophora TriticiRepentis ........................................... 169

Куранда Ю.В. Рост и развитие гибридов астильбы в лесостепи Алтайского края . . . . . . . . . . . . . . . . . . . . . . . . . . . . 173

Курина А.Б., Соловьева А.Е., Артемьева А.М. Генетическое разнообразие и биохимическая ценность культур Raphanus L. коллекции ВИР. . . . 178 Ларина О.В. Современное состояние генофонда рода седум (Sedum L.)

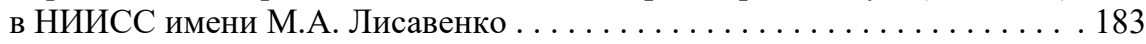

Лихенко Н.Н., Чудная А.П., Капко Т.Н. Изменчивость шишек и семян клонов сосны кедровой сибирской (Pinus sibirica Du Tour) в Краснообске $\quad .188$

Мавлютов Ю.М., Шамустакимова А.О., Клименко И.А. Оценка возможности применения SRAP-маркеров для ДНК-идентификации российских сортов люцерны . . . . . . . . . . . . . . . . . . 193

Михайличенко О.А., Юдаева Н.В. Генофонд и селекция абрикоса в Среднем Приамурье . . . . . . . . . . . . . . . . . . . . . . . . . . . . . . . . . . . 197

Молодиов В.В., Афонников Д.А. Разработка информационной системы для описания наблюдений за фенотипическими признаками сельскохозяйственных растений . . . . . . . . . . . . . . . . . 201 
Муравенко О.В., Земцова Л.В., Зочук С.А., Воловик В.Т., Юркевич О.Ю., Саматадзе T.E., Амосова А.B. Межсортовая хромосомная изменчивость рапса .............................................. 204

Новикова Л.Ю., Наумова Л.Г. Оценка полиморфизма ампелографической коллекции по реакции сортов на изменение агроклиматических показателей . . . . . . . . . . . . . . . . . . . . . . . . . . . . . . . 208

Новохатин В.В., Шеломенцева Т.В. Продуктивность и качество зерна у раннеспелых сортов мягкой яровой пшеницы в Северном Зауралье . . . . 212

Партоев $K$. Прививка томата (Solanum licopersicum L.) на картофель (Solanum tuberosum L.) . . . . . . . . . . . . . . . . . . . . . . . . . . . . . . . . . 219

Пашкевич А.М., Чайковский А.И., Досина-Дубешко Е.С., Медведь Н.В. Мировые генетические ресурсы Phaseolus vulgaris L., их мобилизация, изучение и рациональное использование для решения селекционных задач в Республике Беларусь . . . . . . . . . . . . . . . . . . . . . . . . . 223

Перфильев Р.Н., Щербань А.Б., Салина Е.А. Наследование генов-маркеров к митохондреальной ДНК у аллоплазматических линий $T$. dicoccum x T. aestivum .................................226

Першина Л.А., Трубачеева Н.В., Белан И.А., Россеева Л.П. Особенности предселекции в работе с интрогрессивными аллоплазматическими ДГлиниями мягкой пшеницы . . . . . . . . . . . . . . . . . . . . . . . . . . . 230

Плотникова Л.Я., Пожерукова В.Е. Длительная устойчивость пшеницы к бурой ржавчине с традиционной и молекулярной точек зрения . . . . . . 233

Пшеничникова Т.А., Симонов А.В., Морозова Е.В., Смирнова О.Г. Взаимосвязь между размерами корневой системы и генетическим статусом локуса Vrn-1 у мягкой пшеницы (Triticum aestivum L.) . . . . . . . . . . . 237

Радченко Е.Е., Чумаков М.А., Лоскутов И.Г. Устойчивость местных форм овса из Кавказского региона к обыкновенной злаковой тле. . . . . . . 241

Рогозина Е.В., Чалая Н.А., Кузнецова М.А., Бекетова М.П., Хавкин Э.Е. Разнообразие генофонда дикорастущих видов секции Petota Dumort. рода Solanum L. для современной селекции картофеля . . . . . . . . . . . . 245

Розанова И.В., Лашина Н.М., Ефимов В.М., Афанасенко О.С., Хлесткина E.K. Разработка маркеров, контролирующих устойчивость ярового ячменя к патогену Cochliobolus sativus, на основе ассоциативного картирования ........................................ . 249

Рсалиев А.С., Шайдаюк Е.Л., Кохметова А.М., Гультяева Е.И. Молекулярно-генетический полиморфизм возбудителя листовой ржавчины на твердой пшенице в Казахстане . . . . . . . . . . . . . . . . . . . . . . 253 
Санамьян М.Ф., Бобохужаев Ш.У. Оценка цитогенетической стабильности гибридных растений хлопчатника и их беккроссных потомств с замещениями отдельных хромосом . . . . . . . . . . . . . . . 257

Сатторов Б.Н., Сафаров Х.Р., Партоев К. Влияние стимуляторов роста на содержание хлорофилла "a" и "b" и каротиноидов в листьях пшеницы . 261

Сейтназарова T., Эгамбердиева С.А. Изменчивость качественных параметров волокна у гибридов хлопчатника географически отдаленного происхождения . . . . . . . . . . . . . . . . . . . . . . . . . . 265

Сочалова Л.П., Пискарев В.В., Бойко Н.И. Изучение структуры популяции гриба бурой ржавчины пшеницы в лесостепи Приобья Новосибирской области в 2017-2019 гг. . . . . . . . . . . . . . . . . . . . . . 269

Стасюк А.И., Киселева А.А., Салина Е.А. Отбор с помощью молекулярных маркеров линий яровой мягкой пшеницы с ранним сроком колошения . . . . . . . . . . . . . . . . . . . . . . . . . . . . . . . . . . . . . 274

Торопова Е.Ю., Сухомлинов В.Ю., Пискарев В.В. Системная оценка устойчивости сортов яровой пшеницы к корневым гнилям . . . . . . . 278 Фомина М.Н., Иванова Ю.С., Пай О.А., Брагин Н.А., Белоусов С.А. Источники скороспелости для селекции овса и ячменя в Северном Зауралье . . . 282 Шайдаюк Е.Л., Гультяева Е.И. Устойчивость образцов яровой твердой пшеницы КАСИБ к возбудителю желтой ржавчины . . . . . . . . . . . . . 287

Шаманин В.П., Потоикая И.В., Шепелев С.С., Чурсин А.С., Пожерукова В.Е., Гладких М.С., Моргунов А.И. Создание исходного материала для селекции в Омском ГАУ с использованием синтетической пшеницы . 291

Шоева О.Ю., Стрыгина К.В., Глаголева А.Ю., Гордеева Е.И., Вихорев A.В., Кукоева Т.В., Хлесткина Е.К. Молекулярно-генетические основы для направленной селекции на содержание полифенольных соединений в зерне ячменя . . . . . . . . . . . . . . . . . . . . . . . . 296

Ыскакова Г.Ш., Молдажанова Р.А., Мауленбай А.Д., Рсалиев А.С. Фитопатологический скрининг сортообразцов озимой пшеницы по возрастной устойчивости к основным грибным болезням . . . . . . . . . 300

Якубенко О.Е., Паркина О.В., Плотников К.О. Оценка адаптивности перспективных образцов фасоли овощной в условиях Лесостепи Приобья .............................................. 304

Авторский указатель. . . . . . . . . . . . . . . . . . . . . . . . . . . . . . . . . . . . . . .. 308 


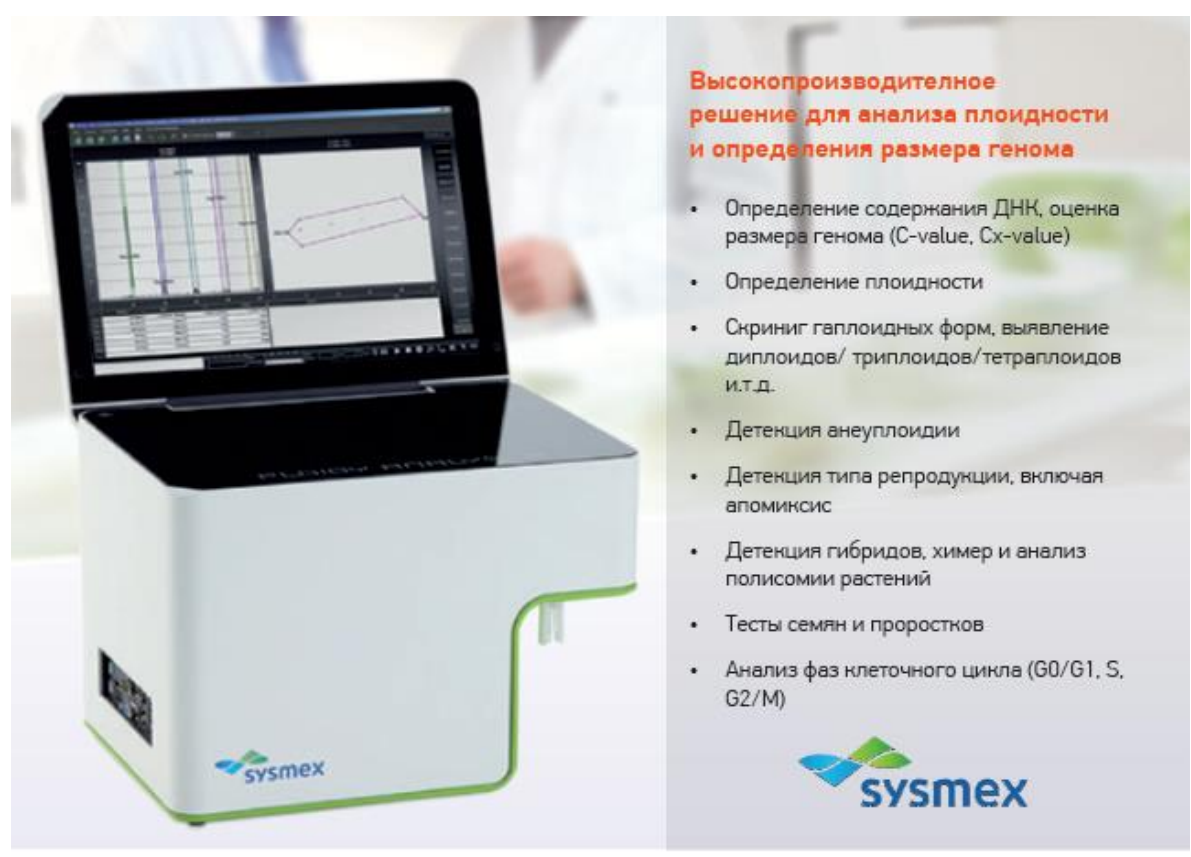

Современные комплексные решения для генетического анализа растений

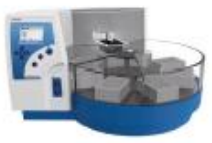

Системы длғ выделения нуклеиновых нислот

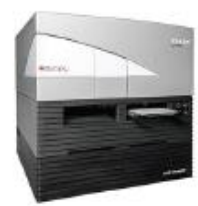

Многофуннциональные микропланшетные ридеры

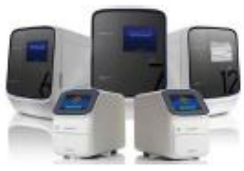

Оборудование и реагенты длн ПЦР в реальном времени

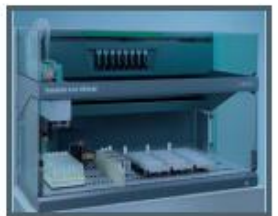

Автоматизированные станции пробоподготовни для ПЦР

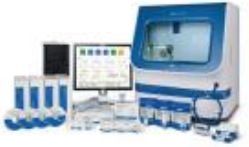

Оборудование и реагенты для секвенирования

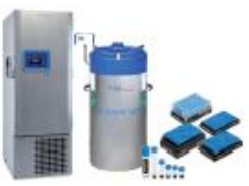

Решениन для хранения и транспортировни образцов

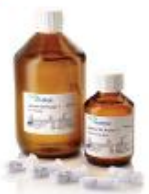

Готовые решения для генотипирования и определения плоидности

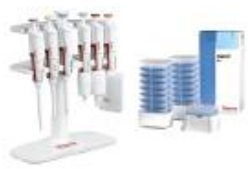

O6щелабораторное оборудование 


\section{ИнтерЛабСервис}

ООО "ИЛС" более 18 лет оснащает лаборатории РФ и СНГ широким спектром оборудования и расходных материалов по направлениям:

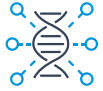

Клиническая молекулярная диагностика

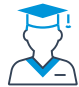

Научные исследования

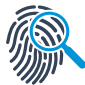

Криминалистика

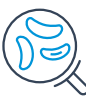

Микробиология

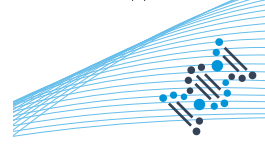

Онкология

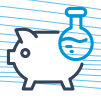

Ветеринария
гМИ и пищевая безопасность
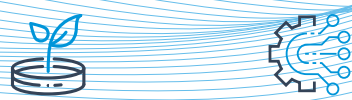

\section{Автоматизация лаборатории и биобанки}

Компания обладает многолетним опытом поставок, запуска лабораторного оборудования, сформированной командой высококвалифицированньх специалистов, сертифицированной службой клиентской поддержки, а также широкой сетью представительств по всей России, в странах СНГ и дальнего зарубежья.

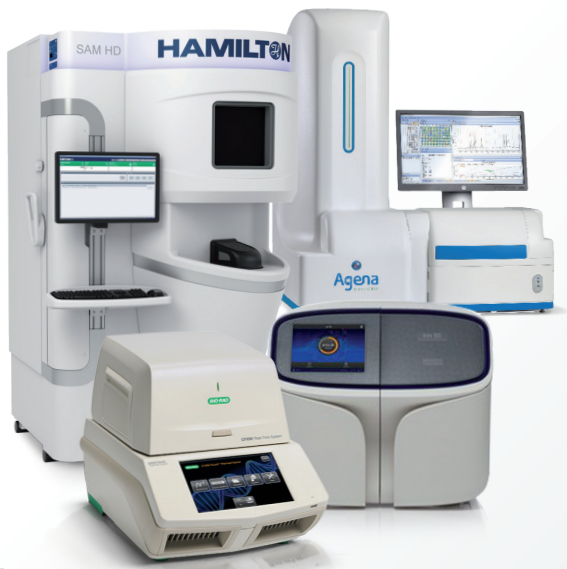

ПРОДУКТОВЫЙ ПОРТФЕЛЬ

компании представлен ведущими российскими и мировыми брендами:

AmpliSens $^{\mathrm{TM}}$, Hamilton, Agena Bioscience, Thermo Fisher Scientific, BioRad, Axygen, Confocal.nl, Aptaka, Mabtech, AmpliPrime ${ }^{\mathrm{TM}}$, YD-Diagnostics $и$ другие. ул. Садовническая, д. 20/13, стр. 2 Тел.: +7 (495) 664-28-84: Факс: +7 (495) 664-28-89 


\section{Биохимические реактивы, оборудование}

\section{и расходные материалы Life Sciences}

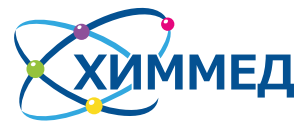

www.chimmed.ru

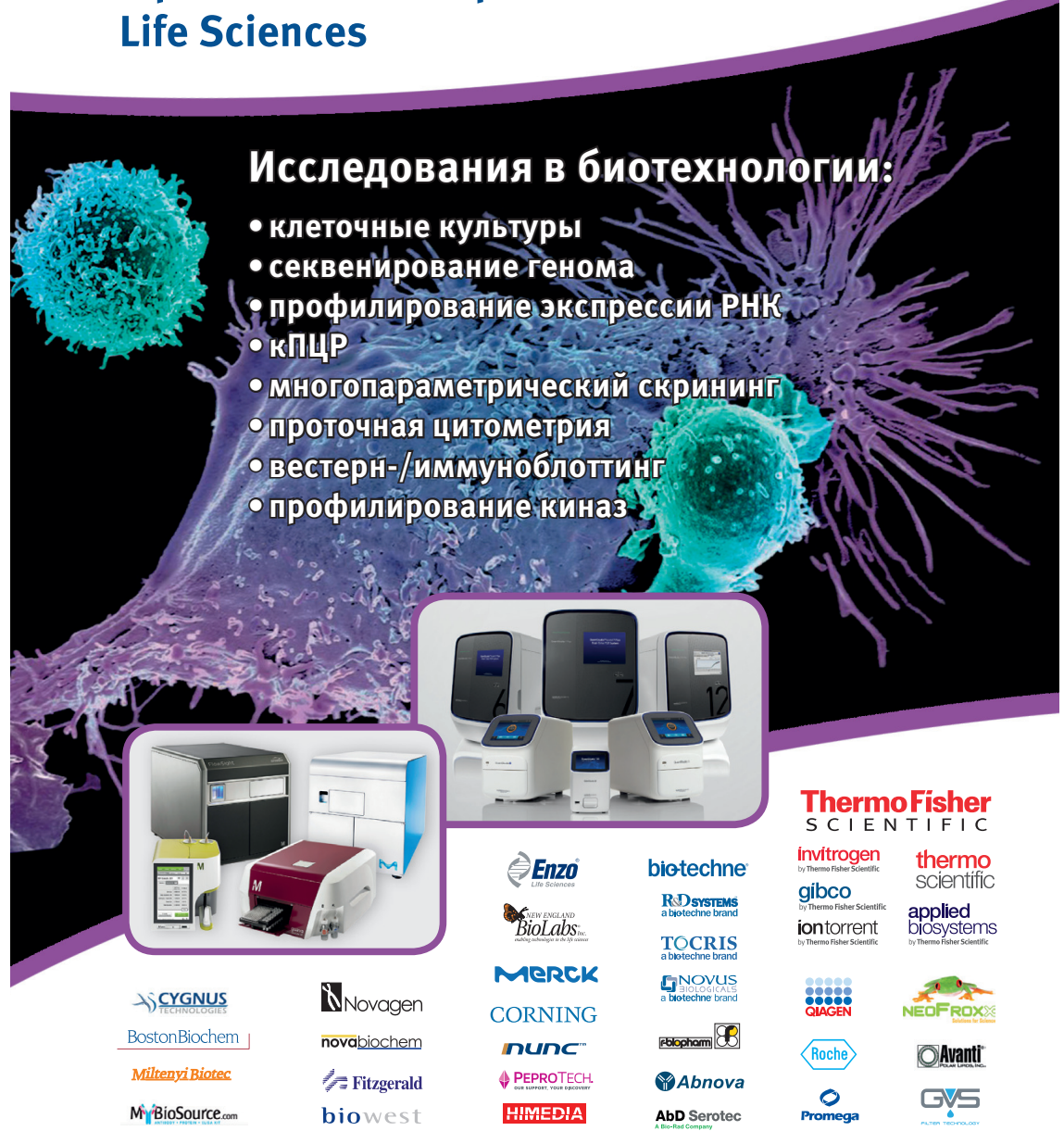

Мы можем предоставить демоверсии приборов в вашу лабораторию! Москва, 115230, Каширское шоссе, д. 9, корп. 3. Тел.: +7 (495) 640 4192, e-mail: bio@chimmed.ru Санкт-Петербург, 195248, просп. Энергетиков, д. 19, оф. 314. Тел.: +7 (812) 605 0061, e-mail: spb@chimmed.ru Казань, 420081, ул. Седова, д. 22. Тел.: +7 (843) 2736761, 272 9786, e-mail: kazan@chimmed.ru Новосибирск, 630090, просп. Академика Лаврентьева, 6/1. Tел.: +7 (383) 3356108, e-mail: sibir@chimmed.ru 


\section{Селекционный комбайн Classic}

Уборка зерновых, зернобобовых

и мелкосеменных культур без смешений

Полная самоочистка после каждой делянюи благодарғ ленточному

транспортеру в жатке и под молотильной камерой, системе обдува жатки,

пневматической транспортировке зерна.

Затаривание зерна в мешки сбоку комбайна или в бункер объемом 400 л

Зерновые жатки 1,25 м или 1,5 м, кукурузная жатка

Возможность установки системы взвешивания и определения влажности с системой отбора проб

Оборудование для уборки различных культур

จ Подбарабанье: 6 мм, 9 мм, 12 мм (стандарт), 18 мм, 24 мм, 36 мм

> Соломотрас: 6 мм, 10 мм, 14 мм, 20 мм, 28 мм

v Решето: с круглыми отверстиями от 4 мм до $28 \mathrm{Mm}$

จ Регулируемое жалюзийное 4-20 мм или 16-30 мм
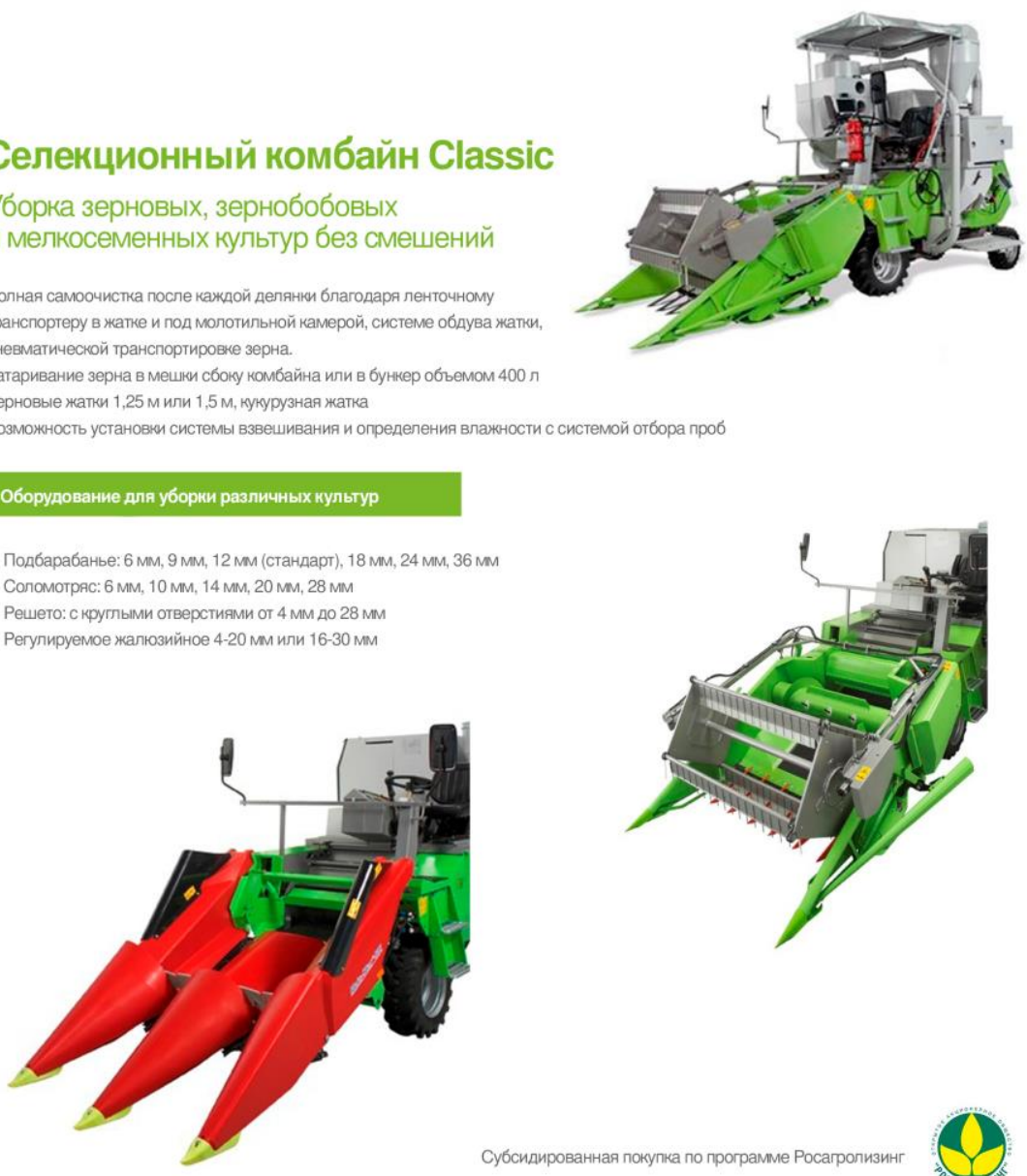

Субсидированная покупка по программе Росагролизинг

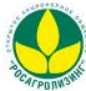




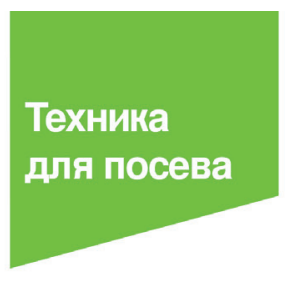

\section{WINTERSTEIGER}

in field research equipment.

\section{Деметра}

Селекционная сеялка сплошного посева

Предназначена для посева семян зерновых, зернобобовых, крупяных культур, а таюже семян трав от 10 г до $2 \mathrm{kr} \mathrm{на}$ делянку. При оборудовании сеялки кассетным столом позволяет сеять однорядковые делянки. Сеялка обеспечивает точный посев семян на делянках без смешений, что позволяет сохранить биологическую чистоту сорта даже при посеве мелкосемянных культур. Конусные высевающие аппараты распределяют порцию семян равномерно по всем рядам, на всю заданную длину делянки. Усиленные сошники позволяют сеять на заданную глубину в тяжелую и плохо обработанную почву с большим ноличеством растительных остатков, а таюже работать по технологии №-Till. Сеялка агрегатируется со всеми тракторами класса 1,4 и выше, в Т. ч. российского производства.

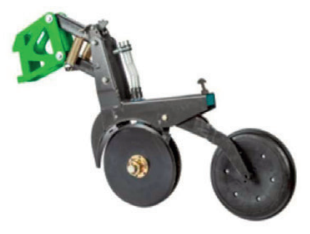

Тяжелый двухдисковый сошник

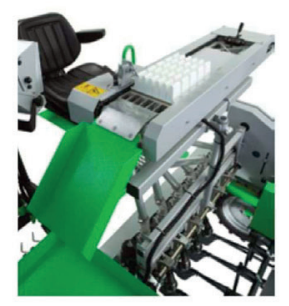

Автоматический кассетный стол на 4 и 6 рядков. Позволяет высевать однорядковые делянки
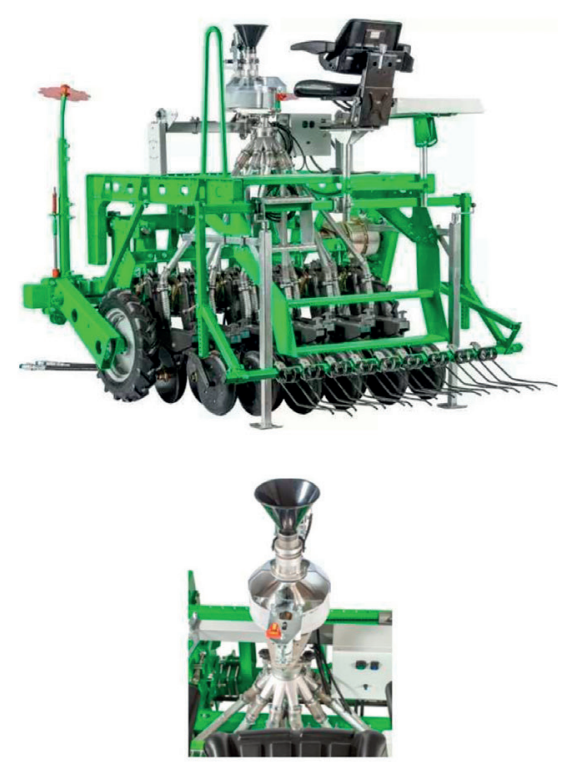

Бопьшой конический дозатор с лентой и электрическим подъемным механизмом

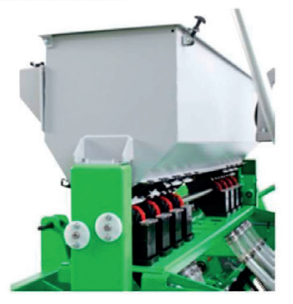

Бункер продолжительного посева для обсевов и первичного семеноводства. Может применяться для одновременного внесения удобрений 


\section{eppendorf}

Более 75 лет Eppendorf является одним из ведущих производителей лабораторного оборудования и расходных материалов для работы в фармацевтической, биотехнологической, химической отраслях. Производственные площадки Eppendorf расположены в Германии, Великобритании, США.

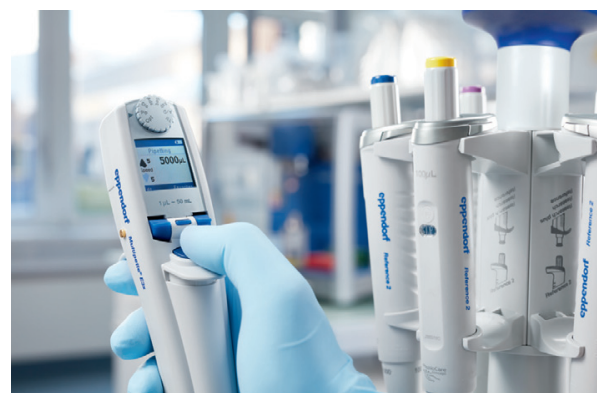

\section{LIQUID HANDLING}

Ручные и автоматические

устройства дозирования

жидкостей и расходные

материалы

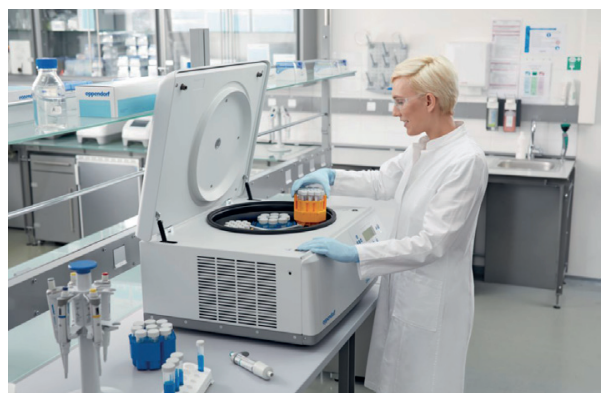

\section{SAMPLE HANDLING}

Пробоподготовка, хранение образцов, ПЦР

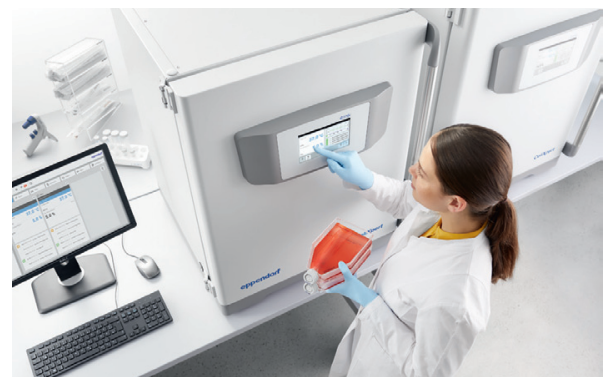

\section{CELL HANDLING}

Культивирование клеток

и микроманипуляции

с клетками

Эппендорф Раша, 000

Представительство в Сибири и на Дальнем Востоке:

Тел.: +7 92562598 33, e-mail: zonov.ev@eppendorf.ru, www.eppendorf.ru 
ПРОФЕССИОНАЛЬНЫЕ АКСЕССУАРЫ ДЛЯ СЕЛЕКЦИОННЫХ ОПЫТОВ

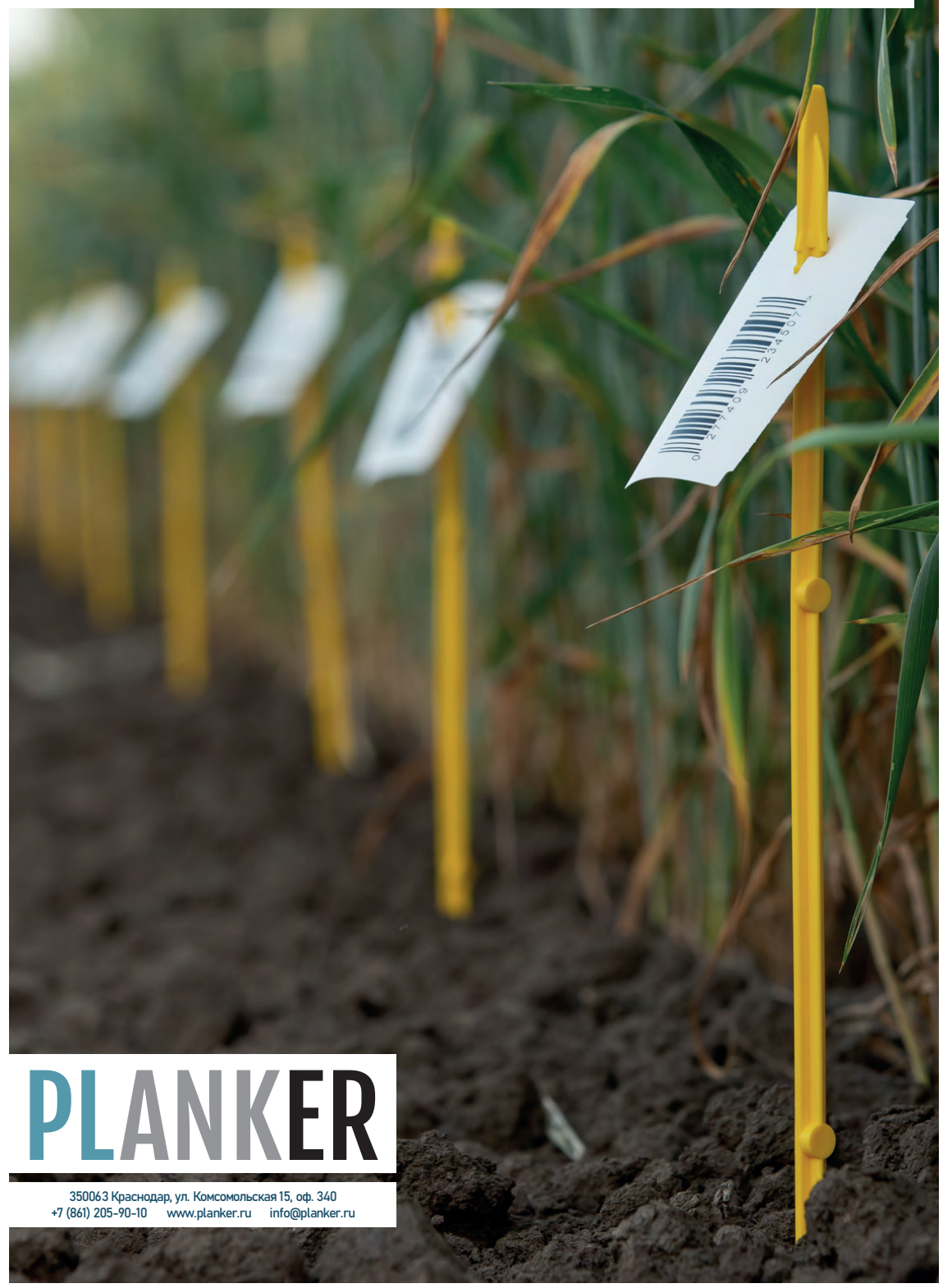


Технологии для геномной селекции и фенотипирования растений

\title{
Генотипирование KASP"m
}

KASPm (Конжрентная Аллель-Специфическая ПЦР) компании LGC Genomics применяется для о6наружения SNP и Вставок/Делеций.

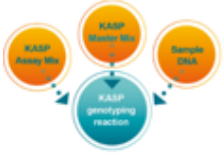

\begin{abstract}
KASP широко применяется для маркерной селекции растений благодаря своей эффективности и очень достүпной цене. Более 2000 пүбликаций по зффективности и точности генотипирования. КАSP совместим с большинством анализ аторов real-time (Biorad, Applied Biosystems, Roche). Для апробации всегда в наличии 6есплатные пробные наборы KASP.
\end{abstract}

\section{Услуги по генетическощу анализу растений}

000 «Максим Медикал» в сотрудничестве с LGC Genomics (Великобритания) представляет сервисы KASPAll Inclusive и SeqSNP"m по генотипированию и секвенированию (GBS) для нүжд геномной селекций растений. Выполняем исследованиями любого масштаба от 48 до тысяч о6разцов, от 1 до 100000 SNP. Срокисполнения от 1 до 3 месцев. Доступные цены

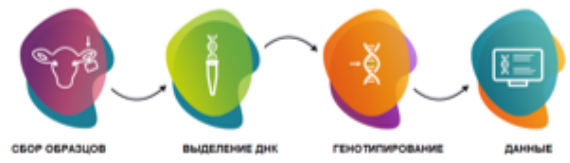

Фенотипирование растений на основе технологии Phenospex:

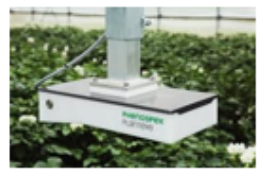

Инновационный 3D-сканер растений Planteye Ђ00 для неинвазивного фенотипирования растений в теплицах и полевых условий.

Системы Microscan, TraitFinder и Gantry TraitFinder для фенотипирования от 1 до 100 растений в ла6ораторных условиях

Системы FieldScan - фенотипирование от 100 до сотен растений в полевых үсловиях.

Систепы DroughtSpotter для гравиметрического анализа растений и воспроиз водения үсловий з асухи в лабораторных и полевых условиях.

Первая система Phe nospex иже установлена в России!

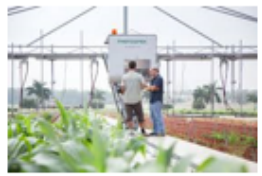

\section{Оборудование для роста растений}

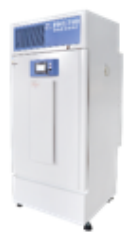

000 «Максим Медикал» является эксклюз ивным партнером HiPoint (Тайвань)

- Камеры роста и инқбаторы для растений, грибов, клеточных қльтур

- Теплицы модульные -

- Компактные спектрофотометры для анализ а фотосинтетической активности. 

Компания Хеликон обеспечивает полный рабочий процесс необходимым 16/6012 оборудованием и расходными материалами для молекулярной и клеточной биологии и прикладных исследований.

\section{ДЕЛАЕМ ВОЗМОЖНОЙ РАБОТУ ЛАБОРАТОРИЙ В РОССИИ НА МИРОВОМ УРОВНЕ}
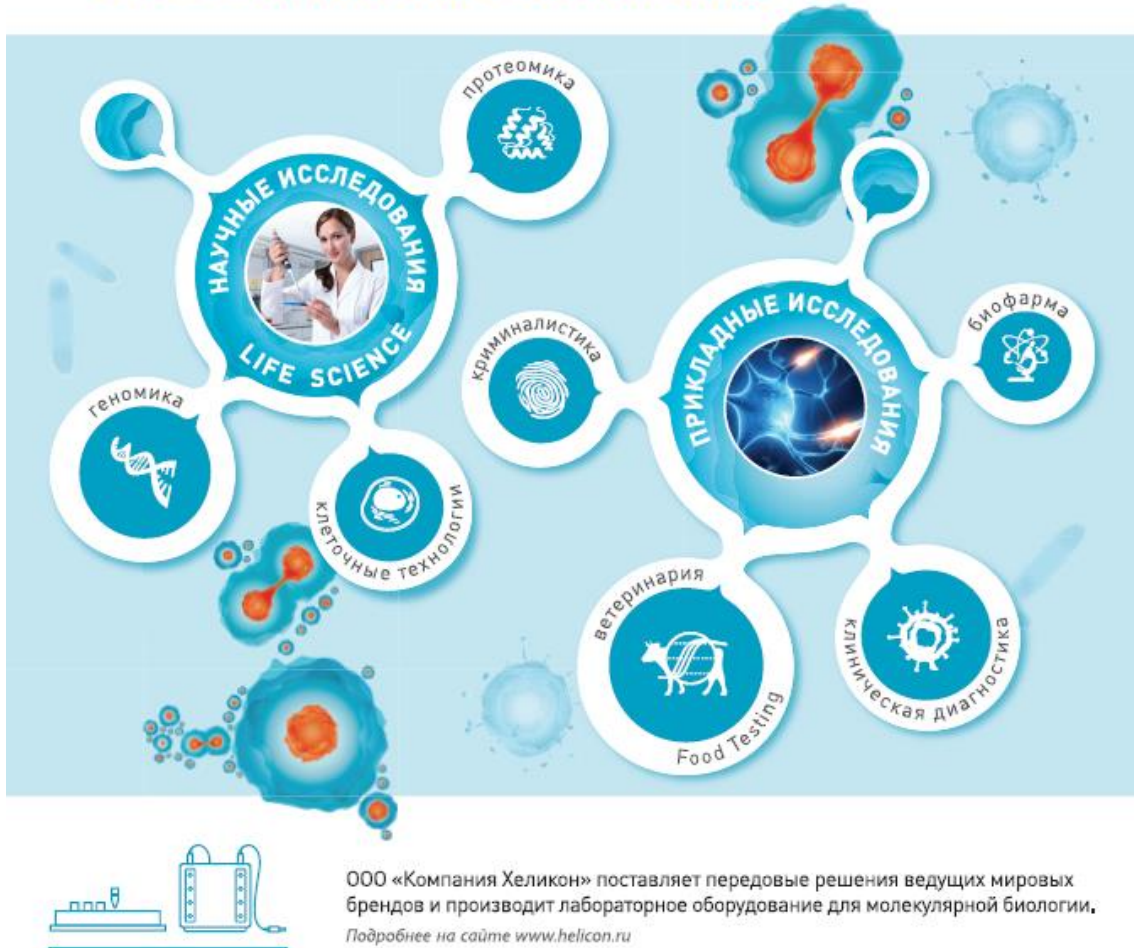

000 «Компания Хеликон» поставляет передовые решения ведущих мировых брендов и производит лабораторное оборудование для молекулярной биологии. กодробніее на caùme www.helicon.ru

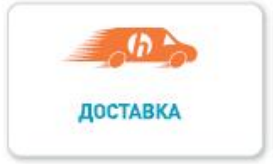

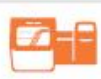

ОБУЧЕНИЕ

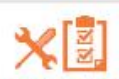

CEРВИСНОЕ ОБСЛУЖИВАНИЕ
Центрапьный офис:

121374 г. Москва, Кутузовский проспект, А. 88 Teл. 8 (800) 770-71-21 Факс +7 (495) 930-00-84 maitahelicon, ru

www,helicon,ru

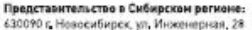

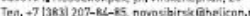

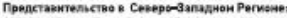

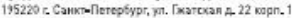

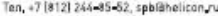

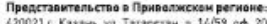
Ter +? (8.43) 202-33-37, volga(shelicorvu

Преястакительстве в Южнон ретионе:

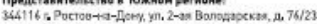
Ten, $77[863] 296-87=66$, rostoviahelizan,ru 
Научное издание

\title{
ГЕНОФОНД И СЕЛЕКЦИЯ РАСТЕНИЙ
}

\section{V Международная конференция}

$$
\text { 11-13 ноября } 2020 \text { г. }
$$

\author{
Доклады и сообщения
}

Публикуется в авторской редакиии

Изадние подготовлено информационно-издательским отделом ИЦиГ СО РАН 630090, Новосибирск, просп. Академика Лаврентьева, 10

Подписано в печать 26.10.2020. Формат 60×84 1/16. Гарнитура Таймс. Бумага офсетная. Усл. печ. л. 18,95. Тираж 110 экз. Заказ № 658

Отпечатано в типографии ООО «Дигит Про», Новосибирск, ул. Журинская, д.78, пом. 208 